\title{
The Bedrock Geology of Massachusetts
}

E. Stratigraphy of the Milford-Dedham Zone, Eastern

Massachusetts: An Avalonian Terrane

F. Stratigraphy of the Nashoba Zone, Eastern Massaciusetts: An Enigmatic Terrane

G. Stratigraphy of the Merrimack Belt, Ceniral Massachusetts

H. Structural and Metamorphic History of Eastern Massachusetts

I. Intrusive Rocks of Eastern Massachusetts

J. Radiometric Ages of Rocks in Massachusetts

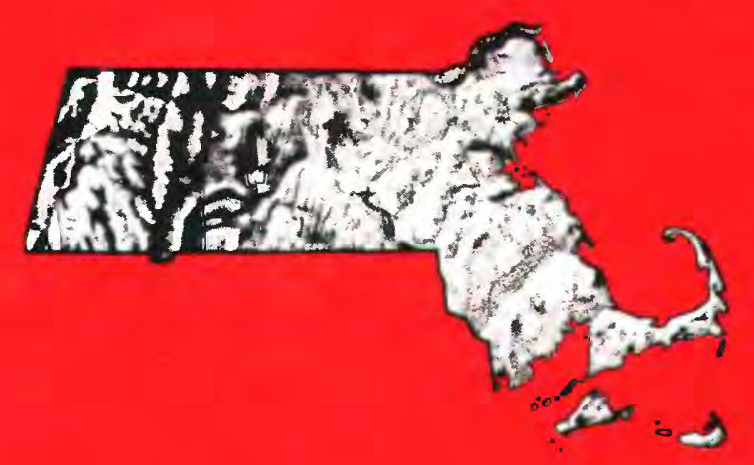

U.S. GEOLOGICAL SURVEY PROFESSIONAL PAPER 1366 -E-J 


\section{The Bedrock Geology of Massachusetts}

NORMAN L. HATCH, JR., Editor

E. Stratigraphy of the Milford-Dedham Zone, Eastern

Massachusetts: An Avalonian Terrane

By RICHARD GOLDSMITH

F. Stratigraphy of the Nashoba Zone, Eastern Massachusetts: An Enigmatic Terrane

By RICHARD GOLDSMITH

G. Stratigraphy of the Merrimack Belt, Central Massachusetts

By PETER ROBINSON and RICHARD GOLDSMITH

H. Structural and Metamorphic History of Eastern Massachusetts By RICHARD GOLDSMITH

I. Intrusive Rocks of Eastern Massachusetts

By DAVID R. WONES and RICHARD GOLDSMITH

J. Radiometric Ages of Rocks in Massachusetts

By ROBERT E. ZARTMAN and RICHARD F. MARVIN

U.S. GEOLOGICAL SURVEY PROFESSIONAL PAPER 1366-E-J

Chapters E-J are issued as a single volume

and are not available separately

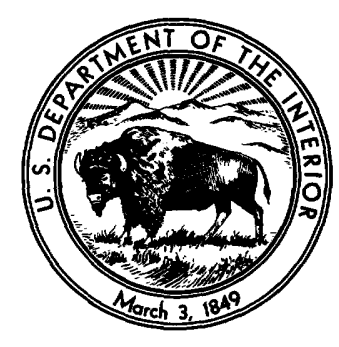

UNITED STATES GOVERNMENT PRINTING OFFICE, WASHINGTON: 1991 


\title{
U.S. DEPARTMENT OF THE INTERIOR
}

MANUEL LUJAN, Jr., Secretary

\section{U.S. GEOLOGICAL SURVEY}

Dallas L. Peck, Director

\begin{abstract}
Any use of trade, product, or firm names in this publication is for descriptive purposes only and does not imply endorsement by the

U.S. Government
\end{abstract}

Library of Congress Cataloging in Publication Data

The bedrock geology of Massachusetts.

(U.S. Geological Survey professional paper ; 1366-E-J)

Bibliography: $p$.

Supt. of Docs. no.: I 19.16:1366E-J

1. Geology-Massachusetts. I. Hatch, Norman L., Jr. II. Series: Geological Survey professional paper ; 1366-E-J. QE123.B44 $\quad 1988 \mathrm{~b} \quad 557.44 \quad 87-600472$

For sale by the Books and Open-File Reports Section, U.S. Geological Survey, Federal Center, Box 25425, Denver, CO 80225 


\section{Editor's Preface to Chapters E through J}

This Professional Paper was planned as a companion to the bedrock geologic map of Massachusetts (Zen and others, 1983; hereafter referred to as the State bedrock map). It is being published as lettered chapters of Professional Paper 1366, six of which are included in this volume, and four of which were published in a single volume as chapters A-D (Hatch, 1988). Compilation of the geology for the State bedrock map was completed in 1980. Some of the chapters in this Professional Paper reflect field or laboratory data that were gleaned as much as 6 years later. Each chapter was prepared, however, with the objective of explaining and further describing the geology as portrayed on the State bedrock map. In some instances, information and interpretations developed since 1980 have caused chapter authors to suggest revisions that they would make to the map if they were able to redraw it, but in each case these suggested revisions are discussed in the context of the map as it was published.

The previous State bedrock map (which also showed the geology of Rhode Island) was published in 1917 by Benjamin K. Emerson as U.S. Geological Survey Bulletin 597. (The publication date of Bulletin 597 is 1917. Some confusion arises from the fact that the bedrock map of the two States, which is included in the pocket of the Bulletin, bears the date of 1916.) All who were involved in the preparation of the new bedrock map, particularly those responsible for the parts of the State in which Emerson himself had done the original field work, feel a great deal of respect for Professor Emerson and his remarkably perceptive and thorough understanding and portrayal of the geology. Although the new map is very different from Emerson's in many aspects, particularly with regard to the interpretation of the geologic history, the basic distribution of map units is remarkably similar.

The State bedrock map and this report are direct outgrowths of a cooperative geologic mapping program between the U.S. Geological Survey and the Commonwealth of Massachusetts, which was begun in 1938. They also include the results of more than 25 years of mapping and topical studies by faculty and students at the University of Massachusetts at Amherst and at many other colleges and universities.

The subdivision of the material in this Professional Paper into the constituent chapters is based on the grouping of the 343 individual lithic units on the State bedrock map into the 8 lithotectonic packages discussed by Hatch and others (1984). The temporal and geographic distributions of these eight packages are indicated on figures 1 and 2 . Also indicated on the figures are the geographic and geologic coverages of the chapters included in this volume. In this packaging scheme, the older, primarily pre-Silurian, rocks of the State are grouped into five "zones" whose exposed and buried parts completely cover the State. From west to east, these zones are the Taconic-Berkshire, the RoweHawley, the Bronson Hill, the Nashoba, and the MilfordDedham. Their mutual boundaries are, or could reasonably be interpreted to be, faults. Overlying and overlapping the zones in the central part of the State are the Connecticut Valley and Merrimack "belts" of primarily Silurian and Devonian strata. Their mutual boundary is somewhat arbitrarily taken to be the east contact of the easternmost exposed Silurian Clough Quartzite. Finally, the Mesozoic "basins" unconformably overlie the Connecticut Valley belt.

For some packages, all aspects of the geology are treated in the same chapter. For others, aspects such as the structure, metamorphism, and tectonics are discussed separately from stratigraphy and lithology. These differences in treatment resulted from peculiarities of the geology and the preferences of the individual authors. Many of the plutonic rocks of the State are described and discussed in chapter I.

Many of the lithologic subdivisions of formal units on the State bedrock map have not been given formal names. In order to avoid potentially cumbersome discussions of such things as "the thick-bedded micaceous quartzite and mica schist unit of the XYZ Formation," many chapter authors have chosen to refer to such units simply by their map symbols. Thus the micaceous quartzite, quartz-mica-garnet schist, and calc-silicate unit of the Devonian Goshen Formation may be referred to simply by its map symbol "Dgq," but in a context where the reader will be easily guided to the correct unit.

The terms "granulite" and "granofels" have been used rather arbitrarily and interchangeably throughout this Professional Paper, although on the State bedrock map the term "granofels" was used exclusively. Both terms are used to describe a metamorphic rock composed 
predominantly of even-sized, interlocking granular minerals; no implication as to the grade of metamorphism is intended by either term. The choice of words merely reflects individual author preference, and we hope that no confusion to the reader will result from the unrestrained use of two words for the same kind of rock.

This volume contains six chapters that deal primarily with terranes of eastern Massachusetts, terranes that were amalgamated and accreted to North America during the Paleozoic. Chapter E, on the stratigraphy of the Milford-Dedham zone, deals with the stratified rocks of the easternmost part of the State, a terrane considered to represent part of Avalonia. Chapter F deals with the stratified rocks of the Nashoba zone, a "suspect terrane" west of the Milford-Dedham zone, that is bounded by the Bloody Bluff fault on the east and the Clinton-Newbury fault on the west. Chapter $\mathrm{G}$ describes the stratigraphy of the Silurian and Devonian rocks of the Merrimack belt, which adjoins and overlies the Nashoba zone on the west. Chapter $\mathrm{H}$ discusses the structure and metamorphism of the rocks of the Milford-Dedham and Nashoba zones and of the easternmost part of the Merrimack belt. Chapter I describes and discusses the critically distinctive intrusive rocks of the eastern part of the State. Finally, Chapter $\mathrm{J}$ tabulates all of the isotopic ages on the rocks of the whole State available as of 1986. Most of these ages are from the abundant plutonic rocks of the eastern part of the State.

We would herein like to acknowledge the invaluable contributions to this Professional Paper of two key people. Jewel Dickson did the cartographic work on the majority of the illustrations, the principal exceptions

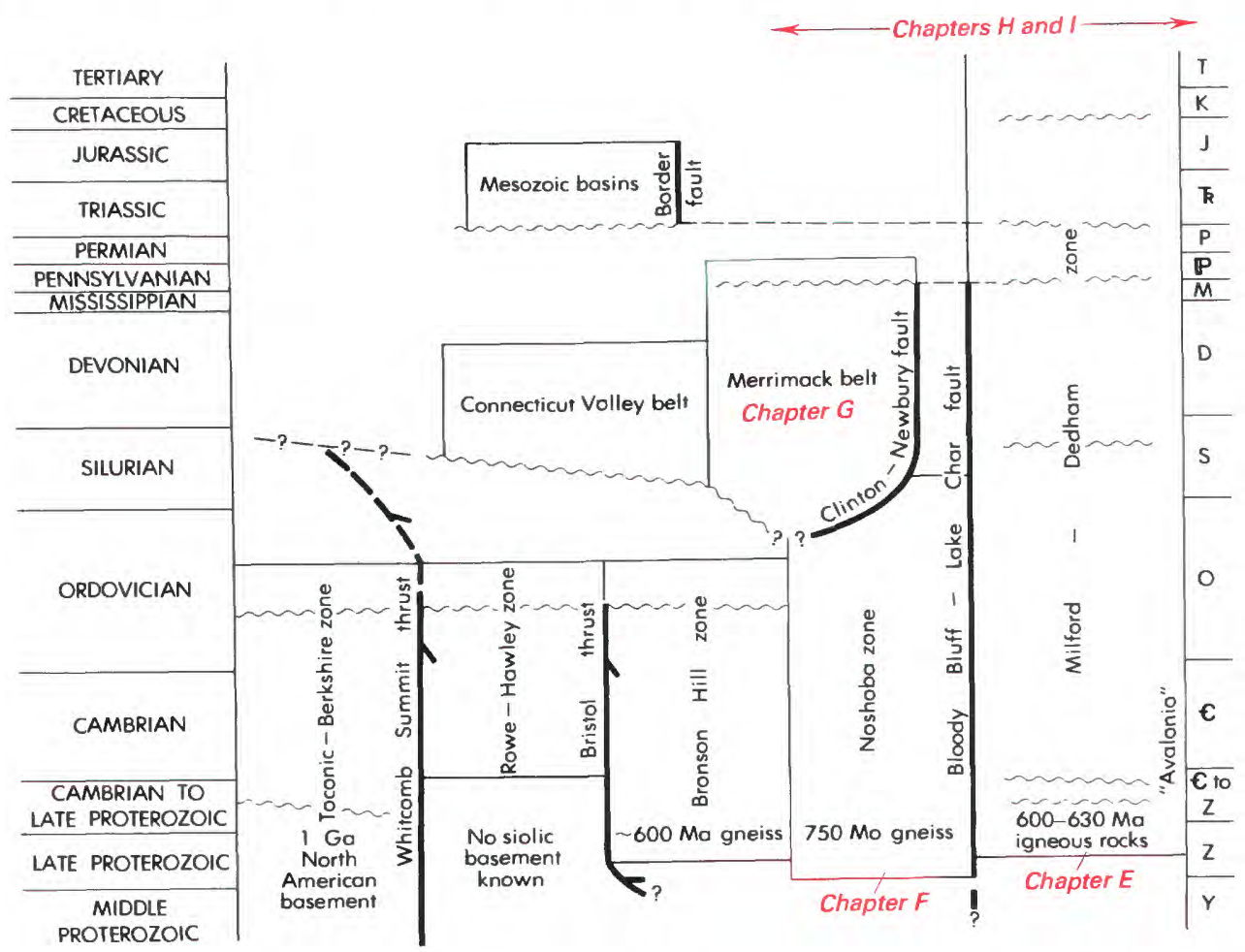

FiguRE 1. - Diagram simplified from the "Correlation of Map Units" on the State bedrock map showing the eight lithotectonic packages into which the rock units have been divided. Also indicated are the letter designation(s) of the chapter(s) in this volume covering various aspects of the geology. Chapter $J$ deals with rocks from the entire State and thus is not shown on the figure. Modified from Hatch and others (1984, fig. 1). 


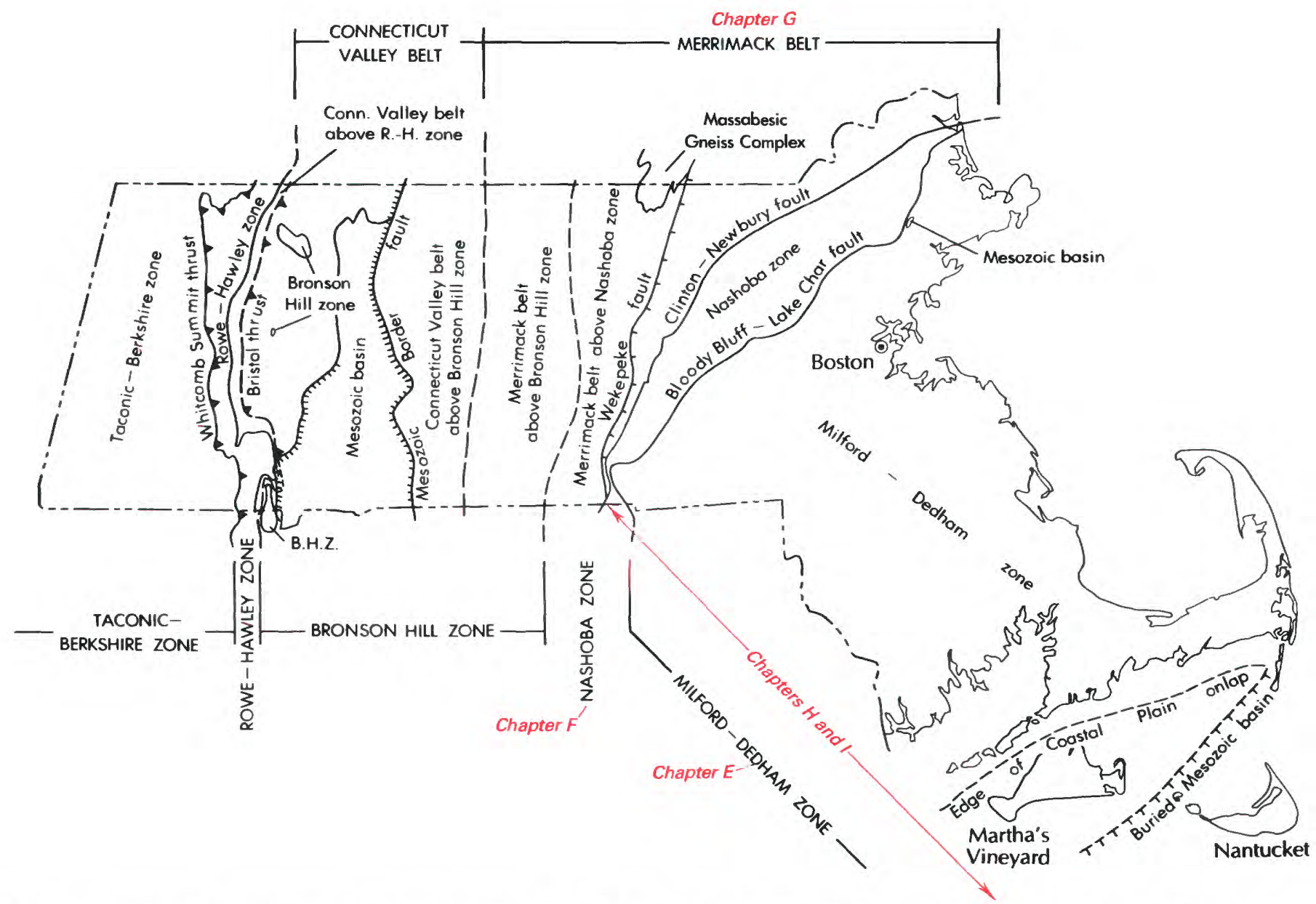

FIGURE 2.-Map of Massachusetts showing the geographic distribution of the eight lithotectonic packages into which the rock units of the State have been grouped and the letter designation(s) of the chapter(s) in this volume in which aspects of the geology are discussed. Chapter J deals with rocks from the entire State and thus is not shown on the figure. Modified from Hatch and and others (1984, fig. 2).

being those prepared by author Peter Robinson. Kathleen Krafft Gohn suffered bravely over the years with the editor and authors of this Professional Paper as its technical editor.

\section{REFERENCES CITED}

Emerson, B.K., 1917, Geology of Massachusetts and Rhode Island: U.S. Geological Survey Bulletin 597, 289 p.
Hatch, N.L., Jr., editor, 1988, The bedrock geology of Massachusetts: U.S. Geological Survey Professional Paper 1366-A-D, variously paged.

Hatch, N.L., Jr., Zen, E-an, Goldsmith, Richard, Ratcliffe, N.M., Robinson, Peter, and Wones, D.R., 1984, Lithotectonic assemblages as portrayed on the new bedrock geologic map of Massachusetts: American Journal of Science, v. 284, p. 1026-1034.

Zen, E-an, editor, Goldsmith, Richard, Ratcliffe, N.M., Robinson, Peter, and Stanley, R.S., compilers, 1983, Bedrock geologic map of Massachusetts: Reston, Va., U.S. Geological Survey, 3 sheets, scale $1: 250,000$. 



\title{
VOLUME CONTENTS
}

\author{
[Letters designate chapters]
}

Editor's Preface to Chapters E through J, by Norman L. Hatch, Jr.

(E) Stratigraphy of the Milford-Dedham zone, eastern Massachusetts: An Avalonian terrane, by Richard Goldsmith

(F) Stratigraphy of the Nashoba zone, eastern Massachusetts: An enigmatic terrane, by Richard Goldsmith

(G) Stratigraphy of the Merrimack belt, central Massachusetts, by Peter Robinson and Richard Goldsmith

(H) Structural and metamorphic history of eastern Massachusetts, by Richard Goldsmith

(I) Intrusive rocks of eastern Massachusetts, by David R. Wones and Richard Goldsmith

(J) Radiometric ages of rocks in Massachusetts, by Robert E. Zartman and Richard F. Marvin

The following chapters of Professional Paper 1366 were published in a single volume in 1988:

(A) The pre-Silurian geology of the Rowe-Hawley zone, by Rolfe S. Stanley and Norman L. Hatch, Jr.

(B) Stratigraphy of the Connecticut Valley belt, by Norman L. Hatch, Jr., Peter Robinson, and Rolfe S. Stanley

(C) Post-Taconian structural geology of the Rowe-Hawley zone and the Connecticut Valley belt west of the Mesozoic basins, by Norman L. Hatch, Jr., and Rolfe S. Stanley

(D) The Whately thrust: A structural solution to the stratigraphic dilemma of the Erving Formation, by Peter Robinson, Norman L. Hatch, Jr., and Rolfe S. Stanley 



\section{Stratigraphy of the Milford-Dedham Zone, Eastern Massachusetts: An Avalonian Terrane}

By RICHARD GOLDSMITH

With a section on MESOZOIC AND TERTIARY STRATIGRAPHY OF CAPE COD AND THE NEARBY ISLANDS

By E.G.A. WEED

THE BEDROCK GEOLOGY OF MASSACHUSETTS

U.S. GEOLOGICAL SURVEY PROFESSIONAL PAPER 1366-E 



\section{CONTENTS}

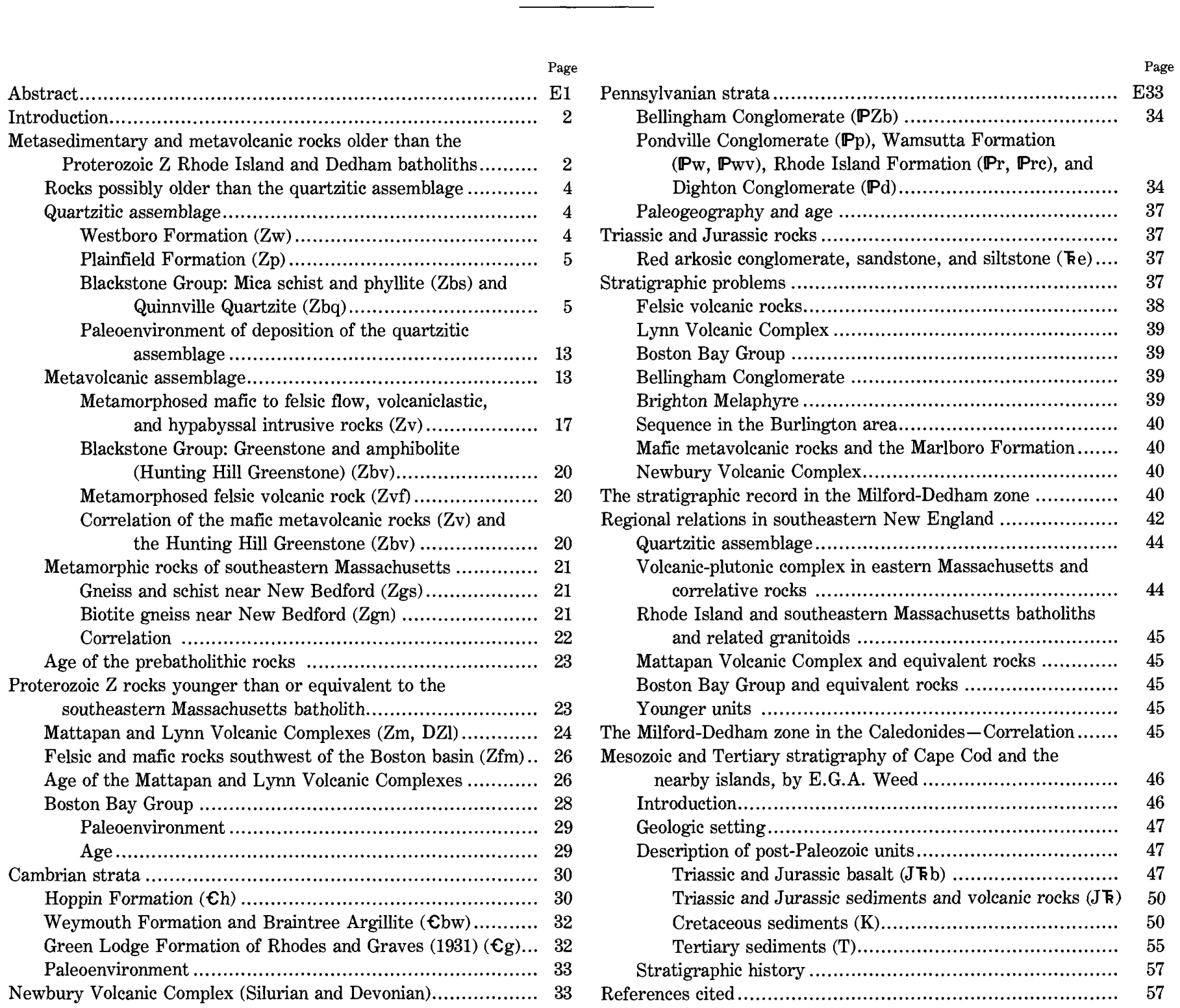

\section{ILLUSTRATIONS}

FIGURE 1. Sketch map of the major features of the geology in the Milford-Dedham zone in eastern Massachusetts ....... 
FIgURES 3-5. Maps of:

3. Stratigraphic units north and northwest of the Boston basin.

4. Stratigraphic units west and southwest of the Boston basin

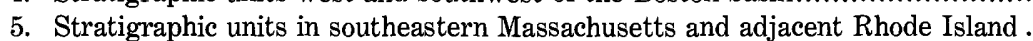

6. Correlation chart of stratified rocks older than Proterozoic Z granitoids in eastern Massachusetts and northern Rhode Island.

7. Correlation chart of stratified rocks older than Proterozoic Z granitoids in southeastern Massachusetts and southern Rhode Island.

8. Map of stratigraphic units in and around the Boston basin

9. Stratigraphic section and lithologic description of the Boston Bay Group

10. Map of stratigraphic units in and around the Narragansett basin ....

11. Geologic map and measured sections on the east side of Hoppin Hill, Attleboro, Mass

12. Measured section of Lower and Middle Cambrian strata of the Hoppin Formation at the north end of Hoppin Hill Reservoir

13. Map showing distribution of major groups of rocks in the Milford-Dedham zone, Massachusetts, Rhode Island, and Connecticut.

14. Correlation diagram of some Proterozoic $\mathrm{Z}$ units in the Milford-Dedham zone in southeastern Connecticut, eastern Massachusetts, and Rhode Island

15. Map showing locations of outcrop and auger- and core-drilling sites that provide information on the pre-Mesozoic basement and Mesozoic and Tertiary deposits in the area of Cape Cod and the nearby islands, Massachusetts

16. Diagram showing correlation of the Cretaceous section in bore hole USGS 6001, Nantucket, with the exposed Cretaceous section in New Jersey.....

\section{TABLES}

TABLE 1. Sedimentary basins in the Milford-Dedham zone, Massachusetts....

2. Nomenclature of stratified metamorphic rocks older than the Proterozoic Z Rhode Island and southeastern Massachusetts batholiths

3. Descriptions from previously published works of stratigraphic units in eastern Massachusetts and northern Rhode Island older than the Proterozoic Z Rhode Island and southeastern Massachusetts batholiths

4. Stratigraphic units of the Boston basin and vicinity

5. Description of stratigraphic units in the Narragansett and Norfolk basins

6. Stratigraphic record in the Milford-Dedham zone

7. Location and identification of outcrops and auger- and core-drilling sites in the area of Cape Cod and the nearby islands, Massachusetts

8. Description of materials encountered in outcrops and in drilled holes in the area of Cape Cod and the nearby islands, Massachusetts 


\title{
STRATIGRAPHY OF THE MILFORD-DEDHAM ZONE, EASTERN MASSACHUSETTS: AN AVALONIAN TERRANE
}

\author{
By RichaRd Goldsmith
}

\begin{abstract}
The sedimentary and volcanic rocks and their metamorphic equivalents in the Milford-Dedham zone include rocks of Proterozoic Y? and Proterozoic Z, Proterozoic Z, Cambrian, Silurian and Devonian, Pennsylvanian, Triassic-Jurassic, and Cretaceous and Tertiary ages. Rocks older than Proterozoic $\mathrm{Z}$ batholithic rocks are divided into two major sequences. A sequence of quartzitic rocks includes the Westboro Formation, the Plainfield Formation, and mica schist and phyllite and Quinnville Quartzite of the lower part of the Blackstone Group. These formations represent shelf-edge sedimentation associated with minor volcanism. A group of largely mafic metavolcanic rocks younger than the quartzitic group, and probably arc related, includes metamorphosed mafic to felsic flow, volcaniclastic, and hypabyssal intrusive rocks, which in the literature of northeastern Massachusetts have been mapped as Middlesex Fells Volcanic Complex, Cherry Hill Formation and associated units, and Marlboro Formation. Included within this group in northern Rhode Island and adjacent Massachusetts are greenstone and amphibolite equivalent to the Hunting Hill Greenstone of the upper part of the Blackstone Group. In southeastern Massachusetts, near New Bedford, rocks older than Proterozoic Z batholithic rocks include gneiss and schist and biotite gneiss. These rocks were derived from metamorphosed clastic, volcaniclastic, and felsic to intermediate volcanic material. The correlation of these rocks to the quartzitic or mafic volcanic assemblages is uncertain.

Proterozoic $\mathrm{Z}$ rocks equivalent to or younger than the batholithic rocks are located primarily in and around the Boston basin. The Mattapan and Lynn Volcanic Complexes, primarily felsic volcanic rocks, may be in part coeval with younger phases of the batholithic rocks. Above the Mattapan and Lynn is the Boston Bay Group, a largely sedimentary, probably turbidite sequence of conglomerate, sandstone, and argillite consisting of the Roxbury Conglomerate and the Cambridge Argillite. Within the Roxbury Conglomerate, in the lower part of the group, are horizons of mafic volcanic rock, the Brighton Melaphyre. The Cambridge Argillite contains Proterozoic Z to Cambrian(?) acritarchs.

Lower and Middle Cambrian strata containing fossil assemblages typical of the Acado-Baltic province overlie the Proterozoic $\mathrm{Z}$ rocks around the Boston basin (Weymouth Formation, Braintree Argillite) and in the northwest corner of the Narragansett basin, near North Attleboro and West Wrentham (Hoppin Formation). The Lower Cambrian consists of basal quartzite, overlain by slaty phyllite, limey phyllite, and limestone; the Middle Cambrian consists primarily of

Manuscript approved for publication November 16, 1987.

argillite and slate. The Upper Cambrian is represented by only one locality near Dedham, where the Green Lodge Formation of Rhodes and Graves consists of quartzite and phyllite.

Silurian and Devonian strata are confined to two narrow faultbounded basins in northeastern Massachusetts, near Newbury and near Middleton. These strata, the Newbury Volcanic Complex, consist in the lower part primarily of volcanic rocks, including felsic and mafic flows and volcaniclastic material, and in the upper part largely of mudstone and siltstone and subordinate volcanic detritus. Fossil fauna, also of Acado-Baltic affinity, range from latest Silurian (Pridolian) to earliest Devonian (Gedinnian).

Pennsylvanian strata occupy one large basin (Narragansett basin) and two smaller basins (Norfolk and Bellingham (Woonsocket) basins). The Pennsylvanian strata are primarily continental sandstone, shale, and conglomerate (Pondville Conglomerate, Wamsutta Formation, Rhode Island Formation, and Dighton Conglomerate). The Wamsutta and Rhode Island Formations contain plant fossils, and the Rhode Island Formation is coal bearing. The strata in the Bellingham basin are nonfossiliferous, and their age is in question. The Wamsutta Formation contains basalt and felsic volcanic rocks in the northwestern part of the Narragansett basin and the southwestern part of the Norfolk basin. The Dighton represents channel deposits high in the sequence.

Red arkosic conglomerate, sandstone, and siltstone of Late Triassic to Early Jurassic age occupy a small fault-bounded basin, the Middleton basin, in northeastern Massachusetts. A Triassic-Jurassic basin lies in the subsurface beneath Coastal Plain sediments on Nantucket Island and Martha's Vineyard and beneath Nantucket Sound. The basin contains Triassic-Jurassic basalt, which was identified in a deep drill hole on Nantucket, and overlying sedimentary strata known only through seismic profiles.

Cretaceous strata of the Atlantic Coastal Plain crop out and are identified in drill holes on Nantucket and Martha's Vineyard. Tertiary strata are identified in drill holes and sparse outcrops on the islands, on Cape Cod, and in the Marshfield area on the mainland. Most material containing Tertiary spores or pollen, however, seems to have been disturbed and is in places physically mixed with, or reworked into, Pleistocene materials.

The stratigraphic record indicates four major episodes. A Proterozoic episode involves several phases: (1) arc margin and volcanic-arc accumulation in a compressional phase (Marlboro Formation; metamorphosed mafic to felsic flow, volcaniclastic, and hypabyssal intrusive rocks), (2) felsic volcanism and plutonism (Mattapan and Lynn Volcanic Complexes; Dedham Granite), (3) uplift and erosion, and (4) flysch to
\end{abstract}


molasse deposition and mafic volcanism in an extensional regime (Boston Bay Group). A second episode began with encroachment of Cambrian seas and shelf-deposition of Cambrian sediments (Hoppin Formation, Weymouth Formation, and Braintree Argillite) on a passive continental margin and lasted with little deposition into the middle Paleozoic. Tectonic conditions were primarily extensional and were characterized by static plutonism, largely alkalic, from Ordovician into Devonian time, but mafic and felsic arc volcanism and marine sedimentation occurred locally(?) in the Late Silurian and Early Devonian (Newbury Volcanic Complex). In the Pennsylvanian, continental sedimentary deposits and minor volcanic material (Pondville Conglomerate, Wamsutta Formation, volcanic rocks in the Wamsutta Formation, Rhode Island Formation, Dighton Conglomerate) accumulated in a shallow basin or basins on the Proterozoic and the older Paleozoic rocks. An episode of sedimentation and volcanism associated with rifting and the opening of the present Atlantic Ocean occurred during Triassic and Jurassic time. A new episode has begun with onlap of Cretaceous and Tertiary coastal plain sediments.

The stratigraphy within the Milford-Dedham terrane is in many respects similar to that in the Avalon terrane of southeastern Newfoundland and can be correlated with that of similar terranes in the Piedmont of the southern Appalachians, in the Maritime Provinces of Canada, in Wales, in England, and in northwest Africa.

\section{INTRODUCTION}

The Milford-Dedham zone is defined as encompassing those rocks and sediments lying east and southeast of the Bloody Bluff-Lake Char fault system. The zone includes Cape Cod and the outer islands and extends eastward an unknown distance beneath the Atlantic Ocean. The zone is further characterized in that it contains intrusive granites of Proterozoic $Z$ age, in contrast to the adjacent Nashoba zone, which lacks such granites. Rocks of the zone continue southward into Rhode Island and adjacent eastern Connecticut.

The Milford-Dedham zone contains two extensive batholithic masses of granitoid rock of Proterozoic $\mathrm{Z}$ age, one in western Rhode Island and in the Milford antiform of adjacent Massachusetts (hereinafter called the Rhode Island batholith) and the other in eastern and southeastern Massachusetts comprising the Dedham and equivalent granites (hereinafter called the southeastern Massachusetts batholith) (fig. 1). Older metasedimentary, metavolcanic, and metaplutonic rocks are preserved in discontinuous belts on the flanks and in septa or roof pendants. Plutons of gabbro to granite, the latter primarily alkalic, of Ordovician to Devonian age intrude the older rocks. Superimposed on the Proterozoic rocks are structural and stratigraphic basins containing unmetamorphosed to variably metamorphosed sedimentary and volcanic rocks ranging in age from latest Proterozoic to Triassic and Jurassic (table 1). Coastal plain deposits of Cretaceous and Tertiary age overlap the bedrock on the southeast. These and their substrata are described later in this chapter. The deposits of Pleistocene age are not shown on the State bedrock map (Zen and others, 1983; hereinafter referred to as the State bedrock map) and are not discussed in this chapter.

The State bedrock map contains 36 named units of sedimentary and volcanic rocks and their metamorphic equivalents in the Milford-Dedham zone (fig. 2). This number is condensed from a larger number of units that have been described and named by many different people working in different areas and at different times in eastern Massachusetts. In addition, the terrane is broken up by many faults so that many units are exposed only in one or two fault blocks. The result is that the geology as presented in this chapter tends to be fragmented. To remedy this, an attempt has been made to group units systematically within the limits of available fossil control and isotopic data.

This chapter summarizes descriptions of stratigraphic units partly described elsewhere, presents more detail in areas where new observations have been made, and concentrates discussion on controversial points of interpretation and on observations that are important in developing a regional synthesis. The plutonic rocks within the zone are described in another chapter (Wones and Goldsmith, this vol., chap. I). The structure is described in chapter $\mathrm{H}$ (Goldsmith, this vol.). The descriptions and discussion to follow are arranged primarily by relative age and only secondarily by structural block or basin. The data in this chapter are drawn from a number of sources used in the preparation of the State bedrock map and listed thereon. Nomenclature used consists of existing names and names modified for use on the State bedrock map (table 2; fig. 2; Goldsmith and others, 1982c). Significant exposures of rock units in the Milford-Dedham zone are described in guidebooks of the New England Intercollegiate Geological Conference published over a long span of years. Some of the stratigraphic units in the Greater Boston area can be seen by following a field guide prepared by Skehan (1979).

\section{METASEDIMENTARY AND METAVOLCANIC ROCKS OLDER THAN THE PROTEROZOIC $Z$ RHODE ISLAND AND DEDHAM BATHOLITHS}

Metasedimentary and metavolcanic rocks older than the Proterozoic $\mathrm{Z}$ granitoids of the Rhode Island and Dedham batholiths are found (1) in a metavolcanicmetaplutonic complex primarily in northeastern Massachusetts (fig. 3), (2) on the flanks of and as inclusions in the Rhode Island batholith (fig. 4), and (3) as septa in the southeastern Massachusetts batholith in the New Bedford area (fig. 5). Most of the lower part of the sequence of stratified rocks in and around the batholiths in Massachusetts consists of an assemblage of metasedimentary formations characterized by significant amounts of 


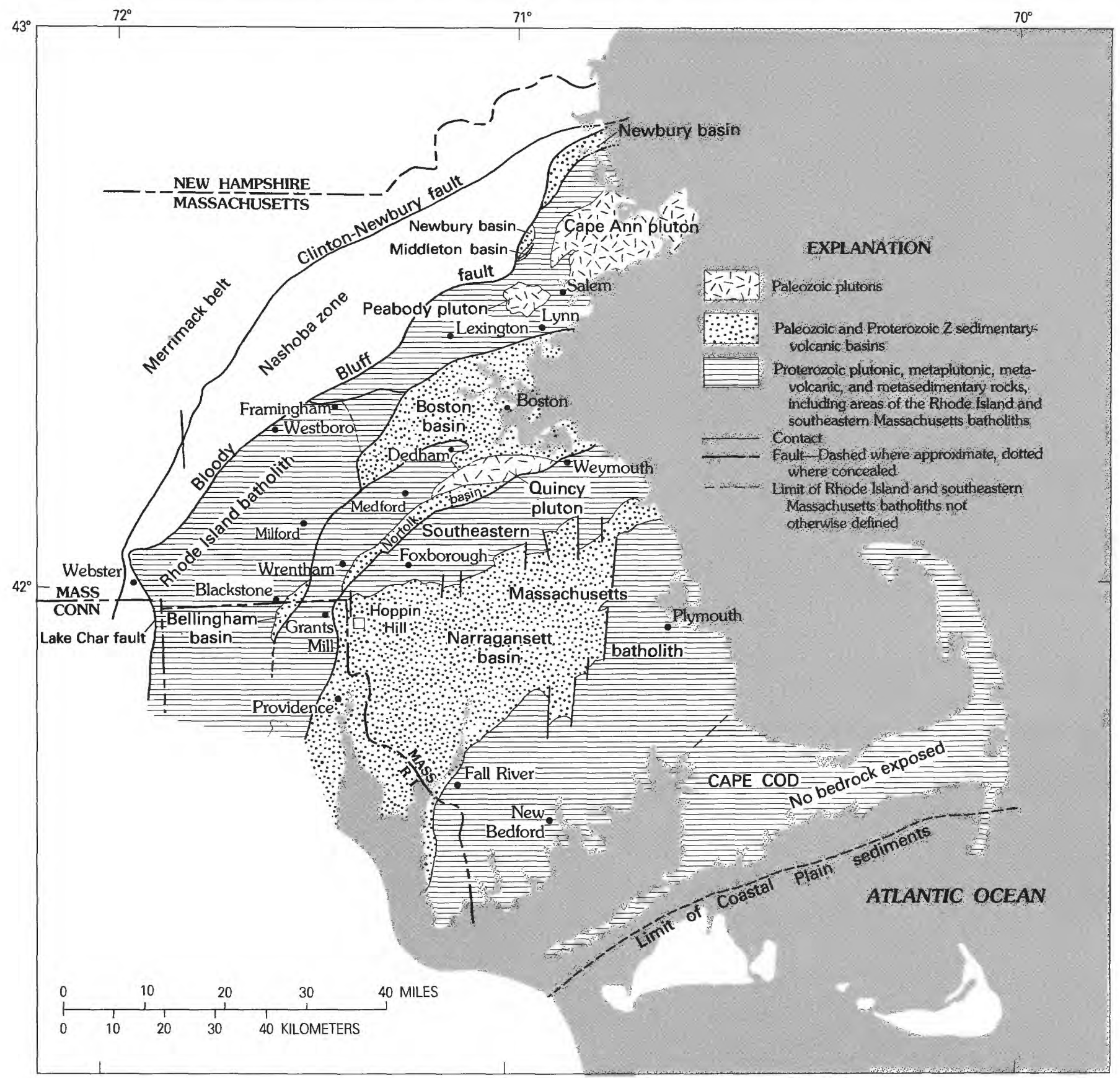

FIGURE 1.-Major features of the geology in the Milford-Dedham zone in eastern Massachusetts.

quartzite-the Westboro Formation (Zw), the Plainfield Formation $(\mathrm{Zp})$, and the lower part of the Blackstone Group (Zbs, Zbq, Zb). Most of the upper part is an assemblage of formations characterized by significant amounts of mafic metavolcanic rocks-metamorphosed mafic to felsic flow, volcaniclastic, and hypabyssal intrusive rocks $(\mathrm{Zv})$; metamorphosed felsic volcanic rocks (Zvf); and greenstone and amphibolite (Zbv) of the Blackstone Group. The two assemblages are gradational through interlayering. Gneiss and schist near New Bed- ford (Zgs) and biotite gneiss near New Bedford (Zgn) are Proterozoic $\mathrm{Z}$ in age, but their correlation with the assemblages mentioned above is uncertain. In a few places, metasedimentary strata apparently lie below the quartzitic assemblage, and, at others, metasedimentary strata apparently lie above the mafic metavolcanic assemblage. These strata, however, are thin and hence are included in one or another of the larger units on the State bedrock map. The correlation of these older stratified rocks is shown in figures 6 and 7, and descriptions 
TABLE 1.-Sedimentary basins in the Milford-Dedham zone, Massachusetts

\begin{tabular}{|c|c|c|c|c|}
\hline Basin & Lithotype & Fossil type & Metamorphism & Age of strata \\
\hline Middleton & $\begin{array}{l}\text { Fluviatile conglomerate, arkose, } \\
\text { and shale. }\end{array}$ & Plant & None & $\begin{array}{l}\text { Late Triassic and Early Juras- } \\
\text { sic. }\end{array}$ \\
\hline Norfolk & $\begin{array}{l}\text { Fluviatile conglomerate, sandstone, } \\
\text { and siltstone; minor volcanic com- } \\
\text { ponent. }\end{array}$ & Plant & $\begin{array}{l}\text { Diagenetic to zeolite facies(?) } \\
\text { (well-developed cleavage in } \\
\text { slaty beds). }\end{array}$ & $\begin{array}{l}\text { Late Mississippian(?) to Pennsyl- } \\
\text { vanian. }\end{array}$ \\
\hline Narragansett & $\begin{array}{l}\text { Fluviatile and deltaic conglomerate, } \\
\text { sandstone, and coal. Minor mafic } \\
\text { and felsic volcanic rocks in north- } \\
\text { west part. }\end{array}$ & Plant & $\begin{array}{l}\text { Diagenetic to greenschist } \\
\text { facies (mainly polydeformed } \\
\text { poor to well-developed cleav- } \\
\text { age). }\end{array}$ & $\begin{array}{l}\text { Late Mississippian to Pennsylva- } \\
\text { nian. }\end{array}$ \\
\hline Newbury & $\begin{array}{l}\text { Mafic and felsic volcanic flows and } \\
\text { tuffs; marine siltstone and mud- } \\
\text { stone. }\end{array}$ & Shelly fauna & None & $\begin{array}{l}\text { Late Silurian and Early Devo- } \\
\text { nian. }\end{array}$ \\
\hline Bellingham & $\begin{array}{l}\text { Fluviatile(?) and marine(?) conglom- } \\
\text { erate, sandstone, and siltstone; } \\
\text { minor felsic volcanic rocks. }\end{array}$ & None & Greenschist facies (foliated) & Proterozoic Z or Pennsylvanian. \\
\hline \multirow[t]{2}{*}{ Boston } & $\begin{array}{l}\text { Marine sandstone, siltstone, shale, } \\
\text { calcareous shale, and limestone. }\end{array}$ & Shelly fauna & Diagenetic & Early and Middle Cambrian. \\
\hline & $\begin{array}{l}\text { Fluviatile and marine conglomerate, } \\
\text { sandstone, siltstone, shale, tillite; } \\
\text { mafic and felsic volcanic rocks. }\end{array}$ & Acritarchs & Diagenetic (incipient cleavage) & $\begin{array}{l}\text { Proterozoic Z to Early } \\
\text { Cambrian. }\end{array}$ \\
\hline
\end{tabular}

from previously published works are summarized in table 3.

\section{ROCKS POSSIBLY OLDER THAN THE QUARTZITIC ASSEMBLAGE}

Bell and Alvord (1976) described "unnamed stratified remnants" consisting of fine-grained gneisses and quartzite from a hill in the western part of Saugus (fig. 3 , table 3). These remnants form a band of poorly exposed slablike xenoliths, lying apparently conformably below thick-bedded quartzite assigned to the Westboro Formation cropping out $0.5 \mathrm{~km}$ to the north, and a zone of scattered inclusions in the Dedham Granite near Lynn. These rocks occupy a limited area and have been included in the Westboro Formation on the State bedrock map.

\section{QUARTZITIC ASSEMBLAGE}

\section{WESTBORO FORMATION (Zw)}

The Westboro Formation (Zw), the Westboro Quartzite of Perry and Emerson (1903, p. 155), is primarily a quartzitic unit consisting of thick- to thin-bedded orthoquartzite and subordinate mica schist, calc-silicate rock, amphibolite, and biotite gneiss and schist, the latter commonly quartzitic. Although the rock sequences of Nelson (1974) and of Bell and Alvord (1976) (table 3) cannot be correlated precisely, their descriptions are similar and typify the formation in eastern Massachusetts. Hepburn and DiNitto's (1978) description of the Westboro is of rocks closest to Emerson's type area near
Westboro. They proposed that the type area of Westboro be exposures in $200 \mathrm{~m}$ of cuts on I-495 north of Mt. Nebo, south of the Southboro-Westboro town line.

West and north of Boston, disconnected masses of quartzite and associated rock in Proterozoic $\mathrm{Z}$ mafic plutonic and volcanic rocks are shown on the State bedrock map as Westboro, although they are not in a continuous belt with the Westboro of Nelson (1974) or of Hepburn and DiNitto (1978). Other isolated masses of quartzite, such as those mapped by Castle (1964) in the Reading area, are also assigned to the Westboro. Bell and Alvord (1976) mapped a thin-bedded quartzite primarily in their Burlington Formation (table 3), in a group of formations near Burlington that lie between the Bloody Bluff fault and their Middlesex Fells Volcanic Complex. Although this unit lies 2,300 $\mathrm{m}$ above the Westboro on their section (table 3), and they cited indirect evidence that the group lies unconformably on the Middlesex Fells, the Burlington has been shown arbitrarily as Westboro on the State bedrock map to indicate its quartzitic composition and to decrease the number of small units on the map. The remainder of this group (Bell and Alvord's Greenleaf Mountain Formation and unnamed gneiss and quartzite; see table 3) has been included in the metamorphosed mafic to volcanic rocks (Zv) of Proterozoic $\mathrm{Z}$ age because these units contain metavolcanic rock. I now believe that the three units should be assigned to a separate metamorphic suite above the main sequence of metavolcanic rocks ( $\mathrm{Zv}, \mathrm{Zvf})$.

Some small masses of quartzite reported in the literature have not been shown on the State bedrock map. Emerson's (1917) map of Massachusetts shows small masses of quartzite in the Essex and Ipswich areas, 
which later geologists mapping in these areas have not recognized. Emerson included many small areas of quartzite, in addition to the larger ones shown as Westboro on the State bedrock map, in his Marlboro Formation (a term now confined to the Nashoba zone for a sequence characterized by amphibolites) because of their intercalation in the Milford-Dedham zone with metavolcanic rocks that he mapped as Marlboro but that are now assigned to the mafic and felsic metavolcanic rocks $(\mathrm{Zv}$, Zvf). Sears (1905, p. 110) mentioned that a well in quartzite at Lynnfield penetrated white limestone interstratified with a light-blue slate and quartzite. A description of the quartzite given by Sears indicates that the rock had been crushed and recrystallized. It may have been a silicified zone.

The Westboro in the Framingham area (figs. 4, 8) and to the northeast is overlain by the assemblage of metamorphosed mafic and felsic volcanic rocks $(\mathrm{Zv}, \mathrm{Zvf})$ (tables 2,3). South of Westborough, the Westboro is truncated by the Bloody Bluff-Lake Char fault system. The Westboro is intruded by Proterozoic Z batholithic rocks.

Nelson (1974) placed a metasedimentary-metavolcanic unit of gneiss, schist, and quartzite he named the Rice Gneiss (table 3) below thick-bedded quartzite of the Westboro in the Natick quadrangle. The Rice Gneiss could be the equivalent of the unnamed stratified remnants of Bell and Alvord on the basis of their descriptions. The gneiss and calc-silicate rocks described as Rice Gneiss by Volckmann (1977) in the Holliston area (fig. 4; table 3), however, do not resemble the description of Rice Gneiss by Nelson (1974). Rocks similar to the Rice Gneiss have not been identified elsewhere in the region, although they may form part of the Blackstone Group in northern Rhode Island. The Rice Gneiss may be equivalent to gneiss and schist lying below the Plainfield Formation in the Lyme Dome of southeastern Connecticut (Lundgren, 1967, p. 14). However, that is a longrange correlation for such a small unit; furthermore, the complicated fold pattern and lack of topping information in southeastern Connecticut render questionable the proper stratigraphic assignment of the inner rocks of the Lyme Dome. Because the Rice Gneiss is not characteristically quartzitic but predominantly feldspathic, and because it lies in a different fault block from the Westboro, it was included in the comprehensive unit of metavolcanic rocks ( $\mathrm{Zv}$ ) of Proterozoic $\mathrm{Z}$ age on the State bedrock map. I now believe that assignment to the Westboro or as a separate unit below the Westboro would be preferable.

The Westboro is equivalent to the Plainfield Formation of eastern Connecticut because it lies in the same strike belt, and the Westboro is believed to be equivalent to the Quinnville Quartzite ( $\mathrm{Zbq}$ ) and mica schist and phyllite (Zbs) of the Blackstone Group. Both have similar stratigraphic positions below mafic metavolcanic rocksgreenstone and amphibolite (Zbv) in northern Rhode Island and metamorphosed mafic and felsic volcanic rocks (Zv, Zvf) in eastern Massachusetts. The boundary between the Westboro and the Blackstone is drawn arbitrarily on the State bedrock map on the basis of proximity of the isolated exposures of the two to their respective type areas. No area of continuous exposure exists between the two units.

\section{PLAINFIELD FORMATION (Zp)}

The Plainfield Formation ( $\mathrm{Zp}$ ) extends into Massachusetts in the Webster-Oxford area (fig. 4) from eastern Connecticut and western Rhode Island along the west flank of the Rhode Island batholith. Elongate lenses of quartzite mapped as Westboro on the State bedrock map, trending northeast through Grafton towards Westborough, are on strike with the Plainfield in the WebsterOxford area.

The lithology of the Plainfield, as described by Goldsmith $(1966,1976)$ in the New London area, southeastern Connecticut, and by Harwood and Goldsmith (1971) and Dixon (1974) in eastern Connecticut, and its structural and stratigraphic position indicate that the Plainfield and Westboro are equivalent formations. For example, Nelson's sequence (1974; as given in table 3) approximates the three-part division of the Plainfield Formation suggested by Goldsmith (1976) in the New London area. However, this division of the Plainfield does not seem to carry northward into the Thompson quadrangle in northeastern Connecticut and northwestern Rhode Island (Dixon, 1974).

The Plainfield is truncated along most of the Connecticut-Rhode Island border by the Lake Char fault, but, in the New London area, the Plainfield is overlain by a suite of largely mafic metavolcanic rocks called the Waterford Group (Goldsmith, 1980). These relations are similar to those of the Westboro Formation $(\mathrm{Zw})$ and overlying metavolcanic rocks $(\mathrm{Zv})$ in Massachusetts. The base of the Plainfield is not known, but possibly gneiss and schist in the center of the Lyme Dome, referred to earlier, lie below the Plainfield.

The Plainfield is believed to be equivalent to the quartzite (Zbq) and schist (Zbs) in the Blackstone Group because of its similar lithology and structural relations with the plutonic rocks of the Rhode Island batholith.

\section{BLACKSTONE GROUP: MICA SCHIST AND PHYLLITE (Zbs) AND QUINNVILLE QUARTZITE (Zbq)}

The Blackstone Group, the Blackstone Series of Woodworth (in Shaler and others, 1899, p. 106; Quinn and others, 1948, 1949), was named for exposures along the 


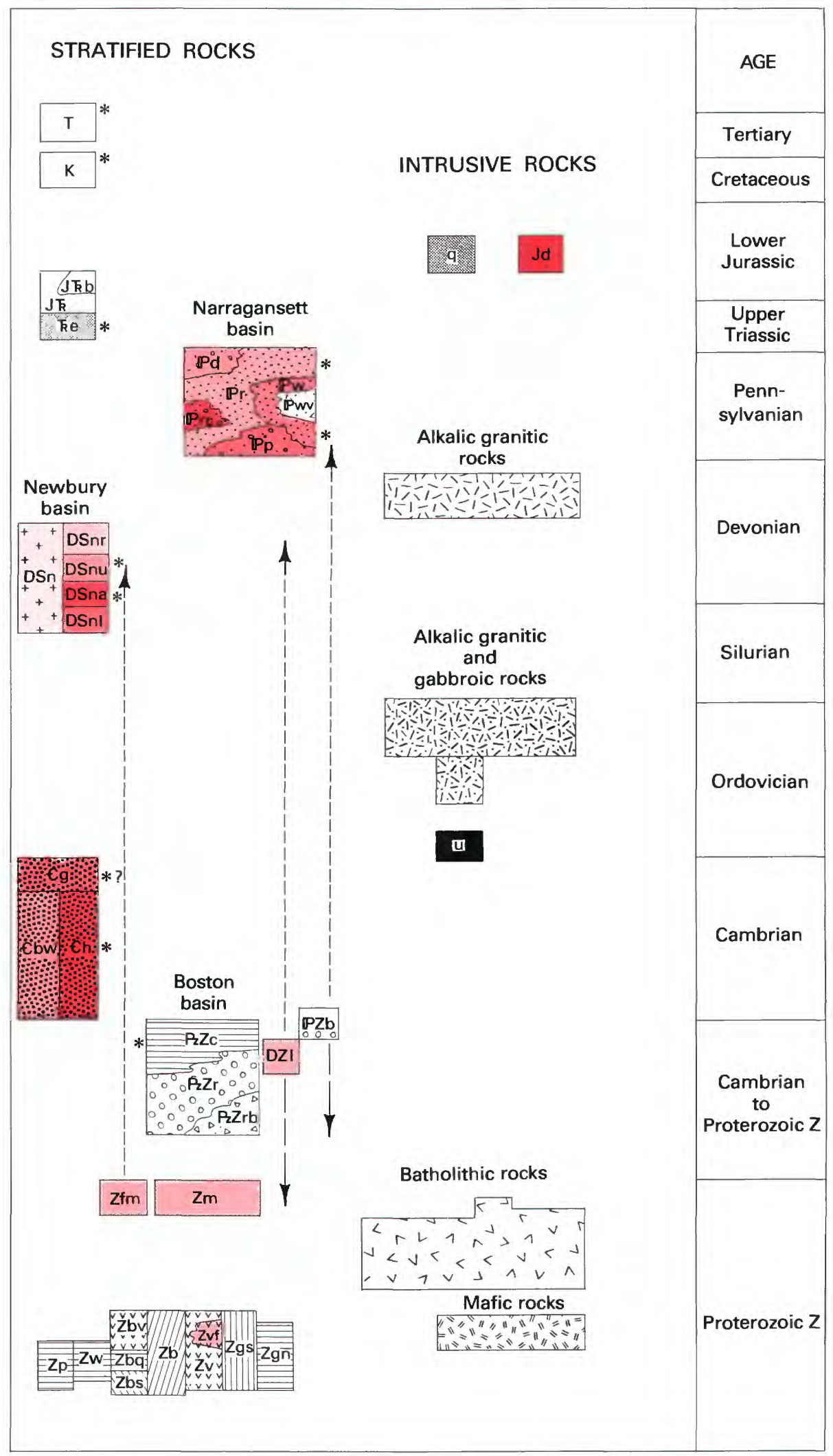

FIgURE 2.-Stratigraphic units in the Milford-Dedham zone. 


\section{EXPLANATION}

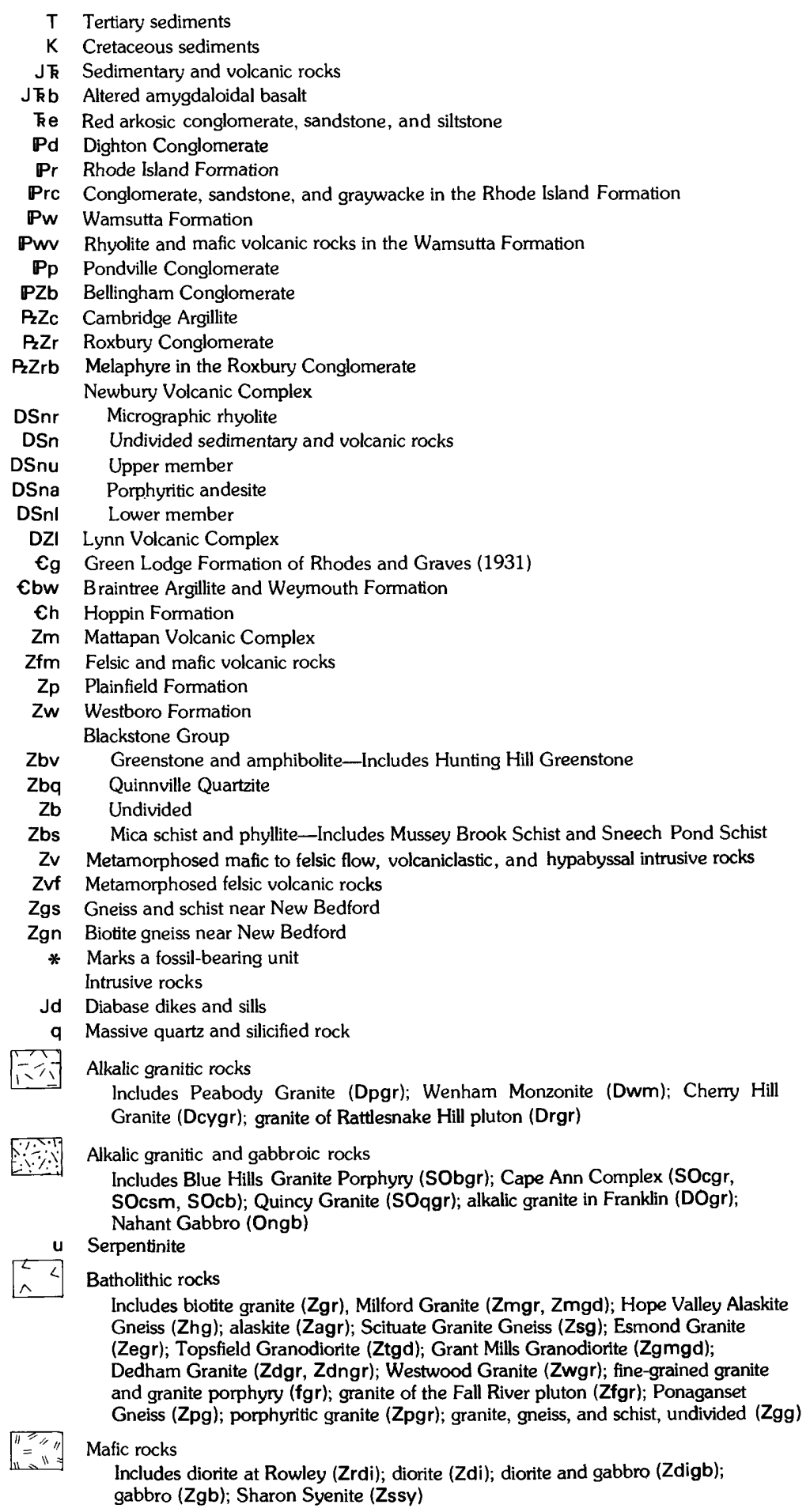

FIGURE 2.-Continued.

Blackstone River in northern Rhode Island. The Blackstone as defined by Quinn and others (1948; table 3) consists of three lower, largely metasedimentary units, the Mussey Brook Schist (Zbs), Quinnville Quartzite
(Zbq), and Sneech Pond Schist (Zbs), and an upper, largely metavolcanic unit, the Hunting Hill Greenstone (Zbv). Only the lower metasedimentary part of the Blackstone Group is correlated with the Westboro and 
TABLE 2. - Nomenclature of stratified metamorphic rocks older than the Proterozoic Z Rhode Island and southeastern Massachusetts batholiths (stratigraphic order only approximate)

\begin{tabular}{ll}
\hline \multicolumn{1}{c}{ Used on State bedrock map } & \multicolumn{1}{c}{ Previously published nomenclature } \\
\hline Metamorphosed mafic to felsic flow, volcaniclastic, and hypabyssal & Burlington Formation \\
intrusive rocks (Zv). Metamorphosed felsic volcanic rocks (Zvf). & Greenleaf Mountain Formation \\
& Unnamed gneiss and quartzite \\
& Claypit Hill Formation \\
& Cherry Brook Formation \\
& Kendall Green Formation \\
& Middlesex Fells Volcanic Complex \\
& Amphibolite, mixed rocks, banded volcanic rocks, biotite-hornblende \\
& schist (Volckmann, 1977) \\
Blackstone Group (Zb): & Rice Gneiss \\
Greenstone and amphibolite (Zbv) & \\
Mica schist and phyllite (Zbs) & Blackstone Group: \\
Quinnville Quartzite (Zbq) & Hunting Hill Greenstone \\
Mica schist and phyllite (Zbs) & Sneech Pond Schist \\
& Quinnville Quartzite \\
Westboro Formation (Zw) & Mussey Brook Schist \\
Plainfield Formation (Zp) & \\
Westboro Formation (Zw) & Westboro Formation \\
Gneiss and schist near New Bedford (Zgs) & Plainfield Formation \\
Biotite gneiss near New Bedford (Zgn) & Unnamed stratified remnants (Bell and Alvord, 1976) \\
\hline
\end{tabular}

*The Plainfield extends into the Webster-Oxford area of Massachusetts from eastern Connecticut and western Rhode Island and is equivalent to the Westboro in Massachusetts.

Plainfield Formations (fig. 6). The base of the Blackstone Group is not known.

The Quinnville Quartzite (Zbq) (table 3) was earlier called Westboro Quartzite by Emerson (1917) and included an Albion Schist Member (of the Quinnville). Other schist in the area distant from the quartzite beds and an interbedded marble were included by him in the Marlboro Formation, as was the greenstone. Quinn (1971) thought the quartzite was not equivalent to the Westboro in the type area; he named the quartzite Quinnville and schists above and below it Sneech Pond and Mussey Brook, respectively. The schists (table 3) contain similar assemblages of rock, and recent mapping by Drier and Mosher (1981) in the Blackstone River area northwest of Pawtucket (fig. 4) indicates no basis for distinguishing the two schist units. Possibly the Quinnville is a quartzitic lens in the sequence, or possibly the schists are repeated by folding. The schist units, including the marble beds, are combined into a unit of mica schist and phyllite (Zbs) on the State bedrock map. This unit and the Quinnville Quartzite (Zbq) are shown only in their type areas. Outside those areas, the Blackstone Group consists of rock believed to be equivalent to the Quinnville Quartzite and the mica schist and phyllite but which cannot be distinguished separately, and the Blackstone is therefore shown as undivided $(\mathrm{Zb})$ on the State bedrock map. The Blackstone also includes, in places, layers, dikes, and sills of greenstone or amphibolite believed to be equivalent to the greenstone and amphib- olite of the Hunting Hill Greenstone (Zbv), which is also shown only in its type area. The amphibolite layers, where present outside the type area, are usually interlayered with quartzite or schist and are not volumetrically large enough to show at the scale of the map.

The undivided Blackstone Group ( $\mathrm{Zb}$ ) extends along the Blackstone River into Massachusetts in the towns of Blackstone, Milford, and Uxbridge (figs. 4, 8). It is also present to the north in the Franklin and Medway areas, where it appears as disconnected segments of phyllite (see below) and locally quartzite in the plutonic rocks. West of Blackstone, the Blackstone Group is difficult to divide because outcrops are poor and quartzite and amphibolite are extensively interlayered. A large area of poorly exposed amphibolite, hornblende gneiss, quartzite, and minor rusty-weathering feldspathic mica-quartz schist occupies a belt from the town of Blackstone north through Hopedale and Milford, mainly west of the Mill River. A similar belt of Blackstone (Zb) extends south from Nipmuck Pond, southwest of Mendon. The Blackstone in both these areas lies largely in valleys. In places sheets of Milford Granite have intruded the Blackstone, producing layered migmatite as on Bear Hill, $1 \mathrm{~km}$ southeast of Milford. Southeast of East Douglas, quartzite is exposed in a large area of undivided Blackstone, which has the form of a large fold nose. Rocks included in the undivided Blackstone Group ( $\mathrm{Zb}$ ) include amphibolite interlayered with quartzite mapped by Shaw (1967) in the Milford area and by McKniff (1964) in the Blackstone 


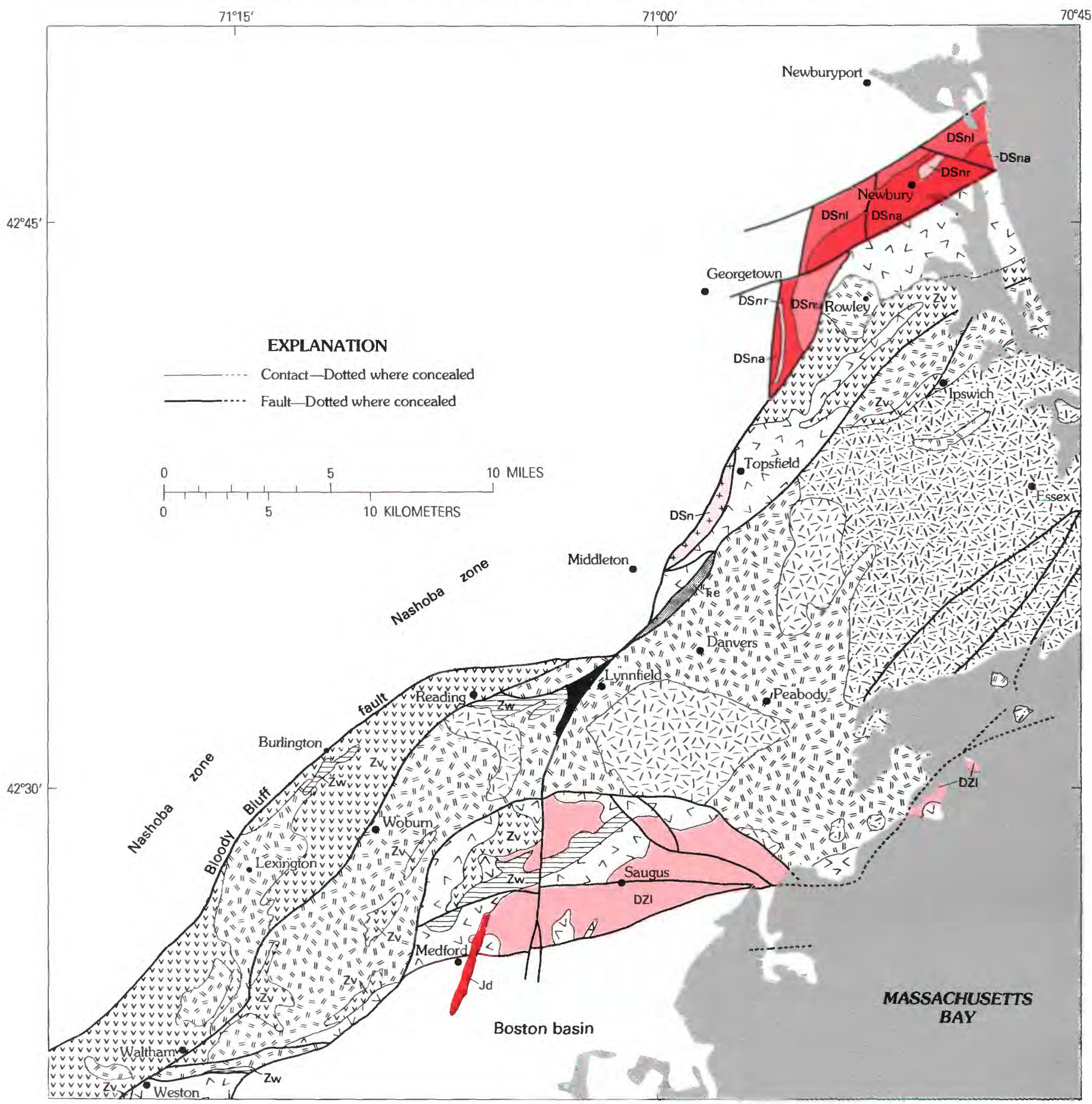

FIGURE 3. - Stratigraphic units in the Milford-Dedham zone north and northwest of the Boston basin. Unit designations as on figure 2.

area, small areas of amphibolite containing epidote pods and stringers, and epidote-biotite-hornblende gneiss in the Franklin and Wrentham areas. The rocks mapped by Shaw and McKniff were considered by them to be correlative with the Hunting Hill Greenstone.

East of the Bellingham basin (also called the Woonsocket basin), the Blackstone Group (Zb) mostly lacks quartzite and consists mainly of phyllite and schist. Gray-green laminated phyllite and schist, locally ankeritic, are conspicuous. Also present are epidotechlorite-biotite schist and small masses of metadiorite. Some of the schists are feldspathic and are subporphyritic metavolcanic rocks. A conglomerate containing lenticular quartzite pebbles and cut by thin sills and dikes of 


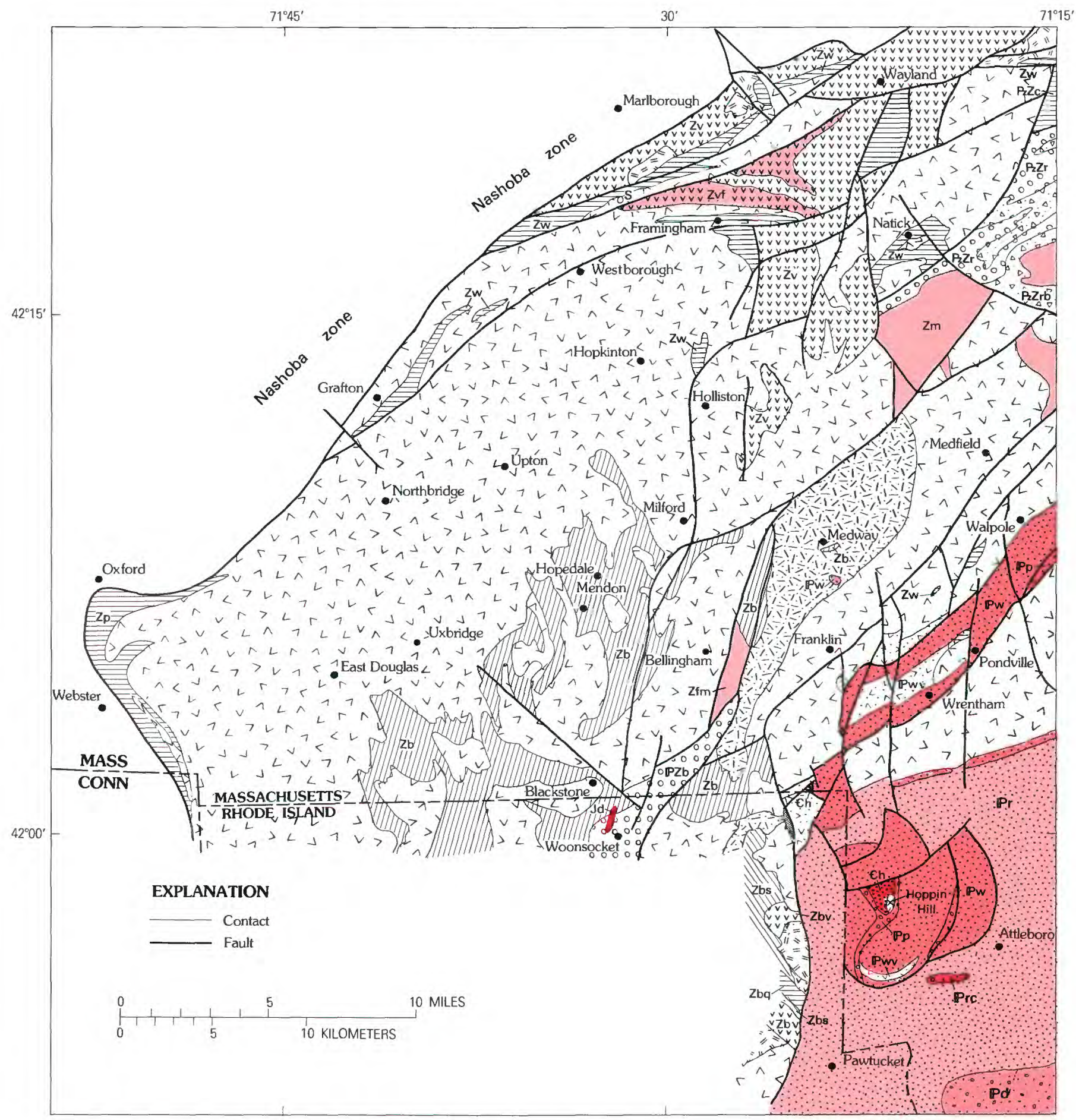

FiguRE 4. - Stratigraphic units in the Milford-Dedham zone west and southwest of the Boston basin. Unit designations as on figure 2.

greenstone crops out on Bound Road, just south of the Massachusetts-Rhode Island State line, west of Woonsocket. A similar conglomerate and clean quartzite crop out sporadically in a zone extending from this area north to Framingham and Natick.
The boundary between rocks mapped as Blackstone Group and rocks mapped as Westboro is arbitrarily drawn as mentioned above, on the basis of proximity to their respective type areas. For example, small areas of quartzite near Walpole, Mass. (figs. 4, 8), have been 


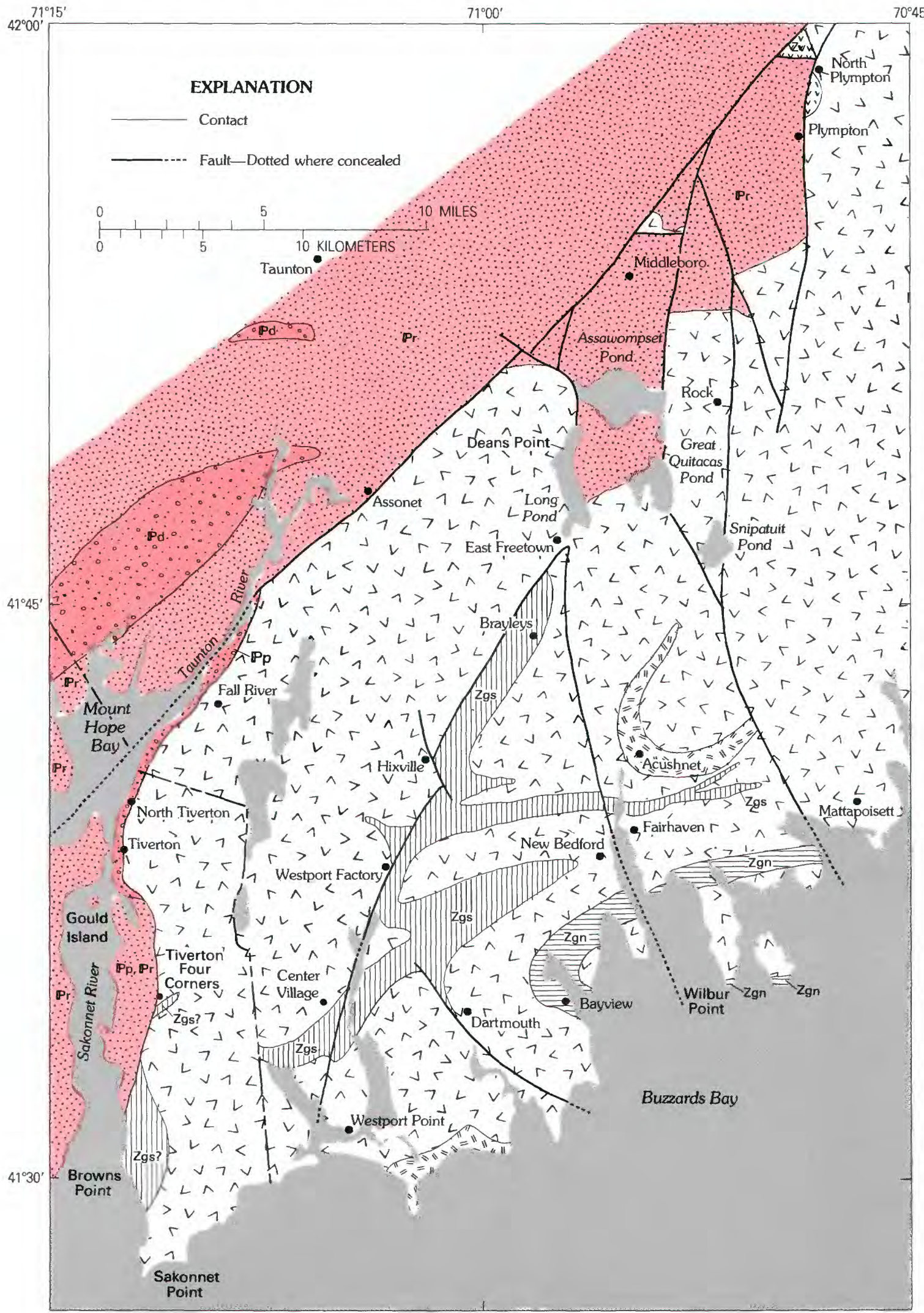

FiguRE 5.-Stratigraphic units in the Milford-Dedham zone in the New Bedford area, southeastern Massachusetts and adjacent Rhode Island. Unit designations as on figure 2. 


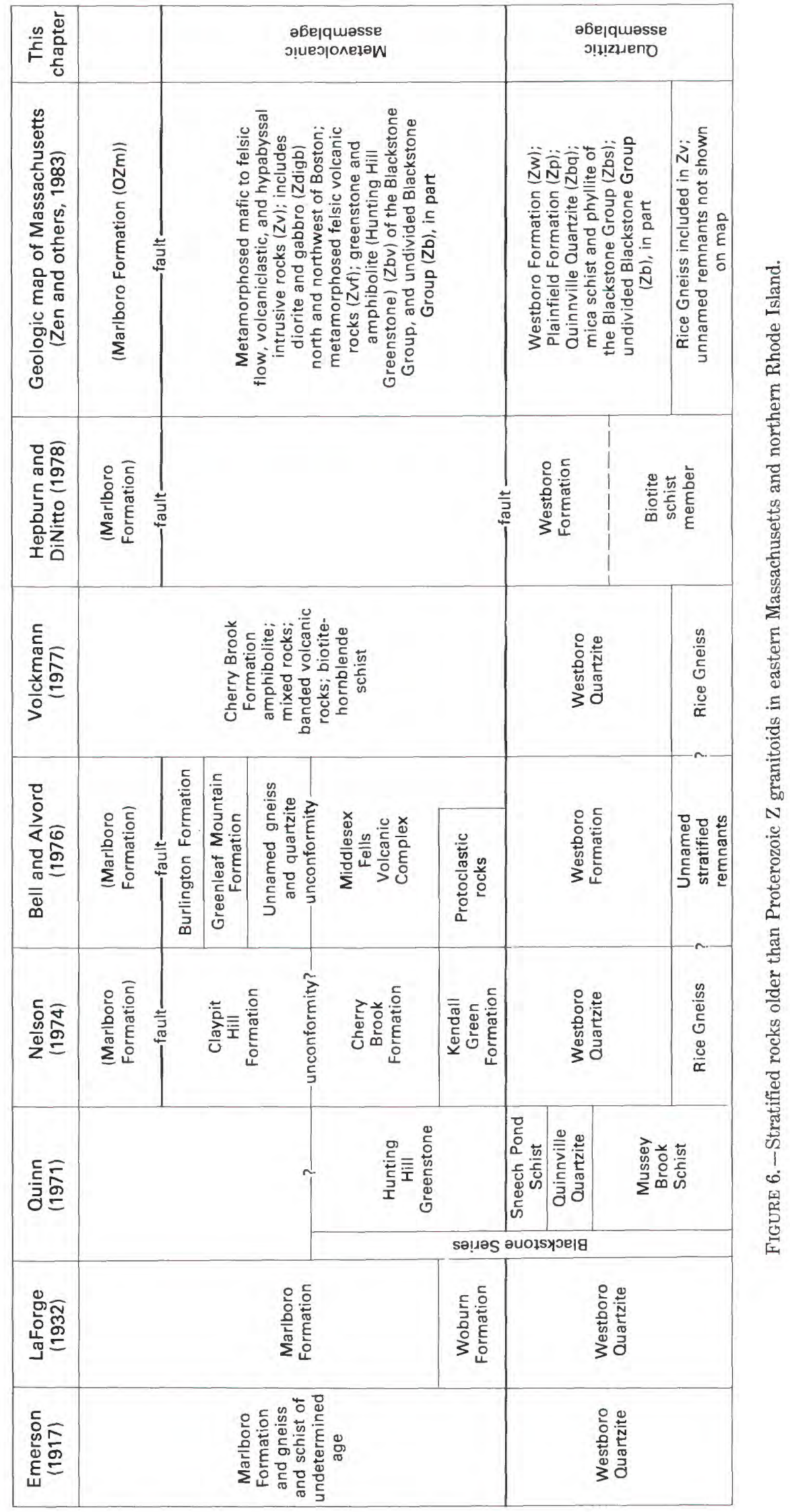




\begin{tabular}{|c|c|c|c|}
\hline \multicolumn{2}{|c|}{ Newport area, Rhode Island } & \multirow{2}{*}{$\begin{array}{c}\begin{array}{c}\text { Sakonnet River area, } \\
\text { Rhode Island }\end{array} \\
\text { Quinn (1971) }\end{array}$} & \multirow{2}{*}{$\begin{array}{c}\text { New Bedford area, Massachusetts } \\
\text { Geologic map of Massachusetts } \\
\text { (Zen and others, 1983) }\end{array}$} \\
\hline Rast and Skehan (1981) & Quinn (1971) & & \\
\hline $\begin{array}{l}\text { Price Neck } \\
\text { Formation }\end{array}$ & $\begin{array}{l}\text { Volcanic tuff, } \\
\text { conglomerate, } \\
\text { and quartzite } \\
\text { of Newport } \\
\text { vicinity }\end{array}$ & \multirow{3}{*}{$\begin{array}{l}\text { Mica-chlorite schist } \\
\text { of Sakonnet; } \\
\text { chlorite-biotite schist } \\
\text { of Tiverton; mica } \\
\text { schist of Bristol }\end{array}$} & $\begin{array}{l}\text { Gneiss and schist } \\
\text { near New Bedford } \\
\text { (Zgs) }\end{array}$ \\
\hline & & & ? \\
\hline $\begin{array}{l}\text { Newport } \\
\text { Formation }\end{array}$ & $\begin{array}{l}\text { Slate and quartzite } \\
\text { of Newport vicinity }\end{array}$ & & $\begin{array}{l}\text { Biotite gneiss } \\
\text { near New Bedford } \\
\text { (possibly a facies } \\
\text { of above) (Zgn) }\end{array}$ \\
\hline
\end{tabular}

FIgURE 7.-Stratified rocks older than Proterozoic Z granitoids in southeastern Massachusetts and southern Rhode Island.

mapped as Westboro Quartzite by Volckmann (1977) but are shown as undivided Blackstone Group ( $\mathrm{Zb})$ on the State bedrock map because they are near the area of Blackstone to the south. Outcrops of quartzite near Hopkinton, Mass. (fig. 4), adjacent to large areas of Westboro Formation in the Framingham area, are shown as Westboro Formation.

Small areas consisting largely of phyllite near Franklin and Medway have been assigned to the Blackstone Group. Tan, crinkled phyllite and phyllitic metawacke crop out west of a sliver of Dedham Granite on Pond Street, Norfolk, $1.5 \mathrm{~km}$ west of Pondville in the middle of the Norfolk basin. The Wamsutta Formation of Lower to Middle Pennsylvanian age to the west is unmetamorphosed. Greenish-gray, calcite-bearing, locally pyritic phyllite and metasandstone are exposed in roadcuts on I-495 at the Maple Street overpass, $2 \mathrm{~km}$ northeast of Bellingham. Gray felsite exposed in these cuts is probably a continuation of an extensive area of felsite to the south on the flanks of the Bellingham basin. Phyllite crops out on the banks of the Charles River south of the Lincoln Street Bridge at Medway.

The correlation of the phyllite in the Franklin and Medway areas is uncertain. On the one hand, its composition and grade of metamorphism are similar to those of pelite in the type area of the Blackstone Group in Rhode Island and its degree of metamorphism contrasts with the lack of metamorphism in the nearby Wamsutta Formation. Thus I have shown it as Blackstone Group (Zbs) on the State bedrock map. On the other hand, its association with felsic volcanic rocks (Zfm; fig. 2), which may be equivalent to the younger Mattapan Volcanic Complex $(\mathrm{Zm})$, suggests that it might be a sedimentary part of that complex in a more metamorphosed regime than the Boston area.

\section{PALEOENVIRONMENT OF DEPOSITION OF THE QUARTZITIC ASSEMBLAGE}

The paleoenvironment of deposition of the quartzitic assemblage was probably the flank of a volcanic arc. Although the Plainfield and Westboro contain calcsilicate layers, and the Blackstone contains marble locally in northern Rhode Island, no carbonates of the shelf or platform type exist in the sequence. On the contrary, the Plainfield, Westboro, and lower part of the Blackstone are in sequence below, and are interlayered with, rocks of primarily mafic volcanic derivation (table 3). This association suggests that the formations of the quartzitic assemblage were deposited on the margins of a probably mature volcanic arc, possibly of the continentalmargin type. Zircons from the Westboro indicate a much older source than the rocks now present in the DedhamMilford zone, and the zircons were probably derived from continental crust (Olszewski, 1980).

\section{METAVOLCANIC ASSEMBLAGE}

In eastern Massachusetts, the assemblage of primarily mafic metamorphosed volcanic rocks ( $\mathrm{Zv}, \mathrm{Zvf}, \mathrm{Zbv}$ ) is associated temporally and spatially with gabbro, diorite, and syenite (Zgb, Zdigb, Zssy); together, these units are 
TABLE 3.-Descriptions from previously published works of stratigraphic units in eastern Massachusetts and northern Rhode Island older than the Proterozoic Z Rhode Island and southeastern Massachusetts batholiths

[Areas described roughly follow a southwest-trending line, from around Boston, Mass., to northern Rhode Island]

\begin{tabular}{|c|c|c|c|c|c|}
\hline Symbol & & & & & \\
\hline $\begin{array}{c}\text { on } \\
\text { State } \\
\text { bedrock } \\
\text { map }\end{array}$ & Stratigraphic unit & Description & Protolith & Thickness & $\begin{array}{l}\text { Metamorphic } \\
\text { facies }\end{array}$ \\
\hline
\end{tabular}

Northeastern Massachusetts (Bell and Alvord, 1976)

Zw Burlington Formation Fine-grained, randomly interlayered impure quartzite, quartz-feldspar gneiss, micaquartz feldspar gneiss, amphibolite, metawacke. Metaconglomerate at top. Layers a few to several centimeters thick. [Age uncertain, Proterozoic Z to Ordovician.].

Zv Greenleaf Mountain Formation.

Zw

Unnamed gneiss and quartzite.

Middlesex Fells Volcanic Complex.

Westboro Formation, upper part.

Westboro Formation, lower part.

$\mathrm{Zw}$

Unnamed stratified remnants.
Fine-grained, thinly laminated, dark-green amphibolite and minor pale-green calcsilicate rock. Layers $1 \mathrm{~cm}$ thick.

Light-colored, fine-grained quartzite, feldspar-quartz gneiss, biotite gneiss and hornblende gneiss as xenoliths in Cape Ann Complex. Bedding obscure.

Fine-grained, dark-gray to black, foliated, thickly layered to massive amphibolite, and hornblende gneiss, pods and lentils of epidote common, locally pillowed; laminated amphibolite, rare quartzite and calc-silicate rock and light-gray metadacite. Tuff predominates in upper part, flows in lower part. An apparently conformable contact with the Westboro Formation is exposed in two places north of Boston.

Fine-grained, white to pale-gray quartzite and pale-green hornblende gneiss. Layers a few centimeters to $15 \mathrm{~m}$ thick.

At top, interlayered fine-grained quartzite, argillite, slate, and quartz-bearing calcsilicate rock in beds a few centimeters to 3 $\mathrm{m}$ thick; in middle, massive white to palegray fine-grained quartzite in lenticular masses 5-60 m long; at bottom, massive quartzite, interbedded quartzite and micaceous quartzite. 3-5 m of reddish-brown biotite quartzite near basal contact.

Very fine grained, gray biotite gneiss in slablike xenoliths. Fine-grained quartzite, feldspathic quartzite, laminated light-gray gneiss containing minute biotite flakes. Forms inclusions in Dedham Granite.
Shallow marine to littoral sands, fine-grained mafic tuff, and volcaniclastic detritus. Metaconglomerate is a channel deposit, possibly unconformable on rest of unit.

Fine-grained marine tuff; some layers contain carbonate.

Epiclastic sediment and tuff.

$300 \mathrm{~m}$

Amphibolite.

Mafic flows and tuffs in marine environment. Amygdular and pillow structures evident.

Shallow marine and littora $680 \mathrm{~m}$

Amphibolite. sand, silt, and mud, partly calcareous, and airborne tuff.

Shallow marine and littoral sands, silt, and mud, partly calcareous.
$225 \mathrm{~m}$

$1,500 \mathrm{~m}$

Greenschist.
Near-shore marine sand and volcaniclastic detritus.
$150 \mathrm{~m}$ for bio- Obscured by tite gneiss; intrusion. thickness of quartzite not known.
Framingham and Natick area, Massachusetts (Nelson, 1974)

\begin{tabular}{|c|c|c|c|c|c|}
\hline $\mathrm{Zv}$ & Claypit Hill Formation & $\begin{array}{l}\text { Mostly dark-gray and greenish-gray, fine- } \\
\text { grained hornblende gneiss interlayered with } \\
\text { two-mica gneiss locally containing garnet }\end{array}$ & Not given & $460-610 \mathrm{~m}$ & $\begin{array}{l}\text { Amphibolite } \\
\text { (sillimanite- } \\
\text { muscovite). }\end{array}$ \\
\hline
\end{tabular}
and sillimanite; biotite-hornblende gneiss, biotite gneiss, and thin beds of amphibolite. Layers $8 \mathrm{~cm}$ to $0.5 \mathrm{~m}$ thick. Unconformable(?) on Cherry Brook Formation. 
TABLE 3.-Descriptions from previously published works of stratigraphic units in eastern Massachusetts and northern Rhode Island older than the Proterozoic Z Rhode Island and southeastern Massachusetts batholiths-Continued

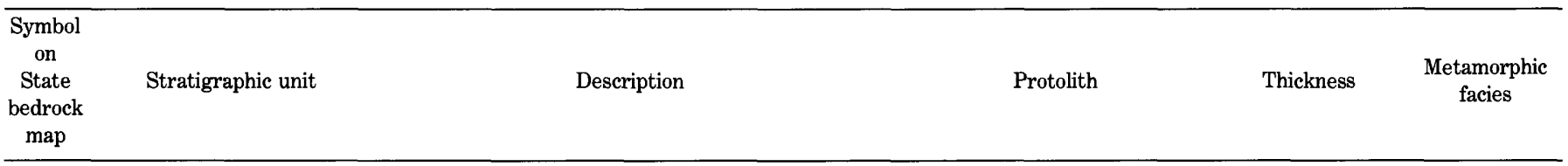

Framingham and Natick area, Massachusetts (Nelson, 1974)-Continued

\begin{tabular}{|c|c|c|c|c|c|}
\hline $\mathrm{Zv}$ & $\begin{array}{l}\text { Cherry Brook Forma- } \\
\text { tion, upper part. }\end{array}$ & $\begin{array}{l}\text { Predominantly amphibolite and minor interca- } \\
\text { lated biotite schist and quartzite. Amphibo- } \\
\text { lite is fine to coarse grained, equigranular, } \\
\text { thin to thick layered, locally massive, } \\
\text { amygdaloidal, and pillowed. }\end{array}$ & $\begin{array}{l}\text { Basaltic and minor andesitic } \\
\text { tuffs and flows. }\end{array}$ & $900->1,200 \mathrm{~m}$ & Amphibolite. \\
\hline $\mathrm{Zv}$ & $\begin{array}{l}\text { Cherry Brook Forma- } \\
\text { tion, lower part. }\end{array}$ & $\begin{array}{l}\text { Light- to pinkish-gray, massive felsic crystal } \\
\text { tuff and a few thin beds of medium-grained } \\
\text { schist. }\end{array}$ & Crystal tuff & $290 \mathrm{~m}$ & Amphibolite. \\
\hline $\mathrm{Zv}$ & $\begin{array}{l}\text { Kendall Green Forma- } \\
\text { tion. }\end{array}$ & $\begin{array}{l}\text { Very fine grained, light-tan, laminated felsic } \\
\text { tuff interlayered with dark-greenish-gray, } \\
\text { fine-grained tuff and discontinuous layers of } \\
\text { quartzite. [A zone of strong shearing. Mylo- } \\
\text { nite according to Castle and others (1976). } \\
\text { Woburn Formation of LaForge (1932).]. }\end{array}$ & Felsic tuff & $215 \mathrm{~m}$ & Not given. \\
\hline $\mathrm{Zw}$ & Westboro Quartzite & $\begin{array}{l}\text { Upper part, light-gray, thick to massively } \\
\text { bedded quartzite, a few thin layers of bio- } \\
\text { tite gneiss near base. Middle part, dark- to } \\
\text { medium-gray, fine-grained biotite and horn- } \\
\text { blende gneiss and schist; relatively pure } \\
\text { quartzite, feldspathic quartzite, and } \\
\text { amphibolite; beds } 3 \mathrm{~cm} \text { to } 1.5 \mathrm{~m} \text { thick. } \\
\text { Lower part, light-gray, thick-bedded } \\
\text { quartzite in beds as much as } 5 \mathrm{~m} \text { thick and } \\
\text { minor interbedded biotite gneiss. }\end{array}$ & $\begin{array}{l}\text { Volcaniclastic detritus and } \\
\text { beach sand. }\end{array}$ & $980 \mathrm{~m}$ & Amphibolite. \\
\hline $\mathrm{Zv}$ & Rice Gneiss & $\begin{array}{l}\text { Medium- to dark-gray, fine- to medium- } \\
\text { grained, equigranular to inequigranular bio- } \\
\text { tite gneiss and schist, two-mica schist, and } \\
\text { thin beds of quartzite and feldspathic } \\
\text { quartzite. }\end{array}$ & $\begin{array}{l}\text { Beach sand and tuffaceous } \\
\text { detritus. }\end{array}$ & $>760 \mathrm{~m}$ & Amphibolite. \\
\hline
\end{tabular}

\begin{tabular}{|c|c|c|c|c|c|}
\hline \multicolumn{6}{|c|}{ Marlboro area, Massachusetts (Hepburn and DiNitto, 1978) } \\
\hline Zw & Westboro Formation & $\begin{array}{l}\text { Light- to dark-gray, tan, and pinkish-gray } \\
\text { feldspathic quartzite, orthoquartzite, and } \\
\text { micaceous quartzite; massive with thin } \\
\text { micaceous partings to well bedded in beds a } \\
\text { few centimeters to } 0.5 \mathrm{~m} \text { thick. Gray } \\
\text { quartz-rich mica schist. Calc-silicate quartz- } \\
\text { ite and granofels in layers and lenses as } \\
\text { much as } 0.5 \mathrm{~m} \text { thick. Light-gray muscovite- } \\
\text { quartz schist and dark-gray rusty- } \\
\text { weathering biotite-quartz-feldspar schist. } \\
\text { Amphibolite and biotite amphibolite in beds } \\
\text { as much as } 1 \mathrm{~m} \text { thick. }\end{array}$ & Not given & Not given & Amphibolite. \\
\hline Zw & $\begin{array}{l}\text { Westboro Formation, } \\
\text { (lower) biotite schist } \\
\text { member. }\end{array}$ & $\begin{array}{l}\text { Dark-gray, fine- to medium-grained biotite } \\
\text { schist and interlayered minor, thin, impure } \\
\text { quartzite. Subordinate biotite amphibolite, } \\
\text { amphibolite, quartz-rich biotite schist, and } \\
\text { biotite-plagioclase gneiss. }\end{array}$ & Not given & Not given & Amphibolite. \\
\hline
\end{tabular}


TABLE 3.-Descriptions from previously published works of stratigraphic units in eastern Massachusetts and northern Rhode Island older than the Proterozoic Z Rhode Island and southeastern Massachusetts batholiths-Continued

[Areas described roughly follow a southwest-trending line, from around Boston, Mass., to northern Rhode Island]

\begin{tabular}{|c|c|c|c|c|c|}
\hline Symbol & & & & & \\
\hline $\begin{array}{c}\text { on } \\
\text { State } \\
\text { bedrock } \\
\text { map }\end{array}$ & Stratigraphic unit & Description & Protolith & Thickness & $\begin{array}{l}\text { Metamorphic } \\
\text { facies }\end{array}$ \\
\hline
\end{tabular}

Holliston and Medfield areas, Massachusetts (Volckmann, 1977) tion. amphibolite, hornblende-biotite gneiss and hornblende-biotite-quartz gneiss; contains relic clasts and bombs as much as $2.5 \mathrm{~m}$ in diameter; layers a few centimeters to $10 \mathrm{~m}$ thick. These rocks overlie the Westboro Quartzite. [Appears to be equivalent to only the upper part of the Cherry Brook Formation of Nelson (1974).].

Zv Amphibolite

Amphibolite and hornblende gneiss containing Not given

thin layers of alternating felsic and mafic constituents; epidote porphyroblasts common; local intercalations of microcline-rich quartz-feldspar rock. [Probably equivalent to part of Cherry Brook Formation of Nelson (1974).].

None Mixed rocks

Interlayered metamorphosed blastoporphyritic andesitic tuff, biotite-epidoteplagioclase schist, chlorite schist, and massive amphibolite.

Zv Banded volcanic rocks Biotite-hornblende gneiss in alternate thin (1 $\mathrm{mm}$ to $2 \mathrm{~cm}$ ) layers of mafic and felsic minerals; interleaved with light-colored biotite gneiss, feldspathic quartzite, and massive black porphyritic rock containing andesine laths as much as $2 \mathrm{~cm}$ in length. [Possibly equivalent to part of Cherry Brook Formation of Nelson (1974).].

None Biotite-hornblende schist.

Zw Westboro Quartzite

Biotite-hornblende (-epidote) schist and gneiss, biotite gneiss; indistinctly layered. [Stratigraphic correlation uncertain.].

Massive to thick-bedded orthoquartzite, minor Not given interbedded quartz-muscovite schist, and biotite-hornblende gneiss. Intruded by hornblende gabbro and Milford Granite.

Zv Rice Gneiss

Interlayered light- to medium-gray and

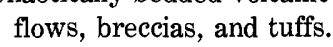

Amphibolite.

Assorted voleanic and vol- $\quad 2,700 \mathrm{~m}$ caniclastic rocks.

Not given

Amphibolite.

Volcanic rocks

$900 \mathrm{~m}$

Amphibolite partly retrograded to greenschist facies.

Amphibolite. greenish-gray biotite gneiss and schist showing a swirled foliation, quartz-feldspar gneiss, epidote-biotite schist, and calcsilicate gneiss. Intruded by diorite and Milford Granite.

Not given $\quad 1,600 \mathrm{~m} \quad$ Amphibolite.

$\begin{array}{lcc}\text { Not given } & 1,200 \mathrm{~m} & \text { Amphibolite. } \\ \text { Not given } & 750 \mathrm{~m} & \text { Amphibolite. }\end{array}$

Northern Rhode Island (Quinn, 1971)

\begin{tabular}{ll}
\hline $\mathrm{Zb}$ & Blackstone Series \\
$\mathrm{Zbv}$ & Hunting Hill Green- \\
& stone.
\end{tabular}

Dark-green, fine-grained greenstone, locally pillowed; contains knots and veins of epidote; local pyroclastic texture. Rare serpentine and steatite. [Drier and Mosher (1981) recognized thin quartzite (chert?) and volcaniclastic layers as well as flows.].
Basaltic and minor andesitic 800-1,200(?) m Greenschist flows and tuffs. Intrusive near Pawdikes and sills.
R. I ; amphibolite in the Milford, Mass., area. 
TABLE 3.-Descriptions from previously published works of stratigraphic units in eastern Massachusetts and northern Rhode Island older than the Proterozoic Z Rhode Island and southeastern Massachusetts batholiths-Continued

\begin{tabular}{|c|c|c|c|c|c|}
\hline $\begin{array}{l}\text { Symbol } \\
\text { on } \\
\text { State } \\
\text { bedrock } \\
\text { map }\end{array}$ & Stratigraphic unit & Description & Protolith & Thickness & $\begin{array}{l}\text { Metamorphic } \\
\text { facies }\end{array}$ \\
\hline \multicolumn{6}{|c|}{ Northern Rhode Island (Quinn, 1971)-Continued } \\
\hline Zbs & Sneech Pond Schist & $\begin{array}{l}\text { Greenish-gray, fine-grained, thin-bedded } \\
\text { chlorite-quartz schist, thin-bedded quartz- } \\
\text { ite, marble, greenstone, amphibolite schist, } \\
\text { feldspathic mica schist, and serpentine. }\end{array}$ & $\begin{array}{l}\text { Marine sand and silt, and } \\
\text { mafic and intermediate } \\
\text { volcanic and volcaniclastic } \\
\text { material. }\end{array}$ & $2,600 \mathrm{~m}$ & $\begin{array}{l}\text { Amphibolite } \\
\text { and green- } \\
\text { schist. }\end{array}$ \\
\hline $\mathrm{Zbq}$ & Quinnville Quartzite & $\begin{array}{l}\text { Light-gray, clean, massive, medium-grained } \\
\text { quartzite and minor thin beds of light-gray } \\
\text { to greenish-gray quartz-mica schist. }\end{array}$ & $\begin{array}{l}\text { Mature quartz sand and } \\
\text { interbedded silt and clay. }\end{array}$ & $1,100 \mathrm{~m}$ & Greenschist. \\
\hline Zbs & Mussey Brook Schist & $\begin{array}{l}\text { Same as Sneech Pond Schist. [Drier and } \\
\text { Mosher (1981) recognized only one schist } \\
\text { unit in the Blackstone. The Mussey Brook } \\
\text { is, then, equivalent to the Sneech Pond } \\
\text { Schist.]. }\end{array}$ & $\begin{array}{l}\text { Same as Sneech Pond } \\
\text { Schist. }\end{array}$ & $\begin{array}{l}\text { Same as } \\
\text { Sneech } \\
\text { Pond Schist. }\end{array}$ & $\begin{array}{l}\text { Same as } \\
\text { Sneech } \\
\text { Pond } \\
\text { Schist. }\end{array}$ \\
\hline
\end{tabular}

here called the mafic volcanic-plutonic complex in eastern Massachusetts. This complex was subsequently intruded by the Dedham Granite (Zdgr) and related Proterozoic Z granitoids. The metavolcanic rocks have been given different names in different areas (table 3), but they appear in general to belong to one episode of Proterozoic $\mathrm{Z}$ volcanism and plutonism.

The stratigraphic positions of many of the assemblages of metavolcanic rocks in eastern Massachusetts are difficult to determine because of the complex fault pattern, which has broken the terrane into numerous wedges and blocks; the lack of topping evidence; and extensive igneous intrusion. On the State bedrock map, the named and unnamed metavolcanic rocks in eastern Massachusetts (table 2) are combined into a single unit of metamorphosed mafic and felsic flow, volcaniclastic, and hypabyssal intrusive rocks $(\mathrm{Zv})$. Mappable areas of metamorphosed felsic rock (Zvf) that appear to be older than the Dedham and Milford Granites are identified by a separate symbol. Greenstone and amphibolite (Hunting Hill Greenstone) (Zbv) of the Blackstone Group in Rhode Island are considered to be the equivalent of the mafic metavolcanic unit in Massachusetts.

Some of the rocks in the metavolcanic assemblage were included in the Marlboro Formation by Emerson (1917). The name Marlboro is not now applicable east of the Bloody Bluff fault. The mafic volcanic-plutonic complex of eastern Massachusetts is intruded by Proterozoic $\mathrm{Z}$ granitoids and lies east of the Lake Char-Bloody Bluff fault zone, whereas the Marlboro Formation is intruded only by Paleozoic granitoids and lies west of the Lake Char-Bloody Bluff fault zone.
METAMORPHOSED MAFIC TO FELSIC FLOW, VOLCANICLASTIC, AND HYPABYSSAL INTRUSIVE ROCKS (Zv)

The metamorphosed mafic to felsic flow, volcaniclastic, and hypabyssal intrusive rocks $(\mathrm{Zv})$ (referred to hereafter as mafic metavoleanic rocks) as shown on the State bedrock map include primarily the Middlesex Fells Volcanic Complex (Bell and Alvord, 1976) and the Cherry Brook Formation (Nelson, 1974) (table 3, fig. 6). The mafic metavolcanic rocks include also the Claypit Hill Formation and unnamed metavolcanic rocks mapped by Nelson $(1975 a, b)$ in the Natick and Framingham areas and by Volckmann (1977) in the Medfield and Holliston areas; biotite-hornblende schist southwest of Holliston (Volckmann, 1977); and the unnamed gneiss and quartzite and Greenleaf Mountain Formation mapped by Bell and Alvord (1976) in the Burlington area. Widely scattered small masses of metavolcanic rock north and east of the Narragansett basin, including the greenstone at North Plympton, are also included in the mafic metavolcanic unit.

North and northeast of Boston in the Salem and Danvers area (fig. 3), small masses of the mafic metavolcanic rocks $(\mathrm{Zv})$-amphibolite, chlorite schist, and augen gneiss-mapped by Toulmin (1964) as Marlboro Formation are engulfed in gabbro and diorite (Zdigb), primarily Salem Gabbro-Diorite (Toulmin, 1964; Wones and Goldsmith, this vol., chap. I). Near the Bloody Bluff fault in the Reading area and northeast in Georgetown, Ipswich, and Rowley are more extensive areas of mafic metavolcanic rock $(\mathrm{Zv})$, primarily amphibolite, and less mafic plutonic rock. Those in the Reading area were mapped as 


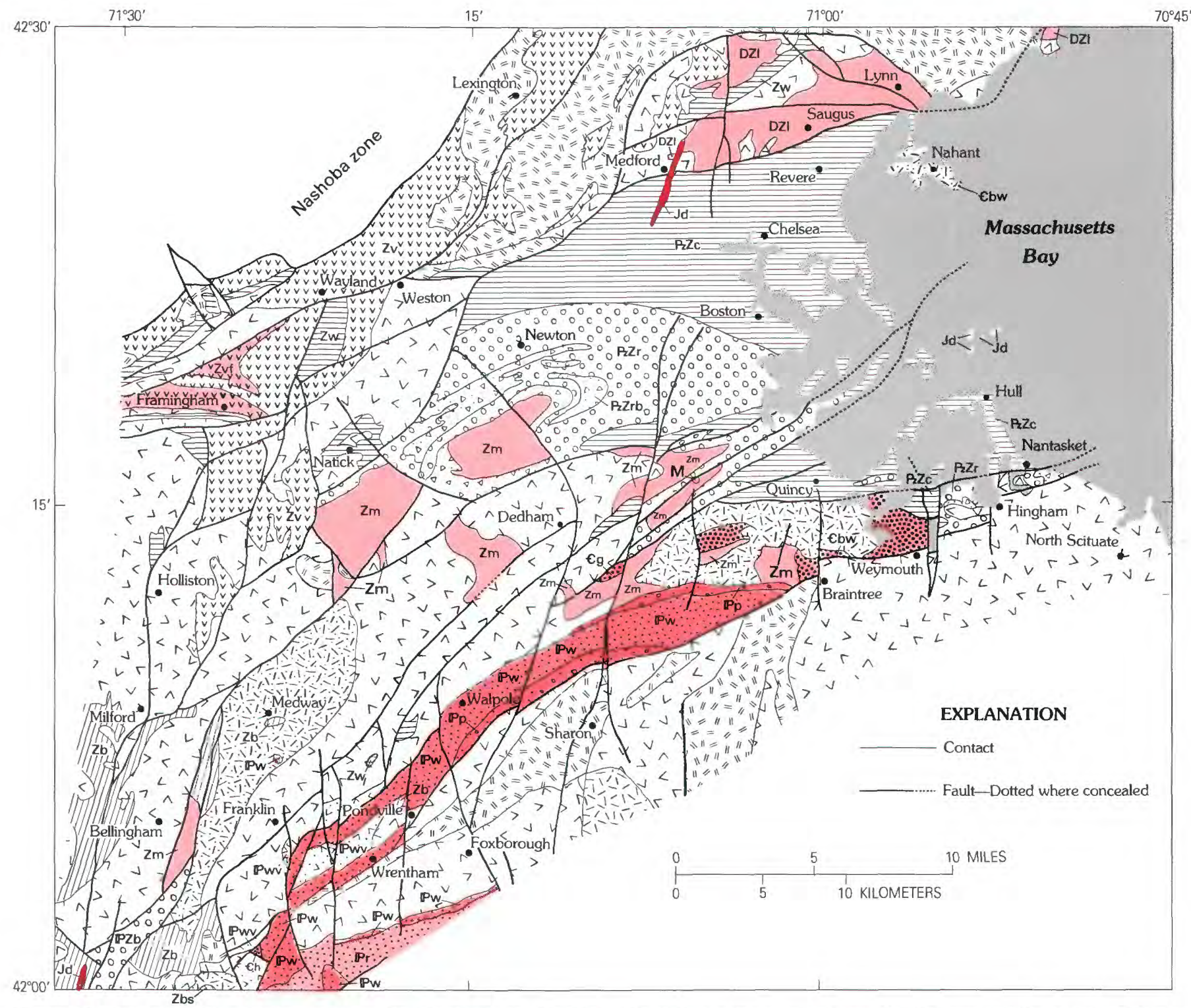

FIGURE 8. - Stratigraphic units in and around the Boston basin. M, Milton. Unit designations as on figure 2. Jd shown on islands east of Boston intrudes PZZc.

Marlboro Formation (Emerson, 1917; Castle, 1964). Those in the Georgetown area were included in the Middlesex Fells Volcanic Complex in the regional synthesis by Bell and Alvord (1976). Parts of this general area, particularly the Danvers area, where plutonic and volcanic rocks are mixed could have been more appropriately shown on the State bedrock map as an undifferentiated volcanic-plutonic complex (volcanic-plutonic complex in eastern Massachusetts).

The Kendall Green Formation as used by Nelson (1974; table 3 ) is included in the mafic metavolcanic rocks ( $\mathrm{Zv})$ on the State bedrock map. The protolith of the Kendall Green Formation (Kendall Green slate of Hobbs, 1899; Woburn Formation of LaForge, 1932; fig. 6) has been the subject of several interpretations in recent years. Nelson
(1974) considered that the Kendall Green represented thinly layered metamorphosed felsic and mafic tuffs. Bell and Alvord (1976) considered the rock to be a protoclastic phase of the Ordovician and Silurian Cape Ann Complex. Castle and others (1976) considered the rock to be a mylonite in the Bloody Bluff fault zone. I think all three interpretations are partly correct. The rock was originally either layered felsic and mafic tuffs or sheets of felsic rock intruded into the mafic pile, which have been smeared out into thinner layers and laminae within the Bloody Bluff and other fault zones in the WestonWaltham area west of Boston. Corresponding rock in a similar stratigraphic position can be seen in southeastern Connecticut, where thinly interlayered fine-grained Hope Valley Alaskite Gneiss and (hornblende)-biotite- 
quartz-plagioclase rock have been milled down in a splay of the Honey Hill fault zone to a fine-grained blastomylonite consisting of alternating thin dark and light layers, lenses, and discontinuous laminae. This blastomylonite lies near the base of a predominantly amphibolitic part of the metavolcanic-plutonic Waterford Group (Goldsmith, 1980). I consider the Kendall Green Formation of Nelson part of the mafic metavolcanic assemblage $(\mathrm{Zv})$ rather than a valid formation; it is merely a zone rendered distinctive through sheetlike intrusion and cataclasis. In eastern Connecticut and adjacent Rhode Island and Massachusetts, felsic layers may be intrusions of Hope Valley or may be felsic volcanic rock that is part of the carapace for the Sterling Plutonic Group and Milford Granite of the Rhode Island batholith. In the Framingham area, mappable zones of felsic volcanic rock ( $\mathrm{Zvf}$ ) interpreted in the latter way are shown on the State bedrock map.

The Claypit Hill Formation and the group of three units of Bell and Alvord (1976) above their Middlesex Fells Volcanic Complex (fig. 6) in the Burlington area are less certainly part of the mafic metavolcanic assemblage $(\mathrm{Zv})$ but have been included in it on the State bedrock map. Nelson (1974) suggested that the Claypit Hill is unconformable on the Cherry Brook Formation, on the basis that attitudes of layering in the Claypit Hill were discordant to those in the Cherry Brook, but he did not discount the possibility that the contact is a fault. The Claypit Hill resembles the Marlboro Formation in the Nashoba zone to the northwest (Goldsmith, this vol., chap. F), and it may be a slice of Marlboro caught in the Bloody Bluff fault zone. The Claypit Hill, according to Nelson's map (1975b), is intruded by Proterozoic Z granite, however, placing it clearly within the MilfordDedham zone.

Two of the three formations exposed in the Greenleaf Mountain area, Burlington (fig. 3; Bell and Alvord, 1976; table 3), are included in the mafic metavolcanic assemblage $(\mathrm{Zv})$. These are an unnamed gneiss and quartzite and the Greenleaf Mountain Formation. The third formation, the Burlington Formation, has been assigned to the quartzitic assemblage on the State bedrock map. These formations form a lens between the Bloody Bluff fault on the west and outcrops of the Middlesex Fells Volcanic Complex on the east. These formations rest unconformably on the eroded surface of the Middlesex Fells Volcanic Complex although no actual contact has been seen (Bell and Alvord, 1976, p. 202-203). They are assigned to the mafic metavolcanic assemblage because they are near the metavolcanic rocks of the Middlesex Fells Volcanic Complex and because they contain biotite gneiss and amphibolite as major components. However, as discussed in the section on the quartzitic assemblage, the three units in the Burlington area should be assigned to a separate suite of their own. They may actually lie in a fault sliver of the Bloody Bluff fault system. In contrast to the Claypit Hill Formation and Middlesex Fells Volcanic Complex, these formations are intruded not by the Proterozoic Z Dedham Granite but only by Paleozoic alkalic granite, and therefore they could be younger than Proterozoic Z. I did not attempt to correlate the Claypit Hill with these units (fig. 6), and their assignment to the mafic metavolcanic assemblage $(\mathrm{Zv})$ on the State bedrock map is arbitrary.

Massive greenstone is exposed on the edge of the Narragansett basin west of Plymouth, at North Plympton (fig. 5). The rock is greenish gray and contains a few scattered, small, greenish-white phenocrysts. It has a weak but measurable cleavage. In thin section, the rock has a relict trachytic or felty texture in a flow pattern and contains scattered larger saussuritized plagioclase grains. Mineral constituents are light-green to yellowish-green amphibole, locally in aggregates as much as $2 \mathrm{~mm}$ in diameter, clinozoisite, olive-green chlorite, yellow epidote, and fine-grained accessory albite, oriented tabular flakes of leucoxene, and white mica. Quartz is dispersed but also forms a few aggregates that contain rutile. The greenschist-facies metamorphism of this rock is in contrast to the lack of metamorphism and cleavage in the adjacent Rhode Island Formation. The relationship can be seen in exposures on a farm $0.8 \mathrm{~km}$ northeast of North Plympton (Lyons, 1977, Plympton quadrangle).

Woodworth (in Shaler and others, 1899, p. 116) considered the greenstone near North Plympton to be of Pennsylvanian age on the basis of comparison with a similar rock cutting fine-grained "granitite" south of the main exposure of the felsite north of Plympton, and thus he considered it to be younger than the southeastern Massachusetts batholith. He correlated the greenstone with the felsite at Attleboro in the Wamsutta Formation $(\mathbb{P w v})$. However, the greenstone at North Plympton is altered, as are the plutonic rocks in the area, and has a cleavage and is thus unlike the adjacent Middle to Upper Pennsylvanian Rhode Island Formation. The rock is either pre-Dedham (and its equivalents), and part of the volcanic-plutonic complex in eastern Massachusetts, or it is para- and post-Dedham and correlatable with the Mattapan Volcanic Complex. On the State bedrock map it is mapped as metamorphosed mafic metavolcanic rock $(\mathrm{Zv})$.

The greenstone at North Plympton is somewhat similar to a flow-banded light-greenish-gray porphyry in ledges $1.3 \mathrm{~km}$ south of Rock. This porphyry contains saussuritized plagioclase phenocrysts as much as $1 \mathrm{~cm}$ in longest dimension and twinned green hornblende, locally clustered, in a matrix of chlorite, quartz, potassium feldspar, epidote, and rare biotite and sphene. Cleavage 
is not apparent in this rock. Its contact with adjacent granite is not exposed. This porphyry, not shown on the State bedrock map because of its small size, is considered to be the same age as the greenstone at North Plympton because it has the same greenschist-facies metamorphism.

\section{BLACKSTONE GROUP: GREENSTONE AND AMPHIBOLITE (HUNTING HILL GREENSTONE) (Zbv)}

The Hunting Hill Greenstone as described by Quinn (Quinn and others, 1948; summarized in Quinn, 1971; table 3 ) is quite similar to the Cherry Brook Formation (Nelson, 1974) and Middlesex Fells Volcanic Complex (Bell and Alvord, 1976) and is in a similar stratigraphic position. In the type area in northern Rhode Island, northwest of Pawtucket, the Hunting Hill forms massive ledges, in some of which pillow structure can be discerned. The Hunting Hill Greenstone also forms sills and dikes in the mica schist and phyllite unit (Zbs) (Sneech Pond and Mussey Brook Schists) in northeastern Rhode Island (Rutherford and Carroll, 1981).

The term "greenstone and amphibolite" (Zbv) used on the State bedrock map was originally meant to include not only the Hunting Hill Greenstone in the type area but also amphibolite and other metavolcanic or metavolcaniclastic rocks of middle to high metamorphic grade in areas west and northwest of the Blackstone type area. However, the amphibolites in these areas could not be readily separated on the scale of the map from the rest of the Blackstone Group and so were included in the undivided Blackstone Group ( $\mathrm{Zb}$ ) rather than being mapped separately. Some of these rocks have been mentioned above in the description of the lower part of the Blackstone Group.

\section{METAMORPHOSED FELSIC VOLCANIC ROCK (Zvf)}

Metamorphosed felsic volcanic rock (Zvf) forms a subordinate part of the metamorphosed mafic and felsic volcanic rock assemblage $(\mathrm{Zv})$. Mappable units of felsic metavolcanic rock are shown only in the Framingham area (figs. 4, 8) on the State bedrock map. The Cherry Brook Formation, as described by Nelson (1974; table 3), has a lower felsic part consisting of a metamorphosed massive crystal tuff containing a few layers of biotite schist. This felsic part was not recognized by Bell and Alvord to the northeast in the Medford area, where pillow lavas of the Middlesex Fells Volcanic Complex rest directly on quartzite (Bell and Alvord, 1976, p. 198), nor was an equivalent zone of felsic rock or interlayered felsic and mafic rock described by Quinn (1971) below the Hunting Hill Greenstone in the Blackstone Group. However, the felsic part of the Cherry Brook may be correlative with felsic layers described by Volckmann (1977) in the units lying below the Cherry Brook Formation (table 3). The Cherry Brook studied by Volckmann is equivalent to only the upper part of the Cherry Brook studied by Nelson. However, Nelson's crystal tuff is similar in composition and texture to, although finer grained than, mafic-mineral-poor felsic rocks north and east of the Milford Granite that Volckmann (1977) mapped as Milford Granite. I have shown the felsic rocks of Volckmann as Hope Valley Alaskite Gneiss on the State bedrock map. I could not separate out the felsic rocks of the Cherry Brook from the rest of the Cherry Brook for compilation as metamorphosed felsic volcanic rocks on the State bedrock map, but my reconnaissance in the Framingham area in preparation for compiling the State bedrock map convinced me that the northern belts of rock that Nelson (1975b) mapped as Milford Granite would be better shown as metamorphosed felsic volcanic rock ( $\mathrm{Zvf}$ ) because of their fine-grained texture and mafic-mineral-poor composition.

\section{CORRELATION OF THE MAFIC METAVOLCANIC ROCKS} (Zv) AND THE HUNTING HILL GREENSTONE (Zbv)

The Middlesex Fells Volcanic Complex, Cherry Brook Formation, Claypit Hill Formation, and Rice Gneiss have been included in the metamorphosed mafic and felsic volcanic rocks $(\mathrm{Zv})$ on the State bedrock map. Bell and Alvord's (1976, p. 199-200) Middlesex Fells Volcanic Complex encompassed the rocks mapped by Nelson as Cherry Brook and Claypit Hill Formations as well as the mafic rocks in the upper part of the Blackstone Group (Bell and Alvord, 1976, p. 199-200) shown on the State bedrock map as greenstone and amphibolite (Hunting Hill Greenstone (Zbv)). The descriptions of the Middlesex Fells Volcanic Complex in the type area by Bell and Alvord (1976) and of the Hunting Hill Greenstone by Quinn and others (1948) are similar (table 3), and the units occupy a similar stratigraphic position. I agree with the correlation of these units.

I used the term "metamorphosed mafic to felsic flow, and volcaniclastic and hypabyssal intrusive rocks" (Zv) on the State bedrock map instead of Middlesex Fells Volcanic Complex because the type area of the Middlesex Fells is in a fault-bounded block unique in containing the Lynn Volcanic Complex (DZl), and I was wary of extending the usage to the amphibolites and gneisses outside the block to the northeast and north, as well as to units which Nelson had already mapped in the Framingham area. Furthermore, the Middlesex Fells contains no felsic rocks like those in the Cherry Brook Formation. Bell and Alvord's (1976) usage of Middlesex Fells Volcanic Complex in a broad sense may be correct, but I thought it better to use an informal lithologic name on the State bedrock map pending further work. 


\section{METAMORPHIC ROCKS OF SOUTHEASTERN MASSACHUSETTS}

Layered schist and gneiss form arcuate and linear septa in the plutonic rocks of the southeastern Massachusetts batholith southeast of the Narragansett basin (fig. 5). Two types of rock are present, thinly layered gneiss and schist (gneiss and schist near New Bedford, $\mathrm{Zgs}$, table 2) and thickly layered biotite gneiss (biotite gneiss near New Bedford, Zgn, table 2). They are exposed primarily in the New Bedford-Fall River area, but the poorly exposed terrane to the east in Plymouth and Barnstable Counties probably contains similar rocks. A deep drill hole near Harwich on Cape Cod (see fig. 15) encountered thinly layered phyllitic schist and subordinate limestone (Koteff and Cotton, 1962). The gneiss and schist near New Bedford (Zgs) and the biotite gneiss near New Bedford (Zgn) are described below in more detail than are rocks in other areas because no previous descriptions of them exist.

\section{GNEISS AND SCHIST NEAR NEW BEDFORD (Zgs)}

The most extensive exposures of the gneiss and schist near New Bedford (Zgs) are in cuts on I-195 near New Bedford (fig. 5). Elsewhere only a few exposures were seen in road reconnaissance. The belt of gneiss and schist shown on the State bedrock map extending from Hixville to Brayleys is based on the trend of a valley, the magnetic pattern (U.S. Geological Survey, 1971a), and the strike of schist in one outcrop. Similarly, the belt trending southwest from the south part of Dartmouth across the East Branch of the Westport River is based on the strike of one outcrop and the magnetic pattern (U.S. Geological Survey, 1971b).

The gneiss and schist are thin-bedded to laminated, medium-gray to dark-greenish-gray rocks differing in proportions of feldspar, quartz, hornblende, biotite, and epidote; they locally contain muscovite. Amphibolite is rare. Rocks exposed on I-195 west of New Bedford consist of garnet-biotite-quartz schist containing small calc-silicate pods and randomly oriented elongate black poikiloblastic hornblende, muscovite-green-biotiteplagioclase-quartz schist, locally containing pyrite, and layers of laminated epidote-biotite-two-feldspar schist or gneiss containing green biotite, clusters of green biotite and epidote, quartz, calcic $\left(\mathrm{An}_{20-29}\right)$ oligoclase, minor hornblende, sphene, allanite, and microcline. Similar rocks are exposed in other places. Microcline-bearing phases tend to be more abundant near granitic contacts. The microcline in some of these layers is poikiloblastic and aggregated with plagioclase and quartz forming light-colored knots. Some layers are of coarse twofeldspar-quartz augen gneiss containing green biotite, accessory epidote, opaque minerals, and sphene. Others are a splintery-weathering, gray, sugary-textured quartz-biotite-feldspar gneiss. A laminated, greenishgray schist near Center Village, Westport, contains plagioclase, biotite, calcite, epidote, allanite, opaque minerals, and rare scattered aggregates of quartz. Flanking the diorite at Acushnet is somewhat granitoid, medium-gray to dark-gray gneiss consisting of clusters of epidote, blue-green hornblende, and green biotite in a matrix of plagioclase and rare quartz. A lighter colored phase lacks hornblende and contains a minor amount of potassium feldspar. In a nearby quarry, a streaked and spotted rock flanking the diorite contains elongate palegreen hornblende prisms in a matrix of greenish-brown biotite locally clustered with fine-grained hornblende and epidote, saussuritized plagioclase, and quartz. In most of the rocks described above, the plagioclase is poorly twinned.

A septum of epidote-biotite schist containing quartz, calcic oligoclase, and accessory apatite and sphene is exposed near the Route 24-I-195 interchange at Fall River. Inclusions of similar rock are abundant in the band of porphyritic granite in that area. Similar schist forms inclusions in the porphyritic granite along Long Pond, north of Deans Point (fig. 5).

The textures and composition of the rocks suggest that their protolith was intermediate to felsic volcaniclastic rocks, primarily tuffaceous sediments and tuffs, deposited in an aqueous environment.

\section{BIOTITE GNEISS NEAR NEW BEDFORD (Zgn)}

Layered granitoid biotite gneiss (Zgn) forms a tightly arcuate band south of New Bedford along the north shore of Buzzards Bay (fig. 5). It is flanked on either side by gneissic alaskite. The biotite gneiss is best exposed at Fort Phoenix Park, Fairhaven, east of New Bedford (fig. 5). Other exposures are at Wilbur Point and on U.S. Route 6, Mattapoisett, $200 \mathrm{~m}$ west of its junction with Mattapoisett Neck Road, Marion quadrangle.

The gneiss is thickly layered, gray, and relatively homogeneous in texture. Layers differ in proportions of feldspars and biotite; some layers are quite poor in mafic minerals. Typical layers are flecked with biotite and magnetite, giving the rock a salt-and-pepper appearance. Foliation is pervasive and approximately parallel to layering. It is marked by uniform orientation of the disseminated biotite flakes. Some dark-gray layers, however, contain elongate clots of biotite, sphene, and allanite. Some small pegmatitic streaks and patches contain only magnetite. Mineralogy is simple. The gneiss consists of plagioclase, quartz, biotite, microcline, and accessory sphene and allanite. The exposure at Mattapoisett contains about 20 percent biotite and augen of fleshcolored potassium feldspar as much as $1 \mathrm{~cm}$ long. The 
biotite gneiss is not well exposed in the hinge of the arc in Dartmouth. Exposures at Bayview, Dartmouth, consist of lineated and foliated inequigranular biotite gneiss containing flesh-colored feldspar 2.5-5 $\mathrm{mm}$ in diameter. Pegmatite masses in these outcrops contain muscovite as well as biotite, quartz, and two feldspars. Exposures in a playground off Front Street in southern New Bedford on strike with the Fort Phoenix exposures are of relatively massive granitoid biotite gneiss in which pegmatite masses have large books of biotite. Granitoid phases at Fort Phoenix approach in composition and aspect gneissic phases of the granite of the Fall River pluton. The biotite gneiss, however, is distinguished by its layered character and greater amount of biotite and magnetite.

The protolith of the biotite gneiss was probably a sequence of layered intermediate to felsic volcanic rocks, more likely flows and massive tuffs rather than waterlain volcaniclastic materials. Alternatively, the gneiss could represent metamorphosed sheeted intrusions.

Contact relations with the granite of the Fall River pluton are not clear. The biotite gneiss appears to be conformable with the adjacent gneissic alaskite and is in fact interlayered with it. On the one hand, both may be part of a plutonic or volcanic assemblage older than the granite of the Fall River pluton. On the other hand, both could be phases of the southeastern Massachusetts batholith but metamorphosed and deformed under higher pressure-temperature conditions than the batholith to the north and west.

\section{CORRELATION}

The gneiss and schist (Zgs) and the biotite gneiss (Zgn) near New Bedford are not well enough exposed to provide a good basis for correlation with rock units of apparently similar age in adjacent Rhode Island (fig. 7). However, on the basis of similar composition and bedding characteristics, they are probably equivalent to mica-chlorite schist and chlorite-biotite schist of Pollock (1964, p. D2) exposed at several places along the east side of the Sakonnet River in the Tiverton area. The mineralogy of the schist as described by Pollock (1964, p. D2-D3) is similar to that in layers in the gneiss and schist in the New Bedford area: "Chief constituents are quartz, biotite, and chlorite; muscovite, epidote, calcite, and hornblende are locally abundant. Minor and accessory constituents are albite, microcline, microperthite, zircon, apatite, sphene, magnetite, ilmenite, and garnet." Quinn (1971), following Pollock (1964), described the micachlorite schist on the Sakonnet River south of Tiverton near Browns Point (fig. 5) as light-gray to greenish-gray, thin-bedded mica-chlorite schist containing thin beds of marble and quartzite. The mica-chlorite schist is intruded by the Bulgarmarsh Granite, which is here considered a phase of the Fall River pluton. Quinn (1971) described the chlorite-biotite schist mapped by Pollock (1964) near Tiverton Four Corners (fig. 5) as green to gray, fine-grained, poorly foliated chlorite-biotite schist containing subordinate layers of amphibolite, epidotehornblende schist, and quartzite. Quinn (1971) equated a pink- to light-gray, thin-bedded, lineated muscovitequartz-biotite schist at Bristol Neck, Rhode Island, northwest of Tiverton, with the rocks in the Sakonnet River area. The rocks in the Sakonnet River and Bristol areas described above are in the greenschist facies to epidote-amphibolite facies of metamorphism.

Not seen in the New Bedford area were the thin beds of limestone in the mica-chlorite schist near Browns Point, nor the quartzite at Tiverton Four Corners, nor a volcanic breccia that Pollock mapped on Gould Island in the Sakonnet River (fig. 5). Pollock tentatively correlated these rocks with the Blackstone Group, but Quinn (1971, p. 54) did not venture such a correlation. The mica schist at Bristol Neck, R.I. (Quinn, 1971, p. 23), resembles some of the gneiss and schist near New Bedford. It is reasonable to correlate the rocks mostly east of the Sakonnet River in Rhode Island, mentioned above, with Proterozoic $Z$ volcanic and sedimentary rocks near Newport on Aquidneck and Conanicut Islands described by Kay and Chapple (1976), and more recently by Rast and Skehan (1981), because they are both intruded by Proterozoic Z granites. Rast and Skehan (1981) assigned the volcanic and sedimentary rocks to two formations. The lower, the Newport Formation, consists of graded graywacke, siltstone and pelite, and minor conglomerate, felsic volcanic rock, quartzite, calc-silicate rock, dolomite, and diamictite containing fragments of quartzite, calc-silicate rock, dolomite, and serpentine. They interpreted the formation as turbidite deposits that included minor felsic volcanic material. The upper formation, the Price Neck Formation, consists primarily of volcanogenic materials: agglomerate breccias (in part lahars), conglomerate, coarse tuff, thinly bedded tuff and laminated sediments; graded-bedded tuff, siltstone and slate; and possible rhyolite flows. Both formations are in the lower greenschist facies of metamorphism.

Correlation of the metavolcanic and metasedimentary rocks in the New Bedford area (Zgs, Zgn) with either the mafic metavolcanic rocks $(\mathrm{Zv})$ or the quartzitic assemblage ( $\mathrm{Zp}, \mathrm{Zw}, \mathrm{Zbs}$, and $\mathrm{Zbq}$ ) north and west of the Narragansett basin is uncertain. Mafic metavolcanic rocks are generally lacking in the New Bedford area of Massachusetts and the Sakonnet River area and Aquidneck and Conanicut Islands in Rhode Island. Volcanic rocks, where they do exist, tend to be felsic. A more likely correlation would be with the mica schist and phyllite (Zbs) of the lower part of the Blackstone Group 
TABLE 4.-Stratigraphic units of the Boston basin and vicinity

[Descriptions and thicknesses adapted from Rehmer and Roy (1976)]

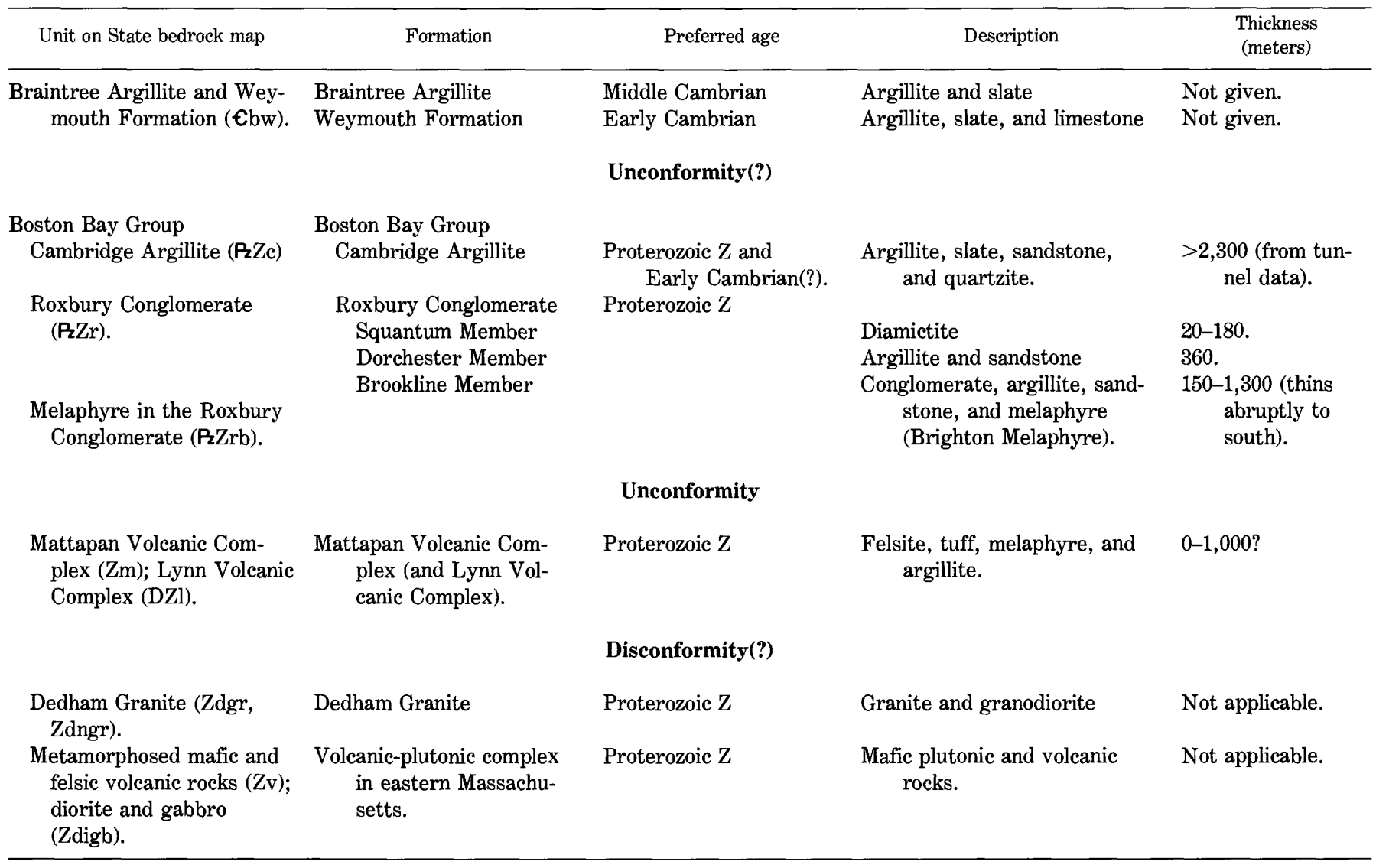

in northern Rhode Island or possibly the lower part of the Cherry Brook Formation (included in $\mathrm{Zv}$ ) in the Framingham area. On the other hand, the gneiss and schist (Zgs) and the biotite gneiss (Zgn) near New Bedford and the rocks in the Sakonnet River area, Rhode Island, are not correlatable directly with either of the major groups of Proterozoic Z, prebatholithic rocks north of the Narragansett basin.

\section{AGE OF THE PREBATHOLITHIC ROCKS}

A minimum age for the metamorphic rocks older than the Rhode Island and southeastern Massachusetts batholiths is established by the Proterozoic $\mathrm{Z}$ age (595-630 Ma) of the plutonic rocks (Dedham Granite, Milford Granite) intrusive into them (Goldsmith, 1980; Zartman and Naylor, 1984; Zartman and Marvin, this vol., chap. $\mathrm{J}$, table 1). A maximum age is indicated by a $1,500-\mathrm{Ma}$ $\mathrm{U}-\mathrm{Pb}$ age on detrital zircon from the Westboro Formation (Olszewski, 1980). It may be, however, that some quartzites now mapped as Westboro or Plainfield and some felsic volcanic rocks now included in the mafic metavolcanic rocks are actually younger than or equiva- lent to the batholithic rocks. Some of these particular problems will be addressed in a later section of this chapter, "Stratigraphic problems."

\section{PROTEROZOIC Z ROCKS YOUNGER THAN OR EQUIVALENT TO THE SOUTHEASTERN MASSACHUSETTS BATHOLITH}

Unmetamorphosed to weakly metamorphosed volcanic and sedimentary rocks of known or of possible Proterozoic $\mathrm{Z}$ to early Paleozoic age occupy and flank structural and stratigraphic basins in the Proterozoic $\mathrm{Z}$ crystalline complex of eastern Massachusetts and Rhode Island. Proterozoic $Z$ volcanic rocks (Zm, PzZrb) and Proterozoic $\mathrm{Z}$ to Cambrian sedimentary rocks ( $\mathrm{PzZr}, \mathrm{P} Z \mathrm{Zc}$ ) have been identified in and around the Boston basin (fig. 8). Similar rocks flanking the Norfolk basin (Pwv), and in the Bellingham basin ( $\mathbb{P Z b}, \mathrm{Zm})$, may be similar in age to those in the Boston basin. In the Boston basin (table 4), the basal Mattapan Volcanic Complex has been shown to be of Proterozoic Z age (602 \pm 3 Ma; Kaye and Zartman, 1980) and in places to intrude and to lie unconformably above the Dedham Granite (LaForge, 1932, p. 31). 
Metasedimentary and metavolcanic rocks of the Boston Bay Group, formerly thought to be of Silurian to Devonian or Pennsylvanian age (Billings, 1979), overlie the Mattapan and are now considered to be of Proterozoic Z to Early Cambrian(?) age (Skehan, 1979; Kaye and Zartman, 1980; Skehan and Murray, 1980a; Billings, 1982; Lenk and others, 1982). The volcanic rocks will be described first.

\section{MATTAPAN AND LYNN VOLCANIC COMPLEXES (Zm, DZl)}

The volcanic rocks in the Boston basin area younger than the Dedham Granite include an earlier, primarily felsic suite (Mattapan (Zm) and Lynn (DZl) Volcanic Complexes) and a later mafic suite (Brighton Melaphyre (PzZrb) of the Boston Bay Group) (table 4). The Mattapan is distributed in the west and southwest part of the Boston basin and beyond, and to the south in the Blue Hills (Chute, 1969; fig. 8); the Lynn is confined to a block north of the Boston basin between the northern border fault and the Walden Pond Fault of Bell and Alvord (1976, fig. 1). The Mattapan and Lynn Volcanic Complexes have similar lithologies. According to Kaye (1980), they consist largely of rhyolite and rhyodacite flows, in part porphyritic; welded ash flows; vitric, lithic, and lapilli tuffs; flow breccias; breccia pipes; and extrusion domes. LaForge (1932, p. 30-33) mentioned the presence of andesitic and basaltic rocks, some of them amygdaloidal. However, he may have been referring to the older Middlesex Fells Volcanic Complex cropping out in the area of the Lynn Volcanic Complex or to the younger Brighton Melaphyre. Rhyolites and rhyodacites in the Mattapan are thinner and less varied in composition and texture than those in the Lynn, and volcanic breccias are largely absent in the Lynn. In composition, the volcanic rocks tend to be sodic rather than potassic (Chute, 1966). The Mattapan contains thick zones of interbedded metasedimentary rocks ranging from laminated argillite with fine-scale graded bedding (Lyons and Goldsmith, 1983) to volcanic conglomerate. Some of the latter have been confused with the Roxbury Conglomerate, as noted by LaForge (1932, p. 34-35). A pinkish-red to red-maroon conglomerate, formerly considered to be Roxbury Conglomerate, containing mainly granite and rhyolite fragments interfingers with welded ash-flow tuff in the northwestern part of the Medfield quadrangle and is part of the Mattapan (Volckmann, 1977). Other kinds of volcanic rock have been noted elsewhere. Nelson (1974) described a laharic unit and andesitic rocks in the Mattapan in the Natick quadrangle. Volckmann (1977) described a quartz-latite crystal-vitric tuff in the Medfield quadrangle. The volcanic rocks in the Blue Hills are masses of red, pink, purple, brown, and gray altered and devitrified rhyolitic flows, ash flows, and breccias (aporhyolite of Emerson, 1917).

The relative stratigraphic position of the Mattapan and Lynn is fairly clear. The Mattapan and Lynn are reported to lie nonconformably on the Dedham Granite and the volcanic-plutonic complex in eastern Massachusetts. LaForge (1932, p. 31) cited exposures near Medford and in the Saugus area where the Lynn overlies weathered plutonic rocks; it consists in one place of a basal arkose and in another of an agglomerate containing disintegrated granite. Bell (1976, p. 289) cited a location in the Saugus area where the Lynn overlies both the Middlesex Fells Volcanic Complex and diorite intruded into it. Mattapan dikes and stocks cut the Dedham Granite and other basement rocks (see Billings, 1976a, p. 8; Kaye and Zartman, 1980, p. 258; Chute, 1966, p. B27). On the other hand, Zarrow (1978, cited by Naylor, 1981) described a mass of Dedham Granite at Pine Hill, Medford, that contains inclusions of Lynn. Kaye (Kaye and Zartman, 1980, p. 258) described two places where the Dedham grades upward through finer grained phases including granophyre into rhyolite and aphanitic rock resembling rhyolite. Chute (1966, p. B15) noted several exposures southwest of Dedham where a fine-grained phase of the Westwood Granite (Zwgr), which intrudes the Dedham Granite (Zdgr), resembles phases of the Mattapan. Thus it would seem that some of the Mattapan is or could be penecontemporaneous with younger phases of the Proterozoic Z Dedham batholith. In support of this contention, no cobbles of Westwood Granite have been observed in the Roxbury Conglomerate that overlies the Mattapan, so that it is possible that the Westwood is an intrusive equivalent of the extrusive Mattapan Volcanic Complex and was not exposed to erosion at the time of deposition of the Roxbury. Radiometric ages, discussed below in the section on ages of the Mattapan and Lynn Volcanic Complexes, permit the possibility of equivalent ages for the Mattapan and the Westwood.

The Mattapan is overlain by the Roxbury Conglomerate of the Boston Bay Group in what was described by LaForge (1932, p. 34) as a fairly continuous horizon. Billings (1929, p. 104) noted an angular relation between the Mattapan and the overlying Roxbury north of the Neponset River in Hyde Park and Mattapan, although elsewhere he observed that the contact seems to be conformable. The Roxbury Conglomerate contains pebbles and cobbles of the volcanic rocks. LaForge (1932, p. 34-35) cautioned against possible confusion in identifying Roxbury Conglomerate because of the similarity of some of its layers containing the volcanic material to some of the sedimentary layers interbedded in the volcanic rocks of the Mattapan. However, the Boston Bay Group in 

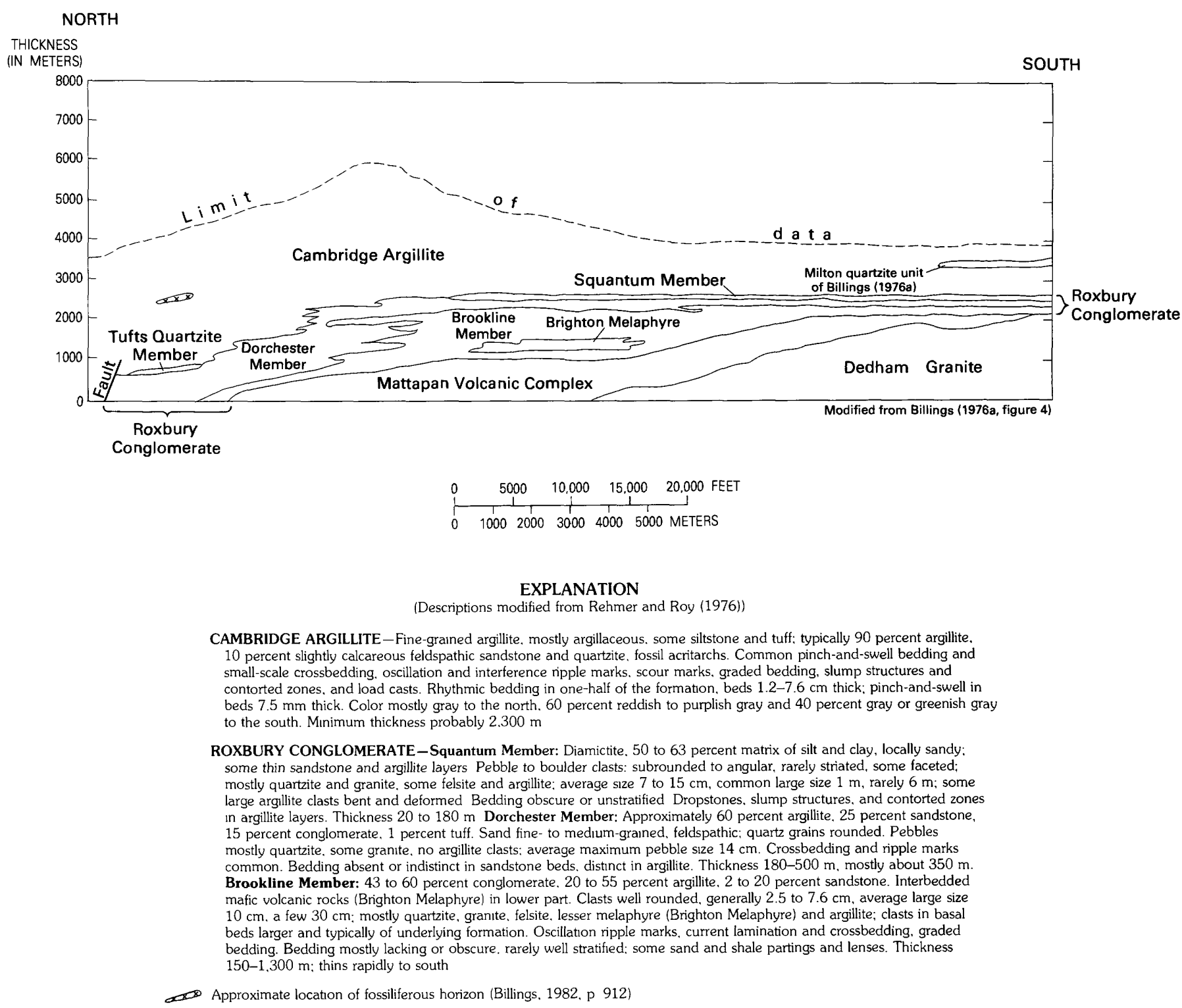

FIGURE 9.-Stratigraphic section and lithologic description of the Boston Bay Group.

general overlies the Mattapan as shown by Billings (1976a,b). The Lynn has no known overlying strata.

The thickness of the Mattapan is indicated on table 4 and figure 9 . It is thickest on the central anticline, Boston (1,000 $\mathrm{m}$ on projection from surface exposure), $600 \mathrm{~m}$ in Hyde Park, near Milton (M, fig. 8), and $760 \mathrm{~m}$ in Natick (Billings, 1979, p. A17), but it is missing to the southeast in Hingham and Nantasket where the Roxbury lies directly on the Dedham Granite (K.G. Bell, written commun., 1976; Billings, 1979). Its extent and thickness to the north under the Charles River syncline between Boston and Medford are not known.

Metavolcanic rocks that resemble the Mattapan in the Blue Hills, south of Boston, are assigned on the State bedrock map to the Mattapan. These rocks were consid- ered for many years to be either Silurian and Devonian (LaForge, 1932; Naylor and Sayer, 1976) or Carboniferous (Emerson, 1917; Billings, 1929). These metavolcanic rocks are chemically and mineralogically distinct from the nearby Blue Hills Granite Porphyry (SObgr), which is comagmatic with the Quincy Granite (SOggr) (Sayer, 1974). Most geologists agree that the volcanic rocks in the Blue Hills are older than the Quincy Granite and the Blue Hills Granite Porphyry (Naylor, 1981), which Billings (1982) postulated to be an Ordovician caldera complex. Chute (1966) could find no difference between the volcanic rocks $(\mathrm{Zm})$ in the Blue Hills and the Mattapan Volcanic Complex in the type area. We have followed Chute in assigning these rocks to the Mattapan Volcanic Complex. 


\section{FELSIC AND MAFIC ROCKS SOUTHWEST OF THE BOSTON BASIN (Zfm)}

Felsic and minor mafic volcanic rocks flanking other basins southwest of the Boston basin are correlated or could be correlated with the Mattapan Volcanic Complex. These rocks lie in a structural belt that also encompasses the Bellingham and Norfolk basins (Emerson, 1917; LaForge, 1932). Modern mapping has carried the Mattapan as far south as Medfield (Volckmann, 1977). Similar felsic volcanic rocks not previously mapped as Mattapan lie on the flanks of the Bellingham and Norfolk basins.

In or on the flanks of the Bellingham basin, a felsite porphyry (Zfm, mislabeled $\mathrm{Zm}$ on the State bedrock map) crops out in a series of exposures east of Maple Street, about $1 \mathrm{~km}$ east of Bellingham. The felsite porphyry contains quartz "eyes" and has a measurable cleavage. Igneous texture is still recognizable in thin section. The porphyry consists of perthite, quartz, both interstitial and in phenocrysts, tabular zoned plagioclase, and interstitial white mica, quartz, and an opaque mineral. The felsite is also exposed on I-495 to the north.

Felsic and minor mafic volcanic rocks exposed west of Lake Pearl, Wrentham, on the west flank of the Norfolk basin are possibly also equivalent to the Mattapan Volcanic Complex but are shown on the State bedrock map as volcanic rocks in the Wamsutta Formation $(\mathbb{P} w v)$. At one stage in the compilation of the State bedrock map, these rocks were shown as being equivalent to the Mattapan, as is the porphyry near Bellingham ( $\mathrm{Zfm}$ ). However, the proximity of these rocks to similar felsite at Diamond Hill, R.I., to the south, mapped by Quinn (1971) as Pennsylvanian, made an assignment to a Pennsylvanian age preferable. These rocks will be described in the section on the Pennsylvanian rocks, under the heading "Rhyolite and mafic volcanic rocks in the Wamsutta Formation."

Two small exposures of rhyolite were mapped by Chute (1965) north of Plymouth in the Duxbury quadrangle at Green Harbor, Duxbury (GH, fig. 10), and at Cripple Rocks (CR) in Kingstown Bay. Their age is not known, and they are not shown on the State bedrock map but are included in the unit granite, gneiss, and schist, undivided (Zgg) underlying the poorly exposed southeast corner of the State. They are possibly correlative with the Mattapan. The granite, gneiss, and schist unit (Zgg) is discussed in more detail in Wones and Goldsmith (this vol., chap. I).

\section{AGE OF THE MATTAPAN AND LYNN VOLCANIC COMPLEXES}

The Mattapan Volcanic Complex was for many years considered to be Pennsylvanian in age, through correla- tion with the volcanic rocks in the Narragansett basin, or Silurian and Devonian, through correlation with the Newbury Volcanic Complex. Recently, however, Zartman (Kaye and Zartman, 1980) reported a U-Th-Pb isotopic age on zircons from the Mattapan of $602 \pm 3 \mathrm{Ma}$. Although Billings (1979) questioned the reliability of zircon ages from volcanic rocks, particularly those from vents, the discovery of Proterozoic $\mathrm{Z}$ acritarchs in the overlying Cambridge Argillite (Lenk and others, 1982) indicates that the zircon age is appropriate.

The age of the Lynn Volcanic Complex, like that of the Mattapan, has been equivocal. Emerson (1917) considered the Lynn, as well as the Mattapan, to be Carboniferous. LaForge (1932) correlated the Mattapan and Lynn with the Newbury Volcanic Complex; Naylor and Sayer (1976) suggested a similar correlation. Billings $(1979,1982)$ accepted a Proterozoic $Z$ age for the Mattapan but preferred to correlate the Lynn with the Newbury because of its proximity and lithologic similarity to the Newbury. The argument based on the proximity of the Lynn to the Newbury is not strong, because the Lynn is geographically and structurally much closer to the Mattapan. The closest Newbury lies in a tectonic wedge $13 \mathrm{~km}$ to the north, whereas projection of the Mattapan northward beneath the Boston Bay Group in the Charles River syncline to the northern border fault of the basin places the Mattapan at most a few kilometers from the Lynn. The throw on the northern border fault probably is not great (Billings, 1976b, p. 41); my reconstruction suggests a throw of $1-1.5 \mathrm{~km}$ on the border fault using top of basement (Dedham Granite) as an approximate horizon. This amount of offset would place the two volcanic complexes within a short distance of each other. Zarrow (1978, cited in Naylor, 1981) has shown that the rare-earth-element pattern in one of the units in the Lynn is identical to that in part of the Mattapan. I think it reasonable to assume that the Lynn and the Mattapan are parts of the same volcanic complex and that the Lynn is also Proterozoic $\mathrm{Z}$ in age. However, in view of the uncertainties in the correlation at the time the State bedrock map was prepared, the Lynn is shown on the map as Lower Devonian, Silurian, or Proterozoic $\mathrm{Z}$.

Although much of the Mattapan and Lynn is younger than the Dedham Granite, some evidence suggests a genetic relation between the Dedham and the felsic volcanic rocks. Kaye (Kaye and Zartman, 1980, p. 258) described the gradation from granite to rhyolite seen in places and pointed out that Crosby $(1880,1893,1900)$ saw field evidence that convinced him that the rhyolitic volcanic rocks were genetically related to the granites. Zarrow (1978, cited in Naylor, 1981) found rock considered to be Dedham containing inclusions of Lynn and apparently truncating mappable members of the Lynn. 


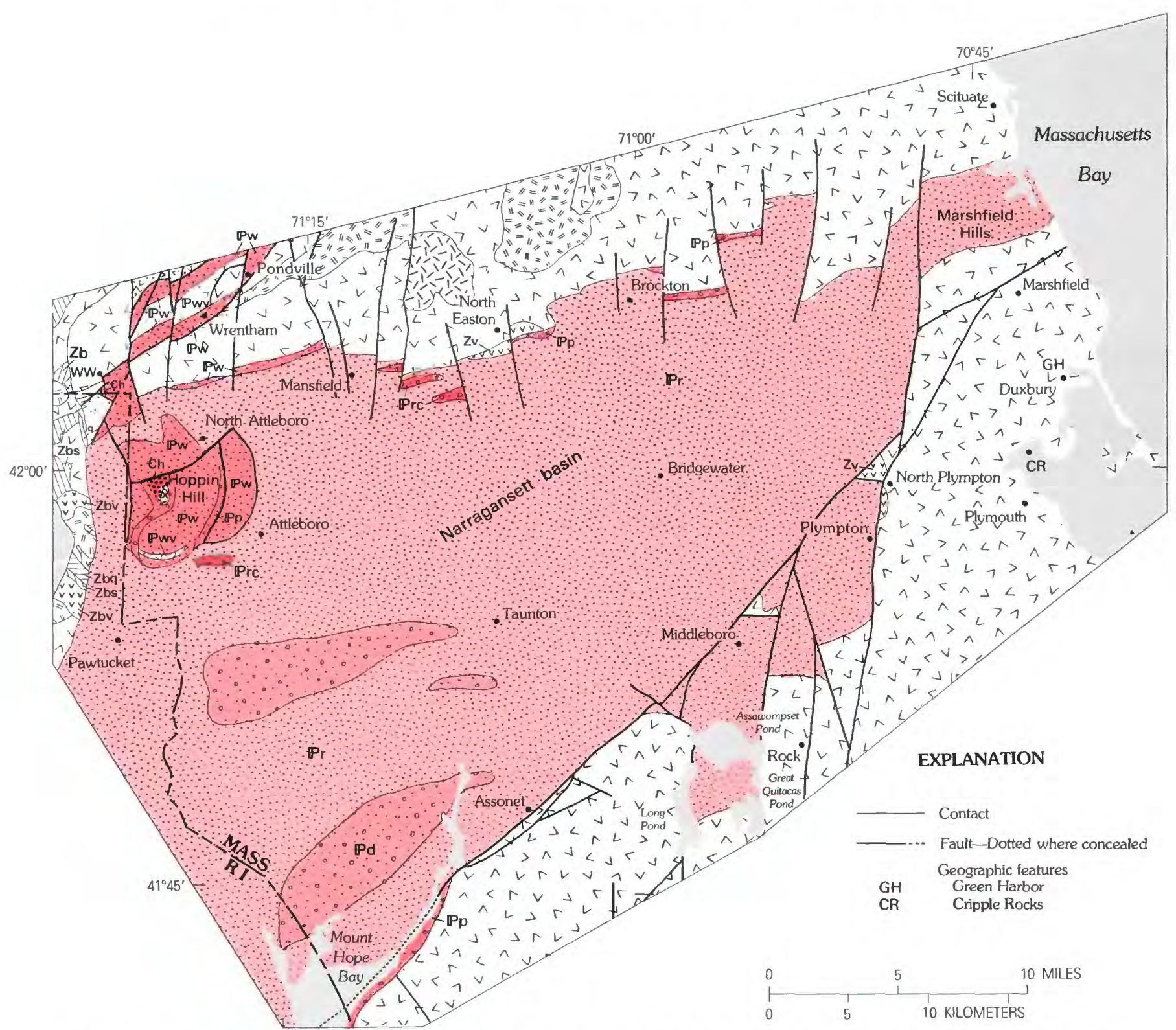

FiguRe 10. - Stratigraphic units in and around the Narragansett basin. WW, West Wrentham. Unit designations as on figure 2.

The identity of granitic rocks intrusive into the Lynn might be questioned, as Bell (1976) mentioned granite dikes of the Paleozoic Cape Ann Complex in a block of rock containing the Lynn. Agreement exists, however, that the intrusive rock is Dedham (G.R. Robinson, Jr., oral commun., 1980). If so, it is more likely to be a younger phase of the Dedham batholith. A similarity in trace-element content between the Lynn and rock mapped by Zarrow as Dedham in this area suggests consanguinity (Zarrow, 1978, cited in Naylor, 1981). The observation that the Mattapan and Lynn are both older and younger than the Dedham is resolved if a genetic affinity does exist between the felsic volcanic rocks and the Dedham and if we recognize that the Dedham consists of several phases. More than one kind of granite is observed in the Dedham batholith of southeastern Massachusetts, where type Dedham Granite is found. The Westwood Granite (Zwgr), also found in the Dedham batholith, is younger than the Dedham (Chute, 1966). A slightly more mafic granite north of Boston mapped as Dedham (Zdngr) is another phase. Kaye (Kaye and Zartman, 1980, p. 259; Kaye, 1980) recognized at least four pulses of intrusion in the block containing the Lynn Volcanic Complex.

The isotopic age for Dedham Granite as a whole is $630 \pm 15 \mathrm{Ma}$ (Zartman and Marvin, this vol., chap. J, table 1). This is probably a maximum age; because multiple intrusions exist, the zircon age of $602 \mathrm{Ma}$ for the Matta- 
pan given by Kaye and Zartman (1980) is quite within reason. It is well below the approximate date of the base of the Cambrian at about $570 \mathrm{Ma}$. Ample time is available for granite plutonism, accumulation of felsic volcanic rocks, and deposition of the Boston Bay Group before commencement of Cambrian deposition. The Mattapan and Lynn quite probably represent a period of felsic volcanism that started during at least the late stages of emplacement of the southeastern Massachusetts batholith.

\section{BOSTON BAY GROUP}

The primarily sedimentary rocks of the Boston Bay Group (table 4) comprise the Roxbury Conglomerate $(\mathrm{PZZr})$, which consists of the Brookline, Dorchester, and Squantum Members and a volcanic unit in the Brookline, the Brighton Melaphyre ( $\mathrm{B} Z \mathrm{Zrb}$ ), and the Cambridge Argillite ( $\mathrm{B}_{z} \mathrm{Zc}$ ). The Boston Bay Group overlies the Mattapan Volcanic Complex disconformably (LaForge, 1932; Billings, 1929). The most detailed and comprehensive studies of the Boston Bay Group have been made by M.P. Billings, by his associates and students over many years, and by LaForge (1932). Early studies of the Boston Bay Group were made by W.O. Crosby in the late 1800 's. More recent work has been done by Kaye (Kaye and Zartman, 1980; Kaye, 1980). Bell (written commun., 1976) has mapped marginal areas of the basin. On the State bedrock map, the three members of the Roxbury Conglomerate ( $\mathrm{BZZr}$ ) are not shown separately. Only the Brighton Melaphyre unit (PzZrb) is shown within the Roxbury Conglomerate. The stratigraphy is summarized in table 4. Bedding characteristics and other distinguishing features of the units of the Boston Bay Group are shown in figure 9.

The Roxbury Conglomerate ( $\mathrm{PZZr}$ ) forms the base of the Boston Bay Group. Both LaForge (1932) and Billings $(1929 ; 1976 \mathrm{a}, \mathrm{b} ; 1982)$ considered the base of the Roxbury to be an unconformity or disconformity. The Roxbury clearly lies nonconformably on the Dedham Granite near Hull, and the base of the Roxbury can be traced above the Mattapan Volcanic Complex as a continuous horizon, according to LaForge (1932). Emerson (1917) and Billings $(1929,1976 a)$ separated the Roxbury into three clearly defined members (table 4). LaForge (1932), however, claimed that the threefold division did not persist throughout the area and that the middle Dorchester Member had no clear base. Since then, Billings and Tierney (1964) found evidence that the Roxbury interfingers with the lower part of the overlying Cambridge Argillite in the northern part of the Boston basin, indicating that the Squantum Member pinches out and that the Dorchester has no clearly defined top in this part of the basin. Conglomerate in the Brookline Member contains clasts of Dedham Granite (Zdgr), quartzite, and volcanic rock from the underlying Mattapan Volcanic Complex $(\mathrm{Zm})$. The source of the quartzite clasts in the Roxbury Conglomerate is most likely the Westboro Formation. If the Dedham Granite was exposed to erosion to provide the clasts of granite, then the Westboro was most likely exposed also. The quartzite clasts in the Roxbury do not contain traces of fossils as do the quartzite pebbles in the Pennsylvanian Purgatory Conglomerate in Rhode Island (Shaler and others, 1899). The Dorchester Member consists of interbedded argillite and sandstone forming an intermediate unit between the primarily conglomeratic Brookline Member and the overlying Cambridge Argillite. The uppermost Squantum Member of the Roxbury is a distinctive diamictite, best exposed north of Quincy; its origin has been subject to differing interpretations, most being that the Squantum Member is a tillite (Cameron, 1979). It is not everywhere a diamictite, however. In Brighton (Newton area) and Hingham, the Squantum Member is a very coarse conglomerate (Billings, 1976a, p. 10). It may not be as continuous as indicated by Billings (Kaye, 1980) and, as mentioned above, appears to pinch out in the northern part of the basin. Most recently, Caldwell (1981) presented arguments indicating that the Boston Bay Group as a whole, including the Squantum, is unlike Pleistocene glacial deposits in that deltaic deposits are lacking, sand-size fractions are rare, the varvelike Cambridge Argillite is too thick to be a glacial-lake deposit, and evidence of multiple episodes of glaciation is lacking.

Within the lowermost Brookline Member of the Roxbury Conglomerate are mafic volcanic rocks, the Brighton Melaphyre (PZZrb). The Brighton Melaphyre consists primarily of quartz keratophyre, keratophyre, and spilite (Kaye, 1980). These are dark-gray to dark-greenishgray and reddish-gray aphanitic rocks. The spilites form flows, pillow lavas, feeder pipes and vents, and pyroclastic rocks. The keratophyres form massive flows, breccias, pillow lavas, and laminated devitrified palagonite tuff. Altered mafic dikes in the Mattapan are considered to be part of the Brighton (LaForge, 1932, p. 42). Nelson (1975a) described the Brighton Melaphyre in the Natick quadrangle as consisting of bluish- to dark-greenish-gray basaltic and andesitic flows and tuffs and minor interbedded, very fine grained ash and slate. Bouchard (1979) described the Brighton in the Newton area as a complex composed primarily of varicolored mafic basaltic extrusive rocks and subordinate andesitic to rhyolitic lavas and tuffs; lahars, mudflows, breccias, and agglomerate are also present. Some of these rocks are aphanitic, others are amygdaloidal, others are lapilli rich.

The Brighton is younger than the Mattapan and intrudes it. Possibly some of the Brighton is contemporaneous with part of the Mattapan. The Brighton appar- 
ently rises no higher in the section than the Brookline Member of the Roxbury, although tuffaceous beds are noted in the Dorchester Member and in the Cambridge Argillite (fig. 9).

The sandy horizons in the Cambridge Argillite $\left(\mathrm{P} Z \mathrm{Z}_{\mathrm{z}}\right)$ are in places quartzite. The most prominent of these are the Milton quartzite unit of Billings (1976a), in the southern part of the basin, and the Tufts Quartzite Member, described by Billings (1929) and LaForge (1932), in the northern part of the basin. Billings (1976a, p. 12) projected the Milton quartzite unit to lie about 820 $\mathrm{m}$ above the Squantum Member of the Roxbury Conglomerate in east Milton. He projected the Tufts Quartzite Member to lie 2,280 m below the Squantum Member (Billings, 1976b, p. 35), which places it quite low in the section (fig. 9). Red sandstone and sandy argillite shown by Kaye (1980) in the Chelsea and Revere area and in the Milton-Quincy area intertongue with green argillite of the Cambridge. Kaye (1980) claimed that the red beds lie above the cleaner quartzites such as the Tufts Member and Milton unit. The possible significance of these quartzites in the otherwise turbidite-type bedding of the Cambridge is discussed in the following section.

\section{PALEOENVIRONMENT}

The descriptions of the formations of the Boston Bay Group given by Rehmer and Roy (1976; fig. 9) indicate that the group was deposited in a fairly low-energy environment in a marine or lacustrine basin. The Roxbury Conglomerate represents deposits proximal to a volcanic source area in an alluvial fan-delta complex. Laminar graded beds of fine-grained sand and silt are interstratified with the coarser clastic beds and the volcanic material. The Cambridge Argillite represents primarily distal deposits of mud and silt characterized by rhythmic bedding but containing wedges of sand from near-shore sources intertonguing with the silt and mud as water levels shifted. It is not certain whether there is more than one quartzite horizon and whether the quartzite represents shoal areas during Cambridge deposition or marine regression followed by transgression in the Cambrian. The presence of acritarchs (Lenk and others, 1982) suggests that the basin was marine, possibly protected in some way. The bedding style in the Cambridge suggests turbidite deposition. The Squantum Member "tillite" could be more aptly considered in this environment to be a submarine-landslide deposit, perhaps derived from glacial deposits, as suggested by Rehmer and Hepburn (1974), or from other sediments, in accordance with the doubts of Caldwell (1981) concerning the glacial origin of the Boston Bay Group. Laminar graded beds like those in the Cambridge are present in the Mattapan Volcanic Complex (Lyons and Goldsmith, 1983), indicating a long-standing basin in which the environment of deposition changed from primarily volcanic (Mattapan) to primarily proximal turbidite (Roxbury) to primarily distal turbidite (Cambridge).

The total thickness of the Boston Bay Group increases from south to north (Billings, 1976a; fig. 9). The Brookline Member is thickest over the central anticline and thins to the south. These relations indicate that the material was derived from a southern and southwestern source and that the basin of deposition deepened to the north and northeast. The center of the basin subsided more rapidly than the margins (Billings, 1976a). The Squantum Member, however, appears to maintain a fairly uniform thickness (fig. 9), suggesting a cessation of subsidence toward the end of Roxbury deposition.

\section{AGE}

The age of the Boston Bay Group has long been a matter of controversy. Suggested ages have ranged from Primordial (Cambrian) (Crosby, 1880) to Pennsylvanian (Crosby, 1900; Emerson, 1917), on the basis of lithologic correlation with the strata in the Narragansett basin and now discounted plant fossils; the most recent suggestion is Proterozoic Z (Kaye and Zartman, 1980; Lenk and others, 1982). Kaye and Zartman concluded that the Boston Bay Group lay below the fossiliferous Cambrian strata located on the margin of the basin, on the basis of an interpretation of field relations between the Cambrian strata and the strata within the basin. This interpretation has been recently supported by the identification of acritarchs in the Cambridge Argillite, including a diagnostic species that ranges in age from Proterozoic $\mathrm{Z}$ to Early Cambrian but that is most abundant in Proterozoic $\mathrm{Z}$ time (Lenk and others, 1982). Billings (1982, p. 912) estimated that the horizon containing the acritarchs lies about $3,300 \mathrm{~m}$ below the highest beds of the Cambridge, as deduced from his tunnel investigations in the Boston area, and about $2,500 \mathrm{~m}$ above the lowest beds (fig. 9). No acritarchs or other microfossils were found by Lenk and others in the known Cambrian rocks adjacent to the basin (P.K. Strother, oral commun., 1982). No reliable diagnostic fossils other than these have been found in the rocks of the Boston Bay Group (Lyons and Goldsmith, 1983). The Proterozoic $Z$ age indicated by the acritarchs is supported on several other counts: none of the plant fossils so numerous in the strata of the Narragansett basin have been found; Kaye (1980) showed that the Quincy Granite of Late Ordovician to Early Silurian age contains argillite inclusions that are on strike with Cambridge Argillite; and the primarily marine stratigraphy is not similar to the terrestrial stratigraphy in the Nar- 
ragansett basin (Mutch, 1968). The basal Cambrian strata in eastern Massachusetts are quite unlike the Roxbury Conglomerate.

Existing evidence thus indicates a certainly Proterozoic $\mathrm{Z}$ to possibly Early Cambrian age for the Boston Bay Group. How much of the Boston Bay Group may be Cambrian is uncertain. David D. Ashenden (written commun., 1980) of the Metropolitan District Commission, who has studied in detail cores of both the Cambridge Argillite in the Roslindale syncline and the Braintree Argillite ( $($ bow on the State bedrock map) at the Old Quincy Reservoir, Braintree, concluded that the two rocks are identical. C.A. Kaye (oral commun., 1979) believed that quartzites like the Tufts Quartzite and the Milton quartzite unit as used by Billings (1976a) and overlying red beds may be basal Cambrian and that overlying red sandstone and sandy argillite are Cambrian strata. These red beds interfinger with green and red argillite mapped as Cambridge in the northern and southern parts of the basin. However, to date, Cambrian strata have been found only on or beyond the margins of the Boston basin.

\section{CAMBRIAN STRATA}

Fossiliferous rocks of Cambrian age in eastern Massachusetts are found in and around the Boston basin, at Hoppin Hill in North Attleboro, and north of Diamond Hill in West Wrentham. The largest area of fossiliferous Cambrian is south of the Boston basin in the Braintree and Weymouth areas (fig. 8) where the Weymouth Formation and Braintree Argillite contain Lower and Middle Cambrian fossils, respectively. The many studies of fossils from these formations have been summarized by Theokritoff (1968). Mr. G. Stinson Lord of Quincy has made extensive fossil collections in these formations. Lower Cambrian fossils have been found on the north side of the Boston basin at Nahant (Foerste, 1889) and at Revere Beach by C.A. Kaye (oral commun., 1981). The Lower and Middle Cambrian Hoppin Formation at Attleboro and West Wrentham (WW, fig. 10) has been described by Foerste (in Shaler and others, 1899), Shaw (1950, 1961), and, more recently, Anstey (1979) and Landing and Brett (1982). Fossils reported as Upper Cambrian by Rhodes and Graves (1931) from the Green Lodge Formation near Dedham, Mass., cannot be reliably assigned to that period according to Shaw (1961, p. 436). The Braintree Argillite and the Weymouth Formation have been combined into a single unit ( $\epsilon$ bw) on the State bedrock map because of their small areal distribution.

Rocks of Cambrian age may be more widely distributed than has been mapped. C.A. Kaye (oral commun.,
1979) believed that some of the red sandstones in the Cambridge Argillite at the northern part of the Boston basin could be Cambrian rather than Proterozoic $\mathrm{Z}$ in age. Chute (1964) described beds resembling Cambrian strata in the Wamsutta Formation in the Norfolk basin, and J.P. Schafer (oral commun., 1982) has observed limestone-bearing beds in the Wamsutta near outcrops of Dedham Granite in the Attleboro area southeast of Hoppin Hill that might be Cambrian strata. Cambrian strata have been found to be much more extensive than previously thought in southern Rhode Island (Skehan and others, 1981), although, as Skehan and others pointed out, Dale $(1885 \mathrm{a}, \mathrm{b})$ early differentiated what are known to be Cambrian strata from the Pennsylvanian strata in Rhode Island.

The Cambrian fossil assemblages in eastern Massachusetts and Rhode Island are all of the Acado-Baltic province (Theokritoff, 1968) and compare favorably with assemblages from southeastern Newfoundland, England, and Morocco (Landing and Brett, 1982; Skehan and others, 1978).

\section{HOPPIN FORMATION $(€ h)$}

A sequence of strata containing Lower Cambrian fauna at Hoppin Hill, North Attleboro (fig. 10), was named the Hoppin Slate by Foerste (in Shaler and others, 1899) and more recently named the Hoppin Formation (Goldsmith and others, 1982a) because the sequence contains rocks other than slate. The Hoppin Formation ( $€ \mathrm{~h}$ ) consists primarily of green and red slaty shale, locally containing calcareous nodules, and lenses and layers of red argillaceous limestone. At the base it contains arkosic quartzite, which is locally conglomeratic, and sandstone. The nonconformity at the base of the Hoppin Formation is clearly exposed at Hoppin Hill (Dowse, 1950). Anstey (1979) studied the Hoppin Formation in detail and measured several sections in and around the Hoppin Hill Reservoir (fig. 11). The section shown in figure 12 , measured by me before I was aware of Anstey's work, duplicates section A of Anstey. On the east side of Hoppin Hill, a basal quartzite and grit unit containing quartz and feldspar grains from the underlying Dedham Granite rests nonconformably on the Dedham. Obscure crossbedding indicates the beds top away from the granite. The quartzite (10-15 m thick), which is conglomeratic in places, is interbedded with and passes upward into arenaceous slate, argillaceous siltstone, and dark-green slate containing thin sandy horizons above scour-fill channels $(18-30 \mathrm{~m})$. This unit is succeeded by red argillaceous limestone, containing fossil fragments (biomicrite, biomicrudite) dominated by Volborthellids, hyolithids, and trilobites, interbedded with red slate $(34-44 \mathrm{~m})$. This limestone and slate unit is overlain by a 


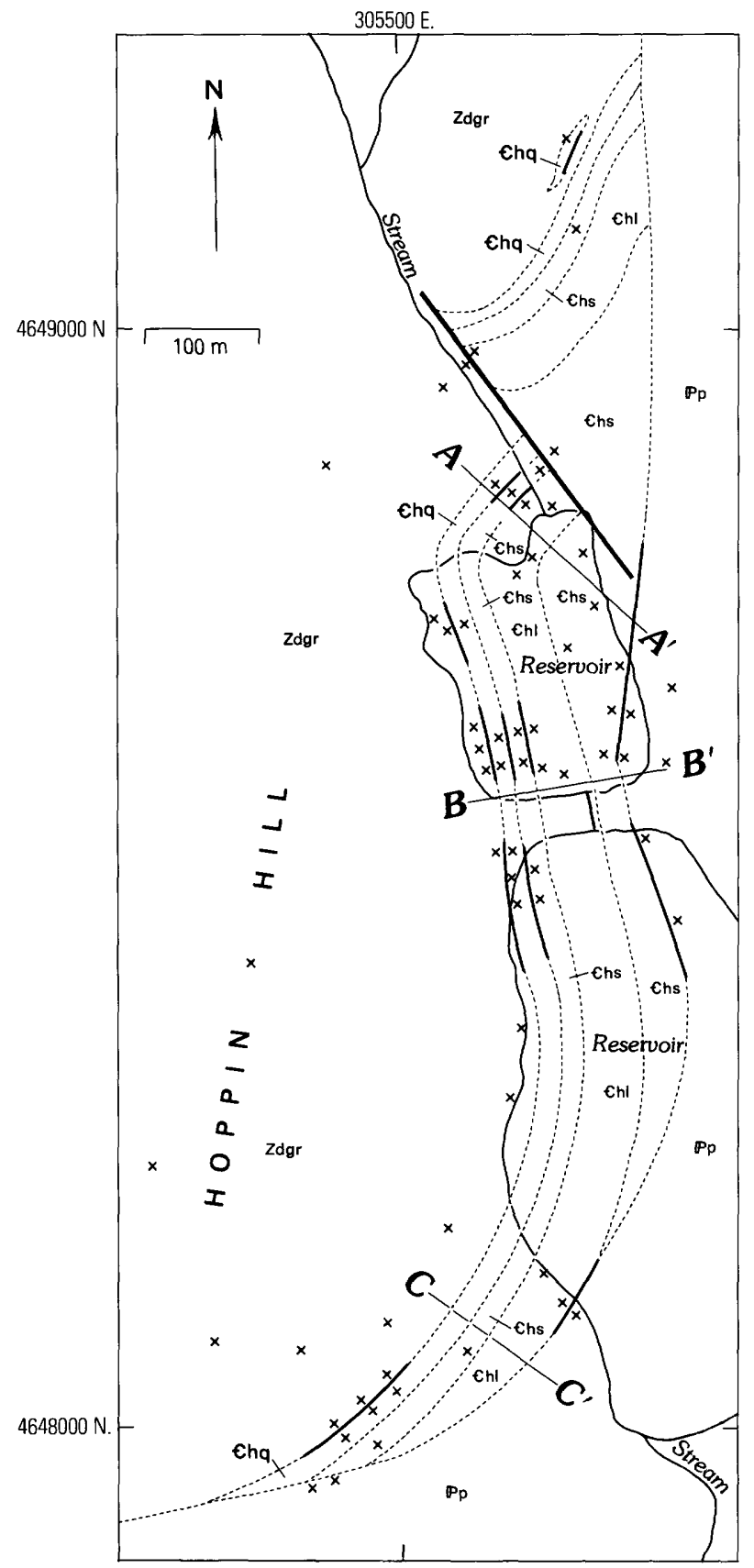

1000-meter Universal Transverse Mercator grid ticks, zone 19, shown for reference
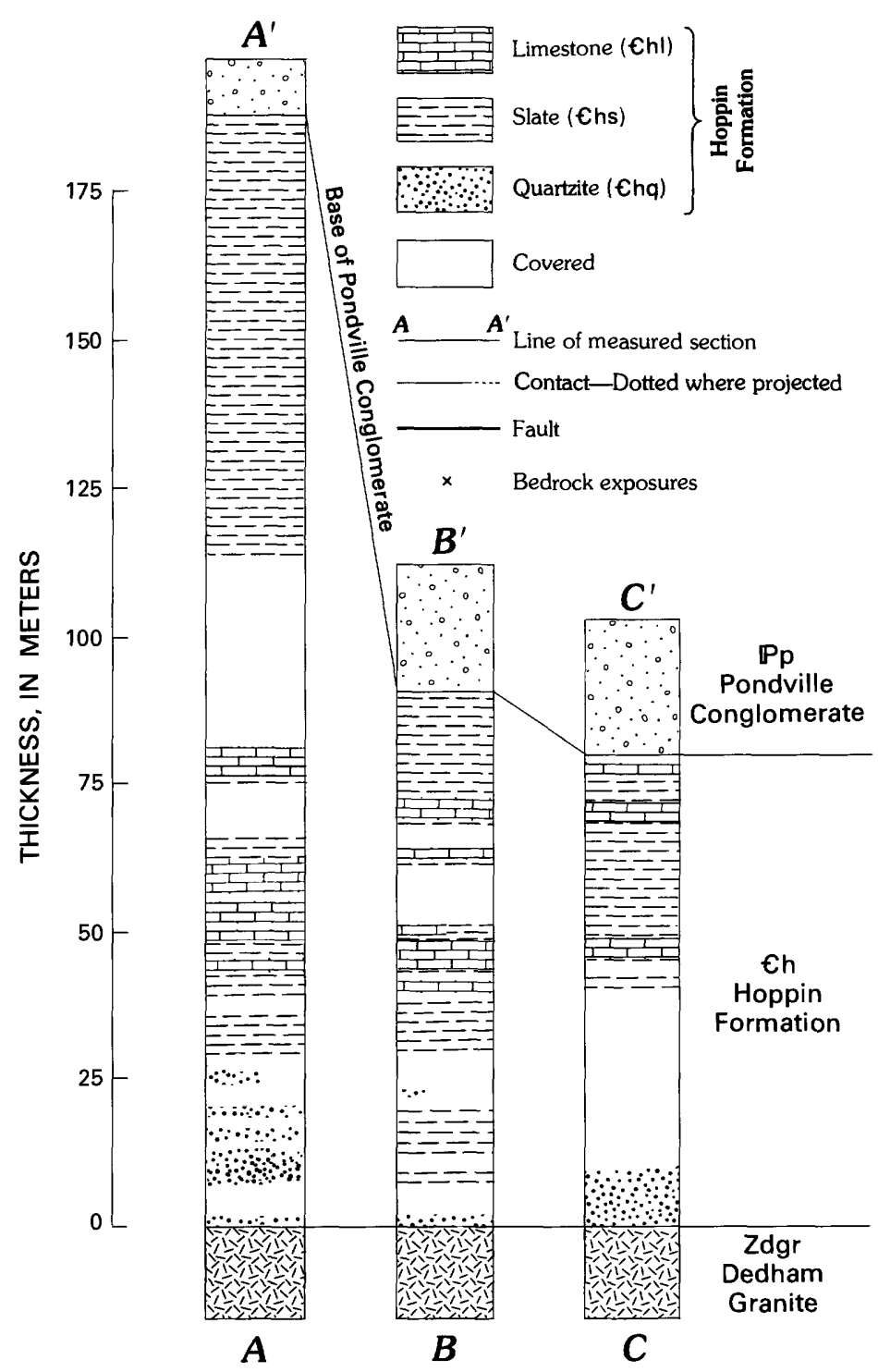

FigurE 11.-Geologic map and measured sections on the east side of Hoppin Hill, Attleboro, Mass.

thick nonfossiliferous section of red and green slate (more than $186 \mathrm{~m}$ ). The top of the sequence is overlain in angular unconformity by the Pondville Conglomerate of Early Pennsylvanian age. Measured sections indicate the exposed maximum thickness of the Hoppin Formation is approximately $244 \mathrm{~m}$. Skehan (1969, p. 798) believed the Hoppin Hill section is similar in lithology to the Manuels Brook section in the Avalon terrane of southeastern
Newfoundland described by Walcott (1890; cited by Hutchinson, 1962).

The Hoppin Formation at West Wrentham is poorly exposed in a hillock beneath a powerline east of Cumberland Street, just north of the Rhode Island State line. Here, red and green slate and red argillaceous limestone containing fossil fragments similar to those at Hoppin Hill can be found. A small outcrop of quartz on the 


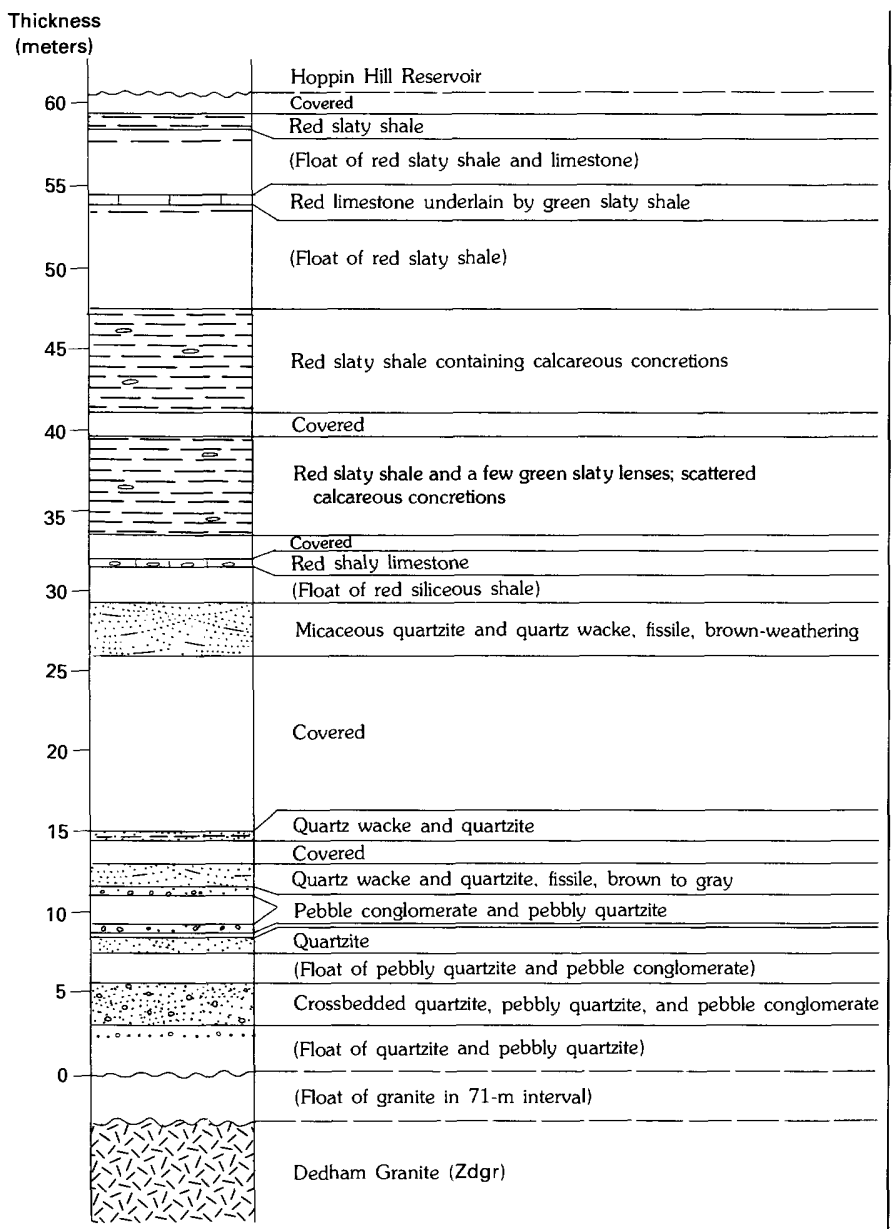

FiguRE 12.-Measured section of Lower and Middle Cambrian strata of the Hoppin Formation at the north end of Hoppin Hill Reservoir.

southwest side of the hillock may be vein quartz, related to the massive vein quartz at Diamond Hill immediately to the south, rather than the basal quartzite. An inclusion of "slate" in ledges of Dedham Granite adjacent to the west mentioned by Foerste (in Shaler and others, 1899 , p. 393) is not the Hoppin Formation strata but is a chloritoid-bearing phyllite (E-an Zen, oral commun., 1979) belonging to the Blackstone Group, which crops out $0.7 \mathrm{~km}$ to the southwest. The contact with the Dedham to the west is probably a fault. To the north and east of the hillock is the Wamsutta Formation, and to the south are the felsic volcanic rocks of Diamond Hill.

\section{WEYMOUTH FORMATION AND BRAINTREE ARGILLITE (Ebw)}

The Weymouth Formation ( $€ b w)$ at Weymouth consists primarily of greenish-gray and dark-red slate containing calcareous nodules, and subordinate beds and lenses of argillaceous limestone. It was locally converted to hornfels by the intrusion of Quincy Granite. At Nahant (fig. 8), the Weymouth includes a layer of greenish-white limestone. Kaye (oral commun., 1981; Kaye, 1980) found exposures of Weymouth Formation at Revere Beach following a storm that scoured sand from the beach, which resembled rock in the exposures at Nahant. Clark (1923, p. 475) reported a concentration of fossiliferous pebbles within a mile of the south end of the beach. Fossils in the Weymouth are largely conoidal forms but include some olenellids. The lithology of the Weymouth is similar to that of the Hoppin Formation at Hoppin Hill, except that the lower quartzitic part of the section has not been recognized. A complete section of the Weymouth Formation has been nowhere described. The base of the Weymouth is not exposed in the Boston area, and its thickness can only be inferred to be at least $100 \mathrm{~m}$ (LaForge, 1932, p. 20).

The Braintree Argillite ( $€ b w)$ is present only south of the Boston basin in and around the Quincy Granite. The formation consists of noncalcareous green to dark-gray or black massive slate or argillite. Adjacent to the Quincy Granite it is a greenish-gray hornfels with indistinct bedding. Chute (1969) described the Braintree in the Blue Hills quadrangle as a dark-gray slate containing thin beds of light- and medium-gray siltstone. The slate is cyclically thinly bedded. LaForge (1932) estimated the thickness to be at least $1,000 \mathrm{ft}(300 \mathrm{~m})$. Its contact with the underlying Weymouth Formation is nowhere exposed, nor is the top of the formation known. No complete section has been described. The faunal assemblage in the Braintree is characterized by Middle Cambrian representatives of Paradoxides. At Conanicut Island in southern Rhode Island, Skehan and others $(1978,1981)$ described a Middle Cambrian sequence 350 $\mathrm{m}$ thick of siltstone and phyllite in which the beds in the lower part coarsen upward, indicating deposition in shallow water, and the beds in the upper part are cyclic and fine grained, indicating deposition in quieter water. The lower part of the sequence contains a trilobite fauna characterized by Badelusia and Paradoxides. The upper part is nonfossiliferous. The lithologies described there appear to be similar to those of the Braintree.

\section{GREEN LODGE FORMATION OF RHODES AND GRAVES (1931) $(€ \mathrm{~g})$}

Poorly preserved brachiopod impressions in a quartzite $(€ g)$ in the Dedham area were reported by Rhodes and Graves (1931). The fossiliferous quartzite is in a sequence of light-gray quartzite overlain by dark-gray phyllite containing siltstone laminae and thin layers of siltstone containing limonite-bearing pits. These rocks were exposed in a hill south of Route 128 near the Westwood-Dedham town line. Rhodes and Graves (1931) named the sequence the Green Lodge Formation and 
assigned it to the Upper Cambrian on the basis of the fossil impressions. Shaw (1961, p. 436), however, examined the fossils from the Green Lodge and said that they were too poorly preserved for reliable assignment. The Green Lodge therefore is shown as questionable Upper Cambrian on the State bedrock map. The outcrops, also seen by Loughlin (1911; Loughlin and Hechinger, 1914) and by Chute (1964), are no longer accessible because of construction. Chute estimated that about $150 \mathrm{~m}$ of phyllite is present overlying an undeterminable thickness of quartzite. Rhodes and Graves estimated the thickness of the Green Lodge to be not less than $300 \mathrm{~m}$. Chute (1964) mapped a locality of similar phyllite on the main Amtrak railroad line in southern Norwood but did not correlate this phyllite with the Green Lodge.

The Green Lodge is most likely the source of the fossiliferous quartzite pebbles found in the Pennsylvanian Purgatory Conglomerate in the Narragansett basin in Rhode Island and also in the glacial drift on Cape Cod and the offshore islands (Kaye, 1983b). Samples of quartzite containing impressions of fossils gathered from outcrops of the Green Lodge shown to me by C.A. Kaye are similar to pebbles he has collected from the drift. The Green Lodge then may be more extensive beneath the glacial drift than it appears; it is shown on the State bedrock map as covering a larger area than originally shown by Rhodes and Graves (1931) and Chute (1964).

\section{PALEOENVIRONMENT}

The Cambrian strata in eastern Massachusetts represent a marine littoral to shelf sequence of sediments. Anstey (1979) described the Lower to Middle Cambrian Hoppin Formation as a deepening-upward transgressive marine sequence. The basal quartzite in the Hoppin Hill area is a littoral deposit lying nonconformably on a Proterozoic $\mathrm{Z}$ granitic terrane. The calcareous fossiliferous beds represent a near-shore shoal deposit, and the overlying nonfossiliferous slates in the upper part of the sequence represent detrital muds washed further offshore. The lithologically similar Weymouth Formation around the Boston basin can be interpreted as representing the same sedimentary sequence. The cyclically bedded fossiliferous silt and shale of the Middle Cambrian Braintree Argillite were deposited in relatively shallow water but in a low-energy environment. The Middle Cambrian at Conanicut Island, R.I., described by Skehan and others $(1978,1981)$ represents a transgressive sequence. A minor regression may have occurred between Early and Middle Cambrian time. If the quartzite of the Green Lodge is indeed Upper Cambrian, then a return to littoral conditions occurred in Late Cambrian time. The paleoenvironment of the Cambrian thus seems to be one of low tectonic activity in which crustal movements were epeirogenic. The volcanic activity of Proterozoic Z time had ceased. The Proterozoic Z batholiths were exposed and were being eroded on a surface of low relief flanked by a transgressing shallow sea.

\section{NEWBURY VOLCANIC COMPLEX (SILURIAN AND DEVONIAN)}

Sedimentary and volcanic rocks of known Silurian and Devonian age in eastern Massachusetts are confined to two wedge-shaped and lenticular fault-bounded basins aligned between Newburyport and Middleton-Topsfield (fig. 3). The Newbury Volcanic Complex (DSn) was carefully described by Shride (1976) in the Newburyport and Rowley area and by Toulmin (1964) in the MiddletonTopsfield area. The information below is condensed from Shride's description.

The lower part of the Newbury Volcanic Complex (DSnl, DSna), 2,900 $\mathrm{m}$ thick, is composed largely of volcanic materials consisting of basalt flows; flow-banded rhyolite, vitrophyre, and ash-flow tuff; and porphyritic andesite flows, breccias, and tuff, partly waterlain. The upper part of the complex (DSnu), 1,500 m thick, consists of shallow marine siliceous siltstone, red sandy mudstone containing some volcanic detritus, and calcareous mudstone. The porphyritic andesite (DSna) contains a shelly fauna indicating a latest Silurian age (Pridolian). The calcareous mudstone of the upper part (DSnu) contains ostracodes having a greater range than the andesite fauna, and it could be as young as earliest Devonian (Gedinnian). Lenticular masses of micrographic rhyolite (DSnr) 100-600 m thick intrude the sequence subparallel to the strata at various horizons. Neither the top nor the bottom of the complex is known. The rocks have undergone no more than diagenesis and propylitization, as indicated by the descriptions by Shride (1976). Primary textures are well preserved.

The Newbury Volcanic Complex can be correlated with rocks along the Appalachian trend to the northeast, but no Upper Silurian and Lower Devonian rocks of this sort are known to the southwest. The Newbury is equivalent to the Leighton Formation of the Pembroke Group in the Eastport area, Maine, on the basis of correlation of the shelly fauna. Faunal assemblages of the Leighton are of Acado-Baltic affinity. The Ames Knob Formation and the Thorofare Andesite of the Penobscot region, Maine, are also temporal equivalents. On the basis of similar lithologies, the Newbury has been equated in the past with the Mattapan and Lynn Volcanic Complexes in the Boston area, but the Mattapan and the Lynn now are believed to be Proterozoic $\mathrm{Z}$ in age.

\section{PENNSYLVANIAN STRATA}

Fossiliferous rocks of Pennsylvanian age in the Milford-Dedham zone in Massachusetts occupy the 
Norfolk and Narragansett basins (figs. 1, 8, 10). These rocks consist of the Pondville Conglomerate $(\mathbb{P p})$, Wamsutta Formation ( $\mathbb{P w}, \mathbb{P w v}$ ), Rhode Island Formation $(\mathbb{P r}, \mathbb{P r c})$, and Dighton Conglomerate ( $\mathbb{P d})$. The nonfossiliferous Bellingham Conglomerate ( $\mathrm{PZb}$ ) occupies the Bellingham basin. The Bellingham is usually correlated with the Pennsylvanian strata in the Narragansett and Norfolk basins, but it may instead be of Proterozoic $\mathrm{Z}$ age. The only other known fossiliferous rocks of Pennsylvanian age in Massachusetts are the Coal Mine Brook Formation ( $(\mathrm{cm})$ at Worcester on the east edge of the Merrimack synclinorium (Goldsmith and others, 1982a). The Coal Mine Brook Formation is discussed in the chapter on the Merrimack belt (Robinson and Goldsmith, this vol., chap. G).

\section{BELLINGHAM CONGLOMERATE (PZb)}

The Bellingham Conglomerate (PZb) (Mansfield, 1906; Hall, 1963; Quinn, 1971) is primarily a conglomerate and lithic graywacke and is confined to the Bellingham basin. The dominant lithology, conglomerate, consists of quartzite and granite pebbles and cobbles, flattened in varying degrees, set in a green and greenish-gray micaceous matrix. Interbedded with the conglomerate and lithic graywacke is chlorite phyllite composed of muscovite, quartz, chlorite, zoisite, magnetite, and locally chloritoid (Warren and Powers, 1914). An outcrop of Bellingham Conglomerate near the intersection of Blackstone Street and River Street in Woonsocket (fig. 4) consists of green conglomerate containing pebbles of granite in a sandy matrix, green sandstone, and darkgreen phyllite containing a lens of gray limestone. The Bellingham Conglomerate contains pebbles of quartzite from the adjacent Blackstone Group and of Milford Granite containing its typical blue quartz; it is therefore locally derived. An instructive exposure lies on the east side of Woonsocket Hill, southeast of Woonsocket. Here cliffs of steeply dipping, thin-bedded, white to gray quartzite of the Blackstone Group stand above green schistose conglomerate, containing many flattened white to gray quartzite pebbles, and interbedded green calcareous quartz schist. The contact is probably a fault here, but the source of the quartz pebbles is obvious. It is difficult to distinguish schists of the Blackstone Group from those of the Bellingham in this area because of the low-grade metamorphism of the Blackstone. Warren and Powers (1914) claimed the distinction could be made in that schists of the Blackstone contain knots of epidote, whereas schists of the Bellingham do not. This criterion is not always reliable, and it is possible, if not probable, that some of the low-grade Blackstone Group mapped in the Blackstone River valley northwest of Woonsocket is part of the Bellingham.
Volcanic rocks are present in a few places in the Bellingham. Near the edge of the basin, in a roadcut on new Route 146 at Premisy Hill, west of Woonsocket, a rhyolite porphyry sill $30 \mathrm{~cm}$ thick cuts actinolitic greenstone, schist, thin gray quartzite, and gray, streaked biotite schist containing epidote pods, rocks probably belonging to the Blackstone Group. East of Bellingham in the Franklin area are exposures of felsite porphyry described in an earlier section that may be the same age as the Bellingham Conglomerate. Warren and Powers $(1914$, p. 448) mentioned the presence of amygdaloids in the Bellingham area, but I could not locate these in my reconnaissance. Exposures are poor in the Bellingham basin north of Woonsocket, and the distribution of the Bellingham is mapped largely from float.

The age of the Bellingham is conjectural. No fossils have been found. Customarily the rocks have been correlated with rocks of the Narragansett basin and thus labeled as Pennsylvanian in age. Rocks in some exposures, such as the one at River Street and Blackstone Street in Woonsocket, resemble outcrops of Roxbury Conglomerate seen in the Boston basin, and it is not unreasonable to assume that the age of the Bellingham conglomerate is similar to that of those rocks in the Boston basin as suggested by Skehan and Murray (in Skehan and others, 1979, p. 14-15). Some support for this conclusion lies in the observation that the Bellingham basin is a structural trough (Goldsmith, this vol., chap. H) that extends southwest from the Boston basin and that separates primarily gneissic Proterozoic Z granitoids from altered but nongneissic Proterozoic Z granitoids (Wones and Goldsmith, this vol., chap. I). In deference to tradition, however, and because a Proterozoic $\mathrm{Z}$ age is not proven but only suspected, the Bellingham Conglomerate in the Bellingham basin is shown as Pennsylvanian to Proterozoic $\mathrm{Z}$ in age on the State bedrock map.

\section{PONDVILLE CONGLOMERATE (Pp), WAMSUTTA FORMATION (Pw, Pwv), RHODE ISLAND FORMATION (Pr, Prc), AND DIGHTON CONGLOMERATE (Pd)}

The Pondville Conglomerate, Wamsutta Formation, Rhode Island Formation, and Dighton Conglomerate are the stratigraphic units of known Pennsylvanian age in the Norfolk and Narragansett basins in Massachusetts. These formations and the Purgatory Conglomerate in Rhode Island were referred to collectively as the Narragansett Bay Group by Skehan and Murray (in Skehan and others, 1979, p. A4). The Pennsylvanian strata in the Narragansett and Norfolk basins have been described by many authors from Shaler and others (1899) through Quinn and Oliver (1962), Mutch (1968), and Skehan and Murray (1978). This work was summarized by Skehan 
Table 5.-Description of stratigraphic units in the Narragansett and Norfolk basins

[Modified slightly from Skehan and others (1979, table 1)]

\begin{tabular}{|c|c|c|c|c|c|}
\hline Name & Description & $\begin{array}{l}\text { Sedimentary } \\
\text { and other } \\
\text { distinguishing } \\
\text { features }\end{array}$ & $\begin{array}{l}\text { Approxi- } \\
\text { mate } \\
\text { thickness } \\
\text { (meters) }\end{array}$ & Age & Additional references ${ }^{1}$ \\
\hline $\begin{array}{l}\text { Purgatory } \\
\text { Conglom- } \\
\text { erate. }\end{array}$ & $\begin{array}{l}\text { Coarse-grained to very coarse grained } \\
\text { conglomerate containing thin lenses of } \\
\text { sandstone and magnetite-rich sand- } \\
\text { stone; clasts in conglomerate consist of } \\
\text { several varieties of quartzite. }\end{array}$ & Not given & 30 & $\begin{array}{l}\text { No Pennsylvanian } \\
\text { flora yet known; } \\
\text { distinetive early } \\
\text { Paleozoic faunas } \\
\text { are present in } \\
\text { quartzite clasts. }\end{array}$ & $\begin{array}{l}\text { Mosher and Wood } \\
\text { (1976). }\end{array}$ \\
\hline $\begin{array}{l}\text { Dighton } \\
\text { Conglom- } \\
\text { erate. }\end{array}$ & $\begin{array}{l}\text { Gray conglomerate consisting primarily } \\
\text { of rounded quartzite cobbles to boul- } \\
\text { ders and containing subordinate } \\
\text { rounded granite cobbles and slate peb- } \\
\text { bles; very little sand matrix; lenses of } \\
\text { medium-grained sandstone form less } \\
\text { than } 20 \text { percent of the unit. }\end{array}$ & $\begin{array}{l}\text { Sandstone lenses are } \\
\text { faintly crossbedded } \\
\text { and coarsen both } \\
\text { upward and down- } \\
\text { ward into adjacent } \\
\text { conglomerate. }\end{array}$ & $<300-450$ & $\begin{array}{l}\text { Late Pennsylvanian; } \\
\text { small isolated } \\
\text { amounts of alloch- } \\
\text { thonous nondiag- } \\
\text { nostic plant debris } \\
\text { are present. }\end{array}$ & None. \\
\hline $\begin{array}{l}\text { Rhode Island } \\
\text { Forma- } \\
\text { tion. }\end{array}$ & $\begin{array}{l}\text { Gray sandstone and siltstone and lesser } \\
\text { amounts of gray to black shale, gray } \\
\text { conglomerate, and coal beds } 10 \mathrm{~m} \\
\text { thick. Sandstone and conglomerate are } \\
\text { quartz rich. }\end{array}$ & $\begin{array}{l}\text { Contains both fining- } \\
\text { and coarsening- } \\
\text { upward sequences; } \\
\text { paleocurrents have } \\
\text { been defined only } \\
\text { locally; conglomerate } \\
\text { is relatively less abun- } \\
\text { dant than in Dighton } \\
\text { Conglomerate. }\end{array}$ & $<3,000$ & $\begin{array}{l}\text { Late and Middle } \\
\text { Pennsylvanian. }\end{array}$ & $\begin{array}{l}\text { Skehan and Murray } \\
\text { (1978), Lyons and } \\
\text { Chase (1976). }\end{array}$ \\
\hline $\begin{array}{l}\text { Wamsutta } \\
\text { Forma- } \\
\text { tion. }\end{array}$ & $\begin{array}{l}\text { Interbedded red coarse-grained conglom- } \\
\text { erate, lithic graywacke, sandstone, } \\
\text { and shale; conglomerate layers less } \\
\text { than } 1.2 \mathrm{~m} \text { thick contain felsite clasts; } \\
\text { a few lenses of limestone, one rhyolite } \\
\text { flow, and several sheets of basalt are } \\
\text { present. }\end{array}$ & $\begin{array}{l}\text { Crossbedding and inter- } \\
\text { fingering of layers are } \\
\text { characteristic. }\end{array}$ & 300 & $\begin{array}{l}\text { Middle and Early } \\
\text { Pennsylvanian; } \\
\text { partly equivalent } \\
\text { to Rhode Island } \\
\text { Formation as the } \\
\text { red layers interfin- } \\
\text { ger with gray and } \\
\text { black; contains a } \\
\text { few plant fossils. }\end{array}$ & Lidback (1977). \\
\hline $\begin{array}{l}\text { Pondville } \\
\text { Conglom- } \\
\text { erate. }\end{array}$ & $\begin{array}{l}\text { At type locality (Pondville Station, } \\
\text { Mass.), interbedded red and green } \\
\text { slate, siltstone, arkose, and quartzite- } \\
\text { pebble conglomerate; elsewhere } \\
\text { includes gray to greenish-gray coarse } \\
\text { conglomerate containing clasts } 15-60 \\
\text { cm in diameter and abundant sandy } \\
\text { matrix (clasts mostly quartzite, but } \\
\text { some are granite or schist) and dark- } \\
\text { gray granule conglomerate containing } \\
\text { pebbles of smoky quartz } 5 \text { mm in } \\
\text { diameter irregularly bedded with } \\
\text { sandstone and lithic graywacke. }\end{array}$ & $\begin{array}{l}\text { First-deposited beds are } \\
\text { siltstone or arkosic } \\
\text { sandstone, rarely con- } \\
\text { glomerate; however, } \\
\text { sandstone and shale of } \\
\text { the Wamsutta Forma- } \\
\text { tion or Rhode Island } \\
\text { Formation may lie } \\
\text { directly on older } \\
\text { rocks. }\end{array}$ & $0-150$ & Early Pennsylvanian & None. \\
\hline
\end{tabular}

${ }^{1}$ These references are in addition to Quinn and Oliver (1962), Mutch (1968), and Quinn (1971), which contain information on all these stratigraphic units.

and Murray and Murray and Skehan (in Skehan and others, 1979). Detailed maps have been made by Chute (1950, 1966, 1969), Hartshorn (1960, 1967), Koteff (1964), and Lyons (1969). Lyons (1977) mapped the Massachusetts part of the Narragansett basin in reconnaissance fashion and reviewed existing detailed work. Drilling by the U.S. Geological Survey (USGS) in 1977 and 1978 showed that the Narragansett basin and its deposits extend to Massachusetts Bay a few kilometers south of Scituate.

The units in the Narragansett and Norfolk basins are described in table 5. Briefly, the strata are primarily fluviatile and consist of sandstone, siltstone, conglomerate, shale, and coal. Volcanic rocks are present in the northwest part of the basin (fig. 10). Chute (1966, p. B32) described lenses of carbonate rock in red and green 
shales in the Wamsutta Formation in the Norwood quadrangle. Limestone has been observed in rock mapped as Wamsutta adjacent to exposed Dedham Granite at the Manchester Pond Reservoir, Attleboro (Schafer, oral commun., 1982). Possibly these red and green shales and calcareous beds are actually Cambrian in age. Total thickness of the strata is estimated to be $3,700 \mathrm{~m}$ (Skehan and Murray, 1978). The Rhode Island Formation is the thickest and most extensive of the formations although it does not extend into the Norfolk basin. Coal beds are found only in the Rhode Island Formation. Only the Pondville Conglomerate and the Wamsutta Formation are present in the Norfolk basin. Chute $(1964,1966$, 1969) recognized a lower boulder conglomerate member and an upper sandstone to pebble conglomerate member in the Pondville in the northeast part of the Norfolk basin, but such a division is not readily made to the southwest because of facies changes. The upper member grades into and interfingers with the Wamsutta Formation; in turn, the Wamsutta interfingers with the Rhode Island Formation in the northwest part of the Narragansett basin. In the northern part of the Narragansett basin, basal beds of the Pondville, the Wamsutta, and in places the Rhode Island Formation rest nonconformably on weathered Dedham Granite. Basal beds are usually sandstone or arkose rather than conglomerate; little indication exists that the material has been transported far. A drill hole near Assonet at the edge of the basin revealed that the basal beds of the Rhode Island Formation were a reworked regolith (J.A. Sinnott, oral commun., 1979). At the northeast end of the Norfolk basin (fig. 8), the Pondville overlies weathered and partly transported Blue Hills Granite Porphyry without clear definition (see Naylor and Sayer, 1976; Naylor, 1981).

Daniels Street, between Medway and Franklin, crosses the top of a hill covered with float of polymict conglomerate containing red-stained gray and white quartzite cobbles and pebbles and fragments of reddishpurple slate. The matrix appears to be reddish-colored sand. No rock was seen in place. The material does not seem to be metamorphic. The bedrock surrounding the hill is granite. This material is shown on the State bedrock map as Wamsutta Formation $(\mathbb{P w})$. It could be Pondville Conglomerate or possibly Bellingham Conglomerate, as it is somewhat on line with the Bellingham basin to the southwest; however, the rock matesial does not seem to be sufficiently metamorphosed to be the Bellingham.

Rhyolite and mafic volcanic rocks in the Wamsutta Formation (Pwv). - A rhyolite flow and two sheets of basalt flanked by fossiliferous horizons lie within the Wamsutta Formation near Attleboro (Lyons, 1977; fig. 10). Here and in the Norfolk basin, conglomerate in the Wamsutta contains many clasts of volcanic rock. Bottino
(1963) attempted to date the rhyolite by using the whole-rock Rb-Sr method, but the material did not yield a reliable date. Differences in initial ratios of strontium isotopes, however, indicated that the rhyolite and the basalts were probably not related (Bottino, 1963).

Northwest of Attleboro, near Grants Mill, R.I., the Diamond Hill Felsite as used by Skehan and Murray (in Skehan and others, 1979, p. A5) is overlain by the Wamsutta Formation at the south end and underlain by the Wamsutta at the north end of the Diamond Hill Reservoir (Quinn and others, 1948, p. 18). The Diamond Hill Felsite is primarily dacite, much altered and cut through by vein quartz; it is gray, greenish gray, and reddish purple, fine grained, and porphyritic (Quinn, 1971, p. 41). Phenocrysts are quartz and altered plagioclase. The rock locally shows flow structure, but much of it is massive. At the north end of the reservoir, I observed greenish-gray, gray, and reddish-purple felsite and agglomerate that pass downward through interbedded tuff, sandstone, slate showing cleavage, and conglomerate containing white quartzite and granite cobbles into red and green conglomerate typical of the Wamsutta Formation. Some faulting has occurred near the contact of the Diamond Hill with the Wamsutta, but displacement appears to have been minor. The amount of volcanic detritus in the Wamsutta indicates that volcanoes were active close to the time of its deposition.

Volcanic rocks somewhat similar to the Diamond Hill Felsite crop out west of Lake Pearl, between Franklin and Wrentham, on the west flank of the Norfolk basin. These are shown as volcanic rocks in the Wamsutta Formation ( $\mathbb{P w v}_{\mathrm{wv}}$ ) on the State bedrock map because of their proximity to Diamond Hill. They also resemble the Mattapan Volcanic Complex, as mentioned in that section of this chapter. The volcanic rocks at Lake Pearl consist of dark- and light-colored aphanitic felsite, agglomerate(?), and breccia. One type is a greenish-gray aphanitic rock containing saussuritized lath-shaped plagioclase and clots of chlorite and iron-oxide in a finegrained matrix of alteration products (white mica, epidote, chlorite). The plagioclase is locally glomerophyric. Another type is a white-weathering, aphanitic rock containing fine-grained angular quartz, feldspar, and rock fragments in a fine-grained sericitic matrix. A lightcolored felsite contains quartz "eyes" like those in the felsite in Franklin. A grayish-green agglomerate or conglomerate containing fragments of felsite porphyry and smaller clasts of quartz and pink feldspar in a greenish-gray sandy matrix exposed on the east side of a large quarry west of Lake Pearl may be part of the volcanic assemblage or it may be basal Wamsutta Formation. Further west, a felsite containing pale-tan phenocrysts in a pale-red aphanitic matrix crops out west of Uncas Brook and east of Summer Street, $2 \mathrm{~km}$ south of 
Franklin. On Summer Street, due west of Uncas Pond, a dike of spherulitic rhyolite containing scattered quartz phenocrysts cuts Dedham Granite. The rocks near and along Summer Street are separated from the volcanic rocks near Lake Pearl by the Wamsutta Formation and a sliver of Dedham Granite but are considered to be part of the volcanic assemblage. Outcrops of fine-grained granite (fgr) and of porphyry exposed in roadcuts north of Lake Pearl in the town of Norfolk and in a few cuts northeast of Lake Pearl near the Wrentham State School may also be part of the volcanic assemblage.

\section{PALEOGEOGRAPHY AND AGE}

Mutch (1968, p. 201-203) discussed the paleogeography of the Narragansett basin; he concluded that a highland supplying most of the detritus for the Narragansett Bay Group of Skehan and Murray (in Skehan and others, 1979) existed to the west and northwest of the basin and that a stable source to the east supplied less material. Current directions measured in the Rhode Island Formation in the northern part of the basin indicate a flow from northeast to southwest. In support of this observation, conglomerate is more abundant on the west and northwest side of the basin than to the east and southeast. In the southern part of the basin in Rhode Island, on the contrary, coarse cobble to pebble conglomerate in the Purgatory Conglomerate is interpreted as being derived from the northeast and east. The center of volcanism was to the northwest. The basin fill is primarily alluvial; conglomerates represent stream channel deposits, and coal beds indicate interchannel swamps.

The age of the deposits ranges from Early to Late Pennsylvanian (table 5), although Skehan and Murray (1980b, p. 69) assigned the lower part of the Pondville to the Upper Mississippian. It is possible that lower parts of the sequence in the Narragansett Bay Group of Skehan and others (1979), below the fossiliferous horizons, may contain Paleozoic strata older than Mississippian or Pennsylvanian. However, little, if any, stratigraphic thickness is present in the northern part of the basin between the fossiliferous horizons and the Cambrian and older rocks, so that such strata must be thin, if they exist. Possibly some nonfossiliferous Cambrian beds have been mistaken for Pennsylvanian beds. The northwest part of the Narragansett basin and the southern part, at least, of the Norfolk basin need critical study in this regard.

\section{TRIASSIC AND JURASSIC ROCKS}

Triassic and Jurassic rocks occupy a small basin, the Middleton basin in Essex County ( $\mathrm{ke}$ ), and lie in the subsurface beneath the Coastal Plain cover in Nantucket Sound and Nantucket Island. The Triassic and Jurassic sedimentary (JK) and volcanic (Jkb) rocks in the Nantucket area are described in a later section of this chapter. An extensive basin of Triassic and Jurassic rocks lies northeast of Essex County in the Gulf of Maine (Uchupi, 1966) and in the Bay of Fundy but is outside the area of the State bedrock map. In this section, only the rocks in the Middleton basin are described.

\section{RED ARKOSIC CONGLOMERATE, SANDSTONE, AND SILTSTONE ( e e)}

A narrow wedge of red to reddish-gray conglomerate, arkosic sandstone, and siltstone ( $\mathrm{k} e$ ) lying near the southernmost of the Newbury basins in the towns of Peabody, Danvers, Middleton, and Topsfield northwest of Salem, Essex County (fig. 3), contains a few shale beds bearing plant fossils of Late Triassic or possibly Early Jurassic age (Kaye, 1983a). Fragments of rock of possible Triassic age were first recognized in the glacial drift in this area (Oldale, 1962). The conglomerate was later exposed on one edge of a quarry in northeast Peabody and called to the attention of C.A. Kaye by A.E. Shride. Plant fossils found later by Peter Robinson from a red shale layer in the conglomerate were examined by E.S. Barghoorn and found to correspond to fossils from the Newark Group of Late Triassic and Early Jurassic age (Kaye, 1983a). The true size and shape of the basin called the Middleton basin by Kaye (1983a) is not known. It is fault bounded on its southeast side. Its northwest side is not exposed; the strata are only exposed in the quarry face. Its size is inferred, from its topography and aeromagnetic signature, to be about $5.7 \mathrm{~km}$ by $0.5 \mathrm{~km}$.

The strata are poorly to well bedded. Conglomerates are poorly sorted and have abundant sandy matrix. The conglomerate contains rounded to subrounded cobbles of nearby granite and granodiorite and poorly rounded to angular fragments of red shale and sandstone.

\section{STRATIGRAPHIC PROBLEMS}

The descriptions of the various units in the MilfordDedham zone and the discussions of their relationships presented in the preceding sections have revealed a number of problems and uncertainties, which need further investigation. All of these problems require field work, but some require an emphasis on petrologic, petrochemical, and isotopic methods; others an attention to structural features and degree and nature of metamorphism; and others a more thorough stratigraphic analysis. 


\section{FELSIC VOLCANIC ROCKS}

Immediately obvious from the descriptions of the rock units presented earlier in this chapter is the confusion between two similar-appearing volcanic assemblages, one dated as Proterozoic Z (the Mattapan and Lynn Volcanic Complexes) and the other dated as Early and Middle Pennsylvanian (the volcanic rocks in the Wamsutta Formation at Attleboro and at Diamond Hill). Emerson (1917) equated the Diamond Hill Felsite with the Mattapan, both of which were then considered to be Carboniferous in age. Since then, the Mattapan has been revealed to be Proterozoic $\mathrm{Z}$ in age, whereas the Diamond Hill Felsite is still considered to be Carboniferous. LaForge (1932), who considered the Mattapan to be Silurian or Devonian, recognized the problem of having dissimilar ages for similar rocks. He said (LaForge, 1932, p. 29):

So far there is no difficulty in correlating the volcanic rocks (Mattapan and Lynn), but an argument of the same sort fails when applied to the volcanic rocks of the Attleboro district, in the Narragansett basin. Those rocks, which are of the same lithologic types as part of those of the Mattapan complex and hence might be supposed to be of the same age, are interstratified with sedimentary rocks that are undoubtedly Pennsylvanian. At what point in the chain of reasoning there is a flaw has not been determined***.

The felsic volcanic rocks flanking the Norfolk basin near Lake Pearl and flanking the northern part of the Bellingham basin lie between the two areas, and their age assignment is moot. Petrologic geochemical studies such as Zarrow's (1978) studies on the Lynn and Mattapan Volcanic Complexes might be of considerable aid in comparing the suites, as would radiometric analyses. Detailed mapping in the different areas might reveal significant differences in the associated sedimentary strata and in the structural position of the rocks. At the present time, I am not convinced that all of the strata mapped as Wamsutta Formation in the northwest Narragansett basin and southern Norfolk basin are of Pennsylvanian age. Just as agglomerate of the Mattapan has been mistaken for Roxbury Conglomerate in the Boston basin, so may fragmental rocks to the south in the Norfolk basin and northwest part of the Narragansett basin have been wrongly assigned to the Carboniferous. In this regard, the volcanic rocks at Attleboro and at Diamond Hill appear only in the part of the basin where basement is shallow and projects in two places through the Pennsylvanian strata; one at Hoppin Hill and another to the south-southwest at Manchester Pond Reservoir, Attleboro (J.P. Schafer, oral commun., 1982), where a sliver of granite like that at Hoppin Hill is brought up along a reverse fault. The granite is overlain by carbonate rocks and red beds (J.P. Schafer, oral commun., 1982) that resemble the Cambrian strata at Hoppin Hill. Perhaps even older strata such as those in the Boston basin may be faulted up in this area. However, in neither area are there volcanic rocks between the Pennsylvanian strata and the basement. The Cambrian, where known, rests directly on granitic basement. Possibly Precambrian rocks are preserved in down-dropped blocks such as the Bellingham basin. The Pennsylvanian age for the volcanic rocks at Attleboro seems fairly firm. The most likely possibility is that the felsic volcanic rocks near Lake Pearl flanking the Norfolk basin are Pennsylvanian but the felsic rocks flanking the Bellingham basin, Zfm ( $\mathrm{Zm}$ on map), are equivalent to the Mattapan. This is the interpretation used on the State bedrock map. The Boston basin and the Bellingham basin lie along the same structural grain (figs. 1, 8), whereas the Norfolk basin is offset south of the Boston basin.

A less obvious problem pertaining to the felsic volcanic rocks in the Milford-Dedham zone is the correlation of the layered felsic rocks in the Natick-Framingham area shown as metamorphosed felsic volcanic rocks (Zvf) on the State bedrock map (lower part of the Cherry Brook Formation of Nelson) and the Mattapan Volcanic Complex in the Boston area, which lies above the Middlesex Fells Volcanic Complex. The felsic volcanic rocks at Framingham have been suggested as being the volcanic cover into which the Milford-Dedham granite plutons intruded. Most of the Mattapan, however, lies nonconformably above the batholithic rocks and is intrusive into them, or in a few places is paracontemporaneous with them. Because the Proterozoic $\mathrm{Z}$ batholiths of eastern Massachusetts comprise several plutons differing in age and composition, the associated felsic volcanic rocks in different areas could be pre-, post-, or syngranite. The Mattapan and the felsic rocks in the Framingham area thus could belong to a suite of felsic volcanic rocks having a range of age similar to that in the granitic plutonic rocks. Similar relations in rocks of the same time interval have been described by Wood (1974) in Anglesey, Wales, and by Hughes and Bruckner (1971) in Newfoundland. Bell and Alvord (1976) did not have a zone of felsic metavolcanic rocks below the Middlesex Fells, and Drier and Mosher (1981) pointed out the lack of felsic volcanic rocks below the Hunting Hill Greenstone in northern Rhode Island. I suggest that the felsic layers in the Framingham area are not volcanic rocks but thin intrusive sheets into the mafic volcanic suite. They are here in a more highly metamorphosed regime than in the Boston basin and in addition are close to and in a zone of ductile shear associated with the Bloody Bluff fault zone (Nelson, 1976). In this interpretation the felsic layers are younger than the mafic volcanic rocks; they are more or less synchronous with emplacement of the Proterozoic Z granites and thus more or less equivalent in age to the Mattapan. A similar situation exists in southeastern Connecticut, where thin sheets of metamorphosed finegrained alaskite are interlayered with metamorphosed 
mafic volcanic rocks above thick intrusive sheets of Hope Valley Alaskite Gneiss. These thin sheets have been ductilely deformed, producing the thinly layered to laminated blastomylonites in the Honey Hill fault zone, referred to earlier, and alternating layers and laminae of felsic and mafic material. Another explanation for the apparent interlayering of mafic and felsic rock is that the mafic layers are dikes, for example dikes of Brighton Melaphyre, cutting the intrusive granite sheets, which have been subsequently brought into parallelism through pervasive ductile shear. One sees a suggestion of this along the Massachusetts Turnpike (I-90) from Natick to west of Framingham. Mafic dikes to the east in lightcolored granite become increasingly sheared, recrystallized, and less discordant to foliation and eventually become black amphibolitic layers parallel to the foliation in gneissic granite. Clearly, the problem of the felsic volcanic rocks of eastern Massachusetts has not yet been resolved.

\section{LYNN VOLCANIC COMPLEX}

The case for a Proterozoic $\mathrm{Z}$ age for the Lynn Volcanic Complex is not entirely closed, although evidence presented in previous pages tends to support that assignment. Additional petrologic work and detailed field studies in the Mattapan, Lynn, and Newbury Volcanic Complexes might provide additional evidence for such an age assignment.

\section{BOSTON BAY GROUP}

A Proterozoic Z to Early Cambrian(?) age for the Boston Bay Group is confirmed by the find of acritarchs of that age range in the Cambridge Argillite. A Pennsylvanian age for the Boston basin even before this find was at any rate quite convincingly ruled out by the difference in paleoenvironment and depositional style between the deposits in the Boston basin and those in the Narragansett basin (fig. 9, table 5) and the lack of plant fossils in the Boston basin as compared with the abundance of plant fossils in the Narragansett basin. However, the question remains as to how much of the Boston basin fill is Cambrian, equivalent to the Weymouth Formation and Braintree Argillite. The proposal by C.A. Kaye (1980) that the quartzites and red beds in the Cambridge Argillite are Cambrian needs to be explored. Are the Tufts Quartzite Member and Milton quartzite unit equivalent to the quartzite and feldspathic quartzite at the base of the Hoppin Formation, or are they merely deposits on shoals formed during Cambridge deposition and before Cambrian encroachment as Billings (1976a) indicated? The Cambridge and other units of the Boston
Bay Group contain many thin to laminar graded beds, which should be useful in detecting an unconformity or disconformity.

\section{BELLINGHAM CONGLOMERATE}

The age of the Bellingham Conglomerate in the Bellingham basin is highly uncertain. Like the rocks in the Boston basin, the Bellingham lacks the plant fossils so abundant in the rocks of the Narragansett basin, and other similarities to the rocks of the Boston basin exist. Skehan and Murray (in Skehan and others, 1979) suggested that the Bellingham Conglomerate is correlative with conglomerates in the Boston basin. The structural alignment of the Boston basin with the Bellingham basin and the North Scituate basin in Rhode Island, their similar lithologies, and their lack of fossils certainly suggest that the three might be of similar age. The rocks in the Bellingham basin are, however, more metamorphosed than are the rocks of the Boston basin.

An ancillary problem that requires careful mapping is the similarity of the Bellingham Conglomerate in the Bellingham basin to the Blackstone Group in the Woonsocket area adjacent to the basin. Both are in the greenschist facies of metamorphism. The criterion of Warren and Powers (1914) involving the presence or absence of epidote to distinguish rocks of the Blackstone Group from the Bellingham Conglomerate needs to be reexamined, although in field reconnaissance the criterion seemed to be useful. The area of particular interest is that occupied by the schist of the Blackstone Group east of the Bellingham basin and north of the belt of Quinnville Quartzite. The State bedrock map probably shows the correct distribution of the two sets of rocks, but in the field it is not easy to distinguish the two nor to draw a line between them with confidence.

\section{BRIGHTON MELAPHYRE}

The Brighton Melaphyre represents an interval of volcanism, predominantly mafic, which is younger than the Mattapan and Lynn (LaForge, 1932, p. 42). As described, it appears to have phases similar to some in the Mattapan Volcanic Complex; these phases may represent the transition from sialic Mattapan volcanism to the more simatic Brighton volcanism. This change in volcanism probably reflects a change to extensional tectonics associated with late Proterozoic $\mathrm{Z}$ rifting. We do not know where similar rocks of this age exist in eastern Massachusetts other than in the Boston area. The areal extent of the Brighton is very small. Possibly the amphibolitized dikes to the west on I-90 described 
above are Brighton. The dikes described as cutting Precambrian $\mathrm{Z}$ rocks in the Jamestown area in Rhode Island might also be of Brighton age. The temporal and areal extent of the Brighton needs study.

\section{SEQUENCE IN THE BURLINGTON AREA}

The units in the Greenleaf Mountain area, Burlington, described by Bell and Alvord (1976; table 3) are not clearly related to the other units in the Milford-Dedham zone. One can only speculate as to where they fit into the stratigraphy. As they are close to the Bloody Bluff fault zone, they might be a fault-bounded slice of allochthonous rock or merely a mylonitized part of the mafic metavolcanic assemblage.

\section{MAFIC METAVOLCANIC ROCKS AND THE MARLBORO FORMATION}

The relationship between the juxtaposed mafic volcanic complex in eastern Massachusetts $(\mathrm{Zv})$, east of the Bloody Bluff fault, and the Marlboro Formation to the west of it is an intriguing question. The Marlboro as described in chapter F (Goldsmith, this vol.) consists of amphibolite, hornblende gneiss, biotite-quartz-feldspar gneiss and granofels, calc-silicate rock and rare marble, rusty-weathering garnet-sillimanite schist, and garnetmuscovite-biotite schist. Some layers contain coticule. The metamorphosed mafic and felsic volcanic rocks of the Milford-Dedham zone (Zv; table 3) contain amphibolite, hornblende gneiss, and minor intercalated schist and quartzite, as well as felsic layers, but lack the calcareous rocks, the rusty schists, and the distinctive coticulebearing layers of the Marlboro. The two contain some rocks that are similar in lithology, primarily the amphibolite and hornblende-bearing rocks; this similarity has led previous workers to consider them to be one suite of rocks (Emerson, 1917). Current studies indicate that they are two different suites, but where to place the boundary between them in the MarlboroughFramingham-Concord area is in places unclear. The Marlboro Formation, on the whole, is a somewhat more varied unit. The primary distinction, as pointed out above in this chapter, is that the Middlesex Fells is intruded by Proterozoic Z granitoids, whereas the Marlboro is not. However, we do not know with certainty the age of the formations in the Nashoba zone. If they are Proterozoic as they seem to be, they are perhaps a part of the Proterozoic volcanic-arc complex, but which accumulated in a different place than where they are at present and which represent a somewhat different facies. Stratigraphic analysis of the formations in the Nashoba zone (Goldsmith, this vol., chap. F) suggested that the center of volcanism was to the east. Possibly, the volcanic-plutonic complex in eastern Massachusetts represented the core of an arc, and the formations of the Nashoba zone were deposited on its flanks. At some later time the original continuity was disrupted and the rocks of the Nashoba zone were transported from their original position relative to the Milford-Dedham zone, to become affixed, probably in telescoped fashion, in their present position against the Milford-Dedham zone. Naylor (1976, p. 422) has noted the juxtaposition of two lithologically similar but probably temporally different terranes along a continuation of the Bloody Bluff fault in southern Connecticut. The rocks of the two zones could, however, have been originally quite unrelated.

\section{NEWBURY VOLCANIC COMPLEX}

Deposition of the Newbury Volcanic Complex does not readily fit into the proposed history of the MilfordDedham zone. The fossil assemblages in the Newbury, however, indicate Acado-Baltic affinities, indicating that the Newbury accumulated on the same side of the Iapetus Ocean as did the Cambrian of the MilfordDedham zone. One can only draw the conclusion that the Newbury did not accumulate at its present site. However, it could possibly have accumulated on the flanks of the zone as a volcanic belt developed along the leading edge of the zone during its westward movement in the middle Paleozoic (Robinson and Hall, 1980). The actual site of the superposition of the Newbury on the crystalline basement has since been obliterated by faulting.

\section{THE STRATIGRAPHIC RECORD IN THE MILFORD-DEDHAM ZONE}

The stratigraphic record in the Milford-Dedham zone (table 6) comprises two dissimilar cycles. A Proterozoic $\mathrm{Y}$ or $\mathrm{Z}$ cycle of arc-margin accumulation, volcanic arc accumulation, and orogenesis followed by Proterozoic $\mathrm{Z}$ plutonism, volcanism, and subsequent flysch to molasse deposition of turbidites during an extensional phase was completed by the Cambrian Period. The Cambrian initiated a new cycle, spanning the Paleozoic, beginning with shelf deposition and closing with deposition during rifting in the Mesozoic. In the earlier cycle, the felsic volcanism (and plutonism) represented by the Mattapan Volcanic Complex (and Dedham Granite) is considered to be a precursor to the opening of the proto-Atlantic Ocean (Iapetus) (Rankin, 1975), and the subsequent basin filling and mafic volcanism (Brighton Melaphyre) to be associated with the actual rifting. The length of the hiatus between the end of development of the volcanic-plutonic complex in eastern Massachusetts and the beginning of the phase of felsic volcanism and plutonism is not known. 
TABLE 6.-Stratigraphic record in the Milford-Dedham zone

\begin{tabular}{|c|c|c|c|}
\hline Event & Paleotectonic environment & Age & Representative units \\
\hline $\begin{array}{l}\text { Deposition of arenite, calc-arenite, } \\
\text { and pelite. A volcanic component } \\
\text { increasing towards top. }\end{array}$ & $\begin{array}{l}\text { Littoral to shelf deposition on unknown } \\
\text { basement. Source of material a 1,500- } \\
\text { Ma terrane, probably to the east. }\end{array}$ & $\begin{array}{l}\text { Middle or Late Proterozoic; } \\
\text { older than } 630 \mathrm{Ma} \text {, } \\
\text { younger than } 1,500 \mathrm{Ma} \text {. }\end{array}$ & $\begin{array}{l}\text { Westboro and Plainfield } \\
\text { Formations; Quinnville } \\
\text { Quartzite and Sneech } \\
\text { Pond Schist. }\end{array}$ \\
\hline $\begin{array}{l}\text { Volcanism and plutonism, predomi- } \\
\text { nantly mafic to intermediate calc- } \\
\text { alkalic; volcaniclastic and epiclas- } \\
\text { tic sedimentation. }\end{array}$ & $\begin{array}{l}\text { Island arc-continental margin(?) associ- } \\
\text { ation in compressional tectonic } \\
\text { regime. }\end{array}$ & $\begin{array}{l}\text { Middle or Late Proterozoic; } \\
\text { older than } 630 \mathrm{Ma} \text {, } \\
\text { younger than } 1,500 \mathrm{Ma} \text {. } \\
\text { Possibly about } 750 \mathrm{Ma} \text {. }\end{array}$ & $\begin{array}{l}\text { Middlesex Fells Volcanic } \\
\text { Complex, Hunting Hill } \\
\text { Greenstone, Salem } \\
\text { Gabbro-Diorite. }\end{array}$ \\
\hline $\begin{array}{l}\text { Intrusion, calc-alkalic to subalkalic } \\
\text { granite and associated volcanism } \\
\text { and later felsic volcanism. }\end{array}$ & $\begin{array}{l}\text { Pre-rifting intrusion and volcanism in a } \\
\text { compressional to extensional tectonic } \\
\text { regime. }\end{array}$ & $\begin{array}{l}\text { Late Proterozoic; } 630 \mathrm{Ma} \\
\text { and younger (about } 600 \\
\text { Ma?). }\end{array}$ & $\begin{array}{l}\text { Dedham, Milford, and } \\
\text { Westwood Granites, Mat- } \\
\text { tapan Volcanic Complex. }\end{array}$ \\
\hline $\begin{array}{l}\text { Deposition of turbidite sequence } \\
\text { accompanied in early stages by } \\
\text { felsic to mafic volcanism. }\end{array}$ & $\begin{array}{l}\text { Post-rifting continental to marine depo- } \\
\text { sition in deepening marginal basin or } \\
\text { aulacogen formed in extensional tec- } \\
\text { tonic regime. Highlands and volcanic } \\
\text { centers to the south, southwest, and } \\
\text { west(?). }\end{array}$ & $\begin{array}{l}\text { Late Proterozoic, probably } \\
\text { younger than } 600 \mathrm{Ma} .\end{array}$ & $\begin{array}{l}\text { Boston Bay Group including } \\
\text { Brighton Melaphyre. }\end{array}$ \\
\hline $\begin{array}{l}\text { Deposition of arenite, pelite, and } \\
\text { carbonate. }\end{array}$ & $\begin{array}{l}\text { Transgressive littoral and shallow-shelf } \\
\text { sequence in epeirogenic regime. }\end{array}$ & $\begin{array}{l}\text { Early and Middle } \\
\text { Cambrian. }\end{array}$ & $\begin{array}{l}\text { Weymouth and Hoppin } \\
\text { Formations and Brain- } \\
\text { tree Argillite. }\end{array}$ \\
\hline $\begin{array}{l}\text { Gabbroic to granite intrusion, typi- } \\
\text { cally alkalic; associated volcanism. }\end{array}$ & $\begin{array}{l}\text { Anorogenic intrusion in epeirogenic- } \\
\text { extensional tectonic regime. }\end{array}$ & Ordovician to Devonian & $\begin{array}{l}\text { Quincy Granite, Cape Ann } \\
\text { Granite, Peabody Gran- } \\
\text { ite, Blue Hill Granite } \\
\text { Porphyry, Nahant Gab- } \\
\text { bro. }\end{array}$ \\
\hline $\begin{array}{l}\text { Mafic to felsic volcanism, and vol- } \\
\text { caniclastic and epiclastic sedimen- } \\
\text { tation. }\end{array}$ & $\begin{array}{l}\text { Island-arc(?) volcanism and sedimenta- } \\
\text { tion in compressional tectonic } \\
\text { regime(?). }\end{array}$ & $\begin{array}{l}\text { Late Silurian and Early } \\
\text { Devonian. }\end{array}$ & $\begin{array}{l}\text { Newbury Volcanic Com- } \\
\text { plex. }\end{array}$ \\
\hline $\begin{array}{l}\text { Deposition of conglomerate, sand, } \\
\text { silt, and coal. Mafic to felsic vol- } \\
\text { canism in early stage(?). }\end{array}$ & $\begin{array}{l}\text { Alluvial-fan fill in shallow basin; high- } \\
\text { lands and volcanic center(?) to north- } \\
\text { west. }\end{array}$ & $\begin{array}{l}\text { Late Mississippian and } \\
\text { Pennsylvanian. }\end{array}$ & $\begin{array}{l}\text { Narragansett Bay Group of } \\
\text { Skehan and others (1979), } \\
\text { volcanic rocks in Wam- } \\
\text { sutta Formation. }\end{array}$ \\
\hline $\begin{array}{l}\text { Plutonism (in southern Rhode } \\
\text { Island). Intrusion of mafic dikes } \\
\text { in Boston area. }\end{array}$ & $\begin{array}{l}\text { Pre-rifting plutonism and volcanism in } \\
\text { extensional tectonic regime. }\end{array}$ & Permian & Narragansett Pier Granite. \\
\hline $\begin{array}{l}\text { Deposition of conglomerate, arkose, } \\
\text { and mud. Extrusion of basalt as } \\
\text { flows, dikes, and sills. }\end{array}$ & $\begin{array}{l}\text { Alluvial filling of rift basin, extrusion } \\
\text { of simatic material in extensional } \\
\text { environment. }\end{array}$ & Triassic and Jurassic & $\begin{array}{l}\text { Middleton-basin fill; Med- } \\
\text { ford dike. }\end{array}$ \\
\hline Deposition of sand, silt, and clay & $\begin{array}{l}\text { Marine transgressive and regressive } \\
\text { sequences on a continental shelf in an } \\
\text { epeirogenic regime. }\end{array}$ & Cretaceous to Tertiary & Coastal plain deposits. \\
\hline
\end{tabular}

A period of uplift and erosion must have occurred before deposition of the Roxbury Conglomerate. A basin must have been available during accumulation of the Mattapan, because the volcanic rocks contain intercalated terrestrial and waterlain beds. This suggests a marine or partly marine basin-and-range environment. The sandstone in the upper part of the Cambridge Argillite indicates shoaling at that time, which may have been a precursor for uplift and erosion before the Cambrian transgression. In the later, Paleozoic cycle, however, the depositional record within the zone does not indicate a period of orogenesis of the sort recorded in the Proterozoic. The tectonic processes were primarily extensional, as indicated by the static Paleozoic plutonism. The western part of the Milford-Dedham zone was involved, however, if only passively, in Paleozoic compressive tectonics (Goldsmith, this vol., chap. $\mathrm{H}$ ). A new cycle has begun with the Cretaceous and Tertiary marine onlap onto the passive continental margin of accreted North America. The scheme of tectonic evolution derived is similar to that proposed by Williams and King (1979) for the Trepassy area of the Avalon Peninsula, Newfoundland. The alternation of compressional and extensional tectonics evident from the depositional history shown in table 6 can be translated into terms of plate-tectonic theory better when Massachusetts and the New England region are considered as a whole in another chapter of this volume (Goldsmith, this vol., chap. $\mathrm{H}$ ). 


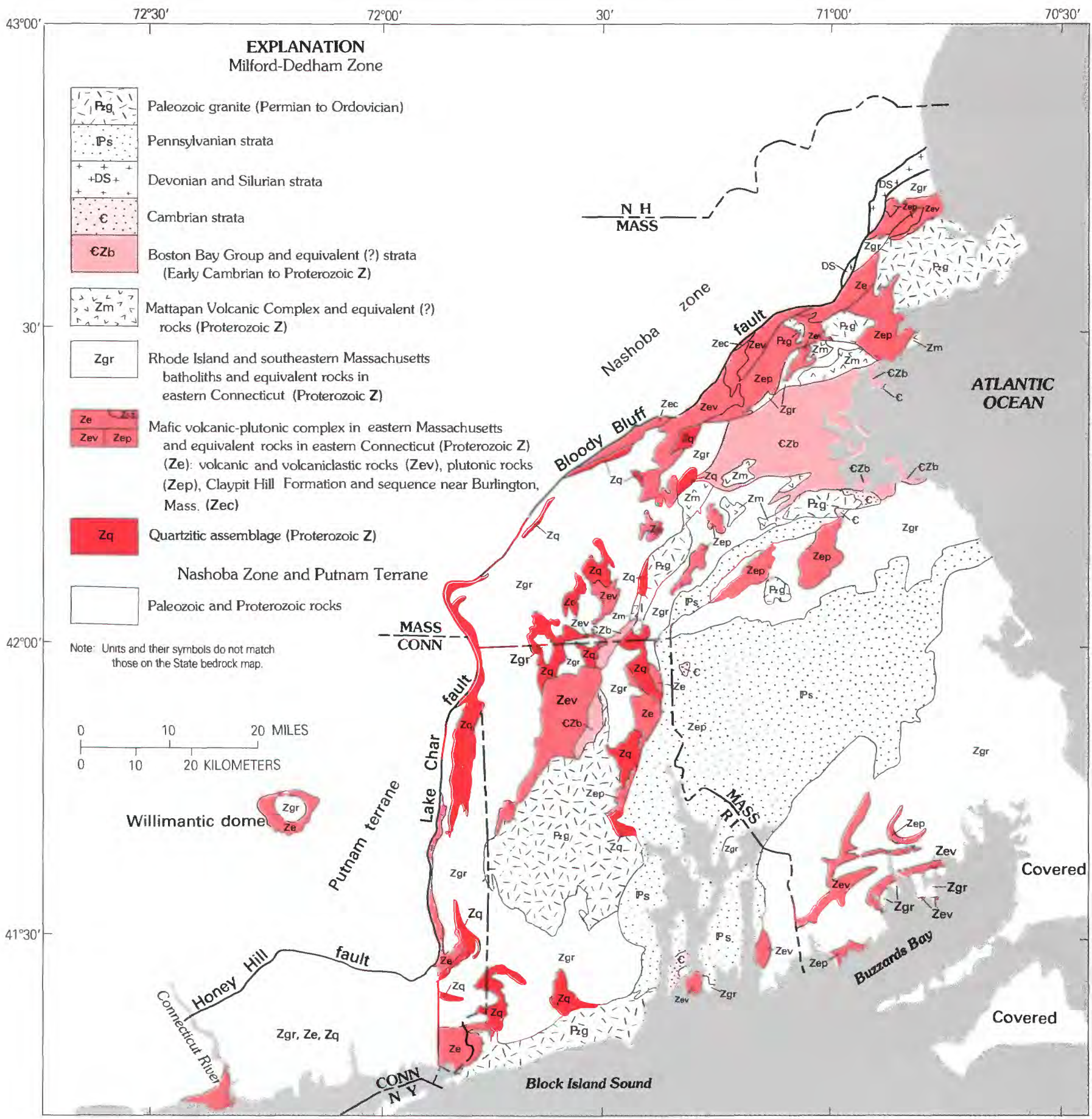

FigURE 13.-Distribution of major groups of rocks in the Milford-Dedham zone, Massachusetts, Rhode Island, and Connecticut.

\section{REGIONAL RELATIONS IN SOUTHEASTERN NEW ENGLAND}

The relations of the Milford-Dedham zone in Massachusetts to the rest of southeastern New England are summarized in figures 13 and 14. Primary sources for the compilation were the State bedrock map, Quinn's (1971) paper on the bedrock geology of Rhode Island, and the preliminary bedrock geologic map of Connecticut (Rodgers, 1982). Structural data have been omitted except for the names of the bounding faults on the west. A certain amount of interpretation has been introduced in the compilation, and some of the debatable units discussed in this chapter have been assigned to age brackets that 


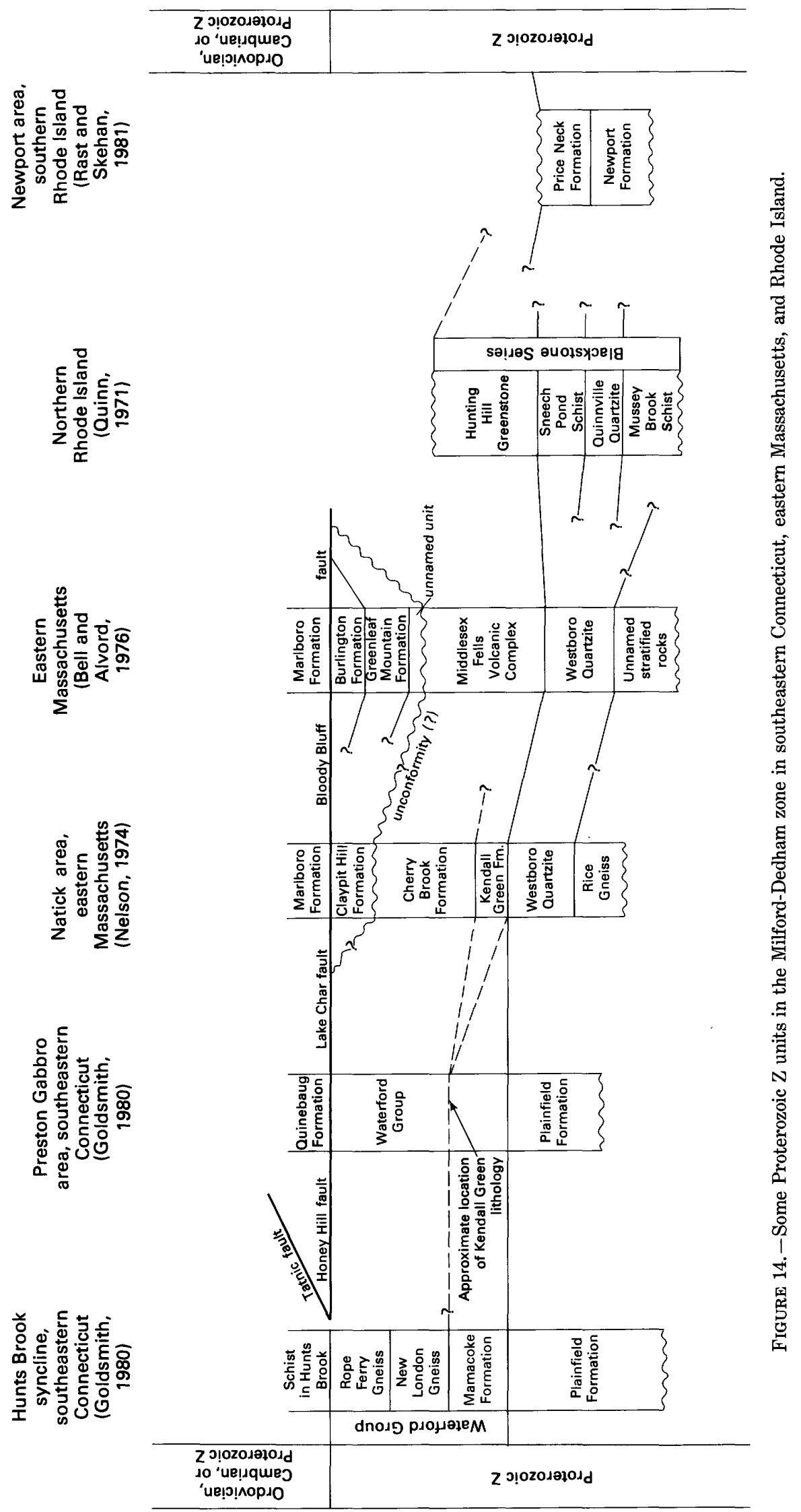


differ from those on the State bedrock map. Such assignments can stimulate future investigation and discussion. These changes are discussed below.

\section{QUARTZITIC ASSEMBLAGE}

The quartzitic assemblages ( $\mathrm{Zq}$ on fig. 13) include the Westboro Formation ( $\mathrm{Zw}$ ), the Plainfield Formation (Zp), the lower part of the Blackstone Group (Zbq, Zbs), part of the undivided Blackstone Group ( $\mathrm{Zb}$ ) in Massachusetts and northern Rhode Island, and rocks mapped as Blackstone Group in southern Rhode Island. The undivided Blackstone in Massachusetts and northern Rhode Island includes some amphibolite and other metavolcanic rocks, but, where quartzite is the most conspicuous lithology, the undivided Blackstone has been included in the quartzitic assemblage, as for example in the town of Uxbridge, Mass. These formations do not contain a particular quartzite layer but represent formations in which quartzite layers are conspicuous if not the predominant lithology.

The Rice Gneiss, which has a volcanic component, has been included in the quartzitic assemblage in figure 13 rather than in the overlying metavolcanic assemblage because the Rice lies stratigraphically below the Westboro (Nelson, 1974) and is in part quartzitic (table 3). Also, as no clear base has been observed for the quartzitic units in the quartzitic assemblage elsewhere, and as the Rice Gneiss occupies only a small area, it is most conveniently placed in the quartzitic assemblage rather than in an isolated unit lying below the quartzitic formations. As described by Nelson (1974), the Rice Gneiss contains lithologies resembling some of those in the Plainfield Formation.

\section{VOLCANIC-PLUTONIC COMPLEX IN EASTERN MASSACHUSETTS AND CORRELATIVE ROCKS}

The metavolcanic assemblage that lies primarily above the quartzitic assemblage is part of the volcanic-plutonic complex in eastern Massachusetts. In Connecticut it is called the Waterford Group (fig. 14); in Rhode Island it is not recognized as a unit but consists of separately mapped metavolcanic rocks and plutons of gabbro and diorite (Zgb, Zdi). Shown on figure 13 are both the metavolcanic component, Zev, and the plutonic component, Zep. Where these components are too mixed or too thin to be shown separately, they are shown as a single unit, Ze.

In northeastern Massachusetts, Bell and Alvord (1976) used the term "Middlesex Fells Volcanic Complex" for the largely mafic metavolcanic rocks older than the Dedham Granite. Their term, as used, includes the Cherry Brook Formation, the Middlesex Fells Volcanic
Complex in its type area, stray pieces of stratified metavolcanic rocks such as the unnamed units of Volckmann (1977) in the Holliston area, amphibolite and augen gneiss mapped by Toulmin (1964) in the Salem quadrangle, and mafic metavolcanic rocks mapped by Bell and others (1977) and Dennen (1975) in the Georgetown and Ipswich quadrangles, respectively. This collective use of the term makes it more useful than the more areally limited term Cherry Brook Formation, in spite of the fact that the term Cherry Brook Formation has priority. Bell and Alvord considered the Middlesex Fells Volcanic Complex to be the equivalent of the Hunting Hill Greenstone of the Blackstone Group. The metamorphosed mafic and felsic volcanic rock unit (Zv) used on the State bedrock map is equivalent to the Middlesex Fells Volcanic Complex as used by Bell and Alvord (1976). On figure 13, however, I have used volcanic and volcaniclastic rocks (Zev) as a collective name for the units in the metavolcanic assemblage that overlies the quartzitic assemblage in eastern Massachusetts and northern Rhode Island.

Included in the metavolcanic assemblage are those parts of the undivided Blackstone Group ( $\mathrm{Zb}$ ) that contain prominent amphibolite, such as near Hopedale and Milford and near Blackstone, Mass. Also included in the metavolcanic assemblage are the three metamorphic units in the Georgiaville quadrangle in northern Rhode Island that Richmond (1952) named the Absalona and Woonasquatucket Formations and the Nipsachuck Gneiss. His description of these rocks suggests that they are largely metamorphosed felsic or intermediate volcanic rocks, in part at least tuffaceous. Their exact stratigraphic position is uncertain (Quinn, 1971, p. 14-15), for they may lie above or below the Blackstone Group. Because they seem to lie above the quartzitic formations on the east flank of the Rhode Island anticlinorium (Goldsmith, this vol., chap. H), I have assigned these rocks to the metavolcanic assemblage.

The plutonic component of the volcanic-plutonic complex in eastern Massachusetts includes all the mafic plutonic rocks older than the granites and granodiorites of the Rhode Island and southeastern Massachusetts batholiths and related plutons; for example, the Dedham Granite (Zdgr, Zdngr), Milford Granite (Zmgr), and Topsfield Granodiorite (Ztgd). These mafic-plutonic rocks consist mostly of gabbro, diorite, and syenite, such as the Salem Gabbro-Diorite (Zdigb), unnamed diorite and gabbro (Zdi, Zgb), and the Sharon Syenite (Zssy). These plutonic rocks are discussed in Wones and Goldsmith (this vol., chap. I). North of Salem and southeast of the Middleton basin, the plutonic and volcanic components are not distinguished separately on figure 13 because of their intermixing. 
The Claypit Hill Formation and the formations of Bell and Alvord (1976) near Burlington (see table 3), which were grouped with the metavolcanic assemblage on the State bedrock map, are shown separately on figure 13 as a possibly younger group of metasedimentary and metavolcanic rocks (Zec) lying above the metavolcanic assemblage (Zev).

In southeastern Connecticut, the Waterford Group (Goldsmith, 1980) is the stratigraphic equivalent of the volcanic-plutonic complex in eastern Massachusetts (fig. 14). It contains both stratified metavolcanic and metasedimentary rocks and metaplutonic rocks; for example, the New London Gneiss, the Rope Ferry Gneiss, and possibly the Stonington Gneiss phase (Rodgers and others, 1959) of the Mamacoke Formation. The volcanic and plutonic rocks in this complex are not distinguished separately on figure 13 because of the thinness of the units.

The older metamorphic rocks of southeastern Massachusetts and the rocks of similar age in the Newport and Sakonnet areas (fig. 7) are included in the metavolcanic assemblage because of their apparently large original volcaniclastic component, although the rocks are not necessarily mafic. They could, however, be all or in part equivalent to part of the mica schist and phyllite (Zbs) of the Blackstone Group in northeastern Rhode Island. These units in southeastern Massachusetts and southern Rhode Island are the gneiss and schist near New Bedford (Zgs), the biotite gneiss near New Bedford ( $\mathrm{Zgn})$, the Proterozoic Z strata at different places along the Sakonnet River (Quinn, 1971), the Jamestown Formation of Skehan and Murray (1980b), and the Price Neck Formation of Rast and Skehan (1981) in the Newport area following the age assignments and the descriptions of Rast and Skehan (1981).

\section{RHODE ISLAND AND SOUTHEASTERN MASSACHUSETTS BATHOLITHS AND RELATED GRANITOIDS}

The Rhode Island and southeastern Massachusetts batholiths (Zgr on fig. 13) occupy much of the area of the Milford-Dedham zone. Units included in this assemblage are the Dedham Granite (Ddgr, Ddngr), Topsfield Granodiorite (Dtgd), Westwood Granite (Zwgr), Milford Granite (Zmgr, Zmgd), Esmond Granite (Zegr), granite of the Fall River pluton (Zfgr), porphyritic granite (Zpgr), alaskite (Zagr), the Ponagansett Gneiss (Zpg), Hope Valley Alaskite Gneiss (Zhg), Scituate Granite Gneiss of the Sterling Plutonic Group (Zsg), and biotite granite (Zgr). In southeastern Connecticut and southern Rhode Island, the units belonging to the Sterling Plutonic Group are present including the Potter Hill Granite Gneiss. Hermes and others (1981) have found that a large area formerly mapped as Scituate Granite Gneiss in central Rhode Island is of middle Paleozoic rather than Proterozoic $Z$ age. (This area is shown on fig. 13 as $\mathrm{P}$.g.) Also included in Zgr are the Newport Granite of Rast and Skehan (1981) and the Willimantic Gneiss in eastcentral Connecticut. The Bulgarmarsh Granite is a phase of the granite of the Fall River pluton.

\section{MATTAPAN VOLCANIC COMPLEX AND EQUIVALENT ROCKS}

The Mattapan and Lynn Volcanic Complexes $(\mathrm{Zm}$, $\mathrm{DZl})$, and the felsite porphyry near Bellingham (Zfm (Zm on the State geologic map)) are shown as $\mathrm{Zm}$ on figure 13. The volcanic rocks near Lake Pearl (Pwv) are shown as equivalent to the Mattapan because of their lithologic similarity and because they lie in a structural trough more or less aligned with the Boston basin. The felsite at Diamond Hill remains assigned to the Pennsylvanian, although detailed mapping in this area might reveal that all or part of the rocks mapped as Wamsutta in this area are actually equivalent to part of the Roxbury Conglomerate.

\section{BOSTON BAY GROUP AND EQUIVALENT ROCKS}

The Bellingham Conglomerate $(\mathbb{P Z b})$ in the Bellingham and North Scituate (Rhode Island) basins is shown on figure 13 as equivalent in age to the Boston Bay Group. The Bellingham resembles the Roxbury Conglomerate, and no fossils have been found in the Bellingham in contrast to the highly fossiliferous Pennsylvanian strata in the Narragansett basin to the east. As mentioned in an earlier part of this chapter, the Bellingham and North Scituate basins lie in a structural trough aligned with the Boston basin.

\section{YOUNGER UNITS}

The distribution of the Cambrian and younger rocks $\left(€, D S, P s\right.$, and $\mathrm{P}_{2 \mathrm{~g}}$ on fig. 13) has not been changed from the State bedrock map except that the Pennsylvanian volcanic rocks near Lake Pearl have been correlated with the Mattapan Volcanic Complex ( $\mathrm{Zm}$ on fig. 13). The distribution of Cambrian strata on Conanicut Island, R.I., is taken from Skehan and others (1981).

\section{THE MILFORD-DEDHAM ZONE IN THE CALEDONIDES-CORRELATION}

The stratigraphic sequence in the Milford-Dedham zone has been correlated by numerous authors with sequences in the Maritime Provinces, Newfoundland, England, Wales, and Morocco. The term "Avalonian" 
(Kay and Colbert, 1965) has been applied to terranes containing these sequences in North America. The Avalonian terranes form a southeastern platform of the Appalachian orogenic belt, as first pointed out by Williams (1964). Summary sections and their correlations in the different terranes, most of which cover eastern Massachusetts, have been presented by Weeks (1957), Schenk (1971), Rast and others (1976), and Strong (1979). The most recent summary descriptions of rocks in the Avalon Peninsula of Newfoundland are by King (1980; O'Brien and King, 1982) and Anderson (1981). Equivalent sequences have been described for example in Anglesey, Wales, by Wood (1974), in the English Midlands by Rast and others (1976), and in Morocco by Affaton and others (1980). The relationship of eastern Massachusetts and Rhode Island to the above terranes is discussed by Skehan (1969, 1973), Skehan and others (1978), Rast (1980), and Skehan and Murray (1980a).

Gross correlation of rocks of eastern Massachusetts with those of the Avalon Peninsula is fairly easily made. The Mattapan Volcanic Complex and Boston Bay Group are similar to the Proterozoic $\mathrm{Z}$ sequence of the Avalon, the Conception Group and Harbour Main Volcanics, as summarized by King (1980; O'Brien and King, 1982) except that there the fossil record is more abundant, the sequence is apparently thicker, and no older basement is exposed. In Nova Scotia and New Brunswick, however, as in Massachusetts, a basement (Basement Complex, Greenhead Group, Kelly Mountain and George River Group, and Brookville gneiss) is present beneath the Proterozoic Z (Hadrynian) rocks (Georgeville Group, Fourchu Group, Coldbrook Group). The basement rocks cannot be readily correlated with the pre-Dedham Granite strata, however. According to Rast (1980, p. 63), these rocks, apparently older than $770 \mathrm{Ma}$, consist of quartzites, argillites, and carbonates in part converted to schists, paragneisses and marbles. J.W. Skehan (written commun., 1983) suggested that these rocks are equivalent to the Westboro Formation and Blackstone Group. None of these rocks clearly resembles the volcanicplutonic complex in eastern Massachusetts. Possibly the Hadrynian(?) Bass River Complex and George River Group (=Greenhead Group) of Nova Scotia (Keppie, 1979; Keppie and Schenk, 1982) are equivalents of the complex.

The eastern Massachusetts terrane has also been correlated with rocks of the slate belt in Virginia, North Carolina, and South Carolina (Glover and Sinha, 1973; Rast and others, 1976; Williams, 1978; Nelson, 1981). The strata in the Carolina slate belt are equivalent to some of the rocks of the Boston basin area in lithology and fossil fauna, but it is not generally realized that the adjacent Charlotte belt bears a remarkable resemblance to the volcanic-plutonic complex in eastern Massachu- setts. In North Carolina, a probably Proterozoic Z volcanic-plutonic complex, consisting largely of plutonic rocks ranging from gabbro to granodiorite and enclosing masses of mafic to felsic volcanic rocks and metasediments, forms the core of the Charlotte belt (Goldsmith and others, 1982b). This complex is flanked by Proterozoic $\mathrm{Z}$ to Cambrian volcanic rocks and sediments of the Carolina slate belt and is intruded by early to midPaleozoic plutons of gabbro (and syenite) to granite and by late Paleozoic plutons of granite. This terrane thus described is quite similar to that in eastern Massachusetts, particularly west and north of the Boston basin. Although no late Paleozoic granites are present in the Boston area, they are present in southern Rhode Island, and late Paleozoic volcanic rocks are present in northern Rhode Island.

\section{MESOZOIC AND TERTIARY STRATIGRAPHY OF CAPE COD AND THE NEARBY ISLANDS}

\author{
By E.G.A. WeED
}

\section{INTRODUCTION}

Cape Cod and the nearby islands, the Elizabeth Islands, Martha's Vineyard, and Nantucket, are almost entirely covered by Quaternary surficial deposits. No pre-Pleistocene rocks are exposed southeast of the Cape Cod Canal, except the distorted beds in the cliffs at the western end of Martha's Vineyard. However, pebbles, fragments, and blocks of older rocks are found in the glacial drift and may be encountered in sand and gravel pits.

Data on the pre-Pleistocene rocks are available only from drill holes and other manmade excavations and the natural exposures on Martha's Vineyard noted above. These few data sources are clearly inadequate to accurately portray the distribution of rocks in the subsurface, even at 1:250,000 scale. Their very paucity, however, makes the information obtained from them all the more critical.

Early studies of the geology of Cape Cod and the nearby islands mostly addressed materials found in outcrop (Emerson, 1917). Cretaceous and Tertiary fossils in this area were found by Lyell (1843), Desor (1849), Shaler (1888, 1889, 1890), White (1890), Dall (1894), Woodworth (1897), Hollick (1906), and Berry (1915), and later by Woodworth and Wigglesworth (1934) and Kaye (1964a,b,c; 1983b). Offshore studies of the U.S. Atlantic margin (Emery and Uchupi, 1972; Weed and others, 1974; Austin and others, 1980) and hydrologic studies on land (Maevsky and Drake, 1963; Kohout and others, 1977; Delaney, 1980; Walker, 1980; Guswa and LeBlanc, 
1985) have contributed to our understanding of the Coastal Plain geology. Geophysical investigations in the Cape Cod area have been made by Hoskins and Knott (1961), Oldale and Tuttle (1964), Oldale (1969), Oldale and others (1973), Ballard and Uchupi (1975), Grow and Schlee (1976), Bothner (1977), and Klitgord and Behrendt (1979, 1980). The mineralogy of the Coastal Plain materials, in particular the clays, has been studied by L.J. Poppe (written commun., 1976) and S.A. WoodNeedell (written commun., 1976).

As part of the investigations made for the State bedrock map (Zen and others, 1983), 15 shallow bore holes (sites 13-17, 23-24 and 26-33, fig. 15; tables 7, 8) were drilled in Martha's Vineyard, Cape Cod, Marshfield, and Scituate from 1977 through 1982. Unconsolidated Tertiary material was recovered in two bore holes (sites 26 and 29). Hard material (granodiorite, sandstone, shale, hardpan (till?)) was reached in eight holes but recovered in only six holes (sites 27-32).

The locations of the drill and auger holes and the natural exposures that serve as sources for the data for this report are shown on figure 15. Lithology, depth, thickness, age, and principal references are presented in table 8. Because the pre-Mesozoic rocks of the subsurface are described by Wones and Goldsmith in chapter I of this volume under the heading "Proterozoic $\mathrm{Z}$ batholithic rocks," only the Mesozoic and Tertiary strata are described in this section. Data on the pre-Mesozoic basement encountered in the holes are included, however, in table 8.

\section{GEOLOGIC SETTING}

The rocks beneath the Quaternary cover on Cape Cod and the islands lie southeast of the exposed rocks of the Milford-Dedham zone (Zen and others, 1983; Wones and Goldsmith, this vol., chap. I), which is interpreted as extending to the east of Cape Cod (Klitgord, 1984). The rocks known to be present in the subsurface of Cape Cod and the islands include, from oldest to youngest, granite, gneiss, and schist of probable Proterozoic Z age (Zgg of the State bedrock map), Triassic and Jurassic basalt (JKb), Cretaceous sediments (K), and Tertiary sediments (T). K-Ar radiometric analyses of biotite and hornblende obtained from samples of the core of the Tubman hole (site 3) gave ages as follows: biotite from granodiorite (depth unknown) $348 \pm 12 \mathrm{Ma}$, hornblende $518 \pm 30 \mathrm{Ma}$; biotite from a mafic xenolith at $190.2 \mathrm{~m}(624$ $\mathrm{ft}$ ) depth $400 \pm 14 \mathrm{Ma}$, hornblende $566 \pm 22 \mathrm{Ma}$; biotite from granodiorite at $294.5 \mathrm{~m}(966 \mathrm{ft})$ depth $380 \pm 19 \mathrm{Ma}$ (Weston Geophysical Research, Inc., 1977; Zartman and Marvin, this vol., chap. J, table 1). As these are minimum ages, a Proterozoic $\mathrm{Z}$ age for at least part of the basement under Cape Cod is confirmed. Probable Prot- erozoic rock was encountered in a few other drill holes on Cape Cod, at the holes at Harwich, Brewster, and Woods Hole (sites 1-5, fig. 15).

The northeastern continuation of the Atlantic Coastal Plain, which is well exposed on the surface as far northeast as northern New Jersey (Weed and others, 1974), and is present in the subsurface in Long Island (de Laguna, 1963; Perlmutter and Todd, 1965; Soren, 1971, 1977; Minard and others, 1974; Weed and others, 1974), lies beneath Cape Cod and the islands. Because the sites of pre-Pleistocene materials known in southeastern Massachusetts are few, each has considerable importance for interpreting the geology of the northern Coastal Plain and the Appalachian region.

\section{DESCRIPTION OF POST-PALEOZOIC UNITS}

Triassic and Jurassic strata consisting of basalt (Jkb) and sedimentary and volcanic rock (JK) have been identified only beneath Nantucket and Nantucket Sound. Cretaceous clay, sand, and silt $(\mathrm{K})$ have been reported from wells and outcrops at many places in southeastern Massachusetts and the islands (table 8), but no rocks of Mesozoic age have been identified in Cape Cod proper. The northwestern limit of Cretaceous materials in the subsurface is shown on the State bedrock map southeast of the main part of the Cape (fig. 15). The boundary passes through Monomoy Point to the northeast and between the Elizabeth Islands and Martha's Vineyard to the southwest. Tertiary deposits are scattered and fragmentary.

\section{TRIASSIC AND JURASSIC BASALT (JKb)}

A 514-m hole drilled on Nantucket (site 7, USGS 6001) encountered Triassic and Jurassic basalt ( $J k b$ ) from 470 $\mathrm{m}$ depth to the bottom of the hole. Interpretations of seismic profiles in the area, including USGS multichannel seismic line 5 (Grow and others, 1979; Austin and others, 1980), indicate that a northeast-trending Triassic and Jurassic basin, here called the Nantucket basin, extends from the middle of Nantucket Sound southeast about 25 $\mathrm{km}$ (fig. 15). It is estimated to be about $100 \mathrm{~km}$ long, and the seismic profile of line 5 indicates that it is about $8 \mathrm{~km}$ deep (Folger and others, 1978, fig. 2). The basalt encountered on Nantucket underlies a sedimentary and volcanic section (JK) interpreted from seismic profiles to be present under Nantucket Sound. The profiles indicate that the beds dip northeastward toward a normal fault south of Cape Cod (cross section $E-E^{\prime}$ on the State bedrock map).

The basalt, although highly altered, is similar in appearance to basalts of the Newark basin in New Jersey (Faust, 1975). The alteration is apparently the result of 


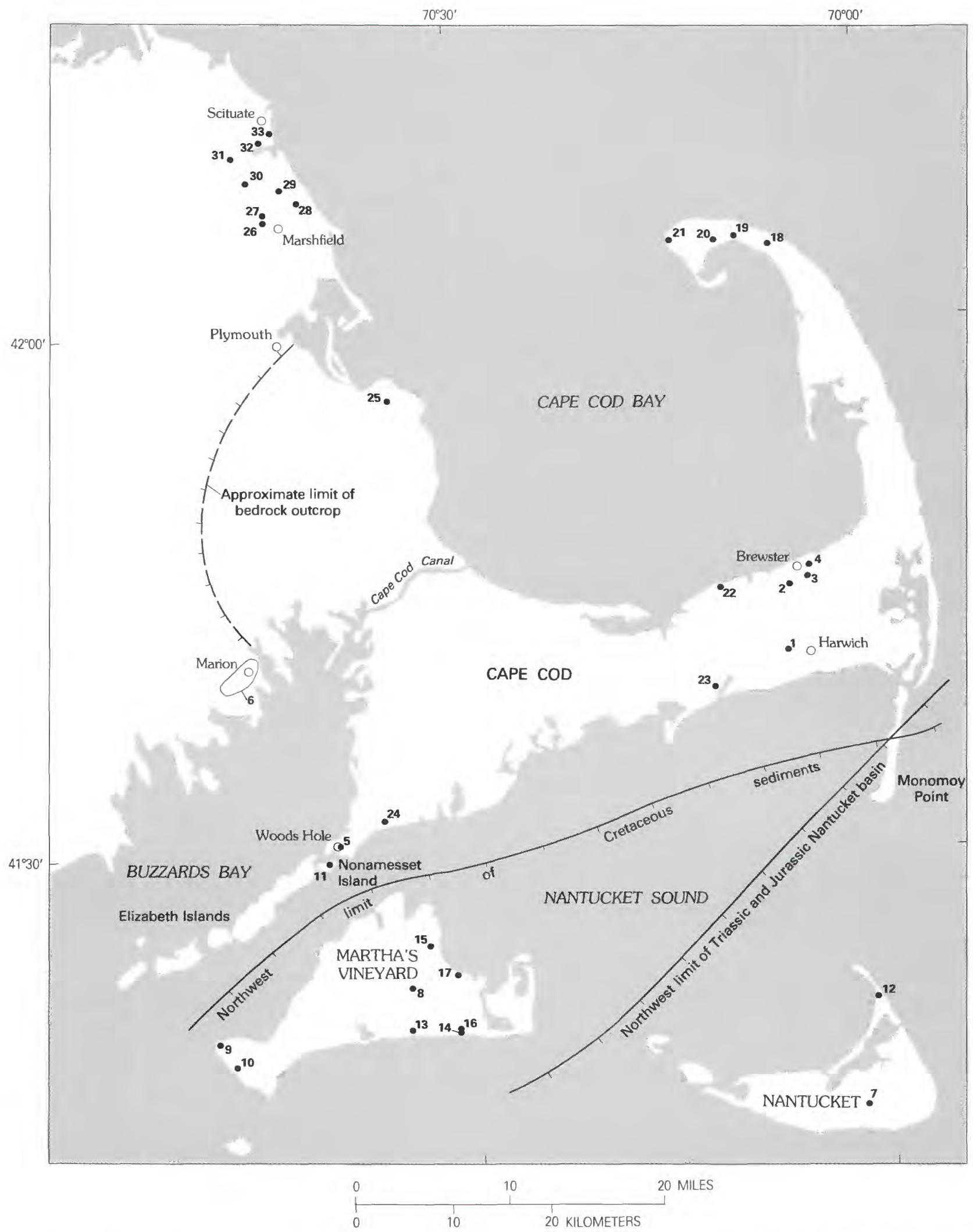

FIGURE 15.-Outcrop and auger- and core-drilling sites that provide information on the pre-Mesozoic basement and Mesozoic and Tertiary deposits in the area of Cape Cod and the nearby islands, Massachusetts. 
TABLE 7.-Location and identification of outcrops and auger-and core-drilling sites in the area of Cape Cod and the nearby islands, Massachusetts

[Locations of sites shown on figure 15; total depth measured from Kelly bushing (K.B.); WHOI, Woods Hole Oceanographic Institution; -, not given. See table 8 for principal data sources]

\begin{tabular}{|c|c|c|c|c|c|c|c|}
\hline $\begin{array}{l}\text { Site } \\
\text { no. }\end{array}$ & Site designation & Location & $\begin{array}{l}\text { Latitude, } \\
\text { longitude }\end{array}$ & $\begin{array}{l}\text { Site altitude, } \\
\text { meters } \\
\text { (feet) }\end{array}$ & $\begin{array}{l}\text { Total depth, } \\
\text { meters } \\
\text { (feet) }\end{array}$ & Recovery method & Year \\
\hline 1 & HJW-106 (Hole A) & Harwich, Cape Cod & $\begin{array}{l}41^{\circ} 41^{\prime} 06^{\prime \prime} \mathrm{N} . \\
70^{\circ} 06^{\prime} 55^{\prime \prime} \mathrm{W} .\end{array}$ & $8.2(26.8)$ & $304.8(1,000)$ & Drilled, core & 1961. \\
\hline 2 & BMW-23 (Hole C) & Brewster, Cape Cod & $\begin{array}{l}41^{\circ} 44^{\prime} 35^{\prime \prime} \mathrm{N} . \\
70^{\circ} 06^{\prime} 22^{\prime \prime} \mathrm{W}\end{array}$ & $21.3(70)$ & $304.8(1,000)$ & Drilled, core & 1962. \\
\hline 3 & $\begin{array}{l}\text { BMW-24 (Hole D) } \\
\text { “Tubman." }\end{array}$ & Brewster, Cape Cod & $\begin{array}{l}41^{\circ} 44^{\prime} 50^{\prime \prime} \mathrm{N} . \\
70^{\circ} 05^{\prime} 11^{\prime \prime} \mathrm{W}\end{array}$ & $22.9(75)$ & $304.8(1,000)$ & Drilled, core & 1962. \\
\hline 4 & BMW-25 (Hole B) & Brewster, Cape Cod & $\begin{array}{l}41^{\circ} 45^{\prime} 03^{\prime \prime} \mathrm{N} . \\
70^{\circ} 05^{\prime} 01^{\prime \prime} \mathrm{W}\end{array}$ & $30.5(100)$ & $132.6(435)$ & Redrilled, core & 1961. \\
\hline 5 & WB-1 (WHOI dock) & $\begin{array}{l}\text { Woods Hole, Cape } \\
\text { Cod. }\end{array}$ & $\begin{array}{l}40^{\circ} 31^{\prime} 30^{\prime \prime} \mathrm{N} . \\
70^{\circ} 40^{\prime} 20^{\prime} \mathrm{W} .\end{array}$ & $-2.4(-8)$ & $85.7(281)$ & Drilled, core & 1965. \\
\hline 6 & $\begin{array}{l}\text { Assorted outcrops in } \\
\text { bay west of Marion. }\end{array}$ & $\begin{array}{l}\text { Buzzards Bay coast } \\
\text { in Plymouth and } \\
\text { Bristol Counties. }\end{array}$ & $\begin{array}{l}41^{\circ} 30^{\prime} \mathrm{N} \text {. to } \\
41^{\circ} 40^{\prime} \mathrm{N} \text {., } \\
70^{\circ} 50^{\prime} \mathrm{W} \text {. to } \\
71^{\circ} 02^{\prime} \mathrm{W} \text {. }\end{array}$ & - & $0(0)$ & Outcrops & 1978. \\
\hline 7 & USGS 6001 & Nantucket & $\begin{array}{l}41^{\circ} 15^{\prime} 55^{\prime \prime} \mathrm{N} . \\
70^{\circ} 02^{\prime} 17^{\prime \prime} \mathrm{W}\end{array}$ & $11(36)$ & $514(1,686)$ & $\begin{array}{l}\text { Drilled, rotary, } \\
\text { split-spoon, and } \\
\text { punch or driven } \\
\text { barrel coring. }\end{array}$ & 1975. \\
\hline 8 & ENW-50 & Martha's Vineyard & $\begin{array}{l}41^{\circ} 23^{\prime} 50^{\prime \prime} \mathrm{N} . \\
70^{\circ} 35^{\prime} 30^{\prime \prime} \mathrm{W}\end{array}$ & $10(33)$ & $262(860)$ & $\begin{array}{l}\text { Drilled, split-spoon } \\
\text { coring. }\end{array}$ & 1976. \\
\hline 9 & Gay Head Cliffs & Martha's Vineyard & $\begin{array}{l}41^{\circ} 21^{\prime} 00^{\prime \prime} \mathrm{N} . \\
70^{\circ} 50^{\prime} 10^{\prime \prime} \mathrm{W}\end{array}$ & $0(0)$ & $0(0)$ & Outcrop & 1888-1984. \\
\hline 10 & Zack's Cliff & Martha's Vineyard & $\begin{array}{l}41^{\circ} 19^{\prime} 30^{\prime \prime} \mathrm{N} . \\
70^{\circ} 48^{\prime} 30^{\prime \prime} \mathrm{W}\end{array}$ & $0(0)$ & $0(0)$ & Outcrop, sea cliffs & 1977. \\
\hline 11 & Nonamesset & $\begin{array}{l}\text { Lackey's Bay, Non- } \\
\text { amesset Island. }\end{array}$ & $\begin{array}{l}41^{\circ} 30^{\prime} 35^{\prime \prime} \mathrm{N} . \\
70^{\circ} 41^{\prime} 25^{\prime \prime} \mathrm{W} .\end{array}$ & $0(0)$ & $0(0)$ & $\begin{array}{l}\text { Outcrop, not } \\
\text { exposed at time } \\
\text { of inspection } \\
\text { (1977). }\end{array}$ & 1934. \\
\hline 12 & Coskata & Nantucket & $\begin{array}{l}41^{\circ} 22^{\prime} 00^{\prime \prime} \mathrm{N} . \\
70^{\circ} 01^{\prime} 30^{\prime} \mathrm{W}\end{array}$ & $0(0)$ & $102.2(335)$ & Drilled, cable tool & 1933. \\
\hline 13 & MV-1 & $\begin{array}{l}\text { West Tisbury, Mar- } \\
\text { tha's Vineyard. }\end{array}$ & - & - & - & Mobile 50 rig auger & 1977. \\
\hline 14 & MV-2 & $\begin{array}{l}\text { Katama Beach, } \\
\text { Martha's Vine- } \\
\text { yard. }\end{array}$ & - & - & - & Mobile 50 rig auger & 1977. \\
\hline 15 & OBW 33-35 (MV-3) & $\begin{array}{l}\text { Sengekontacket } \\
\text { Pond, Martha's } \\
\text { Vineyard. }\end{array}$ & - & - & - & Mobile 50 rig auger & 1977. \\
\hline 16 & $M V-4$ & $\begin{array}{l}\text { Katama Beach, } \\
\text { Martha's Vine- } \\
\text { yard. }\end{array}$ & - & - & - & Mobile 50 rig auger & 1977. \\
\hline 17 & ENW 70-73 & $\begin{array}{l}\text { Trapps Pond, Mar- } \\
\text { tha's Vineyard. }\end{array}$ & - & - & - & Mobile 50 rig auger & 1977. \\
\hline 18 & Holden's Pond & Cape Cod & $\begin{array}{l}42^{\circ} 03^{\prime} 30^{\prime \prime} \mathrm{N} . \\
70^{\circ} 06^{\prime} 25^{\prime \prime} \mathrm{W}\end{array}$ & $3.1(10)$ & $80.5(264)$ & $\begin{array}{l}\text { Pipe driven as cas- } \\
\text { ing, samples. }\end{array}$ & 1960. \\
\hline 19 & Stark's Well & Cape Cod & $\begin{array}{l}42^{\circ} 03^{\prime} 50^{\prime \prime} \mathrm{N} . \\
70^{\circ} 09^{\prime} 00^{\prime \prime} \mathrm{W}\end{array}$ & $4.3(14)$ & $61.9(203)$ & $\begin{array}{l}\text { Pipe driven as cas- } \\
\text { ing, samples. }\end{array}$ & 1960. \\
\hline 20 & Jim's II & Cape Cod & $\begin{array}{l}42^{\circ} 03^{\prime} 25^{\prime \prime} \mathrm{N} . \\
70^{\circ} 11^{\prime} 00^{\prime \prime} \mathrm{W}\end{array}$ & $3.1(10)$ & $66.5(217)$ & $\begin{array}{l}\text { Pipe driven as cas- } \\
\text { ing, samples. }\end{array}$ & 1960. \\
\hline 21 & Race Point & Cape Cod & $\begin{array}{l}42^{\circ} 02^{\prime} 40^{\prime \prime} \mathrm{N} . \\
70^{\circ} 14^{\prime} 40^{\prime \prime} \mathrm{W}\end{array}$ & $6.2(20)$ & $69.8(229)$ & $\begin{array}{l}\text { Pipe driven as cas- } \\
\text { ing, samples. }\end{array}$ & 1960. \\
\hline 22 & DGW-193-195 & $\begin{array}{l}\text { Corporation Beach, } \\
\text { Dennis, Cape } \\
\text { Cod. }\end{array}$ & $\begin{array}{l}41^{\circ} 45^{\prime} 04^{\prime \prime} \mathrm{N} . \\
70^{\circ} 11^{\prime} 21^{\prime \prime} \mathrm{W} .\end{array}$ & $1.6(5)$ & $94.2(309)$ & $\begin{array}{l}\text { Drilled, auger and } \\
\text { split spoon. }\end{array}$ & 1977. \\
\hline 23 & YAW & $\begin{array}{l}\text { Windmill Park, Yar- } \\
\text { mouth, Cape Cod. }\end{array}$ & $\begin{array}{l}41^{\circ} 39^{\prime} 16^{\prime \prime} \mathrm{N} . \\
70^{\circ} 11^{\prime} 48^{\prime \prime} \mathrm{W} .\end{array}$ & $1.6(5)$ & $91.5(300)$ & $\begin{array}{l}\text { Drilled, auger and } \\
\text { split spoon. }\end{array}$ & 1977. \\
\hline
\end{tabular}


TABLE 7.-Location and identification of outcrops and auger-and core-drilling sites in the area of Cape Cod and the nearby islands, Massachusetts-Continued

\begin{tabular}{|c|c|c|c|c|c|c|c|}
\hline $\begin{array}{l}\text { Site } \\
\text { no. }\end{array}$ & Site designation & Location & $\begin{array}{l}\text { Latitude, } \\
\text { longitude }\end{array}$ & $\begin{array}{l}\text { Site altitude, } \\
\text { meters } \\
\text { (feet) }\end{array}$ & $\begin{array}{l}\text { Total depth, } \\
\text { meters } \\
\text { (feet) }\end{array}$ & Recovery method & Year \\
\hline 24 & FA-8-82-1 & $\begin{array}{l}\text { Maravista, } \\
\text { Falmouth, Cape } \\
\text { Cod. }\end{array}$ & $\begin{array}{l}41^{\circ} 32^{\prime} 45^{\prime \prime} \mathrm{N} . \\
70^{\circ} 35^{\prime} 10^{\prime \prime} \mathrm{W}\end{array}$ & $1.6(5)$ & $83.3(273)$ & $\begin{array}{l}\text { Drilled, wire line, } \\
\text { core barrel. }\end{array}$ & 1982. \\
\hline 25 & PH-77-1 & $\begin{array}{l}\text { Pine Hill, Manomet, } \\
\text { Plymouth County. }\end{array}$ & - & - & $33.6(110)$ & Drilled, auger & 1977. \\
\hline 26 & MB-77-1 & Marshfield & - & - & $5.5(18)$ & Drilled, auger & 1977. \\
\hline 27 & MB-77-2 & Marshfield & - & - & $11.6(38)$ & Drilled, auger & 1977. \\
\hline 28 & MK-79-1 & Kent Park & $\begin{array}{l}42^{\circ} 06^{\prime} 00^{\prime \prime} \mathrm{N} . \\
70^{\circ} 41^{\prime} 00^{\prime} \mathrm{W}\end{array}$ & - & $16.2(53)$ & Drilled, auger & 1977. \\
\hline 29 & MH-77-1 & Marshfield Hills & - & - & 39.3 (129) & Drilled, 11 cores & 1977. \\
\hline 30 & MH-78-1, Pine Street & Marshfield Hills & - & - & - & Drilled, auger & 1978. \\
\hline 31 & $\begin{array}{l}\text { NR-78-1, Bridge } \\
\text { Street. }\end{array}$ & $\begin{array}{l}\text { North River, Nor- } \\
\text { well. }\end{array}$ & - & - & - & Drilled, auger & 1978. \\
\hline 32 & SC-79-1 & $\begin{array}{l}\text { Scituate filtration } \\
\text { plant. }\end{array}$ & $\begin{array}{l}42^{\circ} 10^{\prime} 00^{\prime \prime} \mathrm{N} . \\
70^{\circ} 43^{\prime} 00^{\prime \prime} \mathrm{W}\end{array}$ & - & $30.2(99)$ & Drilled, auger & 1979. \\
\hline 33 & TC-77-1 & Third Cliff, Scituate & - & - & $22.6(74)$ & $\begin{array}{l}\text { Drilled, auger, } 10 \\
\text { cores. }\end{array}$ & 1977. \\
\hline
\end{tabular}

hydrothermal activity not long after emplacement of the basalt (Folger and others, 1978). The maroon clay above the basalt (table 8) mimics the structure of the basalt and appears to be a saprolite. This clay is directly overlain by Cretaceous sediments. K-Ar whole-rock age determinations of the basalt of $183 \pm 8 \mathrm{Ma}$ and $164 \pm 3 \mathrm{Ma}$ (Zartman and Marvin, this vol., chap. J, table 1) suggest that the basalt is Early Jurassic or older. The chemistry of the basalt is similar to that of basalts from various Eastern U.S. Mesozoic basins (Gottfried and others, 1977) except that it contains anomalous amounts of titanium and phosphorus (Folger and others, 1978, table 1). The basalt is at least $44 \mathrm{~m}$ thick; its lateral extent is unknown.

\section{TRIASSIC AND JURASSIC SEDIMENTS AND VOLCANIC ROCKS (Jk)}

The presence of the Triassic and Jurassic sediments and volcanic rocks (JK) is inferred from seismic data through comparison of the seismic record with records from down-faulted rift basins in the Gulf of Maine (Ballard and Uchupi, 1975) and the New England continental margin (Grow and others, 1979). The sediments and volcanic rocks in the Nantucket basin are probably similar to Triassic sediments that crop out along the Bay of Fundy and the Gulf of Maine, which are continental red beds that interfinger with tholeiitic basalts. The red beds consist of graywacke, arkose, orthoquartzite, and, at the base in places, sharpstone conglomerate (Powers, 1916; Klein, 1962).

\section{CRETACEOUS SEDIMENTS (K)}

Cretaceous sediments $(\mathrm{K})$ are known from drill holes in Nantucket and Martha's Vineyard and from surface exposures on Martha's Vineyard and Nonamesset (sites 7-11, table 8). Bore hole USGS 6001 in Nantucket (site 7) contains the most complete Cretaceous section in Massachusetts. This section, $329 \mathrm{~m}$ thick, and that at site 8,140 $\mathrm{m}$ thick, are probably representative of the Cretaceous section in the area. The Cretaceous section of clays, silts, and sands in USGS 6001 (site 7) was divided by Folger and others (1978) into a lower unit, $108 \mathrm{~m}$ thick, of unconsolidated clayey sand and an upper unit, $221 \mathrm{~m}$ thick, of silty clay containing a few beds of silt and sand. The unfossiliferous lower unit that rests on the saprolite is considered to be part of the Albian Stage, by correlation on the basis of lithology with the Cretaceous Potomac Group in the Coastal Plain of New Jersey (fig. 16). The lowest $40 \mathrm{~m}$ of the lower unit consists of gray to white, clayey sand composed of quartz, plagioclase, kaolinite, illite, and minor amounts of smectite or mixedlayer illite-smectite. The middle $40 \mathrm{~m}$ of the lower unit consists of dark-red, gray, olive, and white mottled silty sandy clay composed of quartz, plagioclase, orthoclase, kaolinite, illite, and sparse smectite and hematite. The upper $25 \mathrm{~m}$ of the lower unit consists of coarse, light-gray silty sand composed of quartz, plagioclase, orthoclase, kaolinite, illite, and sparse smectite. The basal contact appears to be a disconformity representing Jurassic and Early Cretaceous time during which clastic and carbonate sediments were being deposited in similar basins to 
TABLE 8.-Description of materials encountered in outcrops and in drilled holes in the area of Cape Cod and the nearby islands, Massachusetts [Locations of sites shown on figure 15; datum for unit depths is mean sea level. USGS, U.S. Geological Survey; -, not given]

\begin{tabular}{|c|c|c|c|c|c|c|}
\hline $\begin{array}{l}\text { Site } \\
\text { no. }\end{array}$ & $\begin{array}{c}\text { Site } \\
\text { designation }\end{array}$ & $\begin{array}{l}\text { Unit } \\
\text { depth, } \\
\text { meters } \\
\text { (feet) }\end{array}$ & $\begin{array}{l}\text { Unit } \\
\text { thickness, } \\
\text { meters } \\
\text { (feet) }\end{array}$ & Description of units & Age & Principal data source \\
\hline \multirow[t]{6}{*}{1} & \multirow[t]{6}{*}{$\begin{array}{l}\text { HJW-106 } \\
\quad \text { (Hole A). }\end{array}$} & $+7.3(+24)$ & $48.6(160)$ & $\begin{array}{l}\text { Fine sand and scattered layers } \\
\text { of coarse sand. }\end{array}$ & Quaternary & \multirow{6}{*}{$\begin{array}{l}\text { Maevsky and Drake, 1963; } \\
\text { Koteff and Cotton, 1962; } \\
\text { unpublished well data, } \\
\text { USGS, Boston, Mass.; } \\
\text { Oldale, } 1976 .\end{array}$} \\
\hline & & $-41.3(-136)$ & $46.6(153)$ & $\begin{array}{l}\text { Bluish-gray, coarse to clayey } \\
\text { silt. }\end{array}$ & Quaternary & \\
\hline & & $-87.9(-289)$ & $35.4(116)$ & $\begin{array}{l}\text { Boulder till-boulders, mainly } \\
\text { granite, in silt matrix. }\end{array}$ & Quaternary & \\
\hline & & $-123.4(-405)$ & $1.8(6)$ & Iron-stained till & Quaternary & \\
\hline & & $-125.3(-411)$ & $18.3(60)$ & $\begin{array}{l}\text { Fine-grained, bluish-gray phyl- } \\
\text { litic schist and, in upper } 20 \mathrm{~m} \text {, } \\
30 \text { percent greenish-gray to } \\
\text { gray crystalline limestone in } \\
\text { beds } 1 \mathrm{~cm} \text { thick. }\end{array}$ & Proterozoic(?) & \\
\hline & & $-143.8(-471)$ & $155.5(510)$ & $\begin{array}{l}\text { Phyllitic schist as above lacking } \\
\text { carbonate but containing abun- } \\
\text { dant quartz veins and chlorite } \\
\text { alteration; thinly bedded, well } \\
\text { foliated. } 38 \mathrm{~cm}(15 \mathrm{in}) \text { recov- } \\
\text { ered at }-181 \mathrm{~m}(-173.5 \mathrm{~m} \\
\text { datum) shows good foliation } \\
\text { dipping about } 80^{\circ} \text {. }\end{array}$ & Proterozoic(?) & \\
\hline \multirow[t]{7}{*}{2} & \multirow[t]{7}{*}{$\begin{array}{l}\text { BMW-23 } \\
\quad \text { (Hole C). }\end{array}$} & $+21.3(+70)$ & $36.5(120)$ & $\begin{array}{l}\text { Fine to very coarse yellowish- } \\
\text { brown sand containing scat- } \\
\text { tered layers of gravel. }\end{array}$ & Quaternary & \multirow{7}{*}{$\begin{array}{l}\text { Maevsky and Drake, 1963; } \\
\text { unpublished well data, } \\
\text { USGS, Boston, Mass.; } \\
\text { R.Z. Gore, written com- } \\
\text { mun., 1978. }\end{array}$} \\
\hline & & $-15.2(-50)$ & $21.0(69)$ & $\begin{array}{l}\text { Fine to very coarse gray sand } \\
\text { containing scattered layers of } \\
\text { gravel. }\end{array}$ & Quaternary & \\
\hline & & $-36.3(-119)$ & $26.2(86)$ & $\begin{array}{l}\text { Greenish-gray silty clay contain- } \\
\text { ing sandy layers. }\end{array}$ & Quaternary & \\
\hline & & $-62.5(-205)$ & $42.7(140)$ & $\begin{array}{l}\text { Very fine to very coarse gray } \\
\text { sand containing layers of } \\
\text { gravel. }\end{array}$ & Quaternary & \\
\hline & & $-105.2(-345)$ & $5.5(18)$ & Till & Quaternary & \\
\hline & & $-110.7(-363)$ & $172.9(567)$ & $\begin{array}{l}\text { Quartz-biotite gneiss (three sam- } \\
\text { ples from core examined by }\end{array}$ & Proterozoic Z(?) & \\
\hline & & $-283.7(-930)$ & & $\begin{array}{l}\text { Gore appeared to be granu- } \\
\text { lated granodiorite). }\end{array}$ & & \\
\hline \multirow[t]{3}{*}{3} & $\begin{array}{l}\text { BMW-24 } \\
\text { (Hole D) }\end{array}$ & $+22.9(+75)$ & $120.8(396)$ & Unconsolidated material & Quaternary & \multirow{3}{*}{$\begin{array}{l}\text { Maevsky and Drake, 1963; } \\
\text { unpub. well data, USGS, } \\
\text { Boston, Mass.; Zartman } \\
\text { and Naylor, 1984; Zart- } \\
\text { man and Marvin, this } \\
\text { vol., chap. J, table 1; } \\
\text { R.Z. Gore, written com- } \\
\text { mun., 1964, 1978. }\end{array}$} \\
\hline & “Tubman." & $-97.9(-321)$ & $19.5(64)$ & Granodiorite & Proterozoic Z & \\
\hline & & $-117.4(-385)$ & $160.1(525)$ & $\begin{array}{l}\text { Quartz monzonite; contains xeno- } \\
\text { liths at } 164.7 \mathrm{~m}(540 \mathrm{ft}) \text { and } \\
190.3 \mathrm{~m}(624 \mathrm{ft})\end{array}$ & Proterozoic Z & \\
\hline 4 & $\begin{array}{l}\text { BMW-25 } \\
\text { (Hole B). }\end{array}$ & $+30.5(+100)$ & $130.5(428)$ & $\begin{array}{l}\text { Unconsolidated cobble gravel, } \\
\text { sand, and silt. }\end{array}$ & Quaternary & $\begin{array}{l}\text { Unpub. well data, USGS, } \\
\text { Boston, Mass. }\end{array}$ \\
\hline
\end{tabular}


TABLE 8.-Description of materials encountered in outcrops and in drilled holes in the area of Cape Cod and the nearby islands, Massachusetts-Continued

\begin{tabular}{lccc}
\hline & Unit & Unit & \\
Site & Site & depth, & thickness, \\
no. designation & meters & meters \\
& (feet) & (feet) & Description of units Principal data source \\
\hline
\end{tabular}

\begin{tabular}{|c|c|c|c|c|c|c|}
\hline & & $-102.2(-335)$ & $28.4(90.9)$ & $\begin{array}{l}\text { Unconsolidated material as } \\
\text { above. Refusal at } 130.5 \mathrm{~m}(428 \\
\text { ft) in till or granitic rock. }\end{array}$ & Proterozoic Z(?) & \\
\hline \multirow[t]{2}{*}{5} & $\begin{array}{l}\text { WB-1 } \\
\text { (WHOI }\end{array}$ & $-2.4(-8)$ & $83.0(272)$ & Light-brown fine to coarse sand & Quaternary & $\begin{array}{l}\text { Unpub. well data, Ameri- } \\
\text { can Drilling and Boring }\end{array}$ \\
\hline & dock). & $-85.4(-280)$ & $3.1(10)$ & Gray to pink granodiorite & Proterozoic Z(?) & $\begin{array}{l}\text { Company, Inc., East } \\
\text { Providence, R.I. }\end{array}$ \\
\hline 6 & $\begin{array}{l}\text { Assorted } \\
\text { outcrops } \\
\text { near } \\
\text { Marion. }\end{array}$ & - & - & $\begin{array}{l}\text { Fine- to coarse-grained granitic } \\
\text { rock and local layers and } \\
\text { lenses of gneiss. }\end{array}$ & Proterozoic Z & Williams and Tasker, 1978. \\
\hline \multirow[t]{5}{*}{7} & USGS 6001 & $+11.0(+36)$ & $128.1(420)$ & $\begin{array}{l}\text { Tan, gray, olive, green, medium- } \\
\text { to coarse-grained quartz and } \\
\text { plagioclase sand; dominant } \\
\text { clay mineral is illite, minor } \\
\text { kaolinite. Some glauconite } \\
\text { below -82 m. Material con- } \\
\text { tains sparse Tertiary sporo- } \\
\text { morphs and dinoflagellates and } \\
\text { Cretaceous palynomorphs. }\end{array}$ & Pleistocene & $\begin{array}{l}\text { Folger and others, 1978; } \\
\text { Kohout and others, 1977; } \\
\text { unpub. data, USGS, } \\
\text { Woods Hole; R.A. } \\
\text { Christopher, written } \\
\text { commun., 1982; Walter } \\
\text { Barrett, written com- } \\
\text { mun., 1936; E.G.A. } \\
\text { Weed, unpub. data; L.J. }\end{array}$ \\
\hline & & $-117.1(-384)$ & $221.1(725)$ & $\begin{array}{l}\text { Variegated red, gray, and yel- } \\
\text { low clay and silt interbedded } \\
\text { with light-gray sand; lignite in } \\
\text { darker layers, subbituminous } \\
\text { coal at - } 317 \mathrm{~m} \text {; dominant min- } \\
\text { erals are kaolinite and quartz. }\end{array}$ & Late Cretaceous & $\begin{array}{l}\text { Poppe, written } \\
\text { commun., 1976; S.A. } \\
\text { Wood-Needell, written } \\
\text { commun., } 1976 .\end{array}$ \\
\hline & & $-338.2(-1,109)$ & $108.0(354)$ & $\begin{array}{l}\text { Light-gray, fine- to coarse- } \\
\text { grained quartz sand in kaolin- } \\
\text { ite matrix; subordinate inter- } \\
\text { bedded clay. }\end{array}$ & Late Cretaceous & . \\
\hline & & $-446.2(-1,463)$ & $13.1(43)$ & $\begin{array}{l}\text { Massive maroon clay containing } \\
\text { white blebs and veins. }\end{array}$ & $\begin{array}{l}\text { Jurassic and } \\
\text { Triassic. }\end{array}$ & \\
\hline & & $\begin{array}{l}-459.3(-1,506) \\
-503.3(-1,650)\end{array}$ & $43.9(144)$ & $\begin{array}{l}\text { Altered maroon to gray amygda- } \\
\text { loidal basalt containing veins } \\
\text { and amygdaloid fillings of cal- } \\
\text { cite, zeolite, and saprolite. }\end{array}$ & $\begin{array}{c}\text { Jurassic and } \\
\text { Triassic. }\end{array}$ & \\
\hline \multirow[t]{3}{*}{8} & ENW-50 & $+10.1(+33)$ & $80.2(262)$ & $\begin{array}{l}\text { Medium- to coarse-grained white } \\
\text { sand, lignite, and several lay- } \\
\text { ers of clay. Material contains } \\
\text { Tertiary sporomorphs and } \\
\text { microfossils. }\end{array}$ & Pleistocene & $\begin{array}{l}\text { Hall and others, 1980; } \\
\text { Kaye, 1964a, 1983b; } \\
\text { Delaney, 1980. }\end{array}$ \\
\hline & & $-70.2(-230)$ & $47.9(157)$ & $\begin{array}{l}\text { Medium to fine sand and layers } \\
\text { of silty clay. }\end{array}$ & Cretaceous & \\
\hline & & $-118.0(-387)$ & $92.1(302)$ & $\begin{array}{l}\text { Mottled micaceous silty clay; } \\
\text { white sand at }-119 \mathrm{~m} \text { and lig- } \\
\text { nite between }-164 \text { and }-170 \\
\text { m; layers partly indurated. }\end{array}$ & Cretaceous & \\
\hline
\end{tabular}


TABLE 8.-Description of materials encountered in outcrops and in drilled holes in the area of Cape Cod and the nearby islands, Massachusetts-Continued

\begin{tabular}{|c|c|c|c|c|c|c|}
\hline $\begin{array}{l}\text { Site } \\
\text { no. }\end{array}$ & $\begin{array}{c}\text { Site } \\
\text { designation }\end{array}$ & $\begin{array}{l}\text { Unit } \\
\text { depth, } \\
\text { meters } \\
\text { (feet) }\end{array}$ & $\begin{array}{l}\text { Unit } \\
\text { thickness, } \\
\text { meters } \\
\text { (feet) }\end{array}$ & Description of units & Age & Principal data source \\
\hline \multirow{4}{*}{9} & & $\begin{array}{l}-210.1(-689) \\
-252.2(-827)\end{array}$ & $42.1(138)$ & $\begin{array}{l}\text { Sand and sandstone; clay at } \\
-230 \mathrm{~m} \text {, and red arkosic sand- } \\
\text { stone at bottom. }\end{array}$ & Cretaceous & \multirow{4}{*}{$\begin{array}{l}\text { Kaye, 1964a, 1983b; } \\
\text { Shaler, 1888, 1890; } \\
\text { Woodworth and Wig- } \\
\text { glesworth, 1934; Freder- } \\
\text { icksen, 1984; L.J. } \\
\text { Poppe, written } \\
\text { commun., 1978. }\end{array}$} \\
\hline & $\begin{array}{l}\text { Gay Head } \\
\text { Cliffs. }\end{array}$ & - & - & $\begin{array}{l}\text { Shelly, light-yellow to light-gray } \\
\text { sand, thin beds of fine sand } \\
\text { and silt; massive ferruginous } \\
\text { clay and silt. }\end{array}$ & $\begin{array}{l}\text { Pliocene and } \\
\text { Miocene. }\end{array}$ & \\
\hline & & & & $\begin{array}{l}\text { Greensand, largely glauconite, } \\
\text { minor quartz and feldspar; } \\
\text { contains apatite nodules and } \\
\text { chert. }\end{array}$ & Miocene & \\
\hline & & & & $\begin{array}{l}\text { Kaolinite, red, white, and lig- } \\
\text { nitic clay containing siderite } \\
\text { concretions. Clays largely kao- } \\
\text { linite, minor quartz and feld- } \\
\text { spar. }\end{array}$ & Cretaceous & \\
\hline \multirow[t]{2}{*}{10} & Zack's Cliff & - & - & Greensand & Tertiary & \multirow{2}{*}{$\begin{array}{l}\text { R.A. Christopher, written } \\
\text { commun., } 1977 .\end{array}$} \\
\hline & & & & Greensand & Cretaceous & \\
\hline \multirow[t]{2}{*}{11} & Nonamesset & - & - & Greensand & Miocene & \multirow{2}{*}{$\begin{array}{l}\text { Woodworth and } \\
\text { Wigglesworth, } 1934 .\end{array}$} \\
\hline & & & & $\begin{array}{l}\text { Lignitic clay, gray clay, quartz } \\
\text { gravel, and yellow sand. Sid- } \\
\text { eritic nodules on nearby beach } \\
\text { characteristic of known Creta- } \\
\text { ceous beds at Gay Head. }\end{array}$ & Cretaceous & \\
\hline \multirow[t]{4}{*}{12} & Coskata & $0(0)$ & $44.2(145)$ & Sand and gravel & Pleistocene & \multirow[t]{4}{*}{ Folger and others, 1978.} \\
\hline & & $-44.2(-145)$ & $11.0(36)$ & Silt and clay & $\begin{array}{l}\text { Pliocene and } \\
\text { Miocene. }\end{array}$ & \\
\hline & & $-55.2(-181)$ & $19.8(65)$ & Silty clay & Eocene & \\
\hline & & $\begin{array}{r}-75.0(-246) \\
-102.2(-335)\end{array}$ & $27.1(89)$ & Silty clay & Paleocene & \\
\hline 13 & MV-1 & - & - & $\begin{array}{l}\text { Brown sand } \\
\text { Gray sand }\end{array}$ & Pleistocene & Delaney, 1980. \\
\hline 14 & MV-2 & - & - & No recovery & Pleistocene(?) & Delaney, 1980. \\
\hline 15 & $\begin{array}{l}\text { OBW 33-35 } \\
\text { (MV-3). }\end{array}$ & $-134(-439)$ & - & $\begin{array}{l}\text { Gray sand } \\
\text { Brown sand } \\
\text { Olive sand } \\
\text { Olive clay }\end{array}$ & $\begin{array}{l}\text { Pleistocene } \\
\text { Pleistocene } \\
\text { Pleistocene } \\
\text { early Pleisto- } \\
\quad \text { cene. }\end{array}$ & Delaney, 1980. \\
\hline 16 & $\mathrm{MV}-4$ & - & - & $\begin{array}{l}\text { Brown sand } \\
\text { Gray sand } \\
\text { White sand } \\
\text { Clayey sand } \\
\text { Orange sand } \\
\text { Gray sand }\end{array}$ & Pleistocene & Delaney, 1980. \\
\hline 17 & ENW 70-73 & - & - & $\begin{array}{l}\text { Brown sand } \\
\text { Gray sand } \\
\text { White sand } \\
\text { Olive-gray sand }\end{array}$ & Pleistocene & Delaney, 1980. \\
\hline
\end{tabular}


TABLE 8.-Description of materials encountered in outcrops and in drilled holes in the area of Cape Cod and the nearby islands, Massachusetts-Continued

\begin{tabular}{|c|c|c|c|c|c|c|}
\hline $\begin{array}{l}\text { Site } \\
\text { no. }\end{array}$ & $\begin{array}{c}\text { Site } \\
\text { designation }\end{array}$ & $\begin{array}{l}\text { Unit } \\
\text { depth, } \\
\text { meters } \\
\text { (feet) }\end{array}$ & $\begin{array}{l}\text { Unit } \\
\text { thickness, } \\
\text { meters } \\
\text { (feet) }\end{array}$ & Description of units & Age & Principal data source \\
\hline \multirow[t]{2}{*}{18} & Holden's Pond & $3.1(10)$ & $80.5(264)$ & Clean sand & Pleistocene & Zeigler and others, 1960. \\
\hline & & & & $\begin{array}{l}\text { Silty sand containing Eocene } \\
\text { pollen, possibly reworked. }\end{array}$ & Eocene(?) & \\
\hline \multirow[t]{2}{*}{19} & Stark's Well & $4.3(14)$ & $61.9(203)$ & Clean sand & Pleistocene & Zeigler and others, 1960. \\
\hline & & & & Silty sand & Eocene(?) & \\
\hline \multirow[t]{2}{*}{20} & Jim's II & $3.1(10)$ & $66.5(218)$ & Clean sand & Eocene(?) & Zeigler and others, 1960. \\
\hline & & & & Silty sand & & \\
\hline \multirow[t]{2}{*}{21} & Race Point & $6.2(20)$ & $69.8(229)$ & Clean sand & Eocene(?) & Zeigler and others, 1960. \\
\hline & & & & Silty sand & & \\
\hline \multirow[t]{3}{*}{22} & DGW-193-195 & - & - & Brown sand & Pleistocene & Guswa and LeBlanc, 1985. \\
\hline & & & & Gray sand and silt & & \\
\hline & & & & Brown sand & & \\
\hline \multirow[t]{4}{*}{23} & YAW & - & - & Gray silt and sand & Pleistocene & Guswa and LeBlane, 1985. \\
\hline & & & & Gravel & & \\
\hline & & & $97(300)$ & Gray clay & & \\
\hline & & & & Basal till & & \\
\hline \multirow[t]{4}{*}{24} & FA-8-82-1 & - & $24.4(80)$ & Brown medium sand & Pleistocene & E.G.A. Weed, unpub. \\
\hline & & & $6.1(20)$ & Fine yellow sand & & data, 1982 \\
\hline & & & $51.9(170)$ & Gray silty clay & & \\
\hline & & & & Hard layer (ate bit) & & \\
\hline 25 & $\mathrm{PH}-77-1$ & - & - & $\begin{array}{l}\text { Dry yellow sand, cobbles at } \\
35,50,60 \text {, and } 75 \mathrm{ft} \text {. }\end{array}$ & Pleistocene & $\begin{array}{l}\text { E.G.A. Weed, unpub. } \\
\text { data, } 1977 .\end{array}$ \\
\hline \multirow[t]{4}{*}{26} & MB-77-1 & - & $2.7(9)$ & Gray clayey silty sand & Pleistocene & E.G.A. Weed, unpub. \\
\hline & & & $1.5(5)$ & Yellow sand & Pleistocene & data, 1977. \\
\hline & & & $0.9(3)$ & Greensand & Miocene(?) & \\
\hline & & & & $\begin{array}{l}\text { Rottenstone (disaggregated } \\
\text { granite). }\end{array}$ & Proterozoic Z(?) & \\
\hline \multirow[t]{3}{*}{27} & MB-77-2 & - & $7.6(25)$ & Olive clay, varved & Pleistocene & E.G.A. Weed, unpub. \\
\hline & & & $3.1(10)$ & Yellow sand & Pleistocene & data, 1977. \\
\hline & & $11.6(38)$ & $1.2(4)$ & Granodiorite & Proterozoic Z(?) & \\
\hline \multirow[t]{2}{*}{28} & MK-79-1 & - & - & Sand & Pleistocene & E.G.A. Weed, unpub. \\
\hline & & & $15.6(51)$ & Granite & Proterozoic Z(?) & data, 1977. \\
\hline \multirow[t]{4}{*}{29} & MH-77-1 & - & $4.6(15)$ & Silt and sand & Tertiary & E.G.A. Weed, unpub. \\
\hline & & & $12.2(40)$ & Gray clay & Tertiary & data, 1977 \\
\hline & & & $25.9(85)$ & Yellow sand & Pleistocene & \\
\hline & & & $37.8(124)$ & Granodiorite & Proterozoic Z(?) & E.G.A. Weed, unpub. \\
\hline \multirow[t]{2}{*}{30} & MH-78-1 & - & - & Sand & Pleistocene & data, 1978 \\
\hline & & $33.2(109)$ & $3.1(10)$ & Black shale & Carboniferous & $\begin{array}{l}\text { P.C. Lyons, written com- } \\
\text { mun., } 1979 .\end{array}$ \\
\hline \multirow[t]{2}{*}{31} & NR-78-1 & - & - & Sand & Pleistocene & $\begin{array}{l}\text { E.G.A. Weed, unpub. } \\
\text { data, } 1978 .\end{array}$ \\
\hline & & $18.3(60)$ & - & Red sandstone & Carboniferous & $\begin{array}{l}\text { P.C. Lyons, written com- } \\
\text { mun., } 1979 .\end{array}$ \\
\hline \multirow[t]{2}{*}{32} & SC-79-1 & - & - & Sand & Pleistocene & E.G.A. Weed, unpub. \\
\hline & & $29.6(97)$ & - & Granite & Proterozoic Z(?) & data, 1979 \\
\hline \multirow[t]{3}{*}{33} & TC-77-1 & - & $4.6(15)$ & Dark-gray till & Pleistocene & E.G.A. Weed, unpub. \\
\hline & & & $1.5(5)$ & Clayey sand & & data, 1977. \\
\hline & & & $1.5(5)$ & Gray clay & & \\
\hline
\end{tabular}


TABLE 8.-Description of materials encountered in outcrops and in drilled holes in the area of Cape Cod and the nearby islands, Massachusetts-Continued

\begin{tabular}{|c|c|c|c|c|c|c|}
\hline $\begin{array}{l}\text { Site } \\
\text { no. }\end{array}$ & $\begin{array}{c}\text { Site } \\
\text { designation }\end{array}$ & $\begin{array}{l}\text { Unit } \\
\text { depth, } \\
\text { meters } \\
\text { (feet) }\end{array}$ & $\begin{array}{c}\text { Unit } \\
\text { thickness, } \\
\text { meters } \\
\text { (feet) }\end{array}$ & Description of units & Age & Principal data source \\
\hline & & & $1.5(5)$ & Olive sand & & \\
\hline & & & $3.1(10)$ & Clay layers containing sand & & \\
\hline & & & $3.1(10)$ & Silty clay & & \\
\hline & & & $3.1(10)$ & Brown sand & & \\
\hline & & & $1.5(5)$ & Till & & \\
\hline & & & $4.9(16)$ & $\begin{array}{l}\text { Yellow sand containing } \\
\text { cobbles. }\end{array}$ & & \\
\hline & & $22.6(74)$ & & Till(?), refusal & & \\
\hline
\end{tabular}

the east (Cousminer and Manspeizer, written commun., 1984). The middle unit of Folger and others (1978) is considered by them to extend from the Cenomanian into the Campanian (middle Late Cretaceous). The upper (221-m) unit consists of variegated red, gray, and yellow clay interbedded with light-gray sand. Lignite and subbituminous coal about $20 \mathrm{~m}$ above the top of the lower unit indicate a period of subaerial deposition. Of 30 samples from the Cretaceous part of the core, 13 contained spore and pollen assemblages. These assemblages are correlated with assemblages from the Cretaceous section of the New Jersey Coastal Plain (R.A. Christopher, written commun., 1976). Correlation of the strata in the bore hole with the New Jersey section is shown on figure 16. No formal names have been assigned to the Cretaceous strata in Massachusetts.

Hall and others (1980) divided the Cretaceous section in hole ENW-50 (site 8) into 11 parts, correlated them with USGS 6001 (site 7), and noted the presence of greensand, sphalerite, and lignite, as well as the clays and sand. X-ray diffraction analyses by Hall and others (1980, table 1, p. 11) showed three distinct mineral assemblages with increasing depth: (1) quartz-feldspar to $-50 \mathrm{~m}$; (2) quartz-mica-chlorite-smectite, -50 to $-70 \mathrm{~m}$; (3) quartz-kaolinite, $-70 \mathrm{~m}$ to bottom. These three assemblages have been used to subdivide the Cretaceous section into three units in table 8.

Kaye (1983b) divided the Cretaceous section in the ENW-50 hole (site 8, table 8) into five informal zones: A, white beds, 71-137 $\mathrm{m}$ depth, consisting primarily of white kaolinitic clays and sands; B, gray and black beds, 138-173 m, consisting of interbedded gray clay and silt and some light-gray silt and sandy silt; lignite is present at $161-164 \mathrm{~m}, 166-168 \mathrm{~m}$, and 172-173 $\mathrm{m}$ depth; $\mathrm{C}$, marine horizon, 174-189 m, consisting of greenish-gray to medium-gray, micaceous, glauconitic, silty clay and silty sand that contains foraminifers; $\mathrm{D}$, white beds, 190-224 m, containing white kaolinitic quartz sand and minor sandy silt, and beds of white clay containing thin zones of red and yellow mottling from 202-209 m; and E, dense white beds, $225-245 \mathrm{~m}$, consisting of white clay and coarse sand, more compact and having a higher ratio of clay to sand than the beds just above. Kaye assigned the entire Cretaceous section in this hole to the Upper Cretaceous Raritan Formation. He correlated the marine horizon (C) with marginal marine intervals containing foraminifers and plant fossils in USGS 6001, on Nantucket (site 7) at 310,320 , and $321 \mathrm{~m}$ identified by Folger and others (1978, p. 18).

The Cretaceous at Gay Head, Martha's Vineyard (site 9 ), and at Nonamesset (site 11) is characterized by kaolinite; red, gray and white clays, in part containing siderite concretions; and lignitic clay. Pollen analyses (R.A. Christopher, written commun., 1977) confirm the Late Cretaceous age for the clays at Gay Head, and Christopher correlated them with the bottom part of the Upper Cretaceous section of New Jersey, either the South Amboy Fire Clay Member of the Raritan Formation or the basal part of the Old Bridge Sand Member of the Magothy Formation. Greensand at Zack's Cliff, Martha's Vineyard (site 10), was identified as Cretaceous (R.A. Christopher, written commun., 1977), but most of the greensand in the region is of Tertiary age (Kaye, 1983b).

\section{TERTIARY SEDIMENTS (T)}

Tertiary sediments (T) are scattered and fragmentary and no longer form a continuous stratum. They all appear to be of nearshore marine origin. Sediments containing Tertiary macrofossils and microfossils are incorporated as blocks or disaggregated material within Pleistocene deposits (sites 7, 8, 29, 33). The most complete section of Tertiary deposits is a 58-m sequence of silt and clay on Nantucket (site 12, table 8) that ranges from Paleocene to Miocene and Pliocene in age. Greensand of Tertiary age, identified in places by pollen analyses as Miocene or 


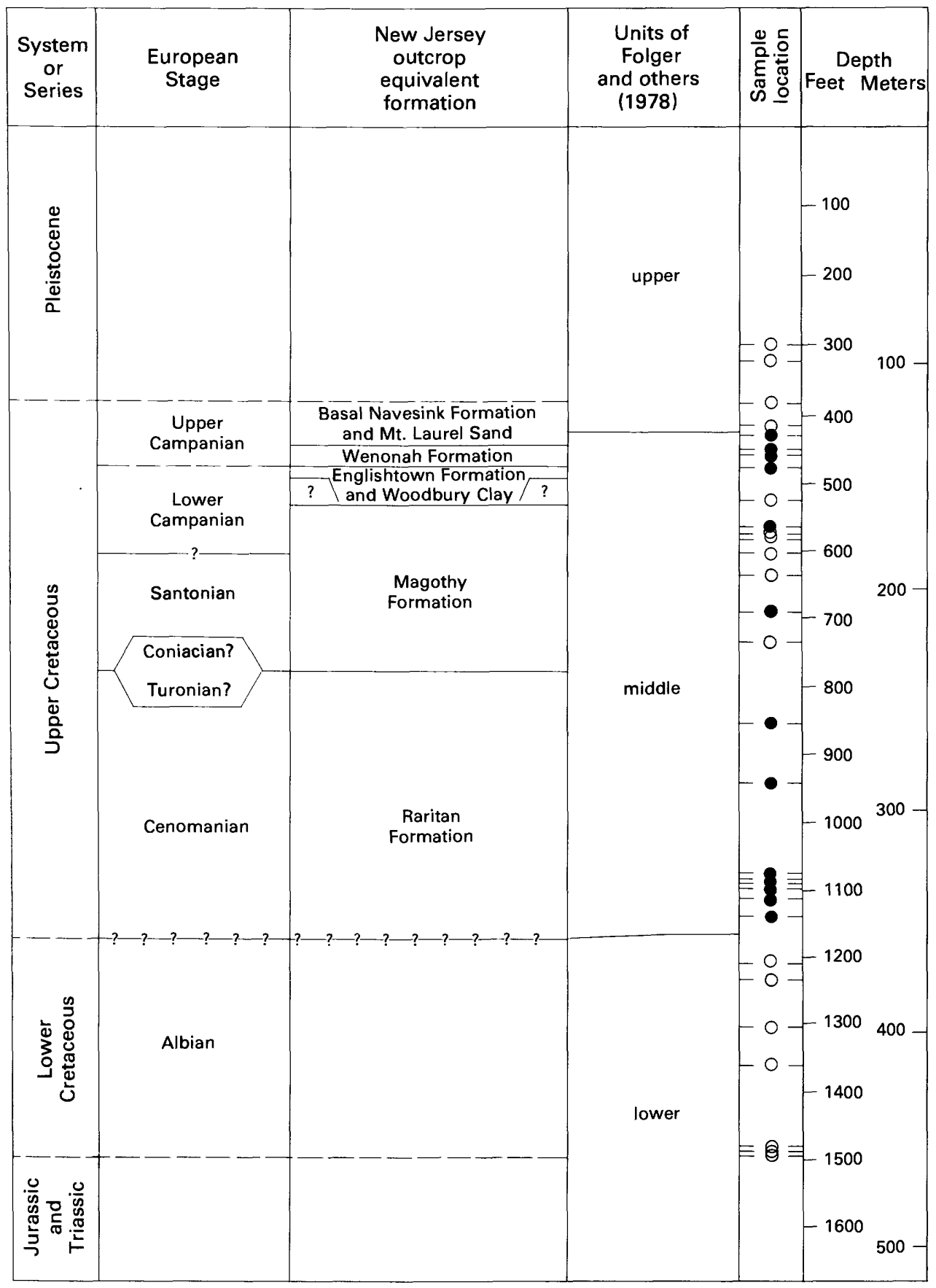

FIGURE 16.-Correlation of the Cretaceous section in bore hole USGS 6001, Nantucket, with the exposed Cretaceous section in New Jersey. Modified from R.A. Christopher (written commun., 1976). Solid circles indicate samples containing microfossils.

Miocene and Pliocene, is exposed on Martha's Vineyard at Gay Head and Zack's Cliff (sites 9 and 10) and on Nonamesset Island (site 11). Greensand has also been reported from Wequobsque Cliff about $9.5 \mathrm{~km}$ east of Gay Head (Kaye, 1983b).

Tertiary sediments of possible Eocene age are reported from the outer tip of Cape Cod (sites 18, 19, 20,
21). Eocene pollen was identified in the silty sand at Holden's Pond (site 18), but this material may be reworked, and there is some doubt that the sediments themselves, and possibly those at sites 19,20 , and 21 as well, are Eocene. Reworking of Tertiary material into Pleistocene sediments is evident at the top of the section at hole ENW-50 (site 8) on Martha's Vineyard. Here the 
inversion of normal stratigraphic position of fossils suggests a disordered structure like that visible at Gay Head as described by Kaye (1964c, 1983b).

A similar disruption of stratigraphic order is evident on the mainland in the Marshfield Hills area. At Marshfield Hills (site 29), the $17 \mathrm{~m}$ of Tertiary silt, sand, and clay overlying Pleistocene glacial deposits is allochthonous. Greensand, probably Miocene, at site 26 appears to be autochthonous, however. Kaye (1983b) described two places in Marshfield near sites 26 and 27 where presumably autochthonous greensand overlies bedrock.

\section{STRATIGRAPHIC HISTORY}

The Triassic and Jurassic basalt and sediments were deposited in the Nantucket basin during rifting of the Proterozoic and Paleozoic basement in the early Mesozoic (Ballard and Uchupi, 1975; Klitgord and Behrendt, 1979; Goldsmith, this vol., chap. H). The sediments were presumably nonmarine, similar to those in the onshore Mesozoic basins of the East Coast. Following an interval of subaerial weathering (see site $7,-446 \mathrm{~m}$, table 8 ) and erosion, littoral and shallow offshore-marine strata were deposited as onlap facies in the Cretaceous as eastern North America became a passive trailing edge of the westward-moving North American plate. Shallowmarine deposition continued into and probably through the Tertiary until disrupted by the glaciation of the Pleistocene. The northwest marine limit of the Tertiary marine deposits may be marked by fragments found in glacial drift, as at Marshfield Hills (site 29, fig. 15).

\section{REFERENCES CITED}

Affaton, Pascal, Sougy, Jean, and Trompette, Roland, 1980, The tectono-stratigraphic relationships between the Upper Precambrian and Lower Paleozoic Volta Basin and the Pan-African Dahomeyide orogenic belt (West Africa): American Journal of Science, v. 280 , p. 224-248.

Anderson, M.M., 1981, The Randon Formation of southeastern Newfoundland; a discussion aimed at establishing its age and relationship to bounding formations: American Journal of Science, v. 281, p. 807-830.

Anstey, R.L., 1979, Stratigraphy and depositional environment of the early Cambrian Hoppin Slate of southeastern New England and its Acado-Baltic fauna: Northeastern Geology, v. 1, p. 9-17.

Austin, J.A., Jr., Uchupi, Elazar, Shaughnessy, D.R., III, and Ballard, R.D., 1980, Geology of the New England passive margin: American Association of Petroleum Geologists Bulletin, v. 64, no. 4, p. 501-526.

Ballard, R.D., and Uchupi, Elazar, 1975, Triassic rift structures in the Gulf of Maine: American Association of Petroleum Geologists Bulletin, v. 59, no. 7, p. 1041-1072.

Bell, K.G., 1976, Pre-Silurian stratified rocks southeast of the Bloody Bluff fault, in New England Intercollegiate Geological Conference, 68th Annual Meeting, Boston, Mass., Oct. 8-10, 1976, Geology of southeastern New England; a guidebook for field trips to the Boston area and vicinity: Princeton, N.J., Science Press, p. 289-290.

Bell, K.G., and Alvord, D.C., 1976, Pre-Silurian stratigraphy of northeastern Massachusetts, in Page, L.R., ed., Contributions to the stratigraphy of New England: Geological Society of America Memoir 148, p. 179-216.

Bell, K.G., Shride, A.F., and Cuppels, N.P., 1977, Preliminary bedrock geologic map of the Georgetown quadrangle, Essex County, Massachusetts: U.S. Geological Survey Open-File Report 77-179, $30 \mathrm{p}$.

Berry, E.W., 1915, The age of the Cretaceous flora of southern New York and New England: Journal of Geology, v. 23, no. 7, p. 608-618.

Billings, M.P., 1929, Structural geology of the eastern part of the Boston basin: American Journal of Science, v. 18, 5th ser., p. 93-137.

- 1976a, Geology of the Boston basin, in Lyons, P.C., and Brownlow, A.H., eds., Studies in New England geology: Geological Society of America Memoir 146, p. 5-30.

1976b, Bedrock geology of the Boston basin, in New England Intercollegiate Geological Conference, 68th Annual Meeting, Boston, Mass., Oct. 8-10, 1976, Geology of southeastern New England; a guidebook for field trips in the Boston area and vicinity: Princeton, N.J., Science Press, p. 28-45.

1979, Boston basin, Massachusetts, in Skehan, J.W., Murray, D.P., Hepburn, J.C., Billings, M.P., Lyons, P.C., and Doyle, R.G., The Mississippian and Pennsylvanian (Carboniferous) Systems in the United States-Massachusetts, Rhode Island, and Maine: U.S. Geological Survey Professional Paper 1110-A, p. A15-A20.

-1982, Ordovician cauldron subsidence of the Blue Hills Complex, eastern Massachusetts: Geological Society of America Bulletin, v. 93, p. 909-920.

Billings, M.P., and Tierney, F.L., 1964, Geology of the City Tunnel extension, Greater Boston, Massachusetts: Journal of the Boston Society Civil Engineers, v. 51, p. 111-154.

Bothner, W.A., 1977, Gravity study of Cape Cod Bay: U.S. Geological Survey Open-File Report 77-497, 10 p.

Bottino, M.L., 1963, Whole rock Rb-Sr studies of volcanics and some related granites, in Massachusetts Institute of Technology Tenth Annual Progress Report for 1962, Variations in isotopic abundances of strontium, calcium, and argon: U.S. Atomic Energy Commission, Contract AT(30-01)-1381, p. 51-54.

Bouchard, Robert, 1979, The stratigraphy and petrography of the Brighton Volcanics in the Boston basin, Massachusetts: Boston, Mass., Boston College, Ph.D. thesis, 165 p.

Caldwell, D.W., 1981, The Boston Bay Group, Quincy, Massachusetts, in New England Intercollegiate Geological Conference, 73d Annual Meeting, Kingston, R.I., Oct. 16-18, 1981, Guidebook to geologic field studies in Rhode Island and adjacent areas: Kingston, R.I., University of Rhode Island, p. 339-344.

Cameron, Barry, 1979, Evidence for glaciation in the Boston basin, in Cameron, Barry, ed., Carboniferous basins of southeastern New England, Guidebook for field trip No. 5, 9th International Congress on Carboniferous geology and stratigraphy, May 14-16, 1979: Falls Church, Va., American Geological Institute, p. 75-80.

Castle, R.O., 1964, Geology of the Andover Granite and surrounding rocks, Massachusetts: U.S. Geological Survey Open-File Report, $550 \mathrm{p}$.

Castle, R.O., Dixon, H.R., Grew, E.S., Griscom, Andrew, and Zietz, Isidore, 1976, Structural dislocations in eastern Massachusetts: U.S. Geological Survey Bulletin 1410, 39 p. 
Chute, N.E., 1950, Bedrock geology of the Brockton quadrangle, Massachusetts: U.S. Geological Survey Geologic Quadrangle Map GQ-5, scale 1:31,680.

1964, Trip G. Geology of the Norfolk basin Carboniferous sedimentary rocks, and the various igneous rocks of the Norwood and Blue Hills quadrangles (Massachusetts), in New England Intercollegiate Geological Conference, 56th Annual Meeting, Chestnut Hill, Mass., Oct. 2-4, 1964, Guidebook to field trips in the Boston area and vicinity: Chestnut Hill, Mass., Boston College, p. 91-114.

1965, Geologic map of the Duxbury quadrangle, Plymouth County, Massachusetts: U.S. Geological Survey Geologic Quadrangle Map GQ-466, scale 1:24,000.

1966, Geology of the Norwood quadrangle, Massachusetts: U.S. Geological Survey Bulletin 1163-B, 78 p.

1969, Bedrock geologic map of the Blue Hills quadrangle, Massachusetts: U.S. Geological Survey Geologic Quadrangle Map GQ-796, scale 1:24,000.

Clark, T.H., 1923, New fossils from the vicinity of Boston: Boston Society of Natural History Proceedings, v. 36, p. 473-485.

Crosby, W.O., 1880, Contributions to the geology of eastern Massachusetts: Boston Society of Natural History Occasional Papers 3, $286 \mathrm{p}$.

1893, Geology of the Boston basin; Nantasket and Cohasset: Boston Society of Natural History Occasional Papers 4, v. 1, pt. 1, p. 1-177.

1900, Geology of the Boston basin; the Blue Hills Complex: Boston Society of Natural History Occasional Papers 4, v. 1, pt. 3, p. 289-563.

Dale, T.N., 1885a, The geology of the mouth of Narragansett Bay: Newport Natural History Society Proceedings, Document 3, p. 5-14.

1885b, On metamorphism in the Rhode Island Coal basin: Newport Natural History Society Proceedings, Document 3, p. $85-86$.

Dall, W.H., 1894, Notes on the Miocene and Pliocene of Gay Head, Martha's Vineyard, Mass., and on the "land phosphate" of the Ashley River district, S.C.: American Journal of Science, 3d ser., v. 48 , p. $296-301$.

de Laguna, Wallace, 1963, Geology of Brookhaven National Laboratory and vicinity, Suffolk County, New York: U.S. Geological Survey Bulletin 1156-A, $35 \mathrm{p}$.

Delaney, D.F., 1980, Groundwater hydrology of Martha's Vineyard, Massachusetts: U.S. Geological Survey Hydrologic Investigations Atlas HA-618, 2 sheets.

Dennen, W.H., 1975, Preliminary bedrock geologic map of the Ipswich quadrangle, Massachusetts: U.S. Geological Survey Open-File Report 75-544, scale 1:24,000.

Desor, E., 1849, Deposit of drift shells in the cliffs of Sancati Island of Nantucket, in a letter to W. C. Redfield: American Association for Advancement of Science Proceedings, v. l, p. 100-101.

Dixon, H.R., 1974, Bedrock geologic map of the Thompson quadrangle, Windham County, Connecticut, and Providence County, Rhode Island: U.S. Geological Survey Geologic Quadrangle Map GQ-1165, scale 1:24,000.

Dowse, A.M., 1950, New evidence for the Cambrian contact at Hoppin Hill, North Attleboro, Massachusetts: American Journal of Science, v. 248 , p. $95-99$

Drier, R.B., and Mosher, Sharon, 1981, The Blackstone Series: Evidence for an Avalonian plate margin in northern Rhode Island, in New England Intercollegiate Geological Conference, 73d Annual Meeting, Kingston, R.I., Oct. 16-18, 1981; Guidebook to geological field studies in Rhode Island and adjacent areas: Kingston, R.I., University of Rhode Island, p. 93-102.
Emerson, B.K., 1917, The geology of Massachusetts and Rhode Island: U.S. Geological Survey Bulletin 597, 289 p.

Emery, K.O., and Uchupi, Elazar, 1972, Western North Atlantic Ocean: Topography, rocks, structure, water, life, and sediments: American Association of Petroleum Geologists Memoir 17, $532 \mathrm{p}$.

Faust, G.T., 1975, A review and interpretation of the geologic setting of the Watchung Basalt flows, New Jersey: U.S. Geological Survey Professional Paper 864-A, $42 \mathrm{p}$.

Foerste, A.F., 1889, The paleontological horizon of the limestone at Nahant, Massachusetts: Boston Society of Natural History Proceedings, v. 24 , p. 261-263.

Folger, D.W., Hathaway, J.C., Christopher, R.A., Valentine, P.C., and Poag, C.W., 1978, Stratigraphic test well, Nantucket Island, Massachusetts: U.S. Geological Survey Circular 773, 28 p.

Fredericksen, N.O., 1984, Stratigraphic, paleoclimatic, and paleobiogeographic significance of Tertiary sporomorphs from Massachusetts: U.S. Geological Survey Professional Paper 1308, 25 p.

Glover, L.G., III, and Sinha, A.K., 1973, The Virgilina deformation, a late Precambrian to early Cambrian(?) orogenic event in the central Piedmont of Virginia and North Carolina: American Journal of Science, Cooper Volume, v. 273-A, p. 234-251.

Goldsmith, Richard, 1966, Stratigraphic names in the New London area, Connecticut: U.S. Geological Survey Bulletin 1224-J, 9 p. 1976, Pre-Silurian stratigraphy of the New London area, southeastern Connecticut, in Page, L.R., ed., Contributions to the stratigraphy of New England: Geological Society of America Memoir 148, p. 271-275.

1980, Stratigraphic names in the New London area, southeastern Connecticut-A revision, in Sohl, N.F., and Wright, W.B., Changes in stratigraphic nomenclature by the U.S. Geological Survey, 1979: U.S. Geological Survey Bulletin 1502-A, p. A91-A103.

Goldsmith, Richard, Grew, E.S., Hepburn, J.C., and Robinson, G.R., 1982a, Formation names in the Worcester area, Massachusetts: U.S. Geological Survey Bulletin 1529-H, p. H43-H56.

Goldsmith, Richard, Milton, D.J., and Horton, J.W., Jr., 1982b, Geologic map of the Charlotte $1^{\circ} \times 2^{\circ}$ quadrangle, North Carolina and South Carolina [abs.]: Geological Society of America Abstracts with Programs, v. 14, nos. 1 and 2, p. 20-21.

Goldsmith, Richard, Wones, D.R., and Shride, A.F., 1982c, Stratigraphic names in eastern Massachusetts: U.S. Geological Survey Bulletin 1529-H, p. H57-H72.

Gottfried, David, Annell, C.S., and Schwarz, L.J., 1977, Geochemistry of subsurface basalt from the deep corehole (Clubhouse Crossroads Corehole 1) near Charleston, South Carolina-Magma type and tectonic implications, in Rankin, D.W., ed., Studies related to the Charleston, South Carolina, earthquake of 1886-A preliminary report: U.S. Geological Survey Professional Paper 1028, p. 91-113.

Grow, J.A., Mattick, R.E., and Schlee, J.S., 1979, Multichannel seismic depth sections and interval velocities over Outer Continental Slope between Cape Hatteras and Cape Cod, in Watkins, J.S., Montadert, Lucien, and Dickerson, P.W., eds., Geological and geophysical investigations of continental margins: American Association of Petroleum Geologists Memoir 29, p. 65-84.

Grow, J.A., and Schlee, J.S., 1976, Interpretation and velocity analysis of USGS multichannel reflection profiles 4,5 , and 6 , Atlantic continental margin: U.S. Geological Survey Miscellaneous Field Studies Map MF-808.

Guswa, J.H., and LeBlanc, D.R., 1985, Digital models of ground-water flow in the Cape Cod aquifer system, Massachusetts: U.S. Geological Survey Water-Supply Paper 2209, 112 p.

Hall, H.T., 1963, Structural geology of the Woonsocket and North Scituate basins, in New England Intercollegiate Geological Con- 
ference, 55th Annual Meeting, Providence, R.I., Oct. 4-6, 1963, Guidebook: New Haven, Conn., Yale University, Department of Geology, p. 53-55.

Hall, R.E., Poppe, L.J., and Ferrebee, W.M., 1980, A stratigraphic test well, Martha's Vineyard, Massachusetts: U.S. Geological Survey Bulletin 1488, 19 p.

Hartshorn, J.H., 1960, Geology of the Bridgewater quadrangle, Massachusetts: U.S. Geological Survey Geologic Quadrangle Map GQ-127, scale 1:24,000.

1967, Geology of the Taunton quadrangle, Bristol and Plymouth Counties, Massachusetts: U.S. Geological Survey Bulletin 1163-D, $67 \mathrm{p}$.

Harwood, D.S., and Goldsmith, Richard, 1971, Bedrock geologic map of the Oneco quadrangle, Connecticut and Rhode Island: U.S. Geological Survey Geologic Quadrangle Map GQ-930, scale $1: 24,000$.

Hepburn, J.C., and DiNitto, R.G., 1978, Preliminary bedrock geologic map of the Marlborough quadrangle, Middlesex and Worcester Counties, Massachusetts: U.S. Geological Survey Open-File Report 78-222, 29 p., 1 pl., scale 1:24,000.

Hermes, O.D., Gromet, L.P., and Zartman, R.E., 1981, Zircon geochronology and petrology of plutonic rocks in Rhode Island, in New England Intercollegiate Geological Conference, 73d Annual Meeting, Kingston, R.I., Oct. 16-18, 1981, Guidebook to geologic field studies in Rhode Island and adjacent areas: Kingston, R.I., University of Rhode Island, p. 315-338.

Hobbs, W.E., 1899, Some new fossils from eastern Massachusetts: American Geologist, v. 23, p. 109-115.

Hollick, C.A., 1906, The Cretaceous flora of southern New York and New England: U.S. Geological Survey Monograph 50, 219 p.

Hoskins, Hartley, and Knott, S.T., 1961, Geophysical investigation of Cape Cod Bay, Massachusetts, using the continuous seismic profiler: Journal of Geology, v. 69, p. 330-340.

Hughes, C.J., and Bruckner, W.D., 1971, Late Precambrian rocks of eastern Avalon Peninsula, Newfoundland-A volcanic island complex: Canadian Journal of Earth Sciences, v. 8, p. 899-915.

Hutchinson, R.D., 1962, Cambrian stratigraphy and trilobite faunas of southeastern Newfoundland: Canada Geological Survey Bulletin $88,123 \mathrm{p}$.

Kay, Marshall, and Colbert, E.H., 1965, Stratigraphy and life history: New York, Wiley, $736 \mathrm{p}$.

Kay, S.M., and Chapple, W.M., 1976, Pre-Pennsylvanian rocks of Aquidneck and Conanicut Islands, Rhode Island, in New England Intercollegiate Geological Conference, 68th Annual Meeting, Boston, Mass., Oct. 8-10, 1976, Geology of southeastern New England; a guidebook for field trips to the Boston area and vicinity: Princeton, N.J., Science Press, p. 428-446.

Kaye, C.A., 1964a, Upper Cretaceous to Recent stratigraphy of Martha's Vineyard, Massachusetts [abs.]: Geological Society of America Special Paper 76, p. 91.

_ _ 1964b, The Pleistocene geology of Martha's Vineyard, Mass.: Friends of the Pleistocene 27th Annual Reunion, Martha's Vineyard, Mass., May 1964, Itinerary, $9 \mathrm{p}$.

$-1964 c$, Outline of Pleistocene geology of Martha's Vineyard, Massachusetts: U.S. Geological Survey Professional Paper 501-C, p. C134-C139.

_ 1980, Bedrock geologic maps of the Boston North, Boston South, and Newton quadrangles, Massachusetts: U.S. Geological Survey Miscellaneous Field Studies Map MF-1241, scale 1:24,000.

1983a, Discovery of a Late Triassic basin north of Boston, Massachusetts, and some implications as to post-Paleozoic faulting in northeastern Massachusetts: American Journal of Science, v. 283 , p. $1060-1079$.

-1983b, The autochthonous and allochthonous coastal plain deposits of Martha's Vineyard and the Marshfield-Scituate area, south- eastern Massachusetts, in Atlantic Coastal Plain Geological Association Field Trip Guidebook, Martha's Vineyard, Massachusetts, Oct. 1-2, 1983: Newark, Del., Delaware Geological Survey, University of Delaware, $31 \mathrm{p}$.

Kaye, C.A., and Zartman, R.E., 1980, A Late Proterozoic Z to Cambrian age for the stratified rocks of the Boston basin, Massachusetts, USA, in Wones, D.R., ed., The Caledonides in the USA, International Geological Correlation Program Project 27-Caledonide Orogen, 1979 Meeting, Blacksburg, Virginia: Virginia Polytechnic Institute and State University Memoir 2, p. 257-262.

Keppie, J.D., 1979, Geological map of the Province of Nova Scotia: Department of Mines and Energy, Nova Scotia, Canada, scale 1:500,000.

Keppie, J.D., and Schenk, P.E., 1982, Geology and tectonics of Nova Scotia, in King, A.F., ed., The guidebook for Avalon and Meguma zones; International Geological Correlation Program (IGCP), Project 27, Caledonide Orogen: St. John's, Newfoundland, Memorial University of Newfoundland, Department of Earth Sciences, p. 159-187.

King, A.F., 1980, The birth of the Caledonides: Late Precambrian rocks of the Avalon Peninsula, Newfoundland, and their correlatives in the Appalachian orogen, in 'Wones, D.R., ed., The Caledonides in the USA, International Geological Correlation Program Project 27-Caledonide orogen, 1979 Meeting, Blacksburg, Virginia: Virginia Polytechnic Institute and State University Memoir 2, p. 3-8.

Klein, G.D., 1962, Triassic sedimentation, Maritime Provinces, Canada: Geological Society of America Bulletin v. 73, no. 9, p. $1127-1146$.

Klitgord, K.D., 1984, Tectonic structure and evolution of the Gulf of Maine [abs.]: Geological Society of America Abstracts with Programs, v. 16 , no. 1, p. 28.

Klitgord, K.D., and Behrendt, J.C., 1979, Basin structure of the U.S. Atlantic margin, in Watkins, J.S., Montadert, Lucien, and Dickerson, P.W., eds., Geological and geophysical investigations of continental margins: American Association of Petroleum Geologists Memoir 29, p. 85-112.

1980, Aeromagnetic anomaly map, United States Atlantic continental margin: U.S. Geological Survey Miscellaneous Field Studies Map MF-913, scale 1:1,000,000.

Kohout, F.A., Hathaway, J.C., Folger, D.W., Bothner, M.H., Walker, E.H., Delaney, D.F., Frimpter, M.H., Weed, E.G.A., and Rhodehamel, E.C., 1977, Fresh ground water stored in aquifers under the Continental Shelf; Implications from a deep test, Nantucket Island, Massachusetts: Water Resources Bulletin, v. 13, no. 2, p. $373-386$.

Koteff, Carl, 1964, Geologic map of the Assawompset Pond quadrangle, Massachusetts: U.S. Geological Survey Geologic Quadrangle Map GQ-265, scale 1:24,000.

Koteff, Carl, and Cotton, J.E., 1962, Preliminary results of recent deep drilling on Cape Cod, Massachusetts: Science, v. 137, no. 3523, p. 34.

LaForge, Laurence, 1932, Geology of the Boston area, Massachusetts: U.S. Geological Survey Bulletin 839, $105 \mathrm{p}$.

Landing, Ed, and Brett, C.E., 1982, Lower Cambrian of Massachusetts: microfaunal sequence and the oldest known borings [abs.]: Geological Society of America Abstracts with Programs, v. 14, nos. 1 and 2, p. 33.

Lenk, Cecelia, Strother, P.K., Kaye, C.A., and Barghoorn, E.S., 1982, Precambrian age of the Boston basin, Massachusetts-New evidence from microfossils: Science, v. 216, p. 619-620.

Lidback, M.M., 1977, Areal geology of the Attleboro, Massachusetts-Rhode Island quadrangle: Boston, Mass., Boston University, Ph.D. thesis, 203 p. 
Loughlin, G.F., 1911, Contributions to the geology of the Boston and Norfolk basins, in The structural relations between the Quincy Granite and the adjacent sedimentary formations: American Journal of Science, 4 th ser., v. 32, p. 17-32.

Loughlin, G.F., and Hechinger, L.A., 1914, An unconformity in the Narragansett basin of Rhode Island and Massachusetts: American Journal of Science, 4 th ser., v. 38, p. 45-64.

Lundgren, Lawrence, Jr., 1967, The bedrock geology of the Old Lyme quadrangle: Connecticut Geological and Natural History Survey, Quadrangle Report 21, $30 \mathrm{p}$.

Lyell, Charles, 1843, On the Tertiary strata of the island of Martha's Vineyard in Massachusetts: Geological Society of London Proceedings, v. 4, p. 31-33.

Lyons, P.C., 1969, Bedrock geology of the Mansfield quadrangle, Massachusetts: Boston, Mass., Boston University, Ph.D. thesis, $282 \mathrm{p}$.

- 1977, Report on the bedrock geology of the Narragansett basin, Massachusetts and Rhode Island: U.S. Geological Survey OpenFile Report 77-816, 42 p., 24 pls., scale 1:31,250.

Lyons, P.C., and Chase, H.B., Jr., 1976, Coal stratigraphy and flora of the northwestern Narragansett basin, in New England Intercollegiate Geological Conference, 68th Annual Meeting, Boston, Mass., Oct. 8-10, 1976, Geology of southeastern New England; a guidebook for field trips to the Boston area and vicinity: Princeton, N.J., Science Press, p. 405-427.

Lyons, P.C., and Goldsmith, Richard, 1983, Pseudo plant fossils in the Boston basin, Massachusetts: Northeastern Geology, v. 5, no. 1, p. 23-28.

Maevsky, Anthony, and Drake, J.A., 1963, Southeastern Massachusetts: U.S. Geological Survey Massachusetts Basic-Data Report no. 7, Ground-Water Series, 55 p.

Mansfield, G.R., 1906, The origin and structure of the Roxbury Conglomerate: Harvard College Museum Comparative Zoology Bulletin 49, p. 91-271.

McKniff, J.M., 1964, The petrology of the south half of the Blackstone quadrangle, Massachusetts and Rhode Island: Providence, R.I., Brown University, Masters thesis, $37 \mathrm{p}$.

Minard, J.P., Perry, W.J., Weed, E.G.A., Rhodehamel, E.C., Robbins, E.I., and Mixon, R.B., 1974, Preliminary report on geology along Atlantic continental margin of Northeastern United States: American Association of Petroleum Geologists Bulletin, v. 58, no. 6, p. 1169-1178.

Mosher, Sharon, and Wood, D.S., 1976, Mechanisms of Alleghenian deformation in the Pennsylvanian of Rhode Island, in New England Intercollegiate Geological Conference, 68th Annual Meeting, Boston, Mass., Oct. 8-10, 1976, Geology of southeastern New England; a guidebook for field trips to the Boston area and vicinity: Princeton, N.J., Science Press, p. 472-490.

Mutch, T.A., 1968, Pennsylvanian non-marine sediments of the Narragansett basin, Massachusetts-Rhode Island: Geological Society of America Special Paper 106, p. 177-209.

Naylor, R.S., 1976, Isotopic dating and New England stratigraphy, in Page, L.R., ed., Contributions to the stratigraphy of New England: Geological Society of America Memoir 148, p. 419-425.

1981, Felsic volcanic units in the Boston area, Massachusetts, in New England Intercollegiate Geological Conference, 73d Annual Meeting, Kingston, R.I., Oct. 16-18, 1981, Guidebook to field studies in Rhode Island and adjacent areas: Kingston, R.I., University of Rhode Island, p. 303-314.

Naylor, R.S., and Sayer, Suzanne, 1976, The Blue Hills Igneous Complex, Boston area, Massachusetts, in New England Intercollegiate Geological Conference, 68th Annual Meeting, Boston, Mass., Oct. 8-10, 1976, Geology of southeastern New England; a guidebook for field trips in the Boston area and vicimity: Princeton, N.J., Science Press, p. 135-146.
Nelson, A.E., 1974, Changes in nomenclature of Upper Precambrian to lower Paleozoic(?) formations in the Natick quadrangle, eastern Massachusetts, and their tentative correlations with rocks in Rhode Island and Connecticut: U.S. Geological Survey Bulletin 1395-E, p. 15.

1975a, Bedrock geology of the Natick quadrangle, Middlesex and Norfolk Counties, Massachusetts: U.S. Geological Survey Geologic Quadrangle Map GQ-1208, scale 1:24,000.

-1975b, Bedrock geologic map of the Framingham quadrangle, Middlesex and Worcester Counties, Massachusetts: U.S. Geological Survey Geologic Quadrangle Map GQ-1274, scale 1:24,000.

-1976, Structural elements and deformational history of rocks in eastern Massachusetts: Geological Society of America Bulletin, v. 87, p. 1377-1383.

1981, Polydeformed rocks of the Lowndesville shear zone in the Greenville $2^{\circ}$ quadrangle, South Carolina and Georgia, in Horton, J.W., Jr., Butler, J.W., and Milton, D.J., eds., Geological investigations of the Kings Mountain belt and adjacent areas in the Carolinas, Carolina Geological Society Field Trip Guidebook 1981; Gaffney, S.C., Oct. 24-25, 1981: Columbia, S.C., South Carolina Geological Survey, p. 181-193.

O'Brien, S.J., and King, A.F., 1982, The Avalon zone in Newfoundland, in King, A.F., ed., The guidebook for Avalon and Meguma zones: International Geological Correlation Program (IGCP), Project 27, Caledonide Orogen: St. John's, Newfoundland, Memorial University of Newfoundland, Department of Earth Sciences, p. 1-28.

Oldale, R.N., 1962, Sedimentary rocks of Triassic age in northeastern Massachusetts; U.S. Geological Survey Professional Paper 450-C, p. C31-C32.

1969, Seismic investigations on Cape Cod, Martha's Vineyard, and Nantucket, Massachusetts, and a topographic map of the basement surface from Cape Cod Bay to the islands: U.S. Geological Survey Professional Paper 650-B, p. B122-B127.

1976, Generalized geologic map of Cape Cod: U.S. Geological Survey Open-File Report 76-765, 23 p., scale 1:125,000.

Oldale, R.N., and Tuttle, C.R., 1964, Seismic investigations on Cape Cod, Massachusetts: U.S. Geological Survey Professional Paper 475-D, p. D118-D122.

Oldale, R.N., Uchupi, Elazar, and Prada, K.E., 1973, Sedimentary framework of the western Gulf of Maine and the southeastern Massachusetts offshore area: U.S. Geological Survey Professional Paper 757, $10 \mathrm{p}$.

Olszewski, W.J., 1980, The geochronology of some stratified metamorphic rocks in northeastern Massachusetts: Canadian Journal of Earth Sciences, v. 17, p. 1407-1416.

Perlmutter, N.M., and Todd, Ruth, 1965, Correlation and Foraminifera of the Monmouth Group (Upper Cretaceous), Long Island, New York: U.S. Geological Survey Professional Paper 483-I, p. I1-I21.

Perry, J.H., and Emerson, B.K., 1903, Geology of Worcester, Massachusetts: Worcester, Mass., Worcester Natural History Society, $166 \mathrm{p}$.

Pollock, S.J., 1964, Bedrock geology of the Tiverton quadrangle, Rhode Island-Massachusetts: U.S. Geological Survey Bulletin 1158-D, $16 \mathrm{p}$.

Powers, Sidney, 1916, The Acadian Triassic: Journal of Geology, v. 24, p. 1-26, 105-122, 254-268.

Quinn, A.W., 1971, Bedrock geology of Rhode Island: U.S. Geological Survey Bulletin 1295, $68 \mathrm{p}$.

Quinn, A.W., and Oliver, W.A., Jr., 1962, Pennsylvanian rocks of New England, in Pennsylvanian system in the United States-A symposium: Tulsa, Okla., American Association of Petroleum Geologists, p. 60-73. 
Quinn, A.W., Ray, R.G., and Seymour, W.L., 1949, Bedrock geology of the Pawtucket quadrangle, Rhode Island-Massachusetts: U.S. Geological Survey Geologic Quadrangle Map GQ-1, scale 1:31,680.

Quinn, A.W., Ray, R.G., Seymour, W.L., Chute, N.E., and Allen, W.B., 1948, The geology and ground water resources of the Pawtucket quadrangle, Rhode Island: Rhode Island Industrial Development Commission Geological Bulletin 3, 85 p.

Rankin, D.W., 1975, The continental margin of eastern North America in the southern Appalachians: The opening and closing of the proto-Atlantic Ocean: American Journal of Science, v. 275-A, p. 298-336.

Rast, Nicholas, 1980, The Avalonian plate in the northern Appalachians and Caledonides, in Wones, D.R., ed., The Caledonides in the USA, International Geological Correlation Program Project 27-Caledonide Orogen, 1979 Meeting, Blacksburg, Virginia: Virginia Polytechnic Institute and State University Memoir 2, p. $63-66$.

Rast, Nicholas, O'Brien, B.H., and Wardle, R.J., 1976, Relationship between Precambrian and lower Paleozoic rocks of the "Avalon Platform" in New Brunswick, the northeast Appalachians and the British Isles: Tectonophysics, v. 30, p. 315-338.

Rast, Nicholas, and Skehan, J.W., 1981, The geology of Precambrian rocks of Newport and Middletown, Rhode Island, in New England Intercollegiate Geological Conference, 73d Annual Meeting, Kingston, R.I., Oct. 16-18, 1981, Guidebook to geologic field studies in Rhode Island and adjacent areas: Kingston, R.I., University of Rhode Island, p. 67-92.

Rehmer, J.A., and Hepburn, J.C., 1974, Quartz sand surface textural evidence for a glacial origin of the Squantum "Tillite," Boston basin, Massachusetts: Geology, v. 2, p. 413-415.

Rehmer, J.A., and Roy, D.C., 1976, The Boston Bay Group: the boulder bed problem, in New England Intercollegiate Geological Conference, 69th Annual Meeting, Boston, Mass., Oct. 8-10, 1976, Geology of southern New England; a guidebook for field trips to the Boston area and vicinity: Princeton, N.J., Science Press, p. 71-91.

Rhodes, E.J., and Graves, W.H., Jr., 1931, A new Cambrian locality in Massachusetts: American Journal of Science, 5th ser., v. 22, p. 364-372.

Richmond, G.M., 1952, Bedrock geology of the Georgiaville quadrangle, Rhode Island: U.S. Geological Survey Geologic Quadrangle Map GQ-16, scale 1:31,680.

Robinson, Peter, and Hall, L.M., 1980, Tectonic synthesis of southern New England, in Wones, D.R., ed., The Caledonides in the USA, International Geological Correlation Program Project 27-Caledonide orogen, 1979 Meeting, Blacksburg, Virginia: Virginia Polytechnic Institute and State University Memoir 2, p. $73-82$.

Rodgers, John, 1982, Preliminary bedrock geologic map of Connecticut, in New England Intercollegiate Geological Conference, 74th Annual Meeting, Storrs, Conn., Oct. 2-3, 1982, Guidebook for field trips in Connecticut and south-central Massachusetts: Connecticut Geological and Natural History Survey Guidebook 5, map in pocket, scale 1:250,000.

Rodgers, John, Gates, R.M., and Rosenfeld, J.L., 1959, Explanatory text for preliminary geologic map of Connecticut, 1956: Connecticut Geological and Natural History Survey Bulletin 84, 64 p.

Rutherford, M.J., and Carroll, M.R., 1981, Igneous rocks of northern Rhode Island, in New England Intercollegiate Geological Conference, 73d Annual Meeting, Kingston, R.I., Oct. 16-18, 1981, Guidebook to geologic field studies in Rhode Island and adjacent areas: Kingston, R.I., University of Rhode Island, p. 103-124.

Sayer, Suzanne, 1974, An integrated study of the Blue Hills porphyry and related units: Cambridge, Mass., Massachusetts Institute of Technology, Masters thesis, $146 \mathrm{p}$.
Schenk, P.E., 1971, Southeastern Atlantic Canada, northwestern Africa, and continental drift: Canadian Journal of Earth Sciences, v. 8 , p. $1218-1251$.

Sears, J.H., 1905, The physical geography, geology, mineralogy, and paleontology of Essex County, Massachusetts: Salem, Mass., Essex Institute, $418 \mathrm{p}$.

Shaler, N.S., 1888, Report on the geology of Martha's Vineyard [Mass.]: U.S. Geological Survey 7th Annual Report, p. 297-363. 1889, The geology of Nantucket: U.S. Geological Survey Bulletin $53,55 \mathrm{p}$.

1890, Tertiary and Cretaceous deposits of eastern Massachusetts: Geological Society of America Bulletin, v. l, p. 443-452.

Shaler, N.S., Woodworth, J.B., and Foerste, A.G., 1899, Geology of the Narragansett basin: U.S. Geological Survey Monograph 33, $402 \mathrm{p}$.

Shaw, A.B., 1950, A revision of several Early Cambrian trilobites from eastern Massachusetts: Journal of Paleontology, v. 24, p. 577-590.

1961, Cambrian of southeastern and northwestern New England, in 20th International Geological Congress, Mexico, 1956, (The Cambrian System, its paleogeography and the problem of its lower boundary), Symposium, part 3, western Europe, Africa, USSR, Asia, America: Moscow, Akademia Nauk USSR, p. 433-471.

Shaw, C.E., Jr., 1967, Geology and petrochemistry of the Milford area, Massachusetts: Providence, R.I., Brown University, Ph.D. thesis, $141 \mathrm{p}$.

Shride, A.F., 1976, Stratigraphy and correlation of the Newbury Volcanic Complex, northeastern Massachusetts, in Page, L.R., ed., Contributions to the stratigraphy of New England: Geological Society of America Memoir 148, p. 147-178.

Skehan, J.W., 1969, Tectonic framework of southern New England and eastern New York, in Kay, Marshall, ed., North Atlantic-Geology and continental drift; a symposium: American Association of Petroleum Geologists Memoir 12, p. 793-814.

1973, Subduction zone between the Paleo-American and PaleoAfrican plates in New England: Geofisica Internacional, v. 13, p. 291-308.

1979, Puddingstone, drumlins, and ancient volcanoes; A geologic field guide along historic trails of Greater Boston: Dedham, Mass., WesStone Press, $63 \mathrm{p}$.

Skehan, J.W., and Murray, D.P., 1978, The coal-bearing Narragansett basin of Massachusetts and Rhode Island: Weston Observatory, Boston College, National Science Foundation Final Report, v. 1, Geology, Grant No. AER 76-02147, 32 p.

1980a, Geologic profile across southeastern New England: Tectonophysics, v. 69 , p. $285-316$.

$-1980 \mathrm{~b}$, A model for the evolution of the eastern margin (EM) of the northern Appalachians, in Wones, D.R., ed., The Caledonides in the USA, International Geological Correlation Program Project 27-Caledonide Orogen, 1979 Meeting, Blacksburg, Virginia: Virginia Polytechnic Institute and State University Memoir 2, p. 67-72.

Skehan, J.W., Murray, D.P., Hepburn, J.C., Billings, M.P., Lyons, P.C., and Doyle, R.G., 1979, The Mississippian and Pennsylvanian (Carboniferous) Systems in the United States-Massachusetts, Rhode Island, and Maine: U.S. Geological Survey Professional Paper 1110-A, $30 \mathrm{p}$.

Skehan, J.W., Murray, D.P., Palmer, A.R., Smith, A.T., and Belt, E.S., 1978, Significance of fossiliferous Middle Cambrian rocks of Rhode Island to the history of the Avalonian microcontinent: Geology, v. 6, p. 694-698.

Skehan, J.W., Rast, Nicholas, and Logue, Daniel, 1981, The geology of Cambrian rocks of Conanicut Island, Jamestown, Rhode Island, in New England Intercollegiate Geological Conference, 73d Annual Meeting, Oct. 16-18, 1981, Guidebook to geologic field studies in 
Rhode Island and adjacent areas: Kingston, R.I., University of Rhode Island, p. 237-264.

Soren, Julian, 1971, Results of subsurface exploration in the mid-island area of western Suffolk County, Long Island, New York: U.S. Geological Survey, Long Island Water Resources Bulletin 1, $60 \mathrm{p}$. 1977, Subsurface geology and paleogeography of Queens County, Long Island, New York: U.S. Geological Survey Water Resources Investigations Report 77-34, $17 \mathrm{p}$.

Strong, D.F., 1979, Proterozoic tectonics of northwest Gondwanaland: New evidence from eastern Newfoundland: Tectonophysics, v. 54, p. 81-101.

Theokritoff, George, 1968, Cambrian biogeography and biostratigraphy in New England, in Zen, E-an, White, W.S., Hadley, J.D., and Thompson, J.B., eds., Studies of Appalachian geology, northern and maritime: New York, Interscience Publishers, p. 9-22.

Toulmin, Priestley, III, 1964, Bedrock geology of the Salem quadrangle and vicinity, Massachusetts: U.S. Geological Survey Bulletin 1163-A, $79 \mathrm{p}$.

Uchupi, Elazar, 1966, Structural framework of the Gulf of Maine: Journal of Geophysical Research, v. 71, p. 3013-3028.

U.S. Geological Survey, 1971a, Aeromagnetic map of the Fall River East quadrangle, Bristol County, Massachusetts: U.S. Geological Survey Geophysical Investigations Map GP-799, scale 1:24,000.

$-1971 \mathrm{~b}$, Aeromagnetic map of the Westport quadrangle, Bristol County, Massachusetts, and Newport County, Rhode Island: U.S. Geological Survey Geophysical Investigations Map GP-809, scale $1: 24,000$.

Volckmann, R.P., 1977, Bedrock geologic map of the Holliston and Medfield quadrangles, Middlesex, Norfolk, and Worcester Counties, Massachusetts: U.S. Geological Survey Miscellaneous Investigations Map I-1053, scale 1:48,000.

Walcott, C.D., 1890, The fauna of the Lower Cambrian or Olenellus zone: U.S. Geological Survey 10th Annual Report, p. 509-763.

Walker, E.H., 1980, Water resources of Nantucket, Massachusetts: U.S. Geological Survey Hydrologic Investigations Atlas HA-615, 2 sheets.

Warren, C.H., and Powers, Sidney, 1914, Geology of the Diamond Hill-Cumberland district in Rhode Island-Massachusetts: Geological Society of America Bulletin, v. 25, p. 435-476.

Weed, E.G.A., Minard, J.P., Perry, W.J., Jr., Rhodehamel, E.C., and Robbins, E.I., 1974, Generalized pre-Pleistocene geologic map of the northern United States Atlantic continental margin: U.S. Geological Survey Miscellaneous Geological Investigations Map I-861, scale $1: 1,000,000$.

Weeks, L.J., 1957, The Appalachian region, in Stockwell, C.H., ed., Geology and economic minerals of Canada: Canadian Department of Mines Technical Survey, Geological Survey of Canada Economic Geology Series 1, p. 123.

Weston Geophysical Research, Inc., 1977 (Revision 1), Boston Edison Company, Pilgrim Unit 2, Geologic Investigations: Docket No. 50-471, Report BE-SG 7603, Appendix G-b, Radiometric Dating, p. 1-7.

White, C.D., 1890, On the Cretaceous plants from Martha's Vineyard: American Journal of Science, 3d ser., v. 39, p. 93-101.

Williams, Harold, 1964, Symmetry in the northern Newfoundland Appalachians [abs.]: Geological Society of America Special Paper 82, p. 225.

-1978, Tectonic-lithofacies map of the Appalachian orogen: Memorial University of Newfoundland, Map No. 1.

Williams, Harold, and King, A.F., 1979, Trepassy map area, Newfoundland: Geological Survey of Canada Memoir 389, $24 \mathrm{p}$.

Williams, J.R., and Tasker, G.D., 1978, Water resources of the coastal drainage basins of southeastern Massachusetts, northwest shore of Buzzards Bay: U.S. Geological Survey Hydrologic Investigations Atlas HA-560, scale 1:48,000.

Wood, D.S., 1974, Ophiolites, melanges, blue schists, and ignimbrites: Early Caledonian subduction in Wales, in Modern and ancient geoclinal sedimentation; problems of palinspastic reconstruction: Society of Economic Paleontologists and Mineralogists Special Publication 19, p. 334-344.

Woodworth, J.B., 1897, Unconformities of Martha's Vineyard and of Block Island: Geological Society of America Bulletin, v. 8, p. 197-212.

Woodworth, J.B., and Wigglesworth, Edward, 1934, Geography and geology of the region including Cape Cod, the Elizabeth Islands, Nantucket, Martha's Vineyard, No Mans Land and Block Island: Harvard College Museum of Comparative Zoology Memoir 52, 322 p., 38 pls.

Zarrow, L., 1978, Structural relationships and geochemical investigations of the Lynn Volcanic Complex, Pine Hill, Boston North quadrangle, Massachusetts: Cambridge, Mass., Massachusetts Institute of Technology, M.S. thesis, $184 \mathrm{p}$.

Zartman, R.E., and Naylor, R.S., 1984, Structural implications of some radiometric ages of igneous rocks in southeastern New England: Geological Society of America Bulletin, v. 95, no. 5, p. 522-539.

Zeigler, J.M., Hoffmeister, W.S., Giese, G.S., and Tasha, H.J., 1960, Discovery of Eocene sediments in subsurface of Cape Cod: Science, v. 132, no. 3437 , p. 1397-1398.

Zen, E-an, editor, and Goldsmith, Richard, Ratcliffe, N.M., Robinson, Peter, and Stanley, R.S., compilers, 1983, Bedrock geologic map of Massachusetts: Reston, Va., U.S. Geological Survey, 3 sheets, scale $1: 250,000$. 


\section{Stratigraphy of the Nashoba Zone, Eastern Massachusetts: An Enigmatic Terrane}

By RICHARD GOLDSMITH

With a section on MASSABESIC GNEISS COMPLEX (OZma)

By PETER ROBINSON

THE BEDROCK GEOLOGY OF MASSACHUSETTS

U.S. GEOLOGICAL SURVEY PROFESSIONAL PAPER 1366-F 



\section{CONTENTS}

\begin{tabular}{|c|c|c|c|}
\hline & Page & & \\
\hline 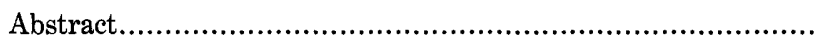 & F1 & 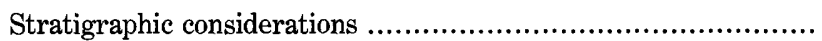 & F7 \\
\hline 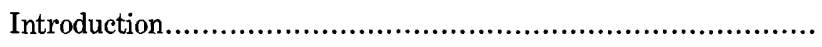 & 1 & Orientation & 7 \\
\hline 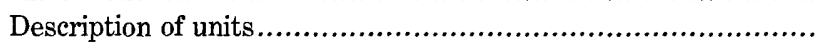 & 3 & 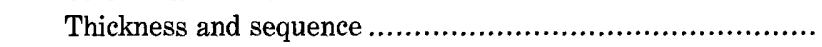 & 8 \\
\hline 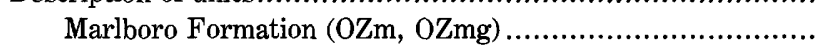 & 3 & Age & 11 \\
\hline Shawsheen Gneiss (OZsh) ......... & 5 & Regional correlations........ & 12 \\
\hline 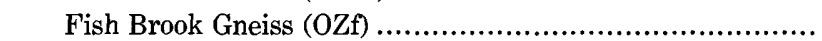 & 6 & 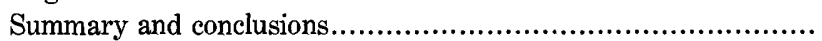 & 17 \\
\hline 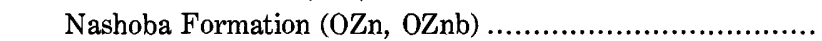 & 6 & Massabesic Gneiss Complex (OZma), by Peter Robinson ............ & 18 \\
\hline 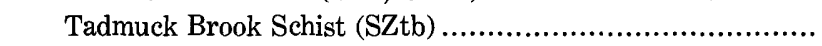 & 7 & References cited & 20 \\
\hline
\end{tabular}

\section{ILLUSTRATIONS}

FIGURE 1. Map showing major rock units and structural features in the Nashoba zone, eastern Massachusetts.

2. Correlation diagram of stratified and major intrusive rock units in the Nashoba zone and some rock units in the Merrimack belt.

3. Lithostratigraphic columns of the formations in the Putnam terrane and Nashoba zone, Connecticut and eastern Massachusetts

4. Diagram showing correlation of units in the Nashoba zone using repetition by faulting: $A$, nomenclature as published; $B$, alternative nomenclature suggested in this paper...

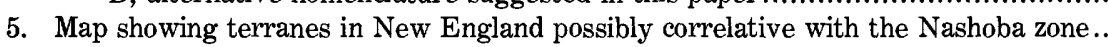

6. Correlation diagram and relative thicknesses of formations in the Nashoba zone and of some possibly correlative formations elsewhere in Massachusetts, Connecticut, New Hampshire, and Maine

7. Lithostratigraphic columns of units in southern and east-central Maine and southeastern New Hampshire that are probably correlative with units of the Nashoba zone.

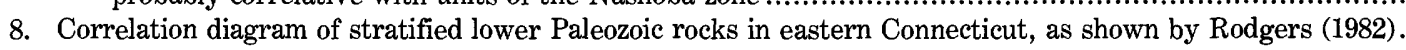





\title{
STRATIGRAPHY OF THE NASHOBA ZONE, EASTERN MASSACHUSETTS: AN ENIGMATIC TERRANE
}

\author{
By RICHARD GOLDSMITH
}

\begin{abstract}
The Nashoba zone is a fault-bounded block of high-grade, steeply dipping metamorphic rocks, largely metavolcanic to the east (Marlboro Formation) and largely metasedimentary to the west (Shawsheen Gneiss, Fish Brook Gneiss, Nashoba Formation, and Tadmuck Brook Schist). The Marlboro Formation, presumably stratigraphically the lowest formation, consists of amphibolite, feldspathic gneiss, and subordinate pelitic schist and calc-silicate rock. The Shawsheen Gneiss, above the Marlboro, is predominantly a pelitic schist and gneiss, commonly rusty weathering. The Fish Brook Gneiss, above, is a conspicuous mottled-appearing feldspathic gneiss believed to be of felsic igneous origin, probably volcanic. The Nashoba Formation, which occupies a large part of the zone, consists of pelitic and semipelitic (metawacke) gneiss and schist, commonly rusty weathering, and subordinate calc-silicate rock, marble, and amphibolite. The Tadmuck Brook Schist, consisting of pelitic schist and phyllite and subordinate quartzite, may lie unconformably above the Nashoba. Protoliths of the Marlboro were volcanic, volcaniclastic, and intercalated epiclastic materials deposited in a marine environment close to a volcanic source, probably to the east. The volcanic materials were primarily basaltic but also included andesitic, dacitic, and rhyodacitic materials. The protoliths of the Shawsheen, Fish Brook, and Nashoba were marine volcaniclastic, epiclastic, and minor volcanic materials and carbonate sediments deposited in a slope or basin off a volcanic center (volcanic arc).

The source of the material seems to be from the east, although two source terranes are indicated-a deeply weathered terrane and a volcanic source. The age of the material is bracketed between a $750-\mathrm{Ma}$ $\mathrm{U}-\mathrm{Pb}$ age on zircons from the Fish Brook Gneiss and a 1,500-Ma U-Pb age on detrital zircon from the Shawsheen Gneiss.

Rocks of the Nashoba zone correlate fairly well with the Tatnic Hill and Quinebaug Formations in Connecticut and with the Cushing Formation of southeastern Maine and the Rye Formation of southeastern New Hampshire. The Passagassawakeag Gneiss of eastern Maine and the rocks of the Gander Group in southeastern Newfoundland bear similarities to the Nashoba Formation. Correlation across strike with rocks of the Brimfield Group or rocks on the flanks of the Bronson Hill anticlinorium is less certain and involves complex structural interpretations. The Massabesic Gneiss Complex of south-central New Hampshire contains rocks resembling those of the Nashoba zone. The
\end{abstract}

Manuscript approved for publication November 16, 1987.
Nashoba zone is distinct from the Merrimack belt, adjacent to the west, and from the Milford-Dedham zone to the east. It is considered to be an accretionary terrane that was part of a volcanic-arc complex lying southeast of the North American plate and containing material probably derived from an African source.

\section{INTRODUCTION}

The Nashoba zone of eastern Massachusetts is defined as that mass of rock lying between the Merrimack belt on the west and the Milford-Dedham zone on the east. The Clinton-Newbury fault system bounds the block on the west and the Bloody Bluff-Lake Char fault system bounds the zone on the east (fig. 1). The zone consists of high-grade metamorphic rocks and intrusive plutonic rocks that together form a distinctive metamorphicplutonic terrane extending northeast across eastern Massachusetts from Oxford, Mass., to the Gulf of Maine, south of Newburyport. Near Newburyport, the zone narrows appreciably between the Clinton-Newbury fault and the faults bounding the Newbury basins. These basins are small tectonic wedges between the Nashoba and Milford-Dedham zones and are discussed in the chapter on the Milford-Dedham zone (Goldsmith, this vol., chap. E). To the southwest, the Nashoba zone narrows at the salient in the Milford-Dedham zone near Oxford, where it is in tenuous continuity with the terrane containing the Putnam Group (Putnam block) in eastern Connecticut.

The rock units within the Nashoba zone are considered to be part of a single lithotectonic entity because common lithologies are interlayered and because the zone is flanked by terranes of different lithologic and structural character. Internally, however, the structure is complex. Early synmetamorphic folds are largely obscured by later folds and faults. Differential vertical and lateral 


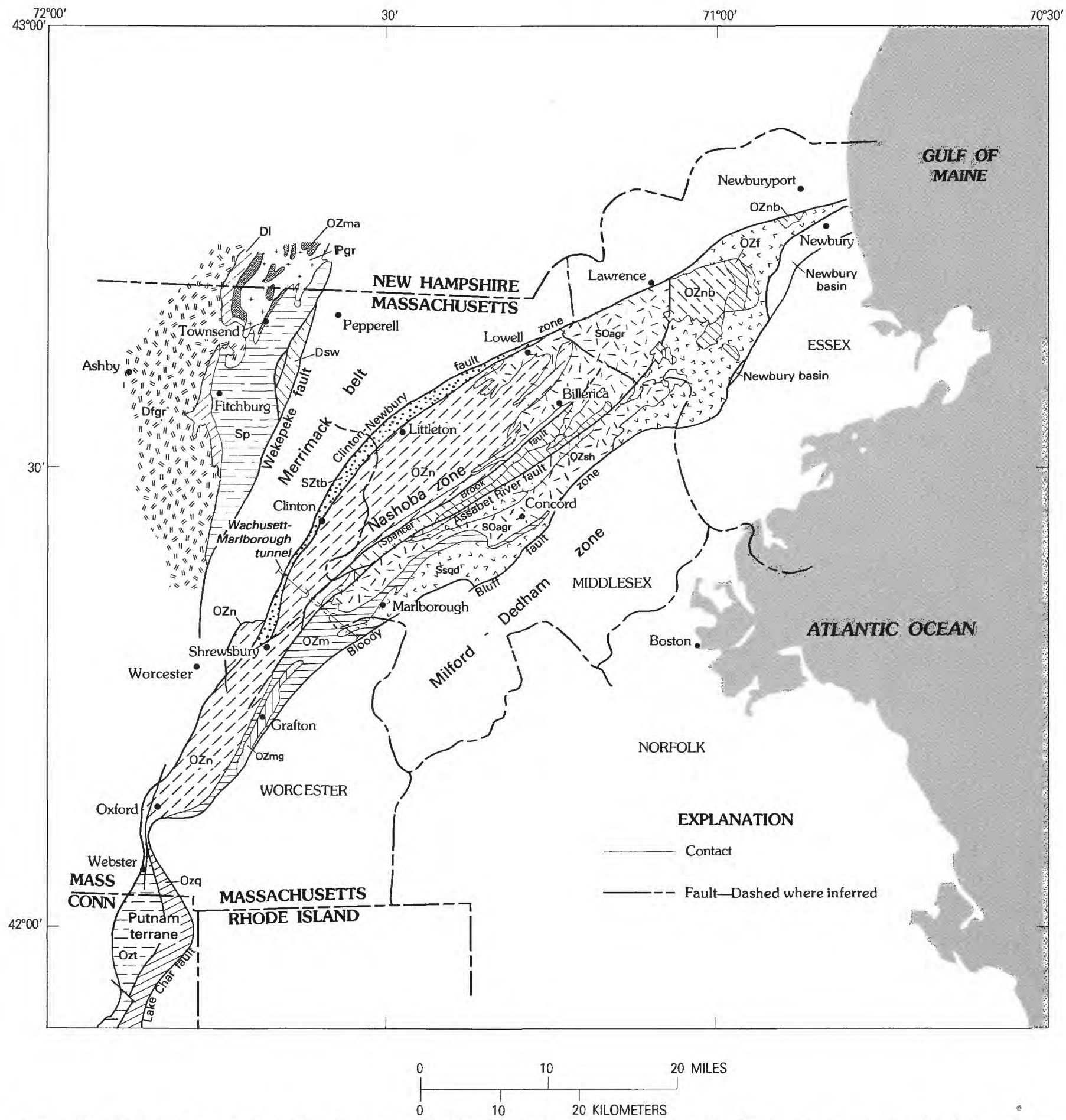

FIGURE 1. - Major rock units and structural features in the Nashoba zone, eastern Massachusetts. Correlation diagram and list of units are shown on figure 2.

translation along faults has cut the zone into lenses of rock, the sequence of which is not now clear.

The five formations of stratified rock within the Nashoba zone in Massachusetts shown on the State bedrock map (Zen and others, 1983; fig. 2)-the Marlboro For- mation (OZm, OZmg), Shawsheen Gneiss (OZsh), Fish Brook Gneiss (OZf), Nashoba Formation (OZn, OZnb), and Tadmuck Brook Schist (SZtb)-represent an assemblage of sedimentary, volcaniclastic, and volcanic strata metamorphosed to nonsulfidic and sulfidic, pelitic and 


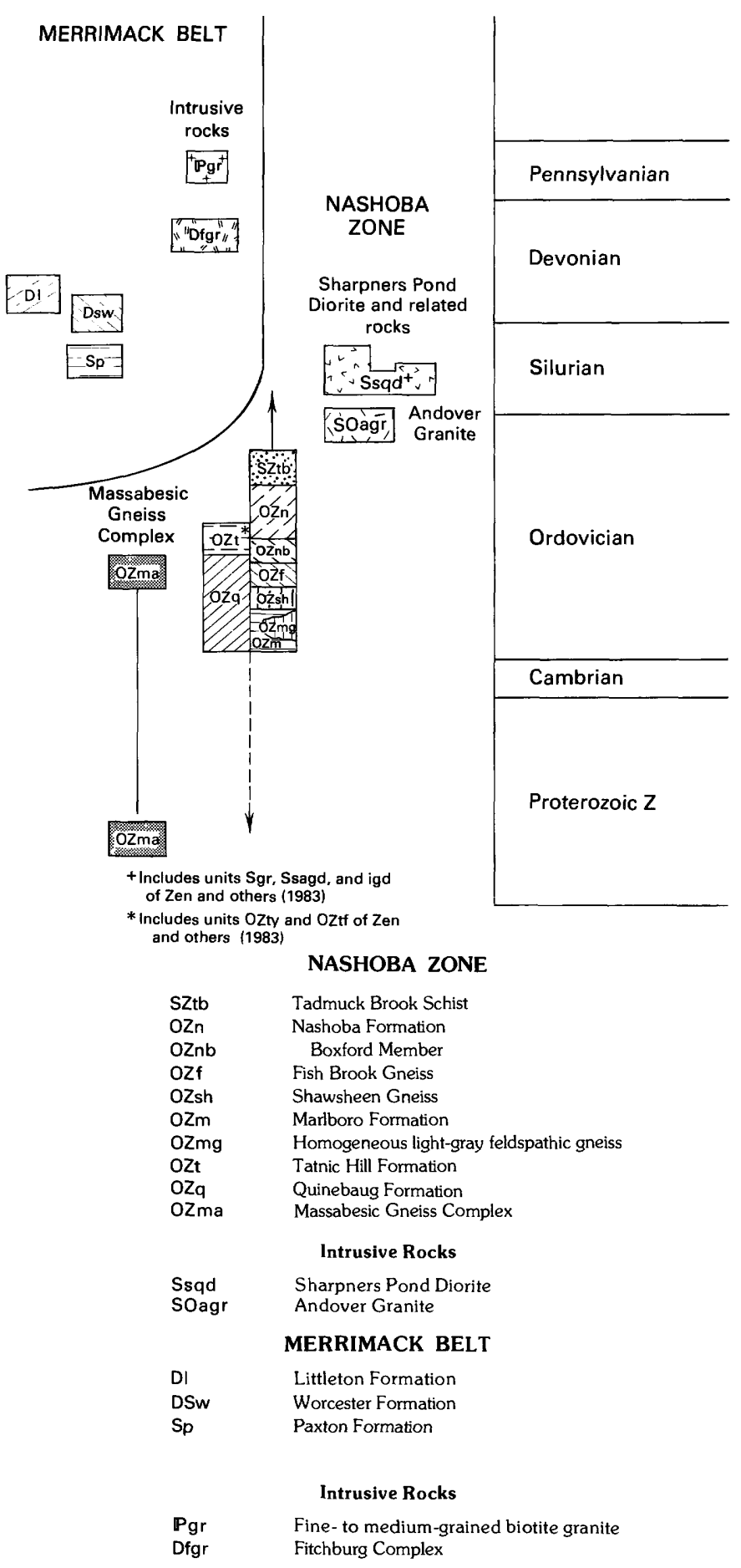

FIGURE 2.-Stratified and major intrusive rock units in the Nashoba zone and some stratified and intrusive rock units in the Merrimack belt.

semipelitic schist and gneiss, calc-silicate rock, amphibolite, felsic gneiss, and subordinate marble and quartzite (fig. 3). In adjacent Connecticut, along the strike of the units, the Quinebaug Formation $(\mathrm{OZq})$ is equivalent to the Marlboro, and the Tatnic Hill Formation (OZt) is equivalent to the Nashoba. In Massachusetts, metavolcanic rocks increase in abundance eastward and presumably downsection, from the Tadmuck Brook Schist to the Marlboro Formation. The Tadmuck Brook Schist and Nashoba Formation are primarily metasedimentary, but the latter has a significant volcaniclastic component (Abu-Moustafa and Skehan, 1976). The Fish Brook Gneiss has a volcanic or volcaniclastic protolith. The Shawsheen Gneiss consists primarily of pelitic and semipelitic metasediments. The Marlboro Formation is primarily metavolcanic but has a significant metasedimentary component. Sulfidic sillimanitic schist and gneiss, calc-silicate rock, amphibolite, and biotite-quartzfeldspar gneiss with and without garnet are present in varying proportions in all the formations except the Fish Brook.

The stratified rocks are intruded by the syn- or late-tectonic Silurian and Ordovician(?) Andover Granite (SOagr), dated by Zartman and Marvin (this vol., chap. $\mathrm{J}$, table 1), and associated but possibly in part younger aplite and pegmatite (Zartman and Naylor, 1984), which was shown on the State bedrock map as part of the Andover map unit, and by a post-tectonic suite of dioritic to granitic plutons that includes the Silurian Sharpners Pond Diorite (Ssqd) and related rocks. The plutonic rocks are particularly abundant near Lowell and Billerica and decrease in abundance to the southwest (fig. 1). The intrusive rocks in the Nashoba zone are described in Wones and Goldsmith (this vol., chap. I).

\section{DESCRIPTION OF UNITS}

\section{MARLBORO FORMATION (OZm, OZmg)}

The Marlboro Formation consists primarily of interlayered metavolcanic and metavolcaniclastic rocks and marine metasedimentary rocks (fig. 3). It was named by Emerson (1917) for ledges of biotite-hornblende schist in the town of Marlboro (in the Township of Marlborough). The Marlboro is bounded on the east by the Bloody Bluff fault zone. North of Concord the Marlboro is cut out by the Bloody Bluff and by plutonic rocks, so that no Marlboro has been identified with certainty north of the Concord area. The Marlboro is in contact east of the fault with different units of the Milford-Dedham zone: Proterozoic Z granitoids, the Proterozoic Z Westboro $(\mathrm{Zw})$ and Plainfield $(\mathrm{Zp})$ Formations, and the Proterozoic volcanic-plutonic complex exemplified by the metamorphosed mafic and felsic volcanic rocks (Zv) and intrusive diorite and gabbro (Zdigb, Zdi, Zgb). The upper contact of the Marlboro is apparently conformable with the Nashoba Formation in the Shrewsbury-Marlborough 
area, Middlesex and Worcester Counties (fig. 1) (Skehan and Abu-Moustafa, 1976), but Hepburn and DiNitto (1978) showed the contact as a fault. Thickness considerations imply that Hepburn and DiNitto were probably correct in this area. To the north, in northern Middlesex County, the contact of the Marlboro with the overlying Shawsheen Gneiss is mostly cut out by the Andover Granite, but Alvord and others (1976, p. 319) believed that the top of the Sandy Pond Member (fig. 3) of the Marlboro was conformable with the Shawsheen Gneiss. In eastern Connecticut, amphibolite increases in abundance downward in the basal member of the Tatnic Hill Formation (OZt) (Dixon, 1974, for example), suggesting conformity with the underlying Quinebaug Formation $(\mathrm{OZq})$, which is equivalent to the Marlboro (fig. 3).

Bell and Alvord (1976) divided the Marlboro into two members (fig. 3), mainly on the basis of mapping in
Essex and northern Middlesex Counties (fig. 1). The lower, unnamed member consists of mica schist, calcsilicate rock, marble, and amphibolite. The upper member, the Sandy Pond Member, is predominantly amphibolitic. Skehan and Abu-Moustafa (1976), mapping in the Wachusett-Marlborough tunnel in southern Middlesex County, divided the Marlboro into 31 members (shown as 10 units on fig. 3). In contrast to Bell and Alvord's section, most of the amphibolitic rocks are at the east or bottom part of Skehan and Abu-Moustafa's section. Hepburn and DiNitto (1978) and Hepburn (1978), mapping the surface rocks above the tunnel in the Marlborough and the Shrewsbury areas respectively, recognized four divisions of the Marlboro, one of which, their Sandy Pond amphibolite member, coincides with the Sandy Pond Member of Bell and Alvord and with the amphibolitic lower part of Skehan and Abu-Moustafa's section.

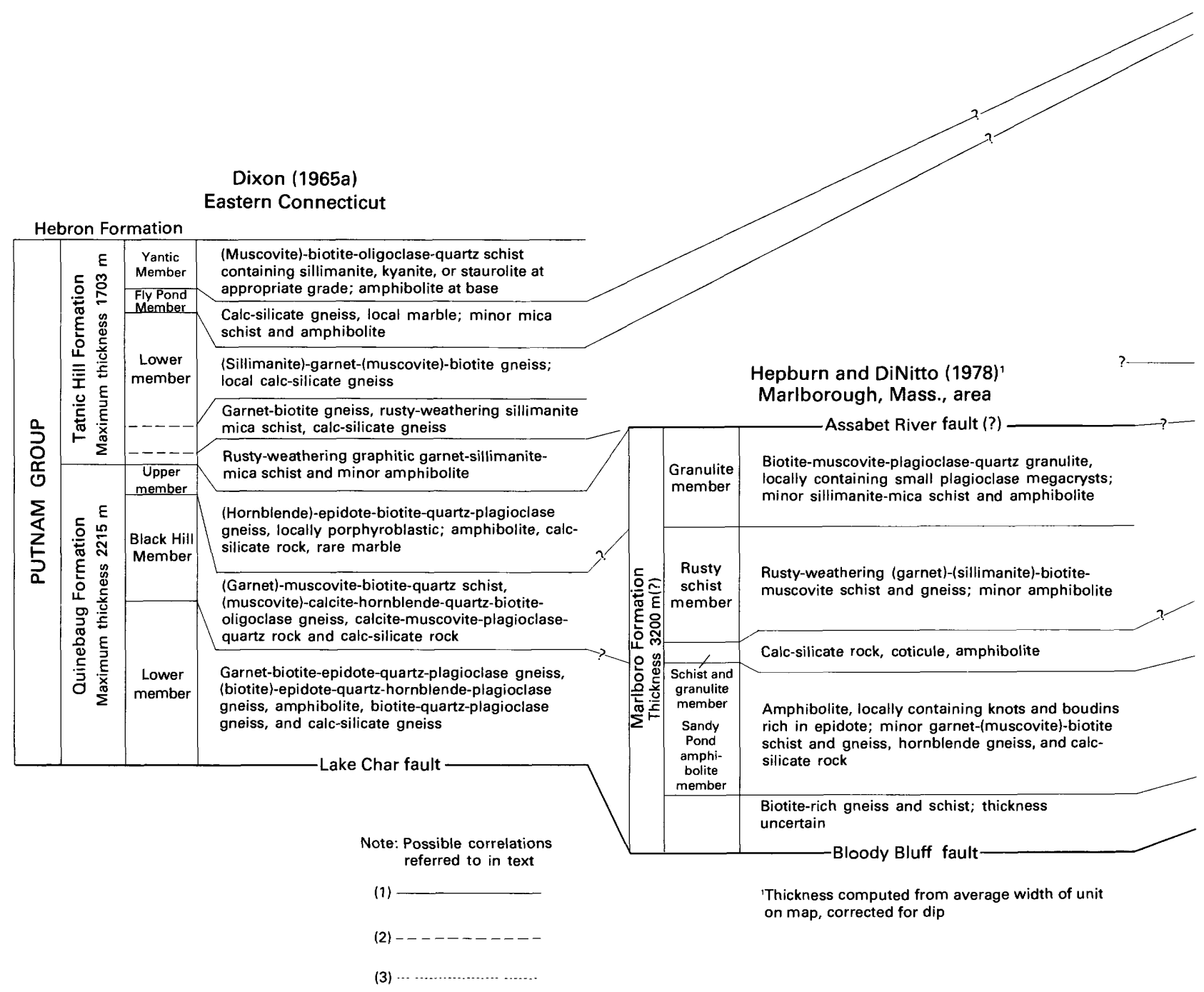

FIGURE 3.-Lithostratigraphic columns of the formations in the Putnam terrane and Nashoba zone, Connecticut and eastern Massachusetts. Column of Bell and Alvord (1976) is at 2.5 times smaller scale than the other columns. 
On the basis of the sections shown on figure 3, it seems likely that Hepburn and DiNitto's Sandy Pond is equivalent to Skehan and Abu-Moustafa's units M5-M16.

A lenticular mass of biotite granodioritic gneiss (OZmg) near Grafton, considered by Emerson (1917) to be a pluton of Milford Granite (Zmgr), does not resemble the Milford and was named informally the Grafton gneiss by Dixon (written commun., 1977). The Grafton is not layered, is fairly uniform in composition, and has a foliation formed by oriented flakes of biotite. The Grafton does, however, contain some inclusions of amphibolite and biotite schist of the Marlboro. Hepburn (1978) considered the Grafton to be a plutonic rock, but it could be a metamorphosed felsic volcanic rock.

\section{SHAWSHEEN GNEISS (OZsh)}

The Shawsheen Gneiss (Bell and Alvord, 1976) consists primarily of sillimanitic muscovite-biotite schist and gneiss, sulfidic near the base, and it contains a few lenses

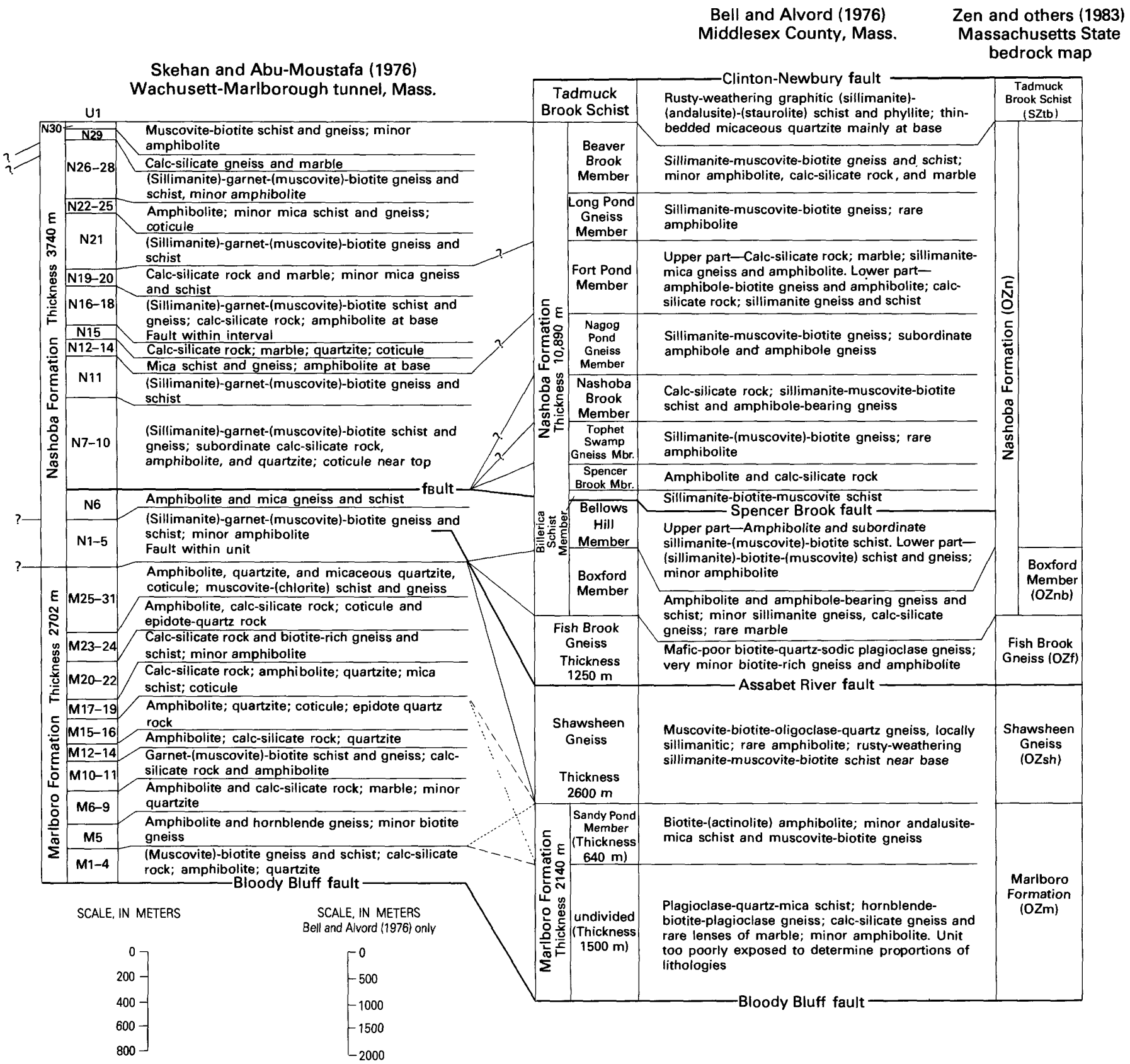

Figure 3.-Continued. 
of layered and massive amphibolite (fig. 3). The Shawsheen is lithologically similar to much of the Nashoba Formation and was considered by Hansen (1956) to be part of the Nashoba. Bell and Alvord (1976) separated the Shawsheen from the Nashoba because the Fish Brook Gneiss intervened between the Shawsheen and the rest of the Nashoba Formation. On the other hand, Barosh and others (1977) included both the Shawsheen and the Fish Brook in the Nashoba. Hansen (1956) did not recognize the rock later called the Fish Brook Gneiss (Castle, 1965) as a mappable unit and similarly included all the rocks in the Nashoba Formation.

\section{FISH BROOK GNEISS (OZf)}

The Fish Brook Gneiss is a fine- to medium-grained, "pearly white to very light gray, distinctly foliated but generally unlayered biotite-quartz-plagioclase rock" (Castle, 1965, p. C81). The foliation is marked by oriented biotite flakes, which are more abundant to the north than to the south. According to Castle, the Fish Brook contains inclusions ranging in size and shape from schlieren to rectangular zones. These inclusions consist of amphibolite, thinly layered biotite gneiss, and other rock types; the foliation in the gneiss generally passes through these inclusions, although it wraps around some zones. The Fish Brook, like other units in the Nashoba zone, is intruded by the Andover and related granites. Castle (1965) considered the Fish Brook to be either a premetamorphic intrusive rock or a core gneiss of intrusive or sedimentary ancestry. Bell and Alvord (1976), however, claimed a volcanic and volcaniclastic origin for it. Zircons from the Fish Brook are almost certainly of volcanic origin (Olszewski, 1980, p. 1411). Alvord and others (1976, p. 320) described an exposure of the contact of the Fish Brook Gneiss and the Nashoba Formation near Billerica, where very thin beds of finegrained amphibolite of the Boxford Member of the Nashoba are interlayered with very thin beds of light-gray Fish Brook Gneiss.

\section{NASHOBA FORMATION (OZn, OZnb)}

The Nashoba Formation (Hansen, 1956) consists of interlayered sillimanite-bearing, partly sulfidic schist and gneiss, (hornblende)-biotite-quartz-feldspar gneiss, calc-silicate gneiss, and subordinate quartzite and marble (fig. 3). Protoliths are primarily volcanogenic sediments, interlayered with limy marine sediments and volcanic rocks (Abu-Moustafa and Skehan, 1976; Bell and Alvord, 1976). Bell and Alvord divided the Nashoba into
10 members on the basis of lithology. Sillimanite-bearing pelitic and semipelitic schist and gneiss are interlayered with other rock types throughout their section. Calcsilicate rocks and marble characterize some members. Amphibolite is most abundant near the presumed base of the Nashoba, primarily in the Boxford Member (OZnb) (Boxford Formation of Castle, 1965). Alvord and others (1976) identified localities where some of their subdivisions of the Nashoba can be seen. Skehan and AbuMoustafa (1976) subdivided the Nashoba as seen in the Wachusett-Marlborough tunnel into 30 members, which I have condensed for economy to 13 on figure 3. Lithologies are similar to those described by Bell and Alvord, and in a general way their sections are similar, although Bell and Alvord's section is much thicker (note scale change for their section on fig. 3). The Boxford Member is not readily identifiable in the tunnel section. Possibly it thins and pinches out or is faulted out before it reaches the tunnel section. The Boxford is, however, extensive in the Lowell-Billerica area, where Castle (1965) divided it into an upper and a lower member. His upper member consists mostly of amphibolite and hornblendeplagioclase gneisses. His lower member consists chiefly of mica schist and quartzofeldspathic gneisses and subordinate amounts of amphibolite and calc-silicate gneiss. This lower member is to a certain extent lithologically like the undivided lower part of Bell and Alvord's Marlboro Formation.

Subdivision of the Nashoba is conjectural south of Marlborough and Shrewsbury where only reconnaissance mapping has been done. Hepburn (1978) and H.R. Dixon (written commun., 1978) identified a rustyweathering sulfidic schist at the base of the Nashoba, which extends from south of Shrewsbury to the Webster area and which is probably the same sulfidic schist that forms the basal member of the Tatnic Hill Formation in Connecticut. Dixon (written commun., 1978) recognized rock in the Nashoba in the Oxford quadrangle that was similar to subdivisions of the Tatnic Hill that she has mapped in Connecticut.

The Boxford Member (OZnb) has been separated out from the rest of the Nashoba on the State bedrock map because this unit is the only one that can be recognized clearly in several areas. I doubt that a definite sequence of units exists throughout the Nashoba because of the lenticularity of assemblages and repetition of rock types, both of which could be accounted for by either sedimentary or tectonic processes. Evidence for tectonism has been found by practically everyone who has mapped in the Nashoba zone (Hansen, 1956; Castle, 1964; Alvord, 1975; Bell and Alvord, 1976; Skehan and Abu-Moustafa, 1976; Barosh, 1978; Hepburn, 1978; Hepburn and DiNitto, 1978). 


\section{TADMUCK BROOK SCHIST (SZtb)}

Bell and Alvord (1976) gave the name Tadmuck Brook Schist to a sequence of largely pelitic rocks lying west of and presumably above the Nashoba (figs. 1, 3). The Tadmuck Brook consists primarily of sillimanite schist, graphitic staurolite-andalusite phyllite, and chloritebiotite-muscovite phyllite in decreasing metamorphic grade from east to west. Near its base to the east, the unit contains subordinate layers and lenses of amphibolite and discontinuous beds of quartzite. Where exposed on Route 2 near Littleton (fig. 1), the Tadmuck Brook is rusty weathering. According to Alvord and others (1976), the Tadmuck Brook intertongues locally with quartzofeldspathic layers of the Nashoba Formation, but, from the Littleton area to the vicinity of Lawrence, the Tadmuck Brook appears to truncate units in the Nashoba; those authors, therefore, suggested the possibility of an unconformity or disconformity. However, as they pointed out, this contact is a fault in most places north of Route 2 (Littleton area) and has been so interpreted by Castle and others (1976) on the basis of a truncation of aeromagnetic pattern along this contact. Skehan and Murray (1980, p. 295) considered the Tadmuck Brook to be unconformable on the Nashoba because of a small angular discordance coupled with absence of fault-related features at the contact and the sharp contrast in deformation and metamorphism between the two units.

The Tadmuck Brook is probably represented in Skehan and Abu-Moustafa's (1976) tunnel section by their unnamed units U1-U9. U1 consists largely of quartzite, and in their section it is shown as lying possibly unconformably on the Nashoba. Hepburn (1978) was unable to identify the Tadmuck Brook south of Shrewsbury where the Boylston Schist (SObo) of the Merrimack belt lies against the Nashoba. To the north, the Tadmuck Brook is truncated at the top, sliced throughout, and locally phyllonitized by the Clinton-Newbury fault system (Alvord and others, 1976).

\section{STRATIGRAPHIC CONSIDERATIONS}

\section{ORIENTATION}

The formations in the Nashoba zone have customarily been considered to be a sequence topping to the west, presumably because they lie on the east flank of the Merrimack synclinorium. This assumption may not be valid, however, because the bounding faults of the zone appear to be major dislocations. Even so, Bell and Alvord (1976) considered the Marlboro-to-Nashoba section to be homoclinal and topping to the west on the basis of many features seen in outcrop that they considered to be relict primary sedimentary features. On the other hand, Castle (1965, p. C84) observed no unambiguous primary structures, at least in the Boxford Member (compare Bell and Alvord, 1976, fig. 4, p. 186). Skehan and Abu-Moustafa (1976) made no mention of primary structures except bedding and presented no topping evidence in their description of their WachusettMarlborough tunnel section. They followed convention, however, and described the section as homoclinal and presumably topping to the west. They cited no evidence in their section that units are repeated by folding or faulting except on a small scale.

I do not believe we can say with certainty which way the units face, nor can we say that the sequence is complete, if it is homoclinal, because of the flanking faults. What evidence there is indicates that the sequence is west facing. We do not see a depositional bottom and probably not a depositional top. We do not know for sure whether the Tadmuck Brook Schist is part of a Nashoba-Marlboro package or if it is the base of an overlying unconformable sequence. However, we can see that a difference exists in sedimentary facies within the terrane. The facies on the east indicate deposition in a marine basin next to a volcanic terrane, as evidenced by the greater amount of amphibolite interpreted to be of volcanic origin. Facies to the west indicate deposition in a somewhat more distal part of the basin, as evidenced by the greater amount of aluminous pelitic schist and gneiss and thinly layered calc-silicate rocks, although these western facies still contain a noticeable volcanic and volcaniclastic component.

Abu-Moustafa and Skehan (1976), who have studied the rocks intensively, described the sediments of the Nashoba and Marlboro as having been derived from two major sources: one a deeply saprolitized, even lateritic, terrane and the other a terrane containing unweathered volcanic and plutonic rocks, whose average composition is dacite, and volcanogenic sediments. The hornblenderich rocks of the Marlboro and Nashoba were volcanogenic sediments and flows and pyroclastic rocks of predominantly basaltic composition and subordinate calcalkalic andesitic dacitic and rhyodacitic compositions (Nockolds, 1954). Abu-Moustafa and Skehan (1976, p. 32) inferred that the paleotectonic environment of deposition of the Nashoba (and presumably also the Marlboro) was a "relatively shallow marine basin that received deeply weathered soils, unaltered volcanogenic sediments, and some volcanic rocks, occasionally interbedded with thin limey beds..., thin quartz and quartz-feldspar sand..., and distinctive manganiferous-iron chert...." This basin presumably flanked an island arc lying to the east. However, the original Nashoba protolith need not have formed where it is now. The Nashoba zone could have 
been moved into place with or without rotation and could have moved a considerable distance.

\section{THICKNESS AND SEQUENCE}

The true thicknesses of the formations are difficult to determine because of the differences in thicknesses given by different authors or estimated by me from their maps. Differences in these thicknesses need to be considered with regard to folding and faulting. Bell and Alvord's (1976) section of the Nashoba Formation is almost five times thicker than Skehan and Abu-Moustafa's (1976) tunnel section. This difference may be a function of differences in allowances for internal folding and faulting in preparing the two sections, although it would appear from their descriptions that the thicknesses in both sections were derived from the width of the lithologic unit or subunit corrected for dip. On the other hand, the units may thin stratigraphically or tectonically southward. In contrast to the discrepancy in thickness of the Nashoba Formation between sections, thicknesses of the Marlboro in Massachusetts given in the two reports are in fairly good agreement and agree also with thicknesses of the equivalent Quinebaug Formation in Connecticut (fig. 3). In fact, the Marlboro is thicker in Skehan and Abu-Moustafa's section than in Bell and Alvord's section, although this might be accounted for by the much greater amount of plutonic intrusive rock in Bell and Alvord's area.

Let us first consider folding. Some repetition of lithologic assemblages is evident in the sections of the Nashoba, as for example the alternations between calcsilicate-bearing assemblages and pelitic schist and gneiss assemblages (fig. 3). These repetitions could be explained by cyclic sedimentation or, alternatively, by folding. Skehan and Abu-Moustafa's cross section (1976, fig. 1, p. 220) shows two major synforms and a central antiform, although all are broken by faults. These large folds were apparently not taken into account in their compilation of aggregate thicknesses because they could recognize no repetitions of units except where layers are repeated by small-scale folding and by drag associated with minor faults. Hansen (1956) did not show a complete section across the Nashoba but showed clearly at least one synform within the Nashoba, an antiform beyond the west flank, and a broad antiform or dome in the Marlboro on the east flank. These relations indicate a synformal structure for the Marlboro-to-Nashoba sequence but with apparent truncation on the west side where there is no Marlboro, unless the Reubens Hill Formation (SOrh) (Skehan, 1967) in the Merrimack belt is the stratigraphic equivalent of the Marlboro. Foliation and layering symbols in the Nashoba on the maps of the Billerica and Westford quadrangles (Alvord, 1975) are steeply dip- ping, but these symbols on their maps form zones of alternate east dip and west dip, suggesting tight folding of layering and foliation and thus probable repetition of units and an exaggerated thickness of section.

Faulting probably has had an appreciable effect on the thicknesses of sections. Skehan and Abu-Moustafa (1976) described numerous faults of different kinds and ages and of large and small magnitude in their tunnel section. Many of Bell and Alvord's (1976) units are totally or in part bounded by faults. Such faults not only make estimates of thickness of each individual unit a minimum, disregarding folding, but also raise the possibility that total thickness of the formations in the zone is exaggerated because of unrecognized repetition of units. The latter would be particularly important if appreciable imbrication has occurred as a result of movement along larger faults such as the Spencer Brook and Assabet River faults (fig. 1). The Assabet River fault separates the Shawsheen from the Fish Brook Gneiss in most places, but this contact is viewed by Bell and Alvord as stratigraphically conformable. The Assabet River fault is not identified in the tunnel section but is either a fault zone in unit N6 (near Station 266+35 of Skehan and Abu-Moustafa, 1976) west of the Nashoba-Marlboro contact or more likely, a thrust fault in N4 (at Station $285+10-15$ of Skehan and Abu-Moustafa, 1976). Hepburn and DiNitto (1978) mapped a fault along the Nashoba-Marlboro contact in the Marlborough quadrangle that may be the Assabet River fault and may be a surface representation of the appreciable faulting near the base of unit N1 described by Skehan and AbuMoustafa. To the north, the Assabet River fault cuts off the top of the Shawsheen (Bell and Alvord, 1976, Appendix 1). The Spencer Brook fault separates the Billerica Schist from the Bellows Hill Member of the Nashoba. Alvord and others $(1976, p .322)$ presumed that if the contact were not obscured by faulting, the two units would intertongue and be conformable. The Spencer Brook may be a fault zone described by Skehan and Abu-Moustafa (1976, table 6) between units N17 and N18 (at Station $177+53$ ), or it could be one of the faults nearer the Marlboro contact. Possibly two faults in the tunnel section, one in N1-N5 and the other at the top of N6, may be the Assabet River and Spencer Brook faults, respectively. The Shawsheen and Marlboro are in normal stratigraphic contact, according to Bell and Alvord, and the Nashoba and Marlboro are in normal stratigraphic contact, according to Skehan and Abu-Moustafa, despite evidence for appreciable faulting in the vicinity of the contact. From Bell and Alvord's map (1976, fig. 1), though, it is not clear that the Shawsheen is ever in contact with the Marlboro without intervening plutonic rocks. The Shawsheen-Fish Brook contact was considered by Alvord and others (1976, p. 320) to be conform- 
able, as were the Fish Brook-Boxford and the Billerica Schist-Bellows Hill contacts. In their view, the numerous faults shown by Bell and Alvord (1976, fig. 4) have done little to disrupt the sections. Yet, looking at the sections as presented in figure 3, we see that a thick wedge of rock comprising the Shawsheen Gneiss, the Fish Brook Gneiss, and possibly the lower part of Bell and Alvord's Nashoba section, including the Boxford Member, is missing in the tunnel section. One explanation is that the Shawsheen and Fish Brook are stratigraphic lenses, although this seems unlikely because the truncation is extremely angular. Another explanation, despite the statement of conformity by Bell and Alvord (1976), is that these units constitute tectonic slices (Goldsmith, this vol., chap. H). Possibly the larger faults, although they do not everywhere determine the formational boundaries, have sliced once-continuous sections of rock into disjointed lenses, so that although masses of like rock may be in contact with each other, they have been transported there from some other part of the strike belt.

A closer look at possible correlations between the sections may resolve the problem of thickness and apparent loss of section. A number of correlation schemes are possible. The most obvious are shown on figure 3 as solid lines; tielines of the more questionable correlations are marked by queries. A reasonable correlation can be made for the upper part of the Nashoba sections of Bell and Alvord (1976) and of Skehan and Abu-Moustafa (1976). However, the Nashoba Brook, Tophet Swamp Gneiss, Spencer Brook, and Billerica Schist Members are not recognizable in the tunnel section. These units may be cut out by the Spencer Brook fault. Possibly the Nashoba Brook is a lens or fold nose, and the Tophet Swamp is equivalent to part of N7-N10. The Bellows Hill Member is correlated with units $\mathrm{N} 1-\mathrm{N} 6$ in the lower part of the Nashoba in the tunnel section. The Boxford Member, the Fish Brook Gneiss, and the Shawsheen Gneiss lens out or are cut out. Possibly the Shawsheen Gneiss is equivalent to Hepburn and DiNitto's rusty schist member of the Marlboro. Their granulite member may be a facies equivalent of the Fish Brook Gneiss. Neither of these units is clearly recognizable in the tunnel section. Bell and Alvord's Sandy Pond Member of the Marlboro Formation can be correlated (possibility 2 of fig. 3) with units M5-M16 (?) of the tunnel section, a correlation supported by lithologic similarity and by the mapping of Hepburn and DiNitto (1978) and Hepburn (1978); this correlation, however, requires accounting for lack of equivalents in Bell and Alvord's section to the interval M17-M31 of Skehan and Abu-Moustafa's section. The missing upper part of the Marlboro in Bell and Alvord's section may be replaced by granite (SOagr) as suggested by the State bedrock map. A third possibility (possibility
3, fig. 3), is that Bell and Alvord's Marlboro sequence is inverted by folding, in which case a fault is required between the Shawsheen and Marlboro. As Hepburn and DiNitto's section approximately corresponds on the surface to the tunnel section below, the discrepancy in detailed description of the units in the two sections, particularly between the interval M25-M31 of the tunnel section and the granulite member, can be construed to mean that the kinds of rock seen in scattered exposures on the surface in the zone of weathering do not necessarily represent the relative abundances of lithologies that can be seen in a corresponding section of rocks underground. Both Hepburn and DiNitto's section and Bell and Alvord's section are based on surface exposures, so it is not surprising that these two correspond somewhat better than either does to the tunnel section.

Other possible correlations that require complicated structure equate the Shawsheen Gneiss and Boxford Member with tunnel units N1-N5 and N6, or alternatively the Shawsheen and Sandy Pond with units N7-N10 and N6 in reverse order. The Fish Brook again would have to terminate in some way, but this is not difficult if it is intrusive. None of the possible correlations is wholly satisfactory, and a fault solution seems the most promising.

A correlation suggested by the lithostratigraphic columns of figure 3 involves repetition by faulting (fig. $4 A$ ). In this scheme, the Boxford is equated with the Sandy Pond Member, the Shawsheen of slice A is repeated above the Assabet River fault in slice B as the Bellows Hill member and above the Spencer Brook fault in slice C as the Billerica Schist and Spencer Brook members. Fault slice $\mathrm{C}$ could consist of other fault slices as the numerous faults in the sections on figure 3 suggest.

This scheme depends on the validity of the correlation of the Boxford with the Sandy Pond. I have pointed out above that the Boxford section of Castle (1965) resembles Bell and Alvord's (1976) Marlboro section. Castle (1965) pointed out the similarity of the Boxford to isolated amphibolitic rocks to the southwest that he mapped as Marlboro. These isolated rocks of Castle are apparently on strike with the type belt of Marlboro extending from Marlborough to Concord. Castle's upper and lower Boxford Formation are similar to Bell and Alvord's upper and lower Marlboro, although seemingly in reverse sequence to the Marlboro in the tunnel section. The Boxford Member of the Nashoba of Bell and Alvord thus could be part of the Marlboro repeated by faulting but representing the opposite limb of an earlier fold. The Fish Brook becomes part of the Marlboro Formation, in a stratigraphic position somewhat similar to that of the Grafton gneiss to the south. Barosh (1976, p. 309) noted rock resembling Fish Brook Gneiss near the top of the Marlboro near the intersection of I-495 and I-290 west of 


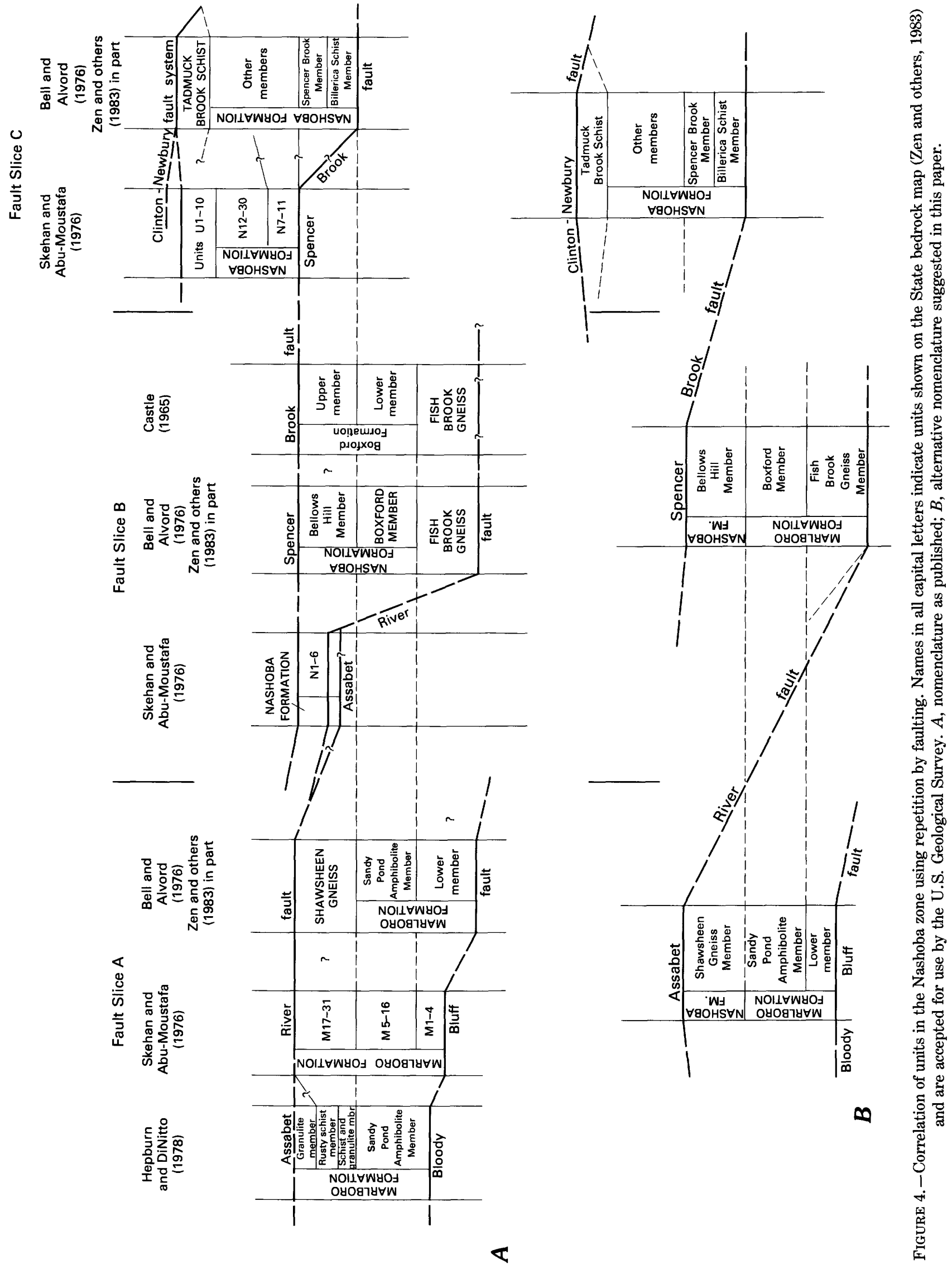


Marlborough. Possibly Hepburn and DiNitto's granulite member of the Marlboro is a facies of the Fish Brook Gneiss and their rusty schist member is equivalent to the Shawsheen Gneiss. If so, the Assabet River fault must cut below the granulite member, as suggested on figure $4 A$. Hepburn and DiNitto's Marlboro section correlates fairly well with the Quinebaug section of Dixon (1965a; fig. 3). If this correlation is carried across to the sections of Skehan and Abu-Moustafa and Bell and Alvord (fig. $4 A$ ), the Shawsheen Gneiss, units N1-N6, and the Bellows Hill, Spencer Brook, and Billerica Schist Members of the Nashoba would be assigned to the Marlboro rather than to the Nashoba.

The correlation scheme presented in figure $4 A$ is, then, probably only one of several possible. The simplest possible scheme would be based on the interpretation that the faults have done little to disrupt the MarlboroNashoba sequence, as was implied by Alvord and others (1976) and that the sequence is homoclinal. The map pattern of Bell and Alvord (1976) can then be interpreted as showing a cross-sectional view of a metamorphosed stack of lenticular and intertonguing sedimentary, volcaniclastic, and volcanic rocks. Certainly intertonguing facies would be expected in the depositional environment of the protoliths described earlier; however, the indications of complex structure mentioned above in the section on thickness and sequence seem to me to make this view oversimplified.

It seems clear from figure 3 that no consistently applied boundary exists between the Marlboro and the Nashoba. Possibly Bell and Alvord (1976) are correct in implying that the Boxford is a tongue of amphibolite in the Nashoba lying well above the Sandy Pond of the Marlboro and that the Shawsheen is a tongue of Nashoba-like schist below the Sandy Pond. The boundary between the Marlboro and the Nashoba can only be placed, then, as it has been in the past, where sequences containing abundant amphibolite give way to sequences in which pelitic schist and gneiss predominate. My suggested assignment of the boundary, based on the interpretation of figure $4 B$, is that the top of the Sandy Pond and the Boxford (of Bell and Alvord, 1976) are more clearly defined boundaries than any of those lying above, such as the top of the Spencer Brook Member or the top of $\mathrm{N} 6$ of the tunnel section, and thus should mark the top of the Marlboro Formation.

The inconsistent thicknesses of major units within the Nashoba zone, the lenticular map patterns of units, the repetition of rock types, and the difficulties in correlation of map units along strike demonstrated in the above discussion suggest that, rather than subdividing the Nashoba Formation into many members or dividing the zone into many formations, it would be preferable to keep only units that are distinct or readily recognizable throughout the zone. This approach has been taken on the State bedrock map, where the column of Bell and Alvord has been used (fig. 3). On this map, the Nashoba and Marlboro are obvious units of formational rank, and the Fish Brook Gneiss and Shawsheen Gneiss are retained as discrete units also of formational rank. The Boxford Member of the Nashoba is the only one of Bell and Alvord's members considered distinct enough to be shown on the map. Actually, the Fish Brook and Shawsheen are limited in area and should not have formational rank. The Fish Brook and Shawsheen were given formational rank by Bell and Alvord (1976) because the Fish Brook has a distinctive lithology and separates the Shawsheen from the Nashoba to the west. However, they saw no reason why the Shawsheen could not otherwise be considered part of the Nashoba. Barosh and others (1977), in their compilation of the Boston $1^{\circ} \times 2^{\circ}$ sheet, placed the Shawsheen in the Nashoba, as did Hansen (1956) originally. Accordingly, in figure $4 B$, I have placed the Shawsheen in the Nashoba. Until unified detailed mapping is done in the Nashoba zone, and the scheme of figure $4 B$ tested, the order of units probably should be kept as on the State bedrock map.

The weight of evidence seems to show that the present distribution of units within the zone is in large part controlled by structure. Folding may be partly responsible, but I would suggest that the pattern can best be explained by faults, along some of which appreciable differential lateral movement has occurred. One can easily visualize that formerly continuous masses of rock have been sliced and transported into disjointed lenses so that masses of rock from different parts of the section are now juxtaposed. These masses have subsequently been given separate formational or member names by people mapping in different parts of the strike belt. A uniform effort of detailed mapping in the Nashoba zone may clarify some of the uncertainties.

\section{AGE}

The stratified rocks of the Nashoba zone are unfossiliferous; their age can only be approximated within limits determined by radiometric data on rocks that intrude them. Upper limits on their age are established by ages on the Sharpners Pond Diorite (Ssqd) and phases of the Andover Granite (SOagr). The Sharpners Pond is nonfoliated and gives a concordant U-Pb age of $430 \pm 5 \mathrm{Ma}$ (Zartman and Marvin, this vol., chap. J, table 1), or early Silurian. The Andover Granite is in part foliated and, from field relations, is believed to be older than the Sharpners Pond. The most reliable age from what appears to be the oldest part of the Andover places it in the Ordovician or possibly early Silurian, on the basis of 
$\mathrm{Rb}-\mathrm{Sr}$ whole-rock ages of $450 \pm 23 \mathrm{Ma}$ (Zartman and Marvin, this vol., chap. J, table 1; Handford, 1965). Thus the youngest possible age for the rocks of the Nashoba zone is Ordovician. A minimum age of Ordovician for the Tatnic Hill Formation (equivalent to Nashoba on strike in southeastern Connecticut) was determined by Zartman and others (1965, p. D6).

The stratified rocks of the Nashoba zone are probably as old as Proterozoic. Olszewski (1980) obtained a $730 \pm 26-\mathrm{Ma}$ age on a concordia plot of apparently igneous zircons from the volcanic (or plutonic) Fish Brook Gneiss. If the Fish Brook Gneiss is a core gneiss, as Castle (1965) suggested, then the zircons date only that unit and not necessarily the surrounding strata. However, field relations seen by Bell and Alvord (cited above in the section on descriptions of units) indicate that the Fish Brook is part of the Nashoba-Marlboro sequence. A concordia plot of probably detrital zircons in the Shawsheen Gneiss gave an age of more than $1,500 \mathrm{Ma}$, thus dating a source terrane, proto-Africa(?), not now present, to the east. Olszewski $(1980$, p. 1414) pointed out that the pattern of ages in the Nashoba and Milford-Dedham zones is similar to the pattern in northwest Africa as described by Schenk (1971) and Hurley and others (1974). He also pointed out that the detrital zircons could be derived from the Grenville terrane to the west as well as from a proto-African source to the east.

Skehan and Murray (1980, fig. 3) suggested that the Tadmuck Brook Schist, which overlies the Nashoba Formation, is Ordovician(?) to Cambrian in age, on the basis of the unconformity at its base and an Ordovician to Silurian age on the Ayer Granite that intrudes the units above the Nashoba in and west of the Clinton-Newbury fault zone. This suggestion is discussed in the chapter on the Merrimack belt (Robinson and Goldsmith, this vol., chap. G).

The rocks of the Nashoba zone are shown on the State bedrock map as Ordovician or Proterozoic Z. This dual age was given because at the time the map was prepared, I was uncertain about the actual rocks sampled by Olszewski (1978), and because I held a strong belief in a correlation of rocks of the Nashoba zone with similar rocks to the west considered to be Ordovician in age (see below). Now, because of the radiometric ages, I believe that the rocks of the Nashoba zone, except possibly for the Tadmuck Brook Schist, could be Proterozoic. If so, however, they are unlike the Proterozoic rocks in the Milford-Dedham zone to the east (Goldsmith, this vol., chap. E).

\section{REGIONAL CORRELATIONS}

The rocks of the Nashoba zone can with some confidence be correlated with units along strike in Connecti- cut and in southeastern Maine (figs. 5, 6). They can be correlated with less confidence with rocks across strike in the Merrimack belt, with those on the east flank of the Bronson Hill anticlinorium in east-central Massachusetts, Connecticut, and southwestern New Hampshire, and with the Massabesic Gneiss Complex of northernmost central Massachusetts and adjacent New Hampshire.

The Nashoba and Marlboro Formations are equivalent to the Tatnic Hill and Quinebaug Formations of eastern Connecticut, respectively (figs. 3, 5, 6). The Nashoba thins near Oxford but is continuous with the Tatnic Hill to the south, although the passage near Webster is along a number of closely spaced fault slices (Barosh, 1974; H.R. Dixon, written commun., 1978). The Marlboro and Quinebaug are not continuous across the salient between Webster and Oxford, but the two have similar lithologies and occupy the same position with respect to the Nashoba and Tatnic Hill. Emerson (1917) and Dixon (1965a) initially correlated the two sequences, and the correlation is now generally accepted (Barosh, 1977; Barosh and others, 1977; H.R. Dixon, written commun., 1978). Detailed lithologic correlation of members within the formations cannot be made between the two terranes (Nashoba and Putnam). However, similar groups of lithologies occupy similar structural positions (fig. 3). Dixon (written commun., 1978) recognized units of the Tatnic Hill in the Nashoba in the Oxford and Grafton areas during reconnaissance mapping for the State bedrock map. The Fly Pond Member of the Tatnic Hill might correspond to either unit N29 or units N12-20 of the tunnel section (Skehan and Abu-Moustafa, 1976). The Quinebaug, on the whole, however, appears to contain less amphibolite than the Marlboro. In Connecticut, the Tatnic fault (Wintsch and Hudson, 1978) separates the Tatnic Hill and the Quinebaug Formation in many places (Dixon, 1965b, 1968, 1974). This fault appears to be a bedding-plane fault that lies close to the normal stratigraphic contact between the two formations. Interlayering of rock types that does not appear to be tectonic is common in the contact zone, and a rusty schist that Dixon considered to be the basal part of the Tatnic Hill (Dixon, 1965a) can be recognized at many places along the contact zone in Connecticut and at the base of the Nashoba in Massachusetts from Webster to Shrewsbury. The Tatnic Hill is much thinner than the Nashoba Formation. This thinning could be stratigraphic but more likely is tectonic, attributable to faulting along the Lake Char, Honey Hill, and Tatnic fault systems in Connecticut (Goldsmith, this vol., chap. H).

Correlation of rocks of the Nashoba zone with rocks to the northeast in southern Maine and New Hampshire (figs. 5-7) must be made across a gap. The Nashoba Formation in the Lowell area is truncated against the 


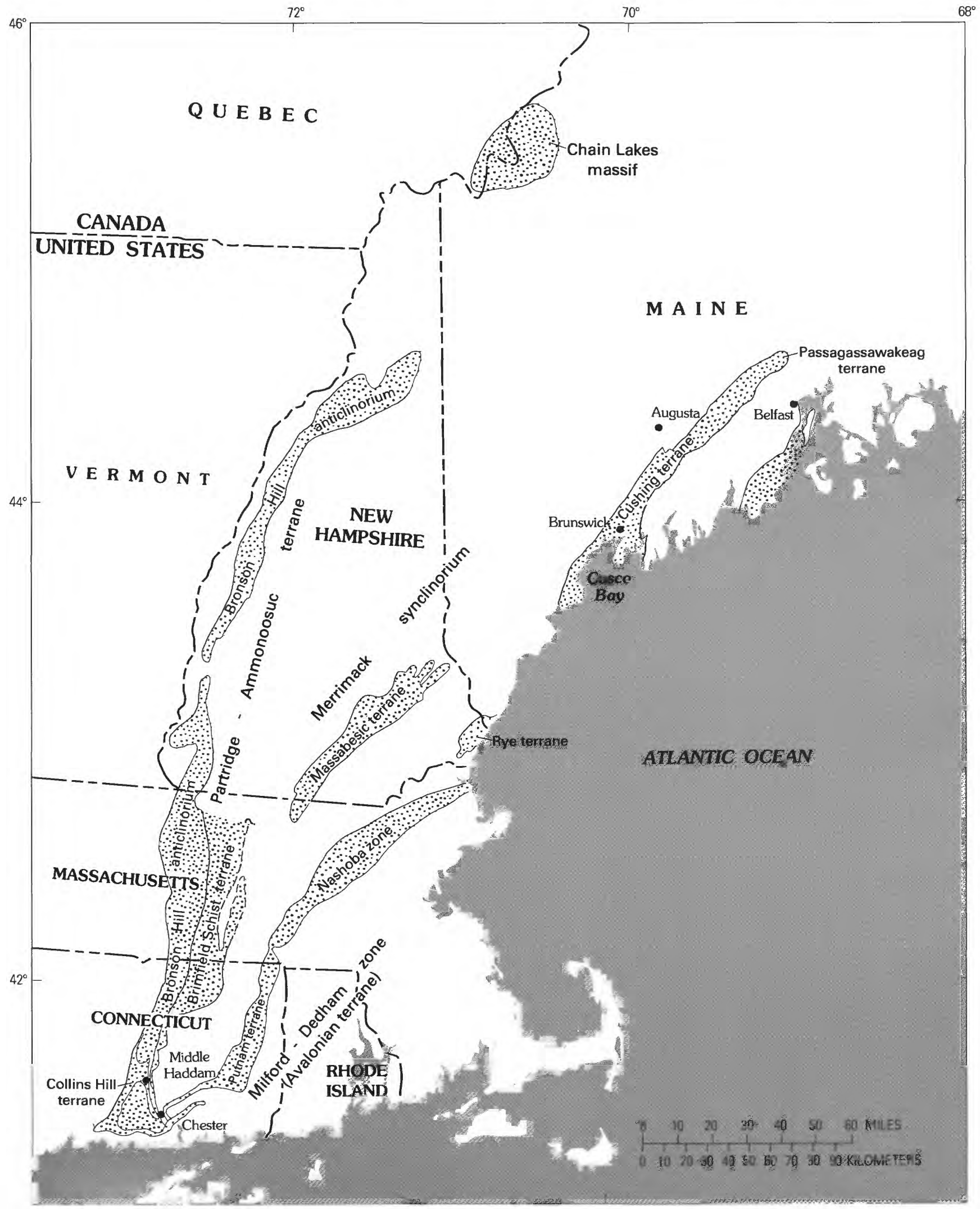

FIGURE 5.-Terranes in New England possibly correlative with the Nashoba zone. Terrane boundaries dashed where uncertain. 


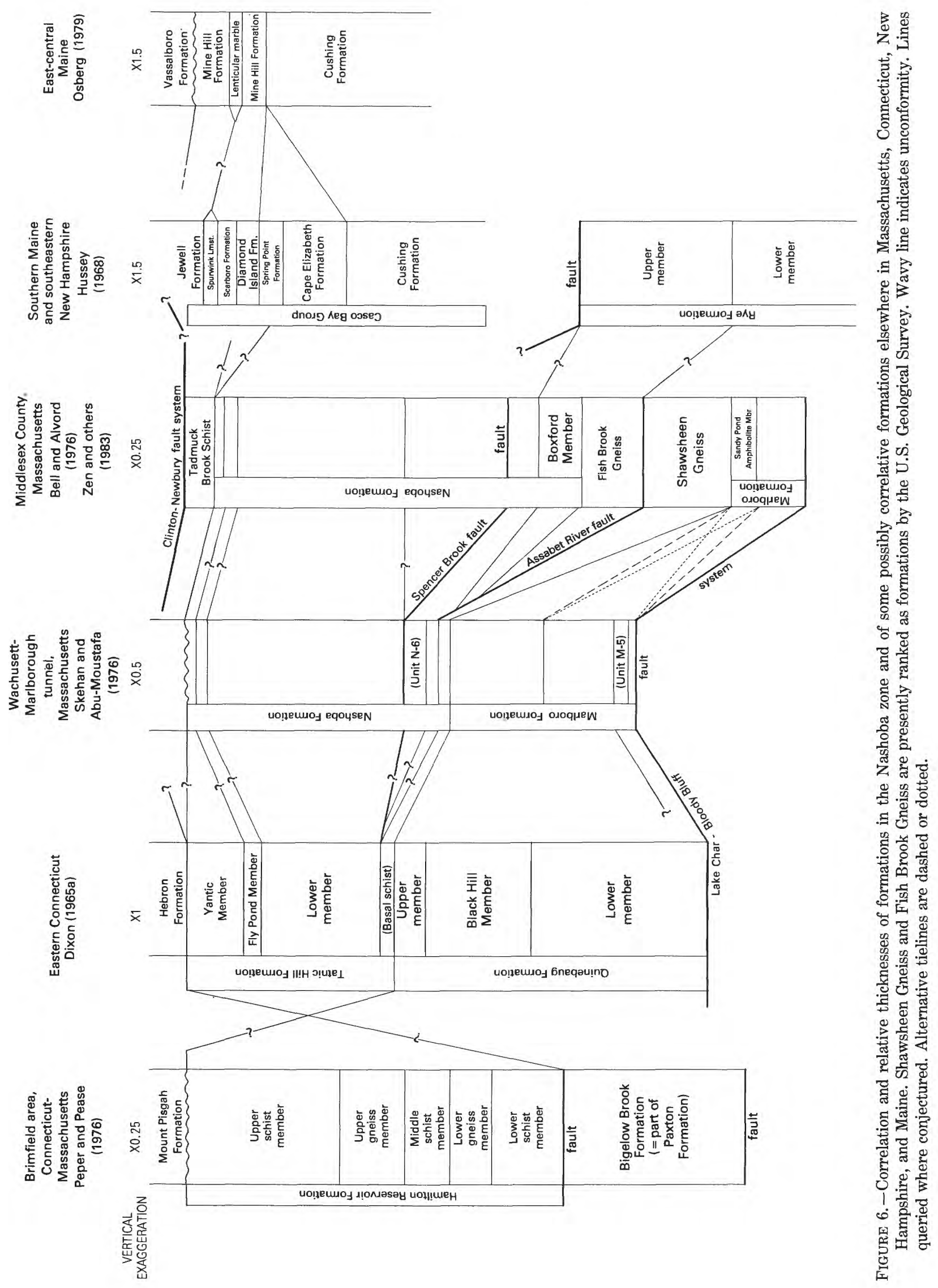




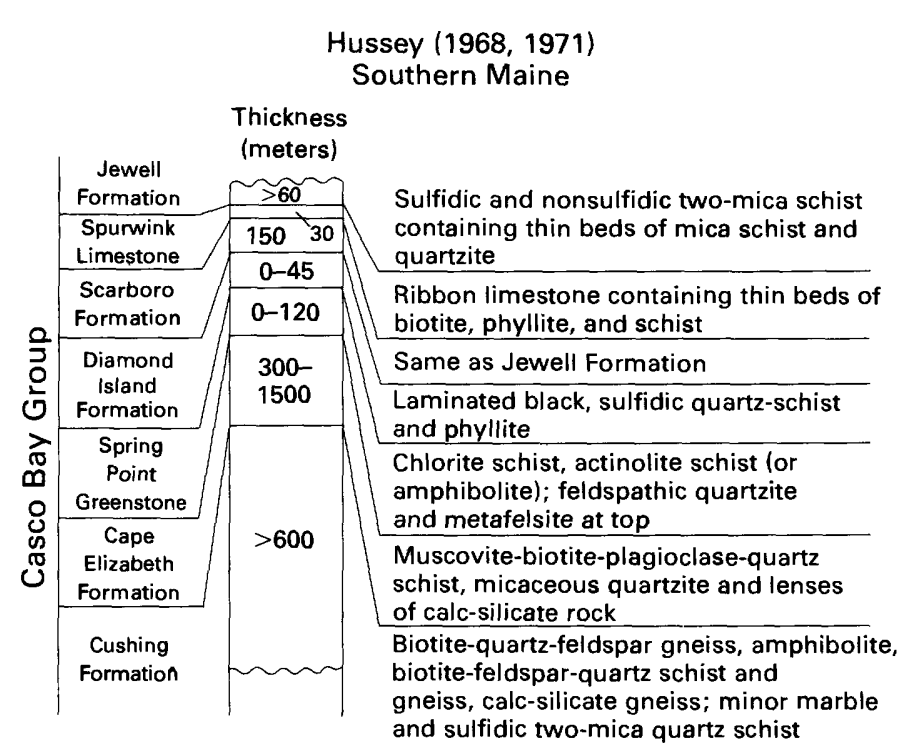

Hussey (1968)

Southeastern New Hampshire

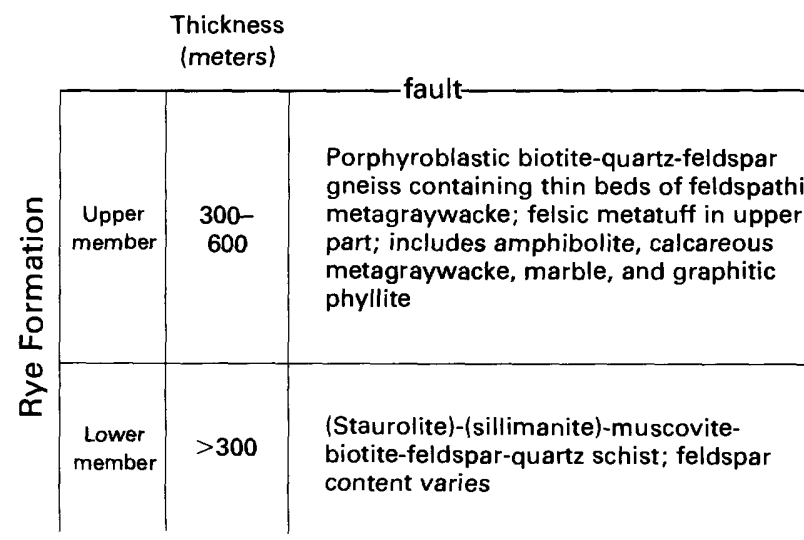

SCALE, IN METERS

Hussey (1968, 1971), Osberg (1979)

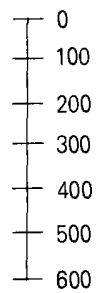

SCALE, IN METERS Novotny (1969)

$$
\begin{aligned}
& 0 \\
& +200 \\
& +400 \\
& +600 \\
& +\quad 800 \\
& +1000 \\
& 1200
\end{aligned}
$$

Osberg (1979)

East-central Maine

\begin{tabular}{|c|c|c|}
\hline \multicolumn{2}{|c|}{$\begin{array}{l}\text { Thickness } \\
\text { (meters) }\end{array}$} & \\
\hline \multirow[t]{2}{*}{$\begin{array}{l}\text { Mine Hill } \\
\text { Formation }\end{array}$} & 200 & $\begin{array}{l}\text { Rusty-weathering quartz mica schist and } \\
\text { phyllite, and sparse quartz-feldspar } \\
\text { layers; contains garnet and sillimanite }\end{array}$ \\
\hline & & Lenticular marble and calc-silicate rock \\
\hline \multirow{2}{*}{$\begin{array}{l}\text { Cushing } \\
\text { Formation }\end{array}$} & \multirow{2}{*}{ 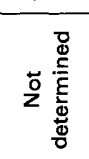 } & $\begin{array}{l}\text { Slightly rusty-weathering garnet- } \\
\text { (sillimanite)-quartz-mica schist }\end{array}$ \\
\hline & & $\begin{array}{l}\text { Upper massive biotite-quartz-plagioclase } \\
\text { gneiss; medial interlayered biotite-quartz- } \\
\text { plagioclase gneiss and biotite amphibolite }\end{array}$ \\
\hline
\end{tabular}

Novotny (1969)

Southeastern New Hampshire

Thickness

(meters)

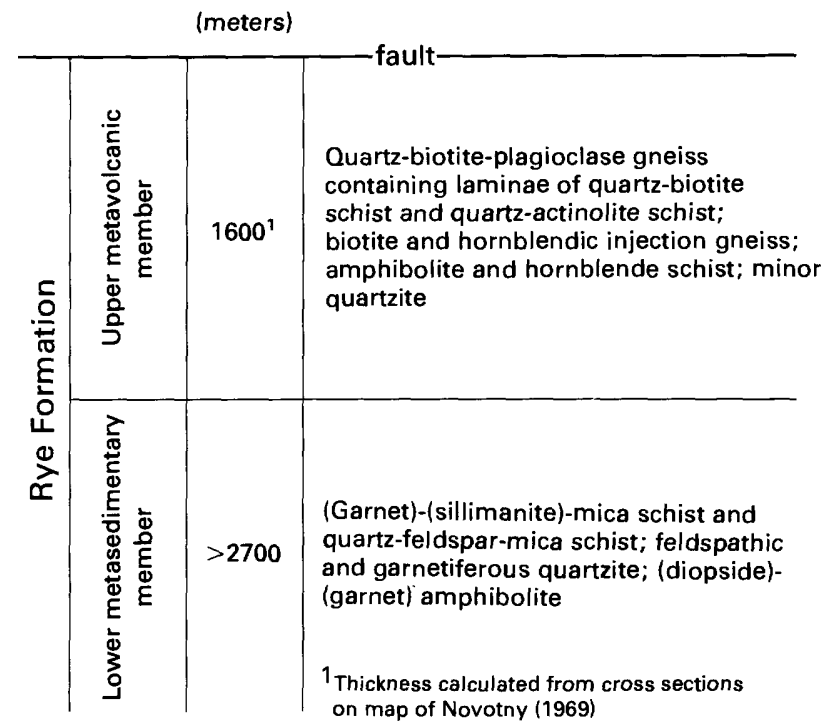

FIGURE 7.-Lithostratigraphic columns of units in southern and east-central Maine and southeastern New Hampshire that are probably correlative with units of the Nashoba zone.

Clinton-Newbury fault and is largely engulfed in granite of the Andover pluton, so that only the Boxford Member of the Nashoba and the Fish Brook Gneiss extend to the Newburyport area and the Gulf of Maine. The Marlboro is similarly truncated or cut out to the northeast. However, a rock sequence similar to the Nashoba is present in southern Maine from south of Augusta at least as far as the Brunswick area (figs. 5-7). These rocks have been mapped by Osberg (1979) as the Cushing Formation, part of the Casco Bay Group of Katz (1918) redefined by Hussey $(1962,1968,1971)$. The age of the Cushing is uncertain, but the unit is considered to lie disconformably below the Silurian turbidite section of eastern and central Maine (Osberg, 1979). The Mine Hill Formation of Osberg (1979) and a similar sulfidic schist mapped by Hussey (1971) in Casco Bay intervene between the 
Cushing and the turbidite section. These sulfidic schists are similar in lithology and occupy the same stratigraphic position relative to the Cushing as the Tadmuck Brook Schist does to the Nashoba (fig. 6), as pointed out by Osberg $(1979$, p. 42). The Cushing terrane in Maine is, however, appreciably offset to the west from the trend of the Nashoba zone in Massachusetts (fig. 5). Farther north, in the Belfast area, Maine, the Passagassawakeag Formation as described by Bickel (1976) appears to resemble the Nashoba Formation. The Passagassawakeag is considered to be probably Precambrian in age. Far to the north, Kennedy's (1976) description of rocks in the Gander zone of Newfoundland is remarkably similar to the descriptions of the rocks in the Nashoba zone. A specific correlation might be made between the Nashoba Formation and the Little Passage Gneisses of the Gander zone (Colman-Sadd, 1980).

Similarities in structural position and in lithology indicate that parts of the Marlboro Formation are quite likely equivalent to the Rye Formation of southeastern New Hampshire and Maine (figs. 3, 6, 7). Castle (1965) suggested correlation of his Boxford Formation with the Rye Formation. Novotny's (1969) Rye section (fig. 7) is similar to, if somewhat thicker than, that of Hussey (1968), although the thickness may be an artifact of my calculations of thickness from Novotny's map and sections. Both Rye sections resemble in lithology the part of Hepburn and DiNitto's Marlboro section above their Sandy Pond amphibolite member (fig. 3). The upper member of the Rye resembles Hepburn and DiNitto's granulite member of the Marlboro and the upper member of the Quinebaug Formation of Dixon (1965a) and resembles the undivided part of the Marlboro Formation of Bell and Alvord (1976) that lies below their Sandy Pond Member. The lower member of the Rye resembles to some extent Hepburn and DiNitto's rusty schist member of the Marlboro and the Shawsheen Gneiss as described by Bell and Alvord (1976). Correlation of the Marlboro Formation with the Rye Formation is not clear cut.

Correlation of the rock units of the Nashoba zone with units west of the Nashoba strike belt, such as those of Peper and Pease (1976) (fig. 6) and the units on the east flank of the Bronson Hill anticlinorium (Robinson, 1979), is less certain. Prior to the isotopic work of Olszewski (1978, 1980), the Nashoba was considered to be of Ordovician age, on the basis of a more or less continuous mapping of rusty-schist lithologies from the Ordovician Partridge Formation, on the west flank of the Bronson Hill anticlinorium in New Hampshire (fig. 5), southward through the Brimfield Schist terrane in Massachusetts, where the rusty schists on the east flank of the anticlinorium and in the Merrimack synclinorium have been called Brimfield Schist (Emerson's (1917) term; Brimfield Group of Peper and Pease (1976)) and, in the Middle
BRONSON HILL ANTICLINORIUM

\section{MERRIMACK SYNCLINORIUM}
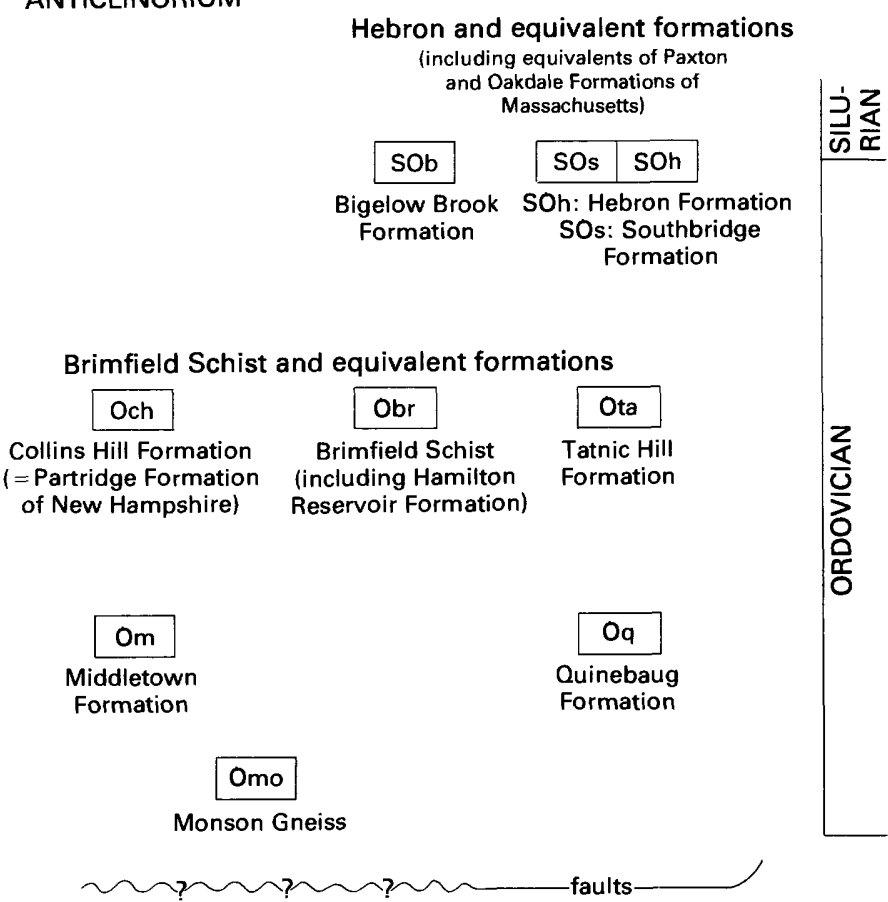

AVALONIAN TERRANE

(Proterozoic Z)

FIGURE 8. -Stratified lower Paleozoic rocks in eastern Connecticut, as shown by Rodgers (1982).

Haddam area, the Collins Hill Schist (Snyder, 1970; Eaton and Rosenfeld, 1972; Collins Hill Formation of Rodgers, 1982, on fig. 8) around the Chester syncline (Dixon and Lundgren, 1968) above the Honey Hill fault into the Tatnic Hill Formation of eastern Connecticut and thence north into the Nashoba Formation. Emerson (1917) mapped rusty schists in the Nashoba as Brimfield. Peter Robinson (oral commun., 1979; Hall and Robinson, 1982, p. 27) pointed out that the Tatnic Hill and Nashoba, although consisting of lithologies similar to those in the Partridge Formation on the Bronson Hill, contain appreciable magnetite and represent a more oxidized metamorphic facies than does the Partridge. The Quinebaug (Marlboro) underlying the Tatnic Hill (Nashoba) was equated with the Middletown Gneiss on the east flank of the Bronson Hill in Connecticut (Dixon and Lundgren, 1968), which in turn was equated by them with the Ammonoosuc Volcanics underlying the Partridge of central Massachusetts and western New Hampshire. This interpretation of the relations was followed by Rodgers (1982) in the preliminary bedrock geologic map of Connecticut from which figure 8 has been adapted.

The continuity on which the above correlation is based has been questioned recently. Wintsch (1979a; Wintsch and Kodidek, 1981) presented evidence that the Tatnic 
Hill is not continuous with the rusty schists in the Chester syncline and with the Brimfield and Collins Hill Schists to the west on the Bronson Hill. Thrust faults beneath the Brimfield Group (Peper and others, 1975) project into a high-angle fault, the Bone Mill Brook fault (Peper and others, 1975; Pease and Fahey, 1978; Pease, 1982) along the east side of the Bronson Hill anticlinorium in Connecticut, which creates a fault wedge of Emerson's type area of Brimfield Schist that is separate from the Bronson Hill sequence. However, Robinson and Tucker (1982) saw no evidence farther north in Massachusetts for a major fault along the east flank of the Bronson Hill; they equated the rusty schists of the Brimfield Group, Peper and Pease's (1976) Hamilton Reservoir Formation, with the Partridge, but in a thickened, basinward section. The Hamilton Reservoir, from detailed descriptions by Peper and Pease (1976) and Peper and others (1975), does not correlate particularly well with the Tatnic Hill Formation, but in general it does somewhat resemble Bell and Alvord's (1976) description of the Nashoba. Regional considerations suggest to some (Snyder, 1970, for example) that the Brimfield Group is inverted, although this does not affect the correlation. In support of this inversion, the Bigelow Brook Formation of Peper and Pease (1976) passes along strike into the Paxton Formation in Massachusetts where it overlies the Partridge-type rocks on the east flank of the Bronson Hill anticlinorium (Peter Robinson, oral commun., 1978). A U-Pb radiometric age of $440 \mathrm{Ma}$ on zircon from a granite gneiss intruding the Hamilton Reservoir Formation (Pease and Barosh, 1981, p. 23) indicates an Ordovician or older age for this part, at least, of the Brimfield Group. G.R. Robinson, Jr. (written commun., 1982), has suggested that possibly only the Tadmuck Brook Schist is correlative with the Partridge and is Ordovician in age. This suggestion is in accord with Skehan and Murray's (1980) interpretation of a Cambrian-Ordovician(?) age for the Tadmuck Brook.

Rocks similar to parts of the Nashoba have been observed in the Massabesic Gneiss Complex of southcentral New Hampshire and adjacent Massachusetts (Massabesic terrane of fig. 5) within what has previously been mapped as the Fitchburg pluton (Billings, 1956). The Massabesic Gneiss Complex also contains rocks resembling the Ordovician Monson Gneiss of the Bronson Hill anticlinorium and the Quinebaug Formation in the Willimantic Dome in east-central Connecticut. U-Pb isotopic data on zircons obtained from the Massabesic, however, indicate both Proterozoic Z (645-Ma) and Ordovician (480-Ma) ages, as well as Permian (275-Ma) ages in late granite (Besancon and others, 1977; Aleinikoff and others, 1979). The Massabesic lies in an anticlinal area within the Merrimack synclinorium, northwest of the Nashoba zone. Its structural position relative to the
Nashoba zone has yet to be determined. The Massabesic Gneiss Complex is described by Peter Robinson in a separate section at the end of this chapter.

\section{SUMMARY AND CONCLUSIONS}

The Nashoba zone is a fault-bounded wedge consisting of high-grade, steeply west-dipping metamorphic rocks, largely metasedimentary to the west (Tadmuck Brook Schist, SZtb; Nashoba Formation, OZn; Fish Brook Gneiss, OZf; and Shawsheen Gneiss, OZsh) and largely metavolcanic to the east (Marlboro Formation, OZm, $\mathrm{OZmg}$ ). These rocks occupy a terrane distinct from the Merrimack belt to the west and the Milford-Dedham zone to the east. Complex faulting and folding and much granite intrusion hinder determination of a stratigraphic sequence throughout the zone. However, two major formations, presumably topping to the west, are recognized: the Nashoba Formation, consisting of pelitic and semipelitic (metawacke) gneiss and schist and subordinate calc-silicate rock, marble, and amphibolite, some of which was formed from impure carbonates; and the Marlboro Formation, consisting of amphibolite, feldspathic gneiss, and subordinate pelitic schist and calcsilicate rock. The Tadmuck Brook Schist, consisting of pelitic schist and phyllite and subordinate quartzite, lies above the Nashoba, probably unconformably. The Shawsheen Gneiss, consisting of pelitic and semipelitic schist and gneiss similar to parts of the Nashoba, lies above the Marlboro. Above the Shawsheen and below the Nashoba is the Fish Brook Gneiss, a lenticular, felsic metavoleanic or intrusive rock. Possible assignment of stratigraphic units that differs from that shown on the State bedrock map is based on the similarity in lithology of the Shawsheen Gneiss to units in the Nashoba and on the observation that the Fish Brook Gneiss appears to be lenticular. According to this scheme, the Shawsheen and the Fish Brook would become members of the Nashoba Formation. A third scheme that can be deduced from the fault pattern within the zone (figs. 1, 4) may be worth consideration. Under this scheme, the Boxford Member of the Nashoba correlates with the Sandy Pond Amphibolite Member of the Marlboro. If the Boxford is reassigned to the Marlboro, the Fish Brook Gneiss, lying below the Boxford Member and above the Assabet River fault, becomes the lowest unit in the Marlboro. The Shawsheen, lying in a different fault block below the Assabet River fault, could be assigned to the Nashoba.

The protoliths of the Marlboro Formation were volcanic, volcaniclastic, and epiclastic materials deposited in a marine environment close to a volcanic source to the east. The protoliths of the Nashoba Formation were volcaniclastic, epiclastic, and minor volcanic materials 
and carbonate rocks deposited in the basin farther from the volcanic center. The minor volcanic component was primarily basaltic but also included andesitic, dacitic, and rhyodacitic materials. The Fish Brook Gneiss is a prominent felsic, probably volcanic unit. The material in the zone seems to have been derived from both a deeply weathered terrane and a volcanic source, according to Abu-Moustafa and Skehan (1976). A 1,500-Ma age for detrital zircon in the Shawsheen Gneiss (Olszewski, 1980) indicates an old source area not now recognized. A source of zircons of this age can be found in northwest Africa. No rocks of this age are known in the Grenville terrane to the west. Nearer at hand is the allochthonous Chain Lakes massif, western Maine (fig. 5), from which a 1.5- to 1.6-Ga age is reported on zircon (Naylor and others, 1973; Boudette and Boone, 1982). The rocks of the Nashoba zone may have been derived from two sources, but if they came from one, the African source seems most likely, on the basis of Olszewski's work.

Igneous zircons from the Fish Brook Gneiss indicate a Proterozoic $\mathrm{Z}$ age (at least $750 \mathrm{Ma}$ (Olszewski, 1980)), older than those so far recorded in the batholithic rocks of the Milford-Dedham zone to the east. Unless the Fish Brook is intrusive, this is a possible age for the Nashoba Formation. The pattern of volcanic and detrital ages is similar to that in northwest Africa in both time of volcanism and source of detritus according to Olszewski. The age of the rocks of the Nashoba zone therefore appears to be Proterozoic $Z$. The rocks can be no younger than Ordovician because they are intruded by the Andover Granite, parts of which could be as old as Ordovician (Zartman and Marvin, this vol., chap. J, table 1). A strongly argued correlation with some of the rocks of the Brimfield Group to the west on the flanks of the Bronson Hill anticlinorium suggests an Ordovician age, but the pattern of deposition and the zircon age would indicate that the Nashoba zone belongs to the eastern basement, as indicated by Osberg (1978), rather than to North American basement or to a lower Paleozoic volcanic island arc.

Rocks of the Nashoba zone occupy the same strike belt as the Putnam Group of eastern Connecticut. To the north, the Nashoba Formation is correlated with the Cushing Formation of the Casco Bay Group in Maine although it is offset to the southeast in strike from the Cushing terrane (fig. 5). The Marlboro Formation is correlated with the Rye Formation in southeastern New Hampshire and Maine. Correlation with rocks in other lithotectonic belts of the Appalachians to the west across strike is uncertain. The rocks may be equivalent to units in the Bronson Hill anticlinorium and to parts of the Massabesic Gneiss Complex of southern New Hampshire and adjacent Massachusetts. If so, considerable structural complexity exists across this part of the orogen
(Goldsmith, this vol., chap. H). If not, or perhaps even so, the Nashoba zone represents an exotic, probably accretionary terrane that was formerly a part of northwest Africa.

\section{MASSABESIC GNEISS COMPLEX (OZma)}

\section{By Peter Robinson ${ }^{1}$}

The Massabesic Gneiss Complex (OZma) of northernmost central Massachusetts and adjacent New Hampshire (figs. 1, 2) forms an isolated area of Proterozoic Z and Ordovician rocks within the broad belt of Silurian and Devonian strata of the Merrimack synclinorium (fig. 5). The Massabesic Gneiss Complex consists of layered Proterozoic Z gneisses and Ordovician granitic gneisses. These rocks are abundantly intruded by fine-grained, pink biotite granite of Pennsylvanian-Permian age (Pgr). Practically none of the rocks in this region are related to the Fitchburg Complex (Dfgr), which is a complex of sheetlike plutons of Devonian age intruding Silurian and Devonian strata in a broadly synclinal region west and southwest of the area of exposed Massabesic Gneiss. The Massabesic is exposed in an anticline, produced during Acadian deformation, that plunges south, so that the Massabesic is exposed only at the north edge of the State bedrock map. On the State bedrock map, the Massabesic is assigned to the Nashoba zone of pre-Silurian strata to the east, rather than to the Bronson Hill zone to the west, for the following reasons: It is geographically closer to the Nashoba zone than to the Bronson Hill zone, and the lithology and tectonic position of the Massabesic vaguely resemble those of the Quinebaug Formation in the Willimantic dome of southeastern Connecticut; the Quinebaug is correlated with the Marlboro Formation of the Nashoba zone. The fault relationships described in the Willimantic dome (Wintsch, 1979b) have not, so far, been identified in the Massabesic, although, like the Willimantic, the Massabesic has the form of an anticline.

Stratigraphic classification of the Massabesic has long been controversial and was undergoing very rapid change as the State bedrock map was being compiled. Billings (1956) classified the Massabesic as part of the Fitchburg pluton of Devonian age. Later investigations of some of the gneissic Massabesic rocks in the Manchester, N.H., area (Besancon and others, 1977) yielded Proterozoic $\mathrm{Z}$ ages. In 1976-77, mapping in the Townsend (Mass.-N.H.) area (Robinson, 1978) and reconnaissance mapping in the Ashby (Mass.-N.H.) area (Peper and Wilson, 1978) showed all the granitoid rocks

\footnotetext{
${ }^{1}$ Department of Geology, University of Massachusetts, Amherst, MA 01003.
} 
as part of a Devonian plutonic complex (Fitchburg Complex). Such an interpretation seemed assured, on the basis of more detailed mapping, in the rest of Massachusetts (Grew, 1970; Hepburn, written commun., 1976; Tucker, 1977; Peper and Wilson, 1978), where the Fitchburg pluton was seen as a complex of granite and granodiorite-tonalite sills (Maczuga, 1981) intruding Silurian and Devonian strata (Tucker, 1977). A radiometric age of $390 \pm 15 \mathrm{Ma}$ on zircon (Zartman and Marvin, this vol., chap. J, table 1) from the probably slightly younger, massive muscovite-biotite granite at Rollstone Hill, Fitchburg (Peper and Wilson, 1978; Maczuga, 1981), appears to support this view.

The Massabesic Gneiss Complex shown on the State bedrock map is based on the detailed mapping and radiometric dating of Aleinikoff (1978) in the Milford, N.H., area, just north of the Massachusetts-New Hampshire border; on field excursions in 1978 with Aleinikoff and J.B. Lyons in the Milford area and the adjacent Townsend, Mass.-N.H., area; and on reconnaissance reinterpretation in 1978 by Peter Robinson of previous work by G.R. Robinson (1978) and Peper and Wilson (1978) in the Townsend and Ashby areas.

The work of Aleinikoff (1978; Aleinikoff and others, 1979 ) in the Milford area showed that the area mapped in the previous literature as Massabesic Gneiss contains no major amount of Devonian plutonic rocks but consists of three major components: (1) layered plagioclase-quartz gneisses believed to be metamorphosed felsic volcanic rocks, yielding zircon ages of around $645 \mathrm{Ma}$ (Proterozoic $\mathrm{Z}$ ), (2) massive coarse-grained pink granitic gneisses, yielding zircon ages of around $480 \mathrm{Ma}$ (Ordovician), and (3) massive fine-grained pink biotite granite ("Milford, N.H., granite"), yielding zircon ages of around $275 \mathrm{Ma}$ (Pennsylvanian-Permian). The first two are assigned on the State bedrock map to the Massabesic Gneiss Complex (OZma); the third is shown separately among the intrusive rocks of the Merrimack belt as pink and gray biotite granite $(\mathbb{P g r})$. Aleinikoff (1978) showed that a geochemical affinity exists between the Ordovician granitic gneisses and the late Paleozoic granites, suggesting the latter might be melting products of the former.

Reinterpretation of the mapping of G.R. Robinson (1978) in the Townsend area showed that almost none of the "Fitchburg Granite" as mapped resembles the Fitchburg Complex farther southwest in Massachusetts, but it can be divided amongst the three rock types identified by Aleinikoff. Specifically, most areas mapped as "granite gneiss" (Dfbg) by G.R. Robinson can be equated with the Proterozoic $\mathrm{Z}$ and Ordovician gneisses of the Massabesic Gneiss Complex proper. Although Proterozoic Z and Ordovician parts of the Massabesic have not yet been separately mapped in the area of the State bedrock map, it is clear that both are present. Thus, unlike other areas labeled "OZ" on the State bedrock map, in the case of the Massabesic (OZma) the "OZ" does not denote uncertainty of age but, rather, indicates that the unit definitely contains rocks of both Ordovician and Proterozoic $\mathrm{Z}$ age. Massabesic Gneiss Complex proper (OZma) has also been identified (Robinson, 1978) in the extreme eastern edge of the Ashby quadrangle.

An interesting feature of the Massabesic of the Townsend area is its pronounced east-west mineral lineation, identical in orientation and character to the lineation in a wide area of Silurian and Devonian stratified and plutonic rocks to the west and southwest and clearly the product of an intermediate stage of the Acadian (Devonian) orogeny (Robinson, 1979).

The fine-grained nonfoliated part of the "Fitchburg granite" (Dfg) mapped by Robinson (1978) is nearly all identified as the late Paleozoic "Milford, N.H., granite" of Aleinikoff (1978). Field areas mapped in detail by G.R. Robinson show how this granite has intruded the Oakdale Formation in the Merrimack belt (So of the State bedrock map, Oqfg of G.R. Robinson) parallel to bedding or foliation to produce a series of elongate, slablike inclusions (Robinson and Goldsmith, this vol., chap. G). Misidentification of this fine-grained granite for Proterozoic $\mathrm{Z}$ parts of the Massabesic might lead to an interpretation based on these contact relations that the Oakdale is Precambrian in age.

In light of their geochemical affinities (Aleinikoff, 1978), it is not surprising that the finer grained parts of the Ordovician granitic gneiss of the Massabesic are very difficult to tell in the field from the late Paleozoic granite (Pgr); hence contacts on the State bedrock map, modified from those of Robinson (1978), are highly tentative. Field separation of the Proterozoic and Ordovician parts of the Massabesic is even more difficult and was not accomplished even by Aleinikoff. An excellent exposure in a small abandoned quarry on the southwest shore of Potanipo Pond, Mass., shows the late Paleozoic granite (Pgr) truncating the foliation of the Massabesic Gneiss Complex (OZma).

A major problem yet to be solved is the nature of the contact between the Massabesic and surrounding stratified rocks, though the problem to the east could be less severe if the Oakdale Formation is Proterozoic (Barosh, 1982; Lyons and others, 1982) or Ordovician(?)-Cambrian (Skehan and Murray, 1980, fig. 4). If the surrounding rocks are mainly Silurian and Devonian, as we think, then a search should be made for either an unconformity or possibly a deformed subhorizontal fault surface similar to others described in southeastern New England (Lundgren and Ebblin, 1972; Castle and others, 1976; Wintsch, 1979b; Goldstein, 1982). 


\section{REFERENCES CITED}

Abu-Moustafa, A.A., and Skehan, J.W., 1976, Petrography and geochemistry of the Nashoba Formation, east-central Massachusetts, in Lyons, P.C., and Brownlow, A.H., eds., Studies in New England geology: Geological Society of America Memoir 146, p. 31-70.

Aleinikoff, J.N., 1978, Structure, petrology, and U-Th-Pb geochronology in the Milford $\left(1^{\prime}\right)$ quadrangle, New Hampshire: Hanover, N.H., Dartmouth College, Ph.D. thesis, 247 p.

Aleinikoff, J.N., Zartman, R.E., and Lyons, J.B., 1979, U-Th-Pb geochronology of the Massabesic Gneiss and the granite near Milford, south-central New Hampshire-New evidence for Avalonian basement and Taconic and Alleghenian disturbances in eastern New England: Contributions to Mineralogy and Petrology, v. 71, no. 1, p. 1-11.

Alvord, D.C., 1975, Preliminary bedrock geologic maps of the Westford and Billerica quadrangles, Middlesex County, Massachusetts: U.S. Geological Survey Open-File Report $75-387,12$ p., 2 pls., scale 1:24,000.

Alvord, D.C., Pease, M.H., Jr., and Fahey, R.J., 1976, The PreSilurian eugeosynclinal sequence bounded by the Bloody Bluff and Clinton-Newbury faults, Concord, Billerica, and Westford quadrangles, Massachusetts, in New England Intercollegiate Geological Conference, 68th Annual Meeting, Boston, Mass., Oct. 8-10, 1976, Geology of southeastern New England; a guidebook for field trips to the Boston area and vicinity: Princeton, N.J., Science Press, p. $315-334$.

Barosh, P.J., 1974, Preliminary bedrock geologic map of the Webster quadrangle, Massachusetts-Connecticut: U.S. Geological Survey Open-File Report 74-192, 2 p., 1 pl., scale 1:24,000.

1976, Faults and related deformation in the Clinton-NewburyBloody Bluff fault complex of eastern Massachusetts, in New England Intercollegiate Geological Conference, 68th Annual Meeting, Boston, Mass., Oct. 8-10, 1976, Geology of southeastern New England; a guidebook for field trips to the Boston area and vicinity: Princeton, N.J., Science Press, p. 301-314.

1977, Preliminary map showing bedrock geology superposed on an aeromagnetic base map of the Worcester region, Massachusetts, Connecticut, Rhode Island: U.S. Geological Survey OpenFile Report 77-131, 46 p., 2 pls., scale 1:125,000.

_-1978, Reconnaissance bedrock geologic map of the Marlborough quadrangle, Massachusetts: U.S. Geological Survey Open-File Report 78-221, scale 1:24,000.

1982, Structural relations at the junction of the Merrimack province, Nashoba thrust belt, and the southeast New England platform in the Webster-Oxford area, Massachusetts, Connecticut, and Rhode Island, in New England Intercollegiate Geological Conference, 74th Annual Meeting, Storrs, Conn., Oct. 2-3, 1982, Guidebook for fieldtrips in Connecticut and south-central Massachusetts: Connecticut Geological and Natural History Survey Guidebook 5, p. 395-418.

Barosh, P.J., Fahey, R.J., and Pease, M.H., Jr., 1977, Preliminary compilation of the bedrock geology of the land area of the Boston $2^{\circ}$ sheet, Massachusetts, Connecticut, Rhode Island, and New Hampshire: U.S. Geological Survey Open-File Report 77-285, 142 p., 1 pl., scale 1:125,000.

Bell, K.G., and Alvord, D.C., 1976, Pre-Silurian stratigraphy of northeastern Massachusetts, in Page, L.R., ed., Contributions to the stratigraphy of New England: Geological Society of America Memoir 148, p. 179-216.

Besancon, J.R., Gaudette, H.E., and Naylor, R.S., 1977, Age of the Massabesic Gneiss, southeastern New Hampshire [abs.]: Geological Society of America Abstracts with Programs, v. 9, no. 3, p. 242 .
Bickel, C.E., 1976, Stratigraphy of the Belfast quadrangle, Maine, in Page, L.R., ed., Contributions to the stratigraphy of New England: Geological Society of America Memoir 148, p. 97-128.

Billings, M.P., 1956, The geology of New Hampshire; Part 2, Bedrock geology: Concord, N.H., New Hampshire State Planning and Development Commission, $203 \mathrm{p}$.

Blackwood, R.F., and Kennedy, M.J., 1975, The Dover fault: western boundary of the Avalon zone in northeastern Newfoundland: Canadian Journal of Earth Sciences, v. 12, p. 320-325.

Boudette, E.L., and Boone, G.M., 1982, Diamictite of the Chain Lakes Massif of Maine: A possible metasuevite? [abs.]: Geological Society of America Abstracts with Programs, v. 14, no. 7, p. 448.

Castle, R.O., 1964, Geology of the Andover Granite and surrounding rocks, Massachusetts: U.S. Geological Survey Open-File Report, $550 \mathrm{p}$.

1965, Gneissic rocks in the South Groveland quadrangle, Essex County, Massachusetts: U.S. Geological Survey Professional Paper 525-C, p. C81-C86.

Castle, R.O., Dixon, H.R., Grew, E.S., Griscom, Andrew, and Zietz, Isidore, 1976, Structural dislocations in eastern Massachusetts: U.S. Geological Survey Bulletin 1410, $39 \mathrm{p}$.

Colman-Sadd, S.P., 1980, Geology of south-central Newfoundland and evolution of the eastern margin of Iapetus: American Journal of Science, v. 280, p. 991-1017.

Dixon, H.R., 1965a, The Putnam Group of eastern Connecticut: U.S. Geological Survey Bulletin 1194-C, 12 p.

$-1965 \mathrm{~b}$, Bedrock geologic map of the Plainfield quadrangle, Windham and New London Counties, Connecticut: U.S. Geological Survey Geologic Quadrangle Map GQ-481, scale 1:24,000.

-1968 , Bedrock geologic map of the Danielson quadrangle, Windham County, Connecticut: U.S. Geological Survey Geologic Quadrangle Map GQ-696, scale 1:24,000.

1974, Bedrock geologic map of the Thompson quadrangle, Windham County, Connecticut, and Providence County, Rhode Island: U.S. Geological Survey Geologic Quadrangle Map GQ-1165, scale $1: 24,000$.

Dixon, H.R., and Lundgren, L.W., Jr., 1968, Structure of eastern Connecticut, in Zen, E-an, White, W.S., Hadley, J.B., and Thompson, J.B., Jr., eds., Studies of Appalachian geologyNorthern and maritime: New York, Interscience Publishers, p. 219-229.

Eaton, G.P., and Rosenfeld, J.L., 1972, Preliminary bedrock geologic map of the Middle Haddam quadrangle, Middlesex County, Connecticut: U.S. Geological Survey Open-File Report, 9 p., scale $1: 24,000$.

Emerson, B.K., 1917, The geology of Massachusetts and Rhode Island: U.S. Geological Survey Bulletin 597, 289 p.

Goldstein, A.G., 1982, Lake Char fault in the Webster, Massachusetts area: Evidence for west-down motion, in New England Intercollegiate Geological Conference, 74th Annual Meeting, Storrs, Conn., Oct. 2-3, 1982, Guidebook for fieldtrips in Connecticut and south-central Massachusetts: Connecticut Geological and Natural History Survey Guidebook 5, p. 375-394.

Grew, E.S., 1970, Geology of the Pennsylvanian and prePennsylvanian rocks of the Worcester area, Massachusetts: Cambridge, Mass., Harvard University, Ph.D. thesis, 263 p.

Hall, L.M., and Robinson, Peter, 1982, Stratigraphic-tectonic subdivisions of southern New England, in St-Julien, Pierre, and Beland, Jacques, eds., Major structural zones and faults of the northern Appalachians: Geological Association of Canada Special Paper 24, p. $15-41$.

Handford, L.S., 1965, Rb-Sr whole rock age study of the Andover and Chelmsford Granites, Massachusetts, in Variations in isotopic abundances of strontium, calcium, and argon and related topics: 
Massachusetts Institute of Technology, 13th Annual Program Report for 1965, U.S. Atomic Energy Commission contract AT(30-1)-1381-13, p. 11-14.

Hansen, W.R., 1956, Geology and mineral resources of the Hudson and Maynard quadrangles, Massachusetts: U.S. Geological Survey Bulletin 1038, $104 \mathrm{p}$.

Hepburn, J.C., 1978, Preliminary reconnaissance bedrock geologic map of the Shrewsbury quadrangle, Worcester County, Massachusetts: U.S. Geological Survey Open-File Report 78-951, 14 p., 1 pl., scale 1:24,000.

Hepburn, J.C., and DiNitto, R.G., 1978, Preliminary bedrock geologic map of the Marlborough quadrangle, Middlesex and Worcester Counties, Massachusetts: U.S. Geological Survey Open-File Report 78-222, 29 p., 1 pl., scale 1:24,000.

Hurley, P.M., Boudda, A., Kanes, W.H., and Nairn, A.E.M., 1974, A plate tectonics origin for late Precambrian-Paleozoic orogenic belt in Morocco: Geology, v. 2, p. 343-344.

Hussey, A.M., II, 1962, The geology of southern York County, Maine: Maine Geological Survey, Special Studies Series, no. 4, 67 p. 1968, Stratigraphy and structure of southwestern Maine, in Zen, E-an, White, W.S., Hadley, J.B., and Thompson, J.B., Jr., eds., Studies of Appalachian geology-Northern and maritime: New York, Interscience Publishers, p. 291-301.

1971, Geologic map of the Portland quadrangle, Maine: Maine Geological Survey Geologic Map GM-1, scale 1:62,500.

Katz, F.J., 1918, Stratigraphy in southeastern New Hampshire and southwestern Maine: U.S. Geological Survey Professional Paper 108-I, p. 165-177.

Kennedy, M.J., 1976, Southeastern margin of the northeastern Appalachians: Late Precambrian orogeny on a continental margin: Geological Society of America Bulletin, v. 87, p. 1317-1325.

Lundgren, Lawrence, and Ebblin, Claude, 1972, Honey Hill fault in eastern Connecticut-Regional relations: Geological Society of America Bulletin, v. 83, p. 2773-2794.

Lyons, J.B., Boudette, E.L., and Aleinikoff, J.N., 1982, The Avalonian and Gander zones in central eastern New England, in St-Julien, Pierre, and Beland, Jacques, eds., Major structural zones and faults of the northern Appalachians: Geological Association of Canada Special Paper 24, p. 43-66.

Maczuga, D.E., 1981, Petrology and geochemistry of the Fitchburg Plutonic Complex, central Massachusetts: University of Massachusetts, Geology and Geography Department, Contribution No. 36, $128 \mathrm{p}$.

Naylor, R.S., Boone, G.M., Boudette, E.L., Ashenden, D.O., and Robinson, Peter, 1973, Pre-Ordovician rocks in the Bronson Hill and Boundary Mountains anticlinoria, New England, USA [abs.]: Eos, v. 54, no. 4 , p. 495.

Nockolds, S.R., 1954, Average chemical composition of some igneous rocks: Geological Society of America Bulletin, v. 65, p. 1007-1032.

Novotny, R.F., 1969, Geology of the sea coast region of New Hampshire: Concord, N.H., New Hampshire Division of Economic Development Quadrangle Report, $46 \mathrm{p}$.

Olszewski, W.J., Jr., 1978, U-Pb zircon ages from stratified metamorphic rocks in northeastern Massachusetts [abs.]: Geological Society of America Abstracts with Programs, v. 10, no. 2, p. 79.

1980, The geochronology of some stratified metamorphic rocks in northeastern Massachusetts: Canadian Journal of Earth Sciences, v. 17, p. 1407-1416.

Osberg, P.H., 1978, Synthesis of the geology of the northeastern Appalachians, USA, in International Geologic Correlation Program Project 27, Contribution No. 1, Caledonian-Appalachian orogen of the North Atlantic Region: Geological Survey of Canada Paper 78-13, p. 137-147.
-1979, Geologic relationships in south-central Maine, in Skehan, J.W., and Osberg, P.H., eds., The Caledonides in the USA, Geological excursions in the northeast Appalachians; Caledonide Orogen Project 27: Weston, Mass., Weston Observatory, p. 37-62.

Pease, M.H., Jr., 1982, The Bonemill Brook fault, eastern Connecticut, in New England Intercollegiate Geological Conference, 74th Annual Meeting, Storrs, Conn., Oct. 2-3, 1982, Guidebook for fieldtrips in Connecticut and south-central Masssachusetts: Connecticut Geological and Natural History Survey Guidebook 5, p. 263-288.

Pease, M.H., Jr., and Barosh, P.J., 1981, Distribution and structural significance of the Oakdale Formation in northeastern Connecticut, in New England Intercollegiate Geological Conference, 73d Annual Meeting, Kingston, R.I., Oct. 16-18, 1981, Guidebook to geological field studies in Rhode Island and adjacent areas: Kingston, R.I., University of Rhode Island, p. 17-34.

Pease, M.H., Jr., and Fahey, R.J., 1978, A reinterpretation of the stratigraphy and structure in part of eastern Connecticut [abs.]: Geological Society of America Abstracts with Programs, v. 10, no. 2, p. 79.

Peper, J.D., and Pease, M.H., Jr., 1976, Summary of stratigraphy in the Brimfield area, Connecticut and Massachusetts, in Page, L.R., ed., Contributions to the stratigraphy of New England: Geological Society of America Memoir 148, p. 253-270.

Peper, J.D., Pease, M.H., Jr., and Seiders, V.M., 1975, Stratigraphic and structural relationships of the Brimfield Group in northeastcentral Connecticut and adjacent Massachusetts: U.S. Geological Survey Bulletin 1389, $31 \mathrm{p}$.

Peper, J.D., and Wilson, F.A., 1978, Reconnaissance bedrock geologic map of the Fitchburg quadrangle and part of the Ashby quadrangle, north-central Massachusetts: U.S. Geological Survey Miscellaneous Field Studies Map MF-959, scale 1:24,000.

Robinson, G.R., Jr., 1978, Bedrock geology of the Pepperell, Shirley, Townsend quadrangles, and part of the Ayer quadrangle, Massachusetts and New Hampshire: U.S. Geological Survey Miscellaneous Field Studies Map MF-957, scale 1:24,000.

Robinson, Peter, 1979, Bronson Hill anticlinorium and Merrimack synclinorium in central Massachusetts, in Skehan, J.W., and Osberg, P.H., eds., The Caledonides in the U.S.A., Geological excursions in the northeast Appalachians, Caledonide Orogen Project 27: Weston, Mass., Weston Observatory, p. 126-174.

Robinson, Peter, and Tucker, R.D., 1982, The Merrimack synclinorium in northeastern Connecticut, Discussion: American Journal of Science, v. 282, no. 10, p. 1735-1744.

Rodgers, John, comp., 1982, Yet another preliminary geological map of Connecticut, in New England Intercollegiate Geological Conference, 74th Annual Meeting, Storrs, Conn., Oct. 2-3, 1982, Guidebook for fieldtrips in Connecticut and south-central Massachusetts: Connecticut Geological and Natural History Survey Guidebook 5, p. 1-4, map in pocket, scale 1:250,000.

Schenk, P.E., 1971, Southeastern Atlantic Canada, northwestern Africa, and continental drift: Canadian Journal of Earth Sciences, v. 8 , p. 1218-1251.

Skehan, J.W., 1967, Geology of the Wachusett-Marlborough tunnel, east-central Massachusetts, a preliminary report, in Farquhar, 0 ., ed., Economic geology in Massachusetts-Conference Amherst, Proceedings: Amherst, Massachusetts University Graduate School, p. 237-244.

Skehan, J.W., and Abu-Moustafa, A.A., 1976, Stratigraphic analysis of rocks exposed in the Wachusett-Marlborough tunnel, east-central Massachusetts, in Page, L.R., ed., Contributions to the stratigraphy of New England: Geological Society of America Memoir 148, p. 217-240. 
Skehan, J.W., and Murray, D.P., 1980, Geologic profile across southeastern New England: Tectonophysics, v. 69, p. 285-319.

Snyder, G.L., 1970, Bedrock geologic and magnetic maps of the Marlborough quadrangle, east-central Connecticut: U.S. Geological Survey Geologic Quadrangle Map GQ-791, scale 1:24,000.

Tucker, R.D., 1977, Bedrock geology of the Barre area, central Massachusetts: University of Massachusetts, Geology and Geography Department, Contribution No. 30, $132 \mathrm{p}$.

Wintsch, R.P., 1979a, Recent mapping in the Chester area, Connecticut, and its bearing on the Chester syncline [abs.]: Geological Society of America Abstracts with Programs, v. 11, no. 1, p. 60. 1979b, The Willimantic fault: a ductile fault in eastern Connecticut: American Journal of Science, v. 279, p. 367-393.

Wintsch, R.P., and Hudson, M.R., 1978, Southeastward thrusting in eastern Connecticut [abs.]: Geological Society of America Abstracts with Programs, v. 10, no. 2, p. 91.
Wintsch, R.P., and Kodidek, K.L., 1981, Local and regional implications of recent mapping in the Essex area, Connecticut [abs.]: Geological Society of America Abstracts with Programs, v. 13, no. 3 , p. 184.

Zartman, R.E., and Naylor, R.S., 1984, Structural implications of some radiometric ages of igneous rocks in southeastern New England: Geological Society of America Bulletin, v. 95, no. 5, p. 522-539.

Zartman, R.E., Snyder, G.L., Stern, T.W., Marvin, R.F., and Buckman, R.C., 1965, Implications of new radiometric ages in eastern Connecticut and Massachusetts: U.S. Geological Survey Professional Paper 525-D, p. D1-D10.

Zen, E-an, editor, and Goldsmith, Richard, Ratcliffe, N.M., Robinson, Peter, and Stanley, R.S., compilers, 1983, Bedrock geologic map of Massachusetts: Reston, Va., U.S. Geological Survey, 3 sheets, scale 1:250,000. 


\section{Stratigraphy of the Merrimack Belt, Central Massachusetts}

By PETER ROBINSON, University of Massachusetts, and RICHARD GOLDSMITH, U.S. GeOLOGIGAL SURveY

THE BEDROCK GEOLOGY OF MASSACHUSETTS

U.S. GEOLOGICAL SURVEY PROFESSIONAL PAPER 1366-G 



\section{CONTENTS}

\begin{tabular}{|c|c|c|c|}
\hline & Page & & \\
\hline 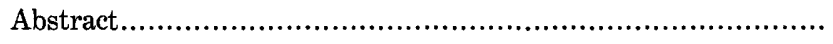 & G1 & 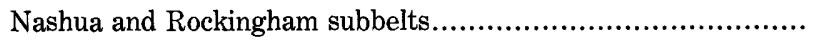 & G24 \\
\hline 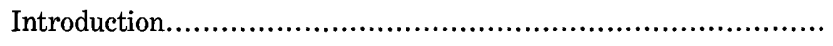 & 2 & 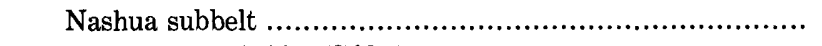 & 25 \\
\hline Ware, Gardner, Southbridge, and Wachusett Mountain & & Boylston Schist (SObo) ......................................... & 25 \\
\hline 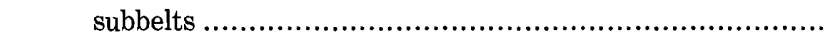 & 8 & 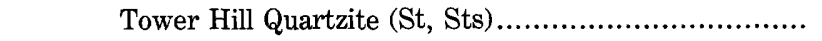 & 26 \\
\hline 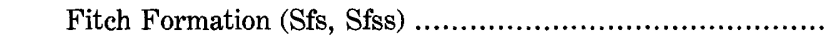 & 8 & 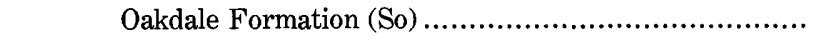 & 27 \\
\hline 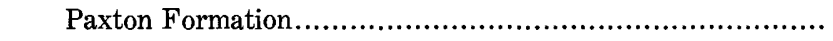 & 12 & Worcester Formation (DSw) ................................... & 27 \\
\hline Sulfidic schist and sillimanite quartzite $(\mathrm{Spsq})$.............. & 12 & 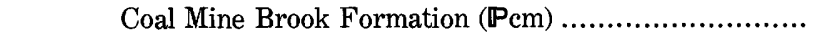 & 28 \\
\hline Sulfidic quartzite and rusty schist (Spqr) ..................... & 14 & 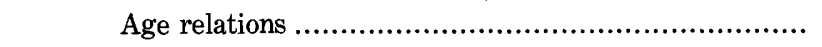 & 29 \\
\hline 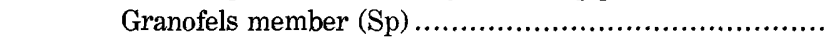 & 15 & 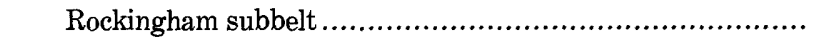 & 29 \\
\hline 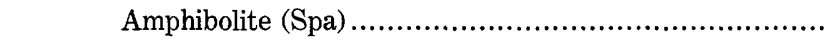 & 18 & 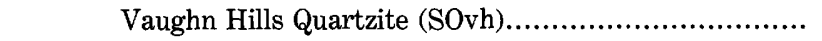 & 30 \\
\hline Bigelow Brook Member (Spbs, Spbc) ....................... & 18 & 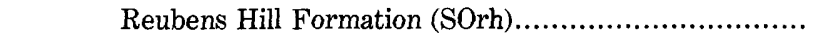 & 30 \\
\hline 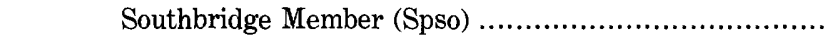 & 18 & Kittery Formation (SOk) .......................................... & 31 \\
\hline 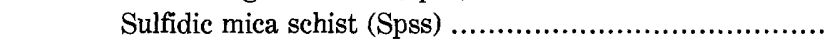 & 18 & 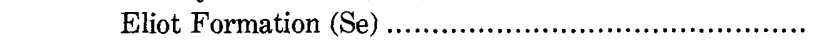 & 31 \\
\hline Littleton Formation (Dl, Dl+Ops, Dlf, Dlo, Dlm) .............. & 19 & 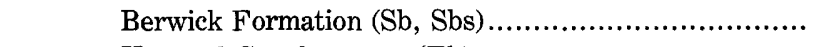 & 31 \\
\hline 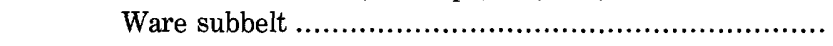 & 20 & 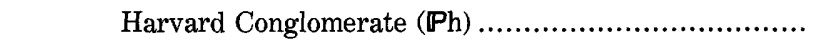 & 32 \\
\hline Gardner subbelt .................................................. & 22 & 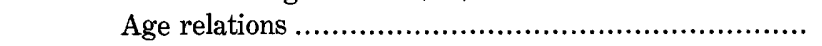 & 32 \\
\hline Wachusett Mountain subbelt.................................... & 22 & 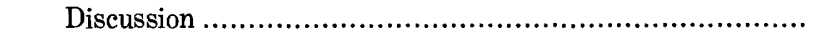 & 33 \\
\hline Harding Hill syncline .............................................. & 23 & 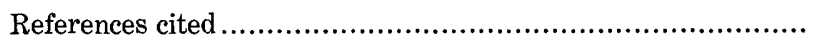 & 34 \\
\hline
\end{tabular}

\section{ILLUSTRATIONS}

Figure 1. Map showing major divisions and structural features of the Merrimack belt and localities of Pennsylvanian strata ..........

2. Correlation chart of sedimentary and volcanic rocks of the Merrimack belt and their metamorphic equivalents.

3-6. Geologic maps showing:

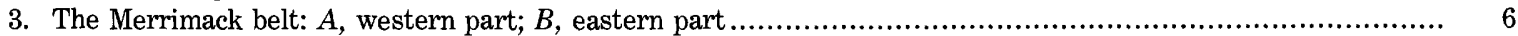

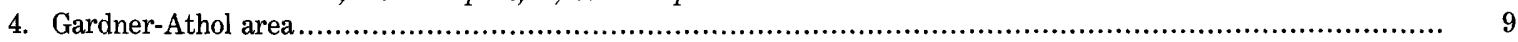

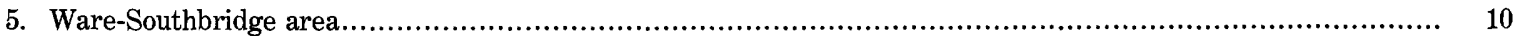

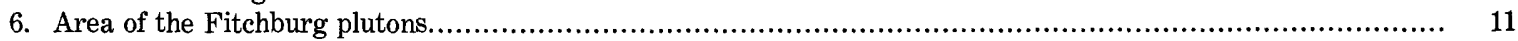

7. Correlation charts of previous nomenclature of stratified units in the eastern part of the Merrimack belt: $A$, Nashua

8. Columnar sections for the eastern part of the Merrimack belt from eastern Connecticut to southeastern

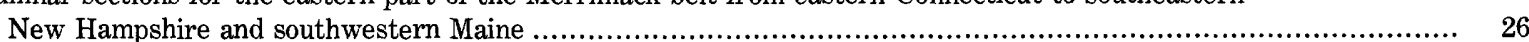

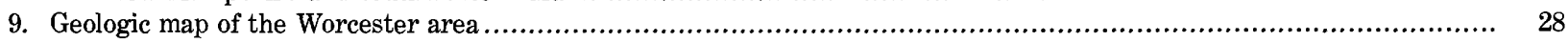

\section{TABLE}

TABLE 1. Distribution of Silurian-Devonian lithic units of the Massachusetts State bedrock map in western subbelts of the Merrimack belt 



\title{
THE BEDROCK GEOLOGY OF MASSACHUSETTS
}

\section{STRATIGRAPHY OF THE MERRIMACK BELT, GENTRAL MASSACHUSETTS}

\author{
By Peter Robinson ${ }^{1}$ and Richard Goldsmith ${ }^{2}$
}

\section{ABSTRACT}

The Merrimack belt of central Massachusetts overlaps the junction between two zones of Ordovician and older rocks, the Bronson Hill zone on the west and the Nashoba zone on the east, and consists of Upper Ordovician, Silurian, Lower Devonian, and local Pennsylvanian strata. Distinctive groups of these strata form six subbelts. These are, from west to east, the Ware, Gardner, Southbridge, and Wachusett Mountain subbelts, in the western and central parts of the belt, and the Nashua and Rockingham subbelts, in the eastern part.

The Fitch Formation, a well-bedded, rusty-weathering, graphitebearing, calc-silicate granofels (Sfs) and subordinate rusty-weathering sillimanite-graphite-pyrrhotite-biotite schist, locally mapped separately (Sfss), is a thin unit confined to the Ware subbelt. The Fitch corresponds to the Fitch Formation in the Lovewell Mountain area, New Hampshire, and to the Francestown Formation (formerly a member of the Littleton Formation) in the Peterborough area and elsewhere in central and southern New Hampshire.

The Paxton Formation (Sp) is a predominantly gray-weathering, slabby quartz-plagioclase-biotite granofels widely distributed in the Gardner, Southbridge, and Wachusett Mountain subbelts. The Paxton is subdivided into members containing distinctive rock types. The lowest unit is a rusty-weathering, white to bluish-gray sulfidic and graphitic, highly magnesian schist and interbedded slabby-weathering, feldspathic, micaceous, and sillimanitic quartzite (Spsq) 30-60 m thick that forms a long belt along the west margin of the Gardner subbelt. The protolith was deposited under reducing conditions, characterized by sulfur-reducing bacteria and slow accumulation of fine-grained Fe-bearing silicate. The magnesian schist differs from underlying schists of the Middle Ordovician Partridge Formation and the Lower Silurian Rangeley Formation in the high magnesium content of the biotite, the abundance of rutile, and the lack of ilmenite and garnet. The unit resembles the Middle Silurian Smalls Falls Formation of northwestern Maine. Sulfidic quartzite and rusty schist (Spqr) forms a unit more than $250 \mathrm{~m}$ thick in the axial zone of a major refolded recumbent anticline in the Wachusett Mountain subbelt. Although graphitic, sulfidic, and rusty-weathering, the unit lacks the $\mathrm{Mg}$-rich biotite and cordierite of the sulfidic schist and quartzite unit (Spsq) but may be a facies equivalent of it. Quartzites in the unit resemble Clough

Manuscript approved for publication November 16, 1987

${ }^{1}$ Department of Geology, University of Massachusetts, Amherst, MA 01003.

${ }^{2}$ U.S. Geological Survey.
Quartzite of the Connecticut Valley belt. It may be broadly equivalent to the Smalls Falls Formation or the uppermost part of the Perry Mountain Formation in Maine.

The granofels member (Sp) forms the bulk of the Paxton Formation. It is a well-layered, purple-gray quartz-calcic plagioclase-biotite granofels commonly interbedded with beds of green to pink calc-silicate granofels and rare beds of diopside-bearing marble. Rusty-weathering, graphitic, sillimanitic mica schist similar to schist of the Partridge and Rangeley Formations is locally interbedded with the granofels except in the western part of the Wachusett Mountain subzone. Tourmalinebearing pegmatites are common in the unit. The unit resembles the Warner Formation in New Hampshire and the Madrid Formation in Maine. It is lithically similar to the Vassalboro Formation in central Maine, the Eliot and Berwick Formations of southeastern New Hampshire, the Oakdale Formation of the Nashua subbelt, and the Hebron Gneiss of Connecticut. The Bigelow Brook Member (Spbs) consists of about equal proportions of thick-bedded granofels and sulfidic schist. It also contains a few marble beds and zones of calc-silicate granofels (Spbc). The Southbridge Member (Spso) consists of interbedded granofels and calc-silicate rock. Schist beds are lacking. Mappable areas of sulfidic mica schist (Spss) occur throughout the Paxton, but the largest area lies in the Gardner anticline above the granofels and below gray schist assigned to the Littleton Formation.

The Littleton Formation (Dl) occupies parallel narrow synclines in the Ware, Gardner, and Wachusett Mountain subbelts. It consists characteristically of gray-weathering schists that differ somewhat in composition in the different synclines. The Littleton schists typically contain sillimanite and garnet, and, at the highest grade of metamorphism, cordierite. In the westernmost Ware subbelt, Littleton resembles Littleton in the Connecticut Valley belt. East of the Hardwick pluton, it is quartz rich and resembles part of Rangeley $\mathrm{C}$ of the Maine sequence. West of the Coys Hill pluton, a belt of schist interbedded locally with fine-grained granofels and flanked on either side by Fitch Formation and characterized by large garnets is correlated with the uppermost part of the Warner Formation of New Hampshire. In the Ware subbelt, east of the Coys Hill pluton, the isoclinal synclines of Littleton lie between belts assigned on the State bedrock map to the Partridge Formation (Dl+Ops), some of which actually should be assigned to the Rangeley Formation. Schist in one syncline coincides with the Mount Pisgah Formation. In another, the schist coincides with gray schist formerly mapped as the upper part of the Hamilton Reservoir Formation. Two synclines contain a white quartz-feldspar gneiss (Dlf); another contains an orthopyroxene-biotite gneiss (Dlo). These units are considered to have igneous protoliths. In the Gardner 
subbelt to the east, Littleton overlying Paxton Formation in synclinal folds contains subordinate beds of calc-silicate rock. In the Wachusett Mountain subbelt, the gray schist of the Littleton shows little variety but locally contains lenses of calc-silicate rock. East of the Fitchburg Complex, the Littleton is at slightly lower metamorphic grade and contains andalusite and locally staurolite. Schist in a syncline at the southern edge of the Wachusett Mountain subbelt contains marble (Dlm). An extension of this belt along the boundary of the Southbridge and Gardner subbelts into Connecticut was formerly mapped as part of the Bigelow Brook Formation.

The Boylston Schist (SObo), 1,000 m thick, at the base of the sequence in the Nashua subbelt, west of the Clinton-Newbury fault, is a rusty-weathering sillimanite schist containing subordinate calcsilicate rock. In fault contact with and above the Boylston, the Tower Hill Quartzite, 0-130 m thick, consists of thin-bedded quartzite (St) and schist and phyllite (Sts). The Tower Hill is considered to be the base of a turbidite sequence that includes the overlying Oakdale and Worcester Formations. The Oakdale Formation (So), possibly as much as 6,000 m thick, consists of ankeritic and actinolitic metamorphosed siltstone and interbedded calcareous phyllite and schist. In bulk composition it is similar to much of the Paxton Formation, but it contains more pelitic lenses and is finer grained and lower grade. The Oakdale may lie in an isoclinal syncline, but it is interpreted to lie in stratigraphic position between the Tower Hill and the Worcester Formation. The Worcester Formation (DSw), 2,000-4,000 m thick, consists of gray and dark-gray interbedded phyllite, fine-grained metamorphosed graywacke, and rare calc-silicate rock and marble. Because the Worcester is conformable with the underlying Silurian Oakdale and yet lithologically resembles the Lower Devonian Littleton Formation, it is assigned a Silurian and Early Devonian age. Unconformably above the turbidite sequence is the Coal Mine Brook Formation ( $\mathbb{P} \mathrm{cm}), 50-330 \mathrm{~m}$ thick, exposed at two places in down-faulted blocks near Worcester. At one, the Coal Mine Brook Formation consists of carbonaceous slate and phyllite and a 2-m-thick bed of metamorphosed anthracite. Plant fossils indicate a Middle Pennsylvanian age. At the other, conglomerate beds are interbedded with phyllite.

At the bottom of the sequence in the Rockingham subbelt, west of the Clinton-Newbury fault, are the Vaughn Hills Quartzite (SOvh) and Reubens Hill Formation (SOrh). The Vaughn Hills, 0-200 m thick, consists of thin-bedded quartzite, interbedded locally rusty-weathering phyllite and schist, and minor beds of calc-silicate rock. The Vaughn Hills is possibly equivalent to the Tower Hill Quartzite of the Nashua subbelt. The Reubens Hill Formation, $600 \mathrm{~m}$ thick, a metamorphosed igneous unit consisting of amphibolite and hornblende-plagioclase gneiss, has no counterpart in the Nashua subbelt. A fault separates the Vaughn Hills and Reubens Hill from the overlying turbiditic sequence that consists of the Kittery Formation (SOk), the Eliot Formation (Se), and the Berwick Formation ( $\mathrm{Sb}, \mathrm{Sbs}$ ). These units, continuous with previously named units in southern Maine and New Hampshire, lithologically resemble the Oakdale and Paxton Formations in the subbelts to the west. The Kittery, $4,000 \mathrm{~m}$ thick, consists of thinbedded calcareous, commonly actinolitic metamorphosed siltstone, phyllite, and schist, and minor quartzite. The Eliot Formation, $300 \mathrm{~m}$ thick, consists of thin-bedded dark-gray to green slate and phyllite, commonly dolomitic, and metamorphosed siltstone, partly actinolitebearing. The Berwick Formation, 2,000 m thick, consists of thin- to thick-bedded calcareous, biotitic metamorphosed siltstone containing actinolite, or, at higher grade, diopside, minor garnet-mica schist, and feldspathic quartzite. Partly rusty-weathering schist and phyllite (Sbs) forms mappable lenses near East Pepperell and near Haverhill. Metamorphic grade increases from greenschist facies in the Kittery and Eliot Formation in the east to amphibolite facies in the Berwick Formation in the west, but metamorphic grade drops to greenschist facies again in the Oakdale Formation in the adjacent Nashua subbelt to the west. Unconformably on the older rocks, and correlated with the
Coal Mine Brook Formation, is the Harvard Conglomerate $(\mathbb{P h})$, estimated to be $100 \mathrm{~m}$ thick, consisting of polymict metamorphosed conglomerate interbedded with, and overlain by, gray, green, and purple chloritoid-bearing phyllite.

The pre-Pennsylvanian units in the Nashua and Rockingham subbelts were shown on the State bedrock map as Ordovician or Silurian, Silurian, and Early Devonian on the basis of correlation with lithologically similar rocks along strike in the Silurian fossiliferous sequence at Waterville, Maine, and the similarity of lithologies and sequences to those in the subbelts of the Merrimack belt to the west whose age assignments are based on continuity of lithologies to fossiliferous strata in New Hampshire and western Maine. Radiometric dating of the intrusive Newburyport Complex indicates that the Kittery Formation might be as old as Ordovician. Recent radiometric dating of intrusions into the Eliot and Berwick Formations in New Hampshire indicate that the stratified rocks in the sequences are Ordovician or older. Some workers in the region consider the sequences to be Late Proterozoic. The similarity of the sequences in the Nashua and Rockingham belts to sequences in the central and western part of the Merrimack belt raises questions that must be answered in future work.

\section{INTRODUCTION}

The Merrimack belt is here defined as the belt of Upper Ordovician, Silurian, Lower Devonian, and local Pennsylvanian strata east of the easternmost exposures of Lower Silurian Clough Quartzite and west of the Clinton-Newbury fault. The strata in the western part of the Merrimack belt closely resemble the Silurian and Lower Devonian strata of northwestern Maine (Moench and Boudette, 1970) and correlatives in central and southern New Hampshire (Hatch and others, 1983). Some firm correlations with these areas had been made at the time the Massachusetts bedrock geologic map (Zen and others, 1983; hereafter referred to as the State bedrock map) was compiled in 1980 , but subsequent mapping has modified what is shown and requires further discussion. The strata in the eastern part of the belt are along strike from and resemble the fossil-bearing Silurian strata of the Waterville area, Maine (Osberg, 1968), but specific correlations have not been established, partly because the stratigraphic position of the Waterville itself has been uncertain until recently (Osberg, 1980). In addition, some field interpretations of the contact relations of the Massabesic Gneiss Complex (Bothner and others, 1984) and some interpretations of the isotopic data on granitoid rocks in the Massabesic, as well as on plutons that intrude the sequence in the eastern part of the Merrimack belt (Zartman and Marvin, this vol., chap. J), suggest to some workers a pre-Silurian age for many of the strata of the belt (Lyons and others, 1982; Hatch and others, 1984; Bothner and others, 1984). Correlations within Massachusetts between the eastern and western parts of the belt are complicated by the fact that the western part is largely sillimanite grade or higher, whereas the eastern part is largely garnet grade or lower and also by the postmetamorphic faults of the Wekepeke system. Nevertheless, 
TABLE 1.-Distribution of Silurian-Devonian lithic units of the Massachusetts State bedrock map (Zen and others, 1983) in western subbelts of the Merrimack belt

\begin{tabular}{|c|c|c|c|c|}
\hline Age & Ware subbelt & Gardner subbelt & Southbridge subbelt & Wachusett Mountain subbel \\
\hline Devonian & $\begin{array}{l}\text { Littleton Formation (Dl) } \\
\text { Feldspar gneiss member } \\
\text { (Dlf) } \\
\text { Orthopyroxene gneiss } \\
\text { member (Dlo) }\end{array}$ & Littleton Formation (Dl) & Littleton Formation (D1) & $\begin{array}{l}\text { Littleton Formation (Dl) } \\
\text { Ribbon marble (Dlm) }\end{array}$ \\
\hline Silurian & $\begin{array}{l}\text { Fitch Formation } \\
\text { Sulfidic calc-silicate (Sfs) } \\
\text { Sulfidic schist (Sfss) }\end{array}$ & $\begin{array}{l}\text { Paxton Formation } \\
\text { Sulfidic schist (Spss) } \\
\text { Granofels (Sp) } \\
\text { Sulfidic schist and quartzite } \\
\text { (Spsq) }\end{array}$ & $\begin{array}{l}\text { Paxton Formation } \\
\text { Granofels (Sp) } \\
\text { Southbridge Member (Spso) } \\
\text { Bigelow Brook Member } \\
\text { (Spbs) } \\
\text { Calc-silicate (Spbc) }\end{array}$ & $\begin{array}{l}\text { Paxton Formation } \\
\text { Sulfidic schist (Spss) } \\
\text { Granofels (Sp) } \\
\text { Quartzite and rusty } \\
\text { schist (Spqr) }\end{array}$ \\
\hline
\end{tabular}

we find general correlations to be clear across the belt and to the north, with fossil-bearing rocks of Maine and New Hampshire. We find no compelling evidence for an important tectonostratigraphic boundary between the eastern and western parts of the belt.

The distribution of stratified rocks within the Merrimack belt, particularly the western part, is controlled by a very complex structural history that we are just beginning to understand. In brief, the outcrop pattern is now (1984) thought to have been produced by four episodes of folding and faulting and one of postmetamorphic faulting, as follows (Robinson, 1979): (1) Early nappes of 15- to $30-\mathrm{km}$ amplitude, originally overfolded from east to west, produced numerous repetitions of stratigraphy but few hinges that can be recognized on a local scale. (2) Complex backfolding, in which the nappe axial surfaces were refolded in major nappelike folds directed from west to east, resulted generally in intense flattening of the rock units. During the later parts of the backfolding stage, prominent east-west mineral lineations formed parallel to minor fold axes and to the internal fabric of mylonites in west-dipping semiductile shear zones. (3) North-northeast-trending recumbent folds in foliation formed parallel to a strong mineral lineation that merges with the lineation pattern of the gneiss domes to the west. (4) A series of broad northtrending arches and depressions in foliation formed across the belt. The most important of these are the Gardner anticline, which makes a foliation anticline out of most of the western part of the Merrimack belt, and the Wachusett syncline, which runs near the center of the Fitchburg plutons and separates a broad area dominated by east dips from the dominant west dips in the eastern part of the belt. (5) Postmetamorphic normal faults formed as part of the Wekepeke fault system in the region east of the Fitchburg plutons.

For convenience of description, the Merrimack belt has been divided into stratigraphic-tectonic subbelts (Robinson, 1979), each with Silurian-Devonian sequences of slightly different character or with a particular arrangement of stratigraphic and tectonic features (table 1, fig. 1). These subbelts are described very briefly here to assist the reader with the stratigraphic description that follows. The reader should here be aware that the horizontal arrangement of rock units in the correlation of map units (fig. 2) is generally based on their present surface distribution from west to east and not on their horizontal distribution at the time of deposition, because the original order may have been reversed by recumbent folding.

The westernmost subbelt, here called the Ware subbelt (figs. 1, $3 A$ ), is characterized by gray-weathering schists assigned to the Littleton Formation exposed in a series of isoclinal synclines. The Ware subbelt is defined to include all those Silurian-Devonian strata that lie east of the west margin of the Hardwick pluton, or a line extended southward from it, and west of the westernmost exposures of the Paxton Formation, units Spsq and $\mathrm{Sp}$ (fig. $3 A$ ). Sulfidic calc-silicate rocks basal to the gray schist are here assigned to the Silurian Fitch Formation (Sfs). Since the final map compilation, several localities have been found that suggest that rocks assigned to the Littleton Formation (Dl) or the Partridge Formation (Op) might be better assigned to the Silurian Rangeley Formation, on the basis of similarity to rocks in the central New Hampshire sequence (Hatch and others, 1983). The general scarcity of Silurian strata in the Ware subbelt may be ascribed to a pre-Devonian unconformity. In southern Massachusetts, the Ware subbelt includes strata mapped as the Mount Pisgah Formation and as gray-weathering schists in the upper schist member of the Hamilton Reservoir Formation by Seiders (1976) and Pomeroy (1977).

The next subbelt to the east, the Gardner subbelt (figs. $1,3 A$ ), is marked by the rather abrupt appearance of thick Silurian strata in the form of members of the Paxton Formation (Sp), dominated by calcareous grano- 


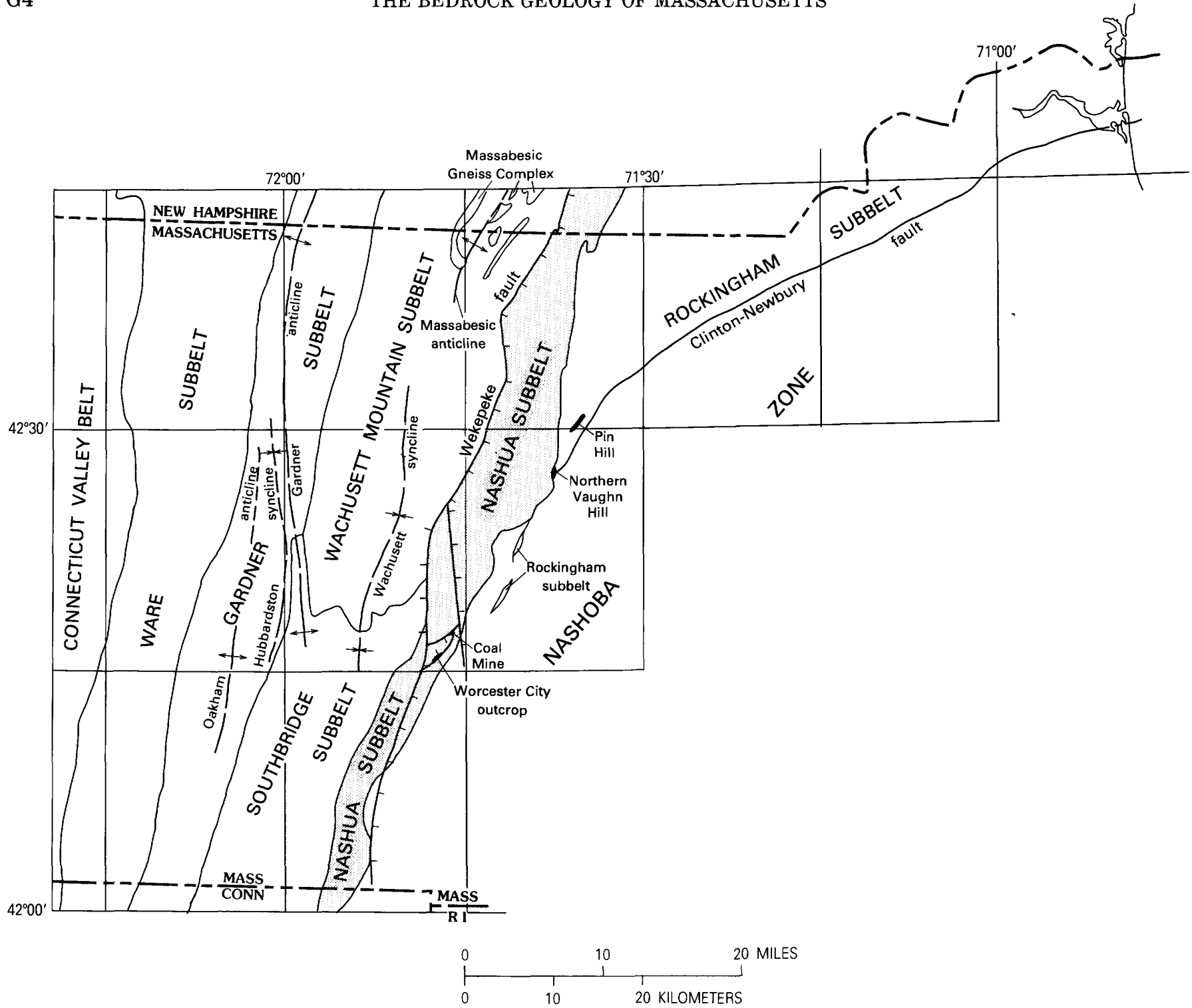

Figure 1.-Major divisions and structural features of the Merrimack belt and localities of Pennsylvanian strata.

fels, below the Devonian schists. The west margin of the subbelt is defined to include exposures of all members of the Paxton Formation. The east margin of the subbelt in northern Massachusetts is taken along the trace of a probable Mesozoic fault and its southern extension and in southern Massachusetts along the west margin of a belt of gray schist that is exposed in the center of the Gardner anticline (figs. 1, 3A). In the northern part of Massachusetts, the Gardner subbelt includes strata dipping both west and east on opposite limbs of the Gardner anticline. In southern Massachusetts, the Gardner subbelt includes some strata mapped here and by Emerson (1917) as part of the Paxton Formation but mapped as parts of the Bigelow Brook and Hamilton Reservoir Formations by Seiders (1976), Pomeroy (1975, 1977), Moore (1978), and
Pease (1972). Our detailed and reconnaissance mapping has shown that calcareous granofels of the Paxton Formation, previously mapped by Pease (1972) as part of the Bigelow Brook Formation, can be traced around the north end of the Oakham anticline directly into rocks previously mapped by Seiders as part of the upper gneiss member of the Hamilton Reservoir Formation.

The next subbelt, the Southbridge subbelt (figs. 1, $3 A$ ), is a broad expanse of rather gently dipping strata of the Paxton and Littleton Formations; it represents an eastern extension of the Gardner subbelt in southern Massachusetts and is bounded on the east by the west margin of the Oakdale Formation. The Littleton Formation is confined to a single complexly refolded isocline that extends from the northeast corner of the subbelt 
Worcester Basin

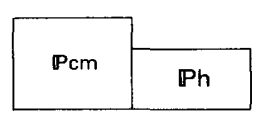

Intrusive Rocks
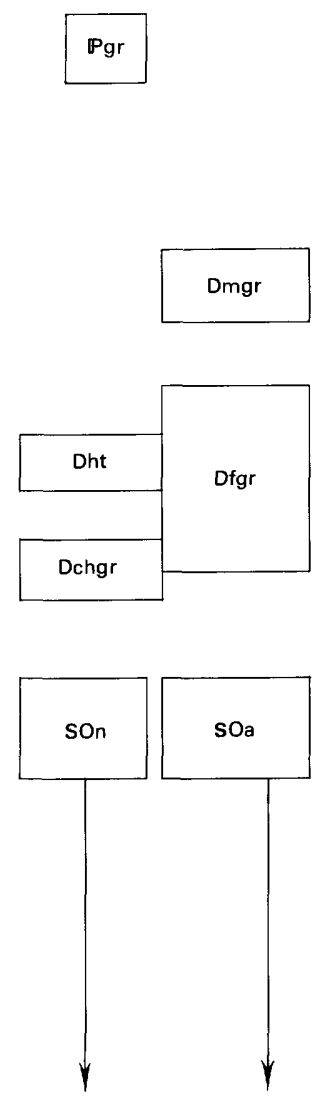

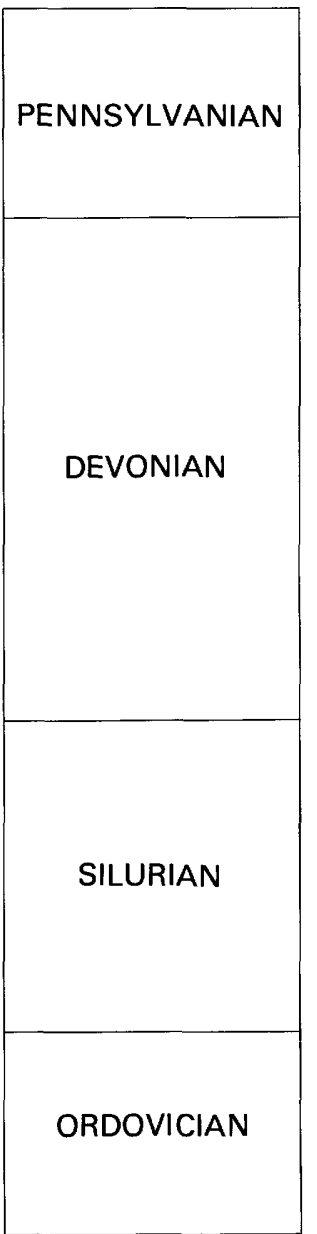

EXPLA NATION

Stratified rocks

\begin{tabular}{|c|c|}
\hline Pcm & Coal Mine Brook Formation (Pennsylvanian) \\
\hline $\mathrm{Ph}$ & Harvard Conglomerate (Pennsylvanian) \\
\hline $\begin{array}{l}\text { DI, Dlo, } \\
\text { DIf, DIm }\end{array}$ & Littleton Formation (Lower Devonian) \\
\hline $\mathrm{DI}+$ Ops & $\begin{array}{l}\text { Littleton Formation (Lower Devonian) and } \\
\text { Partridge Formation (Middle Ordovician), } \\
\text { undivided }\end{array}$ \\
\hline DSw & $\begin{array}{l}\text { Worcester Formation (Lower Devonian } \\
\text { and Silurian) }\end{array}$ \\
\hline $\begin{array}{l}\text { Sfs, Sfss } \\
\text { Sp, Spss, } \\
\text { Spa, Spsq, } \\
\text { Spqr, Spbs, } \\
\text { Spso, Spbc }\end{array}$ & $\begin{array}{l}\text { Fitch Formation (Upper Silurian) } \\
\text { Paxton Formation (Silurian) }\end{array}$ \\
\hline So & Oakdale Formation (Silurian) \\
\hline Sb, Sbs & Berwick Formation (Silurian) \\
\hline $\mathrm{Se}$ & Eliot Formation (Silurian) \\
\hline $\begin{array}{l}\text { St, Sts } \\
\text { SOvh }\end{array}$ & $\begin{array}{l}\text { Tower Hill Quartzite (Silurian) } \\
\text { Vaughn Hills Quartzite (Silurian or } \\
\text { Ordovician) }\end{array}$ \\
\hline
\end{tabular}

SOk Kittery Formation (Silurian or Ordovician)

SOrh Reubens Hill Formation (Silurian or Ordovician)

SObo Boylston Schist (Silurian or Ordovician)

Intrusive rocks

Pgr Biotite granite (Pennsylvanian)

Dmgr Muscovite-biotite granite at Millstone Hill (Lower Devonian)

Dfgr Fitchburg Complex (Lower Devonian or younger)

Dht Hardwick Tonalite (Lower Devonian)

Dchgr Coys Hill Porphyritic Granite Gneiss (Lower Devonian)

SOn Newburyport Complex (Silurian and Ordovician)

SOa Ayer Granite (Lower Silurian and Upper Ordovician?)

FIGURE 2.-Correlation of sedimentary and volcanic rocks of the Merrimack belt and their metamorphic equivalents and rocks intrusive into them that are referred to in text (modified from Zen and others, 1983). 


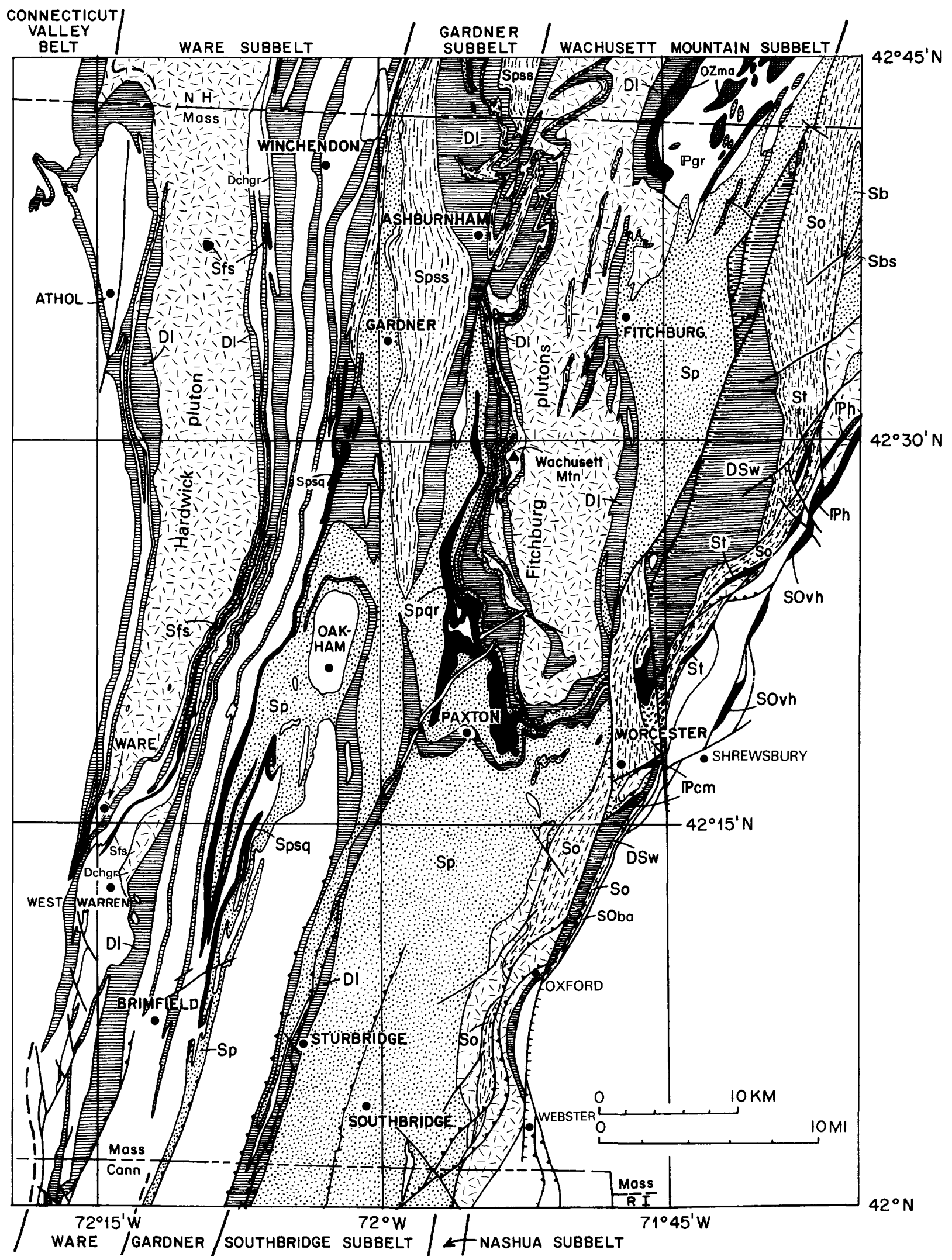

FIGURE 3A.-Geology of the western part of the Merrimack belt. Pre-Silurian rocks and Paleozoic intrusive rocks are labeled only if discussed in text. 


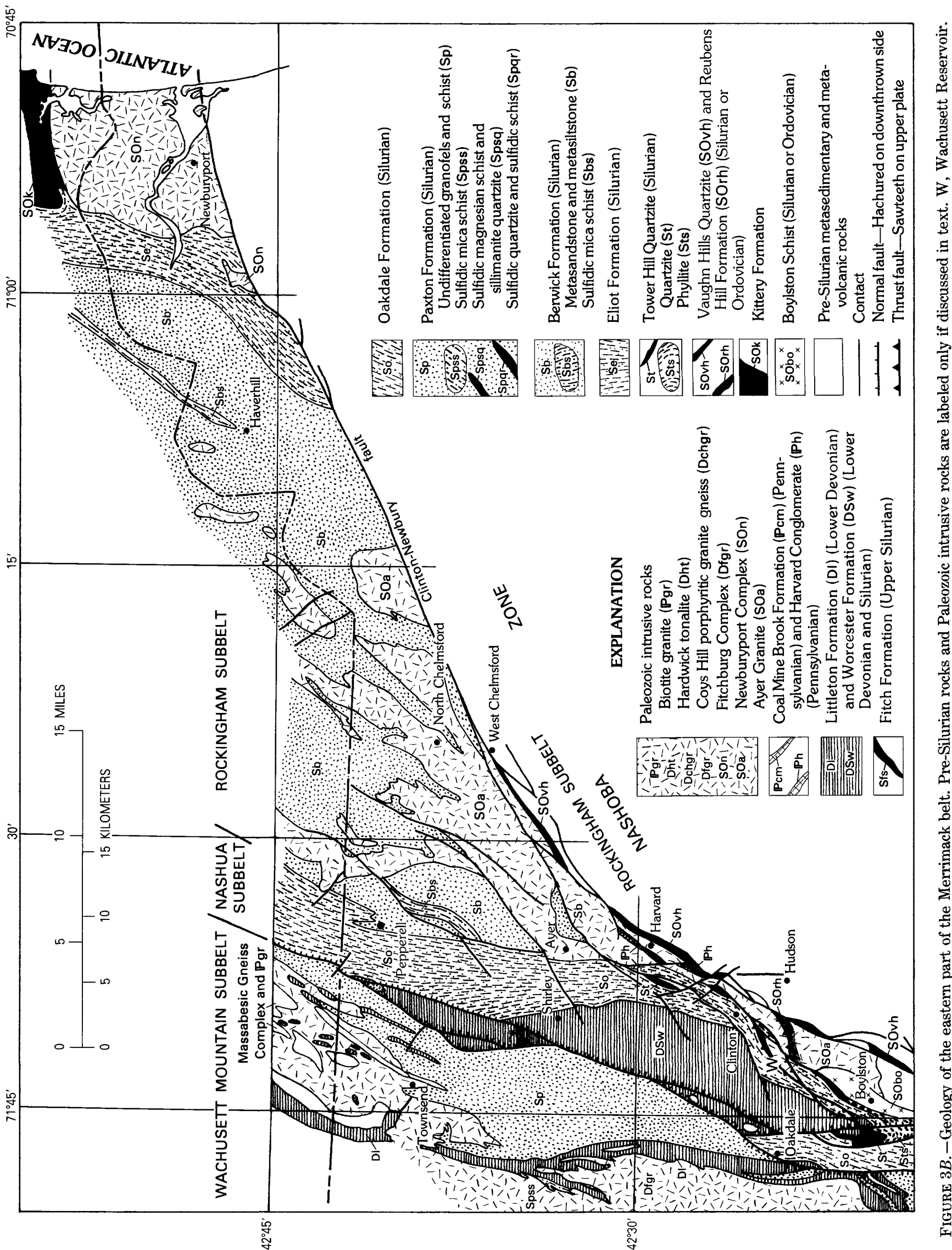


into the Gardner subbelt to the west. In southernmost Massachusetts, the Paxton Formation is divided into a western Bigelow Brook Member and an eastern Southbridge Member, on the basis of earlier work along the Connecticut State line (Barosh, 1974; Moore, 1978), following the usage of Pease (1972) in northern Connecticut.

The Wachusett Mountain subbelt (figs. 1, 3A), east of the Gardner subbelt and north of the Southbridge subbelt, contains strata well out on the east limb of the Gardner anticline and close beneath or intruded by the Fitchburg plutons. It is bounded on the west by a probable Mesozoic fault or its southern extension and on the east by the Wekepeke normal fault system of probable Mesozoic age. In the eastern frontal regions of the backfolded nappes, the strata of this subbelt are believed to be structurally higher than most of the rocks of the Gardner and Southbridge subbelts. If the folding were removed, we believe that these strata would occupy an intermediate position between the strata of the Ware and Gardner subbelts (see cross section $D-D^{\prime}$ of the State bedrock map).

East of the Wachusett Mountain and Southbridge subbelts is the narrow Nashua subbelt (fig. 3), which contains phyllite and metamorphosed calcareous metasiltstone of the Worcester (DSw) and Oakdale (So) Formations overlying an apparently basal phyllite and quartzite assemblage consisting of the Tower Hill Quartzite (St, Sts) and possibly the Boylston Schist (SObo). These rocks lie in a north-trending structural and metamorphic trough called the Nashua synclinal by Crosby (1880). The subbelt narrows to the south between the Southbridge subbelt and the Nashoba zone and extends into Connecticut south of Webster. Although the bulk of the strata are considered to be Silurian to possibly Devonian in age, Pennsylvanian rocks of the Coal Mine Brook Formation ( $P \mathrm{~cm}$ ) (Goldsmith and others, 1982) lie in fault-bounded blocks with older rocks at Worcester. The rocks in the Nashua subbelt are believed to occupy the down-faulted trough of an east-facing recumbent syncline (G.R. Robinson, 1981, p. 59-62), a major element of the backfolded nappe system mentioned above. This syncline may correspond structurally to the synclinal core of the postulated Colchester nappe (Dixon and Lundgren, 1968) in eastern Connecticut. The structural trough coincides with a metamorphic trough of lower grade than the surrounding subbelts (Thompson and Norton, 1968).

The Rockingham subbelt (fig. $3 B$ ), containing strata of the Merrimack Group, forms a northward-widening wedge between the Nashua subbelt and the Nashoba zone. Calcareous metasiltstone, phyllite, metasandstone, and quartzite of the Kittery (SOk), Eliot (Se), and Berwick (Sb, Sbs) Formations forming the Merrimack
Group are shown as Ordovician to Silurian on the State bedrock map, but they may be entirely Ordovician or older (Bothner and others, 1984). The strata for the most part are similar in composition and bedding style to the Paxton and Oakdale Formations of the Nashua trough, although at slightly higher metamorphic grade than the Oakdale. The boundary between the Rockingham subbelt and the Nashua subbelt is the contact between the Oakdale and the Berwick Formations. It is marked primarily by a contrast in metamorphic grade but also by a difference in expression of relict bedding. The bedding characteristics probably reflect premetamorphic differences in grain size at the time of deposition. In addition, the Merrimack Group in the Rockingham subbelt contains mappable zones of rusty-weathering schist and phyllite much like the Paxton Formation to the west in the Wachusett Mountain subbelt. However, rusty schists and phyllites are not found in the rocks of the intervening Nashua subbelt.

\section{WARE, GARDNER, SOUTHBRIDGE, AND WACHUSETT MOUNTAIN SUBBELTS}

In this section, rocks presumed to be Silurian (the Fitch and Paxton Formations) are discussed first, in generally west to east order, followed by discussion of rocks presumed to be Devonian (the Littleton Formation). Alternative interpretations and correlations are given, including some that appear to be more likely now than at the time the map was compiled. The stratigraphy of these rocks is impossible to discuss without at least a rudimentary description of the structural geology, but the emphasis in this chapter is on the stratigraphy. In discussing the distribution of units, repeated references are made to figures 4,5 , and 6 .

\section{FITCH FORMATION (Sfs, Sfss)}

The dominant rock of the Fitch Formation (Sfs) in the Merrimack belt is in outcrop a slabby, rusty-weathering quartz-plagioclase-graphite rock. Biotite is scarce or absent, and broken foliation surfaces show abundant graphite platelets. The rusty-weathering character is due to the presence of pyrrhotite, which makes up 5-6 percent of the rock in some beds. Mineralogically, the rock is a calc-silicate granofels (Field, 1975, table 4) usually containing 20-60 percent quartz, 35-55 percent calcic plagioclase $\left(\mathrm{An}_{65-80}\right), 3-35$ percent diopside, 1-2 percent sphene, 0-2 percent graphite, and local actinolite, calcite, scapolite, clinozoisite, and biotite. Careful examination shows this unit to be well bedded, but bedding is usually obscured by the rusty weathering and the way the rock breaks into rectangular slabs. A 


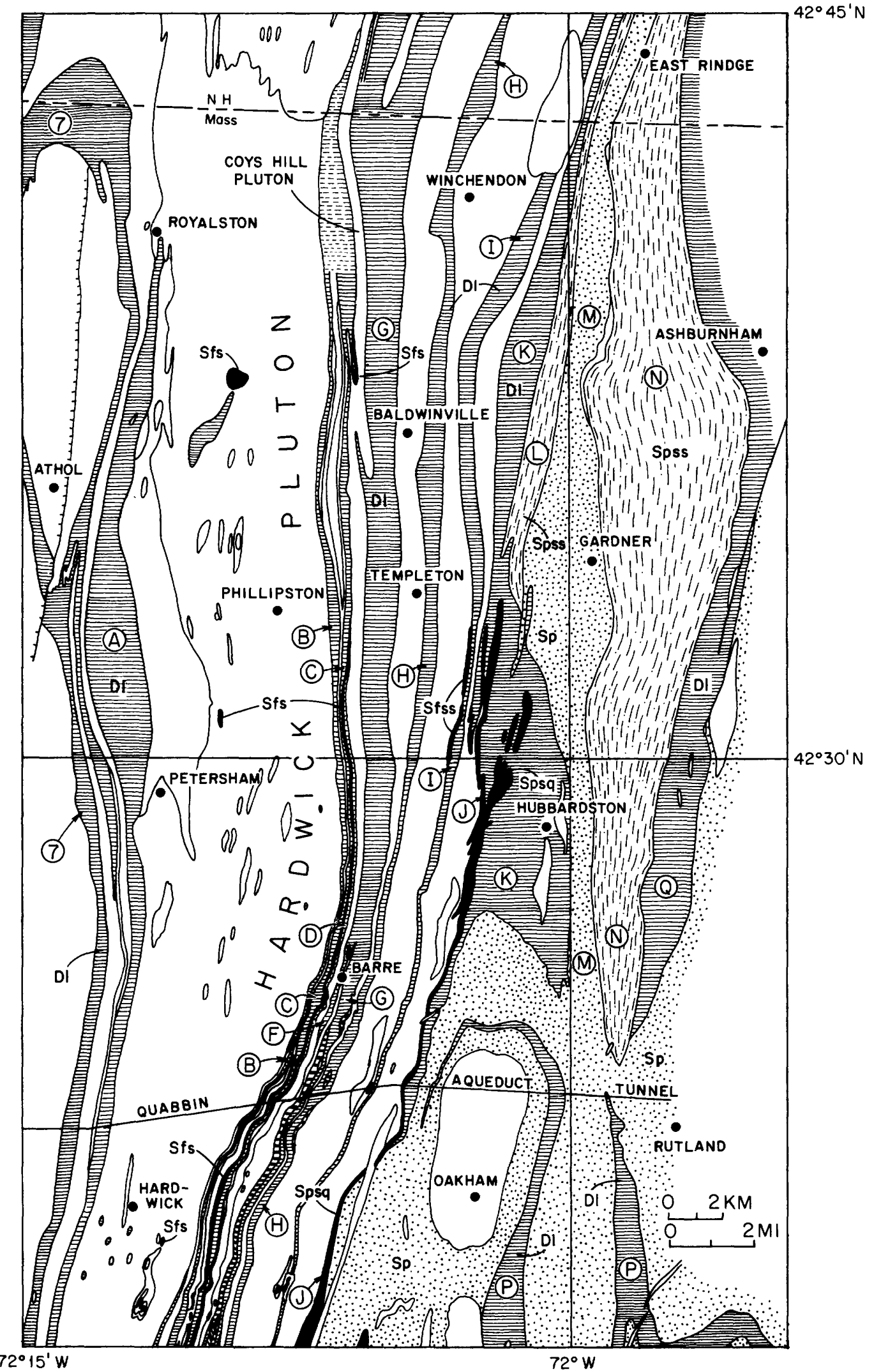

FIGURE 4.-Geology of the Gardner-Athol area. Most Paleozoic intrusive rocks and pre-Silurian rocks are not labeled. Dl, Littleton Formation; Sfs, Sfss, Fitch Formation; Sp, Spsq, Spss, Paxton Formation. Circled letters and numbers are discussed in text. 


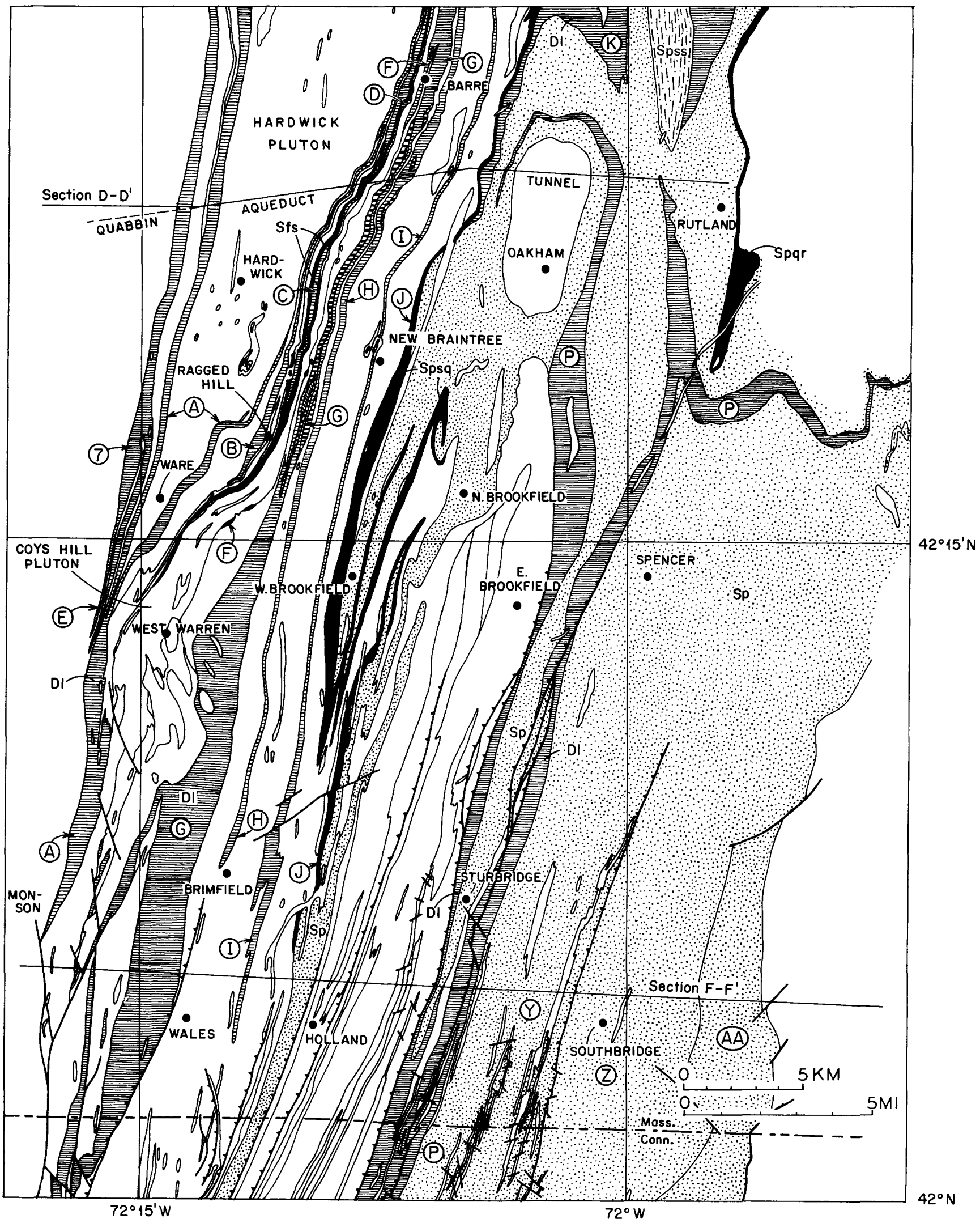

FigURE 5.-Geology of the Ware-Southbridge area. Paleozoic intrusive rocks (except Coys Hill and Hardwick plutons) and pre-Silurian rocks are not labeled. Dl, Littleton Formation; Sfs, Fitch Formation; Sp, Spqr, Spsq, Spss, Paxton Formation. Circled letters and numbers are discussed in text. Cross section lines $D-D^{\prime}$ and $F-F^{\prime \prime}$ are from State bedrock map (Zen and others, 1983). 


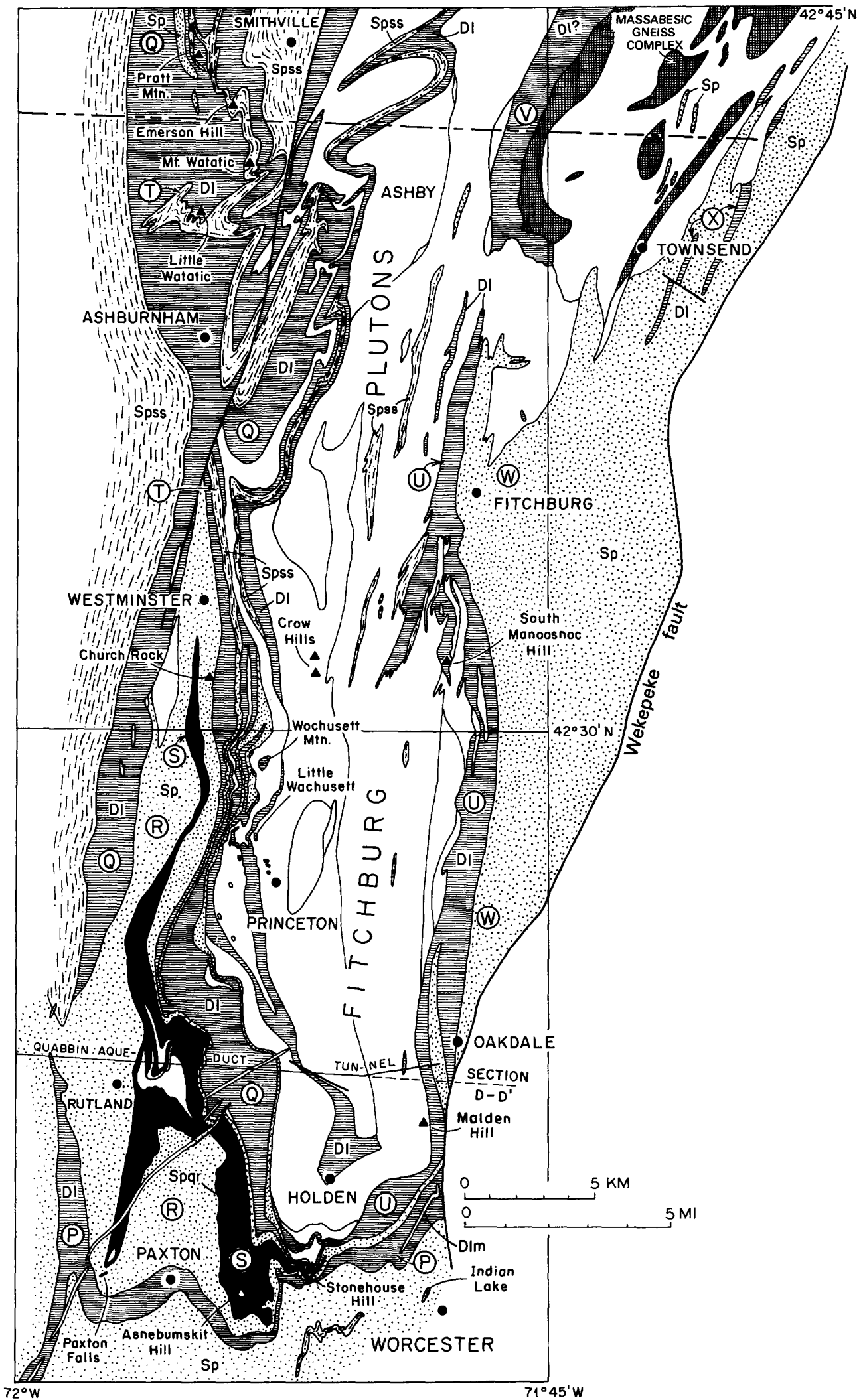

FIGURE 6. - Geology of the area of the Fitchburg plutons. Paleozoic intrusive rocks and pre-Silurian rocks are not labeled. Dl, Dl?, Littleton Formation; Dlm, marble in Littleton Formation; Sp, Spqr, Spss, Paxton Formation. Circled letters are discussed in text. Cross section line $D-D^{\prime}$ is from State bedrock map (Zen and others, 1983). 
subordinate rock type in the Fitch Formation is rustyweathering sillimanite-graphite-pyrrhotite-biotite schist (Sfss), which is very similar to the schist of the sulfidic schist-quartzite unit (Spsq) of the Paxton Formation. The Fitch sulfidic schist is locally interbedded with the Fitch calc-silicate and dominates the two lenses (labeled Sfss on fig. 4) near the eastern edge of the Ware subbelt.

Contacts of the Fitch Formation with adjacent units are poorly exposed but generally are sharp. However, in large exposures on the northeast side of Ragged Hill (Robinson and others, 1982a, Stop 5), slightly rusty interbedded schists and quartzites lie between Fitch calc-silicates and gray "big-garnet" schists of the Littleton.

Field (1975) estimated the thickness of the Fitch Formation in the Ware area to be $15 \mathrm{~m}$. The wider belt in the southern part of the area is believed to have been caused by repetition of the unit thrice by isoclinal folding.

The mineralogy of the Fitch Formation suggests that its protoliths were calcareous and dolomitic shales and siltstones and locally interbedded aluminous shales. The abundance of graphite and pyrrhotite suggests deposition in a reducing environment of poor circulation with preservation of organic matter and much activity by sulfur-reducing bacteria.

The rocks assigned to the Fitch Formation in the Merrimack belt all lie within the Ware subbelt, and most are very close to the Coys Hill Pluton. As early as 1972 Robinson realized that the most distinctive rock type, the rusty-weathering granofels, or quartzite, corresponds exactly to the distinctive lithology of both the "rusty quartzite member" (Dlr) of the Littleton Formation in the Monadnock quadrangle, New Hampshire (Fowler-Billings, 1949), and the Francestown Member of the Littleton Formation in the Peterborough quadrangle, New Hampshire (Greene, 1970). The rusty granofels is also identical to rocks assigned to the Fitch Formation at Gee Mill in the Lovewell Mountain quadrangle, New Hampshire, which overlie Clough Quartzite (Heald, 1950; Thompson and others, 1968; Dean, 1976). On this basis, Field (1975) assigned the rocks in Massachusetts to the Fitch Formation with separate formational status, rather than to a member of the Littleton Formation. Now that the Francestown Formation has been assigned formation status in New Hampshire (Nielson, 1981; Hatch and others, 1983; Thompson, 1983), this rusty granofels in Massachusetts could as well be assigned to the Francestown as to the Fitch. However, the correlation with Fitch is also valid and is emphasized by the occurrence of similar sulfidic rocks in the Fitch of the Connecticut Valley belt in Massachusetts (Robinson, 1963, p. 62; Hatch and others, 1988).

The most continuous outcrops of the Fitch Formation are in two extremely narrow belts (fig. 5 , area $\mathrm{C}$ ) west of the Coys Hill pluton in the Ware quadrangle (Field, 1975). These two belts merge southward into a single belt near Ragged Hill, suggesting that the Littleton Formation between them is an isoclinal syncline. The orily other good exposures on the west side of the Coys Hill pluton are southwest of Barre (fig. 4, area C) and in a large railroad cut northwest of Baldwinville (Robinson, unpub. data). Three widely separated inclusions of Fitch Formation are present in the Hardwick pluton. Two lenses of Fitch Formation lie along the east contact of the Coys Hill pluton (fig. 5, area F), northwest of Warren, between it and the Partridge Formation, and two other lenses are along Littleton-Partridge contacts near the east edge of the Ware subbelt (fig. 4, area I).

\section{PAXTON FORMATION}

The name Paxton Formation is used here to describe all the stratified rocks of presumed Silurian age exposed in the Gardner, Southbridge, and Wachusett Mountain subbelts. The name Paxton Formation is a modification and expansion of the name Paxton Quartz Schist used by Emerson (1917) to describe all areas in central Massachusetts dominated by gray-weathering slabby quartzplagioclase-biotite granofels. The formation is named for the town of Paxton, Mass., where hundreds of stone walls are built of this slabby rock. In December 1976, Robinson and Tucker (Robinson and others, 1982a, Stop 12A) rediscovered the large cascade exposure on the brook draining Eames Pond in the western part of Paxton, which probably was Emerson's type locality (Paxton Falls, fig. 6). In the future, as correlations with fossil-bearing strata in Maine improve, we imagine that various members will achieve formational status, and the name Paxton will either be dropped or be restricted to granofels equivalent to that exposed in Paxton.

In the following section, we have attempted to describe the various members in what we think is the correct stratigraphic order. Where rock units are considered roughly correlative but of different facies, they are discussed in geographic order from west to east without regard to original arrangement before folding. In many examples, the true stratigraphic facing direction and order are unknown, and evidence of complex recumbent folding makes several choices possible.

\section{SULFIDIC SCHIST AND SILLIMANITE QUARTZITE (Spsq)}

This unit forms a nearly continuous, contorted belt along the west margin of the Gardner subbelt (figs. 4, 5, area J) from just south of Route 2 , in the northern part of the State, to well south of the Massachusetts Turnpike in the southern part. Since publication of the State bedrock map, Spsq has been traced several kilometers 
into Connecticut (Berry, 1985). The unit was first defined by Field (1975) as the white schist member of the Paxton Formation of the Ware area and was mapped thence northward through Barre (Tucker, 1977) and into Templeton (H.B. Stoddart, written commun., 1978; D.E. Klepacki, written commun., 1978). In southern Massachusetts, Spsq was lumped with the upper schist member of the Hamilton Reservoir Formation (Seiders, 1976; Pomeroy, 1977) or mapped as schist within the upper gneiss member of the Hamilton Reservoir Formation. The unit changes very slightly in character from the north, where it contains some muscovite in the sillimanite-muscovite-K-feldspar zone, to the south, where the only mica is biotite in the sillimanite-garnetcordierite zone.

The sulfidic schist and quartzite unit tends to form large rounded to overhanging outcrops and holds up a series of relatively high ridges. The surface is extremely rusty, is commonly yellow orange, and generally has coatings of secondary limonite as much as $1 \mathrm{~cm}$ thick. Accumulations of secondary sulfates are common under overhangs. Soils in the vicinity commonly have an orange-red color, and sulfates in surface water have led to such names as "Alum Pond" and "Little Alum Pond." Smooth upper surfaces of outcrops commonly have widely spaced, rounded pits 3 to $8 \mathrm{~cm}$ across within which shiny pyrite is visible. Despite the robust appearance of the outcrops as a whole, the upper surfaces are generally friable, and collecting fresh specimens is extremely difficult. Beneath the crust of secondary limonite, the weathered rock commonly appears white due to the abundance of quartz, feldspar, sillimanite, and white mica and the absence of any dark mineral except discrete flakes of graphite. This characteristic led to the name "white schist member." However, really fresh rock is bluish gray. Interbedded with the typical schist is feldspathic, micaceous, and sillimanitic quartzite that forms hard, tough beds 5 to $8 \mathrm{~cm}$ thick, which weather into slabs. The quartzite is probably responsible for the fact that the unit forms prominent topographic ridges.

First encounters with this unit were in the sillimanitegarnet-cordierite zone many miles from the nearest stable occurrence of muscovite (Field, 1975). The abundance of what appeared to be white mica in the unit, as well as the sulfides, suggested that it might be a zone of secondary hydrothermal alteration. However, optical observations of the white mica consistently showed a $2 \mathrm{~V}$ close to $0^{\circ}$, rather than the $30^{\circ}$ characteristic of muscovite, and thus led to electron probe analyses and to determination that the white mica is pure $\mathrm{Mg}$-biotite (Field, 1975; Tracy and others, 1976; Robinson and Tracy, 1977; Robinson and others, 1982b).

Thin sections of the unit (Field, 1975, table 6; Tucker, 1977, table 4) show that it consists of $40-75$ percent quartz, 2-40 percent andesine, 6-30 percent orthoclase or microcline, 2-10 percent sillimanite, 1-8 percent magnesian biotite, 0-3 percent magnesian cordierite, tr (trace) -4 percent graphite, $0-3$ percent pyrite, tr-1 percent pyrrhotite, and tr-1 percent rutile. Muscovite occurs near the northern end of the outcrop belt. Locally, the sillimanite has the form of pseudomorphs after andalusite. The biotites range from very pale reddishbrown iron-bearing varieties to colorless $\mathrm{Mg}$ end members and have $\mathrm{Mg} /(\mathrm{Mg}+\mathrm{Fe})$ ratios between 0.75 and 0.999 (0.04 weight percent $\mathrm{FeO}$ ). Even the magnesian biotites have octahedral $\mathrm{Al}$ and as much as $0.074 \mathrm{Ti}$ per 11 oxygens, and thus they are not properly phlogopites. The cordierites, present only in the schist and not the quartzite, are charged with graphite and appear as black to bluish lumps. Some are essentially pure $\mathrm{Mg}$ end members with 0.00 weight percent $\mathrm{FeO}$ and only 0.08 weight percent $\mathrm{MnO}$. Even where charged with detrital zircons, these cordierites lack pleochroic halos, presumably because of lack of iron to be oxidized by alpha bombardment. The pure magnesian cordierites contain approximately 2 weight percent $\mathrm{H}_{2} \mathrm{~S}$, due apparently to the high sulfur fugacity of the pyrite-pyrrhotite assemblage in which they formed.

The key to understanding the mineralogy and ultimately the genesis of these rocks lies in the graphiteoxide-sulfide assemblages (for details see Robinson and Tracy, 1977; Robinson and others, 1982b). Specimens containing iron-bearing pale red-brown biotite and ironbearing cordierite invariably contain the assemblage graphite-rutile-pyrrhotite. In these bulk compositions, original pyrite is believed to have reacted with the $\mathrm{Fe}$ component of the hydrous silicates and graphite to produce pyrrhotite plus $\mathrm{Mg}$-richer silicates plus $\mathrm{H}_{2} \mathrm{O}$ plus $\mathrm{CO}_{2}$ until the pyrite was exhausted. Specimens containing the nearly pure magnesian biotite and cordierite contain the assemblage graphite-rutile-pyritepyrrhotite. In these bulk compositions, originally richer in sulfide and poorer in iron-bearing silicate, the same reaction proceeded until the $\mathrm{Fe}$ component of the silicates was exhausted, with some pyrite still remaining. In one sample, from the lower grade north end of the belt, the sense of this reaction is shown by pyrrhotite rims growing around euhedral pyrite cubes. Robinson and others (1982b) showed that the primary deposition of such a unit requires not only reducing conditions and sulfur-reducing bacteria but slow deposition and a high proportion of fine detrital grains of Fe-bearing silicate capable of reacting with bacterially produced $\mathrm{H}_{2} \mathrm{~S}$ in an open-system sedimentary environment. Sulfur-isotope data (Tracy and Rye, 1981) on several outcrops show very light sulfur values with $\delta^{34} \mathrm{~S}$ ranging from -25 to -29 , identical to values obtained from modern muds in highly reduced deep zones of the Black Sea. 
In regions where the unit is relatively rich in pyrrhotite, contacts have been mapped by using a hand-carried magnetometer. The unit is characterized by extremely large-amplitude variations, whereas adjacent units are magnetically flat. This method was particularly successful in mapping the northern part of the Barre quadrangle, where magnetic data show that the unit forms several synclinal outliers capping the summits of hills (D.E. Klepacki, written commun., 1978). Elsewhere, where pyrite predominates over pyrrhotite, the unit is not detectable magnetically. As stated above, this unit was earlier mapped as part of the upper schist member of the Hamilton Reservoir Formation (Seiders, 1976; Pomeroy, 1977), which is now mainly included in the Partridge Formation. In the field the sulfidic schist and quartzite of the Paxton is distinguished from pyrrhotite schist of the Partridge Formation by the extremely pale Mg-rich biotite as compared to dark red-brown biotite in the Partridge, by the local presence of pyrite, by the abundance of rutile, and by the total absence of ilmenite and garnet, which characterize the Partridge. The mineralogy of the Partridge suggests that it contained a much higher proportion of detrital Fe-bearing silicate grains that were too coarse or too rapidly deposited to permit thorough reaction with biologically produced $\mathrm{H}_{2} \mathrm{~S}$.

The western contact of the sulfidic schist and quartzite unit with the Partridge Formation is nowhere exposed within an interval of $100 \mathrm{ft}(30 \mathrm{~m})$ but is presumed to be an unconformity on the basis of regional relations and the apparent lack of rock types correlative with the lower part of the Silurian section in Maine and central New Hampshire (Hatch and others, 1983). The maximum thickness of the unit is probably $30-60 \mathrm{~m}$ in south-central Massachusetts, where it lies between the Partridge Formation and the granofels member of the Paxton. The unit appears to pinch out beneath younger units to the north and to the south.

Those who have seen the units agree that the sulfidic schist and quartzite unit of the Paxton Formation in Massachusetts is a perfect lithic correlative of the Smalls Falls Formation of northwestern Maine (Moench and Boudette, 1970). Similarities include the magnesian biotite and cordierite (Guidotti and others, 1975, 1977), the abundant rutile and pyrrhotite, the andalusite grains or pseudomorphs, the abundance of quartzite beds, and the position in the sequence below a major unit of gray granulites and calc-silicates, which is the Madrid Formation in Maine (Moench, 1971) and the granofels member of the Paxton in Massachusetts.

In summary, the sulfidic schist and quartzite unit appears to be locally the basal Silurian unit in central Massachusetts. Its lithic character suggests that it consisted of clean, fine quartz sand mixed with fine-grained detrital clay and organic matter, which was slowly deposited in a closed marine environment that permitted extensive reaction with biogenically produced $\mathrm{H}_{2} \mathrm{~S}$.

\section{SULFIDIC QUARTZITE AND RUSTY SCHIST (Spqr)}

This unit forms a single continuous belt of strata within the Wachusett Mountain subbelt (fig. 6, area S) and has not been specifically identified anywhere else. The belt is considered to form the axial zone of a major, presently northeast-directed, recumbent anticline, in which apparently younger rocks of the granofels member are both above (right side up) and below (upside down). The belt has been refolded about the Wachusett syncline and several other late folds to form a crude C-shaped outcrop pattern open to the northeast. The ends of the belt, at the points of the " $\mathrm{C}$ " northwest of Wachusett Mountain and southeast of the Fitchburg plutons, are interpreted as hinges of the postulated recumbent fold. The unit is generally not well exposed, but where thickest it does form the high ridges of Asnebumskit Hill (1,395 ft) (425 $\mathrm{m}$ ), and several hills to the north, as well as the top of a cliff on the west face of Stonehouse Hill. The unit occurs entirely within the sillimanite-muscovite zone of Acadian regional metamorphism.

Although the schists of this unit are graphitic, sulfidic, and rusty weathering, they do not apparently contain the extremely $\mathrm{Mg}$-rich biotite and cordierite typical of the sulfidic schist and quartzite unit (Spsq) described above. However, lack of detailed petrographic work and lower metamorphic grade leaves this question somewhat open. In small outcrops and manmade excavations, in particular in a large quarry $3 \mathrm{mi}(5 \mathrm{~km})$ north of Asnebumskit Hill, mica schist is found on most broken surfaces. Only in well-weathered, glacially smoothed outcrops and in slabby float is it apparent that the unit is dominated by fine-grained to locally grit-sized feldspathic quartzite, with subordinate mica schist beds. No other rock in the western part of the Merrimack belt comes as close to resembling the Clough Quartzite of the Connecticut Valley belt.

In the northernmost outcrop in the belt, contact relations with the structurally underlying granofels member are well exposed. Here the typical quartzites of the unit are separated from the granofels by $3-4 \mathrm{~m}$ of sulfidic mica schist.

On the basis of our present structural and stratigraphic interpretation, the quartzite and rusty schist unit (Spqr) is probably a facies equivalent of the sulfidic schist and quartzite unit (Spsq), and the nappe in which it lies may be rooted at the west edge of the Gardner subbelt. Farther afield, the unit is quite similar to an unnamed rusty quartzite exposed on the bank of the Kennebec River in Maine (Osberg, 1980, Stop 3). Osberg 
suggested that this unnamed unit may be equivalent to the Perry Mountain Formation, which overlies the Sangerville Formation and is overlain successively by the sulfidic schists of the Parkman Hill Formation (Smalls Falls) and the calcareous granofels of the Fall Brook Formation (Madrid). Thus, indications are that the sulfidic quartzite and rusty schist unit may be broadly equivalent to the upper part of the Perry Mountain Formation and the Smalls Falls Formation in Maine.

Because the base of the unit is not exposed, only an estimate of a minimum thickness of $250 \mathrm{~m}$ can be given. The depositional environment appears to have been similar to that of the sulfidic schist and quartzite unit (Spsq), except that conditions for fixation of organic sulfur were less ideal.

\section{GRANOFELS MEMBER (Sp)}

The granofels member ( $\mathrm{Sp}$ ) contains the bulk of the Paxton Formation and its most characteristic rock types. The granofels occurs extensively in the Gardner and Wachusett Mountain subbelts (fig. 4, area M; fig. 5, area Y; fig. 6, areas $\mathrm{R}, \mathrm{W}$ ) and dominates the Southbridge subbelt. The outcrop pattern is crucial to major structural interpretations, and the unit appears to be lithically equivalent to the less metamorphosed Oakdale Formation in the Nashua subbelt to the east (fig. 7). Although the granofels member is recognized to have some facies variations, the distribution of these facies has not generally been mapped in detail.

The most characteristic rock type of the granofels member is well-layered slabby-weathering purple-gray quartz-plagioclase-biotite granofels with bedding thickness ranging from $2 \mathrm{~cm}$ to about $30 \mathrm{~cm}$ (Field, 1975; Tucker, 1977). The plagioclase is usually labradorite or bytownite. Commonly interbedded with the biotite granofels are beds 1-5 cm thick of green to pink calc-silicate granofels composed of quartz, plagioclase, diopside, actinolite, clinozoisite, and sphene, and locally scapolite, grossular garnet, graphite, and calcite. A few outcrops contain beds of diopside marble as much as $10 \mathrm{~cm}$ thick. Tourmaline-bearing pegmatites are extremely common in the Paxton granofels and dominate the outcrop in many areas. Commonly small pegmatites have been dismembered by shearing during metamorphism, so that boudins and individual feldspar fragments distributed through the outcrops form a sort of "popcorn rock" (D.R. Wones, oral commun., 1976).

Another important rock type in the granofels member is quartz-feldspar-mica-sillimanite-graphite-pyrrhotite schist. This schist is hardly distinguishable from schist of the Partridge Formation, although in general it lacks delicate bedding and forms more resistant outcrops than does the Partridge. The similarity of the two units creates a serious mapping problem. Rusty schist interbedded with granofels is characteristic of the granofels member of the Paxton from the Barre area southward along the west limb of the Oakham anticline into Connecticut and also east of that anticline into Connecticut. In the very narrow synclines close to Wachusett Mountain, Robert Tucker (written commun., 1978) mapped schist and granofels separately (at a scale of 1:24,000), but they are all lumped as granofels member on the State bedrock map.

The granofels member is very poorly exposed in the center of the Gardner anticline (fig. 4, area M), but the rock that can be seen appears to be dominantly granofels. Emerson (1917) did not extend the Paxton very far north of Gardner, but abundant granofels and calc-silicate float in a gravel pit at Whitney Hill, Winchendon, led us to several localities including an excellent roadside exposure near East Rindge, N.H.

The granofels member in the western part of the Wachusett Mountain subbelt (fig. 6, area R), including the type locality at Paxton, seems to be largely free of sulfidic schist. The granofels also seems to show some internal stratigraphy: lower parts are dominated by well-bedded calc-silicate rocks, and upper parts close to the overlying Littleton Formation are dominated by micaceous granofels layers and gray schists. Similar internal stratigraphy has been described in the Madrid Formation in Maine (Moench, 1971) and the Madrid and Warner Formations in central and southern New Hampshire (Hatch and others, 1983; Thompson, 1983). Since the State bedrock map was published, a similar sequence has been seen in new outcrops of the granofels member low on the west face of New Ipswich and Pratt Mountains, N.H., northwest of Ashburnham (Peterson, 1984).

The Paxton Formation in the Wachusett Mountain subbelt, east of the Fitchburg plutons (fig. 6, area W) and west of the Wekepeke fault, as mapped by G.R. Robinson (1981) and Peck (1976), consists of thin-bedded feldspathic quartzite or metamorphosed siltstone interbedded with calc-silicate rock and subordinate beds and lenses of mica schist. The quartzite is a very fine grained, $\tan$ to brown, locally green-gray equigranular rock containing abundant reddish-brown biotite and some green chlorite. Greenish-gray calc-silicate beds are thin and commonly lenticular. Biotite schist layers, usually garnet and staurolite bearing, are only abundant near the Fitchburg pluton in the western part of the belt. According to G.R. Robinson (1981), bedding in the metasiltstone is expressed by differing modal proportions of quartz, plagioclase, biotite, and muscovite or actinolite. Less than 50 percent of the metasiltstone contains amphibole. Because of the immaturity of the sediments forming the metasiltstone, Peck (1976) suggested that they were derived in part from a volcanic 
terrane. Thin, light-colored calcareous beds containing $\mid$ Beds average 2-12 $\mathrm{cm}$ in thickness and are rarely as plagioclase, quartz, amphibole, and, in some beds, calcite much as $1 \mathrm{~m}$ thick. Graded beds are rare; the rocks in the compose less than 1 percent of the Paxton in this belt. 1 staurolite-kyanite zone in the eastern part have a fine

A

NASHUA SUBBELT

\begin{tabular}{|c|c|c|c|c|c|c|}
\hline Age & $\begin{array}{c}\text { Emerson } \\
\text { (1917) }\end{array}$ & $\begin{array}{c}\text { Hansen } \\
(1956)\end{array}$ & $\begin{array}{c}\text { Skehan } \\
\text { (1967) }\end{array}$ & $\begin{array}{c}\text { Grew } \\
(1970)\end{array}$ & $\begin{array}{c}\text { Peck } \\
(1975,1976)\end{array}$ & $\begin{array}{c}\text { Zen and others } \\
\text { (1983) } \\
\text { State bedrock map }\end{array}$ \\
\hline \multirow[b]{2}{*}{ Pennsylvanian } & \multirow[b]{2}{*}{$\begin{array}{l}\text { Worcester } \\
\text { Phyllite }\end{array}$} & $\begin{array}{l}\text { Worcester } \\
\text { Formation }\end{array}$ & \multirow[b]{2}{*}{$\begin{array}{l}\text { No rocks } \\
\text { assigned }\end{array}$} & $\begin{array}{l}\text { Worcester } \\
\text { Formation }\end{array}$ & \multirow[b]{2}{*}{ No rocks } & \multirow[b]{2}{*}{$\begin{array}{l}\text { Coal Mine Brook } \\
\text { Formation }\end{array}$} \\
\hline & & $\begin{array}{l}\text { Harvard } \\
\text { Conglomerate } \\
\text { Lentil of the } \\
\text { Worcester } \\
\text { Formation }\end{array}$ & & $\begin{array}{c}\text { Harvard } \\
\text { Conglomerate }\end{array}$ & & \\
\hline $\begin{array}{l}\text { Early Devonian } \\
\text { and Silurian }\end{array}$ & $\begin{array}{c}\text { Worcester } \\
\text { Phyllite }\end{array}$ & \multirow{3}{*}{$\begin{array}{l}\text { No rocks } \\
\text { assigned }\end{array}$} & \multirow{4}{*}{$\begin{array}{l}\text { Oakdale } \\
\text { and } \\
\text { Worcester } \\
\text { Formations }\end{array}$} & $\begin{array}{l}\text { - unconformity- } \\
\text { Holden } \\
\text { Formation } \\
\text { (part) }\end{array}$ & Units 3 and 4 & $\begin{array}{c}\text { - unconformity- } \\
\text { Worcester } \\
\text { Formation }\end{array}$ \\
\hline \multirow{3}{*}{ Silurian } & $\begin{array}{l}\text { Oakdale } \\
\text { Quartzite } \\
\text { and } \\
\text { Worcester } \\
\text { Phyllite }\end{array}$ & & & $\begin{array}{l}\text { Oakdale } \\
\text { Formation }\end{array}$ & Unit 2 & $\begin{array}{l}\text { Oakdale } \\
\text { Formation }\end{array}$ \\
\hline & $\begin{array}{l}\text { Oakdale } \\
\text { Quartzite }\end{array}$ & & & $\begin{array}{c}\text { Tower Hill } \\
\text { Quartzite } \\
\text { Member of the } \\
\text { Boylston } \\
\text { Formation }\end{array}$ & Unit 1 & $\begin{array}{l}\text { Tower Hill } \\
\text { Quartzite }\end{array}$ \\
\hline & $\begin{array}{l}\text { Boylston } \\
\text { Schist, } \\
\text { Worcester } \\
\text { Phyllite }\end{array}$ & $\begin{array}{l}\text { Worcester } \\
\text { Formation } \\
\text { (phyllite } \\
\text { facies) }\end{array}$ & & $\begin{array}{l}\text { Boylston } \\
\text { Formation }\end{array}$ & $\begin{array}{l}\text { No rocks } \\
\text { assigned }\end{array}$ & $\begin{array}{c}\text { Boylston } \\
\text { Schist }\end{array}$ \\
\hline \multirow{2}{*}{$\begin{array}{l}\text { Silurian } \\
\text { or } \\
\text { Ordovician }\end{array}$} & \multirow[b]{2}{*}{$\begin{array}{l}\text { No rocks } \\
\text { assigned }\end{array}$} & \multirow[b]{2}{*}{$\begin{array}{l}\text { Vaughn Hills } \\
\text { Quartzite } \\
\text { Member of the } \\
\text { Worcester } \\
\text { Formation }\end{array}$} & $\begin{array}{l}\text { Reubens Hill } \\
\text { amphibolite }\end{array}$ & \multirow[t]{2}{*}{$\begin{array}{c}\text { not } \\
\text { discussed }\end{array}$} & $\begin{array}{c}\text { Reubens Hill } \\
\text { igneous complex }\end{array}$ & $\begin{array}{c}\text { Reubens Hill } \\
\text { Formation }\end{array}$ \\
\hline & & & $\begin{array}{l}\text { Vaughn Hills } \\
\text { Formation }\end{array}$ & & $\begin{array}{c}\text { Vaughn Hills } \\
\text { Member of the } \\
\text { Tadmuck Brook } \\
\text { Schist }\end{array}$ & $\begin{array}{c}\text { Vaughn Hills } \\
\text { Quartzite }\end{array}$ \\
\hline $\begin{array}{l}\text { Silurian (?), } \\
\text { Ordovician, or } \\
\text { Proterozoic Z }\end{array}$ & $\begin{array}{l}\text { Brimfield } \\
\text { Schist }\end{array}$ & $\begin{array}{c}\text { Worcester } \\
\text { Formation } \\
\text { (mica schist } \\
\text { facies) }\end{array}$ & \multirow{2}{*}{$\begin{array}{l}\text { Nashoba } \\
\text { Formation }\end{array}$} & & \multirow{2}{*}{$\begin{array}{l}\text { Tadmuck } \\
\text { Brook } \\
\text { Schist }\end{array}$} & $\begin{array}{c}\text { Tadmuck Brook } \\
\text { Schist }\end{array}$ \\
\hline $\begin{array}{l}\text { Ordovician or } \\
\text { Proterozoic Z }\end{array}$ & $\begin{array}{l}\text { Gneisses and } \\
\text { schists of } \\
\text { undetermined } \\
\text { age }\end{array}$ & $\begin{array}{l}\text { Nashoba } \\
\text { Formation }\end{array}$ & & & & $\begin{array}{l}\text { Nashoba } \\
\text { Formation }\end{array}$ \\
\hline
\end{tabular}

FIGURE 7. - Correlation of previous nomenclature of stratified units in the eastern part of the Merrimack belt: $A$, Nashua subbelt; $B$, Rockingham subbelt. 
lamination, locally showing crossbedding. These features disappear as the rocks become coarser grained to the west in the sillimanite zone around the Fitchburg Complex. The rock adjacent to, and as inclusions in, the Fitchburg Complex is a coarse quartzofeldspathic gneiss. Rusty schists have not been found in this belt of Paxton. The Paxton is overlain conformably by mica schist here assumed to be the Littleton Formation (G.R. Robinson, 1981).

This belt of Paxton coincides in part with the original belt of Oakdale Quartzite of Emerson (1917) and corresponds to the western belt of Oakdale of Grew (1970) and the Oakdale Formation of G.R. Robinson (1978, 1981). Peck (1976) did not give the rocks a formal designation.
We have not followed these authors' or Emerson's exact nomenclature for rocks in this belt because it became clear in the compilation for the State bedrock map (see cross sections $\left.D-D^{\prime}, F-F^{\prime}\right)$ that the Paxton of area W (fig. 6) must be continuous around the Fitchburg plutons with the Paxton of area $R$ (fig. 6), although this continuation is somewhat obscured by the Wekepeke fault south of Oakdale. In addition, this belt of Paxton contains less interbedded pelite than the rocks shown on the State bedrock map as Oakdale, east of the Wekepeke fault in the Nashua subbelt (fig. 7).

The narrow belt of Paxton (fig. 5, area AA) east of the Southbridge Member (Spso) (area Z) consists of rock similar to the Southbridge (described below) but finer

B

ROCKINGHAM SUBBELT

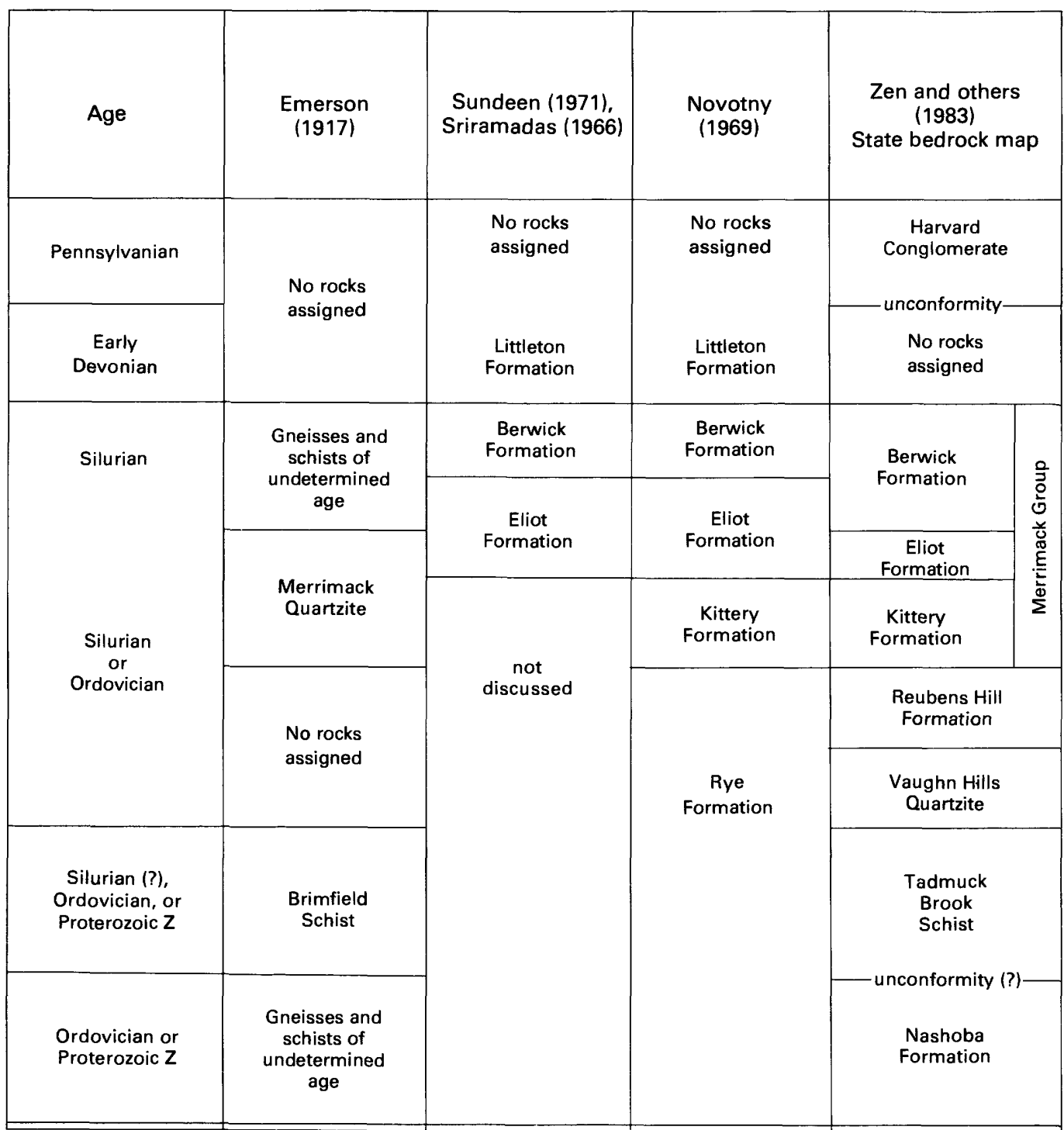

FIGURE 7.-Continued. 
grained and more thinly and uniformly bedded. It corresponds to the Hebron Formation as mapped by Pease (1972) in the Eastford quadrangle, northeastern Connecticut, and was considered by Moore (1978) to be a formation beneath the Southbridge in his Paxton "group." On the geologic map, we have included it in the undifferentiated Paxton Formation (Sp).

The base of the granofels member is generally poorly exposed, but it apparently rests conformably on the sulfidic schist and quartzite unit (Spsq) or the quartzite and rusty schist unit (Spqr) or unconformably on the Partridge Formation. At the top, it either is overlain by separately mapped sulfidic schist or appears to grade into the Littleton Formation. Because of structural complexity, we have no reliable thickness figures. Tucker (1977) suggested a minimum thickness of about $200 \mathrm{~m}$ for the unit in the Barre area.

As hinted above, the granofels member (Sp) of the Paxton Formation, particularly where close to rocks correlated with the Smalls Falls Formation of Maine (Moench and Boudette, 1970) or the Littleton Formation of central New Hampshire (Hatch and others, 1983), is very similar in lithology and sequence to the Madrid and Fall Brook Formations of Maine and the Warner Formation of central New Hampshire, as well as the Fitch Formation of the Connecticut Valley belt. All of these units may be reasonably placed at the top of the Silurian section in their regions. The granofels member of the Paxton is also similar lithically to the Vassalboro Formation in central Maine (Osberg, 1980) and to the Eliot and Berwick Formations of southeastern New Hampshire, the Oakdale Formation in the Nashua subbelt in Massachusetts, and the Hebron Formation in eastern Connecticut.

For the derivation of the protoliths for the granofels member, the model for the Madrid Formation (Moench, 1971 ) is adequate. The member originally consisted of interbedded feldspathic calcareous siltstone and impure calcareous shale and dolomitic limestone, possibly with a contribution of feldspar from volcanic ash. Interbedded schists were sulfidic black shales deposited when the volcanic and silt contributions were less.

\section{AMPHIBOLITE (Spa)}

Amphibolite is not a common rock type in the Paxton Formation, but a number of small lenses have been mapped. Some of these may have been contemporaneous volcanic deposits; others are probably mafic sills. Their structural and stratigraphic setting needs to be more thoroughly investigated.

\section{BIGELOW BROOK MEMBER (Spbs, Spbc)}

The Bigelow Brook Member is a subdivision of the granofels member of the Paxton in southern Massachu- setts (fig. 5, area Y). The unit is defined as the eastern part of the rocks previously mapped as the Bigelow Brook Formation (Pomeroy, 1975; Seiders, 1976; Moore, 1978), specifically excluding the gray-weathering aluminous schists and gneisses that we include in the Littleton Formation. This member consists of about equal proportions of granofels and sulfidic schist usually interbedded in thick beds, as can be seen by looking at a large Massachusetts Turnpike roadcut from the Route 149 overpass. In addition, because of the high metamorphic grade, many aluminous beds within the granofels contain garnets as much as $3 \mathrm{~cm}$ in diameter. A few marble beds crop out, as at the spillway of Westville Dam in Southbridge. Within this interbedded unit a few zones dominated by calc-silicate granofels (Spbc) have been separately mapped.

\section{SOUTHBRIDGE MEMBER (Spso)}

The Southbridge Member (fig. 5, area Z) lies in sharp contact along the Black Pond fault (Peper and Pease, 1976) with the Bigelow Brook Member (Spbs) to the west. In contrast to the Bigelow Brook Member, the Southbridge is free of schist beds and is almost pure interbedded granofels and calc-silicate. Because of either metamorphic grade or bulk composition, it does not have large garnets. The Black Pond fault becomes a beddingplane fault in southern Massachusetts and loses its identity northward, so that in the current state of mapping the Southbridge is not readily distinguished from the main granofels member of the Paxton. The Southbridge Member is most similar to the belt of Paxton between the Fitchburg plutons and the Wekepeke fault.

\section{SULFIDIC MICA SCHIST (Spss)}

Sulfidic mica schist is the designation used for mappable layers of sulfidic mica schist of the Paxton Formation wherever they have been separately mapped. Some of these layers have continuity and are stratigraphically significant, whereas others appear to be merely lenses in other members.

The largest areas of sulfidic mica schist occur at the top of the formation, above the granofels member, in the Gardner subbelt of the northern part of the State, on both limbs of the Gardner anticline. On the west limb of the anticline southwest of Gardner, the granofels member is directly overlain by gray schists of the Littleton Formation (H.B. Stoddart, written commun., 1977), but in giant highway excavations due west of Gardner a broad belt of sulfidic schists reappears rather abruptly below the Littleton (fig. 4 , area L). The contact with the Littleton to the west is exposed in these highway cuts, but the rocks are so folded and sheared that significant interpretation cannot be made. The contact with the granofels member to the east is not exposed. The domi- 
nant rock type is schist containing quartz, plagioclase, orthoclase, sillimanite, muscovite, biotite, garnet, graphite, ilmenite, and pyrrhotite typical of the sillimanite-muscovite-orthoclase zone and identical in character to many schists of the Partridge Formation. Assignment of this rock to the Paxton is encouraged by its stratigraphic position and more particularly by several large boudins as much as $20 \mathrm{~m}$ across of rather typical Paxton purple biotite granofels with spectacular green and pink calc-silicate beds. Also present in this exposure are boudins of a dismembered metamorphosed gabbro dike that cuts the sulfidic schist. North of the highway exposures this sulfidic schist belt is poorly exposed, but it has been tentatively traced north to New Hampshire.

On the east limb of the Gardner anticline is a much more extensive and wide belt (fig. 4, area N) of identical sulfidic schist that has only been studied in reconnaissance. These two belts probably correlate across the crest of the anticline, thus overlying the granofels member (Sp) and underlying the gray schist of the Littleton Formation (Dl) to the east. If our interpretation of the stratigraphic position of these sulfidic rocks is correct, they are possibly equivalent to sulfidic rocks in central New Hampshire (Malinconico, 1982; Hatch and others, 1983) that locally lie between the gray granofels of the Warner Formation and the gray schists of the Littleton Formation.

As previously described, the narrow belts shown as Paxton granofels member (Sp) along the west side of the Fitchburg Complex actually consist of granofels and sulfidic schist that could be mapped separately at $1: 24,000$. One of these belts has been tentatively traced north to the New Hampshire line. In this belt the granofels pinches out and the belt consists entirely of sulfidic mica schist locally containing exposures dominated by feldspathic quartzite. It is here labeled "Spss" (fig. 6, area T). Since the State bedrock map was compiled, Peterson (1984) has completely revised the map pattern near Ashburnham and has demonstrated that these sulfidic rocks are much more extensive than previously shown. At present they pose a stratigraphic dilemma. Their association with typical Paxton granofels at Wachusett Mountain suggests that they may be merely a more schist-rich facies of the granofels member (Sp). Their similarity to rusty schist at the top of the formation (Spss) near Gardner suggests a correlation with the uppermost Silurian. The similarity of the feldspathic quartzite to the quartzite and rusty schist unit (Spqr) of the Wachusett Mountain subbelt suggests a correlation with the lower part of the Silurian. If our structural interpretation of the Wachusett Mountain subbelt is correct and the narrow belts of Silurian strata are in anticlinal east-directed nappes from a western region where the entire Silurian is thin, all three of the tentative correlations may be correct. Sulfidic schist inclusions within the Fitchburg Complex are identical to the sulfidic schists just discussed and are also labeled "Spss" (fig. 6).

Within the Paxton Formation southeast of the Fitchburg plutons, Grew (1970) mapped several isolated lenses of sulfidic schist, here shown as "Spss." Where exposed on the north side of Indian Lake (fig. 6), the rock is a very fine grained black mica schist, which is very magnetic due to abundant pyrrhotite and appears to be much lower in grade than any of the schists described above.

\section{LITTLETON FORMATION \\ (Dl, Dl+Ops, Dlf, Dlo, DIm)}

The Littleton Formation in the Merrimack belt is an extension of gray-weathering schists of the Littleton in the eastern part of the Connecticut Valley belt. Unfortunately all the Littleton rocks of the Merrimack belt are exposed in narrow synclinal belts mostly representing folds of the nappe stage, so that physical tracing of stratigraphy across strike is impossible. That some of the belts are synclinal has been demonstrated by graded bedding, particularly in the syncline that runs through Mt. Pisgah west of Brimfield and Wales (Peper and Pease, 1976) and in two narrow synclines in the village of Barre and just east of it (Tucker, 1977). Many of the synclines in the Ware subbelt contain no recognized Silurian strata, and the gray schists assigned to the Littleton are in contact with rocks mapped as Middle Ordovician Partridge Formation. In some of these synclines, the gray-weathering rocks may not be Littleton Formation and perhaps should be assigned to some other gray-weathering unit in the central New Hampshire sequence. In the Gardner and Wachusett Mountain subbelts, the gray-weathering schists are in sequences with underlying rocks assigned with confidence to the Silurian, which makes their assignment to the Littleton more certain.

The different character of the rock in the different belts of Littleton Formation results from variations in the protoliths, as well as from metamorphic grade and degree of deformation during metamorphism. In the Ware and Gardner subbelts, the grade ranges from sillimanite-muscovite in the north to sillimaniteorthoclase-garnet-cordierite in the south. In the Wachusett Mountain subbelt, metamorphism seems to be in the sillimanite-muscovite zone over a broad area west of the Fitchburg plutons where sillimanite pseudomorphs after andalusite are abundant and assemblages of muscovitebiotite-garnet-cordierite are locally present (Peterson, 1984). Inclusions in the Fitchburg plutons locally contain 
sillimanite-muscovite-orthoclase assemblages again with andalusite pseudomorphs. In the narrow belt of Littleton along the east margin of the Fitchburg plutons, metamorphic grade drops rather abruptly from sillimanitemuscovite assemblages with andalusite pseudomorphs at the western contact through andalusite-muscovite schist to garnet-mica schist locally containing kyanite at the eastern contact of the belt (Nelson, 1975; Peper and Wilson, 1978; Robinson and others, 1978). In the Southbridge subbelt, Littleton only occurs along the border with the adjacent Wachusett Mountain and Gardner subbelts.

\section{WARE SUBBELT}

The Littleton Formation in the western part of the Ware subbelt, west of the Hardwick pluton (fig. 4, area A), is identical in all aspects to the Littleton in areas 7 (figs. 4,5) and 8 (near Amherst in the Connecticut Valley belt (Hatch and others, 1988)). The unit is rather poorly exposed and commonly contains strongly foliated rock of mylonitic aspect in the sillimanite-muscovite-orthoclase and higher grade areas. The rock is commonly a grayweathering, dark, biotite-rich schist with fine sillimanite and garnet grains and conspicuous augen of feldspar. Field (1975) identified narrow, poorly exposed belts of gray schist on either side of the Hardwick pluton in the Ware area (fig. 5, area A) and suggested that the pluton may be in the middle of an isoclinal syncline of Littleton Formation. However, the distribution of Partridge Formation and Fitch Formation as inclusions and along the margins of the pluton near Petersham and Phillipston (C.K. Shearer, written commun., 1980) renders this suggestion improbable.

The next belt of gray schist, entirely east of the Hardwick pluton (figs. 4, 5, area B), appears to hinge out to the south and has been called the Ragged Hill syncline (Field, 1975; Robinson and others, 1982a, Stop 4). These rocks are conspicuously well bedded quartz-rich schists with abundant $0.5-$ to $1-\mathrm{cm}$ grains of garnet, sillimanite, and commonly cordierite. Robinson and others (1982a), on the basis of the quartz-rich character, suggested a correlation with the Perry Mountain Formation of central New Hampshire, but J.B. Lyons and N.L. Hatch, Jr. (oral commun., 1982), suggested that these schists much more closely resemble the lower part of the Rangeley Formation. Correlation with the Rangeley is greatly enhanced by the fact that the belt of red-rusty schists containing calc-silicate pods directly to the west, originally mapped by Field (1975) with considerable uncertainty as the Lyon Road belt of Partridge Formation, is now considered by us to correlate with the upper part of member $\mathrm{C}$ of the Rangeley. Unfortunately both of these belts, exposed over relatively broad areas near Ware, virtually pinch out to the south and north, preventing significant direct correlations.

The next belt of Littleton to the east, flanked on both sides by Fitch Formation north of Ware, has been called the Big Garnet syncline (figs. 4, 5, area C). The hinge of the syncline is located on the east face of Ragged Hill near Ware. Nearly the entire width of the syncline is exposed in a single set of cliffs on the northeast slope of Ragged Hill (Robinson and others, 1982a, Stop 5), and subsequent observation of this outcrop showed excellent graded bedding topping east on the west side and west on the east side. The characteristic rocks of the Big Garnet syncline are poorly exposed in Barre but superbly exposed in the southwest part of the town of Templeton.

The characteristic rock of the Big Garnet syncline is rather homogeneous, poorly layered, gray, medium- to fine-grained, sillimanite-biotite-cordierite-garnet schist. This schist is cut by vein networks, commonly deformed, of quartz, K-feldspar, plagioclase, and cordierite enclosing subhedral to euhedral garnets as much as $4 \mathrm{~cm}$ in diameter. The size difference between garnets in the matrix $(\sim 1-3 \mathrm{~mm})$ and in the feldspathic veins $(1-4 \mathrm{~cm})$, as well as the character and physical arrangement of the veins, strongly suggests that the vein garnets grew in the presence of a felsic silicate melt, probably a product of local fluid-absent melting (Robinson and others, 1982a, p. 341-342). In some exposures southwest of Templeton, the large garnets are set in a more massive matrix of quartz, cordierite, and plagioclase, suggesting that their original melt host may have been transported away during metamorphism. Electron probe analyses of these garnets (Richardson, 1975; Tracy and others, 1976; Robinson and others, 1982a) show that they are completely homogeneous except where their outer edges touch an adjacent grain of cordierite or biotite, permitting localized retrograde ion exchange. Commonly the big garnets contain internal zones of crystallographically oriented ilmenite plates parallel to and several millimeters inside crystal faces. In addition to ilmenite, these rocks also contain traces of magnetite, a mineral not found in any of the other types of Littleton. Field (1975) described two samples of this rock containing sillimanite pseudomorphs after andalusite.

Locally interbedded with the characteristic rock are beds as much as $2 \mathrm{~m}$ thick of fine-grained, light-purplegray biotite-feldspar granofels. This rock type, as well as the big-garnet rock itself, led N.L. Hatch, Jr., and J.B. Lyons (oral commun., 1982) to suggest a direct correlation with the uppermost part of the Warner Formation of central New Hampshire, essentially at its contact with the Littleton. Such a correlation, not shown on the State bedrock map, with the uppermost Warner, rather than 
with the Littleton itself, seems eminently suitable for the rocks of the Big Garnet syncline and would help explain some of their peculiarities.

East of the Big Garnet syncline, the same big-garnet rock also occurs fairly consistently as a selvage a few meters thick between the Fitch Formation and the west contact of the Coys Hill pluton (figs. 4, 5, area D). This relationship supports the contention of Field (1975) that the pluton occupies a position in the stratigraphy equivalent to that of the Littleton Formation. In the southern part of the Ware area, the Coys Hill pluton converges on the east margin of the Monson Gneiss, so that all of the synclinal belts just described are squeezed into a very narrow, poorly exposed zone known to local workers as "The Slot" (fig. 5, near letter E).

East of the Coys Hill pluton, in the Ware subbelt, rocks assigned to the Littleton Formation occur mainly in four synclinal belts (figs. 4, 5): the Coys Hill syncline (area F), the Prouty Road syncline (area G), the Gilbert Road syncline (area $\mathrm{H}$ ), and the Kruse Road syncline (area I). Along much of the east contact of the Coys Hill pluton, the granite is in direct contact with Partridge Formation or with lenses of Fitch Formation, but near Barre a thin strip of gray schist of the Littleton appears along the contact. Several miles farther north, in Barre, the Partridge of the intervening anticline hinges out so that the Coys Hill and Prouty Road synclines merge. In the northern part of the State, the exposure in this region east of the Coys Hill pluton is so poor that several areas have been designated on the State bedrock map only as "interfolded Littleton and Partridge" (Dl + Ops). From Barre south (fig. 5, area G), the Prouty Road syncline contains a large area of Littleton Formation including some unusual rock types interpreted as metamorphosed volcanic rocks. Area G includes the type area of the Mount Pisgah Formation of Peper and others (1975; see also Peper and Pease, 1976; Seiders, 1976; Pomeroy, 1977) shown as Littleton Formation on the State bedrock map. Graded bedding demonstrates the synclinal nature of the belt near Mt. Pisgah and also in Barre (Tucker, 1977). The Gilbert Road and Kruse Road synclines (figs. 4, 5, areas $\mathrm{H}$ and $\mathrm{I}$ ) are the most continuous and consistent belts in the Ware subbelt. They have been traced tentatively from southernmost Massachusetts into New Hampshire. The Kruse Road syncline, though well exposed elsewhere, is hardly exposed at all in the Ware area, where Field (1975) did not show it. In southern Massachusetts the gray schists of these synclines were mapped as part of the upper schist member of the Hamilton Reservoir Formation. The synclinal nature of the Gilbert Road belt is shown by graded bedding in the Barre area (Tucker, 1977).

The gray schists of the Prouty Road syncline (area G) are conspicuously rich in garnet and sillimanite and also commonly contain cordierite or muscovite at appropriate metamorphic grade. Graphite and ilmenite are the opaque minerals. In the Ware and Barre areas, quartzose beds are subordinate, and some are graded (Tucker, 1977). Quartzose beds are conspicuous or even dominant near Mt. Pisgah in the southern part of the State. The schists commonly contain layers and concretionary lenses of gray biotite-plagioclase granofels or green to pink diopside-grossular calc-silicate granofels (Tucker, 1977).

An abundant and locally predominant rock type in the Littleton of the Prouty Road and Coys Hill synclines (figs. 4, 5, areas $\mathrm{G}$ and $\mathrm{F}$, respectively) of the Ware and Barre areas is white quartz-feldspar gneiss (Dlf), mapped as the feldspathic gneiss member by Field (1975) and Tucker (1977) and interpreted as metamorphosed felsic volcanic rocks. The gneiss commonly contains minor garnet and biotite, and locally sillimanite and secondary muscovite, and bears some resemblance to highly metamorphosed and deformed pegmatite and to the felsic upper part of the Ammonoosuc Volcanics (Robinson, 1963). The structural position of the gneiss and its locally intimate interlayering with gray schist favor its interpretation as volcanic rocks within the Littleton.

Also present in the Prouty Road syncline of the Ware area southwest of New Braintree (fig. 5), and commonly associated with the feldspar gneisses, are several lenses of coarse-grained, weakly foliated, brown-weathering orthopyroxene-biotite gneiss (Dlo), mapped as the orthopyroxene gneiss member by Field (1975). The rock consists of andesine or labradorite, intermediate orthopyroxene, cummingtonite, and biotite, with or without hornblende, quartz, and magnetite (Robinson and others, 1982a). Emerson (1917) published an analysis of this rock, which he mistakenly described as "wehrlite," showing 50 percent $\mathrm{SiO}_{2}$ and the composition of a hypersthene-olivine andesite. Because of its stratigraphic position, the orthopyroxene gneiss is considered most probably to have been flows of andesite of unusual composition, although an intrusive origin cannot be ruled out.

The Littleton schists of the Gilbert Road syncline (Field, 1975; figs. 4, 5, area $\mathrm{H}$ ) are gray-weathering, well-bedded sillimanite-garnet-biotite schists with quartzose beds $5-10 \mathrm{~cm}$ thick, showing excellent graded bedding in the Barre area. Garnets are typically $1-2 \mathrm{~cm}$ in diameter. Gray to white beds, $5-8 \mathrm{~cm}$ thick, of equigranular calc-silicate granofels are common in this belt and consist predominantly of quartz and calcic plagioclase with subordinate grossular garnet, diopside, clinozoisite, and sphene. Several zones of feldspathic gneiss (Dlf) were mapped separately in this belt. Pomeroy (1977) mapped these rocks as part ("husg") of 
the upper schist member of the Hamilton Reservoir Formation, and they are also mapped with certainty into outcrops of Littleton feldspathic gneiss north of Route 2 in the Templeton area. The tracing of these rocks northward to New Hampshire and into slightly lower metamorphic grades is based on reconnaissance only. J.B. Lyons and N.L. Hatch, Jr. (oral commun., 1982), suggested that these rocks look more like the lower part of Rangeley member $\mathrm{C}$ of central New Hampshire than like typical Littleton, and the geology of central Massachusetts provides no solid evidence against this correlation.

The Littleton schist of the Kruse Road syncline (fig. 4, area I) east of Barre (Tucker, 1977) typically is wellfoliated, gray-weathering, poorly layered garnetsillimanite-plagioclase schist, commonly with a streaked appearance due to the abundance of pegmatite veins. Garnets are $0.5 \mathrm{~cm}$ in diameter or smaller. This belt was mapped separately by Pomeroy (1977) and Seiders (1976) as the East Hill belt ("husn") of gray sillimanite schist within the upper schist member of the Hamilton Reservoir Formation. It can be found in two or three outcrops near New Braintree and West Brookfield. South of Barre, garnets tend to be larger, and cordierite has been locally identified. North of Barre, muscovite is abundant. The homogeneous, poorly bedded character and the local occurrence of schist of the Fitch Formation (Sfss) on one flank of this belt southeast of Templeton make correlation of these rocks with the Littleton Formation more probable than it was for the rocks of the Gilbert Road syncline.

\section{GARDNER SUBBELT}

The Littleton Formation of the Gardner subbelt occurs in three bands, the first in a complex syncline along the west limb of the Gardner anticline (figs. 4, 5, area K), the second in a deep, complexly refolded syncline that appears to trace westward from near Worcester across several anticlinal features to the vicinity of the Oakham anticline (figs. 4, 5, 6, area P), and the third in the Ashburnham area (figs. 4, 6, western part of area Q). The second band, here called the Harding Hill syncline ("the Worm of central Massachusetts") after Tucker (1977), is discussed separately below. The third band, included in the Gardner subbelt on structural grounds, is better discussed in the stratigraphic context of the Wachusett Mountain subbelt.

The belt on the west limb of the Gardner anticline (area K) was described in detail by Tucker (1977), who identified it as a gray graphitic schist member of the Paxton Formation. In 1978 R.D. Tucker and Peter Robinson reinterpreted the belt as an isoclinal syncline of Littleton Formation, here called the Natty Pond syncline, on the basis of comparisons of the Barre and
Wachusett Mountain areas. The syncline appears to hinge out southward in a poorly exposed area northwest of Oakham between the sulfidic schist and quartzite unit (Spsq) and the granofels member (Sp) of the Paxton Formation. The belt is best exposed in the Hubbardston area and east of Templeton and has been traced in reconnaissance to New Hampshire.

Typical schists of the Natty Pond syncline (Tucker, 1977, p. 36; Robinson, 1979, p. 156) are in the sillimaniteK-feldspar-muscovite zone. They are gray- to slightly brown-weathering schists and subordinate beds of calcsilicate granofels, a few with carbonate cores, and typically have quartzofeldspathic segregations $15-20 \mathrm{~cm}$ long strung out throughout the rock. The dominant minerals are quartz, plagioclase, biotite, muscovite, and garnet (crystals usually 1-3 mm) and minor orthoclase, sillimanite, graphite, and ilmenite. The schist is medium grained and evenly foliated and in places has slight compositional layering, but bedding is poorly displayed. Pegmatite and medium- to fine-grained garnetiferous granitic gneiss sills are generally more abundant than in adjacent units. These schists are quite similar to the Littleton of the Kruse Road syncline and in the Wachusett Mountain subbelt.

Contacts of the Littleton of the Natty Pond syncline with the sulfidic schist and quartzite (Spsq) of the Paxton to the west appear to be sharp and are easily mapped because of the dramatically different character of the rocks. Contacts with the granofels member $(\mathrm{Sp})$ of the Paxton to the east are also generally distinct, but, in areas of particularly good outcrop, as at the top of the cliffs west of Riverside Cemetery east of Barre (Robinson and others, 1982a, Stop 14), biotite granofels and sulfidic schist typical of the Paxton granofels member appear to be interbedded with gray schist typical of the Littleton over several tens of meters. The contact with the sulfidic schist unit (Spss) of the Paxton is exposed in cuts on Route 2 in East Templeton, but pegmatites and complex folding make contact relations cryptic.

\section{WACHUSETT MOUNTAIN SUBBELT}

Gray-weathering schists mapped as Littleton Formation are the dominant stratified rocks of the Wachusett Mountain subbelt and the extreme eastern edge of the Gardner subbelt (figs. 3, 6). They form the envelope surrounding the belts of Paxton Formation that are interpreted as isoclinal anticlines and form inclusions in the Fitchburg plutons. These schists are exposed at the summits, or on high subsidiary peaks, and on the steep slopes of New Ipswich Mountain, Pratt Mountain, Mt. Watatic, Little Watatic, Wachusett Mountain, and Little Wachusett. West of the Fitchburg plutons the schists are in the sillimanite-muscovite zone of regional metamor- 
phism; east of the plutons they appear in a rather steep contact gradient away from the plutons and may be as low as garnet zone.

West of the plutons (fig. 6, area Q), the gray schists show local variety but an overall monotony of aspect. Aluminous beds are fairly abundant and may contain sillimanite pseudomorphs (or retrograded pseudomorphs) after andalusite, which appear as projections on weathered surfaces and are referred to by local workers as "andalumps." Irregular quartzose beds, which do not display graded bedding, and poorly layered, gray quartzplagioclase-biotite-muscovite schists and gneisses are common. Minerals include quartz, plagioclase, sillimanite, biotite, muscovite, garnet (usually 1 to $3 \mathrm{~mm}$ or less in diameter), graphite, and ilmenite. Some outcrops are pitted, due to weathering of secondary chlorite that has replaced garnet. Structural and stratigraphic interpretation is hindered by several generations of quartz veins and pegmatites and by several generations of folding not easily deciphered. Another common feature of these rocks is "footballs" or zoned lenses of gray to green or pink calc-silicate granofels as much as $1 \mathrm{~m}$ in diameter. The lenses usually have an outer zone of gray biotitecalcic plagioclase granofels and an inner zone of spotted plagioclase granofels with diopside and grossular. Cores of the lenses locally contain preserved calcite.

A nearly continuous belt of gray mica schist (fig. 6, area $U$ ) occurs along the east margin of the Fitchburg plutons from Fitchburg south, and similar schist occurs as large (mappable) and small (unmappable) screens within the intrusions. In the Sterling area (northwest of Oakdale in fig. 6), Hepburn (written commun., 1976) called these schists the Bee Hill Formation, and similar rocks south of Malden Hill (fig. 6, areas U and P) were called Holden Formation by Grew (1970). The southern part of Grew's Holden Formation is the Littleton of the Harding Hill syncline at the southern edge of the Wachusett Mountain subbelt. South of Fitchburg the gray schist along the east margin of the Fitchburg plutons is highly varied, depending on metamorphic grade, but locally contains pink or white andalusite. Some exposures show excellent bedding.

Near Fitchburg the gray schist unit consists of gray graded-bedded pelite and rare thin layers of white quartzite (Peper and Wilson, 1978). The schist is composed primarily of muscovite, quartz, biotite, and plagioclase. It commonly contains staurolite and garnet porphyroblasts and rarely kyanite porphyroblasts locally converted to fibrolite. Fibrolitic sillimanite is found primarily adjacent to granite of the Fitchburg plutons. The schist is apparently interbedded at the base with granofels of the underlying Paxton Formation (Peper and Wilson, 1978).
A thin section of an inclusion of gray schist in Fitchburg granite from the Quabbin Tunnel shows andalusite porphyroblasts that have been completely replaced by coarse sillimanite. What was apparently once a rim of muscovite around the andalusite has been completely replaced by fibrous sillimanite and orthoclase. The texture gives insight into possible complexities in the metamorphic history of this region.

The belt of gray schist along the west edge of the Massabesic Gneiss Complex is labeled "Dl?" (fig. 6, area V) but is not like the Littleton described elsewhere. The rock is rather massive, poorly layered schist containing abundant quartz and plagioclase and very coarse biotite and muscovite. It may correspond to rocks mapped as the lower part of Rangeley member $\mathrm{C}$ in central New Hampshire.

The Littleton in the narrow bands interspersed in the Paxton Formation in the Townsend area (fig. 6, area X) consists of lustrous mica schist containing few quartzofeldspathic layers (G.R. Robinson, 1981). Graded beds indicate that the mica schist overlies the Paxton (Robinson, 1981). The thickness of the schist in the Townsend area is from 0 to $235 \mathrm{~m}$.

\section{HARDING HILL SYNCLINE}

The sinuous band of Littleton mapped along the axial surface of the Harding Hill syncline (figs. $4-6$, area $P$ ) is discussed last because it is poorly exposed, because its connections are highly uncertain, and because it passes through or along the boundaries of several subbelts. The band is presently interpreted as the core of a refolded recumbent syncline overfolded to the east, with an inverted section of Paxton Formation structurally above and to the north and a right-side-up section of Paxton structurally below and to the south.

The schist in the syncline is traced westward from a postmetamorphic normal fault east of Holden and north of Worcester (fig. 6, area P) in a sinuous path along the southern edge of the Wachusett Mountain subbelt. The schist is well exposed where the band crosses the axis of the Gardner anticline west of Rutland in a cut on the abandoned Central Massachusetts Railroad known as Shannock's Folly. The schist in this eastern part of the band is typically gray, medium-grained biotitemuscovite-sillimanite schist, similar to the Littleton elsewhere in the Wachusett Mountain subbelt. Southeast of Holden, a narrow, poorly exposed strip of laminated siliceous marble (Dlm) locally contains idocrase (Grew, 1970; J.C. Hepburn, written commun., 1977).

From Rutland the band is traced southward (fig. 5, area $P$ ) through a zone of synmetamorphic faults and diorite intrusions into Connecticut. The band passes across the highly attenuated southern extension of the 
Hubbardston syncline and thence northward along the east limb of the Oakham anticline. For some distance along this limb, the Paxton Formation is missing, and the Littleton is in direct contact with the Partridge Formation of the Oakham anticline, presumably along a synmetamorphic fault. From Rutland southward there is a progressive change in the character of the Littleton from medium-grained sillimanite-biotite-muscovite schist to coarse-grained sillimanite-garnet-cordierite-K-feldspar schist and gneiss within about $15 \mathrm{~km}$ of the Connecticut line. Within the higher grade parts, strongly foliated sillimanite-garnet pegmatites, locally containing graphite, are abundant. Granitic layers contain 1- to 2-cm aggregates of coarse sillimanite and biotite apparently pseudomorphous after cordierite. Within the schists are more feldspathic granulitic layers, several meters thick, that contain diopside-grossular calc-silicate layers 5-10 $\mathrm{cm}$ thick. Sillimanite pseudomorphs of andalusite have been identified at several localities. In overall aspect these higher grade schists look very similar to the Littleton in the southern part of the Ware subbelt. Spectacular exposures in this area include the cut on the north side of the Massachusetts Turnpike where it is crossed by New Boston Road (Robinson and others, 1982a, Stop 11) and outcrops near the southeast end of the pond in Bigelow Hollow State Park in Connecticut, where Seiders (1976) identified several mylonites. Overall these rocks ( $\mathrm{Dl}$ on the State bedrock map) are the ones considered typical by Peper and Pease (1976; Peper and others, 1975) of the western part of their Bigelow Brook Formation.

Fairly extensive exposures of Littleton are present east of the northern oval of Partridge Formation in the core of the Oakham anticline (figs. 4, 5, area P), where Paxton Formation again appears between the Littleton and Partridge. These rocks are again lower grade muscovite-bearing schists. They appear to project northward into an area of no exposure along the line of the Quabbin Aqueduct Tunnel, in which Fahlquist (1935) identified them as the "Middle Member of the Paxton Formation." He characterized the "Middle Member" as mica schist overlain and underlain by typical purple granofels with calc-silicate of his "Upper" and "Lower Members." In the present context the "Middle Member" is interpreted as a recumbent syncline of Littleton structurally overlain and underlain by the granofels member of the Paxton Formation (Sp). Tracing of the recumbent syncline of Littleton around the north end of the Oakham anticline is based entirely on interpretation of Fahlquist's tunnel data and collection of specimens, because there are virtually no surface outcrops. The position of the synclinal hinge west of the Oakham anticline is conjectural.

\section{NASHUA AND ROCKINGHAM SUBBELTS}

The eastern part of the Merrimack belt (and the Merrimack synclinorium) consists of two subbelts: the Nashua subbelt, which lies east of the Southbridge and Wachusett Mountain subbelts and west of the Nashoba zone, and the Rockingham subbelt, which forms a wedge between the Nashoba zone and the Nashua subbelt in the northeast part of the Merrimack belt in Massachusetts (figs. 1, 3B). The subbelts are distinguished partly on the basis of minor differences in rock type, metamorphism, and structure but mostly on historical differences in mapping of units and in terminology. The Nashua subbelt, named for the Nashua River, which drains the area, coincides with a metamorphic and structural(?) trough called the Nashua synclinal by Crosby (1880) and the Nashua trough by Smith and Barosh (1981). The Rockingham subbelt gets its name from the Rockingham anticlinorium, which projects into this area from New Hampshire and southern Maine (Billings, 1956; Hussey, 1968). The western margin of the Nashua subbelt is essentially the Wekepeke and Pine Hill faults of the Mesozoic(?) Flint Hill fault system (Rodgers, 1970, p. 107). The eastern margin of the Merrimack belt and the subbelts is defined by the Clinton-Newbury (also known as Essex) fault system and coincides with the western boundary of the Nashoba Formation of the Nashoba zone.

Appreciable mapping has been done in the Nashua and Rockingham subbelts since the early work of Burbank (1876), Crosby (1880), Emerson (1898), and Perry and Emerson (1903): Grew (1970, 1973, 1976) and Hepburn (written commun., 1976; 1978) in the Shirley and in the Worcester areas, Barosh $(1974,1976,1977)$ and Dixon (1974; written commun., 1977 and 1978) in the Oxford and Webster area, and Peck $(1975,1976)$ in the Clinton area; Skehan (1967) and Skehan and Abu-Moustafa (1976) presented detailed data from the WachusettMarlborough tunnel at the east margin of the Nashua subbelt near Clinton. To the north, G.R. Robinson (1978, 1981) mapped and described the rocks in the Lancaster and Pepperell areas, overlapping the subbelts; Gore (1976) studied the plutonic rocks near Ayer; Sriramadas (1966), Novotny (1969), Sundeen (1971), and more recently Shride (1976) mapped and described the rocks in the Rockingham subbelt. Correlation of previous nomenclature with that used on the State bedrock map is shown in figure 7. Barosh and others (1977) compiled the existing mapping for their map of the geology of the Boston $1^{\circ} \times 2^{\circ}$ quadrangle. Their divisions are similar to those on the State bedrock map, but their unit designations are based largely on lithology. 


\section{NASHUA SUBBELT}

On Emerson's (1917) geologic map of Massachusetts, the east part of the Merrimack belt coincides with the boundary between his "gneisses and schists of undetermined age," which he informally called "Bolton Gneiss" and is now called the Nashoba Formation (Hansen, 1956) to the east and his Worcester Phyllite, Oakdale Quartzite, Boylston Schist, Paxton Schist, and Merrimack Quartzite to the west (fig. 7), all of which he assigned to the Carboniferous on the basis of plant fossils found at Worcester. Grew $(1970,1973,1976)$ showed that the fossiliferous strata at Worcester are isolated in a faultbounded block and that the Carboniferous age assignment is not applicable to the other rocks mapped as Carboniferous by Emerson and Hansen. Emerson's general arrangement of rock units has persisted, however, and for the most part only new age assignments and minor changes in nomenclature have been made during subsequent years (Goldsmith and others, 1982). However, the detailed stratigraphy of the rocks in the subbelts is still a matter of controversy because of differing interpretations of primary sedimentary features and minor structural features in the rocks and because of difficulty in correlating rock units across faulted boundaries.

Most of the rocks in the Nashua and Rockingham subbelts are interlayered calcareous metasiltstone, metapelite, and subordinate quartzite and marble that represent the eastern limit of outcrop of the largely Silurian and Devonian turbidite and fan basin-fill of the Merrimack synclinorium. In the Nashua subbelt, these strata consist of the Boylston Schist (SObo), Tower Hill Quartzite (St, Sts), Oakdale Formation (So), and Worcester Formation (DSw). Unconformably overlying the turbidite sequence is the Pennsylvanian Coal Mine Brook Formation $(\mathbb{P} \mathrm{cm})$ in the Worcester area.

Primary sedimentary features are preserved in the less metamorphosed rocks. Graded bedding in the coarser beds and thin to cyclic laminar bedding in the finer grained beds, as well as local current bedding and scour, suggest turbidite deposition. Orthoquartzite and metaconglomerate in the lower part of the sequence are interpreted as proximal or shoal deposits, whereas the calcareous metasiltstone and pelite higher in the sequence are interpreted as proximal to distal deposits. Noncalcareous carbonaceous phyllite and schist, characteristic of the upper part of the sequence in the axial area of the Merrimack synclinorium, are less abundant in this eastern margin. On the basis of currentdirection studies, Peck (1976, p. 248) suggested that the sediment came from the west. Sulfidic schists are mostly lacking in the Nashua subbelt, except in the basal part of the sequence.
The Ayer Granite (Sagr) and its phases and granite at Millstone Hill (Dmgr) intrude or appear to intrude the sequence on the east, and the Fitchburg Complex (Dfgr) and its phases intrude the sequence on the west. The metamorphic trough lies between these two areas.

Metamorphism ranges from greenschist to amphibolite facies. Rocks are in the chlorite zone in the northern part of the Nashua subbelt but increase in grade to the south. However, the low-grade trough persists southward into eastern Connecticut (Thompson and Norton, 1968). Rocks on the flanks of the Nashua subbelt may reach andalusite-staurolite or locally sillimanite zone. Minerals typical of regional metamorphism in the metasiltstones in the chlorite and biotite zones are chlorite, biotite, ankerite, and locally calcite or dolomite. Actinolite and actinolitic hornblende, garnet, and locally diopside are found in rocks at higher grades. Epidote is present throughout. The mineralogy tends to give many rocks a gray-green color; however, biotite is characteristically brown or red brown and where abundant tends to give these rocks a purplish or brownish tinge on a fresh surface. Noncalcareous pelites tend to be gray to dark gray due to contained carbonaceous material, but at the higher grades of metamorphism they may be silvery and spangled with prominent muscovite. Pelitic layers in the middle grades of metamorphism may contain andalusite and staurolite. Metasiltstone appears to be thicker bedded and coarser grained (sand size rather than silt size) at higher grades than it is at the lower grades (G.R. Robinson, 1981, p. 27-36), and much of it at higher grades has a salt-and-pepper appearance. The coarse grain size in these areas could be in part a primary sedimentary feature as well as a result of recrystallization. A steep metamorphic gradient exists westward from the Nashoba Formation in the sillimanite zone through andalusite in the Tadmuck Brook Schist (fig. 7) into the rocks of the Nashua subbelt, which are in the chlorite and biotite zones.

\section{BOYLSTON SCHIST (SObo)}

The Boylston Schist (Emerson, 1917; Grew, 1970; Hepburn, 1978) consists of gray to dark-gray sillimanitebearing quartz-muscovite schist and gneiss, containing locally prominent quartzofeldspathic layers as much as $0.5 \mathrm{~m}$ thick, and subordinate rusty-weathering sillimanite-mica schist and tan to light-greenish-gray calc-silicate rock. Some beds of schist contain thin lenses of coticule. The Boylston is estimated to be $1,000 \mathrm{~m}$ thick (Grew, 1973; Hepburn, 1978). The distribution of the Boylston is essentially that shown by Emerson (1917, p. 67-68). Grew (1970) included phyllite in his Boylston Formation (Unit B of Grew, 1973) that we now assign to the Worcester Formation. We now assign Grew's medial 
Nashua subbelt

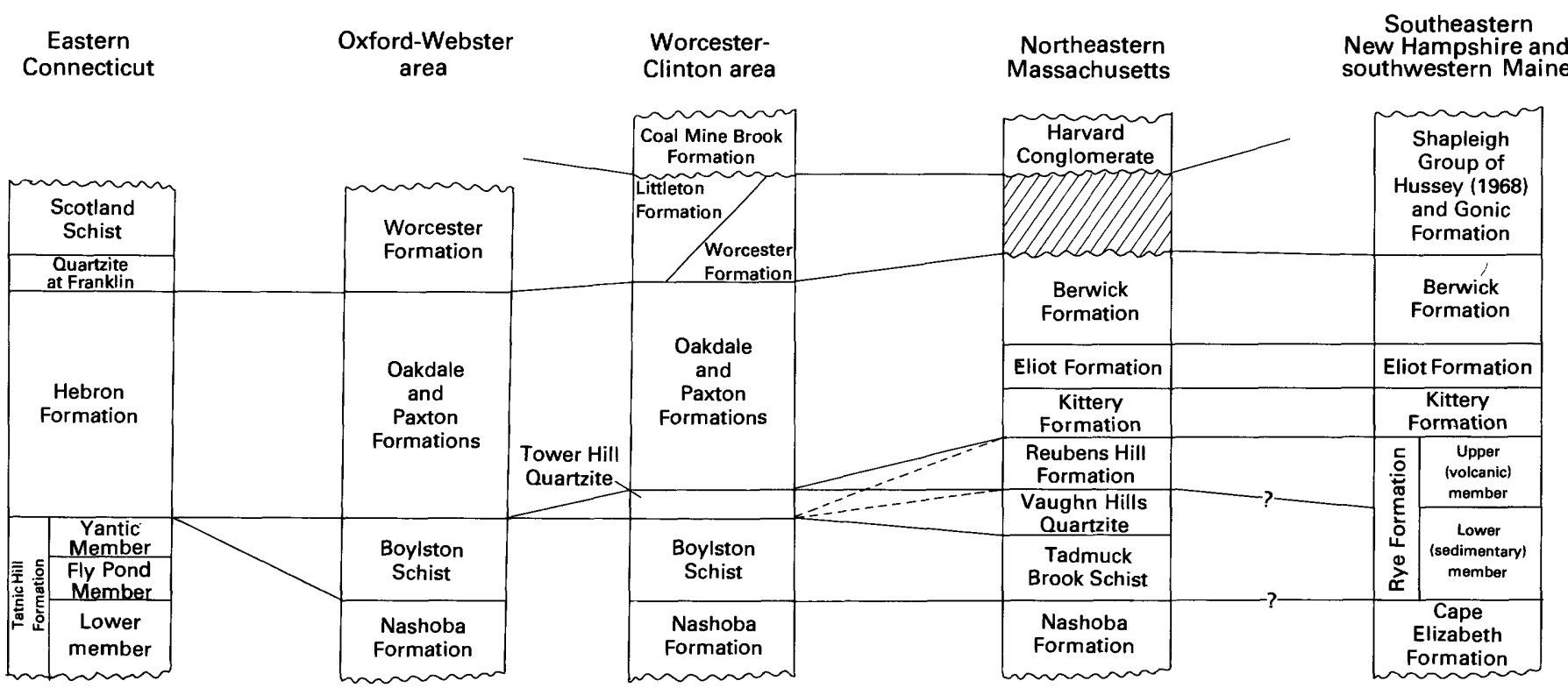

Figure 8.-Columnar sections for the eastern part of the Merrimack belt from eastern Connecticut to southeastern New Hampshire and southwestern Maine. Dashed tielines indicate alternate interpretation. Queried tielines are conjectural.

calc-silicate unit to the Oakdale Formation and have only kept as Boylston his lowest unit, which coincides with part of the Science Park unit of Hepburn (1976). On the State bedrock map, the Boylston forms the base of the sequence from Worcester to Oxford (figs. $3 A, 8$ ). The Boylston lies in a stratigraphic position similar to that of the Tadmuck Brook Schist of the Nashoba zone and possibly part of the Vaughn Hills Quartzite of the Rockingham subbelt (fig. 8). The higher metamorphic grade of the Boylston, in contrast to the typically lower grade of the overlying Oakdale and Worcester Formations, suggests that it could actually be part of the Nashoba zone caught between strands of the ClintonNewbury fault system.

\section{TOWER HILL QUARTZITE (St, Sts)}

Quartzite (St) and schist and phyllite (Sts) between the Boylston Schist and the Oakdale Formation in the Worcester and Clinton areas (fig. $3 B$ ) was named the Tower Hill Quartzite by Grew (1970; Unit C of Grew, 1973). The Tower Hill Quartzite (St) consists of lightgray, finely crystalline quartzite in tabular beds $5 \mathrm{~cm}$ to $1.5 \mathrm{~m}$ thick and minor interbedded dark-gray, carbonaceous laminated phyllite and mica schist that locally contain garnet and chloritoid. The phyllite (Sts) also forms sequences as much as $65 \mathrm{~m}$ thick above and below the main mass of quartzite. Beds of granule and pebble metaconglomerate are found in the Boylston area (Hepburn, 1976) on Green Hill, Tower Hill, and the hill crossed by Pierce St., West Boylston. The thickness of the Tower Hill Quartzite ranges from 0 to $91 \mathrm{~m}$ (Peck, 1976) or $130 \mathrm{~m}$ (Grew, 1973).

Some assignments of previously mapped units have been followed on the State bedrock map; others have not (fig. 7). The Tower Hill is Unit 1 of Peck (1976), which he considered to be the base of the turbidite sequence. The upper part of Grew's (1973) Unit B is shown on the State bedrock map as phyllite (Sts) of the Tower Hill in the Worcester area but is shown as Worcester Formation in the belt from Worcester to Webster (fig. 3A). In support of this assignment in the Worcester area, Grew (1973) described lenses of quartzite in Unit B that are as much as $25 \mathrm{~m}$ thick. The nature of the basal contact of the Tower Hill is not known. As mapped by Peck (1975), it is everywhere a fault except in Clinton (fig. $3 B$ ) and on Green Hill to the south, east of Wachusett Reservoir (W, fig. $3 B$ ), where the quartzite overlies Ayer Granite (Sagr). Emerson (1917, p. 224-226) noted the lack of evidence for intrusion of the Ayer into the Merrimack and Oakdale quartzites. Because of the extensive faulting in the Clinton-Worcester area, it is not certain whether the Tower Hill is equivalent to the Vaughn Hills Quartzite of the Rockingham subbelt or is a quartzite higher in the section. The Tower Hill lies above the Boylston according to the cross section drawn by Grew (1970, p. 117). Hepburn (oral commun., 1978) believed that the Tower Hill lies higher in the section and is equivalent to the quartzite at Franklin in eastern Connecticut, which lies beneath the pelitic Silurian and (or) Devonian Scotland Schist and overlies calcareous and 
dolomitic metasiltstone and schist of the Ordovician and Silurian Hebron Formation.

\section{OAKDALE FORMATION (So)}

The Oakdale Formation (Emerson, 1917; Goldsmith and others, 1982), which conformably overlies the Tower Hill Quartzite (Peck, 1975), consists of interlayered brownish-gray to light-gray ankeritic metasiltstone and greenish-gray, gray, and dark-brown calcareous phyllite in beds $3 \mathrm{~cm}$ to $2 \mathrm{~m}$ thick. Beds are internally laminated and contain cyclic silt-clay couplets. In the actinolite zone of metamorphism, metasiltstone beds contain actinolite. The Oakdale in the Clinton area is $1,220-2,130 \mathrm{~m}$ thick (Peck, 1976); in the Townsend area, it is 2,000-6,000 m thick (G.R. Robinson, 1978, 1981).

The Oakdale forms a large part of the turbidite sequence in the Nashua subbelt and conforms to the eastern part of Emerson's Oakdale Quartzite. The Oakdale extends from Connecticut, where it has been mapped as part of the Ordovician and Silurian Hebron Formation, to the Hollis area, New Hampshire, where it has been mapped as Berwick Formation of the Merrimack Group (Sriramadas, 1966). The Oakdale is shown as stratigraphically underlying the Worcester Formation (DSw) on the State bedrock map. Pease (1972) and Barosh (1976) considered the sequence to be homoclinal and the Worcester to be a large pelitic lens in a westdipping and west-topping Oakdale-Paxton sequence. However, Grew (1973), G.R. Robinson (1981), and Hepburn (1976) gave evidence suggesting that the Oakdale lies in an isoclinal syncline.

The western belt of Emerson's (1917) Oakdale Quartzite from Oakdale north, which we have shown as Paxton Formation on the State bedrock map, was mapped as Oakdale by Grew (1970) and G.R. Robinson (1981) and as gray and brown granofels by Peper and Wilson (1978). However, Peck (1976) distinguished the rock west of the Wekepeke fault (his Unit 5; our Paxton) from the rock east of it (his Unit 2; our Oakdale) on the basis of differences in bedding character. He thought that they might be time-equivalent units but of different depositional regimes (Peck, 1976, p. 244-245). Peper and Wilson (1978) and G.R. Robinson (1981) drew the boundary with the Paxton where bed thickness and grain size increase. This boundary coincides approximately with the sillimanite-andalusite isograd (Peper and Wilson, 1978) and supports the suggestion by Billings (1956) that the difference between Emerson's Paxton and Oakdale is one of metamorphic grade rather than bedding style or original grain size. Emerson $(1917$, p. 60$)$ noted that the Oakdale and Paxton grade into one another west of Worcester. Crosby (1880) depicted the Oakdale and Paxton as equivalents on either side of his Nashua "synclinal." We have elected to show the metasiltstone west of the Wekepeke in the belt north of Oakdale as Paxton for the reasons mentioned in the section on Paxton Formation. We have shown Oakdale west of the Wekepeke fault, however, in the area south of Worcester, following mapping by Barosh $(1974,1977)$ in which the Oakdale is distinguished from the Paxton by the greater amount of interbedded phyllite in the Oakdale.

\section{WORCESTER FORMATION (DSw)}

The Worcester Formation (Emerson, 1889, 1898), a nonsulfidic pelitic and arenaceous unit (figs. $3 B, 7 A, 8$ ), forms an extensive, overall gently west dipping belt north and west of Clinton and a narrower, moderately west dipping belt extending south from Worcester to Oxford. The Worcester Formation comprises most of the rocks mapped by Perry and Emerson (1903) and Emerson (1917) as Worcester Phyllite, except that the fossiliferous rocks of definitive Pennsylvanian age have all been found to be in a separate fault block from the rest of the rock Emerson called the Worcester. The fossiliferous rocks have been renamed the Coal Mine Brook Formation $(\mathbb{P c m})$ (Goldsmith and others, 1982).

The Worcester consists mostly of gray and dark-gray carbonaceous slate and phyllite, in part containing andalusite and chiastolite, and interbedded silt-sized metagraywacke, which is most abundant in the upper part. Beds of gray to brown impure marble, calc-silicate rock, and marble breccia are interbedded sparsely in the slate and phyllite. Beds are tabular and $0.6 \mathrm{~cm}$ to $1.25 \mathrm{~m}$ thick; the thicker beds are in the upper part of the formation. Slate and graywacke beds are internally laminated, and metagraywacke beds are locally crossbedded. The Worcester ranges in thickness from 3,050 to $4,270 \mathrm{~m}$ in the Clinton area (Peck, 1976) and from 2,000 to 3,000 m in the Townsend area (G.R. Robinson, 1978, 1981).

The exact stratigraphic position of the Worcester Formation is uncertain. On the State bedrock map, it is shown as overlying the Oakdale, with which it is conformable (Peck, 1975, 1976). The Worcester Formation is truncated on the west by the Wekepeke fault, and no other formation is known to lie above it. If we assume an upward-younging sequence, the Worcester could be correlative with the Lower Devonian Littleton Formation (Dl) in the Merrimack synclinorium to the west, on the basis of similarity of lithology, or with all or part of the Lower Devonian Gonic Formation or Shapleigh Group of Hussey (1968) along strike in southern Maine. The stratigraphic position of the Worcester at the top of the sequence as indicated by Peck (1975) was questioned by Grew (1973) and G.R. Robinson (1981), who gave evidence from graded beds to suggest that the Worcester underlies the Oakdale. In support of this contention, 
G.R. Robinson (1981) and Hepburn (1976), as mentioned above, have described features suggesting that the Oakdale lies in an east-facing overturned syncline. This interpretation shifts Crosby's synclinal axis from the Worcester to the Oakdale Formation and places the Worcester stratigraphically lower in the section and equivalent to the Tower Hill Quartzite. G.R. Robinson (1981) suggested that the absence of quartzite in the Worcester is because the Worcester is a basinward facies in the overturned limb of this syncline, whereas the quartzite of Tower Hill represents a shoal facies in the normal limb. We have kept this correlation in mind but have shown the Worcester on the State bedrock map as lying above the Oakdale and as partly equivalent to the Littleton (fig. 8). An element of confusion may exist through the similarity of phyllite of the Worcester to phyllite of the Tower Hill (Sts). The Worcester Formation, the phyllite of the Tower Hill Quartzite, and even the Littleton Formation of the Wachusett Mountain subbelt may constitute three or two units or may be all one unit. Grew (1973) and Hepburn (1976) described thin beds of marble alternating with phyllite on the south side of the Wachusett Reservoir, an association recalling the Waterville Formation of Maine (Osberg, 1968). Peck (1976) and Robinson (1981), however, mapping to the north, did not mention beds of marble in their descriptions of the Worcester.

Uncertainty exists about the structural and stratigraphic position of thick pelite units in the turbidite section of the eastern part of the Merrimack synclinorium (see Osberg, 1978). Pelitic units such as the Worcester Formation, the Waterville Formation of Maine, and the Scotland Schist of Connecticut cannot be demonstrated everywhere as infolds of blanket pelites similar to the Devonian Littleton and Seboomook Formations of New Hampshire and Maine. These units may be major lenses of pelitic facies in the turbidite sequence, as suggested by Pease (1972) and Barosh (1976).

\section{COAL MINE BROOK FORMATION ( $\mathbb{P} \mathrm{cm})$}

The Coal Mine Brook Formation ( $P$ cm) (Goldsmith and others, 1982) crops out in two localities near Worcester (fig. 9). One locality, containing an abandoned coal mine (Grew, 1976), is on the property of the Notre Dame Institute, Worcester, and the other is within the City of Worcester. Contact relations of the Pennsylvanian strata with the adjacent Oakdale and Worcester Formations are not visible at the coal mine locality, which is bounded by faults (Grew, 1970, 1973, 1976). Fossil flora found at the coal mine were identified as Middle to Late Pennsylvanian in age (Grew and others, 1970; Lyons and others, 1976). The phyllite and conglomerate beds of the Coal Mine Brook at the other locality are poorly exposed and
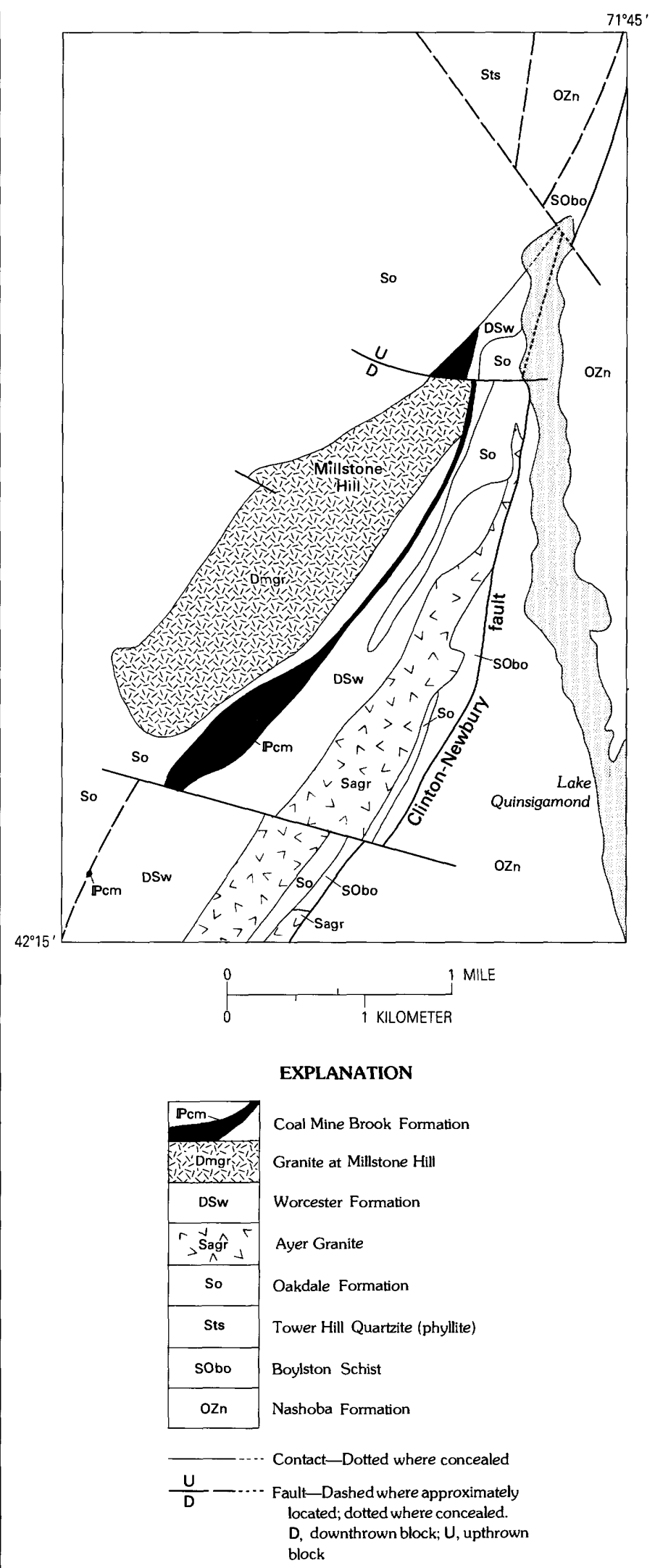

Figure 9.-Geology of the Worcester area. Adapted from Grew (1970). 
unfossiliferous. The conglomerate, however, contains clasts of the adjacent granite at Millstone Hill (Dmgr), which has been dated at $372 \pm 7 \mathrm{Ma}$ and $365 \pm 15 \mathrm{Ma}$ (Zartman and Marvin, this vol., chap. J, table 1). These strata must therefore be of Carboniferous age.

The Coal Mine Brook Formation at the coal mine consists of gray to dark-gray, very carbonaceous slate and phyllite containing a 2-m-thick bed of metaanthracite. The beds at the coal mine, some of which are graded, are $3 \mathrm{~cm}$ to $1 \mathrm{~m}$ thick and total $50 \mathrm{~m}$ in thickness. In Worcester, the Coal Mine Brook consists of interbedded carbonaceous phyllite, white arkose, and polymict conglomerate containing granules and pebbles of phyllite, mica schist, quartzite, granite, and vein quartz. Beds are from $2 \mathrm{~mm}$ to $2 \mathrm{~m}$ thick, and total thickness of the unit is $330 \mathrm{~m}$.

These rocks have undergone low-grade metamorphism. Phyllites contain manganiferous garnet porphyroblasts and have a secondary slip cleavage, but they are not folded as complexly as the Silurian and Devonian strata. All the evidence indicates that the Coal Mine Brook lies unconformably on the older formations in spite of the lack of exposures of the basal contact.

\section{AGE RELATIONS}

The Boylston Schist has been assigned an Ordovician or Silurian age because of its position adjacent to the Proterozoic Z or Ordovician Nashoba Formation to its southeast, because of its high metamorphic grade, like that of the adjacent Nashoba, and because it seems to be part of the overlying turbidite sequence to its northwest. Emerson considered the Boylston to be contactmetamorphosed Worcester Phyllite. From the description of the Boylston, it is more likely correlative with the Tadmuck Brook Schist of the Nashoba zone (fig. 8) or the probably somewhat younger Vaughn Hills Quartzite of the Rockingham subbelt. The Tower Hill Quartzite (St, Sts) and the Oakdale Formation (So) are in contact with the Ayer Granite (Grew, 1973, p. 124; Peck, 1976, p. 242) of Late Ordovician and Early Silurian age (433 $\pm 5 \mathrm{Ma}$; Zartman and Marvin, this vol., chap. J, table 1). If the Ayer is intrusive into the Tower Hill and Oakdale sequence, as we believe, and if the age of the Ayer is accepted as valid, the sequence is probably Ordovician. The sequence is shown as Silurian on the State bedrock map on the basis of regional correlations mentioned earlier. The Worcester Formation is intruded by small stocks of granite or granodiorite of the Early Devonian Fitchburg Complex, which place an upper limit on its age. The Fitchburg Complex has a U-Pb zircon age of $390 \pm 15 \mathrm{Ma}$ and an Rb-Sr age of $402 \pm 11 \mathrm{Ma}$ (Zartman and Marvin, this vol., chap. J, table 1). Because the Worcester is conformable with and physically overlies the Tower Hill and Oakdale, which have been assigned a Silurian age, and because of possible correlation with the Lower Devonian Littleton Formation of New Hampshire, the Worcester has been assigned a Silurian and Early Devonian age on the State bedrock map.

\section{ROCKINGHAM SUBBELT}

Partly calcareous metasiltstone, metasandstone, phyllite, and schist north and west of the Clinton-Newbury fault and east of the northern part of the Nashua subbelt (fig. $3 B$ ) are assigned to the Kittery Formation (SOk), the Eliot Formation (Se), and the Berwick Formation (Sb) of the Merrimack Group (Hitchcock, 1877; Katz, 1917; Billings, 1956; Hussey, 1968) of southeastern Maine and New Hampshire. These formations (fig. $7 B$ ) project into Massachusetts from southeastern New Hampshire along the southerly plunging Rockingham anticlinorium (Billings, 1956; Sriramadas, 1966; Novotny, 1969; Sundeen, 1971). The distribution of the Kittery, Eliot, and Berwick Formations as mapped by Sriramadas (1966), Novotny (1969), and Sundeen (1971) has been modified extensively by the mapping of G.R. Robinson (1981) in the Pepperell area and of Shride (1976; written communs., 1977, 1979) in the Newburyport and Haverhill areas. The lithology of these units is in many respects similar to that of the Oakdale and Paxton Formations. Emerson (1917) called most of these rocks the Merrimack Quartzite, which he equated with his Oakdale Quartzite of the Worcester area. He identified the garnet-grade rocks of the Berwick as gneisses and schists of undetermined age. The Merrimack Group forms the bulk of the strata in the Rockingham subbelt with the addition of the Vaughn Hills Quartzite (SOvh) and its overlying Reubens Hill Formation (SOrh) and the Pennsylvanian(?) Harvard Conglomerate ( $\mathrm{Ph}$ ), which unconformably overlies the sequence. The Vaughn Hills and Reubens Hill are included in the Rockingham subbelt because they appear to project beneath the Merrimack Group northeast of Clinton in the Clinton-Newbury fault zone. However, the two formations do not clearly form a sequence with the Merrimack Group because of the intervening Ayer Granite and faults. The Kittery Formation lies on the west flank of the Rye anticline, which has the Silurian, Ordovician, or older Rye Formation in its core, and thus apparently forms the base of the Merrimack Group. Structural studies indicate that the Eliot and Berwick successively overlie the Kittery to the west (Billings, 1956, p. 42; Hussey, 1968, p. 293).

Metamorphic grade increases progressively through chlorite and biotite zones in the east to garnet zone in the west, but a sharp gradient back to chlorite zone coincides with the contact of the Berwick Formation and the Oakdale Formation to the west in the adjacent Nashua 
subbelt. The boundary marks a change in bedding style and grain size from thin bedded and fine grained (Oakdale) to thick bedded and coarse grained (Berwick).

The Tadmuck Brook Schist (SZtb) was assigned to the Nashoba zone on the State bedrock map because of its composition, a sulfidic pelite, and its high metamorphic grade, although the grade decreases westward within the unit. Because the metamorphism of the Nashoba Formation is considered to be no younger than Late Ordovician, the Tadmuck Brook is most likely Ordovician or older. However, as discussed in the chapter on the stratigraphy of the Nashoba zone (Goldsmith, this vol., chap. F), arguments exist for an unconformable relation between the Nashoba Formation and the Tadmuck Brook Schist (for example, Skehan and Murray, 1980, p. 295). It is possible, then, that the metamorphism of the Tadmuck Brook is younger than Ordovician and the same age as the metamorphism in the adjacent Merrimack belt, which is considered to be Acadian (Late Devonian). If so, the Tadmuck Brook could be part of the turbidite sequence of the east side of the Merrimack belt, and some or all of the unit could be as young as Silurian.

\section{VAUGHN HILLS QUARTZITE (SOvh)}

The Vaughn Hills Quartzite (Hansen, 1956; Grew, 1970; Peck, 1975; Goldsmith and others, 1982) forms the base of the sequence between Shrewsbury and West Chelmsford. Near Shrewsbury the Vaughn Hills and Tadmuck Brook Schist (SZtb) of the Nashoba zone project beneath a slice of Nashoba-zone rocks east of the Rattlesnake Hill fault of the Clinton-Newbury fault system (Hepburn, 1978).

The Vaughn Hills consists of cream- to flesh-colored, fine-grained, thin-bedded quartzite in beds $3 \mathrm{~cm}$ to $1.5 \mathrm{~m}$ thick, interbedded pale-green, locally rusty-weathering, laminated phyllite and mica schist, minor beds of calcsilicate-bearing metawacke, and, in the upper part, partly calcareous chlorite schist. Conglomerate beds are present between Chelmsford and Ayer (Jahns and others, 1959). The unit ranges in thickness from 0 to $100 \mathrm{~m}$.

The identity and stratigraphic position of the Vaughn Hills Quartzite have been subject to several interpretations. Peck (1975) considered the Vaughn Hills to be the upper part of the Tadmuck Brook Schist; similarly, Bell and Alvord (1976) believed that the Tadmuck Brook grades up into the Vaughn Hills. Hansen (1956, p. 26) described gradation of his mica schist facies of the Worcester Formation (now mapped as Tadmuck Brook) into quartzite of the Vaughn Hills. The Vaughn Hills Quartzite is equivalent to part of Skehan and AbuMoustafa's (1976) unnamed units 1 through 12 east of the Rattlesnake Hill fault. Their unit 12, a quartzitic unit, is probably the Vaughn Hills, although Skehan (1969, p.
802) indicated that their unit 1 , which is also a quartzite unit, might be the Vaughn Hills. Unit 1 lies below a sequence consisting largely of schist, units $2-9$, that is the probable equivalent of the Tadmuck Brook Schist. Their quartzite unit is probably equivalent to the lens of quartzite near the base of the Tadmuck Brook shown by Bell and Alvord (1976, fig. 4).

A quartzite, phyllite, and pebble metaconglomerate unit lying west of the Tadmuck Brook Schist and below the Berwick Formation between West Chelmsford and Ayer was mapped by Jahns and others (1959) as Harvard Conglomerate. This unit has been shown as Vaughn Hills Quartzite on the State bedrock map because of its position adjacent to the Tadmuck Brook Schist. Alvord (1975) considered the conglomerate a breccia and mapped the unit as cataclastic rock of the ClintonNewbury fault.

The location of the top of the Vaughn Hills is somewhat uncertain. In the Clinton area, the Vaughn Hills is overlain by the Reubens Hill Formation. The chlorite schist described by Hansen at the top of the Vaughn Hills southeast of Bare Hill Pond (SOvh south of Harvard, fig. $3 B$ ) may be equivalent to part of the overlying Reubens Hill. Nearly everywhere, however, the Vaughn Hills is in fault contact with phases of the Ayer Granite (Sagr, Sacgr) so that it is difficult to establish a sequential relationship with the turbidite sequence west of the Clinton-Newbury fault zone. The Vaughn Hills was apparently included in the Brimfield Schist and Oakdale Quartzite by Emerson (1917).

\section{REUBENS HILL FORMATION (SOrh)}

The Reubens Hill Formation (Skehan, 1967; Goldsmith and others, 1982) lies between the Vaughn Hills Quartzite and the Ayer Granite and lies east of the Clinton fault of Skehan and Abu-Moustafa (1976) of the ClintonNewbury fault system. The Reubens Hill, about $590 \mathrm{~m}$ thick, consists of layered to massive metavolcanic and hypabyssal intrusive rocks. These are, in part, interlayered dark-greenish-gray chlorite-hornblende schist and amphibolite and gray to brownish-gray plagioclasebiotite-quartz schist and biotite-hornblende-plagioclase gneiss and, in part, massive greenish-gray metadiorite and dark-gray hornblende and actinolite rock poor in feldspar. Some amphibolite contains features that are possibly relic pillow structure.

The Reubens Hill has always been readily identifiable because its composition is different from that of adjacent units. It is equivalent to the Diorite of Crosby (1880), the Straw Hollow Diorite of Emerson (1917), the Reubens Hill amphibolite of Skehan (1967), units 13-15 of Skehan and Abu-Moustafa (1976), and the Reubens Hill igneous complex of Peck (1975). Units 13-15 of Skehan and 
Abu-Moustafa contain massive phases principally composed of hornblende and actinolite that suggest a mafic or ultramafic protolith. Peck (1975) mentioned that some of the rock appears to have been derived from pillow lavas and that part of the formation is a massive metadiorite. Layered schist and gneiss in the complex are interpreted by both Peck (1976) and Skehan and Abu-Moustafa (1976) as volcanogenic deposits.

The Reubens Hill occupies only a small area near Clinton and the Wachusett Reservoir within the ClintonNewbury fault zone. The unit is apparently faulted out elsewhere along the east flank of the Merrimack belt, except possibly near the Vaughn Hills (see comments by Thompson and Robinson, 1976, p. 348). Possibly the Reubens Hill appears again in southeastern New Hampshire as the volcanic part of the Ordovician, Silurian, or older Rye Formation (see also Goldsmith, this vol., chap. F, figs. 5, 6).

\section{KITTERY FORMATION (SOk)}

The Kittery Formation (Kittery Quartzite of Katz, 1917; Billings, 1956; Hussey, 1968) is primarily a thinbedded calcareous biotite metasiltstone. In detail, it consists of gray- to greenish-gray feldspathic, calcareous, biotitic metasiltstone; biotite phyllite and schist, which is commonly actinolitic; calc-silicate gneiss; and minor fine-grained quartzite and feldspathic quartzite. A few beds of fine-granule conglomerate lie at the base of thicker graded beds (Novotny, 1969). The finer grained rocks are thinly bedded to laminated; thicker beds show cross lamination, and some are graded. Small-scale scour-and-fill structures and ovoid calcareous concretions are common. The Kittery is $2,350-2,450 \mathrm{~m}$ thick (Hussey, 1968).

The Kittery appears to be intruded by the Newburyport Complex and is truncated to the south along the Clinton-Newbury fault. The Kittery probably rests disconformably (Hussey, 1968, p. 294) on the Ordovician or Silurian, or older, Rye Formation of southeastern New Hampshire, although this contact was shown by Novotny (1969) as a fault (Portsmouth fault) along the west side of the Rye. The Kittery appears to pass upwards or laterally (Billings, 1956, p. 39) into the more pelitic Eliot Formation, although Novotny $(1969$, p. 11) noted a disconformity at one place between the Eliot and the Kittery.

\section{ELIOT FORMATION (Se)}

The Eliot is a dominantly thinly layered pelitic unit as described by Hussey (1968) in Maine, but as mapped by Sundeen (1971) in the Haverhill area, New Hampshire, it includes metasiltstone sequences. The Eliot, $300 \mathrm{~m}$ thick, consists of thinly bedded, dark-gray to dark-green slate and phyllite, commonly dolomitic, and light-gray to lightgray-green to brown, partly calcareous and actinolitebearing metasiltstone (Hussey, 1968; Novotny, 1969).

On the State bedrock map, the wide band of Eliot mapped by Sundeen in the Haverhill area has been narrowed to include only the primarily pelitic facies. The thicker bedded metasiltstone facies mapped by Sundeen has been assigned to the Berwick Formation. A.F. Shride (written commun., 1979) placed the EliotBerwick contact along the Merrimack River east of Haverhill.

\section{BERWICK FORMATION (Sb, Sbs)}

The Berwick in Massachusetts and New Hampshire consists primarily of thin to thick tabular and lenticular beds of calcareous metasiltstone, biotitic metasiltstone, and fine-grained metasandstone. Some layers contain quartz, biotite, and actinolite, others contain diopside, hornblende, and plagioclase. Interbedded with these rocks are small amounts of quartz-muscovite-garnet schist and feldspathic quartzite. Actinolite increases westward at the expense of biotite. In the sillimanite zone, the metasiltstones have a salt-and-pepper appearance on weathered surfaces. Two thick sequences of partly rusty-weathering pyrrhotite- or pyrite-bearing mica schist and phyllite (Sbs) have been shown separately on the State bedrock map (fig. $3 B$ ). The eastern sequence (west of Newburyport) is a black to green pyritiferous phyllite (Sundeen, 1971). The western sequence, located midway between North Chelmsford and Townsend, is a massively bedded, locally cataclastic quartz-rich pyrrhotitic schist containing aggregates of biotite (G.R. Robinson, 1978, 1981). The Berwick is mostly in the garnet zone of metamorphism but in the western part of its outcrop area is in the sillimanite zone. Metamorphism has largely obscured primary sedimentary structures. The unit ranges in thickness from 1,850 to $2,450 \mathrm{~m}$ (Hussey, 1968).

The pyritiferous phyllite as mapped by Sundeen (1971), forming the eastern sequence of Sbs, is a continuation of the Calef Member of the Eliot Formation of Billings (1956). A.F. Shride (written commun., 1976) reported that this phyllite occupies a narrower belt than that shown by Sundeen. Because the enclosing rock is now mapped as Berwick rather than Eliot, the pyritiferous phyllite is assigned to the Berwick Formation. Sundeen considered this phyllite to lie in the east limb of a north-trending anticlinal structure, whose axis would pass west of Haverhill. Shride traced Sundeen's phyllite unit into Massachusetts at Haverhill. The western sequence of Sbs in the east Pepperell area was mapped by G.R. Robinson (1981) as part of his Merrimack 
Formation. These rocks have been assigned to the Berwick Formation on the State bedrock map.

\section{HARVARD CONGLOMERATE $(\mathbb{P h})$}

The Harvard Conglomerate (Burbank, 1876) is nonfossiliferous; it rests unconformably on Ayer Granite (Thompson and Robinson, 1976) of Late Ordovician(?) and Early Silurian age (Zartman and Marvin, this vol., chap. J, table 1). The Harvard consists of polymict conglomerate containing mostly flattened and stretched pebbles of green and gray quartzite less than $10 \mathrm{~cm}$ in length but also pebbles of slate, phyllite, mica schist, and milky quartz, in an argillitic matrix. The conglomerate is in lenticular beds a few centimeters to $1 \mathrm{~m}$ thick. Interbedded with and overlying the conglomerate is gray, green, and pale-purple phyllite containing quartz, chloritoid, chlorite, and white mica. The thickness of the unit is indeterminate because of faulting.

The Harvard has traditionally been correlated with the conglomerate beds of the Pennsylvanian Coal Mine Brook Formation in Worcester because of its apparent unconformity on the older rocks. The Harvard crops out in two localities, both bounded by faults: the classic locality at Pin Hill near Harvard, described by Emerson (1917), Thompson and Robinson (1976), and Gore (1976), and at the northern of the two hills known as Vaughn Hills near Bolton, described by Hansen (1956). At Pin Hill (fig. 1), the conglomerate is clearly unconformable upon Ayer Granite, but at Vaughn Hills to the south, Hansen, who did not recognize the Clinton-Newbury fault, described the conglomerate as part of a sequence from Vaughn Hills Quartzite into phyllite and into Harvard Conglomerate. Reconnaissance by G.R. Robinson, Jr., and Goldsmith in the area of Vaughn Hills indicated not only that quartzite of the Vaughn Hills tongues out into phyllite similar to that of the Tower Hill Quartzite but that the polymict conglomerate mapped by Hansen as Harvard Conglomerate tongues out into the same phyllite. At that time, we interpreted the conglomerate in this area to be a submarine-channel slide deposit near or at the base of the turbidite sequence. The angularity of some rock fragments in the conglomerate was noted by Emerson (1917, p. 66, pl. VIIIB), Hansen (1956), and Thompson and Robinson (1976). However, in most places the quartzite pebbles are flattened, as is clearly seen in the roadside quarry south of Pin Hill. The greenish quartzite beds in the phyllite that is gradational with Harvard Conglomerate were compared by Hansen (1956, p. 25) with the quartzite beds of the Vaughn Hills. The quartzite clasts in the conglomerate beds are generally believed to have been derived from quartzites of the turbidite sequence (Currier and Jahns, 1952). Possibly some of the quartzite clasts in the conglomerate are dismembered thin quartzite beds. Emerson (1917, p. 66), however, described the clasts as consisting of several kinds of quartzite (Oakdale quartzite, Westboro quartzite, and vein quartz) and several kinds of slate. The relations of rocks mapped as Harvard Conglomerate in the past, such as at Vaughn Hills and those mapped by Jahns and others (1959) southwest of West Chelmsford, need to be reexamined to see the differences between the Vaughn Hills and the Harvard and to determine if two conglomerates are present, one Ordovician and Silurian and the other Pennsylvanian.

\section{AGE RELATIONS}

The age of the rocks in the Rockingham subbelt is Ordovician and (or) Silurian and older. A Silurian age can be inferred on the basis of correlation with the Silurian Vassalboro Formation and associated units in central Maine (Hussey, 1968; Osberg, 1968; Ludman, 1976). The age assignments on the State bedrock map are based partly on this correlation and partly on the similarity of the strata with the Silurian formations, such as the Paxton, in central Massachusetts. An Ordovician or older age, however, has been determined for at least part of the Merrimack Group largely on the basis of the age of intrusions into the sequence (Zartman and Marvin, this vol., chap. J; Gaudette and others, 1984). Zartman and Marvin (this vol., chap. J, table 1) reported a U-Pb age of $455 \pm 15 \mathrm{Ma}$ on zircon from granodiorite of the Newburyport Complex. The Newburyport is believed to have intruded the Kittery and Eliot Formations (Novotny, 1969), and the map pattern in the Newburyport East and West quadrangles (Shride, 1976) seems to support this interpretation. A search of the literature reveals no observation of an actual intrusive contact or of inclusions of Kittery or Eliot in the Newburyport Complex, nor does the pattern of metamorphic isograds in that area seem to conform to the shape of the complex. However, the U-Pb age of the Newburyport Complex and similar $\mathrm{Rb}-\mathrm{Sr}$ isotopic ages on intrusions into the Kittery and Eliot Formations of the Merrimack Group farther north in New Hampshire (Gaudette and others, 1984) show that part of the Merrimack Group, and probably all of it, is Ordovician or older. D.R. Wones (oral commun., 1979) correlated the Merrimack Group with pre-Silurian rocks of similar lithology that he studied in the Penobscot Bay area of Maine (Stewart and Wones, 1974).

On the State bedrock map, the Kittery was assigned an Ordovician or Silurian age because of the possible Ordovician age of the Newburyport Complex. At the time the map was prepared, the isotopic age of the Newburyport Complex was less certainly Ordovician $(445 \pm 15 \mathrm{Ma}$, Zartman and Naylor, written commun., 1978), and the dating of intrusions farther north in New 
Hampshire had not begun. The Eliot, even though it is in contact with the Newburyport Complex, was assigned a Silurian age through correlation with the Silurian Vassalboro Formation in central Maine. The Berwick was similarly assigned a Silurian age.

Both the Vaughn Hills Quartzite and the Reubens Hill Formation are assigned an Ordovician or Silurian age because of their position at the base of the section or below the turbidite sequence and because the Vaughn Hills seems to be in a sequence with the Tadmuck Brook Schist of Proterozoic Z, Ordovician, or Silurian age. Their relation to the Ayer Granite could not be established.

The radiometric ages discussed above suggest that the strata in the Nashua and Rockingham subbelts are Ordovician or older, which is older than expected from lithologic correlation with the Silurian strata to the north in Maine. No stratigraphic break is discernible between the rocks of the Nashua and Rockingham subbelts and the Silurian and Devonian rocks in the synclinorium to the west, however. Probable age range of the sequence at present is from Cambrian and (or) Ordovician to Early Devonian although Cambrian and (or) Ordovician to Silurian is most likely. J.B. Lyons and others (1982, p. 54) suggested a Proterozoic age for the sequence on the basis of 1,188-Ma ages of detrital zircons from the Berwick Formation (Aleinikoff, 1978). Olszewski and others (1984) and Bothner and others (1984) supported a Proterozoic $\mathrm{Z}$ age for the sequence because of its apparent conformity with the Massabesic Gneiss Complex, which contains rock dated at $646 \mathrm{Ma}$ (Aleinikoff and others, 1979; Lyons and others, 1982). The Massabesic Gneiss Complex is similar in part to rock in the Nashoba zone and has produced similar isotopic ages; however, we feel that the rocks of the Merrimack Group are a sequence that differs in lithology and depositional style from the rocks of the Nashoba zone and the Massabesic Gneiss Complex. The problem remains concerning the similarity in lithology and apparent continuity, in places, of the Merrimack Group sequence, if Proterozoic Z, with the Oakdale-Worcester and Paxton-Littleton sequences in the rest of the Merrimack belt, which are mapped as Silurian to Lower Devonian.

\section{DISCUSSION}

At the present time, uncertainties connected with the stratigraphy along the east flank of the Merrimack synclinorium are so numerous that one can only speculate as to the actual stratigraphic relations. On the basis of the structure and topping evidence available, several correlation schemes could be prepared. One is based on G.R. Robinson's (1978) evidence that the Worcester underlies the Oakdale and is equivalent to the Tower
Hill; another on Pease and Barosh's (1981) contention that the Scotland Schist (equals Worcester) is a pelitic lens in the Hebron Formation (equals Oakdale and Paxton). Our preferred scheme and that shown on the State bedrock map is shown in figure 8 . We believe that the Tadmuck Brook, Vaughn Hills, Reubens Hill, and Boylston are the base of the section and are probably Ordovician or older in age. We believe that the BoylstonOakdale-Worcester sequence in the narrow belt from Worcester to Webster is a greatly compressed section of that north of Worcester. It is possible, however, that reexamination of this sequence might show that it is equivalent to the upper units of the Tatnic Hill Formation, so that the Oakdale is equivalent to the calcsilicate-bearing Fly Pond Member of the Tatnic Hill and the Worcester as mapped is equivalent to the twomica-schist-bearing Yantic Member. The Boylston would be equivalent to part of the lower member of the Tatnic Hill. The Boylston, as described, contains several different lithologies including calc-silicate-bearing beds (Grew, 1973; Hepburn, 1976), as does the Vaughn Hills (Hepburn, 1976). Thus, lithologies seem to interfinger near the base of the section. The adjacent Nashoba Formation also contains calc-silicate-bearing zones (Bell and Alvord, 1976). The Boylston Schist lithologically most resembles the Tadmuck Brook Schist, and the Tower Hill Quartzite resembles the Vaughn Hills Quartzite. As mapped by Peck (1975), the Tower Hill lies west of the ClintonNewbury fault zone and the belt of Ayer Granite, whereas the Vaughn Hills lies within and east of the Clinton-Newbury fault zone and the belt of Ayer Granite, so that the Tower Hill and the Vaughn Hills never meet. J.C. Hepburn (oral commun., 1979) suggested that the Tower Hill occupies a position similar to that of the Franklin Quartzite in Connecticut. The latter lies in upright position beneath graded metagraywacke beds of the Scotland Schist and above calcareous metasiltstone and phyllite assigned to the Hebron Formation. The Hebron Formation also lies above the Scotland, either in normal stratigraphic order (Pease and Barosh, 1981) or in an overturned section (Dixon and Lundgren, 1968). In the Clinton area, the Tower Hill lies in upright position beneath the calcareous metasiltstone and phyllite of the Oakdale Formation, and the Worcester Formation overlies the Oakdale in normal stratigraphic order (Peck, 1976) or in an overturned section (G.R. Robinson, 1981). If the Scotland Schist is merely a pelitic lens in the Hebron Formation, as Pease and Barosh (1981) stated, the Scotland Schist could be anywhere in the Hebron section and the correlation of the Tower Hill with the Franklin Quartzite could be more reasonably made. The Reubens Hill Formation of the Rockingham subbelt must wedge out between the Tower Hill and the Oakdale, an interpretation for which there is no evidence, or, if the 
Tower Hill does not correlate with the Vaughn Hills but lies higher in the section, as Hepburn believed, the Reubens Hill and the Vaughn Hills wedge out above the Boylston Schist. The Tower Hill, then, might correlate across into the Rockingham subbelt with the Kittery Formation (part of Emerson's (1917) Oakdale Quartzite with part of Katz's (1917) Kittery Quartzite). A correlation, not strongly held by us, of the Reubens Hill Formation, Vaughn Hills Quartzite, and Tadmuck Brook Schist of the Rockingham subbelt with the Rye Formation of southeastern New Hampshire and southwestern Maine (fig. 8) results from the position of the Rye with respect to the Kittery Formation. An alternative correlation is presented by Goldsmith (this vol., chap. F), in which the Rye is correlated with the Marlboro Formation of the Nashoba zone. The Reubens Hill Formation is a key unit, worth more study, in making a correlation between the Rye, the Marlboro, and the lower part of the sequence in the Rockingham subbelt.

On the basis of lithology and what little we know of the sequence, the rocks of the Nashua and Rockingham subbelts should not have different nomenclatures. The Paxton is much like the Berwick in lithology, and the Eliot and Kittery are somewhat like the Oakdale. The Eliot and Oakdale represent pelitic facies, rarely at high grade however, so that contained micas would not have been converted to less hydrous phases to produce a less schistose rock, like much of the Berwick.

The formations are largely distinguished on the basis of bedding style, grain size, and mica content, which probably represent differences in sedimentary facies, as well as in degree of metamorphism. A single formational name could very well apply to the whole sequence, in the same way as the Hebron Formation is used in Connecticut (Rodgers, 1985). Ideally, as the Merrimack terminology has historical precedence (Hitchcock, 1877; Katz, 1917; Billings, 1956; Hussey, 1968) over Oakdale and Paxton (Perry and Emerson, 1903; Emerson, 1917) in Massachusetts and over Hebron Formation (Rice and Gregory, 1906; Gregory and Robinson, 1907) in Connecticut, it should be applied throughout the region. Unfortunately, the subunits of the Merrimack Group have not been clearly defined in southeastern New Hampshire in the zone between southeastern Maine and Massachusetts. Formation boundaries are drawn in different places by different people. Rather than use formational names for these units, the best approach might be to call the sequence Merrimack Formation, rather than Group, as G.R. Robinson (1981) has done. This formation could then be subdivided into members on the basis of differences in sedimentary facies characteristics recognized beneath the metamorphic overprint. A somewhat arbitrary boundary has been established on the State bedrock map between units certainly of the Merrimack
Group and units like the Oakdale and Paxton, which are well established by Emerson in Massachusetts. We have chosen to carry Emerson's terminology as far as possible, except that Emerson's western belt of Oakdale is now assigned to the Paxton.

We have not here suggested a revised nomenclature. A unified study of the stratigraphy and structure along the east side of the Merrimack belt in Massachusetts is needed in order to better understand the relations before the nomenclature can be revised. This study should be tied in closely with mapping in the same belt in southeastern New Hampshire and southern Maine.

\section{REFERENCES CITED}

Aleinikoff, J.N., 1978, Structure, petrology and U-Th-Pb geochronology in the Milford $\left(15^{\prime}\right)$ quadrangle, New Hampshire: Hanover, N.H., Dartmouth College, Ph.D. thesis, 247 p.

Aleinikoff, J.N., Zartman, R.E., and Lyons, J.B., 1979, U-Th-Pb geochronology of the Massabesic Gneiss and the granite near Milford, south-central New Hampshire-New evidence for Avalonian basement and Taconic and Alleghenian disturbances in eastern New England: Contributions to Mineralogy and Petrology, v. 71 , no. 1, p. 1-11.

Alvord, D.C., 1975, Preliminary bedrock geologic maps of the Westford and Billerica quadrangles, Middlesex County, Massachusetts: U.S. Geological Survey Open-File Report 75-387, 12 p., 2 pls., scale 1:24,000.

Barosh, P.J., 1974, Preliminary bedrock geologic map of the Webster quadrangle, Massachusetts-Connecticut: U.S. Geological Survey Open-File Report 74-192, 2 p., 1 pl., scale 1:24,000.

-1976, Stratigraphy of the Webster-Worcester region, Massachusetts, in New England Intercollegiate Geological Conference, 68th annual meeting, Boston, Mass., Oct. 8-10, 1976, Geology of southeastern New England; a guidebook for field trips to the Boston area and vicinity: Princeton, N.J., Science Press, p. 352-365.

-1977, Preliminary map showing bedrock geology superposed on aeromagnetic base map of the Worcester region, Massachusetts, Connecticut, Rhode Island: U.S. Geological Survey Open-File Report 77-131, 46 p., 2 pls., scale 1:125,000.

Barosh, P.J., Fahey, R.J., and Pease, M.H., Jr., 1977, Preliminary compilation of the bedrock geology of the land area of the Boston $2^{\circ}$ sheet, Massachusetts, Connecticut, Rhode Island, and New Hampshire: U.S. Geological Survey Open-File Report 77-285, 142 p., 1 pl., scale 1:125,000.

Bell, K.G., and Alvord, D.C., 1976, Pre-Silurian stratigraphy of northeastern Massachusetts, in Page, L.R., ed., Contributions to the stratigraphy of New England: Geological Society of America Memoir 148, p. 179-216.

Berry, H.N., IV, 1985, The Silurian Smalls Falls Formation in southcentral Massachusetts and adjacent Connecticut [abs.]: Geological Society of America Abstracts with Programs, v. 17, no. 1, p. 4.

Billings, M.P., 1956, The geology of New Hampshire; Part 2, Bedrock geology: Concord, N.H., New Hampshire State Planning and Development Commission, 203 p.

Bothner, W.A., Boudette, E.L., Fagan, T.J., Gaudette, H.E., Laird, Jo, and Olszewski, W.J., 1984, Geologic framework of the Massabesic anticlinorium and the Merrimack trough, southeastern New Hampshire, in New England Intercollegiate Geological Confer- 
ence, 76th Annual Meeting, Danvers, Mass., Oct. 12-14, 1984: Salem, Mass., Salem State College, Department of Geological Sciences, p. 186-206.

Burbank, L.S., 1876, On the conglomerate of Harvard, Massachusetts: Boston Society of Natural History Proceedings, v. 18, p. 224-225.

Crosby, W.O., 1880, Contributions to the geology of eastern Massachusetts: Boston Society of Natural History Occasional Papers, no. $3,286 \mathrm{p}$.

Currier, L.W., and Jahns, R.H., 1952, Geology of the "Chelmsford Granite" area; Guidebook for field trips in New England, Nov. 10-12: New York, Geological Society of America, p. 105-117.

Dean, C.S., 1976, Stratigraphy and structure of the Sunapee septum, southwestern New Hampshire: Cambridge, Mass., Harvard University, $\mathrm{Ph} . \mathrm{D}$. thesis, $248 \mathrm{p}$.

Dixon, H.R., 1974, Bedrock geologic map of the Thompson quadrangle, Windham County, Connecticut, and Providence County, Rhode Island: U.S. Geological Survey Geologic Quadrangle Map GQ-1165, scale 1:24,000.

Dixon, H.R., and Lundgren, L.W., Jr., 1968, Structure of eastern Connecticut, in Zen, E-an, White, W.S., Hadley, J.B., and Thompson, J.B., Jr., eds., Studies of Appalachian geologyNorthern and maritime: New York, Interscience Publishers, p. 219-229.

Emerson, B.K., 1889, Porphyritic and gneissoid granites in Massachusetts: Geological Society of America Bulletin, v. 1, p. 559-561.

-1898, Geology of old Hampshire County, Massachusetts, comprising Franklin, Hampshire, and Hampden Counties: U.S. Geological Survey Monograph 29, $790 \mathrm{p}$.

-1917, Geology of Massachusetts and Rhode Island: U.S. Geological Survey Bulletin 597, $289 \mathrm{p}$.

Fahlquist, F.E., 1935, Geology of the region in which Quabbin Aqueduct and Quabbin Reservoir are located; Appendix to Report of Chief Engineer, Annual Report of the Metropolitan District Water Supply Commission: Massachusetts Public Document No. 147, $47 \mathrm{p}$.

Field, M.T., 1975, Bedrock geology of the Ware area, central Massachusetts: University of Massachusetts Geology Department Contribution No. $22,186 \mathrm{p}$.

Fowler-Billings, K., 1949, Geology of the Monadnock region of New Hampshire: Geological Society of America Bulletin, v. 60, no. 8, p. $1249-1280$.

Gaudette, H.E., Bothner, W.A., Laird, Jo, Olszewski, W.J., Jr., and Cheatham, M.M., 1984, Late Precambrian/Early Paleozoic deformation and metamorphism in southeastern New Hampshire, confirmation of an exotic terrane [abs.]: Geological Society of America Abstracts with Programs, v. 16, no. 6, p. 516.

Goldsmith, Richard, Grew, E.S., Hepburn, J.C., and Robinson, G.R., 1982, Formation names in the Worcester area, Massachusetts: U.S. Geological Survey Bulletin 1529-H, p. 43-56.

Gore, R.Z., 1976, Ayer crystalline complex of Ayer, Harvard, and Clinton, Massachusetts, in Lyons, P.C., and Brownlow, A.H., eds., Studies in New England geology: Geological Society of America Memoir 146, p. 103-124.

Greene, R.C., 1970, The geology of the Peterborough quadrangle, New Hampshire: New Hampshire Department of Resources and Economic Development Bulletin 4, 88 p.

Gregory, H.E., and Robinson, H.H., 1907, Preliminary geological map of Connecticut: Connecticut Geological and Natural History Survey Bulletin 7, $39 \mathrm{p}$.

Grew, E.S., 1970, Geology of the Pennsylvanian and prePennsylvanian rocks of the Worcester area, Massachusetts: Cambridge, Mass., Harvard University, Ph.D. thesis, $263 \mathrm{p}$.

-1973, Stratigraphy of the Pennsylvamian and pre-Pennsylvamian rocks of the Worcester irea, Massachusetts: American Journal of Science, v. 273, p. 113-129.
1976, Pennsylvanian rocks of east-central Massachusetts, in New England Intercollegiate Geological Conference, 68th Annual Meeting, Boston, Mass., Oct. 8-10, 1976, Geology of southeastern New England; a guidebook for field trips to the Boston area and vicinity: Princeton, N.J., Science Press, p. 383-404.

Grew, E.S., Mamay, S.H., and Barghoorn, E.S., 1970, Age of plant fossils from the Worcester coal mine, Worcester, Massachusetts: American Journal of Science, v. 268, no. 2, p. 113-126.

Guidotti, C.V., Cheney, J.T., and Conatore, P.D., 1975, Coexisting cordierite, biotite and chlorite from the Rumford quadrangle, Maine: Geology, v. 3, p. 147-148.

Guidotti, C.V., Cheney, J.T., and Guggenheim, Stephen, 1977, Distribution of titanium between coexisting muscovite and biotite in pelitic schists from northwestern Maine: American Mineralogist, v. 62, p. $438-448$.

Hansen, W.R., 1956, Geology and mineral resources of the Hudson and Maynard quadrangles, Massachusetts: U.S. Geological Survey Bulletin 1038, $104 \mathrm{p}$.

Hatch, N.L., Jr., Moench, R.H., and Lyons, J.B., 1983, SilurianLower Devonian stratigraphy of eastern and south-central New Hampshire; extensions from western Maine: American Journal of Science, v. 283, p. 739-761.

Hatch, N.L., Jr., Robinson, Peter, and Stanley, R.S., 1988, Stratigraphy of the Connecticut Valley belt, in Hatch, N.L., Jr., ed., The bedrock geology of Massachusetts: U.S. Geological Survey Professional Paper 1366, p. B1-B34.

Hatch, N.L., Jr., Zen, E-an, Goldsmith, Richard, Ratcliffe, N.M., Robinson, Peter, Stanley, R.S., and Wones, D.R., 1984, Lithotectonic assemblages as portrayed on the new bedrock geologic map of Massachusetts: American Journal of Science, v. 284, p. 1026-1034.

Heald, M.T., 1950, Structure and petrology of the Lovewell Mountain quadrangle, New Hampshire: Geological Society of America Bulletin, v. 61 , p. $43-89$.

Hepburn, J.C., 1976, Lower Paleozoic rocks west of the ClintonNewbury fault zone, Worcester area, Massachusetts, in New England Intercollegiate Geological Conference, 68th Annual Meeting, Boston, Mass., Oct. 8-10, 1976, Geology of southeastern New England; a guidebook for field trips to the Boston area and vicinity: Princeton, N.J., Science Press, p. 366-382.

1978, Preliminary reconnaissance bedrock geologic map of the Shrewsbury quadrangle, Worcester County, Massachusetts: U.S. Geological Survey Open-File Report 78-951, 14 p., 1 pl., scale $1: 24,000$.

Hitchcock, C.H., 1877, Geology of New Hampshire, v. 2: Concord, New Hampshire, E.A. Jenks, State Printer, 621 p.

Hussey, A.M., II, 1968, Stratigraphy and structure of southwestern Maine, in Zen, E-an, White, W.S., Hadley, J.B., and Thompson, J.B., Jr., eds., Studies of Appalachian geology-Northern and maritime: New York, Interscience Publishers, p. 291-301.

Jahns, R.H., Willard, M.E., and White, W.S., 1959, Preliminary bedrock geologic map of the Lowell-Westford area, Mass.: U.S. Geological Survey Open-File Report.

Katz, F.J., 1917, Stratigraphy in southwestern Maine and southeastern New Hampshire: U.S. Geological Survey Professional Paper 108, p. $165-177$.

Ludman, Allan, 1976, Fossil-based stratigraphy in the Merrimack synclinorium, central Maine, in Page, L.R., ed., Contributions to the stratigraphy of New England: Geological Society of America Memoir 148, p. 65-78.

Lyons, J.B., Boudette, E.L., and Aleinikoff, J.N., 1982, The Avalonian and Gander zones in central eastern New England, in St-Julien, Pierre, and Beland, Jacques, eds., Major structural zones and faults of the northern Appalachians: Geological Association of Canada Special Paper 24, p. 43-66. 
Lyons, P.C., Tiffney, Bruce, and Cameron, Barry, 1976, Early Pennsylvanian age of the Norfolk basin, southeastern Massachusetts, based on plant megafossils, in Lyons, P.C., and Brownlow, A.H., eds., Studies in New England geology: Geological Society of America Memoir 146, p. 181-200.

Malinconico, M.A.L., 1982, Stratigraphy and structure of the southeast Rumney 15-minute quadrangle, New Hampshire: Hanover, N.H., Dartmouth College, M.A. thesis, 246 p.

Moench, R.H., 1971, Geologic map of the Rangeley and Phillips quadrangles, Franklin and Oxford Counties, Maine: U.S. Geological Survey Miscellaneous Investigations Series Map I-605, scale $1: 62,500$.

Moench, R.H., and Boudette, E.L., 1970, Stratigraphy of the northwest limb of the Merrimack synclinorium in the Kennebago Lake, Rangeley, and Phillips quadrangles, western Maine, Rangeley, Maine, in New England Intercollegiate Geological Conference, 62d Annual Meeting, Oct. 2-4, 1970, Guidebook for field trips in the Rangeley Lakes-Dead River basin region, western Maine: Syracuse, N.Y., Syracuse University Department of Geology, p. 1-25.

Moore, G.E., Jr., 1978, Preliminary bedrock, surficial, and structural data maps of the Southbridge quadrangle, Massachusetts and Connecticut: U.S. Geological Survey Open-File Report 78-220, 81 p., 1 pl., scale 1:24,000.

Nelson, C.E., 1975, Structure and petrology of the Thorndike Pond area, southwestern New Hampshire: Hanover, N.H., Dartmouth College, M.A. thesis, $76 \mathrm{p}$.

Nielson, D.L., 1981, The bedrock geology of the Hillsboro quadrangle, New Hampshire: New Hampshire Department of Resources and Economic Development Bulletin 8, 76 p.

Novotny, R.F., 1969, Geology of the sea coast region of New Hampshire: Concord, N.H., New Hampshire Division of Economic Development Quadrangle Report, $46 \mathrm{p}$.

Olszewski, W.J., Jr., Gaudette, H.E., Bothner, W.A., Laird, Jo, and Cheatham, M.M., 1984, The Precambrian(?) rocks of southeastern New Hampshire-A forgotten land [abs.]: Geological Society of America Abstracts with Programs, v. 16, no. 1, p. 54.

Osberg, P.H., 1968, Stratigraphy, structural geology, and metamorphism of the Waterville-Vassalboro area, Maine: Maine Geological Survey Bulletin 20,64 p.

-1978, Synthesis of the geology of the northeastern Appalachians, USA, in International Geologic Correlation Program Project 27, Contribution No. 1, Caledonian-Appalachian orogen of the North Atlantic region: Geological Survey of Canada Paper 78-13, p. $137-147$.

-1980, Stratigraphic and structural relations in the turbidite sequence of south-central Maine, in New England Intercollegiate Geological Conference, 72d Annual Meeting, Presque Isle, Maine, Oct. 10-13, 1980, A guidebook to the geology of northeastern Maine and neighboring New Brunswick: Chestnut Hill, Mass., Boston College Press, p. 278-296.

Pease, M.H., Jr., 1972, Geologic map of the Eastford quadrangle, Windham and Tolland Counties, Connecticut: U.S. Geological Survey Geologic Quadrangle Map GQ-1023, scale 1:24,000.

Pease, M.H., Jr., and Barosh, P.J., 1981, Distribution and structural significance of the Oakdale Formation in northeastern Connecticut, in New England Intercollegiate Geological Conference, 73d Annual Meeting, Kingston, R.I., Oct. 16-18, 1981, Guidebook to geologic field studies in Rhode Island and adjacent areas: Kingston, R.I., University of Rhode Island, p. 17-34.

Peck, J.H., 1975, Preliminary bedrock geologic map of the Clinton quadrangle, Worcester County, Mass.: U.S. Geological Survey Open-File Report 75-658, 30 p., 3 pls., scale 1:24,000.
1976, Silurian and Devonian stratigraphy in the Clinton quadrangle, central Massachusetts, in Page, L.R., ed., Contributions to the stratigraphy of New England: Geological Society of America Memoir 148, p. 241-252.

Peper, J.D., and Pease, M.H., 1976, Summary of stratigraphy in the Brimfield area, Connecticut and Massachusetts, in Page, L.R., ed., Contributions to the stratigraphy of New England: Geological Society of America Memoir 148, p. 253-270.

Peper, J.D., Pease, M.H., Jr., and Seiders, V.M., 1975, Stratigraphic and structural relationships of the Brimfield Group in northeastcentral Connecticut and adjacent Massachusetts: U.S. Geological Survey Bulletin 1389, $31 \mathrm{p}$.

Peper, J.D., and Wilson, F.A., 1978, Reconnaissance bedrock geologic map of the Fitchburg quadrangle and part of the Ashby quadrangle, north-central Massachusetts: U.S. Geological Survey Miscellaneous Field Studies Map MF-959, scale 1:24,000.

Perry, J.H., and Emerson, B.K., 1903, Geology of Worcester, Massachusetts: Worcester, Mass., Worcester Natural History Society, $166 \mathrm{p}$.

Peterson, V.L., 1984, The structure and stratigraphy of the bedrock in the Ashburnham-Ashby area, north-central Massachusetts: University of Massachusetts, Department of Geology and Geography Contribution No. 47, $182 \mathrm{p}$.

Pomeroy, J.S., 1975, Preliminary bedrock geologic map of the East Brookfield quadrangle, Worcester County, Massachusetts: U.S. Geological Survey Open-File Report 75-530, 12 p., 2 pls., scale $1: 24,000$.

1977, Bedrock geologic map of the Warren quadrangle, Worcester, Hampden, and Hampshire Counties, Massachusetts: U.S. Geological Survey Geologic Quadrangle Map GQ-1358, scale $1: 24,000$.

Rice, W.N., and Gregory, H.E., 1906, Manual of the geology of Connecticut: Connecticut State Geological and Natural History Survey Bulletin 6, $273 \mathrm{p}$.

Richardson, S.M., 1975, Fe-Mg exchange among garnet, cordierite, and biotite during retrograde metamorphism: Cambridge, Mass., Harvard University, Ph.D. thesis, 225 p.

Robinson, G.R., Jr., 1978, Bedrock geology of the Pepperell, Shirley, Townsend quadrangles and part of the Ayer quadrangle, Massachusetts and New Hampshire: U.S. Geological Survey Miscellaneous Field Studies Map MF-957, scale 1:24,000.

-1981, Bedrock geology of the Nashua River area, Massachusetts-New Hampshire: U.S. Geological Survey Open-File Report $81-470,172 \mathrm{p}$.

Robinson, Peter, 1963, Gneiss domes of the Orange area, Massachusetts and New Hampshire: Cambridge, Mass., Harvard University, Ph.D. thesis, $253 \mathrm{p}$.

1979, Bronson Hill anticlinorium and Merrimack synclinorium in central Massachusetts, in Skehan, J.W., and Osberg, P.H., eds., The Caledonides in the U.S.A., Geological excursions in the northeast Appalachians, Caledonide Project 27: Weston, Mass., Weston Observatory, p. 126-174.

Robinson, Peter, and Tracy, R.J., 1977, Sulfide-silicate-oxide equilibria in sillimanite-K-feldspar grade pelitic schists, central Massachusetts [abs.]: Eos, v. 58, p. 524 .

Robinson, Peter, Field, M.T., and Tucker, R.D., 1982a, Stratigraphy and structure of the Ware-Barre area, central Massachusetts, in New England Intercollegiate Geological Conference, 74th Annual Meeting, Storrs, Conn., Oct. 2-3, 1982, Guidebook for field trips in Connecticut and south-central Massachusetts: Connecticut Geological and Natural History Survey Guidebook 5, p. 341-373.

Robinson, Peter, Tracy, R.J., Hollocher, K.T., and Dietsch, C.W., $1982 \mathrm{~b}$, High grade Acadian regional metamorphism in southcentral Massachusetts, in New England Intercollegiate Geological Conference, 74th Annual Meeting, Storrs, Conn., Oct. 2-3, 1982, 
Guidebook for field trips in Connecticut and south-central Massachusetts: Connecticut Geological and Natural History Survey Guidebook 5, p. 289-340.

Robinson, Peter, Tracy, R.J., and Tucker, R.D., 1978, The Acadian (Devonian) metamorphic high of central Massachusetts [abs.]: Geological Society of America Abstracts with Programs, v. 10, no. 7, p. $479-480$.

Rodgers, John, 1970, The tectonics of the Appalachians: New York, Interscience Publishers, $271 \mathrm{p}$.

1985, Bedrock geological map of Connecticut: Hartford, Conn., Connecticut Geological and Natural History Survey, scale 1:125,000.

Seiders, V.M., 1976, Bedrock geologic map of the Wales quadrangle, Massachusetts and Connecticut: U.S. Geological Survey Geologic Quadrangle Map GQ-1320, scale 1:24,000.

Shride, A.F., 1976, Preliminary maps of the bedrock geology of the Newburyport East and Newburyport West quadrangles, Massachusetts-New Hampshire: U.S. Geological Survey Open-File Report 76-488, 4 pls., scale 1:24,000.

Skehan, J.W., 1967, Geology of the Wachusett-Marlborough tunnel, east-central Massachusetts, a preliminary report, in Farquhar, 0 . ed., Economic geology in Massachusetts Conference, Amherst, Proceedings: Amherst, Mass., Massachusetts University Graduate School, p. 237-244.

1969, Tectonic framework of southern New England and eastern New York, in Kay, Marshall, ed., North Atlantic-Geology and continental drift, a symposium: American Association of Petroleum Geologists Memoir 12, p. 793-814.

Skehan, J.W., and Abu-Moustafa, A.A., 1976, Stratigraphic analysis of rocks exposed in the Wachusett-Marlborough tunnel, east-central Massachusetts, in Page, L.R., ed., Contributions to the stratigraphy of New England: Geological Society of America Memoir 148, p. 217-240.

Skehan, J.W., and Murray, D.P., 1980, Geologic profile across southeastern New England: Tectonophysics, v. 69, p. 285-316.

Smith, P.V., and Barosh, P.J., 1981, Structural geology of the Nashua trough, southern New Hampshire [abs.]: Geological Society of America Abstracts with Programs, v. 13, no. 3, p. 178.

Sriramadas, Alaru, 1966, Geology of the Manchester quadrangle, New Hampshire: New Hampshire Department of Resources and Economic Development Bulletin 2, 92 p.
Stewart, D.B., and Wones, D.R., 1974, Bedrock geology of the northern Penobscot Bay area, in New England Intercollegiate Geological Conference, 66th Annual Meeting, Orono, Maine, Oct. $12-13,1974$, Guidebook for field trips in east-central and northcentral Maine: Orono, Maine, University of Maine, p. 223-239.

Sundeen, D.A., 1971, The bedrock geology of the Haverhill 15' quadrangle, New Hampshire: New Hampshire Department of Resources and Economic Development Bulletin 5, $125 \mathrm{p}$.

Thompson, J.B., Jr., and Norton, S.A., 1968, Paleozoic regional metamorphism in New England and adjacent areas, in Zen, E-an, White, W.S., Hadley, J.B., and Thompson, J.B., Jr., eds., Studies of Appalachian geology-Northern and maritime: New York, Interscience Publishers, p. 319-328.

Thompson, J.B., Jr., and Robinson, Peter, 1976, Geologic setting of the Harvard Conglomerate, Harvard, Massachusetts, in New England Intercollegiate Geological Conference, 68th Annual Meeting, Boston, Mass., Oct. 8-10, 1976, Geology of southeastern New England; a guidebook for field trips to the Boston area and vicinity: Princeton, N.J., Science Press, p. 345-351.

Thompson, J.B., Jr., Robinson, Peter, Clifford, T.N., and Trask, N.J., Jr., 1968, Nappes and gneiss domes in west-central New England, in Zen, E-an, White, W.S., Hadley, J.B., and Thompson, J.B., Jr., eds., Studies of Appalachian geology-Northern and maritime: New York, Interscience Publishers, p. 203-218.

Thompson, P.J., 1983, Silurian-Devonian stratigraphy, Monadnock quadrangle, New Hampshire [abs.]: Geological Society of America Abstracts with Programs, v. 15, no. 3, p. 186.

Tracy, R.J., Robinson, Peter, and Field, M.T., 1976, Phase relations of natural pure magnesian cordierite and biotite from pyritesillimanite-orthoclase schist, central Massachusetts [abs.]: American Geophysical Union Transactions, v. 57, p. 338-339.

Tracy, R.J., and Rye, D.M., 1981, Origin and mobility of sulfur in graphitic schists, central New England [abs.]: Geological Society of America Abstracts with Programs, v. 13, no. 7, p. 569.

Tucker, R.D., 1977, Bedrock geology of the Barre area, central Massachusetts: University of Massachusetts Geology Department Contribution No. $30,132 \mathrm{p}$.

Zen, E-an, editor, and Goldsmith, Richard, Ratcliffe, N.M., Robinson, Peter, and Stanley, R.S., compilers, 1983, Bedrock geologic map of Massachusetts: Reston, Va., U.S. Geological Survey, 3 sheets, scale $1: 250,000$. 



\section{Structural and Metamorphic History of Eastern Massachusetts}

By RICHARD GOLDSMITH

THE BEDROCK GEOLOGY OF MASSACHUSETTS

U.S. GEOLOGICAL SURVEY PROFESSIONAL PAPER 1366-H 



\section{CONTENTS}

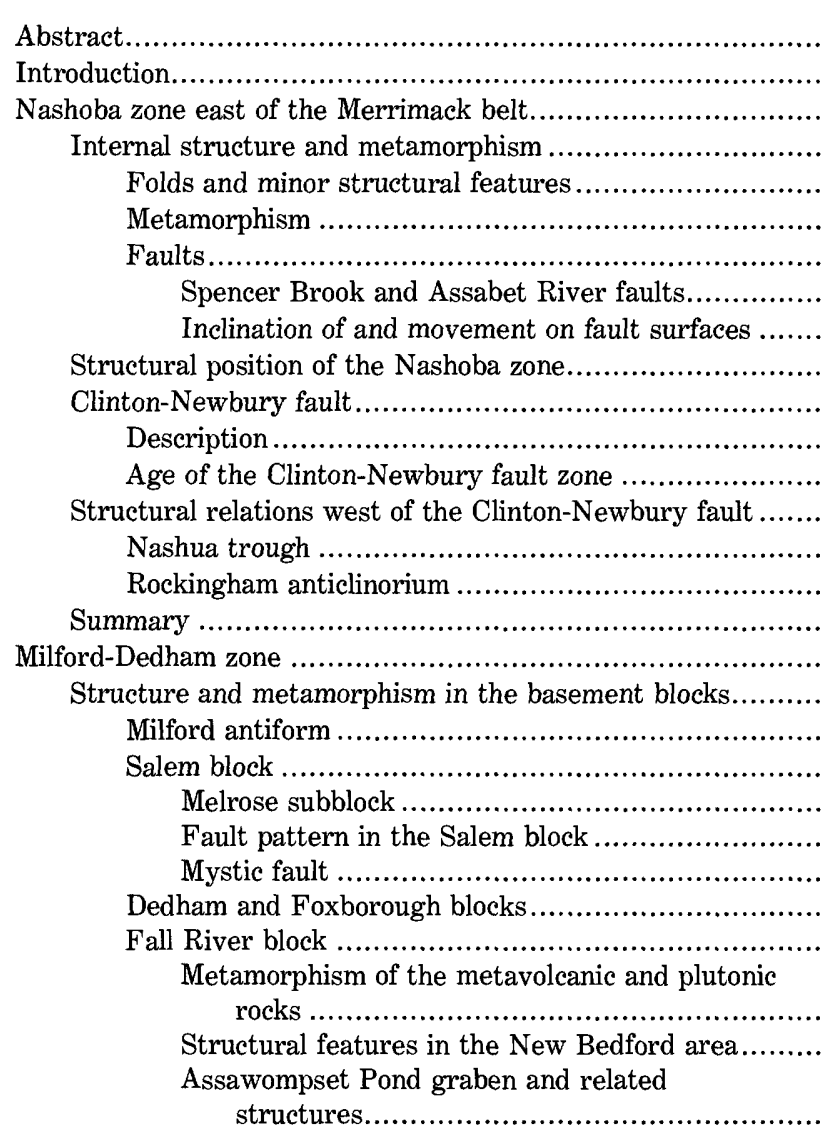

Page

H1

2

4

4

4

5

8

9

9

9

11

11

16

16

16

18

20

20

21

21

24

24

26

26
Milford-Dedham zone-Continued

Structure and metamorphism in the basement blocksContinued

Fall River block-Continued

Joints ..... $\mathrm{H} 32$

Summary and discussion ............................ 32

Proterozoic metamorphism ..................................... 33

Structure and metamorphism of the basins in the MilfordDedham zone ................................................

Boston basin ................................................. 33

Newbury basins ............................................ 36

Bellingham basin ............................................ $\quad 36$

Narragansett basin ....................................... $\quad 37$

Norfolk basin .............................................. 40

Middleton basin ............................................... 41

Nantucket basin .............................................. 41

Mafic dikes ...................................................... 41

Summary of blocks and basins of the Milford-Dedham zone.. 42

Bloody Bluff fault zone ............................................ 43

Burlington mylonite zone ................................. 45

Wolfpen lens ................................................ 46

Attitudes of fault surfaces and sense of movement in the Bloody Bluff fault zone .............................. 46

Age of the Bloody Bluff fault zone......................... 47

Tectonic events in eastern Massachusetts .......................... 47

Milford-Dedham zone ....................................... 47

Nashoba zone ..................................................... 53

Newbury basins ................................................ 53

East flank of the Merrimack belt................................. 54

Zone boundaries .................................................. 55

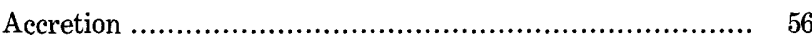

References cited .................................................. 58

\section{ILLUSTRATIONS}

FiguRE $\quad 1$. Index map showing major structural features of eastern Massachusetts ......................................................... H3

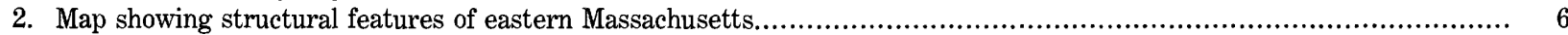

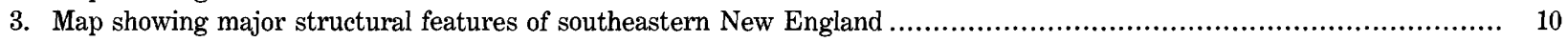

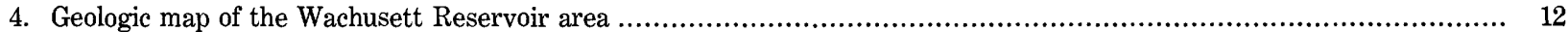

5. Geologic map of the east flank of the Merrimack belt, Massachusetts and New Hampshire, showing locations of cross sections ( $A-A^{\prime}-A^{\prime \prime}, B-B^{\prime}, C-C^{\prime}$ of figure 7 )

6. Schematic section near cross section $C-C^{\prime}$ across the Nashua "synclinal" as drawn by Crosby (1880, pl. III) ....................... 18

7. Schematic cross sections across the east flank of the Merrimack belt, Massachusetts and New Hampshire.................... 19 8-10. Maps showing:

8. Basins of the Milford-Dedham zone, eastern Massachusetts .

9. Form lines on foliation and direction of plunge of lineation in the Milford antiform, eastern Massachusetts....

10. Structural features in and adjacent to the Salem block of the Milford-Dedham zone, eastern Massachusetts ........

(3)

6

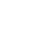

.

1


FiguRE 11. Maps of the Fall River-New Bedford area, southeastern Massachusetts, showing: $A$, Structural features;

12-15. Maps showing:

$B$, Interpretive cross sections; and $C$, Joints.

12. Structural features of the Boston basin, eastern Massachusetts.

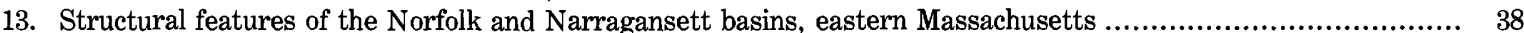

14. Structural features along part of the Bloody Bluff fault zone, northeastern Massachusetts..............................

15. Tectonic events in eastern Massachusetts corresponding approximately to time intervals indicated on table 3 .......

\section{TABLES}

TABLE 1. Metamorphism, plutonism, and faulting in besement rocks of the Milford-Dedham zone, eastern Massachusetts

2. Metamorphism and structure of cover rocks in basins of the Milford-Dedham zone, eastern Massachusetts..

$\mathrm{H} 21$

3. Tectonic events in eastern Massachusetts 


\title{
STRUCTURAL AND METAMORPHIC HISTORY OF EASTERN MASSACHUSETTS
}

\author{
By RichaRd GOLDSMITH
}

\section{ABSTRACT}

Two terranes differing in stratigraphy, plutonism, and metamorphism compose most of eastern Massachusetts. On the bedrock geologic map of Massachusetts (hereafter called the State bedrock map), these are the Nashoba zone east of the Merrimack belt and the MilfordDedham zone. The Nashoba zone, bounded on the west by the Clinton-Newbury fault and on the east by the Bloody Bluff fault system, is a high-grade metamorphic terrane of northeast-trending, steeply dipping Proterozoic $\mathrm{Z}$ or Ordovician schist, paragneiss, and metavolcanic rocks intruded by synkinematic Ordovician S-type and postkinematic Silurian I-type plutons. The Nashoba zone may be synformal; only a few large-scale folds have been identified. The zone contains many small-scale, mostly easterly verging folds. The zone is cut by many northeast-trending longitudinal faults, many of which are younger than the Silurian plutons. Early faults, both within the zone and in the Clinton-Newbury fault system, are west-dipping thrusts and reverse faults characterized by mylonite in which movement sense is to the east and southeast. Later faults tend to be steep and characterized by brecciation and gouge. The Science Park block near Worcester on the east flank of the Merrimack belt is interpreted to be a detached slice of Nashoba-zone rock within the Clinton-Newbury fault zone. Structural features within the eastern flank of the Merrimack belt are believed to be primarily Acadian and can be related only in part to structures in the adjacent Nashoba zone.

The Clinton-Newbury fault zone extends from the MassachusettsConnecticut boundary to the Gulf of Maine. It dips steeply and truncates the rock units on either side of the zone at a low angle to the south and a high angle to the north. Within the fault zone are early, possibly Acadian, low-angle eastward-directed thrusts and reverse faults; later faults are younger than the Pennsylvanian strata in the Worcester area and may be in part Mesozoic.

The Milford-Dedham zone is that part of eastern Massachusetts east and southeast of the Bloody Bluff fault system. It is probably bounded on the east, off shore, by an extension of the Meguma terrane of Nova Scotia. The zone consists largely of a mostly crystalline Proterozoic Z plutonic-metamorphic basement in which older Proterozoic $\mathrm{Z}$ metasediments and mafic voleanic and plutonic rocks have been intruded by younger Proterozoic $\mathrm{Z}$ granite and granodiorite batholiths. In the lower and middle Paleozoic, the zone was intruded by plutons of Ordovician to Devonian gabbro and alkalic granite. The terrane has been broken by normal and reverse faults into upthrown blocks of basement rock and downthrown blocks containing sedimentary and volcanic cover rocks

Manuscript approved for publication November 16, 1987. ranging in age from Proterozoic $Z$ to Triassic-Jurassic. The Milford antiform, to the west, a northeast-plunging foliation arch, and the southern part of the Fall River block, which lies southeast of the Narragansett basin, contain variably gneissic granitoid rocks and amphibolite-facies metasediments in which less deformed areas are bounded by more intensely deformed shear zones. The Milford antiform is truncated to the north by the northeast-trending Bloody Bluff fault. Proterozoic Z plutonic rocks in the Salem, Dedham, and Foxborough blocks, in northeastern Massachusetts, and the northern part of the Fall River block are at most brittlely deformed in the greenschist facies. The Salem block is appreciably sheared near the Bloody Bluff fault zone, as for example in the 8-km-wide Burlington mylonite zone. A prebatholithic metamorphism in the Proterozoic $\mathrm{Z}$ metasedimentary and metavolcanic and plutonic rocks is greenschist facies to the east and amphibolite facies to the west.

The major basins between basement blocks of the Milford-Dedham zone contain strata of Proterozoic $\mathrm{Z}$ and Cambrian, Silurian and Devonian, Pennsylvanian, and Triassic-Jurassic age. Fossils in strata of Cambrian, Silurian, and Devonian age are of Acado-Baltic affinity. The unmetamorphosed Proterozoic $\mathrm{Z}$ marine strata in the Boston basin that lie unconformably on the batholithic rocks, and the coal-bearing alluvial Pennsylvanian strata in the Norfolk and Narragansett basins, have both been folded and cut by reverse faults that trend eastnortheast, indicating a synchronous compressional event probably Alleghenian in age. This event has been suggested as having been produced by a left-lateral shear system striking northeast. North-south faults and diabase dikes that cut the east-northeast-trending structures indicate a succeeding tensional regime.

The two narrow, fault-bounded Newbury basins between the Milford-Dedham and Nashoba zones in northeastern Massachusetts probably lie in a graben of Mesozoic age in the same fracture zone as the Triassic and Jurassic Middleton basin to the south. The Bellingham basin (also known as the Woonsocket basin) contains greenschist-facies, unfossiliferous, metamorphosed Pennsylvanian or possibly Proterozoic $\mathrm{Z}($ ?) rocks that lithologically resemble those of the Boston basin. The bounding faults of the basin are continuous with faults forming the southwest end of the Boston basin.

The Bloody Bluff fault system has a long history of movement. Mylonites in the system formed by ductile deformation at amphiboliteto greenschist-facies metamorphism have had superimposed brittle deformation. Shearing in the Burlington mylonite zone, part of the Bloody Bluff fault system in northeastern Massachusetts, is older than 
the Early Devonian Peabody Granite, ${ }^{1}$ but radiometric data from a continuation of the fault zone in Connecticut indicate an Alleghanian age for the latest movement in the Bloody Bluff system. At its north end, the Bloody Bluff system may be offset to the north along north-trending faults flanking the Middleton and Newbury basins. The Wolfpen lens, near Framingham, is a splinter of basement caught between branches of the fault zone. Fault surfaces in the Bloody Bluff system dip steeply westward in most places, and movement has been generally considered to be toward the east and southeast. There seems to be little evidence that the Bloody Bluff is a major strike-slip zone.

In the Milford-Dedham zone, a Proterozoic $\mathrm{Z}$ volcanic-plutonic arc was intruded by Proterozoic Z granite batholiths and was metamorphosed and deformed to at least greenschist facies in the east and possibly amphibolite facies to the west. A subsequent dilational event also in Proterozoic $\mathrm{Z}$ time led to development of a rift system accompanied by felsic volcanism and deposition of turbidite. Deposition of Cambrian shelf sediments ushered in a period of stability and subsidence. Throughout early and middle Paleozoic time, the MilfordDedham zone was in an extensional regime during which alkalic and gabbroic plutons were intruded. During Devonian to Pennsylvanian time, compressive movements tied to collision of the plate containing the Milford-Dedham zone with the North American plate resulted in east- to southeast-directed thrusting, uplift, erosion, and deposition of fluvial Pennsylvanian strata in a marginal basin. About this time deep-seated deformation under amphibolite-facies conditions along the margins of the zone produced orthogneisses in the Milford antiform and the New Bedford area and produced alteration and fracturing in the batholithic rocks in the center of the zone. Recent investigations in Rhode Island have led to the useful proposition that the MilfordDedham zone consists of two terranes of similar age but of dissimilar history. The gneissic terrane on the west appears to have underlain the Merrimack belt during the Acadian orogeny. The nongneissic terrane to the east, which contains features most like those on the Avalon peninsula of Newfoundland, was juxtaposed to the gneissic terrane later, in the Alleghanian. This proposition remains to be tested, however. Continued compression deformed the Pennsylvanian and older rocks in the basins. Renewed movement occurred along such preexisting zones of weakness as the Bloody Bluff and ClintonNewbury faults, during which the Newbury basins probably formed. Subsequent rapid uplift followed by east-west extension led to formation of the Triassic and Jurassic basins and widespread north-south faulting of basement and basin rocks. A period of subsidence resulted in Cretaceous overlap of coastal-plain deposits.

The Nashoba zone had a different history until the Pennsylvanian. The high-grade dynamothermal metamorphism of these rocks is penecontemporaneous with emplacement of the Silurian or Ordovician Andover Granite. Intrusive Silurian calc-alkaline granite and granodiorite, differing chemically from Paleozoic alkalic intrusives of the Milford-Dedham zone and from Ordovician to Devonian calc-alkaline and peralkaline intrusive rocks in the east flank of the Merrimack zone, were not metamorphosed. The rocks of the Nashoba zone project beneath the rocks of the Merrimack belt, as must those of the Milford-Dedham zone, and could be the basement for the strata of the Merrimack belt. The difference in nature of the plutonic rocks in the Nashoba and Milford-Dedham terranes indicates, however, that the two terranes were not connected until late in, or after, Devonian time. Both the origin and the placement of the Nashoba terrane are enigmatic. Features in the bounding fault zones suggest a long, complex

\footnotetext{
${ }^{1}$ The Peabody Granite is shown as Middle Devonian on the State bedrock map on the basis of $\mathrm{Rb}-\mathrm{Sr}$ and $\mathrm{K}-\mathrm{Ar}$ age determinations by Zartman and Marvin (1971). Refinement of isotopic age determinations since the map was compiled indicates an Early Devonian U-Pb age for the Peabody (Zartman and Marvin, this vol., chap. J, table 1).
}

history of movement in which pre-Devonian and post-Devonian ductile deformation preceded later brittle deformation. Evidence for Taconic or Acadian compressive deformation in the Milford-Dedham zone is lacking, but Acadian deformation is recognized on the east flank of the Merrimack belt and possibly the west flank of the Nashoba zone. The Ordovician dynamothermal event that affected the Nashoba zone is not necessarily in the same tectonic framework as the Taconic event of western Massachusetts. The original times of accretion of these terranes to each other and to North America is uncertain, but the present configuration of the terranes in eastern Massachusetts is a result largely of Alleghanian movements on which has been superimposed early to middle Mesozoic faulting.

\section{INTRODUCTION}

Eastern Massachusetts east of the Merrimack belt consists of two terranes ${ }^{2}$ of rock, the Milford-Dedham zone and that part of the Nashoba zone exposed at the surface east of the Merrimack belt (fig. 1). The term "Nashoba zone" is used in this restricted sense in this chapter. These terranes differ in stratigraphy and in metamorphic and plutonic history from each other and from rocks to the west (Goldsmith, this vol., chaps. E and F; Wones and Goldsmith, this vol., chap. I). The two terranes are bounded by major fault systems, and these fault systems also have differing metamorphic and tectonic histories. Thus, the terranes constitute distinct blocks of the Earth's crust. The Clinton-Newbury fault system on the west separates the Nashoba zone from the Merrimack belt. The Nashoba zone contains sedimentary and volcanic rocks of Proterozoic $\mathrm{Z}$ or possibly early Paleozoic age metamorphosed to high grade and intruded by Ordovician syn- or late-metamorphic S-type granite (Andover Granite) and by Silurian I-type postkinematic plutons of granodiorite and tonalite that are unique in composition in New England (Wones and Goldsmith, this vol., chap. I). The Bloody Bluff fault system separates the Nashoba zone from the Milford-Dedham zone to the east. The Milford-Dedham zone contains 590- to 630-Ma calc-alkaline granite batholiths that intrude medium- to low-grade metasedimentary, metavolcanic, and mafic plutonic and metaplutonic rocks of probable Proterozoic $\mathrm{Z}$ age. Overlying this basement, preserved in basins, are slightly metamorphosed to unmetamorphosed remnants of sedimentary and volcanic sequences of Proterozoic Z, Cambrian, Silurian and Devonian, and Pennsylvanian age. Plutons of alkalic granite of Ordovician and Devonian age and gabbro of Ordovician age intrude the

${ }^{2}$ The term "terrane" is used in a broad sense for an area of rock having a different lithostratigraphic, metamorphic, and deformational history from adjacent areas. It is equivalent to a zone or belt as these terms are used on the bedrock geologic map of Massachusetts (Zen and others, 1983) but is also used for a distinctive area within a larger unit; for instance, Putnam terrane in the Nashoba zone, ductilely deformed terrane in the Milford-Dedham zone. The rationale for use of the terms "zone" and "belt" on the State bedrock map is explained in Hatch and others (1984). 


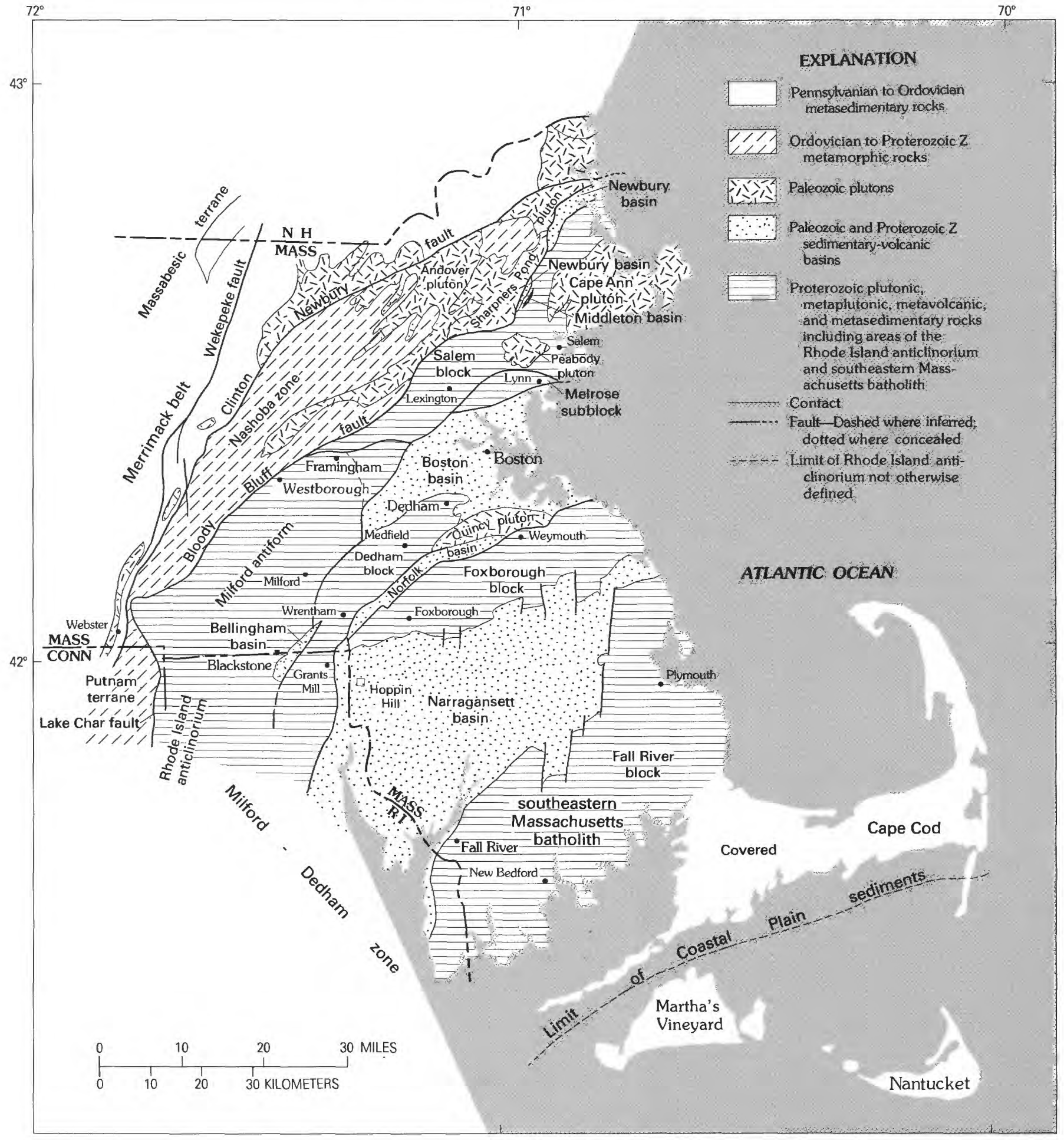

FIGURE 1.-Index map and major structural features of eastern Massachusetts.

basement and the pre-Ordovician cover rocks. The eastern boundary of the Milford-Dedham zone may lie east of Cape Cod where a different terrane, possibly an extension of the Meguma terrane of Nova Scotia, is reflected in magnetic signatures (Klitgord, 1984).
The arrangement of this chapter is based largely on geographic distribution of the zones, which may reflect sequential docking onto the eastern edge of North America. Within each of the two terranes, the arrangement follows the relative age of recognizable tectonic events. 
A description of the structure and metamorphism of the Nashoba zone and of its western boundary, the ClintonNewbury fault system, begins the chapter. Because the oldest events in the Milford-Dedham zone are recorded in the Proterozoic basement rocks, the structure and metamorphism of each basement block within the MilfordDedham zone are described next, followed by the description of the overlying sedimentary basins in the zone and the nature of their boundaries. A description of the Bloody Bluff fault system concludes the section on the structure and metamorphism of the Milford-Dedham zone. A summary section attempts to place the tectonic events into a sequential development of accreted eastern North America, a concept implied on the State bedrock map (Zen and others, 1983).

The material described and discussed in this chapter is derived almost entirely from the work of others, and in only a few areas are the descriptions based on original observations of mine. The sources of data are many and include those listed on the State bedrock map as well as those referred to specifically in this chapter. The selection of structural features shown on the map was my responsibility. The selection process was aided by ideas resulting from discussions with colleagues involved in compilation of the State bedrock map and others involved in the geology of eastern Massachusetts, in particular Marland P. Billings, L. Peter Gromet, J.C. Hepburn, O. Don Hermes, Richard S. Naylor, and James W. Skehan.

\section{NASHOBA ZONE EAST OF THE MERRIMACK BELT}

The Nashoba zone east of the Merrimack belt, between the Clinton-Newbury fault system on the west and the Bloody Bluff fault system and faults bounding the Newbury basins on the east (figs. 1, 2), is distinct from the Milford-Dedham zone to the east and the Merrimack belt to the west. The Nashoba zone consists of gneisses and schists of high metamorphic grade, primarily the Nashoba and Marlboro Formations, that are derived from sedimentary and volcanic protoliths (Goldsmith, this vol., chap. F), synkinematic plutonic rocks of Ordovician age, and distinctive postkinematic plutonic rocks of Silurian age (Zartman and Marvin, this vol., chap. J; Wones and Goldsmith, this vol., chap. I). The zone has a magnetic signature that contrasts with that of adjoining zones (Alvord and others, 1976; Castle and others, 1976; Harwood and Zietz, 1976). Foliation and layering dip steeply throughout the zone, and the rocks apparently have been folded and extensively cut and imbricated by faults, most of the traces of which are aligned parallel and subparallel to the trend of the rock units (Bell and
Alvord, 1976, fig. 4; Skehan and Abu-Moustafa, 1976). Metamorphism is at the upper limit of the amphibolite facies (sillimanite metamorphic zone) throughout most of the zone, dropping somewhat lower (andalusitestaurolite metamorphic zone) on the northwest flank. Intrusion of the Ordovician Andover Granite provides a younger (upper) limit for the age of the formations, but these formations may be as old as Proterozoic Z. Olszewski (1980) determined a U-Pb isotopic age of $730 \pm 26 \mathrm{Ma}$ on zircon from the Fish Brook Gneiss. The main period of metamorphism is believed to have occurred close to the time of intrusion of the S-type Andover Granite. The complex internal folding and faulting within the zone make it difficult to determine the stratigraphic order of the units. The Nashoba and Marlboro Formations have been interpreted to be an upright homoclinal sequence facing west (Bell and Alvord, 1976; Skehan and AbuMoustafa, 1976; Skehan and Murray, 1980b); however, the map pattern of the lithologies (Bell and Alvord, 1976) and the magnetic pattern (Alvord and others, 1976) mentioned above suggest that this is not a homoclinal sequence. Some aspects of the folding and faulting within the Nashoba zone have been discussed in chapter $\mathrm{F}$ of this volume and will only be summarized here.

\section{INTERNAL STRUCTURE AND METAMORPHISM}

\section{FOLDS AND MINOR STRUCTURAL FEATURES}

Major folds in the Nashoba zone have been identified in only a few places, whereas most mappers have recognized widespread small-scale folding. Hansen (1956) mapped major folds on the west flank of the Nashoba zone and indicated an overall synformal structure for the Nashoba-Marlboro sequence; however, the west flank of this synform has been truncated, eliminating the Marlboro Formation. If the Reubens Hill Formation is equivalent to the Marlboro Formation, small remnants of the truncated west limb are preserved in small fault-bounded blocks in the Merrimack belt. Skehan and Abu-Moustafa (1976, fig. 1) showed a somewhat schematic set of two synforms and a central antiform in their cross section of the Wachusett-Marlborough tunnel, which extends from the Wachusett Reservoir, southwest of Bolton, to Marlborough. Foliation symbols on the maps of the Billerica and Westford quadrangles (Alvord, 1975) indicate zones of alternating steep east and west dips. As this foliation is parallel to compositional layering that represents modified bedding, one might deduce that the original bedding has been flattened into tight folds about steep axial surfaces. Such folds are suggested by the map pattern, by repetition of lithologic units, and by the aeromagnetic pattern (Alvord and others, 1976; Castle and others, 1976; Harwood and Zietz, 1976; Barosh, 
1977), but they cannot be unequivocally mapped. Hinges of such folds would be difficult to identify in this highly deformed terrane. Traces of Hansen's large-scale folds are parallel to the general northeast trend of the gneissosity and schistosity in the zone. A synform at Rattlesnake Hill in Bolton (fig. 2) mapped by Hansen (1956) plunges gently northeastward and has a wavelength of about $0.8 \mathrm{~km}$. Another synformal fold of his near Boxborough also plunges northeast, but steeply.

Most minor folds in the Nashoba Formation fold both bedding and a parallel foliation. Folds of layering, to which the foliation is axial planar, have not been recorded. Younger minor folds have locally been superposed on the earlier generation. Axial planes of the older folds described by Hansen (1956, p. 52) strike parallel to the trend of the rock units, dip to the west, and plunge moderately to the north, northeast, and southwest. Hansen has deduced from lengths of fold limbs that the major structure is synformal. Skehan and Abu-Moustafa (1976) described the same sense of folding in minor folds in their tunnel section. Locally in the tunnel, axial planes have been rotated into the horizontal. Many of the small-scale folds described by Skehan and Abu-Moustafa are related to faulting. On the southeast side of the Nashoba zone in the Marlboro Formation, Hansen (1956) observed that the minor folds trend obliquely to the trend of the units. Minor structures have a similar trend in the Marlborough area to the south (Hepburn and DiNitto, 1978). These minor folds range in size from minute wrinkles related to slip cleavage to broad undulations as much as a meter in wavelength. Their axial surfaces dip west or southwest, and their axes plunge steeply north to northwest. This geometry suggests either a significant lateral component of movement or rotation into the plane of a major thrust zone. Many folds here are broken or displaced by small thrust faults. Skehan and Abu-Moustafa confirmed these observations in the east end of the tunnel section near the MarlboroNashoba contact. These relationships suggest a structural discordance between the Nashoba and Marlboro Formations. Indeed, Hepburn and DiNitto (1978) mapped a fault along this contact. Hansen suggested that the Marlboro underwent a second period of folding, which is obscured in the Nashoba Formation by a difference in competency. Hansen (1956, p. 55) suggested, on the basis of orientation of superposed obliquely trending minor folds, that the Nashoba moved northeastward relative to the flanking formations. He noted (p. 57-58) that, at a few localities on the west side of the Nashoba zone, flow cleavage and schistosity in his mica schist facies of the Worcester Formation, now the Tadmuck Brook Schist, are axial planar to small isoclinal fold hinges in relatively competent quartzite layers.
In summary, the rocks of the Nashoba zone may be tightly folded on a large scale, but such folds have not been recognized in the map pattern of rock units. Vergence of the early minor folds is generally to the east and southeast, but the orientation of later folds, particularly on the eastern side of the zone, indicates subsequent lateral transport in a northeast to east direction.

The primary schistosity predates the emplacement of the Silurian Sharpners Pond Diorite and related plutons and also predates, but possibly not by much, the emplacement of the Ordovician Andover Granite. Hansen (1956, p. 55) observed that most of the major and minor folds were formed before feldspathization (that is, development of granitic and pegmatitic stringers and lenses, or partial melting). Most of these stringers and lenses lie in the plane of the foliation and are presumed to have formed while the regional stress field that produced the primary foliation in the Nashoba Formation still prevailed. This I interpret to mean that the peak of deformation preceded the thermal peak of metamorphism at sillimanite grade. The thermal peak was presumably close to the period of generation of the Andover Granite. The only deformation later than emplacement of the Silurian Sharpners Pond Diorite and the Ordovician Andover Granite appears to be related to faulting during movement on the regional Bloody Bluff and ClintonNewbury systems. In this regard, it is worthwhile to point out here that the Ordovician Andover Granite is considered to have been emplaced as a wet granite at considerable depth, whereas the younger, Silurian plutonic rocks such as the Sharpners Pond Diorite that also intrude the rocks of the Nashoba block are dry and presumably were intruded at a higher level in the crust (Wones and Goldsmith, this vol., chap. I).

\section{METAMORPHISM}

The Nashoba zone lies in a narrow north-south belt of high-grade metamorphism in southern New England (Thompson and Norton, 1968). Pelitic rocks of the Nashoba Formation, the Shawsheen Gneiss, and the eastern part of the Tadmuck Brook Schist contain sillimanite-muscovite and sillimanite-orthoclase mineral assemblages characteristic of the upper amphibolite facies. Pelitic rocks of the Marlboro Formation and the western part of the Tadmuck Brook Schist have assemblages containing staurolite and andalusite. These assemblages are truncated abruptly on the east by the Bloody Bluff fault and on the west by the ClintonNewbury fault. Formations to the west, in the eastern part of the Merrimack belt, lie in a trough (Nashua Trough) and contain garnet-, biotite-, and chlorite-zone assemblages. To the east, the metamorphic rocks of the Milford-Dedham zone are low to middle amphibolite 


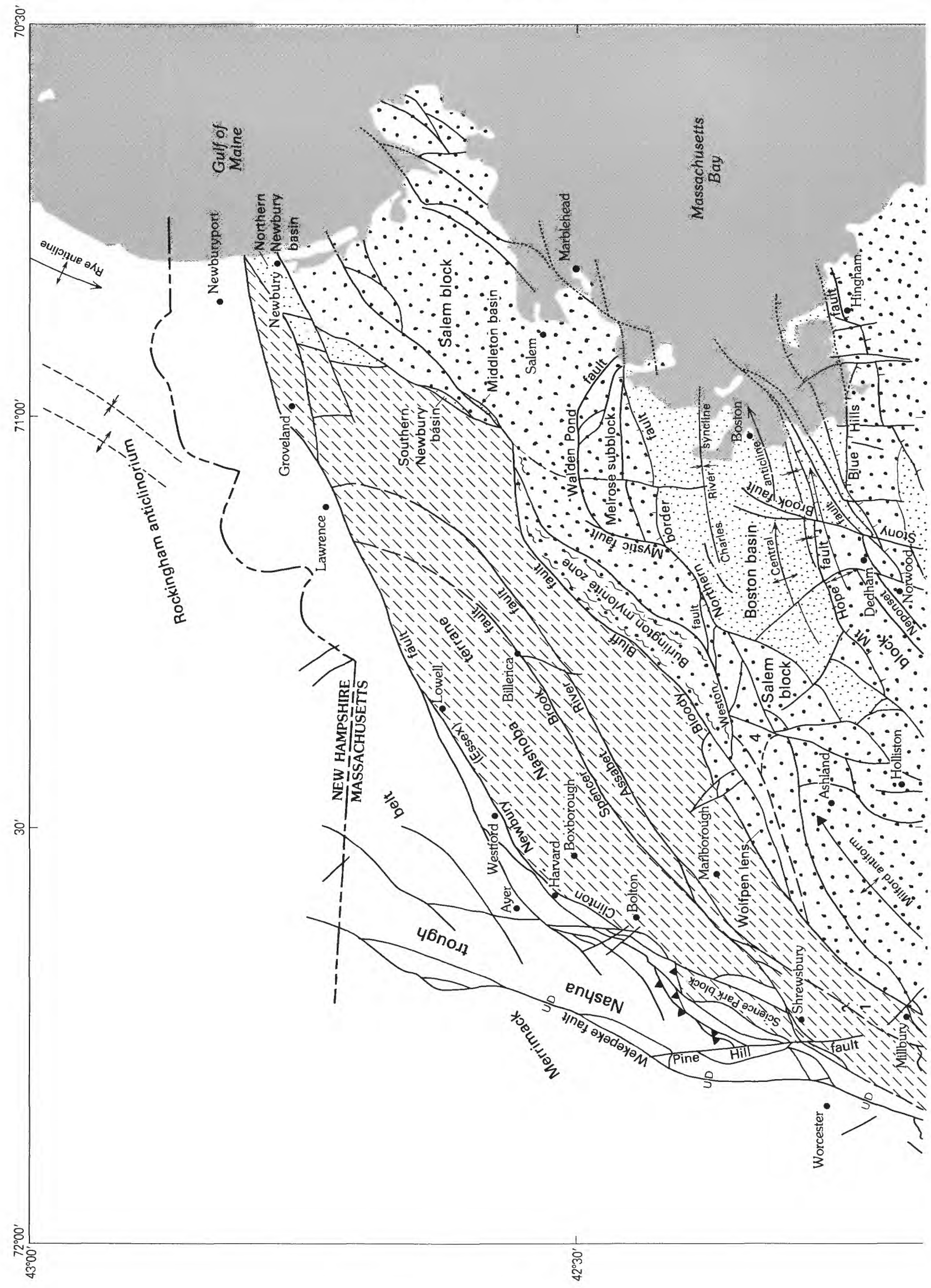




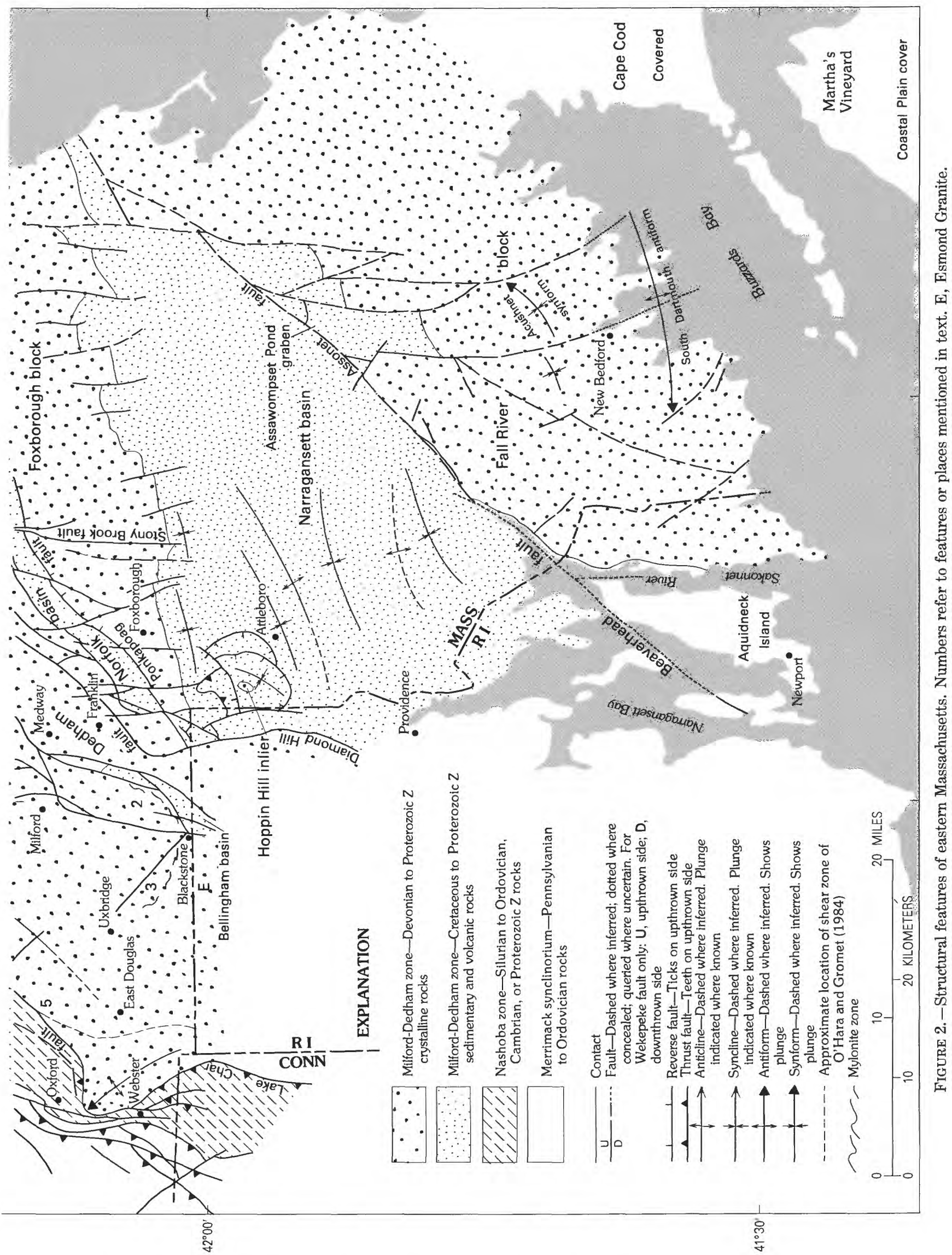


facies near the boundary and are greenschist facies farther east. The Silurian and Devonian Newbury Volcanic Complex is at subgreenschist facies, judging from the descriptions by Shride (1976b).

Abu-Moustafa and Skehan (1976) gave the most thorough description of the metamorphism in the Nashoba zone in their study of the Wachusett-Marlborough tunnel. They described pelitic assemblages containing sillimanite +orthoclase and sillimanite+muscovite. The orthoclase is commonly porphyroblastic. Garnet and clinozoisite are common. They placed the assemblages in the sillimanite-almandine-orthoclase subfacies of the almandine-amphibolite facies. The mineral associations suggested to them that the rocks of the Nashoba zone recrystallized at about $625-650{ }^{\circ} \mathrm{C}$ and at about $6 \mathrm{kbar}$, indicating a depth of cover of more than $23 \mathrm{~km}$, assuming $P_{\text {load }}=P_{\mathrm{H}_{2} \mathrm{O}}$. Thompson and Norton (1968) placed the Nashoba zone east of and on the lower pressure side of the isobaric triple-point line for New England, on the basis of the assemblages. No one knows how much of the muscovite present is prograde dynamothermal and how much is later static hydrothermal. Examination of the rocks in some places suggests that some muscovite has replaced aluminum silicate. Presumably some muscovite was crystallized during late emplacement of the relatively hydrous Andover Granite (Castle, 1965a). Olszewski (1980) has shown from $\mathrm{Rb}-\mathrm{Sr}$ data that a massive resetting of the $\mathrm{Rb}-\mathrm{Sr}$ systems and a widespread fluid activity occurred about $450 \mathrm{Ma}$, about the time of emplacement of the Andover Granite (Handford, 1965); this then was apparently close to the peak of thermal metamorphism of the rocks. Emplacement of the Silurian Sharpners Pond Diorite and related rocks apparently had little metamorphic effect. Olszewski found no evidence for an Acadian metamorphic event, but he did recognize in his isotopic work the Carboniferous and Permian thermal event so widespread in southern New England (Zartman and others, 1970). The metamorphism we see in the Nashoba zone is, in part at least, penecontemporaneous with an early Paleozoic thermal-plutonic event. We do not know if an earlier (Proterozoic?), lower grade metamorphism was overprinted by the early Paleozoic metamorphism. The truncation of isograds by the bounding faults on the flanks of the zone indicates that the block was metamorphosed before moving to its present position.

\section{FAULTS}

Faulting within the zone has been fairly well documented and also widely inferred. A complex fracture pattern is shown on the bedrock geologic map of the Boston $1^{\circ} \times 2^{\circ}$ quadrangle by Barosh and others (1977), a pattern that probably includes joints, faults, and other lineaments (Barosh and others, 1974; Alvord and others, 1976). Most of these features are not shown on the State bedrock map of Zen and others (1983), on which only faults having significant displacement are shown. Careful study by Skehan (1968) and Skehan and AbuMoustafa (1976) of the many major and minor faults cutting the Nashoba and Marlboro Formations in the Wachusett-Marlborough tunnel showed that faulting in the zone is indeed complex. Faults are most abundant on the flanks of the zone in the vicinity of the ClintonNewbury and Bloody Bluff faults, but some that Skehan and Abu-Moustafa considered significant are located in the tunnel section between the bounding faults. Most faults described by them are reverse and thrust faults having a sense of movement to the east. A few are highor low-angle normal faults. They recognized different ages of faults in the tunnel section: some control emplacement of pegmatite and granite; others cut and displace these masses. Some faults are characterized by mylonite and ultramylonite, and these, in places, are cut by later faults. Later faults are usually characterized by brecciation, alteration, silicification, and zones of gouge. The Marlboro Formation is particularly broken by faults of both types, and the number of faults increases toward the Bloody Bluff fault on the east side of the Marlboro. The faults generally dip to the west, and movement sense is generally to the east and southeast, in the same general direction as the vergence of the minor folds. A few faults show a vertical sense of movement, and one fault in the lower part of the Nashoba, unit N9 of Skehan and Abu-Moustafa (1976), has a right-lateral sense of movement. Basalt dikes in the lower part of the Marlboro noted by Skehan and Abu-Moustafa cut granite and minor folds and in places appear to be controlled by preexisting faults and fractures.

The faults observed by Skehan and Abu-Moustafa in the Wachusett-Marlborough tunnel have not been directly related to faults mapped on the surface in the Nashoba zone by Alvord (1975), Barosh (1976, 1978), and Hepburn and DiNitto (1978) nor to faults deduced from the aeromagnetic pattern by Alvord and others (1976) and Castle and others (1976). Alvord and others (1976) showed unnamed thrust faults at the top and bottom of the Fort Pond Member of the Nashoba Formation; the upper thrust would pass through the middle of the Nashoba in the tunnel section. Alvord and others showed this fault as a continuation of a northeast-trending fault near Shrewsbury (fig. 2) that splays off the ClintonNewbury fault zone and truncates the upper part of the Nashoba. Castle and others (1976) showed the northeasttrending fault but did not extend it northward. Instead, they continued it to the northeast to end near Marlborough. I have shown the interpretation of Castle and others on the State bedrock map. This fault could coin- 
cide with a fault zone that lies between units N18 and N17 of Skehan and Abu-Moustafa (1976), which they suggested may be regionally important.

Spencer Brook and Assabet River Faults

The Spencer Brook and Assabet River faults (Alvord and others, 1976; Bell and Alvord, 1976) (fig. 2) are shown on the State bedrock map because as mapped the faults truncate the Shawsheen Gneiss and Fish Brook Gneiss. Castle and others (1976) did not show the Spencer Brook fault but did show a fault coinciding with the Assabet River fault. Skehan and Abu-Moustafa (1976) did not identify the Spencer Brook and Assabet River faults of Alvord and others as such in the tunnel section. North of the Concord area, I have shown the Spencer Brook fault as curving to the north following a continuous foliation pattern in the Andover Granite shown on Castle's (1964) maps of the Wilmington and Salem Depot quadrangles and connecting two areas of sheared rock shown by Castle and others (1976, pl. 1). This interpreted fault intersects the Clinton-Newbury fault south of Lawrence. I have shown the Assabet River fault as similarly following the curvilinear contact of the east edge of the main mass of Andover Granite. Castle (1964) showed no features crossing the foliation pattern that might suggest that the faults trend east-northeasterly to the Newbury area, as is shown by Barosh and others (1977), to meet the east-trending faults forming the boundaries of the northern part of the Newbury basins (fig. 2). Nor do any features on the aeromagnetic maps indicate that such a connection exists.

The continuation of the Spencer Brook and Assabet River faults south of the Marlborough area is not clear. Barosh (1977) showed the faults coming together in an anastomosing pattern west of Marlborough near the intersection of I-290 and I-495 and continuing as one fault south to the Bloody Bluff-Lake Char fault zone. Castle and others (1976) showed an inferred fault coinciding with the Assabet River fault and merging south of Shrewsbury into an inferred fault near the top of the Sandy Pond Amphibolite Member of the Marlboro Formation, a fault not shown by Alvord and others (1976). Skehan and Abu-Moustafa (1976) showed a fault zone of probable significant displacement west of the contact of the Nashoba and the Marlboro, which may be the junction of the Spencer Brook and Assabet River faults. The mapping of Hepburn and DiNitto (1978) and Hepburn (1978) suggests that the Assabet River fault in the Marlborough and Shrewsbury areas cuts downward below the basal schist of the Nashoba and truncates higher units of the Marlboro. The Tatnic fault (Dixon and Lundgren, 1968, p. 227; Wintsch and Hudson, 1978) in eastern Connecticut between the Quinebaug and the
Tatnic Hill Formations occupies a similar position in places between the basal rusty schist of the Tatnic Hill and the Quinebaug. Dixon (written commun., 1979), however, recognized no fault between the rusty schist of the Nashoba and the Marlboro in the Grafton quadrangle in her reconnaissance. Accordingly, on the State bedrock map I have shown the continuation of the Assabet River fault (1, fig. 2) as lying above the rusty schist of the Nashoba rather than below it. However, exposures are insufficient to locate the fault at either stratigraphic level, if a fault exists. Possibly it cuts down below the Nashoba as suggested by the mapping of Hepburn and DiNitto (1978) and cuts down to the Bloody Bluff-Lake Char fault as shown by Barosh (1977). If it does not do so south of Marlborough, it certainly must do so to the south near Oxford. Without detailed mapping in the Grafton and Worcester South quadrangles, the location of the southern continuation of the Spencer Pond and Assabet River faults can only be speculated upon.

Inclination of and Movement on Fault Surfaces

Little information is available concerning the amount of dip of the fault surfaces within the Nashoba zone. The inferred faults of Castle and others (1976) dip $60^{\circ}-70^{\circ}$ to the west, as computed from aeromagnetic data. This dip coincides with the dips of many of the younger faults in the Wachusett-Marlborough tunnel section. Some of the apparently older faults characterized by mylonite dip $30^{\circ}-45^{\circ}$ west. Observations in the tunnel are not sufficient to say which faults control the map pattern of the units. Several ages of faulting have clearly been superposed.

Barosh (1977) showed numerous faults in the Nashoba Formation in the area between Marlborough and Oxford and referred to the whole zone as the Nashoba thrust belt. The numerous faults observed in the WachusettMarlborough tunnel indeed show the zone as highly faulted. However, most of the faults in the tunnel appear to have insignificant displacement and accordingly are not shown on the State bedrock map. Major displacement is confined primarily to the faults at and near the flanks of the zone. Discussion of the stratigraphy in the zone (Goldsmith, this vol., chap. F) led to an interpretation that the lithologic units within the block are imbricated to some extent on such faults as the Spencer Brook and Assabet River faults. Movement on most faults, as described above, is east directed, west side up, and right lateral, at least at a late stage.

\section{STRUCTURAL POSITION OF THE NASHOBA ZONE}

The Nashoba zone (figs. 2,3 ) forms a lens-shaped block thinning to both north and south and tapering down dip to the west. If the trends of the two major fault zones 


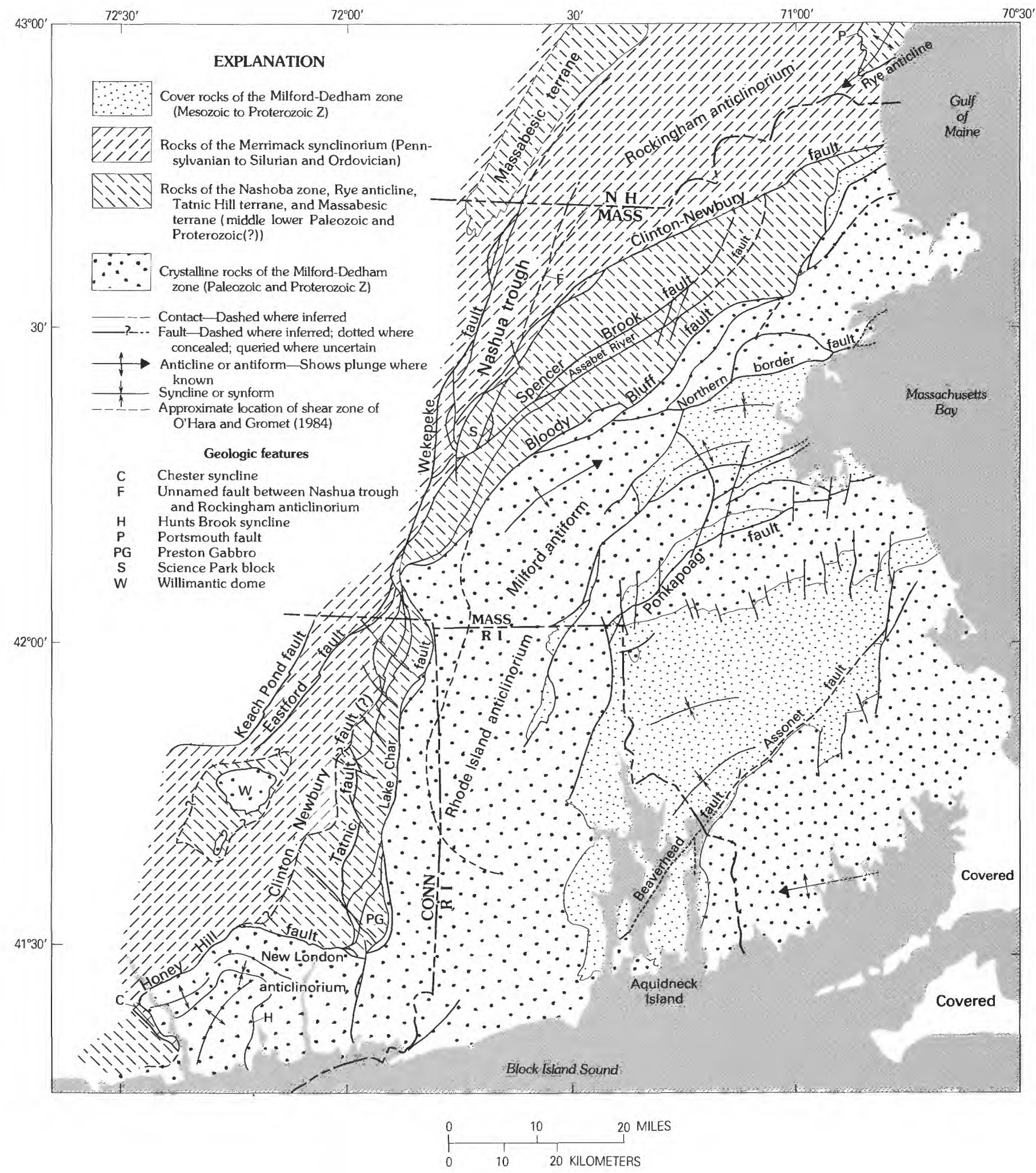

FIGURE 3.-Major structural features of southeastern New England. 
remain the same, the Nashoba zone lenses out somewhere in the Gulf of Maine. The Nashoba zone narrows considerably in southern Massachusetts near Webster but widens in outcrop width in Connecticut where it is represented by the Putnam terrane. The Nashoba Formation and the Fish Brook and Shawsheen Gneisses decrease in thickness southward from $8,765 \mathrm{~m}$ (I arbitrarily use one-half Bell and Alvord's (1976) thickness because of suspicion of repetition by faulting and folding) in the Westford-Billerica area to $3,740 \mathrm{~m}$ in the Wachusett tunnel section and to $1,701 \mathrm{~m}$ in the Tatnic Hill Formation in Connecticut (Dixon, 1965a; see Goldsmith, this vol., chap. F). Eastward along the Honey Hill fault, in southeastern Connecticut, the Tatnic Hill thins even more. Near Chester, Conn., less than $155 \mathrm{~m}$ of Tatnic Hill is present (Lundgren, 1963). The Marlboro Formation and the equivalent Quinebaug Formation in Connecticut are fairly uniform in thickness from north to south: 2,140, 2,702, and 2,215 $\mathrm{m}$ (Bell and Alvord's section has not been halved in these measurements because there appears to be no internal duplication of units). In southeastern Connecticut, the Quinebaug thins and is eventually cut out by eastward convergence of the Tatnic and Honey Hill faults (Rodgers, 1982). The Tatnic Hill Formation thins between the Tatnic fault and a fault at a still higher level, possibly the inferred ClintonNewbury, at the base of the Canterbury Gneiss, so that only the Yantic Member of the Tatnic Hill Formation can still be recognized in the vicinity of the Chester syncline (C, fig. 3) (Wintsch, 1979) in the keel of the Merrimack synclinorium. However, rocks lithologically similar to parts of the Tatnic Hill can be recognized in the Chester and Hunts Brook synclines (H, fig. 3) in the Proterozoic $\mathrm{Z}$ terrane of southeastern Connecticut (Lundgren, 1967; Goldsmith, 1967a,b). The Proterozoic $\mathrm{Z}$ basement is exposed (Snyder, 1964) in the Willimantic window (W, fig. 3) in central-eastern Connecticut beneath the Willimantic fault, which is equivalent to the Honey Hill fault (Wintsch, 1979). Here the Quinebaug equivalent is very much thinned and lies between the Willimantic-Honey Hill fault and a fault that is either the Tatnic fault or a higher level fault.

These observations indicate that the Nashoba zone is a downward-thinning wedge between the Milford-Dedham zone and the Merrimack belt. The shallowness of the discontinuity beneath the Nashoba zone is indicated by the trace of the Bloody Bluff, Lake Char, and Honey Hill faults in southeastern Connecticut and the presence of Milford-Dedham basement in the Willimantic window. As the Merrimack belt plunges north from southern Connecticut, sections across the Nashoba zone and Putnam terrane can only show the two terranes by projection as shallow westward-dipping wedges (cross section $F-F^{\prime}$ on the State bedrock map) beneath the rocks of the
Merrimack belt. The Science Park block of Nashoba (figs. 2, 4) mapped by Hepburn (1978) near Worcester is apparently an upthrust sliver of the Nashoba wedge caught in the Clinton-Newbury fault zone. The depth to the Nashoba zone or its equivalent beneath the Paxton Formation to the west is highly speculative (cross sections $D-D^{\prime}$ and $F-F^{\prime}$ on the State bedrock map). The Massabesic Gneiss Complex may be a larger upthrust slice of Nashoba-zone rocks than the Science Park block. The argument for low dips for the Clinton-Newbury and Bloody Bluff faults at depth, which is based on observed distribution of Proterozoic $\mathrm{Z}$ basement in Massachusetts and Connecticut, is in opposition to the argument for appreciable transcurrent movement for the faults postulated by Zen and Palmer (1981) and Zen (1983). It is possible that transcurrent movement has occurred, an idea more easily accommodated in the steeply dipping segment north of Ayer and perhaps the Rattlesnake Hill fault than to the south. Any transcurrent movement must be late. We do not yet have a clear picture of the three-dimensional disposition of the major blocks of rock in southeastern New England.

\section{CLINTON-NEWBURY FAULT}

\section{DESCRIPTION}

The Clinton-Newbury fault (fig. 2) forms the boundary between the Nashoba zone and the Merrimack belt. Northeast of Ayer, it truncates units of both the Merrimack belt and the Nashoba zone, but south of Ayer its trace coincides with the trend of units in both terranes, and it lies below and locally within what are apparently the lowermost stratigraphic units of the Merrimack belt. The fault forms the southern boundary of the Newburyport Complex in the Newburyport area, and the Ayer Granite lies west of the main trace of the fault throughout its extent.

Segments of the Clinton-Newbury fault were identified as early as 1880 (Crosby, 1880, p. 95-96; Clapp, 1921, pl. 1). Other workers suspected but could not identify a convincing break between the less metamorphosed rocks of the Merrimack belt on the west and the more metamorphosed rocks of the Nashoba zone on the east (Emerson, 1917, p. 77-78; Hansen, 1956, p. 20). The fault was first recognized as a major dislocation by Castle (1964; 1965a,b) in the Lawrence-Groveland area (fig. 2) but was named by Skehan (1968, p. 281-283; Skehan and Murray, $1980 \mathrm{~b}$ ) for the northeast-trending fault zone extending from the Wachusett Reservoir at Clinton, Mass., northeast to the vicinity of Newbury and Newburyport. Castle and others (1976) reviewed the history of identification of the zone and named the fault the Essex fault; however, 


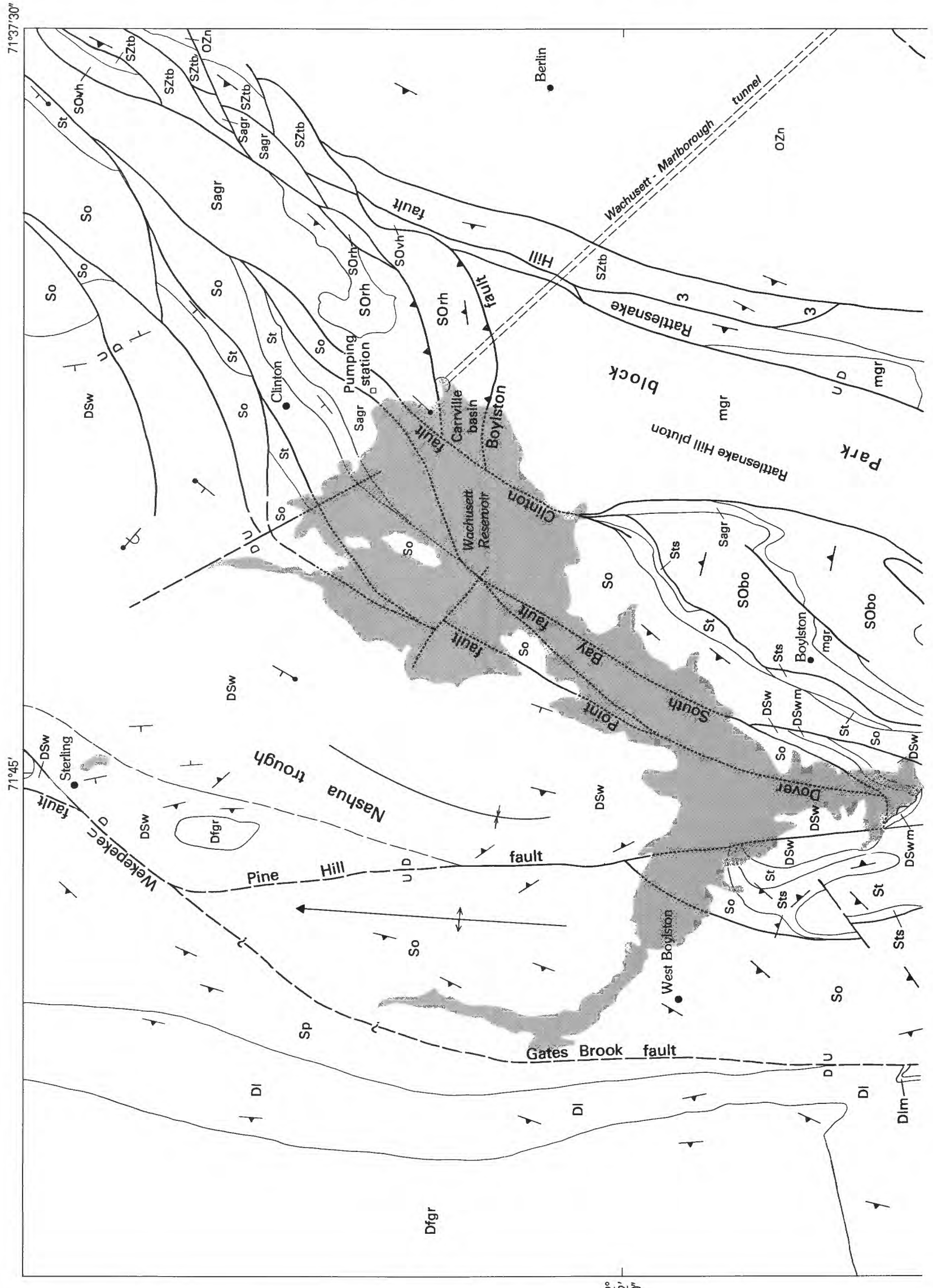




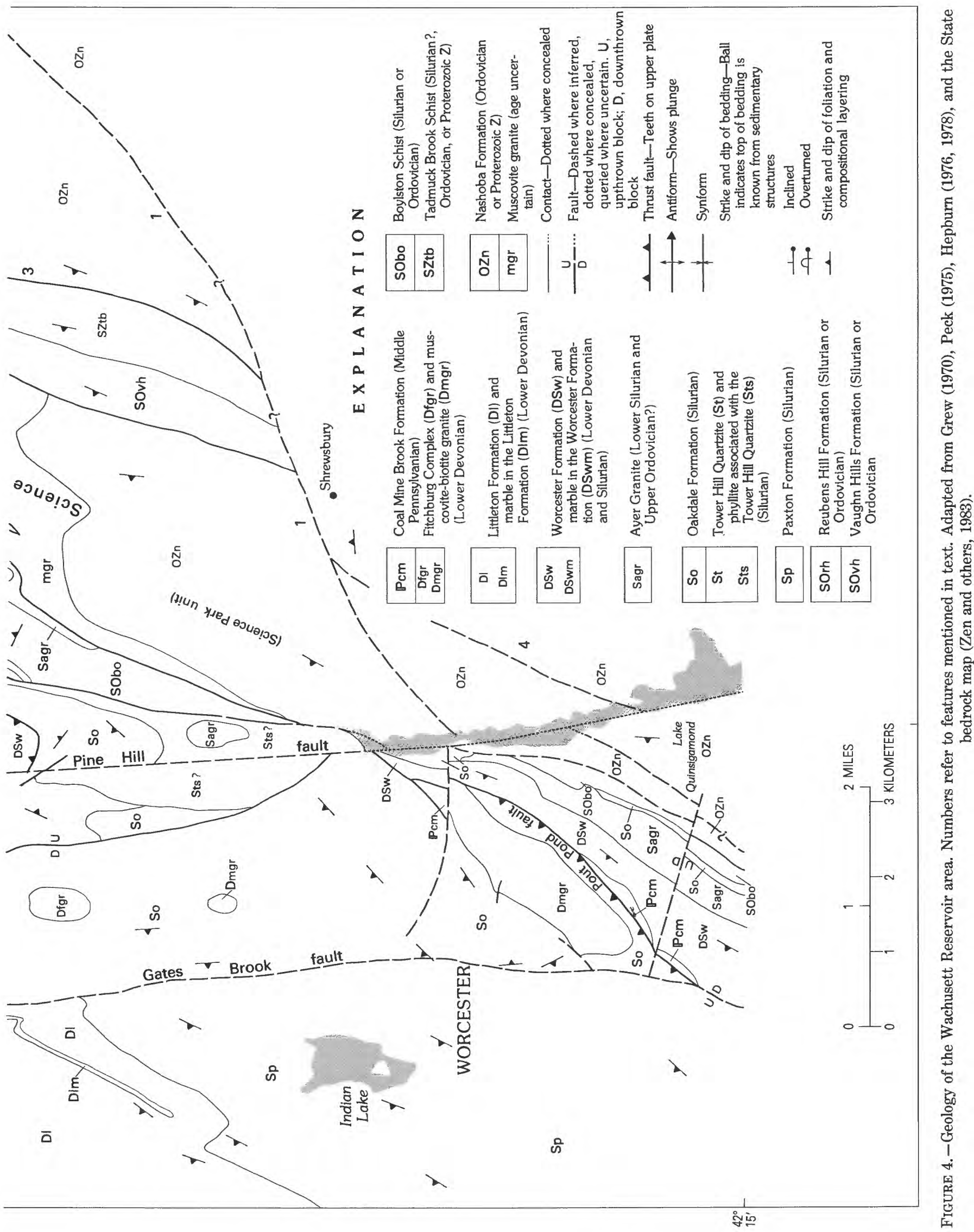


by this time the term "Clinton-Newbury" had come into common use.

The Clinton-Newbury fault has fairly clear linear expression between Newburyport and Lowell where it consists of a single strand (Castle, 1964; Shride, 1976a). To the south, however, it is depicted as an anastomosing system of faults (Alvord, 1975; Peck, 1975; Gore, 1976b). The trace of the Clinton-Newbury fault on the branch southeast of the Tadmuck Brook Schist, southeast of Ayer, is based in large part on truncation of aeromagnetic pattern and lithic units in the Nashoba Formation along this line. Alternatively this truncation has been suggested to be an unconformity beneath the Tadmuck Brook Schist (Bell and Alvord, 1976).

Skehan (1968) identified a group of fault zones at the west end of the Wachusett-Marlborough tunnel in the Clinton area, which he later included in the ClintonNewbury fault zone. These are the Rattlesnake Hill fault zone, the Boylston fault zone, the Clinton fault zone, and the Wachusett Reservoir fault zone. Between the Rattlesnake Hill fault zone and the Boylston fault zone is the Science Park block, an apparently upthrust mass of Nashoba Formation (the Science Park unit of Hepburn, 1976) and muscovite granite forming a lens that extends as far south as the Worcester area. South of Worcester the main trace is not clearly identified and is somewhat arbitrarily shown as separating the Nashoba Formation from the Boylston Schist of the Merrimack belt.

Castle and others (1976) argued that the ClintonNewbury fault is misnamed and should be called the Essex fault for its clear expression in Essex County where it dips steeply, because the Clinton fault, as identified, is a thrust. They felt that the main trace of the Essex fault is the steep Rattlesnake Hill fault of Skehan that bounds the allochthonous block of Nashoba near Shrewsbury on the east side (fig. 4) rather than the more gently dipping Boylston and Clinton faults that lie west of this block. However, the Rattlesnake Hill fault has not been traced as such south of Shrewsbury, and, as mentioned above, the name "Clinton-Newbury" is now well established in the literature for the whole zone. The Clinton fault of Skehan (1968) is not necessarily the main trace of the Clinton-Newbury zone even though it forms the lower limit of the masses of Ayer Granite. No Ayer Granite is presently identified in the Nashoba zone, and the Ayer appears to be entirely confined to the rocks of the Merrimack belt. The Tadmuck Brook Schist, the Vaughn Hills Quartzite, the Boylston Schist, and the Tower Hill Quartzite of the Merrimack belt lie west of the Rattlesnake Hill fault. Skehan and Murray (1980b, p. 288-289) showed these units as part of the Nashoba zone. Hepburn (1978), however, showed a fault bounding these units on the east side (3, fig. 4) as part of the Clinton-
Newbury fault zone. This fault is shown on the State bedrock map.

The main trace of the Clinton-Newbury fault as defined above dips steeply in its northern part. A.F. Shride (oral commun., 1979) stated that the dip is steep in the Newburyport area, where the Clinton-Newbury coincides with Shride's (1971) Scotland Road fault. Mylonites close to the fault west of Groveland dip $60^{\circ}$ to the west (Castle and others, 1976). Near Harvard the fault dips steeply and is characterized by zones of mylonite and mylonite gneiss, most conspicuous in Ayer Granite. Near Harvard the fault splits into two strands in the Tadmuck Brook Schist and forms a lens containing Ayer Granite and Harvard Conglomerate at Pin Hill in Harvard. Dips are steep in sheared Ayer Granite on both the west side of Pin Hill (Barosh, 1976, p. 311; Gore, 1976a, p. 106, and written commun., 1978) and the east side (Thompson and Robinson, 1976, p. 348). Farther south, the Rattlesnake Hill fault of Skehan (1968) dips $60^{\circ}-65^{\circ}$ to the west and was shown by Skehan and Abu-Moustafa (1976) as a reverse fault. The Clinton and Boylston faults to the west and those in the Carville basin of the Wachusett Reservoir have dips of $30^{\circ}-45^{\circ}$ (Skehan, 1968). Sense of movement on these faults is northwest over southeast. In the Wachusett-Marlborough tunnel section, steeper faults, such as the Rattlesnake Hill fault, locally fold and truncate the more shallowly dipping faults (Skehan and Murray, 1980b). The Boylston fault, however, according to Skehan and Abu-Moustafa (1976), is characterized by hydrothermal alteration, the presence of pyrite, and development of chlorite. This association suggests that it is a younger, shallower fault than the fault associated with ductile mylonites observed in the Harvard area to the north. G.R. Robinson, Jr. (written commun., 1984), observed, in the steeply dipping part of the Clinton-Newbury fault near Ayer, evidence for an earlier right-lateral displacement followed by left-lateral displacement.

The location of the principal strand of the ClintonNewbury fault system south of Clinton is arguable. The structural position of the block of rock (fig. 4) containing Hepburn's (1976) Science Park unit and the Rattlesnake Hill pluton that lies between the Rattlesnake Hill and the Clinton and Boylston faults is obscure (see Castle and others, 1976). I have interpreted the Science Park block as a slice of Nashoba Formation thrust up eastward along the Rattlesnake Hill fault to override a thin sequence of units that may lie unconformably on the Nashoba (Skehan and Murray, 1980b). To have been brought up from the west, the rocks of the Nashoba zone must extend at shallow depth an appreciable distance westward under the east flank of the Merrimack belt. Such a configuration is shown on cross section $F-F^{\prime}$ of the State bedrock map. 
The location of the Rattlesnake Hill fault south of Shrewsbury is uncertain. Hepburn's (1978) fault (3, fig. 4) that diverges from the southeast margin of the Rattlesnake Hill pluton bounds a narrow wedge of Tadmuck Brook Schist and Vaughn Hills Quartzite (Skehan and Abu-Moustafa's (1976) units U1 through U10). Whether this fault rejoins the Rattlesnake Hill fault is not known. South of Shrewsbury, Castle and others (1976) showed the Rattlesnake Hill fault as offset to the west along a northeast-trending lineament and inferred fault $(1$, fig. 4), coinciding with an abrupt cessation of north-trending magnetic anomalies. South of this offset they showed the Essex (Rattlesnake Hill) fault as continuing within the Nashoba Formation (4, fig. 4) to join the trace of the Clinton-Newbury near Oxford. They also raised the possibility that the fault trends directly south to join the Lake Char fault east of Oxford.

On the State bedrock map, I have extended the Rattlesnake Hill fault southwestward to the northeasttrending lineament $(1$, fig. 4$)$, which incidentally is shown fairly well by a discordance in structural data on Hepburn's Shrewsbury map (unpub. data, 1979), and thence offset it along the lineament so that it eventually joins, near Lake Quinsigamond, the faults lying west of the Science Park block (fig. 4). On figure 4, I have shown the fault as offset again to the north along the Pine Hill fault at Lake Quinsigamond. South of Worcester I have placed the main trace of the Clinton-Newbury fault at the boundary between the Boylston Schist and the Nashoba Formation. This location coincides with an unnamed fault of Castle and others (1976), lying between their Essex (Rattlesnake Hill) fault and their westernmost fault, the Clinton. In the Oxford-Webster area, I have placed the main trace at the base of the Ayer Granite (Sagr) following Barosh (1978) and Dixon (unpub. data, 1978). I have interpreted Castle and others' (1976) Clinton fault south of Worcester as a continuation of the high-angle Wekepeke fault (Peck, 1975) because it bounds the low-grade Worcester Formation on the west as the Wekepeke does farther north. The different generations of faults in the Oxford-Webster area have not been identified to my satisfaction. Somewhere in this area the north-south Flint Hill fault system (Rodgers, 1970; Skehan and Murray, 1980b, p. 294), characterized by brecciation, silicification, and hydrothermal alteration of probable Triassic and Jurassic age, of which the Wekepeke fault (Pine Hill fault of Castle and others) is a part, must connect with the similar fault system typified by the Lantern Hill fault in southeastern Connecticut (Goldsmith, 1985) and to the north-trending silicified and brecciated rocks that roughly coincide with the Lake Char ductile fault zone in eastern Connecticut (Dixon, 1965b, 1968). The trace of the Clinton-Newbury fault southeast of Webster is speculative. Possibly it curves southwestward to lie at the base of the Canterbury Gneiss (Ayer equivalent) in eastern Connecticut, as shown by Pease (1982, fig. 1). There it merges with the Honey Hill fault zone south of Colchester, Conn. In support of this idea, the base of the Canterbury Gneiss exposed along Connecticut Route 11 west of Salem Four Corners, Conn., has a cataclastic foliation dipping about $20^{\circ}$ to the northwest. On the other hand, Castle and others (1976) projected the Clinton-Newbury fault (Essex and Clinton faults) into faults within the Tatnic Hill Formation shown by Dixon $(1974,1982)$ in northeast Connecticut. The west-dipping faults like the Clinton of Skehan (1968) must be truncated by the steeply dipping Wekepeke fault, and their trace should theoretically be offset to the north by uplift on the west side of the Wekepeke. No such fault or faults have been mapped. Numerous thrusts involving Ayer Granite, however, are shown south of Worcester by Barosh (1974, 1977).

The Clinton-Newbury fault projects eastward into the Gulf of Maine where Simpson and others (1980) suggested that it is aligned with the trend of the South Atlas fault, or it may in some way connect with the CobequidChedebucto fault of Nova Scotia. It may connect with the Isleboro fault of eastern Maine, although the latter seems more identifiable with the Bloody Bluff fault from the nature of the rocks on either side of it. It does not appear to project into the Norumbega fault (Wones and Thompson, 1979) of eastern and southeastern Maine. The Norumbega seems rather to project toward the Massabesic terrane to the west, as suggested by Lyons and others (1982). Structural features of eastern Maine and northeastern Massachusetts are not directly correlatable.

The north-northeast-trending Portsmouth fault of Novotny (1969), which lies between the Rye Formation of southern New Hampshire and the Kittery Formation of the Merrimack Group, does not project on the surface into the Clinton-Newbury as might be expected from its strike. Carrigan (1984a) found that the mylonites of the Portsmouth fault (P, fig. 3) are folded eastward around the south-plunging nose of the Rye anticline. This folded mylonite suggests that the Portsmouth fault may mark the reappearance to the north of the ductile portion of the Clinton-Newbury fault. The lithology and metamorphism of the Rye as described by Carrigan (1984b) resemble those of the Marlboro Formation in the Nashoba zone. Such an interpretation changes the position of the trend of the Clinton-Newbury and brings the fault closer to projected connections with the faults in Maine. An important fact to be emphasized is that the ClintonNewbury fault, although it appears to be a boundary between major basement blocks, coincides on the surface in Massachusetts with an apparent unconformity between the rocks of the Merrimack synclinorium and 
the rocks of the subjacent Nashoba zone (Robinson and Goldsmith, this vol., chap. G). Typical Nashoba rocks, although disrupted by the Clinton-Newbury fault, project below the rocks of the Merrimack belt, as discussed above, and form part of the basement on which the Merrimack-belt strata are deposited. An alternative explanation is that part or all of the overlying Merrimack strata have moved into their present position on an early detachment surface.

\section{AGE OF THE CLINTON-NEWBURY FAULT ZONE}

The Clinton-Newbury is a composite fault zone, including both thrusts and reverse faults that have formed over a period of time. Some of the movement may have been as old as Acadian, particularly the low-angle thrusts, which may be related to the east-directed back-thrusting recorded by Robinson and Hall (1980) in the Bronson Hill zone to the west. Some of these thrusts contain sillimanite-grade mylonites, according to G.R. Robinson, Jr. (written commun., 1984). The deformation of the Devonian plutons suggests, however, that the bulk of the movement, particularly on the steeply dipping segments, is Late Devonian or younger. Faults in the ClintonNewbury zone are clearly younger than the metamorphism of the rocks in both the Nashoba zone and the Merrimack belt, and faults in the zone clearly cut the Devonian muscovite granite of the Rattlesnake Hill pluton. It is not certain how faults that enclose the Middle Pennsylvanian Coal Mine Brook Formation at Worcester are related to the Clinton-Newbury or to the probably Triassic and Jurassic faults of the Flint Hill fault system.

In summary, at least three different styles and ages of faulting are present in the Clinton-Newbury fault zone. The oldest is low-angle, east-directed thrusts and reverse faults. They are possibly of Acadian age but could be late Paleozoic. The next group is high-angle faults that truncate the former and that in places contain evidence of strike-slip movement. These are probably late Paleozoic. Both of these groups are ductile. The third style of faults is high-angle, apparently normal faults characterized by brecciation and silicification. They are probably Mesozoic in age.

\section{STRUCTURAL RELATIONS WEST OF THE CLINTON- NEWBURY FAULT}

The Clinton-Newbury fault now forms much of the presently exposed east margin of the Merrimack belt. The east flank of the Merrimack belt, as here defined, is that area between the Wekepeke fault and the Eastford fault in Connecticut (figs. 3, 5), on the west, and the Nashoba zone, on the east. It is a structurally complex area containing an assemblage of rocks whose sequence is uncertain but which are younger than the rocks of the Nashoba zone (Robinson and Goldsmith, this vol., chap. G). The area can be divided structurally into the Nashua trough (Crosby, 1880; Smith and Barosh, 1981), to the west and northwest, and the Rockingham anticlinorium (Billings, 1956), to the north and northeast. The boundary between the Nashua trough and the Rockingham anticlinorium in Massachusetts is in part a fault (F, fig. 3) coinciding with a metamorphic gradient, but near the New Hampshire border the boundary is primarily a metamorphic gradient and coincides with the contact between the Oakdale Formation and the Berwick Formation (or the equivalent units mapped by G.R. Robinson, 1978). The Rockingham anticlinorium is truncated diagonally by the Clinton-Newbury fault so that to the south, near Worcester, rocks of the Nashua trough lie adjacent to rocks of the Nashoba zone across the ClintonNewbury fault. The Nashua trough persists to the south into Connecticut through a complex system of faults near the Massachusetts-Connecticut border and appears to coincide with a low-grade metamorphic trough extending southward through eastern Connecticut (Thompson and Norton, 1968) that contains units such as the Scotland Schist (Dixon and Lundgren, 1968). The Rockingham anticlinorium and the Nashua trough contain similar lithologies, but differences in metamorphic grade between the two structural belts and the complex style of deformation make it difficult to establish stratigraphic sequences that could aid in determining the structure.

\section{NASHUA TROUGH}

The structure within the Nashua trough remains to be convincingly worked out. Crosby (1880) considered the Nashua trough to be synclinal (fig. 6) so that the Oakdale and Paxton Formations were equivalent units on opposite limbs and the Worcester Formation lay in the trough. Peck (1975) showed overturned beds in the Worcester Formation, but he also showed upright beds a short distance across strike so that the folding in these rocks may be primarily megascopic; his section, like that of Grew (1970), on the whole is upright and west facing. On the other hand, Grew (1973), Hepburn (1976), and G.R. Robinson (1981) presented evidence that suggests that the Oakdale Formation lies in an isoclinal syncline so that the Tower Hill Quartzite and the Worcester Formation are on opposite limbs. Crosby's Nashua "synclinal" possibly exists but in more complicated fashion than he figured. The whole section may be recumbently folded (G.R. Robinson, 1981, p. 59-63; fig. 7B,C). Robinson (1981) and Peper and Wilson (1978) both noted, in the area east of the Fitchburg Complex, a flat cleavage that deforms an earlier, relatively flat regional schistosity 


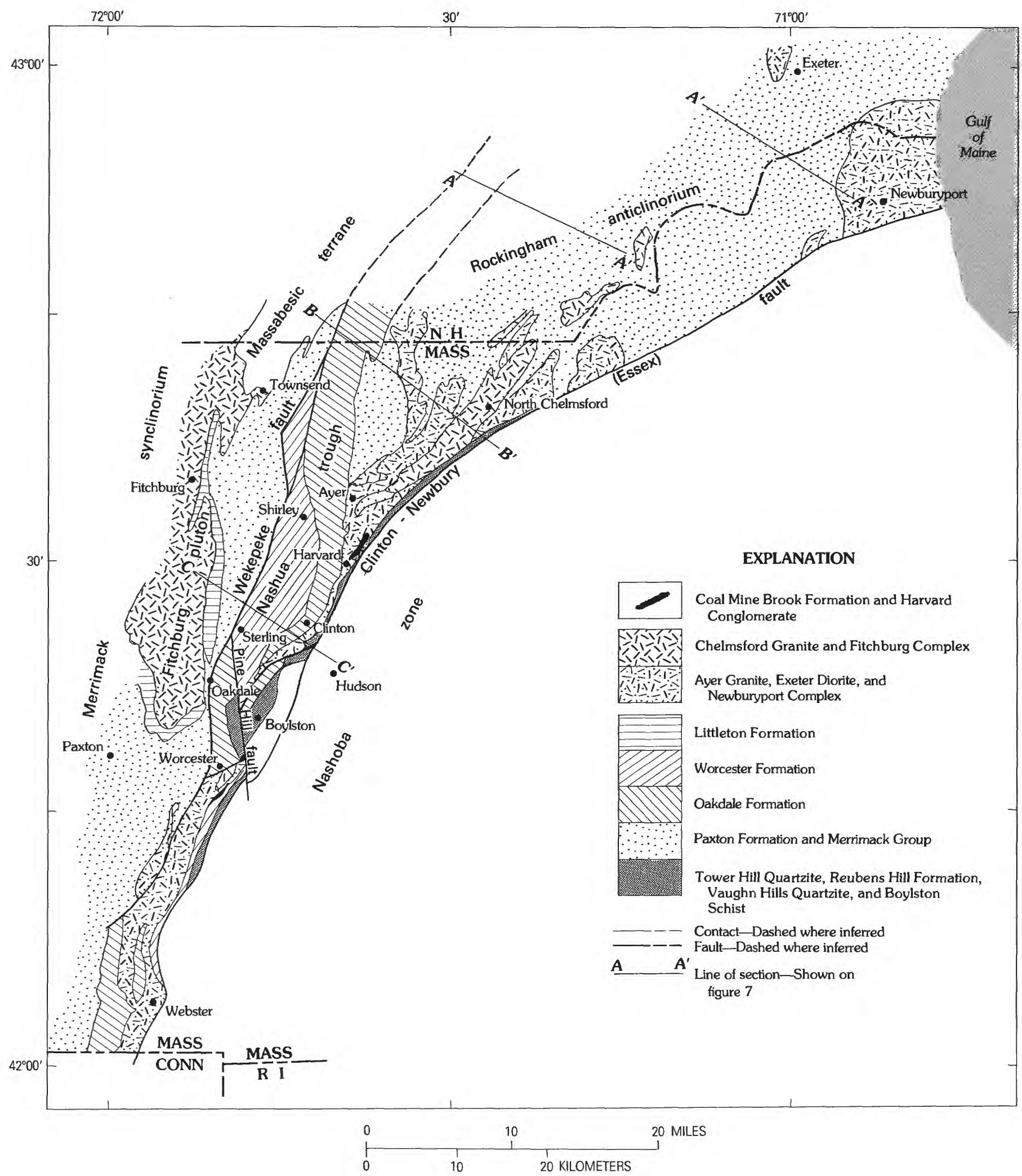

Figure 5. - Geology of the east flank of the Merrimack belt, Massachusetts and New Hampshire, showing locations of cross sections $\left(A-A^{\prime}-A^{\prime \prime}\right.$, $B-B^{\prime}, C-C^{\prime}$ of figure 7). 

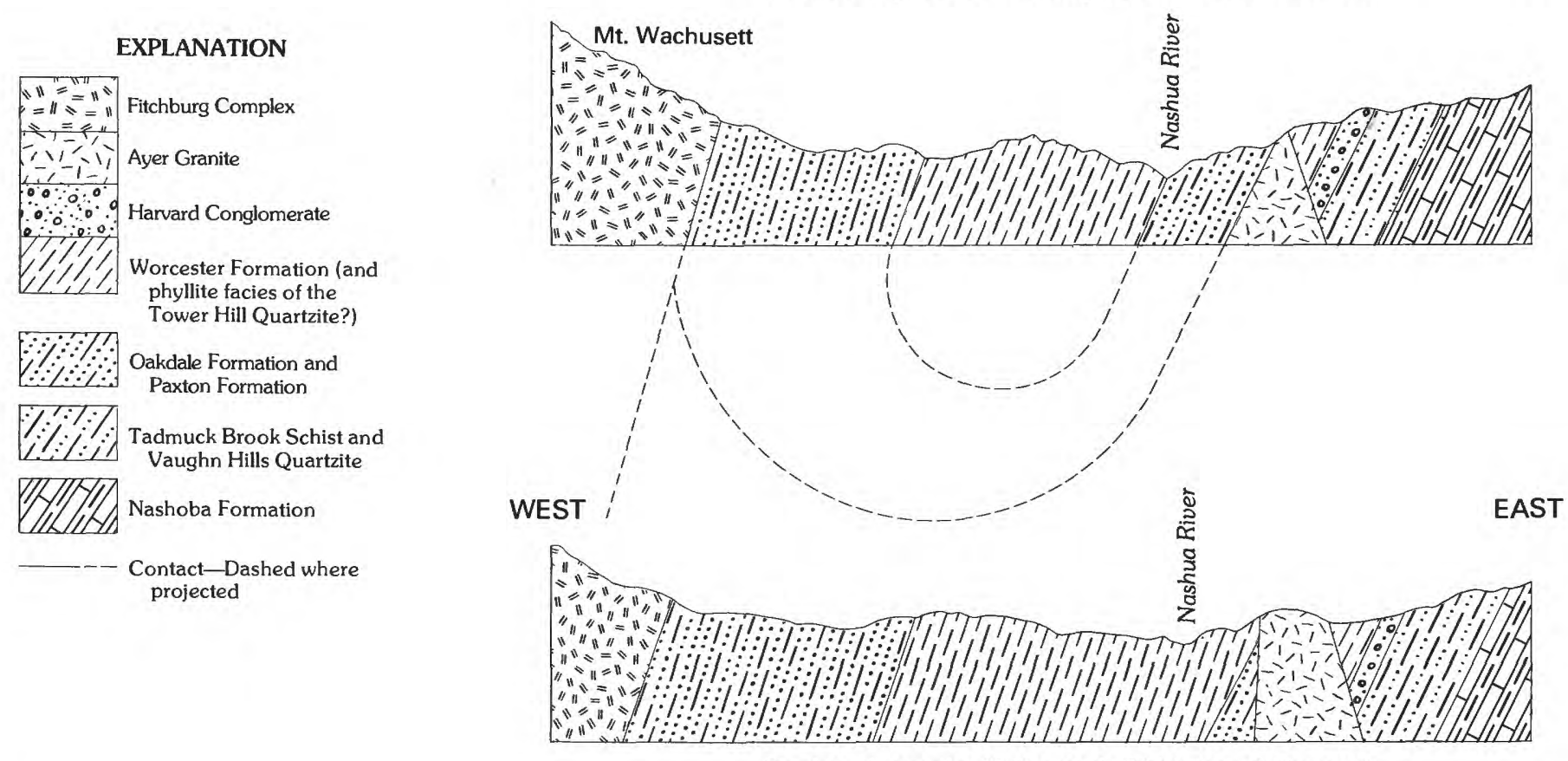

Nashua "synclinal" through Shirley and Harvard

FIGURE 6. -Schematic section near cross section $C-C^{\prime}$ (see fig. 5 for location) across the Nashua "synclinal" as drawn by Crosby (1880, pl. III). Unit names are those used on the State bedrock map (Zen and others, 1983).

accompanied by small-scale isoclinal folds. This deformation pattern suggests at least two stages of horizontally directed stress. Tucker (1978) described early stages of recumbent folding followed by open, upright folding to the west in the Wachusett Mountain area. These flat folds are indicated on cross section $D-D^{\prime}$ of the State bedrock map. The configurations shown in figure 7 are largely the result of the latest folding. Such inferences can be made to account for the discrepancies in topping evidence between Peck (1975) and Robinson (1981), presuming a regional northward plunge. However, no really satisfactory interpretation accommodates all the mapping. It is possible that submarine slides have disrupted the original depositional sequence. Furthermore, lateral stratigraphic facies changes can obscure equivalencies of units and thus lead to false inferences as to structure.

The formations in the Nashua trough are at lower metamorphic grade than are those in adjacent belts, and they coincide with a metamorphic trough (Thompson and Norton, 1968). The Nashua trough is bounded on its west side by a high-angle fault, the Wekepeke fault, that brings up higher grade metamorphic rocks on the west in and adjacent to the Fitchburg Complex and to the Massabesic Gneiss Complex in the Massabesic anticlinorium. The Worcester Formation contains andalusite in the western part of its outcrop area near the Wekepeke fault and the Fitchburg Complex. The Wekepeke fault is part of the Flint Hill-Silver Hill fault system of probable Permian age (Lyons and others, 1982) and (or) Mesozoic age (Rodgers, 1970).

\section{ROCKINGHAM ANTICLINORIUM}

The Rockingham anticlinorium consists of folded but overall gently dipping low- to medium-grade metamorphic rocks of the Merrimack Group (figs. 5, 7). In New Hampshire, the Rye Formation of Proterozoic Z or early Paleozoic age is exposed in the easternmost anticline, the Rye anticline, but the Rye Formation does not reach Massachusetts on the surface. The formations are in open folds about steep axial surfaces on which are superimposed local zones of tight folding. The folding is tighter and more discordant to the west, and early isoclinal folds on a mesoscopic scale (not indicated in the section, fig. $7 \mathrm{~A}$ ) are locally present. Existing sections imply that the strata are not severely deformed. G.R. Robinson's study (1978) suggested that the structure within the Merrimack Group in the Pepperell-Ayer area, at least, is not one of simple anticlines and synclines but that these are at least second-generation folds and that more than one earlier generation of folds is present. The cross sections of Sriramadas (1966) in the Nashua area of the Nashua trough indicate fairly tight folding, but in the Rockingham anticlinorium to the east the rocks of the Merrimack 

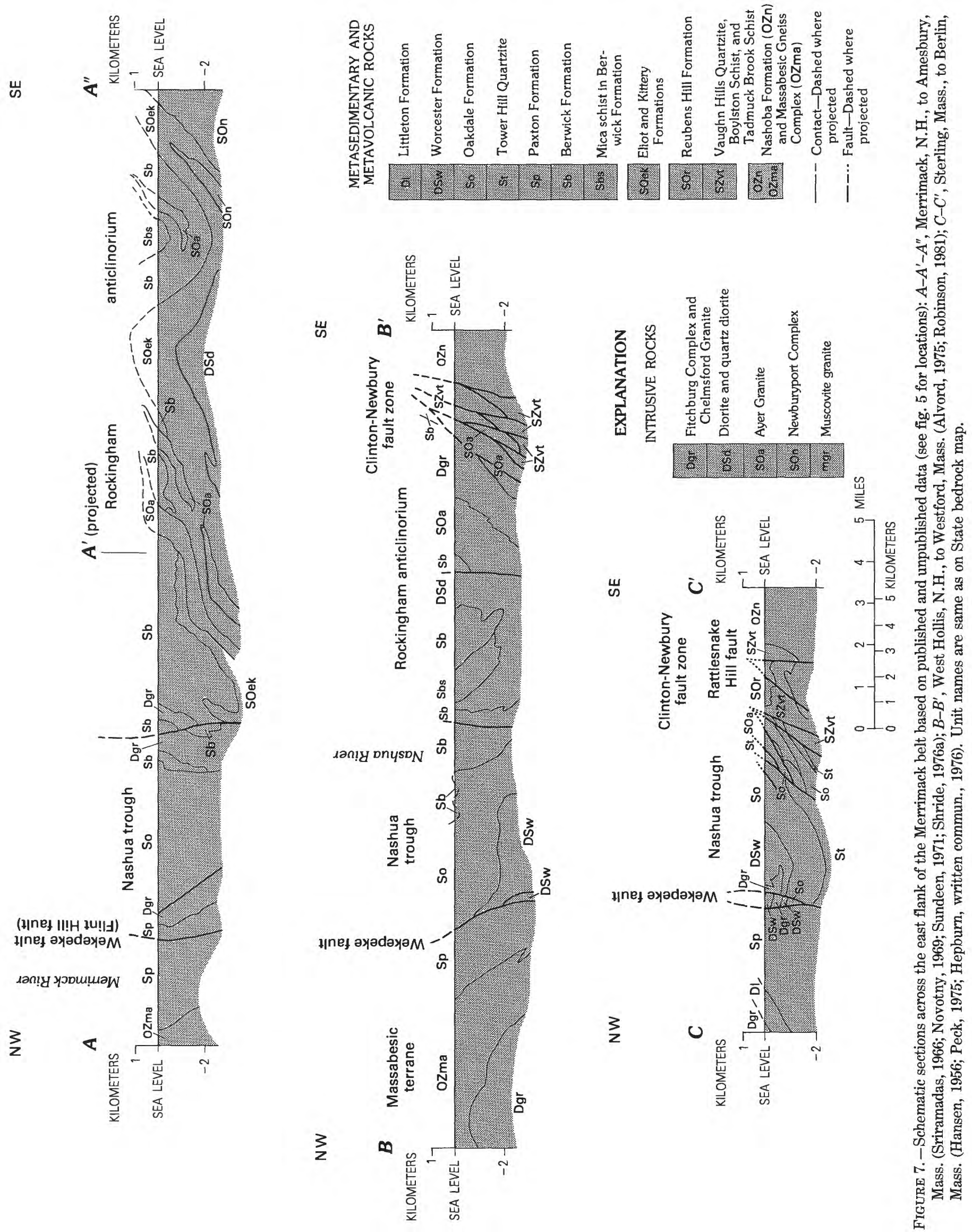
Group appear to be less deformed and in more open folds (fig. 7A). However, an earlier generation of small-scale isoclinal folds seen in outcrops (Sundeen, 1971) suggests that the structure here too may be complex. Robinson (1978, section $\left.B^{\prime \prime}-B^{\prime \prime \prime}\right)$ showed a unit equivalent to the Berwick Formation overlying a unit equivalent to the Oakdale Formation in the Pepperell area. The section is probably a combination of intertonguing facies and softsediment deformation that has subsequently been polydeformed.

Metamorphic grade increases across the Rockingham anticlinorium. The formations are in the chlorite and biotite zones in the east and reach garnet grade to the west. The garnet zone coincides with an area containing many plutons of granite and diorite of Silurian and Devonian age. A sharp gradient back to chlorite zone forms the boundary between the Rockingham anticlinorium and the Nashua trough in the Pepperell area. This boundary coincides with the contact of the Berwick and Oakdale Formations; it marks a change in bedding style and grain size from thin bedded and fine grained (Oakdale) to thick bedded and coarse grained (Berwick). The metamorphic zones, like the rock units, are truncated to the south by the Clinton-Newbury fault.

\section{SUMMARY}

In summary, the Nashoba zone is a lens of internally folded and faulted high-grade paragneiss and metavolcanic rock bounded by major fault systems. These faults separate the zone from terranes different in lithology, metamorphism, and plutonism. Regional relations indicate that the Nashoba zone projects beneath the Merrimack belt to the west. The paragneiss is intruded by late-metamorphic granite and quartz diorite of Ordovician age and postmetamorphic granite and granodiorite of Silurian and Devonian age. The main period of thermal metamorphism and folding is Ordovician or older. Faults range in age from Late Devonian (postgranite) to probably Triassic and Jurassic. East-directed thrusts and reverse faults are older than high-angle faults. The folding and thrusting on the east flank of the Merrimack belt are thought to be Acadian because the Upper Ordovician(?) and Lower Silurian Ayer Granite is involved.

\section{MILFORD-DEDHAM ZONE}

The Milford-Dedham zone has been broken by normal and reverse faults into upthrown blocks of Proterozoic plutonic and metamorphic basement rock and downthrown blocks containing sedimentary and volcanic cover rocks of Proterozoic Z, Cambrian, Silurian-Devonian, Pennsylvanian, and Triassic-Jurassic age (figs. 1, 8). The

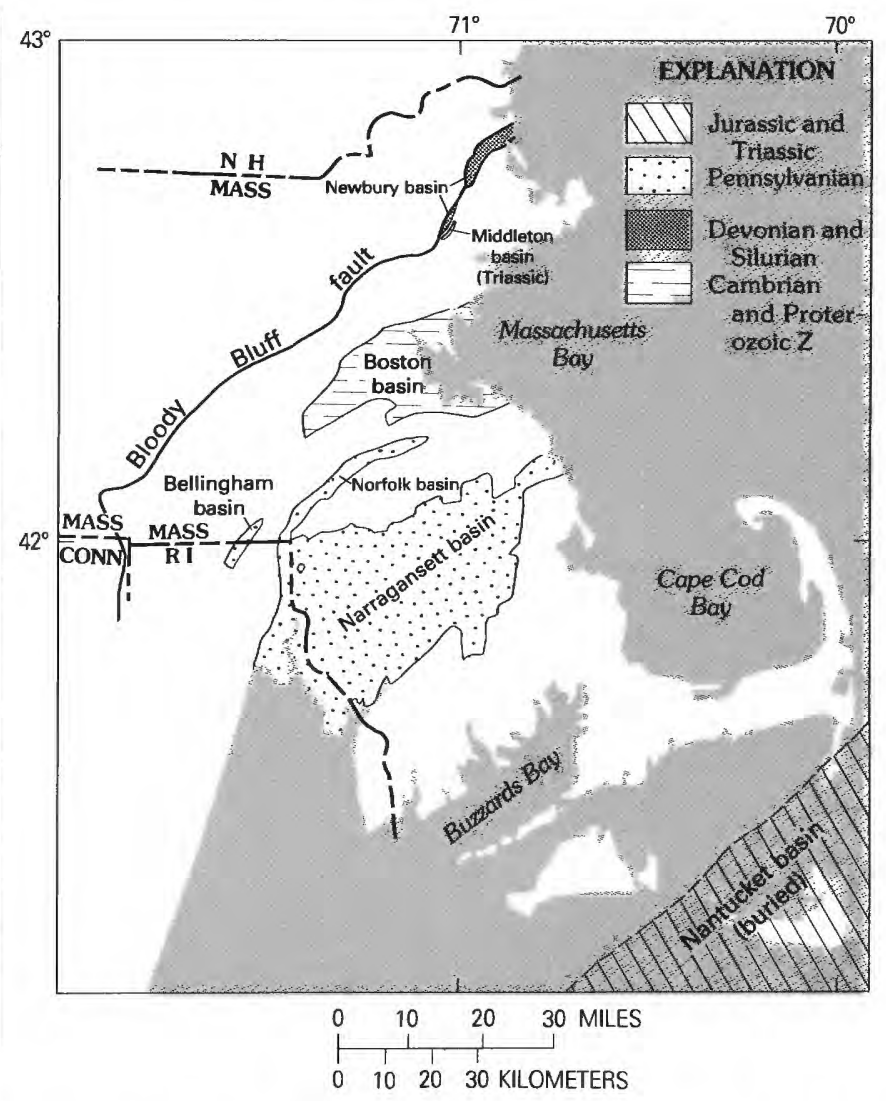

Figure 8.-Basins of the Milford-Dedham zone, eastern Massachusetts.

major blocks of basement are the gneissic Milford antiform at the north end of the Rhode Island anticlinorium, the brittlely deformed Salem block to the northeast, and the southeastern Massachusetts batholith, subdivided into the Dedham, Foxborough, and Fall River blocks. Intervening basins are, from north to south, the Newbury, Middleton, Boston, Norfolk, Bellingham (also locally known as Woonsocket), Narragansett, and Nantucket basins. The Milford-Dedham zone east of the Bloody Bluff fault is at least $200 \mathrm{~km}$ wide. U.S. Geological Survey seismic line 5 (cited by Grow and others, 1979) places the edge of the continental crust at about the northern edge of the East Coast magnetic anomaly (Klitgord and Behrendt, 1979) about $190 \mathrm{~km}$ south of Nantucket. Klitgord (1984) suggested that the boundary between the Avalon terrane (Milford-Dedham zone) and the Meguma terrane exposed in southern Nova Scotia is either within the Gulf of Maine platform or at the boundary of the Georges Bank rift basin. In the latter case, the edge of the Milford-Dedham zone would lie east of Nantucket Island and Cape Cod. In the former case, the boundary could not lie west of Cape Cod Bay and probably lies east of Cape Cod judging from the materialin cores drilled at Harwich, Mass. (Goldsmith, this vol., chap. E; Wones and Goldsmith, this vol., chap. I). 
TABLE 1.-Metamorphism, plutonism, and faulting in basement rocks of the Milford-Dedham zone, eastern Massachusetts

\begin{tabular}{|c|c|c|c|c|c|c|}
\hline & \multirow{2}{*}{ Milford antiform } & \multirow{2}{*}{ Salem block } & \multirow{2}{*}{ Dedham block } & \multirow{2}{*}{ Foxborough block } & \multicolumn{2}{|c|}{ Fall River block } \\
\hline & & & & & Northwest & Southeast \\
\hline \multicolumn{7}{|c|}{ Paleozoic intrusive rocks } \\
\hline Rock type & $\begin{array}{l}\text { (In Rhode Island } \\
\text { Devonian alkalic } \\
\text { granite, partly } \\
\text { gneissic). }\end{array}$ & $\begin{array}{l}\text { Devonian to Ordo- } \\
\text { vician alkalic } \\
\text { granite and gab- } \\
\text { bro. }\end{array}$ & $\begin{array}{l}\text { Devonian to Ordo- } \\
\text { vician alkalic } \\
\text { granite. }\end{array}$ & $\begin{array}{l}\text { Devonian alkalic } \\
\text { granite. }\end{array}$ & Not present & Not present. \\
\hline \multicolumn{7}{|c|}{ Cambrian strata } \\
\hline Rock type & Not present & $\begin{array}{l}\text { Argillite and mar- } \\
\text { ble. }\end{array}$ & $\begin{array}{l}\text { Slate, argillite, } \\
\text { sandstone, and } \\
\text { quartzite. }\end{array}$ & $\begin{array}{l}\text { Slate, argillite, and } \\
\text { quartzite. }\end{array}$ & Not present & Not present. \\
\hline Metamorphism & & $\begin{array}{l}\text { Contact metamor- } \\
\text { phosed. }\end{array}$ & Subgreenschist & Subgreenschist & & \\
\hline \multicolumn{7}{|c|}{ Proterozoic Z plutonic rocks } \\
\hline Rock type & $\begin{array}{l}\text { Orthogneiss and } \\
\text { granite to dio- } \\
\text { rite. }\end{array}$ & $\begin{array}{l}\text { Granite to gabbro, } \\
\text { partly cataclastic } \\
\text { and altered. }\end{array}$ & $\begin{array}{l}\text { Granite to gabbro, } \\
\text { partly cataclastic } \\
\text { and altered. }\end{array}$ & $\begin{array}{l}\text { Granite to gabbro, } \\
\text { partly cataclastic } \\
\text { and altered. }\end{array}$ & $\begin{array}{l}\text { Granite, partly cat- } \\
\text { aclastic and } \\
\text { altered. }\end{array}$ & $\begin{array}{l}\text { Orthogneiss, } \\
\text { granite, } \\
\text { and dio- } \\
\text { rite; } \\
\text { locally cat- } \\
\text { aclastic. }\end{array}$ \\
\hline Metamorphism & Amphibolite & $\begin{array}{l}\text { Greenschist to sub- } \\
\text { greenschist. }\end{array}$ & $\begin{array}{l}\text { Greenschist to sub- } \\
\text { greenschist. }\end{array}$ & $\begin{array}{l}\text { Greenschist to sub- } \\
\text { greenschist. }\end{array}$ & $\begin{array}{l}\text { Greenschist to sub- } \\
\text { greenschist. }\end{array}$ & Amphibolite. \\
\hline \multicolumn{7}{|c|}{ Proterozoic $\mathbf{Z}$ stratified rocks } \\
\hline Rock type & $\begin{array}{l}\text { Gneiss, schist, } \\
\text { quartzite, and } \\
\text { amphibolite. }\end{array}$ & $\begin{array}{l}\text { Gneiss, schist, } \\
\text { quartzite, } \\
\text { amphibolite, fine- } \\
\text { grained para- } \\
\text { gneiss and green- } \\
\text { stone. }\end{array}$ & $\begin{array}{l}\text { Phyllite, quartzite, } \\
\text { and greenstone. }\end{array}$ & $\begin{array}{l}\text { Phyllite and green- } \\
\text { stone. }\end{array}$ & $\begin{array}{l}\text { Phyllite and green- } \\
\text { stone. }\end{array}$ & $\begin{array}{l}\text { Gneiss and } \\
\text { schist. }\end{array}$ \\
\hline Metamorphism & Amphibolite & $\begin{array}{l}\text { Amphibolite to } \\
\text { greenschist. }\end{array}$ & Greenschist & Greenschist & Greenschist & Amphibolite. \\
\hline \multicolumn{7}{|c|}{ Faults } \\
\hline & Largely ductile & Ductile and brittle & Brittle & Brittle & Brittle & $\begin{array}{r}\text { Brittle and } \\
\text { ductile(?). }\end{array}$ \\
\hline
\end{tabular}

\section{STRUCTURE AND METAMORPHISM IN THE BASEMENT BLOGKS}

\section{MILFORD ANTIFORM}

The largely batholithic rocks of the Rhode Island anticlinorium project into Massachusetts as the Milford antiform (Milford anticline of Hall and Robinson, 1982, fig. 1). The Milford antiform consists of gneissic plutonic rocks of the Proterozoic Z Sterling Plutonic Suite (Goldsmith, 1966; Goldsmith and others, 1982) of Connecticut, Rhode Island, and Massachusetts, the Proterozoic Z Milford Granite and adjacent unnamed granite (Zgr, on the State bedrock map) in Massachusetts, and the metasedimentary and metavolcanic rocks of the Plainfield and Westboro Formations and the Blackstone Group. A large area of Devonian granite has been identified in central Rhode Island in what was formerly considered to be part of the Sterling Plutonic Suite (Hermes and others, 1981), but this rock does not extend into Massachusetts. Metasedimentary and metavolcanic rocks of the Plainfield and Westboro Formations and the Blackstone Group flank the antiform on the west, north, and east, respectively, and form septa within it. These rocks are mostly in the amphibolite facies of metamorphism (table 1). Rocks of the Proterozoic $\mathrm{Z}$ mafic metamorphicplutonic complex (Zv and Zdigb) of eastern Massachusetts are most abundant north of the antiform in the Salem block.

The Milford antiform is bounded on the west by the Lake Char fault. The antiform plunges northeastward in 


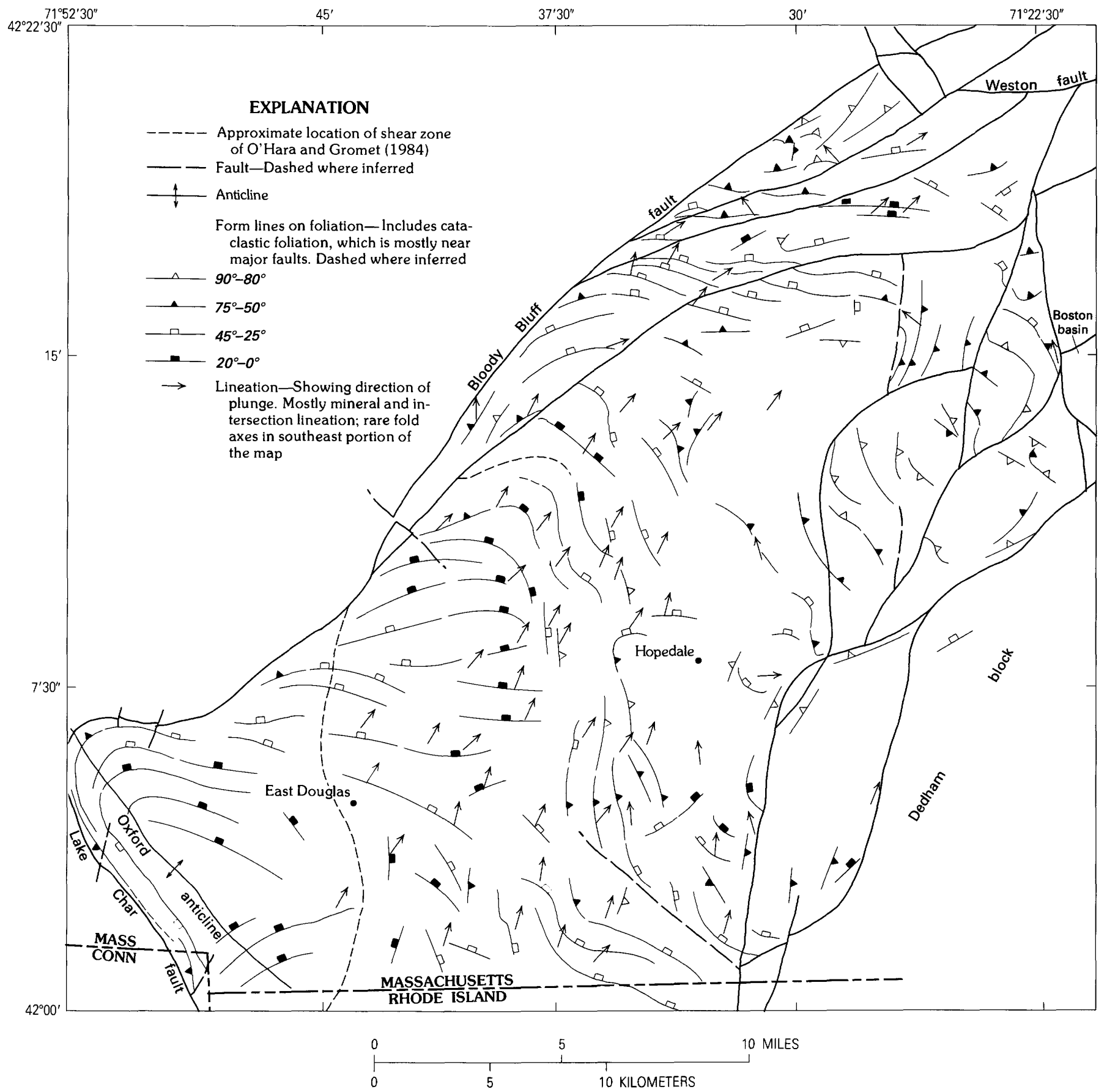

FIGURE 9. - Form lines on foliation and direction of plunge of lineation in the Milford antiform, eastern Massachusetts. Data from McKniff (1964), Shaw (1967), Barosh (1974, 1978), Dixon (1974, written commun., 1977 and 1978), Nelson (1975a,b), Volckmann (1977), and Hepburn and DiNitto (1978).

the Marlborough-Framingham area where it is truncated obliquely by the Bloody Bluff fault. The trend of gneissosity and rock units in the Milford antiform forms a partial arc around a core of Milford Granite (figs. 2, 9). Internally, the antiform shows an interference pattern of fold structures evident in the East Douglas area. Low plunges of lineations combined with the complex map pattern of units on the east side of the antiform near the Massachusetts-Rhode Island border suggest the presence of refolded nappe structures or of low-angle ductile deformation, which is reminiscent of features characteristic of metamorphic core complexes in the Western United States (see Coney, 1980). The west-projecting node at Oxford and Webster, called by Barosh (1982) the 
Oxford anticline, is apparently younger than the Lake Char fault because it folds the fault.

The Proterozoic metasedimentary and metavolcanic rocks $(\mathrm{Zp}, \mathrm{Zw}, \mathrm{Zb})$ within the Milford antiform are in the amphibolite facies and contain minor folds older than the gneissic fabric in the plutonic rocks. These folds are less noticeable in the west, where the plutonic rocks have a marked gneissic fabric, than to the east, where the plutonic rocks are less deformed, for example in and east of Hopedale. In most places, however, the foliation in the metamorphic rocks tends to parallel the foliation in the plutonic rocks, indicating that the two were deformed together.

In general the intensity of deformation increases from east to west across the Milford antiform toward the Bloody Bluff fault. However, within the antiform are zones of rock more gneissose than adjacent rock. Discrete zones of gneissic rock can be seen north and south of the Milford Granite; O'Hara and Gromet (1984) identified in northern Rhode Island a discrete zone of gneissosity (fig. 3), separating the Hope Valley Alaskite Gneiss (Zhg) to the west from the Ponaganset Gneiss (Zpg) and Devonian Scituate Granite to the east, that they believed to be the southward continuation of the Bloody Bluff fault. The gneissosity is more apparent in biotitic rocks, such as the Ponaganset Gneiss and the biotitic phase of the Milford Granite ( $\mathrm{Zmgd}$ ), than in the biotite-poor Hope Valley Alaskite Gneiss (Wones and Goldsmith, this vol., chap. I). The gneissosity is marked by preferred orientation of biotite, where present, and by flat lenses and laminae of quartz and of feldspar. This foliation is parallel to that in the metavolcanic and metasedimentary rocks, although the plutonic rocks can be seen in places to truncate layering and an earlier foliation in the metasedimentary rocks at a low angle. In places, the Hope Valley clearly cuts the other plutonic rocks. The fabric in the Milford Granite (Zmgr), in the core of the Milford antiform, is a lineation rather than a foliation (parallel planar metamorphic fabric), although the more biotitic phase (Zmgd) as mentioned above does have a foliation in places, particularly north of the central core. The Milford Granite and the unnamed granite (Zgr) to the north and east of the Milford are less deformed than are the orthogneisses to the west. They are characterized by rounded aggregates of bluish quartz and more equant feldspars, rather than flat aggregates of quartz and of feldspar characterizing the rocks to the west. To the northeast, the Hope Valley Alaskite Gneiss exposed in many roadcuts along the Massachusetts Turnpike in the Framingham area and within the Bloody Bluff fault zone is fine grained (which I believe is due to tectonic comminution of grain size) and has a marked foliation. East of the Milford Granite, in the Ashland-Holliston area, the foliation is less distinct. Southeast of the Milford Granite, the unnamed granite ( $\mathrm{Zgr}$ ) and the Esmond Granite (Zegr) are not conspicuously deformed except for a north-northeast-trending zone of shear and cataclasis as much as $0.5 \mathrm{~km}$ wide in Zgr (2, fig. 2) along the northwest side of the Bellingham basin in Franklin and Blackstone. This cataclasis is little recrystallized and forms a mylonite gneiss rather than a blastomylonite like that present in the Bloody Bluff fault zone to the north. A thin east-trending strand of well-foliated Scituate Granite Gneiss (Zsgr) flanks the Blackstone Group in the Blackstone River valley on the south side of the less deformed Milford Granite (3, fig. 2). The structural significance of this narrow zone of penetrative deformation is not readily apparent. On the State bedrock map I have indicated that the gneissic terrane includes the Milford and the unnamed granite and that the division between the gneissic and nongneissic terranes falls about on a line from the southwest end of the Boston basin through the Bellingham basin. This line may be offset to the west along the Blackstone River valley and may lie at the west side of the Esmond Granite in Rhode Island (E, fig. 2). The Milford and the unnamed granite are included in the gneissic terrane because of their blastocataclastic fabric (blue quartz aggregates) and local zones of lineation and marked gneissosity. West of the line southwest from the Boston basin are variably penetratively deformed plutonic rocks (orthogneisses) and amphibolite-facies quartzite and paragneisses. East of the line are fractured, brittlely deformed, and partly hydrothermally altered plutonic rocks and greenschistfacies metasedimentary and metavolcanic rocks. The line coincides with faults that are a continuation of the northern boundary fault of the Boston basin and that project in the area of the Bellingham basin. The cataclastic zone in the unnamed granite $(\mathrm{Zgr})$ west of the boundary is considered to be the result of deformation along this boundary. Sheared granite crops out sporadically elsewhere along the bounding fault and along the trace of the fault splaying southwestward off the boundary fault from west of Medway toward Milford. Gromet and O'Hara (1984) and O'Hara and Gromet (1984) believed that a discrete boundary separates the terrane characterized by the less foliated Milford Granite from the terrane characterized by the more foliated Hope Valley to the west. They placed this boundary west of the outcrop area of the Ponaganset Gneiss and thence north to intersect the Bloody Bluff fault (figs. 2, 3,9) and thus would exclude the Milford Granite from the gneissic suite of rocks.

In summary, the Milford antiform is the northeastward-plunging nose of the polydeformed Rhode Island anticlinorium in which the foliation ares around a more or less lineated and less deformed core and eastern flank. The Proterozoic $\mathrm{Z}$ plutonic rocks within the antiform 
are markedly gneissose on the west and north and decrease in gneissosity eastward. The decrease is not systematic, however, for the width of the zone and the intensity of deformation vary, and narrow zones of gneissic rock, like that described by O'Hara and Gromet (1984), flanked by less gneissic rock extend both eastward and northeastward. The zones of gneissosity decrease in prominence eastward to about a line extending from the Boston basin to the Bellingham basin, along which there is increased shearing and cataclasis.

The relations described above indicate a greater degree of pervasive deformation and recrystallization to the west than to the east. This distinction indicates not only a concentration of deformation but also a higher temperature regime to the west. The age of the deformation that produced the gneissosity is discussed below in the section on Proterozoic metamorphism. In the Milford antiform, the metasedimentary and metavolcanic formations are in the amphibolite facies of metamorphism (table 1). There is some evidence to indicate that they were metamorphosed before the intrusion of the plutonic rocks, but a subsequent differentially pervasive dynamic and thermal metamorphism involving the plutonic rocks has rendered such relationships obscure, particularly in the more highly deformed areas.

\section{SALEM BLOCK}

The basement north of the Milford antiform between Framingham and Newbury is here called the Salem block because of the extensive distribution of diorite and gabbro (Zdigb) (Salem Gabbro-Diorite, in part; Wones and Goldsmith, this vol., chap. I) within it (figs. 1, 2). It is bounded on the west by the Bloody Bluff fault, on the southeast by the northern border fault of the Boston basin, and on the south by faults and the northwesttrending rocks at the north end of the Milford antiform (4, fig. 2; fig. 10). The block consists primarily of mafic plutonic rocks (Zdi, Zgb, Zrdi, Zdigb), mafic to felsic metavolcanic rocks $(\mathrm{Zv})$, and minor metasedimentary rocks $(\mathrm{Zw})$. The diorite at Rowley (Zrdi) has a K-Ar age of $656 \pm 16 \mathrm{Ma}$ (Zartman and Marvin, this vol., chap. J, table 1). These rocks have been intruded by the somewhat younger Proterozoic Z Dedham Granite and Topsfield Granodiorite and by early and middle Paleozoic alkalic granite and gabbro. The Lynn Volcanic Complex lies in the Melrose subblock of the Salem block. The Newbury basins containing Upper Silurian-Lower Devonian strata (Newbury Volcanic Complex), and the Middleton basin containing unmetamorphosed Triassic strata ( $\mathrm{ke}$ ), flank the Salem block on the northwest side. The Boston basin lies to the southeast.

The metavolcanic rocks in the Salem block contain assemblages typical of the amphibolite facies (table 1). Northwest of Salem the rocks are primarily epidote- and andesine-bearing amphibolite and feldspathic augen gneiss (Toulmin, 1964; Bell and Alvord, 1976). Nelson (1974, p. 10) noted the presence of sillimanite in his Claypit Hill Formation (included in $\mathrm{Zv}$ on the State bedrock map) in the Framingham area, and his units are within the garnet-amphibolite facies. Chlorite-bearing assemblages are probably partly retrogressive. The Proterozoic Z Salem Gabbro-Diorite intruded these mafic metavolcanic rocks (Toulmin, 1964, p. 69), and all these rocks are sheared in the Burlington mylonite zone (fig. 2; Castle and others, 1976, p. 33).

The Proterozoic Z plutonic rocks of the Salem block are not pervasively gneissic like those on the west side of the Milford antiform. They have, however, been subjected to a variably distributed cataclasis that moderately fractured quartz and feldspar grains and was accompanied by crystallization of epidote and chlorite-group minerals along fractures and shear planes. These assemblages indicate metamorphism no higher than greenschist facies. The deformation and retrogression are more pronounced toward the Bloody Bluff fault and within the Burlington mylonite zone and less pronounced to the east, as, for example, near Salem. The Topsfield Granodiorite is much more extensively altered than the Dedham Granite to the south.

In the Salem block then, we see evidence of an amphibolite-facies metamorphism in the stratified metavolcanic rocks before or during intrusion of the mafic plutonic rocks. A retrogressive greenschist-facies metamorphism was superposed on the mafic metavolcanicplutonic complex as well as on the younger Dedham Granite and Topsfield Granodiorite and may have accompanied the shearing along the major faults in the area.

\section{Melrose Subblock}

Bell and Alvord (1976) and Kaye (1980) have outlined an area herein called the Melrose subblock bounded on the south by the northern boundary fault of the Boston basin, on the west by the Mystic fault (M, fig. 10), and on the north and east by the curvilinear Walden Pond fault (figs. 2, 10). This subblock, much of it in the town of Melrose, contains the outcrop area of the Lynn Volcanic Complex and the type area of the Middlesex Fells Volcanic Complex. I have applied the name Melrose to this subblock rather than using one of the rock unit names. Bell and Alvord (1976) showed the Walden Pond fault as intersecting the northward-trending Mystic fault at a sharp angle. Kaye (1980) modified this arrangement by dropping the Mystic fault north of the Melrose block and considered the remaining southern part of the Mystic fault to be a continuation of the curvilinear Walden Pond fault. This is approximately the configuration shown on the State bedrock map. 


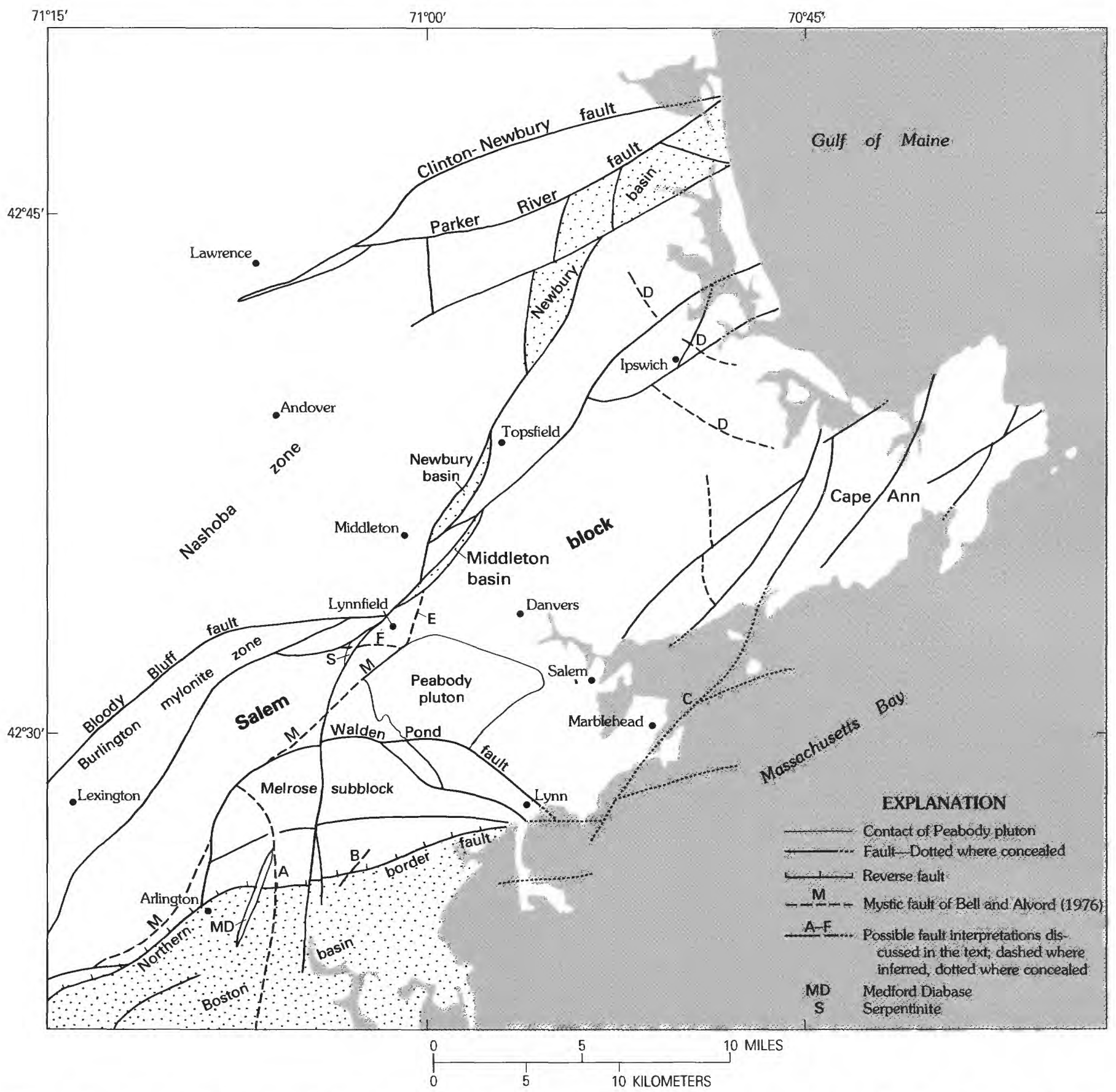

FIGURE 10. -Structural features in and adjacent to the Salem block of the Milford-Dedham zone, eastern Massachusetts. Basins are indicated by pattern.

The subblock contains an assemblage of rocks somewhat different from that in the Salem block to the north. The most abundant unit is the Lynn Volcanic Complex, which does not crop out outside the Melrose subblock, at least to the north and west, except for outcrops on Marblehead Neck. The Lynn on Marblehead Neck and adjacent islands may actually be part of the Melrose subblock offset to the north along a north-northeast trending fault through Marblehead harbor (C, fig. 10). Other units in the subblock are older and include the Proterozoic Z Dedham Granite, the Westboro Formation, and mafic metavolcanic rocks ( $\mathrm{Zv}$ ) of the Middlesex Fells Volcanic Complex. The older metavolcanic rocks are metamorphosed to amphibolite facies and contain a 
foliation parallel to layering. A common mineral assemblage, similar to that in the rest of the Salem block, includes hornblende, oligoclase and andesine, and epidote, the latter forming pods and lenses in some places (Bell and Alvord, 1976). These rocks are locally chloritized. Because the grade of metamorphism in the overlying Lynn Volcanic Complex is at most greenschist facies, a Proterozoic episode of amphibolite-facies metamorphism must have occurred before deposition of the Lynn Volcanic Complex. The rock assemblage in the Melrose subblock suggests that this subblock represents a shallower stratigraphic level than the rest of the Salem block; it is equivalent to the assemblage of rocks immediately beneath the Boston Bay Group in the Boston basin in the south. Significantly, C.A. Kaye (oral commun., 1979) identified a small area of Roxbury Conglomerate within the subblock, supporting the suggestion that the subblock contains shallow-level rocks. A sliver of the Melrose subblock may lie south of the northern border fault of the Boston basin in the Nahant area (see discussion of Boston basin below).

\section{Fault Pattern in the Salem Block}

The Salem block has been appreciably broken by faulting. Individual faults are difficult to locate because of intermittent exposures and similarity of rock types. Several different interpretations of the fault pattern exist (Bell and Alvord, 1976; Castle and others, 1976; Nelson, 1976; Barosh and others, 1977). Faults shown on the State bedrock map were taken from original quadrangle maps modified by recent observations by Kaye (1980) and A.F. Shride (written commun., 1979). Only the more significant faults have been shown. Shride (as reported in U.S. Geological Survey, 1980, p. 62) described the faults and fault zones in northeastern Massachusetts as varying greatly in their characteristics:

Some of the principal faults (that is, strike-slip faults of regional extent with displacement measurable in kilometers to tens of kilometers) [Bloody Bluff fault system and Burlington mylonite zone] are marked by zones that are narrow along lengths of many kilometers and are composed of cohesive mylonitic materials; these faults give way abruptly to bordering rocks that exhibit little cataclasis. Other regional faults are characterized by central zones whose widths are variable but approach $1 \mathrm{~km}$, bordered by zones of pervasively shattered rock measuring hundreds of meters wide. Some central zones are dominantly mylonite or ultramylonite, whereas, in others, breccias make up considerable parts. Some of the weak and, therefore, rarely exposed fault zones are made up of thinly sheeted highly friable rock parted along innumerable slickensided shear surfaces; incoherent gouge, apparently, is a rare constituent. The cataclastic zones of secondary faults, those with displacements of no more than 1 to $2 \mathrm{~km}$, are mostly only a few meters wide and sharply defined; a few exceptional zones are more than $250 \mathrm{~m}$ in width. Breccias seemingly are more characteristic of secondary faults than faults of regional extent.
The Walden Pond fault (fig. 10) is a steeply dipping fault, most likely a north-dipping reverse fault like the northern border fault to the south. Its curvilinear trace may actually mark the locus of a series of straight short faults that intersect at obtuse angles. The Melrose subblock has dropped down on these faults relative to the rest of the Salem block and moved up relative to the Boston basin. Although mapped, the Walden Pond fault itself has not been described by anyone.

\section{Mystic Fault}

Bell and Alvord (1976, fig. 1) showed the Mystic fault (M, fig. 10) extending northeastward from the Boston basin at Arlington to the structurally complex area near Lynnfield, where the Burlington mylonite zone and the Bloody Bluff fault meet and lose their identities. The southern segment of the Mystic fault joins the Walden Pond fault on the State bedrock map. Bell and Alvord's Mystic fault, if projected to the northeast, would come close to or truncate the northwest margin of the main pluton of Peabody granite at Peabody. From there the fault could reasonably be drawn on the basis of the aeromagnetic pattern as the fault shown by Castle and others (1976) (E, fig. 10) striking north to the Bloody Bluff fault zone near Lynnfield. However, neither Castle and others (1976) nor A.F. Shride (oral commun., 1979) found evidence in surface exposures for a connection between the Mystic fault at the edge of the Melrose subblock and a fault north of the main pluton of the Peabody Granite. I have chosen arbitrarily to shift Castle and others' (1976) fault to the west where it passes through the serpentinite mass at Lynnfield (S, fig. 10) and thence continues southward west of the Peabody pluton to intersect the Walden Pond fault. The northsouth fault through the serpentinite is connected on the State bedrock map with a fault that extends across the Melrose subblock from the Boston basin. Other northsouth faults of small displacement (A,B, fig. 10) that extend from the Melrose subblock into the Boston basin have been mapped by Kaye $(1980,1983)$. The significance of an east-west fault (F, fig. 10) shown by Castle and others (1976) cutting across the serpentinite mass from the Burlington mylonite zone to the pluton at Peabody is not apparent.

The north-south faults shown on the State bedrock map that extend from the Boston basin into the Melrose subblock (Billings, 1976a, b; Kaye, 1980, 1983) are apparently the youngest faults in northeastern Massachusetts; they probably are the same age as the fault bounding the Triassic Middleton basin and perhaps the faults bounding the Silurian-Devonian Newbury basins. 


\section{DEDHAM AND FOXBOROUGH BLOCKS}

Southeast of the Salem block and the Milford antiform in the Milford-Dedham zone is a terrane containing the Proterozoic Z southeastern Massachusetts batholith. This terrane is divided into the Dedham block, the Foxborough block, and the Fall River block (figs. 1, 2). The first two blocks are discussed here, and the third in the next section. Metasedimentary and metavolcanic rocks of Proterozoic age are not abundant in the Dedham and Foxborough blocks and primarily form inclusions and screens within the Proterozoic $\mathrm{Z}$ plutonic rocks. The Dedham block can be construed as continuing southwestward to northeastern Rhode Island, where it contains the Blackstone Group, Esmond Granite, and associated rocks east of the Bellingham basin. To the north it is interpreted to abut the Salem block beneath the Boston basin (fig. 2).

The metasedimentary and metavolcanic rocks $(\mathrm{Zb}$, $\mathrm{Zw}$ ) in the Dedham and Foxborough blocks are primarily amphibolite, phyllite, and quartzite, in the upper greenschist- and epidote-amphibolite facies of metamorphism (table 1). In the Norwood area, metabasalt contains green amphibole, and metarhyolite contains saussuritized plagioclase and green biotite variably altered to chlorite (Chute, 1966). Scattered exposures of quartzsericite phyllite locally containing pyrite cubes are present in the Dedham block to the southwest. In northern Rhode Island there is evidence for a period of regional dynamothermal metamorphism in the Blackstone Group before intrusion of the Esmond and Dedham Granites (Coyle and others, 1984). North of Woonsocket, the Ordovician-Silurian granite (SOqgr) clearly intrudes folded and metamorphosed (epidote-amphibolite facies) Blackstone Group. Lack of evidence for early Paleozoic metamorphism in the zone indicates that the metamorphism is probably Proterozoic.

Textures in the plutonic rocks of the Dedham and Foxborough blocks are similar to those in the less deformed parts of the Salem block, but the rocks on the whole are less fractured and altered. Most of the cataclasis and alteration is concentrated along north- to north-northwest-trending faults that transect the boundaries of the blocks. The rocks of the Foxborough block are appreciably shattered and altered at its southwestern end where the Norfolk and Narragansett basins merge. The diorite and gabbro (Zdigb) retains its igneous texture, but some feldspars are saussuritized and mafic minerals altered to chlorite and epidote. Where diorite or gabbro has been intruded by Dedham Granite, hornblende has been altered to biotite, and in places a hybrid rock has been produced. The alteration to chlorite and sericite in the Dedham is primarily along small shear fractures most numerous near faults. Small veinlets containing epidote and quartz are common in these altered areas. The batholithic rocks in the eastern part of the Foxborough block are little altered.

Numerous north-trending faults chop the rocks into slices, as shown by the crenulate contact of the south side of the Foxborough block. The principal fault of this sort is the Stony Brook fault, which projects into the Boston basin (fig. 2) and is further described in the section on that basin. A similar north-south fault set is present in the basement beneath the Pennsylvanian strata in the eastern part of the Narragansett basin (Williams and Willey, 1973) and in the exposed basement in the northern part of the Fall River block (Koteff, 1964). Vein quartz is associated with these north-trending faults (Lyons, 1977). The border faults along the edges of many of the blocks are discussed in sections describing the structure of these basins.

\section{FALL RIVER BLOCK}

Structural features and metamorphism in the Fall River block have not hitherto been described and have been mapped only in two places: the Assawompset Pond area (Koteff, 1964) and the Tiverton area (Pollock, 1964). Accordingly, features in this block are described more completely in the following pages than has been done for the other areas.

The structural and metamorphic features in the northern part of the Fall River block (fig. 11) are in general similar to those in the Foxborough block north of the Narragansett basin. The batholithic rocks closely resemble those north of the basin, not only in composition and texture but also in degree of deformation and alteration. Like them, they are not foliated and lack gneissosity. The Proterozoic metavolcanic-metasedimentary septa are in the greenschist facies of metamorphism. In the southern part of the Fall River block, however, the plutonic rocks tend to be gneissose, and the metavolcanic rocks are in the amphibolite facies (table 1).

Metamorphism of the Metavolcanic and Plutonic Rocks

Metamorphism of the Proterozoic metaigneous rocks ( $\mathrm{Zgs}, \mathrm{Zgn})$ in the Fall River block appears to be relatively simple. The gneiss and schist (Zgs) have a principal foliation parallel to the layering, which is locally crenulated by a later slip cleavage. Foliation in both gneiss and schist is marked by a preferred mineral orientation, primarily of the micas. Lineation is prominent only in the noses of the major folds in biotite gneiss. It appears to be an intersection lineation marked by streaks of biotite and rodding of quartz and feldspar. Splintery, lineated rock in other areas may mark noses of isoclinal or tight folds, but no minor folds of this sort were seen in outcrop. The slip cleavage strikes to the northwest and dips steeply. 


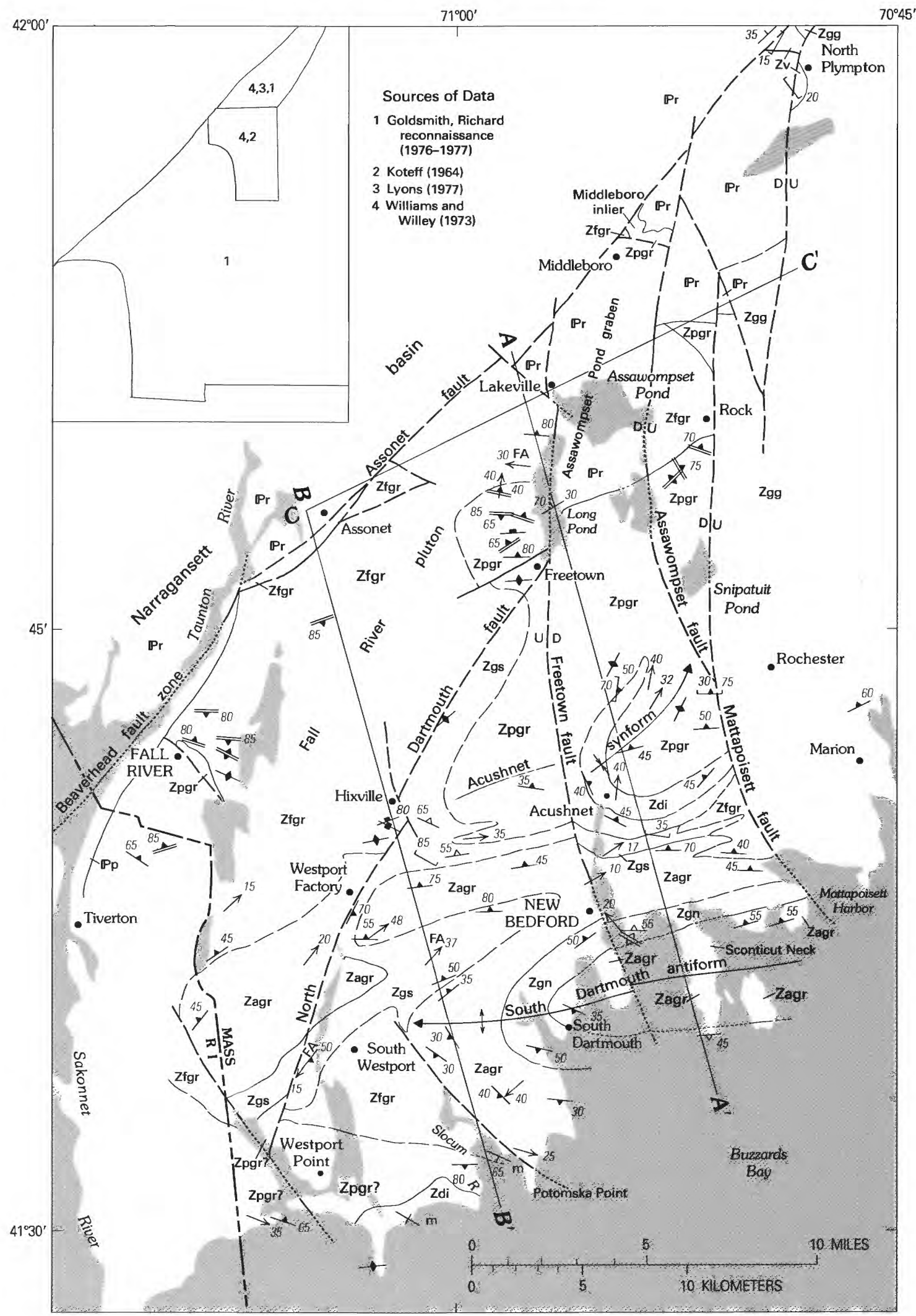

FIgURE 11A. - Structural features of the Fall River-New Bedford area, southeastern Massachusetts. Pr, Rhode Island Formation; Pp, Pondville Conglomerate; Zfgr, granite of the Fall River pluton; Zpgr, porphyritic granite; Zagr, alaskite; Zdi, diorite; Zgg, granite, gneiss, and schist, undivided; Zv, metamorphosed mafic to felsic flow, volcaniclastic, and hypabyssal intrusive rocks; Zgs, gneiss and schist near New Bedford; Zgn, biotite gneiss near New Bedford. 


\section{EXPLANATION}

Contact-Dashed where approximately located;
dotted where concealed

FIgURE 11A.-Continued.

The textures in the gneiss and schist indicate that a static thermal phase succeeded an earlier dynamothermal stage. The thermal phase could be attributed to the emplacement of the plutonic rocks. However, because the plutonic rocks described below also seem to be involved in the thermal progression, the thermal phase may have been superposed much later, in the same way as the late Paleozoic (Alleghanian) thermal event was superposed on the Proterozoic rocks of southeastern Connecticut and southern Rhode Island (Lundgren, 1966; Zartman and others, 1983). Mineral assemblages in the metaigneous rocks of southeastern Massachusetts indicate greenschist-facies metamorphism to the north and amphibolite-facies metamorphism to the south. To the north, around Long Pond and Assawompset Pond (fig. 11A), inclusions and septa in the granites are in the greenschist facies. Koteff (1964) mapped a sericitequartz-feldspar schist on the west side of Long Pond and noted a fine-grained inclusion in granite to the west that contains quartz, sericite, and subordinate epidote, opaque minerals, and apatite. A metadacite porphyry near Rock (fig. 11A) contains relic igneous texture but greenschist-facies mineral assemblages: saussuritized plagioclase, interstitial epidote, and biotite altered to chlorite. Primary indicators of the amphibolite-facies metamorphism to the south are the coexistence of epidote, calcic oligoclase, and blue-green hornblende. No truly pelitic assemblages are known here. The biotite gneiss along the shores of Buzzards Bay contains abundant discontinuous pegmatite patches and veins, locally exhibiting a swirled pattern indicating plasticity and local melting.

The plutonic rocks in the northern and western parts of the Fall River block are little deformed except by faulting. They locally contain an indistinct foliation. From about Long Pond southward and southwestward, the plutonic rocks show widely spaced, discrete shear zones containing feldspar augen and reoriented streaks of mafic minerals. These zones become more numerous southward, so that the rocks develop a pervasive gneissic fabric and become augen and flaser gneiss. This transition is best seen in the porphyritic granite (Zpgr) that extends from Long Pond to Acushnet near New Bedford. Granite of the Fall River pluton (Zfgr) to the east is equigranular and poor in mafic minerals, and in it the transition is not well demonstrated, although zones of shear can be recognized locally. South of Fall River in the Tiverton area, the local phase, the Bulgarmarsh Granite, is relatively unfoliated, but, to the southeast near Westport Point, Zfgr is gneissic. Foliation symbols in the Long Pond area shown on figure $11 \mathrm{~A}$ represent recognizable zones of gneissosity in the granite of the Fall River pluton and in the porphyritic granite. These zones have a general west to west-northwest trend.

The gneissic terrane is primarily east of a prominent topographic lineament (the inferred North Dartmouth fault, fig. 11A) that marks the contact between the granite of the Fall River pluton and the belt of gneiss and schist extending from the south end of Long Pond south-southwest to Westport Factory, North Dartmouth. From there the belt of gneiss and schist extends southwestward in a vaguely defined zone toward the Rhode Island State line west of Center Village, Westport. The east-west change is more abrupt than the north-south change and is in part attributed to a difference in competency between the relatively maficmineral-poor granite of the Fall River pluton and the porphyritic granite to the west. Mafic-mineral-poor rocks such as the alaskitic granite (Zagr) are gneissic, however, in the Westport-New Bedford area. The increase in gneissosity southward and southeastward is somewhat similar, but in reverse direction, to the increase in gneissosity on the west side of the Rhode Island anticlinorium in western Rhode Island and eastern Connecticut.

\section{Structural Features in the New Bedford Area}

All the units in the New Bedford area are complexly folded, as shown by the trend of gneissosity and schis- 

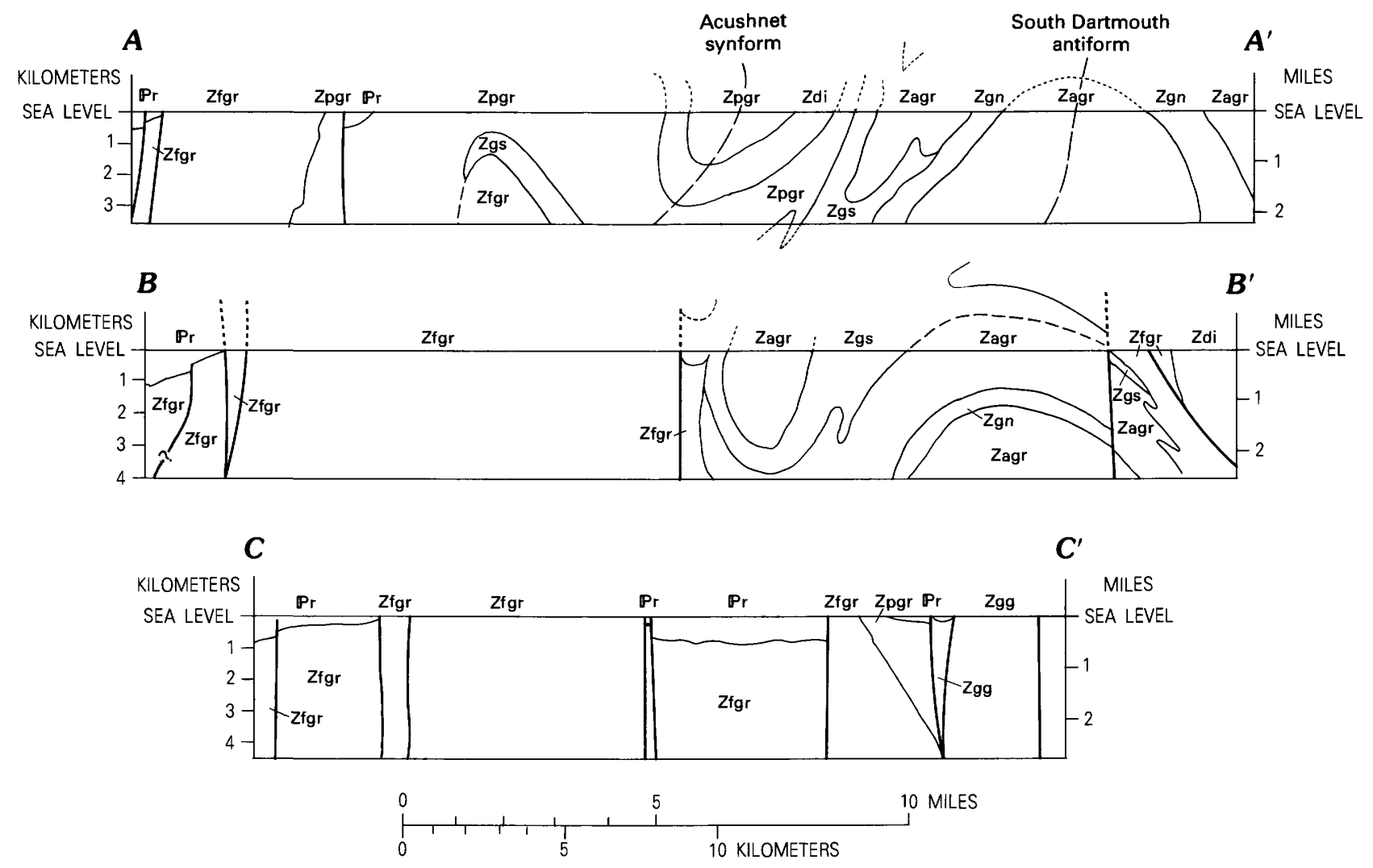

\section{EXPLANATION}

-... Contact-Dashed where inferred; dotted where projected

.. Fault-Dotted where projected

FiguRE 11B. - Interpretive cross sections of the Fall River-New Bedford area, southeastern Massachusetts.

tosity as well as by contacts between units. Lineation is prominent in fold hinges, particularly in the alaskitic granite in the South Dartmouth antiform. Foliation in the plutonic rocks is formed by parallel orientation of biotite and flattened feldspar megacrysts. Lineation is formed primarily by elongated biotite clots and by quartz and feldspar rods.

The orientation of these major folds is not consistent. Axial surfaces strike east-northeast, and vergence seems to be to the south (fig. 11B). The South Dartmouth antiform (fig. 11A,B) extending from Sconticut Neck through South Dartmouth to South Westport plunges to the west. However, the diorite at Acushnet (Zdi) to the north forms a phacolithic body in the variably northeastplunging Acushnet synform (fig. 11A,B); to the southwest, in the vicinity of Westport Point, lineation in gneissic granite plunges to the southeast. A zone of interfingering units and probably of tight folding and rotation, possibly associated with east-trending strikeslip faults, lies between the Acushnet synform and the
South Dartmouth antiform. A shear zone may separate the South Dartmouth antiform from the area of southeast plunges near Westport Point, but exposures are poor in this area. Two mylonite seams are exposed on the shores of Buzzards Bay in the Slocum River area. The more prominent zone, striking $\mathrm{N}$. $65^{\circ} \mathrm{W}$. and dipping $65^{\circ} \mathrm{S}$., is well exposed on Potomska Point, Dartmouth. Asymmetry of feldspar augen tails and folding of sheared pegmatite indicate right-lateral displacement along the zone. A thin seam is exposed in ledges on a road to the east in rock containing a lineation $\mathrm{S}$. $65^{\circ} \mathrm{E}$. plunging $25^{\circ}$. The relatively steep plunges of lineation in the New Bedford region suggest a significant component of lateral movement between structural domains.

The systematic increase in gneissosity from the Long Pond area to the New Bedford area may be more apparent than real because of lack of continuity of exposures. The west- to west-northwest-trending shears in the porphyritic granite in the Long Pond area have the same trend as the cleavage in the metamorphic rocks. 


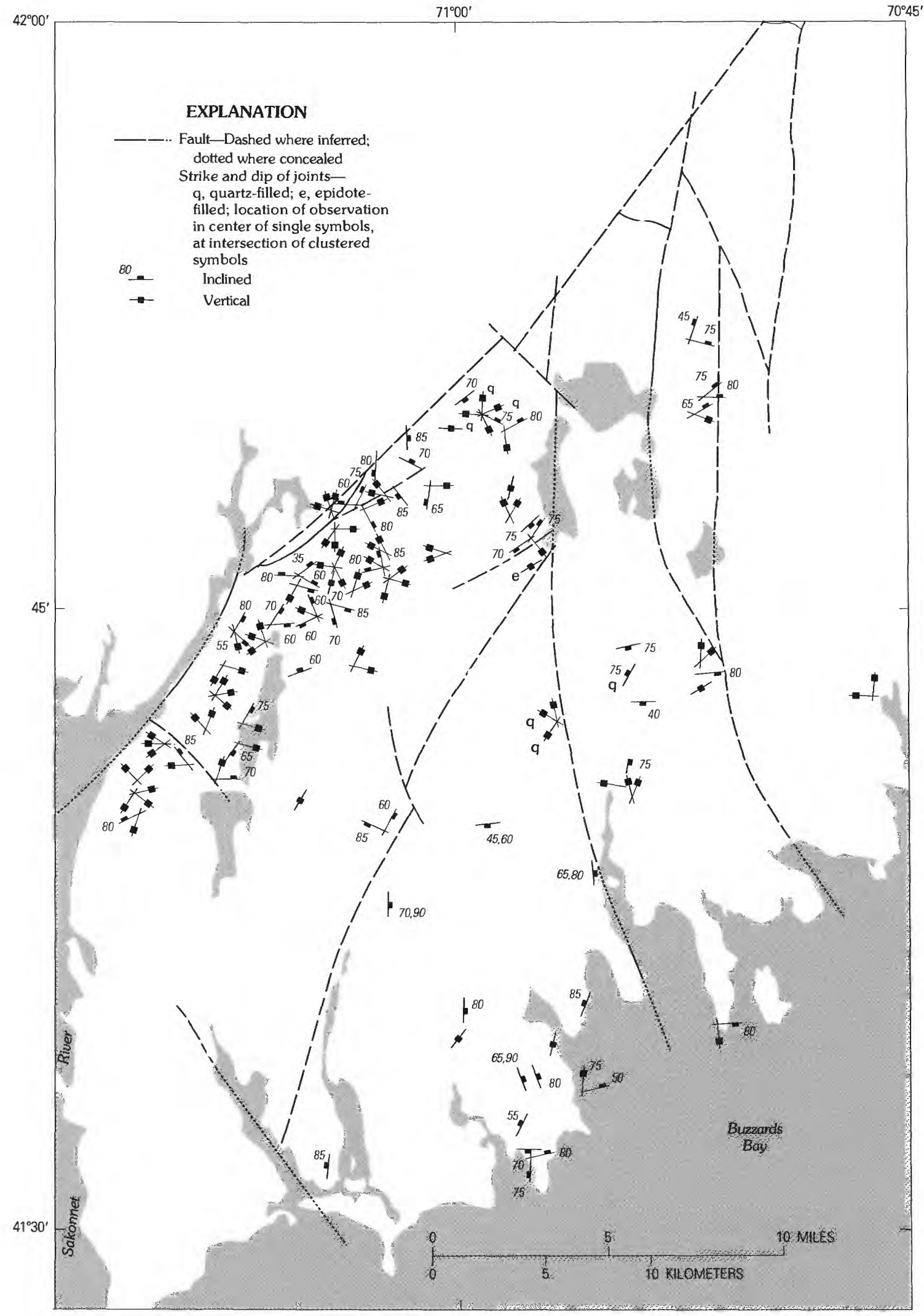

Figure 11C.-Joints in the Fall River-New Bedford area, southeastern Massachusetts. 
Neither is parallel to the axial surfaces of the major folds in the New Bedford area. These shears may be younger than the gneissosity, and movement on them may have caused the discrepancy in direction of plunge in the different fold domains. The gneissic terrane may have a relatively sharp northeast-southwest boundary, but in reconnaissance in the area no sharp boundary was observed.

Assawompset Pond Graben and Related Structures

A downdropped block containing Rhode Island Formation was mapped by Koteff (1964) south of Middleboro in the Assawompset Pond area (figs. 2, 11A). Slickensides in the northeast corner of the quadrangle plunge steeply down dip, and the contact of the porphyritic granite (Zpgr) with granite of the Fall River pluton (Zfgr) is not greatly offset. Koteff cited seismic studies that indicate that two buried preglacial channels across Mason Road in Freetown and North Avenue in Rochester coincide with the position of the faults. Koteff believed that the faults do not extend far south of the quadrangle; however, some evidence indicates that the western bounding fault continues south to the New Bedford area. Here, easttrending units appear to be slightly offset across the Acushnet River, and, at the Route 140 interchange with Phillips Street north of New Bedford, an outcrop of crushed and broken granite is laced by quartz veins trending both $\mathrm{N} .15^{\circ} \mathrm{E}$. and N. $50^{\circ} \mathrm{W}$. and dipping $85^{\circ}$ and $35^{\circ} \mathrm{N}$., respectively. The veins are cut by steeply dipping fractures N. $40^{\circ} \mathrm{E}$. and N. $10^{\circ} \mathrm{W}$. This outcrop is about on the probable trend of the western bounding fault. The continuation of the eastern bounding fault is less clear. It either dies out or, as shown on figures 2 and 11, turns southeast and merges with an inferred fault along a pronounced topographic break and an abrupt cessation of outcrop east of a line from Rock through Snipatuit Pond to Mattapoisett Harbour. I have interpreted the eastern bounding fault to project northward east of the inlier at Middleboro as Lyons (1977) showed it, rather than to the west as Williams and Willey (1973) suggested. This interpretation eliminates what would be a long, narrow horst east of the graben that at its north end would encompass the inlier.

The North Dartmouth fault trending south-southwest from Long Pond to North Dartmouth is largely inferred from topography, although the linear topographic low may be entirely or in part due to differential erosion along a belt of gneiss and schist (Zgs). This valley serves to separate altered but not pervasively gneissic plutonic rocks from mostly gneissic plutonic rocks. This fault is inferred to continue south down the east branch of the Westport River, although a more southwesterly trend would align it with a northeast-trending magnetic linea- ment east of Kirby Corner and Central Village, Westport (U.S. Geological Survey, 1971a,b). A northwesttrending fault through Hixville that splays off the North Dartmouth fault is inferred because of apparent offset of the gneiss and schist and granite of the Fall River pluton. Granite exposed in a gravel pit south of Hixville is partly crushed and sheared and has an anastomosing shear fabric varying from N. $60^{\circ} \mathrm{W}$. to N. $70^{\circ} \mathrm{E}$. Other small northwest-trending faults are shown at Fall River, where some rock is sheared in a northwest direction; along the west branch of the Westport River, for which there is little evidence except topography and an aeromagnetic lineament; and at the north end of the Fall River pluton at Lakeville. The fault at the west end of Assawompset Pond is based primarily on the basement configuration shown by Williams and Willey (1973) and by the observation that much of the granite exposed on Route 140 to the south is veined with quartz.

\section{JOINTS}

Joint sets in the plutonic rocks (fig. $11 C$ ) reflect shear and fault directions. One set of joints strikes westnorthwest to east-northeast generally parallel to shear directions in the rocks. This set does not seem to be reflected in the Pennsylvanian rocks to the west nor to noticeably affect the boundary between the plutonic rocks and the Pennsylvanian strata. Another set strikes northeast, about parallel to the east boundary of the Narragansett basin. Still another strikes north in the same direction as faults that cut the Narragansett basin. The north- and northeast-striking joints in many places contain vein quartz. Quartz-filled fractures are abundant in exposures along State Route 140 southwest of Lakeville. Northeast-trending joints along the west side of the Fall River pluton near Assonet are parallel to crushed and altered zones. The generally east-trending sets are considered to be older than the northeast- and north-trending sets and to have formed in a more compressive environment. They are possibly related to the stresses producing the east-west or west-northwest shears in the basement rock.

\section{Summary and Discussion}

The metasedimentary and metavolcanic rocks in the Fall River block range in metamorphic grade from greenschist facies in the north to amphibolite facies in the south. As well as can be determined, the metamorphism preceded or was contemporaneous with the intrusion of the batholithic rocks. The foliation is folded and is cut locally by a northwest-striking slip cleavage. The plutonic rocks become gneissic to the south and are folded along with the metasedimentary and metavolcanic rocks into a complex pattern. This deformation apparently took 
place at relatively high temperature, because there is little apparent retrogressive metamorphism in the plutonic rocks of the New Bedford area, in contrast to the situation to the north. Therefore I infer a late source of heat to the south and stresses producing structures oriented in an east-northeast to east direction superimposed on structures trending northerly. The relations are similar to those west of the Narragansett basin in southern Rhode Island and southeastern Connecticut.

The age of the metamorphism of the metavolcanic rocks is not clear. To the west in the Newport, R.I., area (fig. 2), metavolcanic rocks probably of the same age as those in the Fall River block were metamorphosed to low grade before intrusion of the Newport Granite (Kay and Chapple, 1976; Rast and Skehan, 1981). The metavolcanic rocks in the Fall River block were presumably metamorphosed at about the same time, before intrusion of the granite of the Fall River pluton; however, later deformation has obscured the relations.

\section{PROTEROZOIC METAMORPHISM}

The metamorphism and structure in basement rocks of the Milford-Dedham zone are summarized in table 1. Evidence exists in several places that the basement rocks were involved in a Proterozoic $\mathrm{Z}$ episode of metamorphism. The Cambrian strata have undergone no greater metamorphism than nearby Carboniferous strata, or, in the Boston area, than Proterozoic $\mathrm{Z}$ basin fill. I have cited evidence in my discussion of the Milford antiform and Salem blocks that there was at least a low-grade greenschist-facies metamorphism to the east and a middle-grade amphibolite-facies metamorphism to the west in the Proterozoic metavolcanic and metasedimentary rocks before intrusion of the 630-Ma Dedham and related granites. However, we do not know to what extent the amphibolite-facies metamorphism in the western and the extreme southeastern parts of the zone was produced during the Proterozoic metamorphic event and how much was superimposed during a late Paleozoic event known to be more intense to the south and less intense to the north. The Proterozoic rocks described by Nelson (1974), Volckmann (1977), Bell and Alvord (1976), and Goldsmith (this vol., chap. E, table 3) in the less intensely metamorphosed area of the Salem and Dedham blocks are all in the amphibolite facies, although in many places they contain retrogressive assemblages that include epidote, chlorite, and sericite (Nelson, 1974; Bell and Alvord, 1976). As the Dedham and related granites are also involved in this retrogressive metamorphism, it must be post-Dedham. The overprinted amphibolitefacies metamorphism in these blocks is pre-Dedham. In the Milford antiform, where the batholithic rocks tend to be gneissic, the metasedimentary and metavolcanic rocks are also in the amphibolite facies. There the post-Milford Granite deformation is more intense and is amphibolite rather than greenschist facies, so no retrogressive assemblages are found in this area. Devonian alkalic granite in Rhode Island is partly gneissic (O'Hara and Gromet, 1984), as are the metamorphic rocks in the New Bedford area. In parts of the Dedham and Foxborough blocks, and in the northern part of the Fall River block, the metamorphosed Proterozoic rocks are in the greenschist facies, although some uncertainty exists as to the proper age assignment for the phyllites ( $\mathrm{Zb}, \mathrm{Zbs}$ ) and volcanic rocks (Pwv, Zv) in the Wrentham, Dedham, Medfield, and Plympton areas. The interpreted pattern of Proterozoic metamorphism is shown on the State bedrock map. The western part of the Salem block could have been shown in the amphibolite facies, but the superimposed Paleozoic greenschist-facies metamorphism is pronounced in this area and masks the older metamorphic mineral assemblages.

\section{STRUCTURE AND METAMORPHISM OF THE BASINS IN THE MILFORD-DEDHAM ZONE}

Analysis of the structures affecting basins containing cover rocks that overlie the Proterozoic basement helps us interpret the tectonic events that affected both basement and cover in the Milford-Dedham zone. The major basins (fig. 8) are the Boston basin, occupied by Proterozoic Z sedimentary and volcanic rocks, the Newbury basins, occupied by Silurian and Devonian sedimentary and volcanic rocks, the Bellingham basin, occupied by Pennsylvanian (or Proterozoic Z) sedimentary and volcanic rocks, the Norfolk basin, occupied by Pennsylvanian sedimentary rocks, and the Narragansett basin, occupied by Cambrian and Pennsylvanian sedimentary rocks. A small basin containing Triassic sedimentary rocks, the Middleton basin, has been identified in the LynnfieldMiddleton area (Kaye, 1983). A larger basin containing Triassic and Jurassic sedimentary and volcanic rocks, the Nantucket basin, is located in the subsurface beneath Nantucket and Nantucket Sound. These basins, and the structures within and bounding them, will be described in order of decreasing age of contained rocks. Discussion of the ages of the fold and fault systems in the basins is given in the section on blocks and basins of the MilfordDedham zone.

\section{BOSTON BASIN}

The structure of the Boston basin has been described and summarized by M.P. Billings in a series of papers (Billings, 1929; 1976a,b; 1979) based on engineering studies by him and others in tunnels in the Boston area, on surface mapping by him and his students, and on 


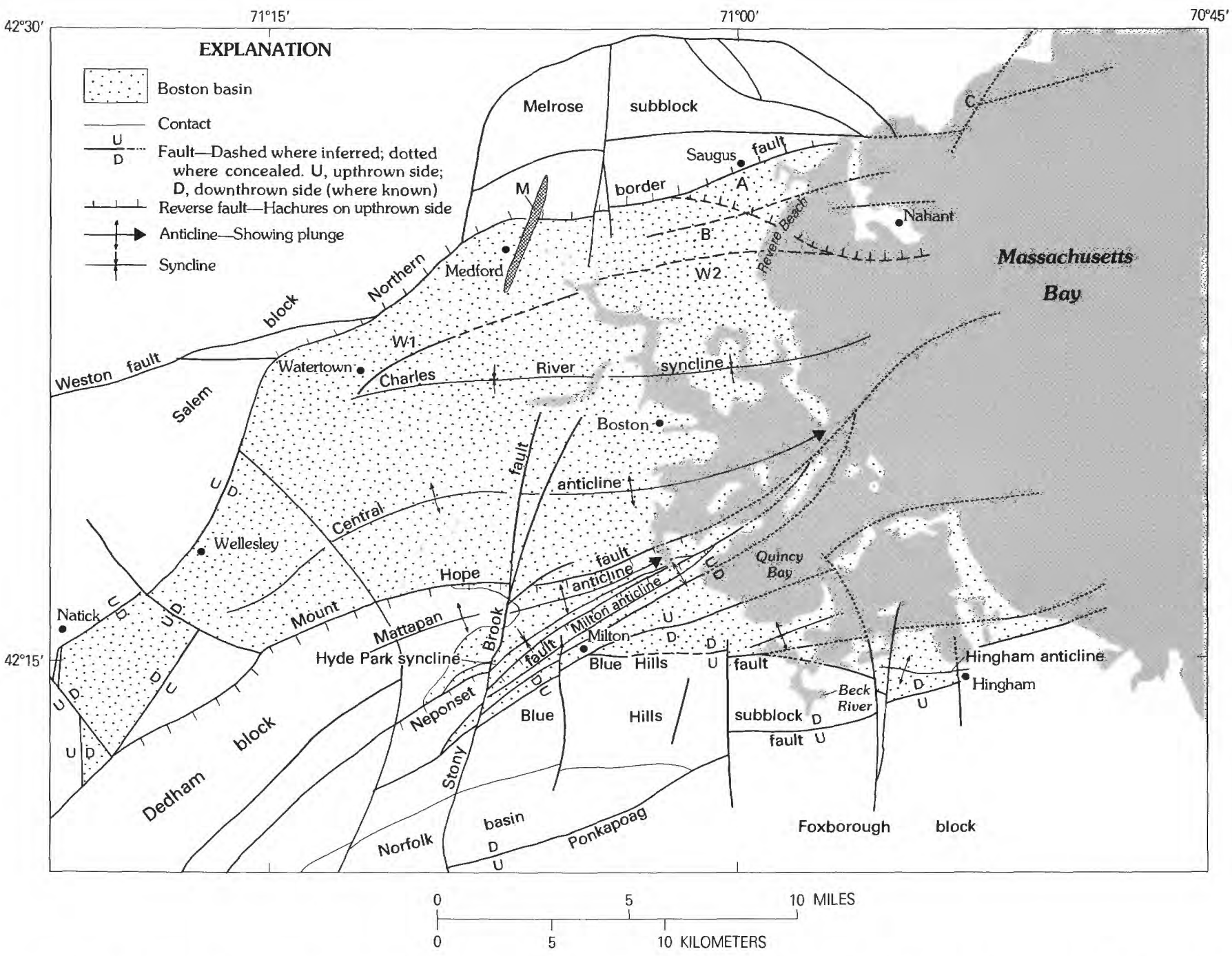

FIGURE 12.-Structural features of the Boston basin, eastern Massachusetts. A, B, C, W1, and W2 are alternative interpretations of faults and fault blocks referred to in text. M, Medford Diabase.

earlier mapping by W.O. Crosby (cited by Billings) and LaForge (1932). Billings' studies have been recently supplemented by Bell (written commun., 1976), who mapped primarily on the periphery of the basin, and by Kaye (1980; written commun., 1978, 1979).

The Boston basin contains unmetamorphosed Proterozoic Z sedimentary and volcanic rocks that are in gentle to tight open folds and are cut by mostly reverse faults. Both faults and folds trend east-northeast. The basin is bounded on the north and northwest by the northern border fault (figs. 2, 12) and on the south by the Mount Hope and Blue Hills faults. West of Hingham, in the Hingham anticline (fig. 12), Roxbury Conglomerate rests nonconformably on Dedham Granite. The southwest end of the basin is terminated by north- to northwesttrending high-angle normal faults that are younger than the reverse faults. Folds are open to the north but become tighter and higher in amplitude to the south. Plunge of the major folds averages $8^{\circ}-15^{\circ}$ east-northeast to east, steepening to as much as $18^{\circ}$ toward the southern part of the basin. However, folds between the Mattapan anticline and the Blue Hills fault plunge gently to the southwest (Billings, 1976a, p. 42). The Hingham anticline, which contains Dedham Granite in its core, plunges steeply to the west. High-angle faults cut off the limbs of some of the folds in the southern half of the basin so that they are almost coincident with synformal axes named by Billings (1976a) (not shown on fig. 12, but see cross section $C-C^{\prime \prime \prime}$ on the State bedrock map). Drag along these faults has produced locally steep dips. Axial surfaces of the folds dip steeply north. Cleavage is developed locally in the Mattapan Volcanic Complex and Boston Bay Group and also dips steeply north. However, the cleavage is not axial planar to the folds in the basin 
(Billings, 1929, p. 101-102) and does not seem to be present in the older rocks (Nelson, 1976, p. 1379).

The northern border fault is a reverse fault that thrusts the Melrose subblock and Salem block southward and southeastward over the Boston Bay Group. It is at least $38 \mathrm{~km}$ long, extending from south of Natick into Massachusetts Bay near Nahant. As exposed in the Malden tunnel (Billings and Rahm, 1966), the fault dips about $55^{\circ}$ north and is knife sharp. Billings (1976a, p. 41) suggested that the stratigraphic throw is not great. My reconstruction of the geology in cross section $C-C^{\prime}$ on the State bedrock map suggests a throw of about $1.3 \mathrm{~km}$. The border fault has customarily been drawn at the base of the topographic scarp near Medford and Saugus. However, south of this scarp, the Nahant peninsula and the adjacent shore at Revere Beach contain Cambrian strata, rather than strata of the older Boston Bay Group, and contain the Ordovician Nahant Gabbro, the only Paleozoic intrusive rock in the basin. These observations suggest that the Nahant Gabbro and adjoining rocks are in a displaced segment (A, fig. 12) of the Melrose subblock from north of the northern border fault as suggested by Billings (1979, fig. 7; written commun., 1979). C.A. Kaye (written commun., 1978) suggested that the fault shown on the State bedrock map in the Boston basin in Watertown (W1, fig. 12) continues east to pass south of Nahant (W2, fig. 12). These interpretations are not shown on the State bedrock map because of their speculative nature.

The location of a projection of the border fault into Massachusetts Bay is uncertain. The fault appears to be offset along the northeast-trending fault from Nahant Bay through Marblehead Harbor (C, fig. 12). To the west and southwest, the northern border fault loses its identity near Watertown and may splay off to join the Weston fault. South of this juncture, Nelson (1975a) showed the border fault as a normal fault having throw to the south (fig. 12). On the other hand, it may be represented in the system of faults trending southwesterly and forming the west side of the Boston basin through Wellesley and Natick. The possibility that it is part of the system of faults extending toward Woonsocket that separates the Milford block from the Dedham block has been mentioned above. The northern border fault is cut by the Mesozoic Medford Diabase (JKd), which places an upper limit on its age.

A series of east-northeast-trending faults, the Mount Hope, Neponset, and Blue Hills faults, within the basin parallel the northern border fault (fig. 12). They dip steeply, and downthrow is to the north. Billings $(1976 a, b)$ believed that these faults were originally northward-directed thrusts dipping less than $45^{\circ}$, which have since been rotated to near vertical. He calculated throw on the Mount Hope fault from two sites to be 183 $\mathrm{m}$ and $350 \mathrm{~m}$, the greater throw to the east. Throw on the Neponset fault is about $610 \mathrm{~m}$. The Mount Hope fault extends southwest to join with northerly trending faults enclosing the southwest end of the Boston basin. To the east, the Mount Hope fault extends into Massachusetts Bay along the north limb of the Mattapan anticline. The Neponset fault cuts off the southeast limb of the Hyde Park syncline and the north limb of the narrow Milton anticline. The Neponset fault becomes indistinct to the west where it cuts into the crystalline rocks. To the east, the Neponset fault extends into Quincy Bay, where it appears to merge with the Mount Hope fault. Billings (1982) presented convincing arguments for the existence of the Blue Hills thrust fault, despite contrary strong arguments by Kaye and Zartman (1980, p. 258). North of Hingham the Blue Hills fault juxtaposes members of the Dedham Granite and Roxbury Conglomerate on the south with the Cambridge Argillite on the north. West of Milton the Blue Hills fault swings to the southwest, where it is disrupted by north-trending faults and cannot be recognized in the crystalline Dedham Granite. The fact that Cambrian and Ordovician rocks to the south are thrust over the older Proterozoic Z Boston Bay Group to the north on the Blue Hills fault was explained by Billings (1982) as due to an earlier Ordovician cauldron subsidence of the complex in the Blue Hills consisting of the Quincy Granite and Blue Hills Granite Porphyry. These rocks and their overlying Carboniferous cover on the south have since been thrust northward, rotated, and tilted to the south (Billings, 1982, p. 919). Billings credited W.O. Crosby (1900) with first suggesting the southward tilting of the Blue Hills block. The amount of cauldron subsidence was postulated by Billings to be on the order of $5,000 \mathrm{~m}$. He suggested that some of the north-south faults in the Blue Hills may have been originally the bounding faults of the Ordovician cauldron subsidence. These north-south faults are clearly postPennsylvanian and are possibly Mesozoic but could have followed the loci of the Ordovician faults. He also suggested that the southwest-trending part of the Blue Hills fault west of Milton may coincide with a former ring fault.

The fault shown on the State bedrock map near Watertown (W1, fig. 12) brings up conglomerate and tuffaceous beds on its south side. Billings (1929) formerly placed a fault here but in a later paper (1976a, p. 43) indicated that this conglomerate is a tongue of Roxbury projecting into the Cambridge Argillite at a fairly low horizon and that a fault is not needed. I have preferred to keep the fault, because the exposure is close to the axis of the Charles River syncline where lower stratigraphic units would not be expected to appear on the surface. Kaye's (written commun., 1978) fault W2 (fig. 12), deduced from review of the tunnel data of Billings, may 
be a continuation of this fault, as mentioned above. A parallel fault deduced by Kaye is shown as B on figure 12 . The orientation of the folds in the Boston Bay Group indicates to me that they are related to the eastnortheast-trending faults in the basin and that the stresses were compressional.

North- and northwest-trending faults shown by Billings $(1976 \mathrm{a}, \mathrm{b})$ and Kaye (1980) truncate the eastnortheast-trending faults and folds. Some of these younger faults offset the Pennsylvanian strata in the Norfolk basin and are therefore post-Pennsylvanian in age. The largest of these is the Stony Brook fault, which Billings (1976a) considered a normal fault along which the west side has been downthrown $640 \mathrm{~m}$. It appears to be part of an en echelon system extending from the Narragansett basin to north of the northern border fault.

\section{NEWBURY BASINS}

The Newbury Volcanic Complex lies in two faultbounded, wedge-shaped and lenticular basins between the Nashoba zone and the Milford-Dedham zone in northeastern Massachusetts. A very small area near Lynnfield shown as Newbury strata by Castle and others (1976) is probably the Triassic and Jurassic Middleton basin. The exact nature and attitudes of the faults bounding the Newbury basins are uncertain. The eastnortheast-trending faults that flank the east-trending segment of the northern basin (fig. 10) were shown by Shride (1976a) to continue southwest to the Andover area. The northernmost, called the Parker River fault by Shride (1976b, fig. 1), has more recently been shown by Shride (written commun., 1979) to merge with the Clinton-Newbury fault near Lawrence and is shown thus on the State bedrock map. The southern fault cannot be carried far with confidence into the Nashoba zone to the west. Movement sense appears to be right lateral on both faults (Shride, 1976a). Barosh and others (1974, 1977) and Bell and Alvord (1976) showed these two faults as continuous with the Spencer Brook and Assabet River faults, respectively, of the Nashoba zone. However, there seems to be little evidence for such a connection in the maps of Castle (1964). Castle and others (1976) limit the faults to the arcuate borders of the basins and show them to be offset by north-south faults. The northern basin contains steeply dipping strata overturned to the east and southeast and topping into the basement rocks, thus requiring a fault on the southeast side. The eastern fault forming the boundary of the southern, wedgeshaped part of the northern basin truncates units of the Newbury Volcanic Complex more clearly than the northtrending fault on the west.

The smaller basin southwest of Topsfield (fig. 10) mapped by Toulmin (1964) is probably also fault bounded on both sides. The strata strike northeast about parallel to the contacts and dip $40^{\circ}-75^{\circ}$ to the northwest. It is not known whether or not the strata are overturned. If they are right side up, a fault is required on the west side, as Toulmin (1964, p. A71) hypothesized. Shride (1976b, p. 151) argued that the eastern boundaries of both basins are faults. Castle and others (1976) and Shride (1976b, fig. 1) showed faults on both sides of the basin at Topsfield.

Because of the attitude of the Silurian-Devonian strata in the basins, the beds must have been appreciably rotated since their deposition, yet the rocks of the basins are little metamorphosed. Shride (1976b, p. 151) noted the lack of cataclasis in the Newbury as opposed to the relatively pervasive cataclasis and alteration of the adjacent Proterozoic Z Topsfield Granodiorite. In the adjacent Nashoba zone to the west, the paragneisses and schists are in the upper amphibolite facies of metamorphism. Because the contacts are tectonic, it is difficult to say where the rocks of the Newbury Volcanic Complex were in relation to the adjacent Nashoba-zone rocks at the time of their metamorphism or to the Proterozoic rocks to the east at the time of their alteration and cataclasis. As the Newbury is subgreenschist facies at best and is not sheared, it most likely lies in a graben possibly of Mesozoic age. The location of the bounding faults of the basins could well be predetermined by the presence of the older Bloody Bluff fault system.

\section{BELLINGHAM BASIN}

The Bellingham basin contains poorly exposed metasedimentary and metavolcanic rocks, which have been considered to be of Pennsylvanian age but in which no fossils have been found. It could possibly be all, or in part, of Proterozoic $\mathrm{Z}$ age, like the rocks in the Boston basin (Goldsmith, this vol., chap. E). The basin is bounded by faults that are an extension to the southwest of the northern and western bounding faults of the Boston basin and the Mount Hope fault. The attitude of the faults bounding the Bellingham basin is not certain, but the linearity of the basin boundaries suggests that it is probably steep. However, the granite west of the basin is pervasively sheared in a zone about $0.5 \mathrm{~km}$ wide, as noted in the section on the Milford antiform above. Foliation in the granite dips moderately to shallowly to the west. A shear zone this wide is not characteristic of faults in and flanking the Boston basin. I believe that the shallowly dipping shear zone is older than the apparently steep faults now forming the west side of the basin. A narrow, steeply dipping shear zone in granite is exposed on the east side of the basin near Woonsocket, but the few exposures of alkalic granite on the flanks of the basin to the north are not noticeably sheared. 
The strata in the Bellingham basin are metamorphosed in the greenschist facies. Pebbles and cobbles in metaconglomerate are extremely to moderately flattened in the plane of the foliation, which in turn is locally folded and crenulated. Dips of bedding and schistosity range from moderately flat to steep. According to Rose and Murray (1984), the earliest deformation produced a northwest to west-northwest schistosity dipping north. Axes of later folds and crenulations trend northeast to east-northeast. The western boundary of the Bellingham basin effectively forms the boundary between the largely brittlely deformed terrane to the east and the variably gneissic, more ductilely deformed terrane to the west. Phyllite assigned to the Blackstone Group east of the basin is at lower metamorphic grade than rocks of the Blackstone in the Milford antiform to the west.

\section{NARRAGANSETT BASIN}

The structure of the Narragansett basin (figs. 2, 13) has received considerable attention because of interest in the coal-bearing Rhode Island Formation. Early observations were made principally by Woodworth (in Shaler and others, 1899); Skehan and others (1979) and Skehan and Murray (1980a,b) summarized the structure more recently. In the central and eastern parts of the northern Narragansett basin, Massachusetts, the Pennsylvanian strata lie in broad, east-trending, open folds and are not metamorphosed (Hepburn and Rehmer, 1981). In the northwest corner of the basin, the structure is complicated by reverse faults and thrusts and north- to northeast-trending folds. Farther south, in Rhode Island, the structure again becomes complex (Mosher, 1983), and the rocks reach sillimanite grade. The following description deals only with that part of the basin in Massachusetts.

The strata within the northern part of the Narragansett basin in Massachusetts east of Attleboro and between Mansfield and the Taunton River lie in broad, open, east-northeast-trending folds (Lyons, 1977) and are cut by a single cleavage. The Dighton Conglomerate, the highest unit in the Narragansett Bay Group (Skehan and others, 1979), occupies the synclines. There is no convincing evidence for more than one period of deformation in this area (Woodworth, in Shaler and others, 1899 , p. 157), in contrast to the more complex history found in the southern Narragansett basin (Murray and Skehan, 1979; Burks and others, 1981; Mosher, 1983, for example). In the Attleboro area, at the northwest corner of the basin, the Pennsylvanian strata are folded about north-northeast axes and have been cut by northtrending, but curvilinear, reverse faults as well as by the ubiquitous north-south normal faults (Lyons and Chase, 1976; Lyons, 1977). The Blake Hill fault block (Wood- worth, in Shaler and others, 1899, p. 183) near Plainville (A, fig. 13) is a gently to moderately dipping block of rock that appears to have been thrust northward over steeply dipping strata. To the south, a large north-trending synclinal fold passes south and east of the inlier of Hoppin Hill (Lyons, 1977). East-directed thrusts lie on the east side of the syncline. The Hoppin Hill inlier contains Dedham Granite and its fossiliferous Cambrian cover. The shallowness of the basin in this area is affirmed not only by the exposures at Hoppin Hill but also by the presence of a small inlier of granite exposed at the southwest end of the Manchester Pond Reservoir (J.P. Schafer, oral commun., 1979) southeast of Hoppin Hill. The complexity of deformation in the northwest corner of the basin is probably due to adjustments of basement blocks near their junctions during compressive post-Pennsylvanian deformation of the Narragansett and Norfolk basins.

The shape of the Narragansett basin is only partly determined by observed faults. Depositional contacts of the Pennsylvanian strata on the Proterozoic $\mathrm{Z}$ basement are present on the north and southeast sides. Predepositional or syndepositional faults are inferred to be present around much of the basin, however. On the north margin of the basin, basal Pennsylvanian strata can be seen to rest nonconformably on the Dedham Granite in several places. North of Mansfield, weathered granite regolith passes upward into bedded arkose. At another site near Plainville, moderately north-dipping red arkosic sandstone fills a fracture in the granite. Dips in the Pennsylvanian strata near the contact are moderately steep to the south, but basinward dips are flatter, indicating that the basement block moved during or after deposition. Woodworth (in Shaler, 1899, p. 128) noted that from Mansfield to Brockton, the dip of the basal beds becomes steeper than that of the higher beds as the contact is approached. To explain this discrepancy, he suggested that an unconformity exists between the basal Pennsylvanian red beds and the overlying gray carbonaceous beds typical of the Rhode Island Formation. However, he also conceded that the steeper dips along the border could be attributed to drag upward along the edges of the basin due to downfaulting of rocks in the basin. Woodworth described several places where small northeast-trending faults can be seen near the edge of the basin. The attitudes of the Pennsylvanian strata are the opposite of what would be expected in listric faulting. An inferred fault concealed beneath the strata at the surface is shown along this contact in cross section $C-C^{\prime \prime \prime}$ on the State bedrock map.

A north-to-south gravity traverse by Peter Sherman (Weston Observatory, Boston College, 1976, fig. 6B) from Mansfield to Assonet that crosses the northern part of the basin indicates what might be the general config- 


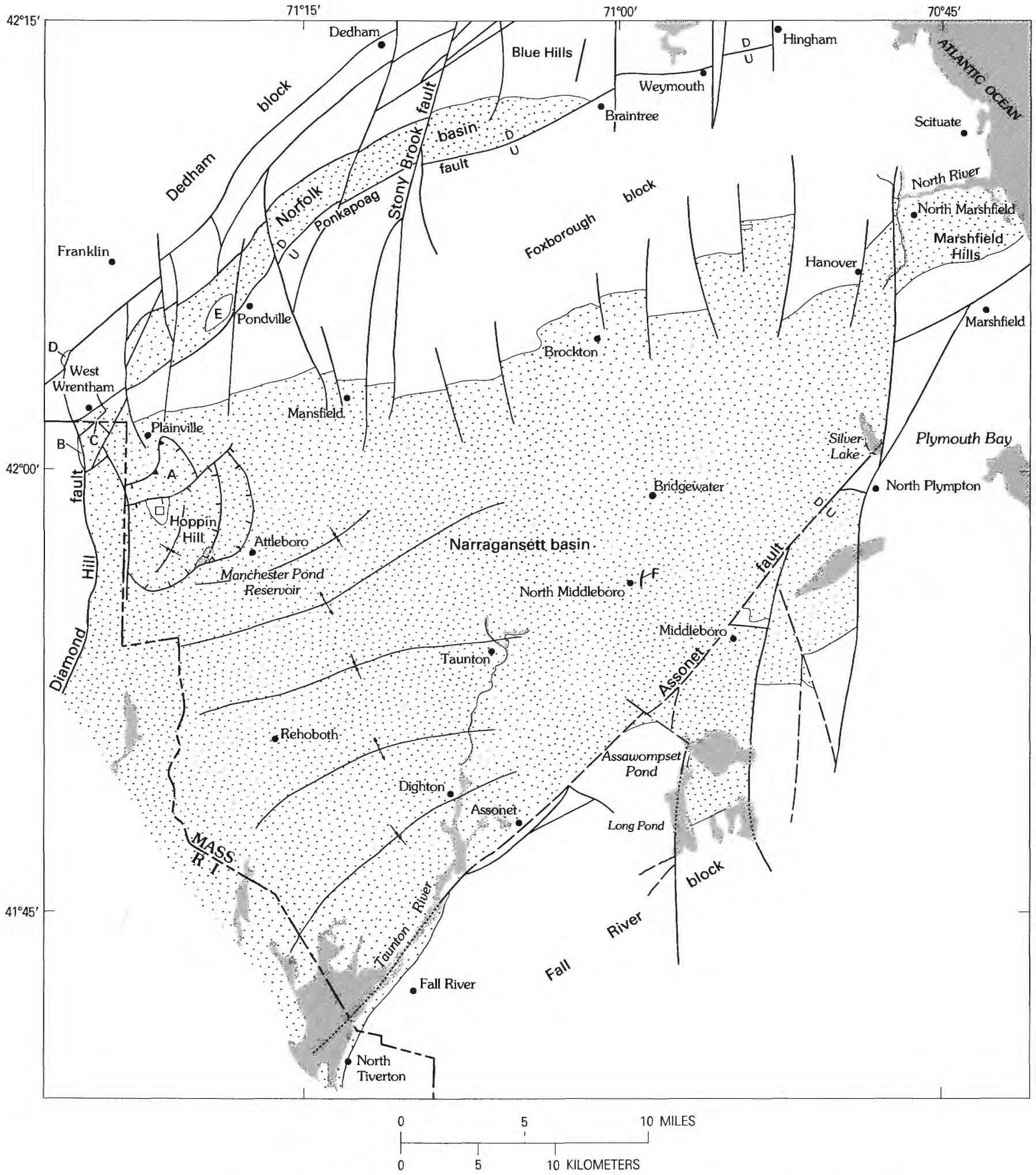

FiguRE 13. - Structural features of the Norfolk and Narragansett basins (stippled) in eastern Massachusetts. 


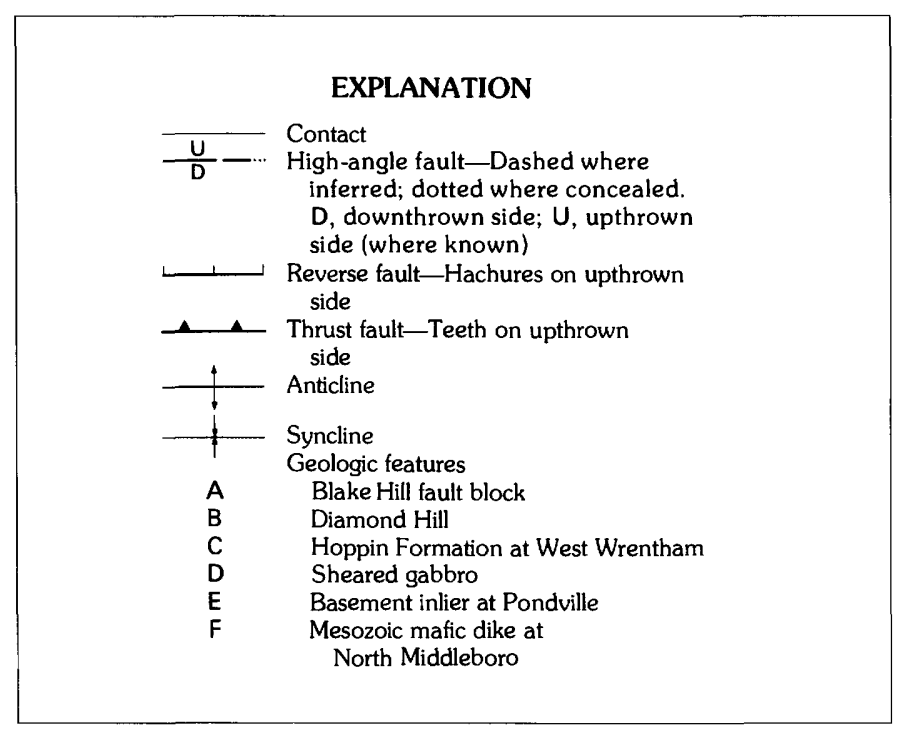

FIGURE 13.-Continued.

uration of the floor of the basin and the possible slope of the margins. The profile indicates a little more than $2 \mathrm{~km}$ of downthrow on the northern and southern margins along fault planes that dip moderately into the basin. Skehan and Murray (1980b, fig. 4) showed a normal fault downthrown to the south within the basin and south of the northern contact with the crystalline rocks to account for an abrupt thickening of the Pennsylvanian strata. On the basis of the abrupt thickening and lack of observed faulting at the predepositional to syndepositional surface, a fault that does not reach the surface is shown along the northern margin of the basin on cross section $C-C^{\prime \prime \prime}$ on the State bedrock map. Between Rehoboth and Dighton, the floor of the basin is about $1 \mathrm{~km}$ shallower than it is to the north, but the basin deepens toward the south edge. A moderately dipping normal fault is inferred in the profile on the north side of this block. The gravity profile indicates that a normal fault is present on the south side of the basin near Assonet (figs. 11A, $B ; 13$ ). Yet at the contact here, as on the north side of the basin, the Pennsylvanian strata seem to rest nonconformably on the granitic basement because, near Assonet, shallow drill holes basinward from the contact indicate that reworked regolith lies at the base of the Carboniferous beds (J.A. Sinnott, oral commun., 1979). Thus, if a fault of the amount of displacement indicated by the gravity profile exists, it must be farther out in the basin. Even so, the granite of the Fall River pluton just east and south of Assonet shows fracturing and alteration. The existence of a northeast-trending fault here is supported by the abrupt increase in depth to top of basement shown (Williams and Willey, 1973) in the hydrologic map of the Taunton River drainage area west of the inlier of basement located north of the town of Middleboro (Wood- worth, in Shaler and others, 1899; Hartshorn, 1960; Lyons, 1977). On the basis of the above data, an inferred fault has been drawn along the southeast side of the Narragansett basin from the Fall River area to the North Plympton area. It may be farther away from the contact of the Pennsylvanian strata with the basement than shown on cross section $C-C^{\prime \prime \prime}$ and may be in part or all pre- or syn-Carboniferous, like the fault inferred at the north side of the basin. From Fall River south, Pennsylvanian pebble conglomerate rests nonconformably on the Proterozoic $\mathrm{Z}$ basement. The fault, if present, presumably lies to the west. The existing scarp at the boundary of the basin may be due solely to difference in rock resistance to weathering and erosion. This inferred northeast-trending fault is along the same trend as the Beaverhead fault (Murray and Skehan, 1979) of southern Rhode Island and may represent a continuation of it or one of a parallel zone of faults (Barosh and Hermes, 1981; Burks and others, 1981, p. 268). This fault may be offset by faults bounding a small horst of basement shown by Quinn (1971) on the north end of Aquidneck Island west of Tiverton. Skehan and Murray (1980b, fig. 6) showed a series of west-directed thrust faults south of this locality, which have moved the crystalline rocks westward over the basin strata. In this case, the inclination of the Assonet fault may actually be to the southeast.

The shape of the east end of the Narragansett basin is largely controlled by north-trending faults in part determined by mapping and in part inferred from the hydrologic maps of Williams and Willey (1973) and Williams and others (1975). The most notable feature is the Assawompset Pond graben mapped by Koteff (1964) and described above (figs. 2, 11). Similar faults of lesser magnitude offset the contact of the basin to the northeast. The north-trending faults that offset the Pennsylvanian-basement rock boundary in the Hanover area are based on basement configuration, well information, surface topography, and alignment of boulders of vein quartz observed by Lyons (1977). A northeasttrending fault extending from Silver Lake to Marshfield is inferred from topography and outcrops of shattered and silicified rock and veined rock near Marshfield (Chute, 1965).

The extension of the Narragansett basin to the area north of the Marshfield Hills is based on drilling in 1979 by the U.S. Geological Survey (E.G.A. Weed, unpub. data, 1979). Two shallow drill holes along the North River, one north of North Marshfield and the other near the coast south of Scituate, passed through red sandstone of either the Wamsutta Formation or the Rhode Island Formation. The Marshfield Hills and adjoining areas to the south proved to be underlain by granite. The boundaries of the basin shown on the State bedrock map 
in this area are only approximate, but the east-west reach of the North River south of Scituate surely lies within the basin.

The west side of the Narragansett basin lies primarily in Rhode Island, where the boundary is considered to be a fault (fig. 13). This fault, the Diamond Hill fault, projects northward north of the Massachusetts-Rhode Island State line and the mass of vein quartz at Diamond Hill (B, fig. 13) (Quinn, 1971, p. 45). The area north of Diamond Hill coincides with the faulted southern termination of the Norfolk basin and its junction with the Narragansett basin. The small outcrop of Cambrian Hoppin Formation south of West Wrentham (C, fig. 13) appears to lie in a fault wedge at this juncture. A splay of the western boundary fault of the basin appears to project to the north into a fault shown by Volckmann (1977) that extends from Franklin through the Dedham area toward the Boston basin. A sliver of sheared gabbro is exposed along this trace northwest of West Wrentham (D, fig. 13).

\section{NORFOLK BASIN}

The Norfolk basin is a partly fault-bounded, eastnortheast-trending synclinal basin between the Dedham and Foxborough blocks (fig. 13). Basin fill consists of the alluvial Pondville Conglomerate and the Wamsutta Formation. These Pennsylvanian strata are folded and cleaved but are unmetamorphosed (Hepburn and Rehmer, 1981). Cazier (1984) mapped two sets of minor folds in the Pennsylvanian strata, both having horizontal axes that strike roughly east-northeast parallel to the trend of the basin margins. The first is isoclinal and has a related pressure-solution cleavage dipping about $40^{\circ} \mathrm{N}$.; the second is open and has an axial planar cleavage dipping about $50^{\circ} \mathrm{N}$. Cazier noted that thrust faults along the southeast margin of the basin deform both cleavages. The north side of the basin appears to be an unconformity that now dips steeply. The south side of the basin is the clearly defined Ponkapoag ${ }^{3}$ fault. The basin is offset along its length by the faults of the late north- to north-northwest-trending system that offset the bounding faults of the Narragansett and Boston basins.

The Ponkapoag fault separates the Pennsylvanian strata from the Proterozoic Z Dedham Granite of the southeastern Massachusetts batholith. East of Braintree, the Pennsylvanian rocks are cut out by the fault so that the Ordovician and Silurian Quincy Granite and the Cambrian Braintree Formation lie against the Dedham. Near Hingham, the fault cuts into the batholithic rocks,

\footnotetext{
${ }^{3}$ Although the town near this fault is labeled Ponkapog on the State bedrock map, the name of the fault was spelled Ponkapoag by Billings (1976a, 1982), and this usage is followed here.
}

isolating a patch of Dedham Granite north of the fault and nonconformably overlying Roxbury Conglomerate in the Hingham anticline. The Ponkapoag fault appears to dip steeply throughout its extent. Near Weymouth the fault dips about $80^{\circ} \mathrm{N}$.; farther west it dips about $60^{\circ} \mathrm{N}$., although Cazier (1984) described thrust faults along the southeast margin of the basin that dip $25^{\circ}$. Billings $(1976 a, b)$ computed the stratigraphic throw near Hingham to be about $410 \mathrm{~m}$. He believed then that the fault was originally a northward-directed thrust, which had been rotated back to the south, like some of the faults in the Boston basin. Billings (1982, p. 919) more recently proposed that the fault is normal and that the downthrown block is to the north.

The north side of the Norfolk basin in the vicinity of the Blue Hills is not a fault but an unconformity (Chute, 1969). Here the basal Pondville Conglomerate dips about $60^{\circ} \mathrm{S}$., slightly less steeply than the underlying Blue Hills Granite Porphyry (SObgr) in the Blue Hills (Billings, 1982, p. 917). These relations led Billings to conclude that the block between the Blue Hills fault and the Norfolk basin has been tilted about $60^{\circ}$, up to the north and down to the south, since deposition of the Pennsylvanian strata.

Elsewhere along the north side of the Norfolk basin, the relations are less clear. West of the Stony Brook fault (fig. 13), Chute (1964, p. 41-42) cited truncation of units as evidence for a southeastward-directed thrust. I suggest that the discontinuous nature of Pondville Conglomerate along the flanks of the basin need not indicate faulting but could be due to nondeposition. No basal conglomerate is present to the south, on the north side of the Narragansett basin, but lenses of conglomerate indicating channels are present within the Rhode Island Formation above the base of the section (Lyons, 1977). However, on the State bedrock map I have shown Chute's (1964) fault on the north side of the basin as continuing south into the Franklin area, because the geometry there seems to require it.

The southwestern end of the Norfolk basin is appreciably broken by faults and is flanked in part by felsic volcanic rocks of uncertain age. The Sharon Syenite just east of the Ponkapoag fault exposed on I-495 south of Franklin is appreciably altered and fractured, but elsewhere faults themselves are not exposed. A horst or inlier (E, fig. 13) near Pondville containing Dedham Granite and fine-grained granite flanked by steeply dipping Pennsylvanian strata splits the southwestern end of the basin into two parts. The Wamsutta Formation in the southern part is continuous with Wamsutta in the Narragansett basin. The Wamsutta in the northern part, near Weymouth, is cut off against the Ponkapoag fault. 


\section{MIDDLETON BASIN}

The Middleton basin, containing Upper Triassic and Lower Jurassic red beds (Kaye, 1983), lies in the same north-northeast-trending structural zone as the Newbury basins and is close to the southern Newbury basin (figs. 2, 10). The Middleton basin is estimated to be about $5.7 \mathrm{~km}$ long and no greater than $0.5 \mathrm{~km}$ wide; however, the strata are actually exposed in only one place. A normal fault striking northeast, exposed on the southeast margin of the basin, separates the basin from sheared rock of the Proterozoic basement. Kaye (1983) estimated the throw on this fault to be greater than $500 \mathrm{~m}$. The western contact of the basin is not exposed. Beds of arkosic conglomerate contain cobbles of crystalline rocks of the area, and the beds are clearly unconformable on the crystalline rocks. The Triassic and Jurassic red beds are not sheared but dip to the west, more steeply at the bounding fault than away from it. If the dips do not reverse, a fault should lie at the west side of the basin also, but Kaye indicated that the beds probably do dip to the southeast on the west side. This contact, then, which is shown on the State bedrock map as a fault, could instead be an unconformity.

The basin lies at a location where the Bloody Bluff fault and the Burlington mylonite zone cease to be readily identified and where the contact between the Nashoba zone and the Milford-Dedham zone turns northerly from its general northeast trend. The fault at the southeast side of the basin is clearly post-Late Triassic and indicates that Mesozoic faulting has occurred in the area. The faults bounding the Newbury basins in this same zone are quite possibly, in part at least, Mesozoic. This younger faulting would account for the lack of pervasive mylonitic texture in the Newbury rocks such as characterizes the basement rocks in the Bloody Bluff and Burlington mylonite zones, which have had a longer history of deformation (see section below on the Bloody Bluff fault zone).

\section{NANTUCKET BASIN}

A northeast-trending basin containing sandstone and basalt of Triassic and Jurassic age is buried beneath the Coastal Plain sediments on Nantucket Island and under Nantucket Sound (Weed, in Goldsmith, this vol., chap. $\mathrm{E}$; cross section $E-E^{\prime}$ of the State bedrock map). This basin trends northeast and is inferred to be about $25 \mathrm{~km}$ wide and $100 \mathrm{~km}$ long (Austin and others, 1980). The northern boundary, beneath the middle of Nantucket Sound, is interpreted as a southerly dipping normal fault, on the basis of seismic-reflection profiles (Ballard and Uchupi, 1975). The strata within the basin appear to dip north. The shape of the floor of the basin is not known, nor is the nature of the southern boundary. The deposits are at least $1 \mathrm{~km}$ thick. A smaller northeast-trending basin extending from the lower arm of Cape Cod across Cape Cod Bay has been postulated by Ballard and Uchupi (1975), on the basis of seismic-reflection profiles and magnetic data.

The Nantucket basin, like the Middleton basin, is part of the system of Mesozoic rift basins of the Eastern United States and maritime Canada (Klitgord and Behrendt, 1979; Grow and others, 1979), a swarm of which are present to the north in the Gulf of Maine and the Bay of Fundy (Ballard and Uchupi, 1975; Klitgord, 1984).

\section{MAFIC DIKES}

The orientations and ages of mafic dikes in eastern Massachusetts provide clues to the pattern of regional stress through time. The larger dikes such as the Medford Diabase and the dike in the Bellingham basin are shown on the State bedrock map. A few smaller dikes are shown elsewhere, as on islands in Boston Harbor and in the Marlborough area. One dike noted by Lyons (1977) is shown cutting the Rhode Island Formation at North Middleboro (F, fig. 13). Most dikes trend north-south and are considered to be of Mesozoic age. A few thin northsouth dikes not shown on the map can be seen in the crystalline basement southwest and west of Boston in highway cuts along I-495 and I-90. Dikes are more numerous in the Milford-Dedham zone than is shown on the State bedrock map, and they are not all of Triassic or Jurassic age. LaForge (1932) and Ross (1981) described dikes of diabase and lamprophyre of several ages in the Boston area. Ross, who studied the dikes most recently, found from isotopic work that most are probably Triassic and Jurassic in age, but they range in age from Devonian to Jurassic. The orientation of the dikes in relation to age has not been measured systematically. LaForge (1932), however, divided the dikes into an older group, striking west to northwest and dipping variably, and a younger group, striking north and dipping steeply. Kaye (oral commun., 1981) noted that diabase dikes present on some of the islands in Boston Harbor are sill-like. The older west-striking dikes are presumably of late Paleozoic age, whereas the younger north-striking dikes are Mesozoic. Some of LaForge's older dikes are probably related to the Brighton Melaphyre and therefore would be Proterozoic $\mathrm{Z}$ in age rather than post-Pennsylvanian. No data are available on these dikes. Some lamprophyre dikes could be lower and middle Paleozoic and related to the alkalic plutons in the area; others may be younger.

Dikes and faults of similar ages have similar orientations in the Boston basin area. The Triassic and Jurassic dikes are aligned in the general north- to north- 
TABLE 2.-Metamorphism and structure of cover rocks in basins of the Milford-Dedham zone, eastern Massachusetts

\begin{tabular}{|c|c|c|c|c|c|c|}
\hline & Newbury basins & Middleton basin & Boston basin & Bellingham basin & Norfolk basin & Narragansett basin \\
\hline Rocks & $\begin{array}{l}\text { Mudstone, silt- } \\
\text { stone, rhyolite, } \\
\text { and basalt. }\end{array}$ & $\begin{array}{l}\text { Arkose, conglom- } \\
\text { erate, and } \\
\text { shale. }\end{array}$ & $\begin{array}{l}\text { Slate, argillite, } \\
\text { conglomerate, } \\
\text { and volcanic } \\
\text { rocks. }\end{array}$ & $\begin{array}{l}\text { Phyllite, metacon- } \\
\text { glomerate, and } \\
\text { volcanic rocks. }\end{array}$ & $\begin{array}{l}\text { Metasandstone, } \\
\text { conglomerate, } \\
\text { and volcaniclas- } \\
\text { tic rocks. }\end{array}$ & $\begin{array}{l}\text { Sandstone, conglomer- } \\
\text { ate, meta-anthracite } \\
\text { and volcanic rocks. }\end{array}$ \\
\hline Age & $\begin{array}{l}\text { Silurian and } \\
\text { Devonian. }\end{array}$ & $\begin{array}{l}\text { Triassic and } \\
\text { Jurassic. }\end{array}$ & $\begin{array}{l}\text { Proterozoic } \mathrm{Z} \text { to } \\
\text { Cambrian. }\end{array}$ & $\begin{array}{c}\text { Pennsylvanian or } \\
\text { Proterozoic } Z \text {. }\end{array}$ & Pennsylvanian & Pennsylvanian. \\
\hline Metamorphism & Low greenschist & None & Subgreenschist & Greenschist & Subgreenschist & $\begin{array}{l}\text { Subgreenschist to } \\
\text { greenschist (in } \\
\text { Massachusetts). }\end{array}$ \\
\hline $\begin{array}{l}\text { Oldest bounding } \\
\text { faults. }\end{array}$ & $\begin{array}{l}\text { East-northeast } \\
\text { and north- } \\
\text { northeast; high- } \\
\text { angle, east- } \\
\text { northeast faults } \\
\text { could be } \\
\text { reverse faults } \\
\text { (rotation } \\
\text { toward basin). }\end{array}$ & $\begin{array}{l}\text { Northeast, high- } \\
\text { angle, normal. }\end{array}$ & $\begin{array}{l}\text { East-northeast } \\
\text { reverse faults, } \\
\text { movement } \\
\text { toward basin. }\end{array}$ & $\begin{array}{l}\text { North-northeast } \\
\text { to northeast, } \\
\text { high-angle, may } \\
\text { be reverse } \\
\text { faults toward } \\
\text { basin. }\end{array}$ & $\begin{array}{l}\text { East-northeast } \\
\text { reverse fault } \\
\text { toward basin on } \\
\text { south side. Part } \\
\text { of north side } \\
\text { high-angle, pos- } \\
\text { sibly reverse } \\
\text { fault toward } \\
\text { basin. }\end{array}$ & $\begin{array}{l}\text { North-south, high- } \\
\text { angle, normal on } \\
\text { west side; none } \\
\text { known on north side } \\
\text { unless buried. Possi- } \\
\text { ble northeast- } \\
\text { trending buried fault } \\
\text { on southeast side. } \\
\text { North-south, high- } \\
\text { angle on east side. }\end{array}$ \\
\hline $\begin{array}{l}\text { Major deforma- } \\
\text { tion and trend } \\
\text { of stress. }\end{array}$ & $\begin{array}{l}\text { North-northwest } \\
\text { compression; } \\
\text { rotation of } \\
\text { strata. }\end{array}$ & $\begin{array}{l}\text { West-northwest } \\
\text { tension; tilting } \\
\text { of strata. }\end{array}$ & $\begin{array}{l}\text { North-northwest } \\
\text { compression; } \\
\text { open to tight } \\
\text { folds. }\end{array}$ & $\begin{array}{l}\text { West-northwest } \\
\text { to northwest } \\
\text { compression; } \\
\text { fold flattening. }\end{array}$ & $\begin{array}{l}\text { West-northwest } \\
\text { compression; } \\
\text { rotation of } \\
\text { strata. }\end{array}$ & $\begin{array}{l}\text { West-northwest com- } \\
\text { pression, open folds; } \\
\text { reverse faults and } \\
\text { thrusts in northwest } \\
\text { corner. }\end{array}$ \\
\hline $\begin{array}{l}\text { Age of major } \\
\text { deformation. }\end{array}$ & $\begin{array}{l}\text { Post-Early Devo- } \\
\text { nian. }\end{array}$ & Jurassic(?) & Alleghanian & Alleghanian & Alleghanian & Alleghanian. \\
\hline
\end{tabular}

northwest trend of the young faults that cut the basin margins. The older east- to northeast-trending dikes are parallel to the east-northeast-trending faults bounding and within the Boston basin.

\section{SUMMARY OF BLOCKS AND BASINS OF THE MILFORD- DEDHAM ZONE}

Rocks in the basins of the Milford-Dedham zone are folded and faulted but, except for those in the Bellingham basin, are little metamorphosed (table 2). The Proterozoic $\mathrm{Z}$ strata in the Boston basin and the Cambrian strata there and at Hoppin Hill are no more metamorphosed than are the strata in the Silurian and Devonian Newbury basins and the Pennsylvanian strata in the Norfolk basin and northern part of the Narragansett basin. The Triassic-Jurassic rocks of the Middleton basin have only been faulted and are not metamorphosed at all. Some of the strata in the Bellingham basin are no more deformed and metamorphosed than strata in the Boston basin. The other greenschist-facies rocks mapped within the Bellingham basin may actually be equivalent to the Proterozoic Z Blackstone Group rather than the Pennsylvanian Bellingham Conglomerate. The evidence thus indicates that little deformation or metamorphism occurred within the zone between the Proterozoic $\mathrm{Z}$ time and the late Paleozoic. The folding and metamorphism seem to be related to compressive crustal movements in the late Paleozoic Alleghanian orogeny. Stresses at that time consisted primarily of west-northwest-east-southeast compression that broke up the crystalline basement and preserved covering strata in differentially down-dropped blocks flanked by reverse faults. Farther south in Rhode Island, Alleghanian events described by Mosher (1983) and Murray and Mosher (1984) involved early east-west compression producing westward-directed folds and thrusts, followed by a regional strike-slip component producing folds oriented slightly more northeasterly and verging eastward. Their third phase of folding is localized along an east-northeast-trending shear related to a regional east-west megashear system to the south. It is not clear how these structures relate to the deformation observed to the north in Massachusetts. Probably the major control in eastern Massachusetts was preexisting zones of weakness in the Proterozoic Z basement, which were reactivated during crustal movements in the late Paleozoic. Such preexisting zones of weakness may have controlled the original shapes and locations of the basins and may have controlled the formation of the Boston basin during a Proterozoic $\mathrm{Z}$ rifting event.

The Pennsylvanian strata were deposited in an alluvial plain possibly in a broad intermontane or rift basin that formed following the Devonian extensional volcanicplutonic events. McMaster and others (1980) postulated sinistral shearing on northeast-trending faults to form 
the basins, followed by dextral shearing on the same set of faults in the Permian to cause the post-Pennsylvanian compressional events and north-south extension, permitting intrusion of the east-trending Narragansett Pier Granite. The abundant north- to north-northwest- and locally north-northeast-trending faults are clearly later than the faults and folds of Alleghanian age and are ascribed to early Mesozoic rifting.

The north-south faults are clearly younger than deposition of the Pennsylvanian deposits in the Narragansett basin, as they offset the contact with the crystalline rocks at the northeastern and northern edges of the basin. Some of these faults, such as those at Diamond Hill and in the Hanover area, are associated with vein quartz. Brecciation and veining by quartz is typical of faults of Triassic and Jurassic age in eastern New England (Rodgers, 1970), and I consider the generally north-south faults in eastern Massachusetts to be Mesozoic in age. The Assawompset Pond graben is probably a Mesozoic structure. The west- and northwest-trending faults are possibly of similar age or older. The northeasttrending Beaverhead fault of southern Rhode Island must be post-Pennsylvanian because it cuts out Pondville Conglomerate on southern Conanicut Island. The inferred Assonet fault, however, may be an older fault in the basement that partly determined the location of the margin of the Narragansett basin before deposition of the Pennsylvanian strata. Apparently, postPennsylvanian movement here has not been great. The steeply dipping, west-trending shear zones in the crystalline rocks of the Fall River block are possibly prePennsylvanian because no such shearing has been reported in the Pennsylvanian strata in the basin. The age of the northwest-striking thin mylonite zones in South Dartmouth is not known. No clear relationship is seen between structures in the crystalline complex of the Fall River block and polydeformation recorded in the pre-Pennsylvanian rocks in the southern Narragansett basin to the east (Kay and Chapple, 1976; Rast and Skehan, 1981). The gneissic plutonic rocks in the New Bedford area were deformed at higher temperatures than were the rocks at Newport, R.I., but these are in a different block. It is most likely that the Fall River block was relatively rigid during Alleghanian deformation. Possibly the primary foliation formed earlier, at the same time as the $S_{1}$ cleavage in the greenschist-facies Proterozoic $\mathrm{Z}$ metasedimentary and metavolcanic rocks at Newport, R.I., described by Kay and Chapple (1976) and Rast and Skehan (1981). The east-northeast-trending, southward-verging fold pattern in the crystalline rocks in the New Bedford area could be related to development of $\mathrm{S}_{2}$ cleavage in the Newport rocks, but the supposition is weak. In the Pennsylvanian rocks of the southern Narragansett basin, the oldest deformation is visualized as east-west compression in which the Fall River block moved westward (Burks and others, 1981, p. 272). Possibly the east-west shears in the block are tears that developed during this process.

In the Boston, Norfolk, and northern Narragansett basins, vergence of folding and thrusting has been to the south and generally oriented north-northeast. The strata in the Newbury basins are tilted into orientations approximating the trends of the bounding faults, which are east-northeast in the northern part of the northern basin and north-northeast in the southern part and in the southern basin. The east-northeast trends in the Boston, Norfolk, and northern Narragansett basins seem to me to form a pattern of deformation that, because it affects Pennsylvanian rocks, indicates the deformation is a reflection of Alleghanian crustal movements. This deformation increases in intensity from north to south. The greater complexity of structures at the northwest end of the Narragansett basin near its junction with the Norfolk basin is probably due to complications arising from the adjustments in cover rocks as basement subblocks were jostled during Alleghanian deformation. The controlling stress could be the left-lateral shear system striking northeast mentioned above.

\section{BLOODY BLUFF FAULT ZONE}

The Bloody Bluff fault (Cuppels, 1961, p. D46; Skehan, 1968, p. 282) forms the boundary between the MilfordDedham zone and the Nashoba zone in eastern Massachusetts from near Westborough to Lynnfield (figs. 1, 14). The history of recognition of the fault and its configuration are described by Castle and others (1976). The boundary between the Milford-Dedham zone and the Nashoba zone from south of Marlborough to Oxford is the Lake Char fault, which on the State bedrock map is shown as coinciding with the trace of the Bloody Bluff. ${ }^{4}$ The fault is not well exposed in this interval. In Connecticut the Lake Char fault forms the boundary between the gneissic part of the Milford-Dedham zone in the Rhode Island anticlinorium and the Putnam terrane as far south as the Preston Gabbro (PG, fig. 3) in North Stonington, Conn., where the boundary turns west as the Honey Hill fault.

The main zone of the Bloody Bluff fault is a polydeformed zone of ductile deformation and cataclasis as much as $3.2 \mathrm{~km}$ wide near Framingham (Nelson, 1976) and $5 \mathrm{~km}$ wide in the Burlington area where it is the Burlington mylonite zone of Castle and others (1976). However, at the type locality of the fault at Bloody

${ }^{4}$ Since the State bedrock map was prepared, O'Hara and Gromet (1984) have identified a shear zone east of the Lake Char fault, which they consider to be the southward continuation of the Bloody Bluff fault (see figs. 3, 9). 

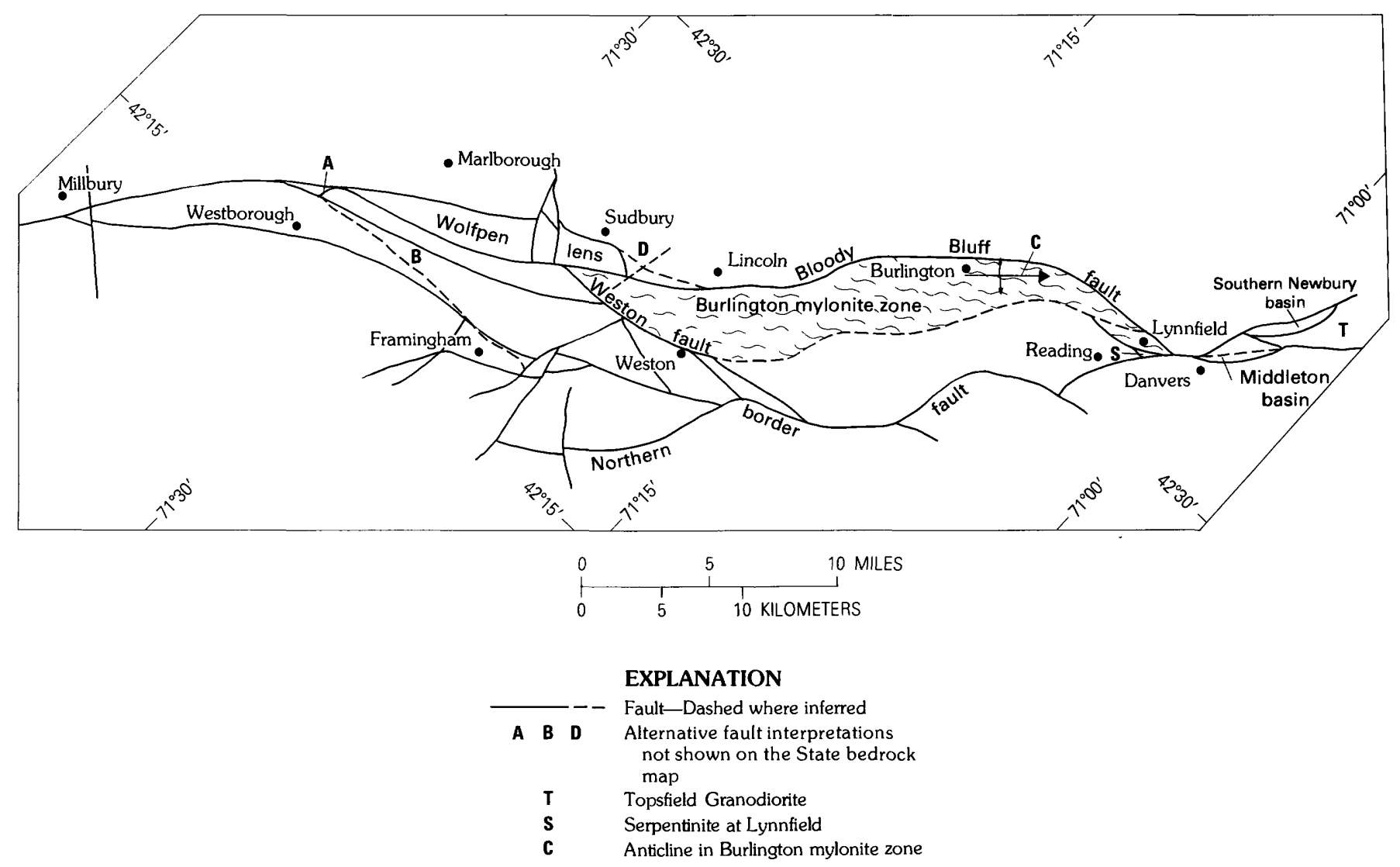

FIGURE 14.-Structural features along part of the Bloody Bluff fault zone, northeastern Massachusetts.

Bluff (fig. 14) (Cuppels, 1961) and other places, brittle deformation structures are common. This complexity indicates that the Bloody Bluff zone has had a long history of deformation. Within the zone of mylonitic rocks are markedly layered blastomylonites of felsic and mafic rock and mylonites of quartzite. Similar rocks can be seen in the Proterozoic Z Waterford Group in the lower plate of the Honey Hill fault zone southeast of the Preston Gabbro in southeastern Connecticut (Goldsmith, 1980, 1985).

Southwest of Westborough, mylonitic rocks form a relatively narrow zone. The fault is exposed on I-495 east of Westborough. From Westborough northeast, the Bloody Bluff-Lake Char fault system widens and splits into several east-trending branches. The central splay is the main Bloody Bluff fault of Cuppels (1961, p. D46; Skehan, 1968, p. 282). A southern splay, trending east toward the Boston basin, was called the Weston fault by Nelson (1975a,b; 1976). The northern splay is arcuate and less well documented. Castle and others (1976) ended the Bloody Bluff fault against (A, fig. 14) a fault (B, fig. 14) extending from Westborough to Framingham, which they called the Lake Char fault. The splay off the Bloody
Bluff fault from near Millbury to the Framingham area shown on the State bedrock map is largely interpreted from discordance of foliation pattern. O'Hara and Gromet (1984) placed their split between the Lake Char and Bloody Bluff faults south of Millbury (5, fig. 2). The location of some of these faults is interpretive, and other fault patterns could be drawn in northeastern Massachusetts. Castle and others (1976) and Nelson (1976) based much of their interpretations of the location of major faults on aeromagnetic patterns. Because the faults are zones of crushed rock rather than discrete surfaces, they could have been shown more accurately on the State bedrock map as patterned areas, rather than as discrete fault traces. On the State bedrock map the significant fault in the Bloody Bluff system is considered to be the westernmost fault, the one that separates recognizable Milford-Dedham rock assemblages from Nashoba assemblages.

The Bloody Bluff fault ends as a discrete entity in the Danvers-Lynnfield area of Essex County, at the southern end of the southern Newbury basin and the Middleton basin. This locality appears to be a structural nexus, for it is about here that the Burlington mylonite zone is 
no longer recognized, and the postulated Mystic fault of Bell and Alvord (1976, fig. 1; fig. 10) intersects the Bloody Bluff fault. This nexus probably represents the intersection of fault systems of somewhat different trends and ages. The identity of the Bloody Bluff fault northeast of the Lynnfield-Danvers area is questionable, and the fault may change character. The Proterozoic $\mathrm{Z}$ plutonic rocks in this area have a nonsystematically oriented crushed fabric and a retrogressive mineral assemblage, unlike the directed, well-recrystallized fabric of the mylonite zones to the southeast. The western boundary of the Milford-Dedham zone from Lynnfield north is marked by narrow fault zones, such as those forming the boundaries of the Newbury basins and at least one side of the Middleton basin (Kaye, 1983). The Bloody Bluff and the Burlington mylonite zone have northeasterly trends, whereas the faults bounding the Newbury basins have more northerly trends. The northtrending faults bounding the basins are later than, and have truncated and offset, the zones of more pervasive northeasterly deformation in the Bloody Bluff and Burlington zones. Possibly a splay of the Bloody Bluff continues northeast along the southern boundary of the Topsfield Granodiorite (T, fig. 14), to the Gulf of Maine where it lies under the Quaternary sands of Plum Island.

The Weston fault of Nelson $(1975 a, b)$ splays easterly from the Bloody Bluff fault near Westborough toward the northern border fault of the Boston basin in the vicinity of Weston (fig. 14). This area is so broken by faults that it is difficult to determine the actual relationship of the Weston fault to the border fault; however, the north-northeast-trending Burlington mylonite zone projects southwestward into the trace of the Weston fault, and I have accordingly shown the eastern boundary of the zone as a fault branching off the Weston fault near Weston. The Burlington mylonite zone is described below.

The fault shown on the State bedrock map splaying off the Lake Char fault in the vicinity of Millbury is drawn to connect with an east-northeast-trending fault mapped by Nelson (1975a) south of Framingham. This fault offsets rock units as much as $6 \mathrm{~km}$ in a right-lateral sense. Southwest of Framingham near Marlborough, Nelson's fault was not recognized by Barosh (1978) or by Hepburn and DiNitto (1978). Although its existence southwest of the Framingham quadrangle is questionable, it is drawn on the State bedrock map along contacts of units aligned parallel to its possible projected trace and parallel to the gneissic foliation in the plutonic rocks in this area.

\section{BURLINGTON MYLONITE ZONE}

The Burlington mylonite zone of Castle and others (1976) extends from Weston to Lynnfield and Danvers (figs. 2, 14). They visualized the northwest side of the zone as the primary locus of dislocation on the Bloody Bluff fault. As described by Castle and others (1976), the mylonite zone is about $1.5 \mathrm{~km}$ thick although it has been folded and faulted to produce an outcrop width of as much as $5 \mathrm{~km}$. Castle (1964) showed a north-plunging fold of foliation in the zone southwest of Lynnfield (C, fig. 14). The rocks range from ultra-fine-grained laminated mylonites to coarse augen and flaser gneisses. Mylonitic quartz schist and blastomylonitic, thinly layered, leucocratic, siliceous rocks are seen in thin section to have a ribbon-like fluxion structure. The augen and flaser gneisses tend to be near the center of the zone, and the more laminated rocks are on the flanks. This division may reflect original differences in rock composition as well as degree of deformation. Within the zone are areas of layered mafic nonmylonitic rock and areas of massive mafic rock sheared only around the margins. The latter form large-scale augen of competent rock around which the strain was distributed. Bands and seams of chlorite schist are common in sheared mafic rock. The zone of serpentine mapped by Castle (1964) near Lynnfield (S, fig. 14) is mostly antigorite. Kaye (1983, p. 1076) suggested that it was ultramafic material squeezed up in a shear zone. The ductile mylonites are cut by later brittle faults (Castle and others, 1976).

The Burlington mylonite zone does not seem to persist as a discrete feature northeast of Lynnfield nor southwest of Weston. To the northeast, its last good expression seems to be at the south end of the Newbury and Middleton basins. Castle and others $(1976$, p. 17) concluded that the Burlington mylonite zone does not extend seaward toward the Gulf of Maine but turns northward and is cut out against, or dips beneath, weakly magnetic plutonic rocks (Sharpners Pond Diorite and related rocks) and the Newbury Volcanic Complex. Kaye (1983) did not show the mylonite zone extending beyond the Lynnfield and Danvers area but did suggest (oral commun., 1980) that it swings to the east following the southern edge of the Topsfield Granodiorite ( $T$, fig. 14). However, as the Topsfield is part of the Milford-Dedham assemblage, this zone cannot be the main boundary between the Nashoba and Milford-Dedham blocks, which must lie beneath the Newbury basins. To the south, the Burlington mylonite zone ends near the Weston fault of Nelson (1976). On the State bedrock map, I have shown the eastern boundary of the mylonite zone as a fault continuing south to merge into the Weston fault near Weston. This fault line does not represent a discrete fault surface but a boundary between mostly sheared and mostly unsheared rock.

It is quite likely that the Burlington mylonite zone is of composite age. However, Castle and others (1976) stated that the Burlington mylonite zone is intruded by the 
Paleozoic alkalic granites, presumably in this case the Early Devonian Peabody Granite (Dpgr). This provides an upper (young) age limit for some of the deformation, at least in this part of the zone.

Mylonitic and cataclastic rocks of the kind described by Castle and others (1976) in the Burlington zone and by Nelson (1976) along the Bloody Bluff fault zone are repeated to the south, although often in a narrower zone, along the Lake Char and Honey Hill faults in eastern and southeastern Connecticut (Lundgren and Ebblin, 1972; Goldstein, 1982; Dixon, written commun., 1983; Goldsmith, 1985) and in the zone east of the Lake Char fault identified by O'Hara and Gromet (1984). The wide, nonuniform distribution of faults and shear zones, such as the Burlington mylonite zone in northeastern Massachusetts, may be the culmination at a shallower level of the more pervasive, ductile strain evident in the western side of the Rhode Island anticlinorium to the south. The irregular distribution of the deformation is probably in large part caused by the distribution of rocks of different competencies; in addition, this area is a major boundary between different terranes in which movement is distributed over a fairly wide zone forming a typical anastomosing cataclastic pattern, albeit on a regional scale. The gabbroic rocks of the diorite and gabbro suite act as resistant knots around which the strain was distributed, as is the case with the Preston Gabbro in Connecticut. The major strain appears to have been accommodated by the quartzitic and quartzofeldspathic rocks of the Westboro Formation and the overlying volcanic units to produce the quartzitic mylonites noted by Castle and others (1976).

\section{WOLFPEN LENS}

A lens of rock called the Wolfpen lens (figs. 2, 14) lies between the northern branch and the main trace of the Bloody Bluff north of Framingham and east of Marlborough. It consists of sheared amphibolite and metaplutonic rock that was called the Wolfpen Tonalite by Emerson (1917) and "altered and sheared rocks" by Hepburn and DiNitto (1978). A question exists as to whether these rocks belong to the Milford-Dedham zone or to the Nashoba zone. Nelson (1975b) showed the Wolfpen lens as much smaller than is shown on the State bedrock map. To the west of the boundary of Nelson's lens, he mapped a poorly exposed unnamed granite, which in its eastern part contains an inclusion of his Proterozoic Z Claypit Hill Formation. The western part of this granite, which Nelson showed as intruding the Marlboro Formation, is now mapped as granodiorite of the Indian Head pluton (igd on the State bedrock map) and assigned to the Nashoba zone. If, as mapped by Nelson, there is only one granite, then this is the only place in southeastern New England where plutonic rock straddles the boundary between the Milford-Dedham zone and the Nashoba zone. Because the Claypit Hill is a formation in the Milford-Dedham zone, the granite that encloses it must also belong to the Milford-Dedham zone. Either the rocks mapped as Claypit Hill Formation are misidentified and are actually Marlboro Formation, or two different granites exist here. Mapping by Barosh (1978) and Hepburn and DiNitto (1978) in the Marlborough area indicates that Nelson's granite may be two different plutonic rocks. Hence I have drawn the northwest boundary of the lens along a topographic lineament aligned with Barosh's and Hepburn and DiNitto's faults bounding the zones so that the Wolfpen inclusion of Claypit Hill is within the Milford-Dedham zone. This lens ends near Sudbury where its northern bounding fault rejoins the main strand of the Bloody Bluff fault. The sharp bend in the trace of the fault north of the junction was shown by Castle and others (1976) as an offset on a transecting north-south fault. Barosh and others (1977) also showed a north-south fault here (D, fig. 14) that offsets the Bloody Bluff fault to the south. They continued the Bloody Bluff to intersect the main trace near Lincoln. Shride (written commun., 1979), however, did not recognize a fault here and believed the trace of the Bloody Bluff fault is only folded. Following Shride, the north-south fault is not shown on the State bedrock map.

\section{ATTITUDES OF FAULT SURFACES AND SENSE OF} MOVEMENT IN THE BLOODY BLUFF FAULT ZONE

The attitudes of fault surfaces in the Bloody Bluff fault system have been measured directly in several places. The sense of movement is less well determined. The Lake Char fault in Connecticut dips about $25^{\circ}$ to the west in northeastern Connecticut, as determined by measurements of mylonitic fabric. Dips steepen to about $45^{\circ}$ as this fault is traced into Massachusetts and steepen to $60^{\circ}$ and more where the fault becomes the Bloody Bluff and starts to curve easterly in the Westborough area. Castle and others (1976) computed dips of $60^{\circ}$ on the basis of magnetic data in the Bloody Bluff zone near Marlborough. Mylonite on the west edge of the Burlington zone dips $60^{\circ}-85^{\circ}$ to the west. Nelson (1975a) showed dips of $60^{\circ}-65^{\circ}$ on branches of the Bloody Bluff fault in the Framingham area. Castle and others (1976) stated that the Bloody Bluff dips more gently at about $20^{\circ}$ northwest where the fault turns from northeasterly to northerly near Lynnfield.

The sense of movement on the main Bloody Bluff fault system has been generally considered to be a thrust or high-angle fault with movement toward the southeast and east (Skehan, 1969; Nelson, 1976). The opposite sense of movement has been proposed at least for the latest movements on the Lake Char fault (Goldstein, 
1982) and the related Honey Hill fault (Lundgren and Ebblin, 1972) in Connecticut. A strike-slip component of movement on the Bloody Bluff was proposed by Bell (as cited in U.S. Geological Survey, 1969, p. A21-A22) at least from Framingham north. At the type locality, Smith and Barosh (1983) recognized dextral displacement that deformed an earlier foliation aligned parallel to the fault trend. O'Hara and Gromet (1984) stated that movement sense in the shear zone east of the Lake Char fault is dextral. However, Castle and others (1976) pointed out that "b" lineations in minor folds associated with the mylonites have gentle plunges. Any translational movements like those noted by Smith and Barosh (1983) may have been relatively late. Nelson (1976) saw little evidence for lateral displacement in the ductilely deformed rocks.

Some transcurrent movement has been reported for minor and probably young faults in the zone. Northeast of Lynnfield, where the major fault zones are not exposed, sense of movement on northeast- and northnortheast-trending faults flanking the basins (fig. 10) is right lateral, according to Bell and others (1977). Other and younger minor faults (D, fig. 10) strike northwest across the trend of the rocks and dip at high angles. In the Cape Ann and Ipswich area, Dennen (1975) showed the northeast-trending faults as having right-lateral transport and also a vertical component, up on the northwest. Dips are not indicated but are presumably steep to the northwest.

\section{AGE OF THE BLOODY BLUFF FAULT ZONE}

The metamorphic mineral assemblages and textures of the ductilely deformed rocks within the Bloody Bluff zone indicate that they were formed initially at pressures and temperatures prevailing at medium metamorphic grade. According to Nelson (1976), movement may have commenced during or after the regional metamorphism of the metasedimentary and metavolcanic rocks. This metamorphism probably occurred before intrusion of the Proterozoic Z Dedham Granite. Retrogressive mineral assemblages, cataclasis, and hydrothermal alteration indicate that deformation continued, or occurred later, within the fault zone at lower temperature and pressure. The Ordovician Andover Granite in the adjacent $\mathrm{Na}$ shoba block is mylonitized (Nelson, 1976, p. 1383). An upper age limit on at least some of the movement is provided by Castle and others (1976), who, as mentioned above, observed that the Early Devonian Peabody Granite intrudes and is not deformed by the Burlington mylonite zone. Nelson (1976, p. 1382) mapped undeformed pegmatite cutting cataclastic rock of the Bloody Bluff zone, but its age is unknown. The contrast in deformation between the Newbury Volcanic Complex and the adjacent Topsfield Granodiorite suggests a postProterozoic, pre-Late Silurian movement on the Bloody Bluff in that area. However, a growing weight of evidence indicates that extensive crustal movements occurred in the late Paleozoic during the Alleghanian orogeny in eastern New England (Rast and Skehan, 1983; Gromet and O'Hara, 1984; Hermes and Zartman, written commun., 1984; Murray and Mosher, 1984). From this evidence, some of the deformation along the Bloody Bluff fault zone might have occurred in the late Paleozoic. Because the fault that bounds the Triassic Middleton basin on its south side cuts the mylonitic rocks, one can conclude that Mesozoic movement has occurred in other places also along the Bloody Bluff zone. Therefore, I conclude that the Bloody Bluff fault zone had a long history starting with postmetamorphic pervasive ductile deformation, before the Late Silurian and Early Devonian, and concluding with shallow, brittle deformation probably ending in the Mesozoic.

\section{TECTONIC EVENTS IN EASTERN MASSACHUSETTS}

Eastern Massachusetts consists of all or parts of three lithotectonic zones or belts distinguished by differences in stratigraphy and in metamorphic, plutonic, and deformational history (Goldsmith, this vol., chaps. E, F; Robinson and Goldsmith, this vol., chap. G; Wones and Goldsmith, this vol., chap. I). These three are the Milford-Dedham zone, the Nashoba zone east of the Merrimack belt, and the east flank of the Merrimack belt. The Newbury basins, described as part of the Milford-Dedham zone (Goldsmith, this vol., chap. E), are not readily assignable to either of the adjacent zones and are treated as a separate terrane for purpose of discussion in the following section. The present positions of the zones are largely determined by post-Pennsylvanian tectonic events. Before that time the terranes had differing geologic histories (table 3, fig. 15). The sources of these terranes and their times of mutual accretion are only partly understood. Questions and uncertainties about the tectonic events summarized in table 3 and figure 15 are discussed below, as are speculations on the history of accretion of the terranes.

\section{MILFORD-DEDHAM ZONE}

The Milford-Dedham zone is fragmented by faults into blocks of exposed basement and blocks containing Proterozoic $\mathrm{Z}$ to Mesozoic cover rocks. This fragmentation took place primarily in the Permian and TriassicJurassic, but earlier events probably predetermined loci of later deformation. Earlier events include the forma- 


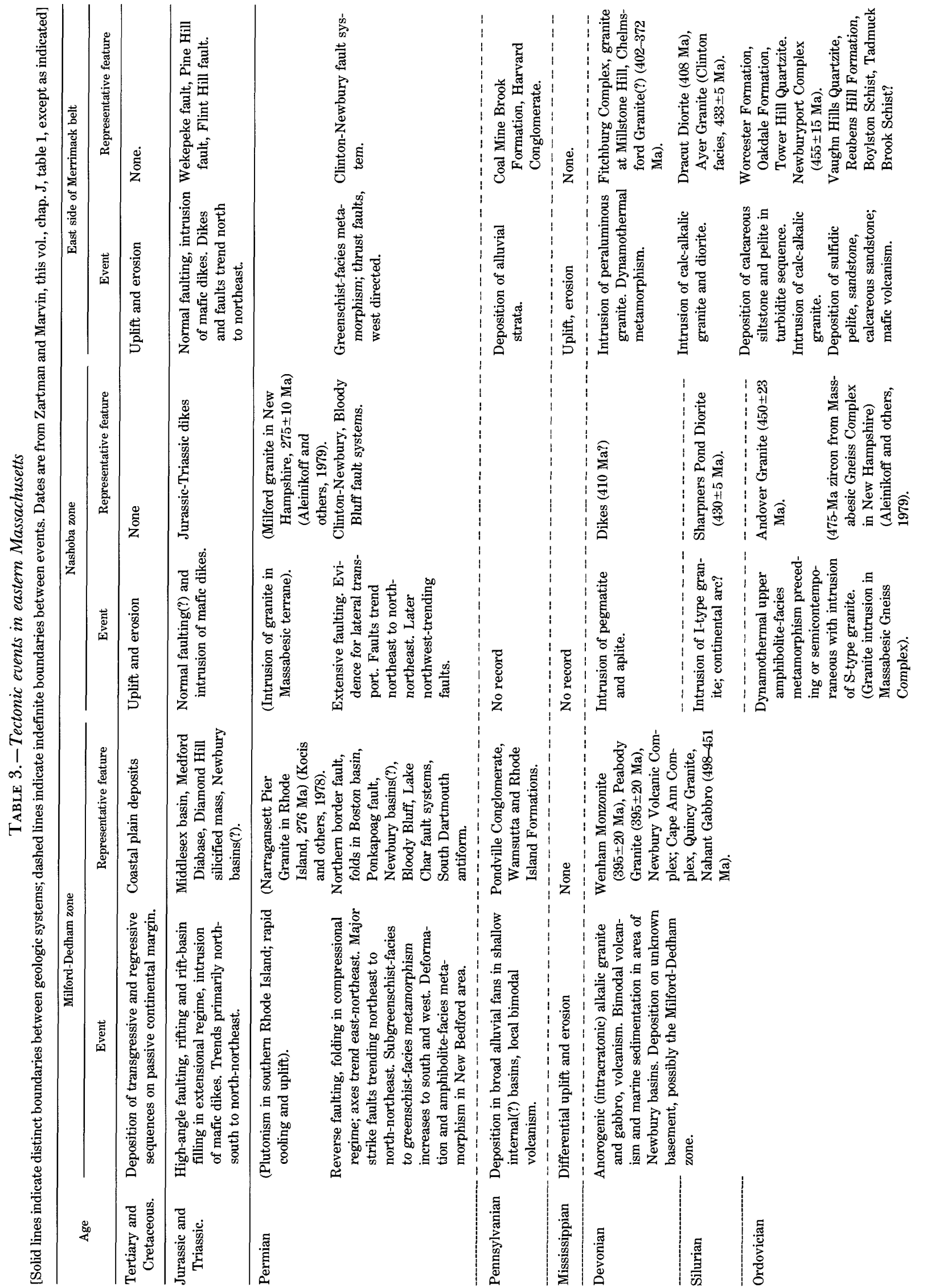




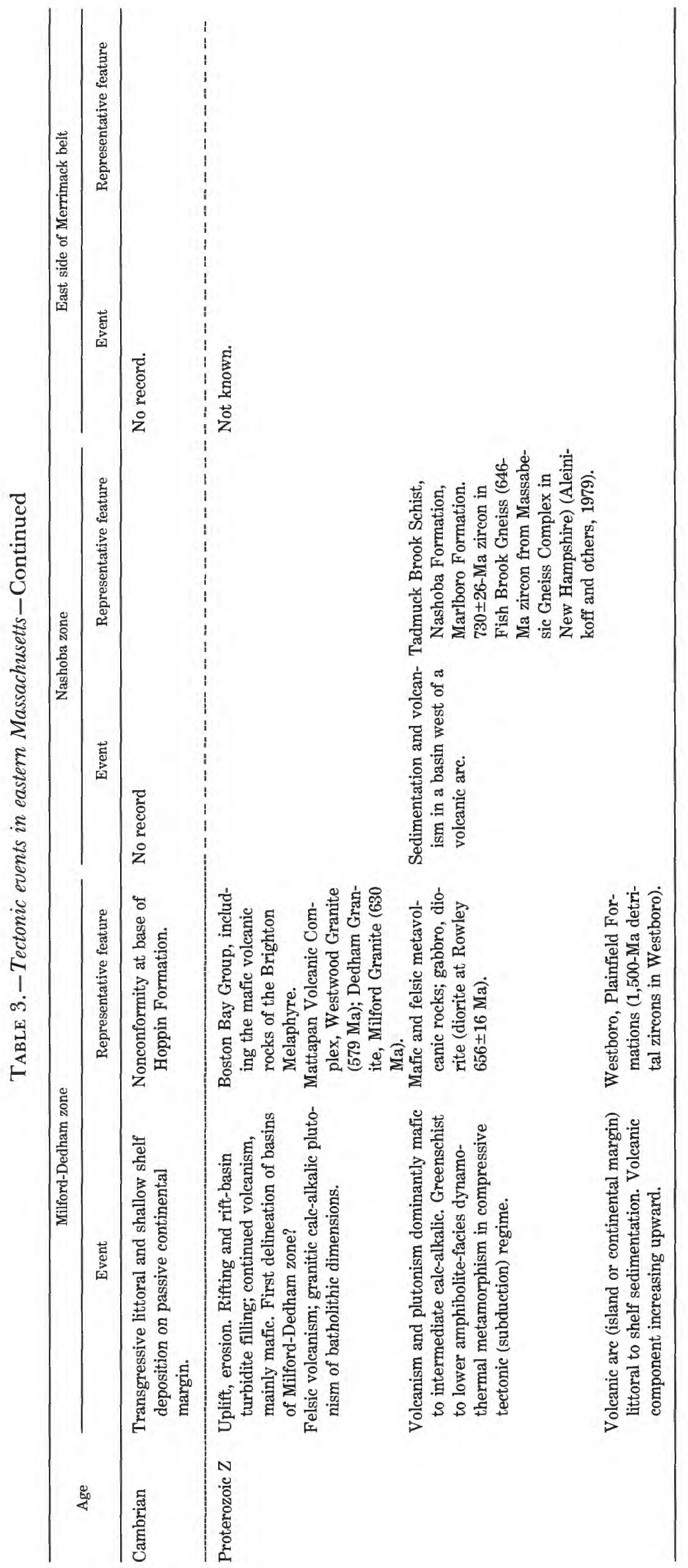




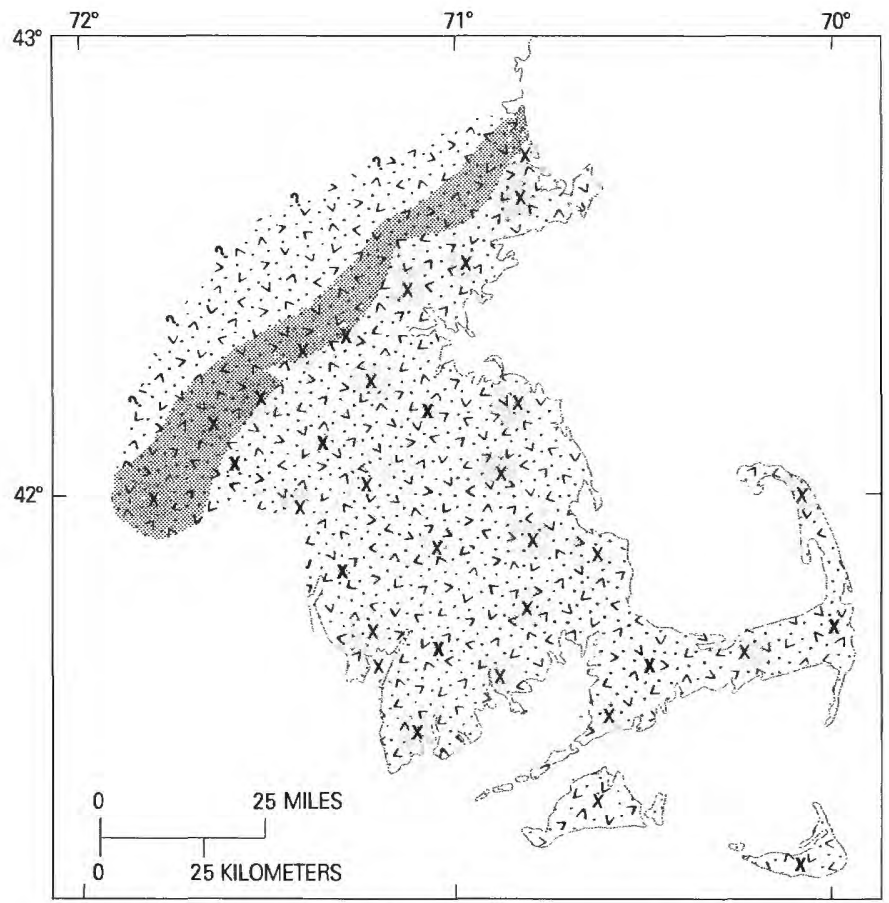

A. Proterozoic Z, older than $610 \mathrm{Ma}$

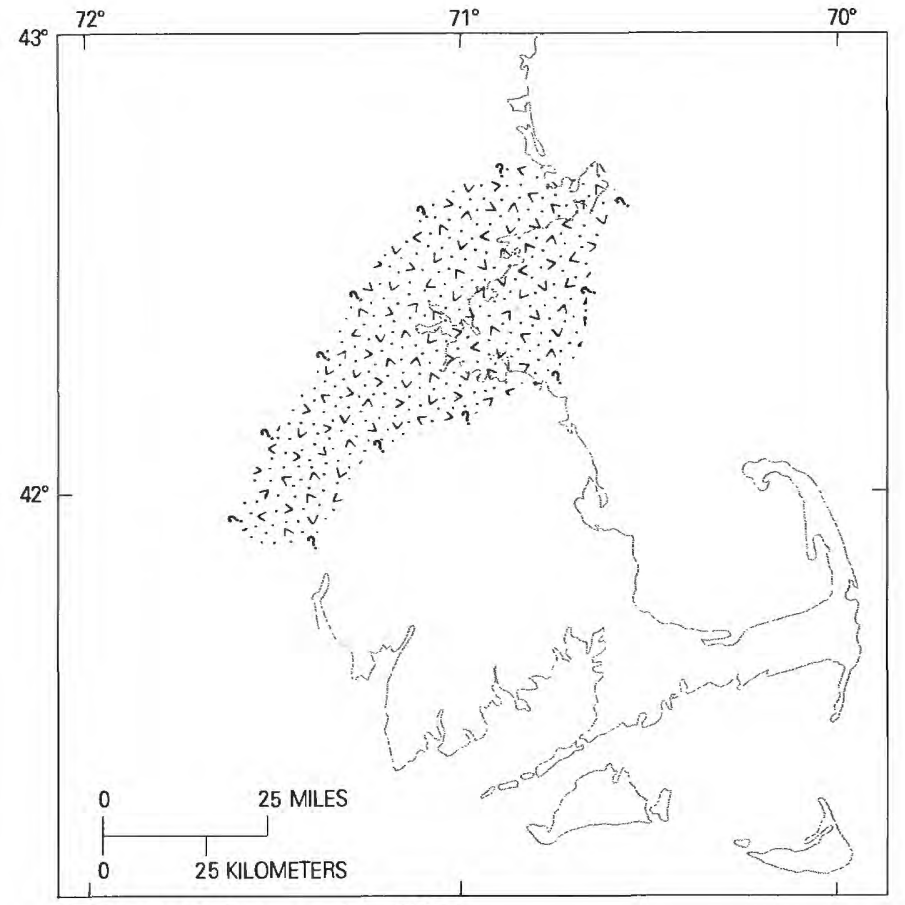

B. Proterozoic $Z$, younger than $610 \mathrm{Ma}$

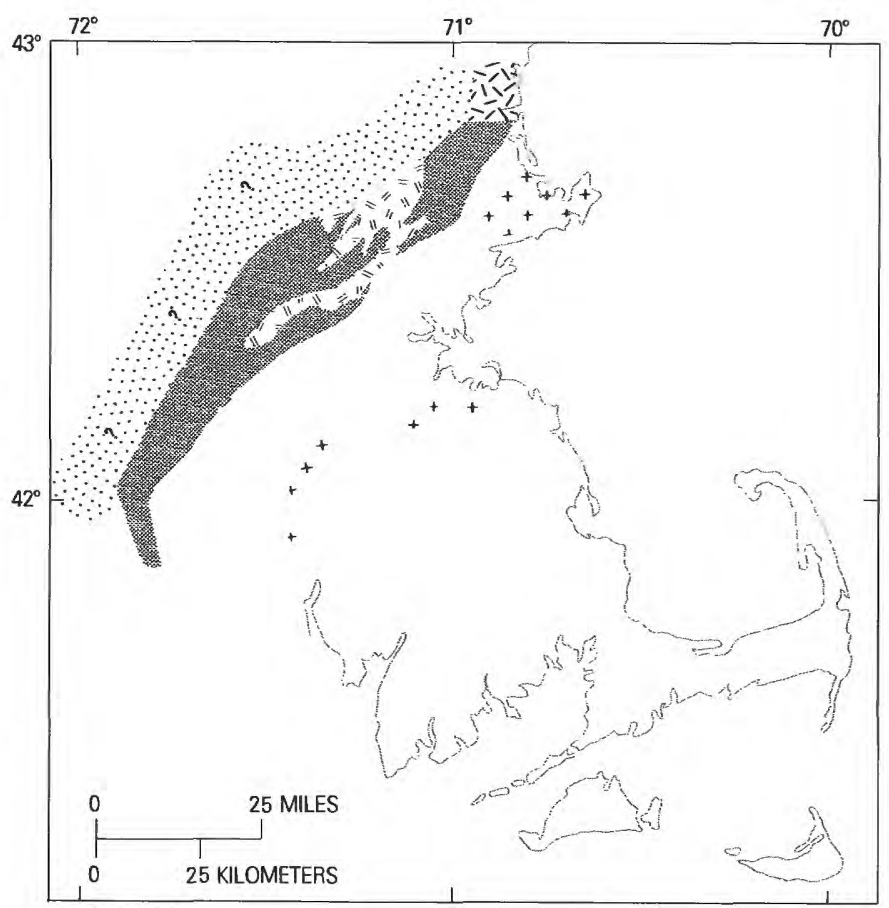

C. Ordovician

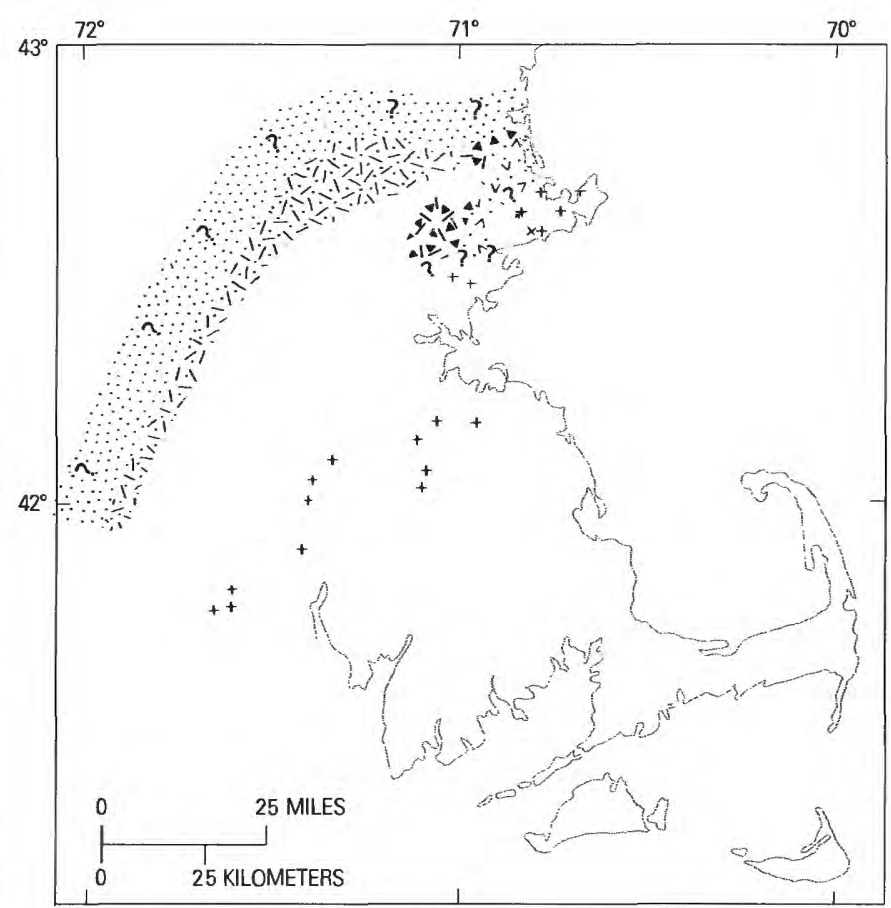

D. Silurian and Devonian

FIGURE 15. - Tectonic events in eastern Massachusetts corresponding approximately to intervals of time indicated on table 3. Nashoba and Milford-Dedham zones are exotic terranes accreted to the North American craton during the Paleozoic. Base is present-day arrangement of lithotectonic units. Explanation for figure 15 follows on p. H52. 


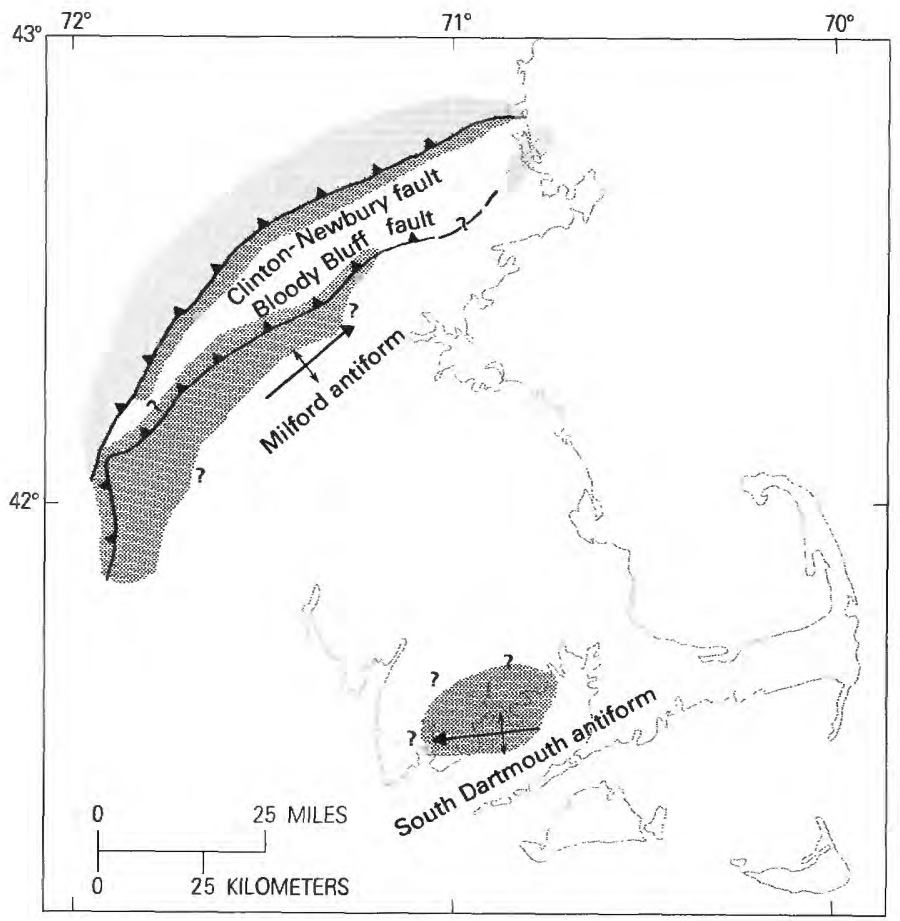

E. Late Devonian and Mississippian

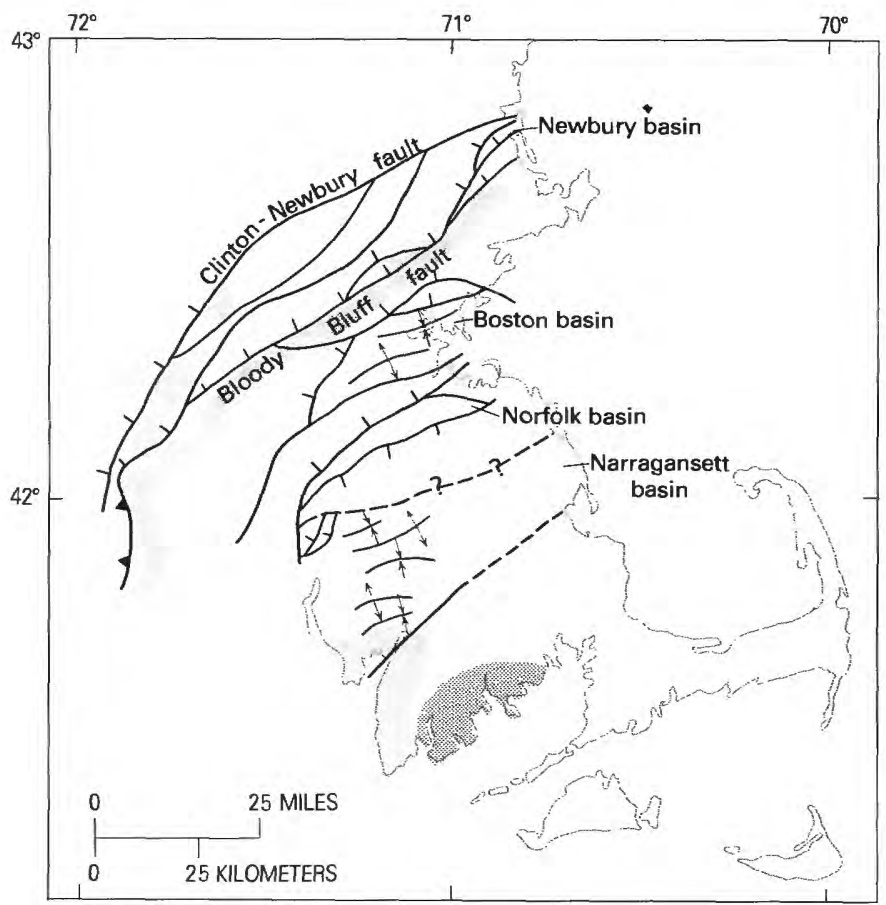

G. Permian

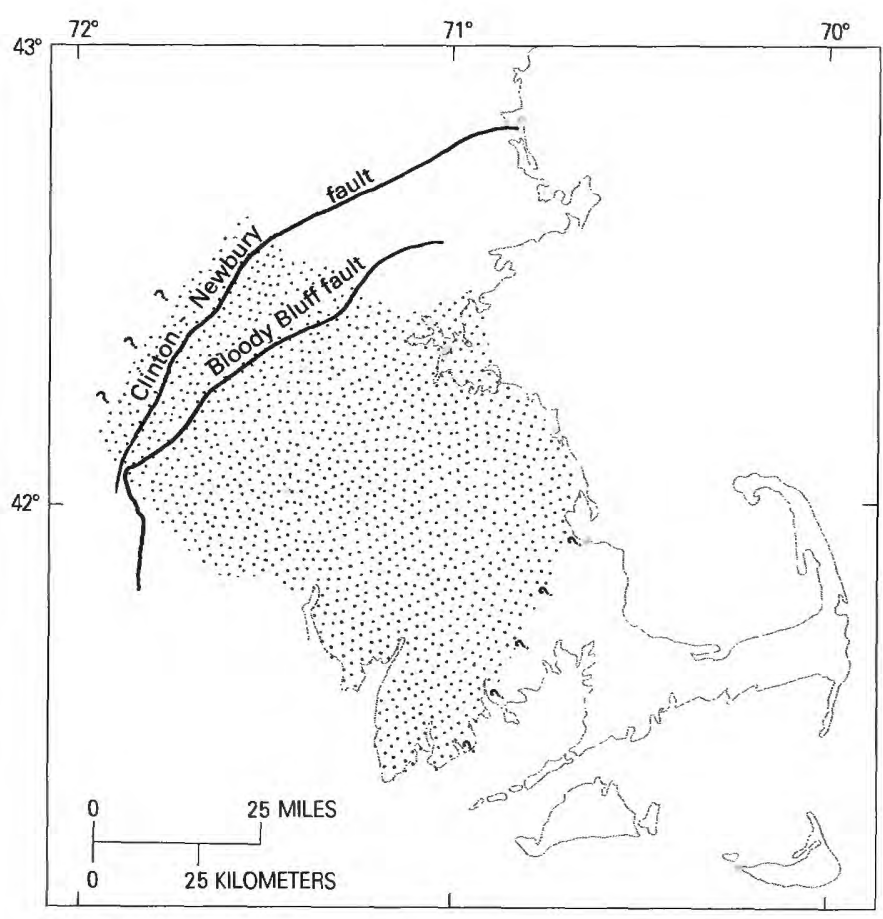

F. Pennsylvanian

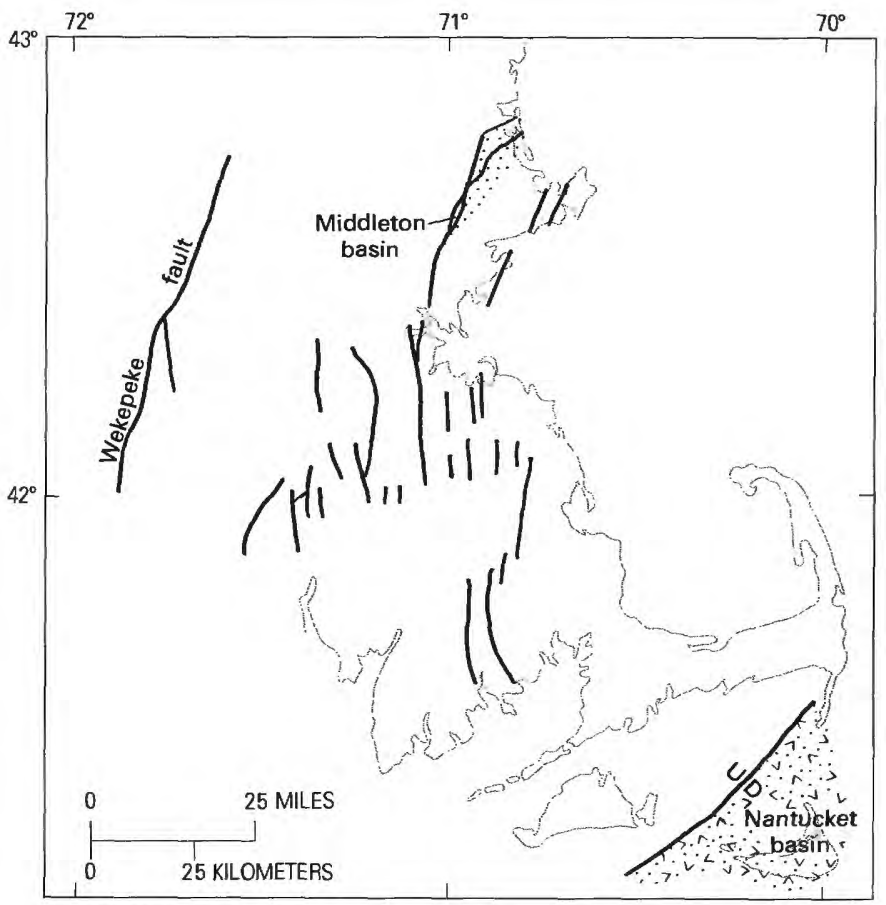

$H$ Triassic and Jurassic

FIGURE 15.-Continued. 


\section{EXPLANATION}

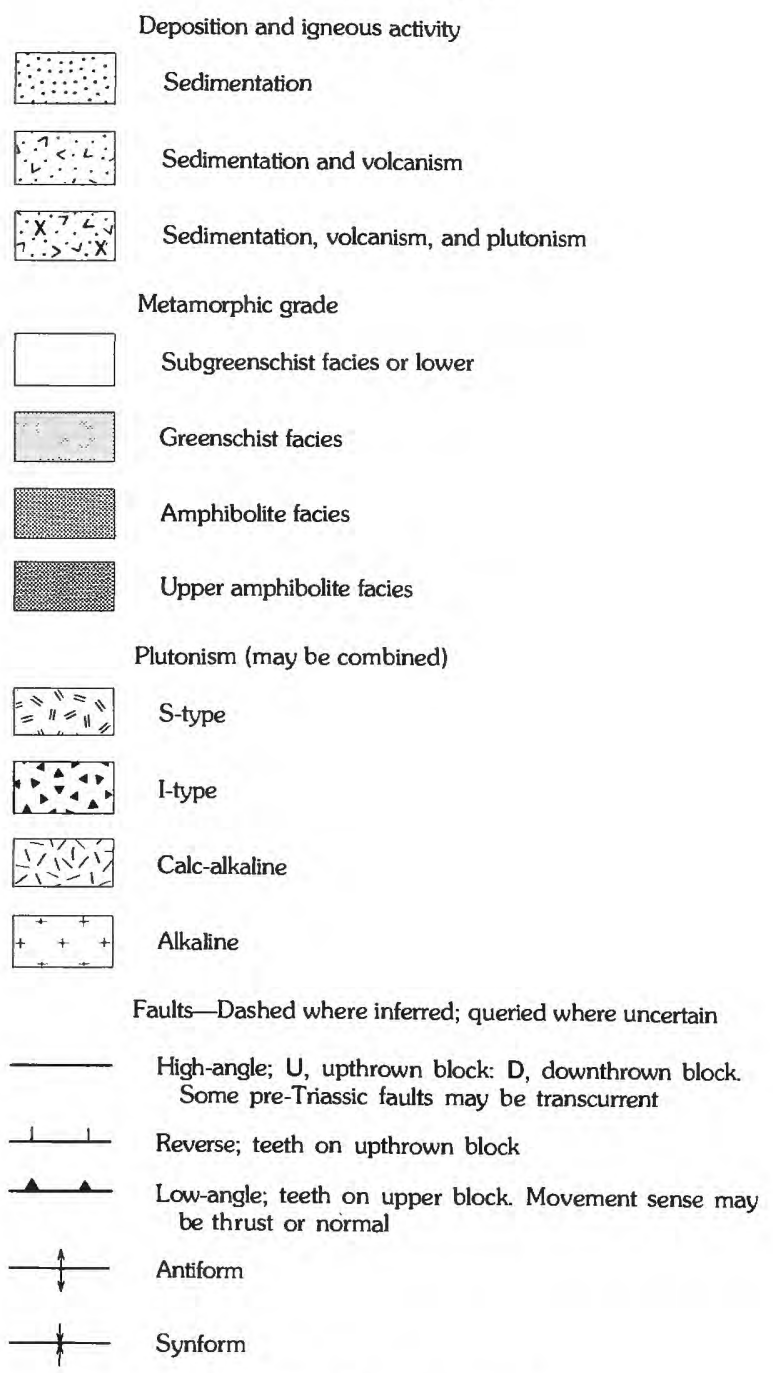

FIGURE 15.-Continued.

tion of a Proterozoic Z magmatic arc, probably on a continental margin, eventual rifting of this margin, and a poorly documented post-Devonian, pre-Pennsylvanian orogenic (collisional?) event, which led in the Pennsylvanian to uplift, erosion, and subaerial sedimentation from an eastern source no longer present. Compressive deformation and dynamothermal metamorphism probably related to subduction, recorded in the stratified rocks of the Proterozoic basement, appear not to have occurred again until the Late Pennsylvanian and Permian. In the interim, through much of the Paleozoic, a static, essentially extensional, intracratonic plutonic-volcanic regime prevailed.

The actual timing of the Proterozoic metamorphism and the subsequent events that led to development of the present map pattern are not entirely clear. The stratified rocks were metamorphosed before intrusion of the batholiths, but how much earlier is not certain. Because the metamorphosed mafic and felsic volcanic rocks (Zv) are considered to be precursors to, or penecontemporaneous with, the mafic plutonic rocks (Zgb, Zdi, Zdigb), the time of metamorphism could lie between the times of their emplacement, as indicated by the 656-Ma date on the diorite at Rowley, and the emplacement of the Dedham Granite at $630 \mathrm{Ma}$ (table 3). However, it is possible that the Westboro Formation and its equivalents and the overlying mafic volcanic rocks (Zv) were metamorphosed earlier, before emplacement of the mafic plutonic rocks. The dated diorite at Rowley is little deformed and may represent a fairly young phase of the mafic plutonism.

The metamorphic rocks are at greenschist facies throughout much of the zone. They are, however, in the amphibolite facies along the west side of the Rhode Island anticlinorium and the Milford antiform and in the New Bedford area. In these areas, the Proterozoic Z plutonic rocks have also been deformed in the amphibolite facies (O'Hara and Gromet, 1984). Therefore, the time of amphibolite-facies metamorphism on the west and southeast sides of the Milford-Dedham zone is open to question. I have shown this metamorphism on the State bedrock map as Proterozoic in age. However, other possibilities are that the greenschist-facies Proterozoic metamorphism has been overprinted by an amphibolite facies at the time of metamorphism of the Nashoba zone, at the time of the widespread Permian dynamothermal event of southern New England, or in the Late Devonian. The first seems rather unlikely because the steep metamorphic gradient between the two zones and their distinctly different Paleozoic plutonic signatures preclude the two zones being in juxtaposition before and during the early Paleozoic. The Permian event is more likely in view of the mounting evidence that an intense thermal metamorphism affected basement and cover alike in southern Rhode Island and southeastern Connecticut (see, for example, Skehan and Murray, 1980a,b). This event extended northward into central Rhode Island where Day and others (1980) implied fairly shallow northerly dipping isotherms. However, there is no record of a Permian amphibolite-facies metamorphism affecting the Nashoba zone. The somewhat higher grade of metamorphism on the west and southeast flanks of the Milford-Dedham zone as opposed to the generally lower grade of metamorphism in the center could be interpreted primarily as resulting from greater uplift along the western and southeastern parts of the zone during the Permian, which exposed deeper levels of the crust, in similar fashion to the greater uplift inferred along coastal Rhode Island and Connecticut (Lundgren and Ebblin, 1972). There is a good possibility, though, that the deformation that transformed the Proterozoic plutonic rocks into orthogneisses may have begun earlier than the Permian. Castle and others (1976) noted that the Early 
Devonian Peabody Granite intrudes but is not deformed by the Burlington mylonite zone. Nelson's (1976) observation that pegmatite cuts the mylonite in the Bloody Bluff fault zone suggests a pre-Devonian age for the mylonite. To the south along the zone boundary, Pignolet and others (1980) have dated cataclasis in the Honey Hill fault zone (fig. 3) and deformation in the Silurian and Devonian Canterbury Gneiss of the upper plate as Devonian, although O'Hara and Gromet (1983) questioned their interpretation of the data. Losh and Bradbury (1984) recognized both pre-424-Ma and Acadian movements in the Honey Hill fault zone. The Proterozoic rock units in southeastern Connecticut are multiply deformed, producing an interference pattern (Goldsmith, 1985). This deformation involves a Carboniferous alkalic granitoid (R.E. Zartman, oral commun., 1981) formerly assigned to the New London Gneiss (the Joshua Rock Member). It seems likely that a post-mid-Devonian metamorphism, probably Carboniferous, ranging from amphibolite to greenschist facies has been superimposed on the earlier Proterozoic greenschist- or possibly lower amphibolite-facies metamorphism. Although the age of earlier movements is not well documented, all agree that latest major movements on the Lake Char and Honey Hill faults in this region are at greenschist facies and are of Permian age. Because the same age and kind of rocks having similar styles of metamorphism and cataclasis exist along the Milford-Dedham zone boundary at the north end of the Rhode Island anticlinorium as in southeastern Connecticut, I feel somewhat confident in using the conclusions reached in southeastern Connecticut to support the conclusions reached from observations made on the boundary of the Milford-Dedham zone in Massachusetts.

\section{NASHOBA ZONE}

The Nashoba zone is a relatively homogeneous terrane containing high-grade metamorphic rocks derived from volcanic and sedimentary rocks of Proterozoic $\mathrm{Z}$ or early Paleozoic age (table 3; showil as Proterozoic on fig. 15A). Compositional layering, metamorphic foliation, and unit contacts dip steeply throughout the zone. The metamorphic rocks are intruded by foliated peraluminous granite of Ordovician age and nonfoliated diorite, granodiorite, and granite of Silurian and perhaps also Devonian age. The zone is cut by numerous faults of late Paleozoic and probably Mesozoic age. The timing of the high-grade dynamothermal metamorphism in the Nashoba zone (table 3) is not clearly defined. The parallelism of the foliation in the Ordovician Andover Granite to the metamorphic foliation in the host Nashoba and Marlboro Formations indicates that intrusion of the Andover was paracontemporaneous with the regional metamorphism. Accordingly the metamorphism is shown as Ordovician on figure $15 C$. However, there could also have been an earlier metamorphism of Proterozoic $\mathrm{Z}$ age. As mentioned above, the relatively steep metamorphic gradient between the Nashoba zone and the Milford-Dedham zone indicates that the two zones were not juxtaposed at the time of high-grade metamorphism in the Nashoba zone. The fact that the Nashoba contains a suite of Paleozoic plutonic rocks distinct from those in the Milford-Dedham zone (Wones and Goldsmith, this vol., chap. I) indicates that the two were not juxtaposed through the Silurian and perhaps the Devonian. The Silurian intrusive rocks of the zone (fig. $15 D$ ) are of a type associated with continental volcanic ares (Wones and Goldsmith, this vol., chap. I). Some aplite and pegmatite in the Andover Granite are younger than the bulk of the Andover Granite (Wones and Goldsmith, this vol., chap. I) and are possibly of Silurian and (or) Devonian age. Evidence for Alleghanian metamorphism and plutonism is lacking in the Nashoba zone. Retrogressive assemblages have not been developed to any great extent (see Abu-Moustafa and Skehan, 1976) except for an episode of hydration, which is probably associated with Andover plutonism. There is, however, a considerable amount of late Paleozoic faulting. Within the Nashoba zone, the older dynamothermal metamorphic fabric has been cut in more or less imbricate fashion by later shearing and faulting that strikes subparallel to the bounding faults (Skehan, 1967, 1968) so that the whole block could be considered a zone of shear, the Nashoba thrust belt of Barosh (1982), between the Bloody Bluff fault zone and the ClintonNewbury fault zone. However, we can only speculate as to whether the movement sense was dominantly lateral or dominantly inclined. The Clinton-Newbury fault zone itself contains both moderately dipping and steeply dipping fault surfaces, which seem to be of different ages and textural fabrics and which have not been sorted out satisfactorily. The Bloody Bluff fault zone likewise contains differently dipping fault surfaces and both ductile and brittle fabrics. Most of the faults within and on the flanks of the Nashoba zone appear to be fairly steep, judging from surface observations and the data of Castle and others (1976). The movements could be largely translational; however, the regional relations require that the faults flatten with depth (cross sections $D-D^{\prime}$ and $F-F^{\prime}$ of the State bedrock map) and that earlier movements were thrusts. Any strike-slip or normal movement is probably late.

\section{NEWBURY BASINS}

The Newbury basins are fault bounded, so that their relationship to the adjacent Nashoba and MilfordDedham zones is uncertain. We do not see the basement for the Newbury Volcanic Complex. The rocks of the 
Newbury Volcanic Complex are at a much lower metamorphic grade than the rocks of the adjacent Nashoba zone and are much less deformed and altered than the adjacent Proterozoic rocks of the Milford-Dedham zone. The Newbury basins are apparently wedges of higher level material emplaced between the two larger bounding blocks. Presumably the Newbury lies unconformably on one or the other of them, most likely on the MilfordDedham Proterozoic Z basement, as seems to be indicated by correlation with similar units in the Coastal Volcanic belt of eastern Maine. The Newbury Volcanic Complex is correlated on the basis of similar AcadoBaltic faunal assemblages with the Leighton Formation of the Pembroke Group in the Eastport area, Maine; the Leighton, however, contains no volcanic rocks (Shride, 1976b). Volcanic rocks of similar age are present in the Milford-Dedham zone in the East Greenwich Group of central Rhode Island (Quinn, 1971; Hermes and others, 1981). These rocks are alkalic, like the lower and middle Paleozoic plutonic rocks of the Milford-Dedham zone and like those in the Gulf of Maine (Hermes and others, 1978). The Newbury Volcanic Complex is also comparable to the Silurian and Devonian Castine Volcanics of the Penobscot Bay area, Maine, described and dated by Brookins and others (1973). The Castine consists of bimodal volcanic rocks and sedimentary rocks that rest unconformably on metamorphosed Ellsworth Schist (Stewart and Wones, 1974). The Castine, like the Newbury, lies in an area of appreciable faulting that has produced many blocks containing different sequences of rock. The Castine is intruded by the mildly alkalic Bays-of-Maine Igneous Complex of Chapman (1962) of roughly comparable age. If the Castine and Newbury are equivalents, then the Newbury could be related to the alkalic and peralkalic rocks of the plutons of the MilfordDedham zone by correlating Chapman's Bays-of-Maine with the alkalic rocks from the Gulf of Maine. It would be helpful in placing the Newbury in context if one could correlate the lower Paleozoic Ellsworth Schist on which the Castine rests with a rock unit in eastern Massachusetts. This correlation has not been made to date. The Silurian plutonic rocks of the Nashoba zone are unique to New England (Wones and Goldsmith, this vol., chap. I) and are probably not genetically related to the Newbury; comparisons of trace elements may help prove or disprove this relationship. The Newbury Volcanic Complex most likely belongs to the Milford-Dedham zone rather than the Nashoba zone but may be the remnant of an entirely separate terrane. The present position of the Newbury basins and the Newbury Volcanic Complex can only be attributed to post-Early Devonian faulting. There has, of course, also been post-Triassic faulting in this area (Kaye, 1983).

\section{EAST FLANK OF THE MERRIMACK BELT}

The east flank of the Merrimack belt, consisting of the Nashua trough and the Rockingham anticlinorium (Robinson and Goldsmith, this vol., chap. G), has a somewhat uncertain history primarily because the age of the stratified rocks is uncertain. However, the arguments presented below indicate that the rocks of the Nashoba zone underlie, at least in part, those of the Merrimack belt and in fact may be the basement upon which the Merrimackbelt rocks were deposited. The Nashoba zone projects beneath the Merrimack belt west of the ClintonNewbury zone as indicated by the "cross-sectional" map view of the Merrimack synclinorium exposed in southeastern Connecticut (fig. 3; see Rodgers, 1970). There the Tatnic Hill and Quinebaug Formations, which are the equivalents of the Nashoba and Marlboro Formations in the Putnam terrane, extend westward beneath the turbidite section of the Merrimack belt and above the Proterozoic Z basement. The Science Park block of the Nashoba zone (figs. 2, 4) must have been thrust up from beneath the Merrimack-belt rocks to the west. Whether the Putnam terrane extends to the Bronson Hill anticlinorium is a matter of controversy (Rodgers, 1981; Pease, 1982; Robinson and Tucker, 1982; London, 1984). In eastern Connecticut, the rocks of the Putnam terrane pinch out westward between the Honey Hill fault and the probable extension of the Clinton-Newbury fault. A terrane similar to the Nashoba, containing the Massabesic Gneiss Complex, forms a structural high within the Merrimack synclinorium. To the north in Maine, a terrane similar to the Nashoba, the Passagassawakeag, containing the Casco Bay Group, is shown on the latest bedrock geologic map of Maine (Osberg and others, 1984) as resting upon, rather than underlying, the turbidite sequence of the Kearsarge-central Maine synclinorium, a division of the Merrimack synclinorium. However, a preliminary seismic profile across this terrane (Stewart and others, 1986) suggests that the Passagassawakeag terrane structurally underlies the turbidite sequence.

The rock units of the Merrimack belt exposed in the Clinton-Newbury fault zone near the contact with the Nashoba zone are quartzites and conglomerates and are probably basal to the sequence in the Merrimack belt. A strong possibility exists that the Vaughn Hills Quartzite, the Reubens Hill Formation, the Kittery Formation, and possibly the Tower Hill Quartzite are Ordovician (or older) in age and lie unconformably on the Ordovician or Proterozoic Z Nashoba Formation (Robinson and Goldsmith, this vol., chap. G). The Clinton-Newbury fault zone thus appears to coincide with a hinge line because littoral facies of the Merrimack sequence appear within the zone. The Merrimack belt and the Nashoba zone have been parts of a single terrane from at least early Paleo- 
zoic time if the apparent unconformity is correctly interpreted. However, subsequent deformation and metamorphism have clearly affected both terranes. Arguing against an early docking of the Nashoba zone and the east flank of the Merrimack belt is the steep metamorphic gradient between them (Thompson and Norton, 1968) and the apparent difference in type of early and middle Paleozoic plutonism (Wones and Goldsmith, this vol., chap. I), which suggests that the two terranes were not together until after the Devonian. The metamorphic and structural style of the Nashoba zone differs from that of the Merrimack belt. This difference is in part because the Nashoba zone appears to have undergone an earlier period of early Paleozoic or older metamorphism. Staurolite and andalusite porphyroblasts in the Merrimackbelt rocks and in the Tadmuck Brook Schist of the Nashoba zone were formed in a primarily static thermal environment, either at the time of intrusion of the Silurian and Devonian granites of the Merrimack belt or during the Permian. However, some of the Ayer Granite and rocks of the Fitchburg Complex, as well as the Canterbury Gneiss of Connecticut, have a fabric suggesting that they were emplaced during a period of dynamothermal metamorphism that is the Late Devonian metamorphism indicated on the State bedrock map. This event (fig. 15E) probably culminated in the orogenic events that preceded and accompanied the deposition of the Pennsylvanian strata. The Middle Pennsylvanian Coal Mine Brook Formation at Worcester is metamorphosed to garnet grade, so clearly a post-Pennsylvanian metamorphism affected the rocks of the eastern flank of the belt also (fig. 15G). Successive metamorphic overprints may have smoothed out the steep gradient between the high-grade Nashoba zone and the low-grade sequence in the east flank of the Merrimack belt. PostPennsylvanian faulting (fig. $15 G, H$ ), however, has upset the preexisting pattern of isograds, bringing together rocks earlier metamorphosed at different levels.

\section{ZONE BOUNDARIES}

The two major zones, the Milford-Dedham and the Nashoba, were separate at least through the end of the Devonian and did not reach their present relative positions until after the Permian events. The earliest possible time for docking of the Milford-Dedham zone to the Nashoba zone would be after intrusion of the unique Silurian granites and diorites. The first bridge is the probably synchronous deposition of the Middle Pennsylvanian Coal Mine Brook Formation in the Merrimack belt to the west and the stratigraphically equivalent Rhode Island Formation in the Milford-Dedham zone to the east (fig. $15 F$ ). Subsequent late Paleozoic and early
Mesozoic faulting and erosion have disrupted the Pennsylvanian depositional blanket (fig. 15G,H).

The major zones of dislocation have been active over an appreciable period of time and under different regional stress systems. Castle and others (1976) and Nelson (1976) indicated evidence for at least preDevonian deformation along the Bloody Bluff fault zone, and there is clear evidence for Permian movement from both field and isotopic work (O'Hara and Gromet, 1983). In addition, Mesozoic faulting is present in the Bloody Bluff fault zone in the Middleton area and apparently also in the Worcester-Clinton area on the east flank of the Merrimack belt. In places, low-angle thrusting and later high-angle faulting under ductile conditions have been succeeded by high-angle tensional normal faulting. We have then a reactivation of zones of crustal weakness over a period from possibly early Paleozoic to Mesozoic under differing conditions of regional stress.

In the Penobscot Bay region of Maine, terranes similar to those in eastern Massachusetts have been separated by faults, one of which is dated as pre-Middle Devonian because it was cut by a pluton of that age (Stewart and Wones, 1974). Other faults in this region are younger (Wones and Thompson, 1979). Farther north in New Brunswick and Newfoundland, the major faults range from early Carboniferous to post-Pennsylvanian (Zen, 1983, and references therein). In Massachusetts we lack the evidence of plutonic intrusion across faults to delimit the time of faulting.

The major fault zones of eastern Massachusetts have been interpreted as thrust and reverse faults (Harwood and Zietz, 1976; Barosh and others, 1977; Skehan and Murray, 1980a) and as possible parts of a strike-slip fault system of regional extent on the basis of paleomagnetic data (Irving, 1977; Kent and Opdyke, 1978, 1979, 1980; Brown, 1980). The descriptions of the fault zones indicate that the ductile zones tend to be earlier and flatter and that the brittle faults tend to be later and steeper, so that possibly both views are correct. The attitudes of the ductile fault surfaces vary from place to place, however, although the zones appear to be relatively linear. The Bloody Bluff fault has both steeply and shallowly dipping segments. The Lake Char fault is typically shallow dipping. Such variations are most likely due to subsequent folding. The Rattlesnake Hill fault of Skehan (1968), which seems to be the principal fault separating the Nashoba zone from the Merrimack belt (Castle and others, 1976; Gore, 1976b; Skehan and Murray, 1980b), is relatively steep and is younger than the flatter ductile mylonite zones like the thrusts in the Clinton-Wachusett Reservoir area or parts of the Bloody Bluff. Several proposals have been made for the direction of movement on the flatter faults. The Lake Char fault (fig. 3) of Connecticut has been proposed to be a thrust bringing 
the higher grade Putnam Group over the Proterozoic Z basement (Dixon and Lundgren, 1968; Wintsch, 1979) and a décollement or "normal" fault in which the Putnam Group has slid off the Proterozoic Z basement (Lundgren and Ebblin, 1972; Goldstein, 1982; Danforth and Owens, 1984). The décollement concept might be likened to the movement within the metamorphic core complexes of the Great Basin in the Western United States (Coney, 1980). By analogy, one would expect the ductile part of the Bloody Bluff fault to have a sense of movement similar to that of the Lake Char, although O'Hara and Gromet (1984) believed these to be two separate faults in northern Rhode Island. However, the normal fault movement conflicts with the southeast vergence of folds and thrusts seen in the Nashoba and Putnam terranes and in the New London anticlinorium (fig. 3) of southeastern Connecticut (Goldsmith, 1985). The normal sense of movement thus is probably only a late phenomenon.

The Permian pattern of deformation (fig. 15G) can probably be tied to a single stress field. It could be argued that the east-northeast pattern of compressive Permian deformation in the Milford-Dedham zone is the result of major northeast-trending right-lateral movement along the Bloody Bluff and Clinton-Newbury zones. Mosher (1983), Murray and Mosher (1984), and McMaster and others (1980) postulated large-scale rightlateral transcurrent movement in the Alleghanian to account for the structural configuration in the southern Narragansett basin. However, no clear evidence exists to prove significant strike-slip motion along the major faults of eastern Massachusetts, although the steep dips in places of some of the major fault surfaces are suggestive. The steep lineations in the Nashoba zone could be indicators of strike-slip movement, but they also could have been produced by intersection of later structural features of slightly different orientation on already steeply dipping rocks. Eberly (1984) commented on the paucity of faults showing strike-slip movement in a traverse across eastern Connecticut. Nevertheless, the paleomagnetic data of Kent and Opdyke (1978, 1979, 1980 ) and of others indicate considerable lateral displacement of terranes in New England in the Late Pennsylvanian to Permian, and a number of reconstructions have been made to accommodate the data (Van der Voo, 1983; Le Fort, 1983, for example). On the other hand, recent articles such as that of Irving and Strong (1985) suggest caution in reconstructing plate positions from paleomagnetic data.

\section{ACCRETION}

The Nashoba and Milford-Dedham zones are exotic terranes that have been accreted to the North American craton during the Paleozoic. It is generally agreed that the Taconian suture marking the closing of the Iapetus Ocean and accretion of an island arc lies west of the Merrimack synclinorium (Stanley and Hatch, 1988) and that further collisional events occurred in Acadian time. The nature and time of amalgamation of the terranes east of the Taconian suture are less certain. Accreted terranes in the Appalachian region, with specific reference to eastern Massachusetts, have been discussed recently by Williams and Hatcher (1983) and Zen (1983). From the evidence presented in this chapter, and in chapter $\mathrm{E}$ (Goldsmith, this vol.), it is possible that Nashoba-type rocks were basement for the Merrimack strata by at least Ordovician time and that the Milford-Dedham zone, or at least the gneissic part of it, was joined to the Nashoba zone by Carboniferous time; this join thus may mark the site of an Acadian suture. Crustal adjustments in the Permian and later in the Mesozoic disrupted this amalgamation and produced the arrangement we see now. Gneissic rocks similar to those in the Milford antiform reappear in the Willimantic dome in eastern Connecticut and the Pelham dome in central Massachusetts. These gneissic rocks have apparently been involved in the Acadian orogeny that affected central Massachusetts, whereas there is little or no evidence of an Acadian orogeny in the eastern, nongneissic part of the Milford-Dedham zone. The gneissic terrane on the west may be considered to have underlain the Merrimack and Nashoba rocks at an early stage, certainly before the Pennsylvanian and apparently before th. Late Devonian. The eastern, nongneissic part , the MilfordDedham zone is most like the rocks of the Avalon Peninsula in Newfoundland. O'Hara and Gromet (1984) suggested from evidence in Rhode Island that the gneissic, western part of the Milford antiform is actually a separate block from that containing the Dedham and Esmond batholiths to the east, even though the two contain rocks of the same age. They suggested that the two parts were joined during the Alleghanian, whereas the gneissic rocks were deformed primarily earlier in the Acadian orogeny. This suggestion seems to resolve several problems in treatment of the Milford-Dedham zone as a single entity on the State bedrock map, particularly the discrepancy in metamorphic grade and style of deformation between the ductilely and brittlely deformed terranes and the uncertainty of the timing of the amphibolite-facies metamorphism in the gneissic terrane. It permits the gneissic terrane, or at least that part beneath the Merrimack synclinorium, to have been involved in Acadian or earlier deformation without requiring Acadian deformation in the rest of the MilfordDedham zone. However, if two terranes are present, the significance of the Clinton-Newbury fault is called into question. 
The two distinct boundaries in eastern Massachusetts on the surface are those between the Milford-Dedham and Nashoba zones and between the Nashoba zone and the Merrimack belt. The first boundary, the Bloody Bluff fault system in Massachusetts and the Lake Char and Honey Hill fault systems in Connecticut, may mark the site of a cryptic suture. Osberg (1978) suggested that the Paleozoic volcanic-plutonic assemblage (Newbury Volcanic Complex and alkalic plutons) of eastern Massachusetts and coastal Maine is part of an arc formed adjacent to a suture; this may be the cryptic Acadian suture of Le Fort (1983) between an African plate, in which he included eastern Massachusetts but not the Avalon Peninsula of Newfoundland, and an Avalon prong to the northwest. Le Fort's Silurian and Devonian volcanicplutonic arc represents an Andean- or Cordilleran-type margin developed on the African plate during the closing of the Theic Ocean on an east-dipping subduction zone. How the Nashoba zone fits into this scheme is not clear. I consider the Nashoba to be equivalent to part of the Gander zone of Newfoundland (Goldsmith, this vol., chap. F). There is no evidence of ocean-floor material in or near this suture zone unless one considers the serpentinite at Lynnfield or the Reubens Hill Formation on the east flank of the Merrimack belt as described by Peck (1975) to be such.

The Milford-Dedham zone of eastern Massachusetts has been suggested to be formerly part of a microcontinent lying between an African plate and the North American plate (Schenk, 1971; Skehan and others, 1978; Strong, 1979; Rast, 1980) and to have close affinity to rocks in northwest Africa (Hurley and others, 1974; Skehan and others, 1978; Olszewski, 1980; Simpson and others, 1980). The $730 \pm 26$ - Ma zircon age on the Fish Brook Gneiss and the 1,500-Ma age on detrital zircon from the Shawsheen Gneiss (Olszewski, 1980), both of the Nashoba zone, form a pattern that has a counterpart in northwest Africa. However, the original spatial relation of the Nashoba to the Milford-Dedham zone is unknown. The two may have been originally from different environments on the same plate, as suggested by Skehan and Murray (1980b, p. 313), equivalent to the northern apron of the Avalon platform of Rast (1980), or they may have been parts of two different plates. On the other hand, following the model of O'Hara and Gromet (1984), perhaps the gneissic terrane of the MilfordDedham zone has been attached to the Nashoba terrane longer than has the nongneissic terrane.

If the Nashoba and Milford-Dedham zones were joined together and accreted to North America before the Pennsylvanian, then the Permian deformation and metamorphism were produced not by collision of the MilfordDedham zone with the terranes to the west but by movement and rotation of these terranes along preexist- ing sites of juncture or other zones of weakness as a result of intraplate adjustments or impact of another plate or microplate that lay south or east of the already accreted terranes. This zone of Permian movement is the Variscan orogenic belt of Rast and Skehan (1984). The rotation in a clockwise direction of Africa (the MilfordDedham zone) against the Nashoba (and Putnam) zone to the west in the Permian proposed by Wintsch and Le Fort (1983) does not necessarily mean the closing of a suture but could reflect continued or renewed movement along a zone in which the suture had already formed. The Clinton-Newbury fault zone can easily be construed as an intraplate movement zone of this sort. The collision and slip hypothesis developed to explain the features in the southern Narragansett basin (McMaster and others, 1980; Mosher, 1983; Murray and Mosher, 1984) seems reasonable. Broad-wavelength magnetic anomalies (Zietz and others, 1980) and regional gravity patterns (Haworth and others, 1980) suggest an east-northeasttrending zone of discordance between crustal domains south of the New England coast, which may be a complementary part of the regional northeast strain pattern. Rast and Skehan (1984) using other arguments also speculated on a dislocation in Long Island Sound. Whether this is an interplate boundary or intraplate boundary is unknown.

Although the sequence of events in eastern Massachusetts is not entirely clear, it appears that the accretionary sequence is Nashoba-type basement beneath the Merrimack belt, Nashoba zone east of the Merrimack belt, and Milford-Dedham zone. The Nashoba-type rocks and the gneissic Milford-Dedham rocks appear to have been present beneath the Merrimack belt at the time of Acadian deformation and thus correspond perhaps to the craton X basement of Zen (1983). Most of the exposed Nashoba, east of the Merrimack belt, and the nongneissic Milford-Dedham rocks show no evidence of Acadian deformation, either because they were in place but far removed from the center of Acadian orogeny, as Zen suggested, or because they were moved into place later. The rotation and subgreenschist-facies metamorphism of the Newbury Volcanic Complex might be construed as Acadian, but there is no evidence for metamorphism of this age in the adjacent structural blocks, whereas there is for Alleghanian deformation. The sequence of events discussed above does fit in a general way the west-to-east, oldest-to-youngest accretionary model of Williams and Hatcher (1983).

The arrangement of terranes resembling the Nashoba and Milford-Dedham zones along the coast of New England and the Maritime Provinces of Canada indicates that they are now wedges or splinters of once more continuous terranes extending to Europe and Africa (see, for example, Rast and others, 1976). Reconstructing the 
whole requires careful consideration of the details of stratigraphy and structure in each area and careful correlation of these details between areas.

\section{REFERENCES CITED}

Abu-Moustafa, A.A., and Skehan, J.W., 1976, Petrography and geochemistry of the Nashoba Formation, east-central Massachusetts, in Lyons, P.C., and Brownlow, A.H. eds., Studies in New England geology: Geological Society of America Memoir 146, p. 31-70.

Aleinikoff, J.N., Zartman, R.E., and Lyons, J.B., 1979, U-Th-Pb geochronology of the Massabesic Gneiss and the granite near Milford, south-central New Hampshire-New evidence for Avalonian basement and Taconic and Alleghenian disturbances in eastern New England: Contributions to Mineralogy and Petrology, v. 71 , no. 1 , p. $1-11$.

Alvord, D.C., 1975, Preliminary bedrock geologic maps of the Westford and Billerica quadrangles, Middlesex County, Massachusetts: U.S. Geological Survey Open-File Report 75-387, 12 p., 2 pls., scale 1:24,000.

Alvord, D.C., Bell, K.G., Pease, M.H., Jr., and Barosh, P.J., 1976, The aeromagnetic expression of bedrock geology between the Clinton-Newbury and Bloody Bluff fault zones, northeastern Massachusetts: U.S. Geological Survey Journal of Research, v. 4, no. 5, p. 601-604.

Austin, J.A., Jr., Uchupi, Elazar, Shaughnessy, D.R., III, and Ballard, R.D., 1980, Geology of New England passive margin: American Association of Petroleum Geologists Bulletin, v. 64, no. 4, p. $501-526$.

Ballard, R.D., and Uchupi, Elazar, 1975, Triassic rift structures in the Gulf of Maine: American Association of Petroleum Geologists Bulletin, v. 59, p. 1041-1072.

Barosh, P.J., 1974, Preliminary bedrock geologic map of the Webster quadrangle, Massachusetts-Connecticut: U.S. Geological Survey Open-File Report 74-192, 2 p., 1 pl., scale 1:24,000.

-1976, Faults and related deformation in the ClintonNewbury-Bloody Bluff fault complex of eastern Massachusetts, in New England Intercollegiate Geological Conference, 68th Annual Meeting, Boston, Mass., Oct. 8-10, 1976, Geology of southeastern New England, a guidebook for field trips to the Boston area and vicinity: Princeton, N.J., Science Press, p. 301-314.

-1977, Preliminary map showing bedrock geology superposed on an aeromagnetic base map of the Worcester region, Massachusetts, Connecticut, and Rhode Island: U.S. Geological Survey Open-File Report 77-131, 46 p., 2 pls., scale 1:125,000.

-1978, Reconnaissance bedrock geologic map of the Marlborough quadrangle, Massachusetts: U.S. Geological Survey Open-File Report 78-221, 17 p., 1 pl., scale 1:24,000.

1982, Structural relations at the junction of the Merrimack province, Nashoba thrust-belt and the southeast New England platform in the Webster-Oxford area, Massachusetts, Connecticut, and Rhode Island, in New England Intercollegiate Geological Conference, 74th Annual Meeting, Storrs, Conn., Oct. 2-3, 1982, Guidebook for fieldtrips in Connecticut and south-central Massachusetts: Connecticut Geological and Natural History Survey Guidebook 5, p. 395-416.

Barosh, P.J., Fahey, R.J., and Pease, M.H., Jr., 1977, Preliminary compilation of the bedrock geology of the land area of the Boston $2^{\circ}$ sheet, Massachusetts, Connecticut, Rhode Island, and New Hampshire: U.S. Geological Survey Open-File Report 77-285, 142 p., 1 pl., scale 1:125,000.
Barosh, P.J., and Hermes, O.D., 1981, General structural setting of Rhode Island and tectonic history of southeastern New England, in New England Intercollegiate Geological Conference, 73d Annual Meeting, Kingston, R.I., Oct. 16-18, 1981, Guidebook to geological field studies in Rhode Island and adjacent areas: Kingston, R.I., University of Rhode Island, p. 1-16.

Barosh, P.J., Pease, M.H., Jr., Schnabel, R.W., Bell, K.G., and Peper, J.D., 1974, Geologic interpretation of the lineaments on the aeromagnetic map of southern New England: U.S. Geological Survey Miscellaneous Field Studies Map MF-885, scale 1:250,000.

Bell, K.G., 1968, Faults in eastern Massachusetts [abs.]: Geological Society of America Special Paper 115, p. 250.

-1976, Pre-Silurian stratified rocks southeast of the Bloody Bluff fault, in New England Intercollegiate Geological Conference, 68th Annual Meeting, Boston, Mass., Oct. 8-10, 1976, Geology of southeastern New England, a guidebook for field trips to the Boston area and vicinity: Princeton, N.J., Science Press, p. 289-290.

Bell, K.G., and Alvord, D.C., 1976, Pre-Silurian stratigraphy of northeastern Massachusetts, in Page, L.R., ed., Contributions to the stratigraphy of New England: Geological Society of America Memoir 148, p. 179-216.

Bell, K.G., Shride, A.F., and Cuppels, N.P., 1977, Preliminary bedrock geologic map of the Georgetown quadrangle, Essex County, Massachusetts: U.S. Geological Survey Open-File Report 77-179, 30 p., 4 pls., scale 1:24,000.

Billings, M.P., 1929, Structural geology of the eastern part of the Boston basin: American Journal of Science, v. 18, 5th ser., p. 93-137.

-1956, The geology of New Hampshire: Part 2, Bedrock geology: Concord, N.H., New Hampshire State Planning and Development Commission, $203 \mathrm{p}$.

-1976a, Bedrock geology of the Boston basin, in New England Intercollegiate Geological Conference, 68th Annual Meeting, Boston, Mass., Oct. 8-10, 1976, Geology of southeastern New England; a guidebook for field trips to the Boston area and vicinity: Princeton, N.J., Science Press, p. 28-45.

1976b, Geology of the Boston basin, in Lyons, P.C., and Brownlow, A.H., eds., Studies in New England geology: Geological Society of America Memoir 146, p. 5-30.

1979, Boston basin, Massachusetts, in Skehan, J.W., Murray, D.P., Hepburn, J.C., Billings, M.P., Lyons, P.C., and Doyle, R.G., The Mississippian and Pennsylvanian (Carboniferous) Systems in the United States-Massachusetts, Rhode Island, and Maine: U.S. Geological Survey Professional Paper 1110-A, p. A15-A20.

1982, Ordovician cauldron subsidence of the Blue Hills Complex, eastern Massachusetts: Geological Society of America Bulletin, v. 93, p. 909-920.

Billings, M.P., and Rahm, D.A., 1966, Geology of the Malden tunnel, Massachusetts: Journal of the Boston Society of Civil Engineers, v. 53 , p. $116-141$.

Brookins, D.G., Berdan, J.M., and Stewart, D.B., 1973, Isotopic and paleontological evidence for correlating three volcanic sequences in the Maine coastal volcanic belt: Geological Society of America Bulletin, v. 84, p. 1619-1628.

Brown, Laurie, 1980, Paleomagnetic results from northern Maine and the western limit of "Avalon" in the mid-Paleozoic [abs.]: Geological Society of America Abstracts with Programs, v. 12, no. 2, p. 26.

Burks, R.J., Mosher, Sharon, and Murray, D.P., 1981, Alleghenian deformation and metamorphism of southern Narragansett basin, in New England Intercollegiate Geological Conference, 73d Annual Meeting, Kingston, R.I., Oct. 16-18, 1981, Guidebook to 
geological field studies in Rhode Island and adjacent areas: Kingston, R.I., University of Rhode Island, p. 265-284.

Carrigan, J.A., 1984a, Ductile faulting in the Rye Formation southeastern New Hampshire [abs.]: Geological Society of America Abstracts with Programs, v. 16, no. 1, p. 7.

1984b, Metamorphism of the Rye Formation; a reevaluation [abs.]: Geological Society of America Abstracts with Programs, v. 16 , no. 1, p. 7.

Castle, R.O., 1964, Geology of the Andover Granite and surrounding rocks, Massachusetts: U.S. Geological Survey Open-File Report, $550 \mathrm{p}$.

-1965a, A proposed revision of the subalkaline intrusive series of northeastern Massachusetts: U.S. Geological Survey Professional Paper 525-C, p. C74-C80.

1965b, Gneissic rocks in the South Groveland quadrangle, Essex County, Massachusetts: U.S. Geological Survey Professional Paper 525-C, p. C81-C86.

Castle, R.O., Dixon, H.R., Grew, E.S., Griscom, Andrew, and Zietz, Isidore, 1976, Structural dislocations in eastern Massachusetts: U.S. Geological Survey Bulletin 1410, 39 p.

Cazier, E.C., 1984, Tectonic evolution of the Norfolk basin, Mass.; fluvial sedimentation and polyphase deformation [abs.]: Geological Society of America Abstracts with Programs, v. 16, no. 1, p. 8.

Chapman, C.A., 1962, Bays-of-Maine igneous complex: Geological Society of America Bulletin, v. 73, p. 883-888.

Chute, N.E., 1964, Trip G. Geology of the Norfolk basin Carboniferous sedimentary rocks, and the various igneous rocks of the Norwood and Blue Hills quadrangles (Massachusetts), in New England Intercollegiate Geological Conference, 56th Annual Meeting, Chestnut Hill, Mass., Oct. 2-4, 1964, Guidebook to field trips in the Boston area and vicinity: Chestnut Hill, Mass., Boston College, p. 91-114.

1965, Geologic map of the Duxbury quadrangle, Plymouth County, Massachusetts: U.S. Geological Survey Geologic Quadrangle Map GQ-466, scale 1:24,000.

1966, Geology of the Norwood quadrangle, Norfolk and Suffolk Counties, Massachusetts: U.S. Geological Survey Bulletin 1163-B, $78 \mathrm{p}$.

1969, Bedrock geologic map of the Blue Hills quadrangle, Norfolk, Suffolk, and Plymouth Counties, Massachusetts: U.S. Geological Survey Geologic Quadrangle Map GQ-796, scale $1: 24,000$.

Clapp, C.H., 1921, Geology of the igneous rocks of Essex County, Massachusetts: U.S. Geological Survey Bulletin 704, 132 p.

Coney, P.J., 1980, Cordilleran metamorphic core complexes: An overview: Geological Society of America Memoir 153, p. 7-31.

Coyle, Marylou, Skehan, J.W., and Rast, Nicholas, 1984, The deformation of the "older gneisses" of the Avalon platform in Rhode Island [abs.]: Geological Society of America Abstracts with Programs, v. 16, no. 1, p. 11.

Crosby, W.O., 1880, Contributions to the geology of eastern Massachusetts: Boston Society of Natural History Occasional Papers, no. $3,286 \mathrm{p}$.

1900, Geology of the Boston basin; the Blue Hills Complex: Boston Society of Natural History Occasional Papers, no. 4, v. 1, pt. 3, p. 289-563.

Cuppels, N.P., 1961, Post-Carboniferous deformation of metamorphic and igneous rocks near the Northern Boundary fault, Boston basin, Massachusetts: U.S. Geological Survey Professional Paper 424-D, p. D46-D48.

Danforth, William, and Owens, J.P., 1984, A characterization of the western margin of the Avalonian terrane of southeast New England [abs.]: Geological Society of America Abstracts with Programs, v. 16 , no. 1 , p. 11.
Day, H.W., Brown, V.M., and Abraham, Kurt, 1980, Precambrian(?) crystallization and Permian(?) metamorphism of hypersolvus granite in the Avalonian terrane of Rhode Island: Geological Society of America Bulletin, pt. II, v. 91, p. 1669-1741.

Dennen, W.H., 1975, Preliminary bedrock geologic map of the Ipswich quadrangle, Massachusetts: U.S. Geological Survey Open-File Report 75-544, 26 p., 2 pls., scale 1:24,000.

Dixon, H.R., 1965a, The Putnam Group of eastern Connecticut: U.S. Geological Survey Bulletin 1194-C, 12 p.

$-1965 \mathrm{~b}$, Bedrock geologic map of the Plainfield quadrangle, Windham and New London Counties, Connecticut: U.S. Geological Survey Geologic Quadrangle Map GQ-481, scale 1:24,000.

1968, Bedrock geologic map of the Danielson quadrangle, Windham County, Connecticut: U.S. Geological Survey Geologic Quadrangle Map GQ-696, scale 1:24,000.

1974, Bedrock geologic map of the Thompson quadrangle, Windham County, Connecticut, and Providence County, Rhode Island: U.S. Geological Survey Geologic Quadrangle Map GQ-1165, scale 1:24,000.

1982, Bedrock geologic map of the Putnam quadrangle, Windham County, Connecticut: U.S. Geological Survey Geologic Quadrangle Map GQ-1562, scale 1:24,000.

Dixon, H.R., and Lundgren, L.W., 1968, Structure of eastern Connecticut, in Zen, E-an, White, W.S., Hadley, J.B., and Thompson, J.B., Jr., eds., Studies of Appalachian geology-Northern and maritime: New York, Interscience Publishers, p. 219-229.

Eberly, P.O., 1984, Brittle fracture petrofabric along an east-west traverse from the Connecticut Valley to the Narragansett basin [abs.]: Geological Society of America Abstracts with Programs, v. 16 , no. 1, p. 14.

Emerson, B.K., 1917, Geology of Massachusetts and Rhode Island: U.S. Geological Survey Bulletin 597, 289 p.

Goldsmith, Richard, 1966, Stratigraphic names in the New London area, Connecticut: U.S. Geological Survey Bulletin 1224-J, 9 p.

1967a, Bedrock geologic map of the Montville quadrangle, New London County, Connecticut: U.S. Geological Survey Geologic Quadrangle Map GQ-609, scale 1:24,000.

$1967 \mathrm{~b}$, Bedrock geologic map of the Niantic quadrangle, New London County, Connecticut: U.S. Geological Survey Geologic Quadrangle Map GQ-575, scale 1:24,000.

1980, Stratigraphic names in the New London area, southeastern Connecticut-A revision, in Sohl, N.F., and Wright, W.B., Changes in stratigraphic nomenclature by the U.S. Geological Survey, 1979: U.S. Geological Survey Bulletin 1502-A, p. A91-A103.

1985, Bedrock geologic map of the Old Mystic and part of the Mystic quadrangles, Connecticut, New York, and Rhode Island: U.S. Geological Survey Miscellaneous Investigations Map I-1524, scale $1: 24,000$.

Goldsmith, Richard, Wones, D.R., and Shride, A.F., 1982, Stratigraphic names in eastern Massachusetts and adjacent States: U.S. Geological Survey Bulletin 1529-H, p. 57-72.

Goldstein, A.G., 1982, Lake Char fault in the Webster, Massachusetts area: Evidence for west-down motion, in New England Intercollegiate Geological Conference, 74th Annual Meeting, Storrs, Conn., Oct. 2-3, 1982, Guidebook for fieldtrips in Connecticut and south-central Massachusetts: Connecticut Geological and Natural History Survey Guidebook 5, p. 375-394.

Gore, R.Z., 1976a, Ayer crystalline complex of Ayer, Harvard, and Clinton, Mass., in Lyons, P.C., and Brownlow, A.H., eds., Studies in New England geology: Geological Society of America Memoir 146, p. 103-124.

$-1976 \mathrm{~b}$, Cataclastic and plutonic rocks within and west of the Clinton-Newbury fault zone, east-central Massachusetts, in New England Intercollegiate Geological Conference, 68th Annual Meet- 
ing, Boston, Mass., Oct. 8-10, 1976, Geology of southeastern New England, a guidebook for field trips to the Boston area and vicinity: Princeton, N.J., Science Press, p. 335-344.

Grew, E.S., 1970, Geology of the Pennsylvanian and prePennsylvanian rocks of the Worcester area, Massachusetts: Cambridge, Mass., Harvard University, Ph.D. thesis, 263 p.

-1973, Stratigraphy of the Pennsylvanian and pre-Pennsylvanian rocks of the Worcester area, Massachusetts: American Journal of Science, v. 273, p. 113-129.

Gromet, L.P., and O'Hara, K.D., 1984, Two distinct late Precambrian terranes within the Avalon zone, southeastern New England and their late Paleozoic juxtaposition [abs.]: Geological Society of America Abstracts with Programs, v. 16, no. 1, p. 20.

Grow, J.A., Mattick, R.E., and Schlee, J.S., 1979, Multichannel seismic depth sections and interval velocities over Outer Continental slope between Cape Hatteras and Cape Cod: American Association of Petroleum Geologists Memoir 29, p. 65-84.

Hall, L.M., and Robinson, Peter, 1982, Stratigraphic-tectonic subdivisions of southern New England, in St-Julien, Pierre, and Beland, Jacques, eds., Major structural zones and faults of the northern Appalachians: Geological Association of Canada Special Paper 24, p. $15-41$.

Handford, L.S., 1965, Rb-Sr whole rock age study of the Andover and Chelmsford Granites, Massachusetts, in Variations in isotopic abundances of strontium, calcium, and argon and related topics: Massachusetts Institute of Technology, 13th Annual Program Report for 1965, U.S. Atomic Energy Commission contract AT(30-1)-1381, MIT-1381-13, p. 11-14.

Hansen, W.R., 1956, Geology and mineral resources of the Hudson and Maynard quadrangles, Massachusetts: U.S. Geological Survey Bulletin 1038, $104 \mathrm{p}$.

Hartshorn, J.H., 1960, Geology of the Bridgewater quadrangle, Massachusetts: U.S. Geological Survey Geologic Quadrangle Map GQ-127, scale 1:24,000.

Harwood, D.S., and Zietz, Isidore, 1976, Geologic interpretation of an aeromagnetic map of southern New England: U.S. Geological Survey Geophysical Investigations Map GP-906, 12 p., scale 1:250,000.

Hatch, N.L., Jr., Zen, E-an, Goldsmith, Richard, Ratcliffe, N.M., Robinson, Peter, Stanley, R.S., and Wones, D.R., 1984, Lithotectonic assemblages as portrayed on the new bedrock geologic map of Massachusetts: American Journal of Science, v. 284, p. 1026-1034.

Haworth, R.T., Daniels, D.L., Williams, Harold, and Zietz, Isidore, 1980, Bouguer gravity anomaly map of the Appalachian orogen: Memorial University of Newfoundland Map 3a, scale 1:1,000,000.

Hepburn, J.C., 1976, Lower Paleozoic rocks west of the ClintonNewbury fault zone, Worcester area, Massachusetts, in New England Intercollegiate Geological Conference, 68th Annual Meeting, Boston, Mass., Oct. 8-10, 1976, Geology of southeastern New England; a guidebook for field trips to the Boston area and vicinity: Princeton, N.J., Science Press, p. 366-382.

-1978, Preliminary reconnaissance bedrock geologic map of the Shrewsbury quadrangle, Worcester County, Massachusetts: U.S. Geological Survey Open-File Report 78-951, 14 p., 1 pl., scale 1:24,000.

Hepburn, J.C., and DiNitto, R.G., 1978, Preliminary bedrock geologic map of the Marlborough quadrangle, Middlesex and Worcester Counties, Massachusetts: U.S. Geological Survey Open-File Report 78-222, 29 p., 1 pl., scale 1:24,000.

Hepburn, J.C., and Rehmer, Judith, 1981, The diagenetic to metamorphic transition in the Narragansett and Norfolk basins, Massachusetts and Rhode Island, in New England Intercollegiate Geological Conference, 73d Annual Meeting, Kingston, R.I., Oct. 16-18,
1981, Guidebook to geologic field studies in Rhode Island and adjacent areas: Kingston, R.I., University of Rhode Island, p. $47-65$.

Hermes, O.D., Ballard, R.D., and Banks, P.O., 1978, Upper Ordovician peralkalic granites from the Gulf of Maine: Geological Society of America Bulletin, v. 89, no. 12, p. 1761-1774.

Hermes, O.D., Gromet, L.P., and Zartman, R.E., 1981, Zircon geochronology and petrology of plutonic rocks in Rhode Island, in New England Intercollegiate Geological Conference, 73d Annual Meeting, Kingston, R.I., Oct. 16-18, 1981, Guidebook to geologic field studies in Rhode Island and adjacent areas: Kingston, R.I., University of Rhode Island, p. 315-338.

Hurley, P.M., Boudda, A., Kanes, W.H., and Nairn, A.E.M., 1974, A plate tectonics origin for late Precambrian-Paleozoic orogenic belt in Morocco: Geology, v. 2, p. 343-344.

Irving, E., 1977, Drift of the major continental blocks since the Devonian: Nature, v. 270, p. 304-309.

Irving, E., and Strong, D.F., 1985, Paleomagnetism of rocks from the Burin peninsula, Newfoundland; hypothesis of late Paleozoic displacement of Acadia criticized: Journal of Geophysical Research, v. 90 , no. B2, p. 1949-1962.

Kay, S.M., and Chapple, W.M., 1976, Pre-Pennsylvanian rocks of Aquidneck and Conanicut Islands, Rhode Island, in New England Intercollegiate Geological Conference, 68th Annual Meeting, Boston, Mass., Oct. 8-10, 1976, Geology of southeastern New England; a guidebook for field trips to the Boston area and vicinity: Princeton, N.J., Science Press, p. 428-446.

Kaye, C.A., 1980, Bedrock geologic maps of the Boston North, Boston South, and Newton quadrangles, Massachusetts: U.S. Geological Survey Miscellaneous Field Studies Map MF-1241, scale 1:24,000. 1983, Discovery of a late Triassic basin north of Boston, Massachusetts, and some implications as to post-Paleozoic faulting in northeastern Massachusetts: American Journal of Science, v. 283, p. $1060-1079$.

Kaye, C.A., and Zartman, R.E., 1980, A late Proterozoic Z to Cambrian age for the stratified rocks of the Boston basin, Massachusetts, U.S.A., in Wones, D.R., ed., The Caledonides in the USA, International Geologic Correlation Program Project 27-Caledonide Orogen, 1979 Meeting, Blacksburg, Virginia: Virginia Polytechnic Institute and State University Memoir 2, p. 257-262.

Kent, D.V., and Opdyke, N.D., 1978, Paleomagnetism of the Devonian Catskill redbeds, evidence for motion of the coastal New EnglandCanadian maritime region relative to cratonic North America: Journal of Geophysical Research, v. 83, p. 4441-4450.

1979, The early Carboniferous paleomagnetic field for North America and its bearing on tectonics of the northern Appalachians: Earth and Planetary Science Letters, v. 44, p. 365-372.

1980, Paleomagnetism of Siluro-Devonian rocks from eastern Maine: Canadian Journal of Earth Sciences, v. 17, p. 1653-1665.

Klitgord, K.D., 1984, Tectonic structure and evolution of the Gulf of Maine: Geological Society of America Abstracts with Programs, v. 16 , no. 1, p. 28.

Klitgord, K.D., and Behrendt, J.C., 1979, Basin structure of the U.S. Atlantic margin, in Watkins, J.S., Montadert, Lucien, and Dickerson, P.W., eds., Geological and geophysical investigations of continental margins: American Association of Petroleum Geologists Memoir 29, p. 85-112.

Kocis, D.E., Hermes, O.D., and Cain, J.A., 1978, Petrologic comparison of the pink and white facies of the Narragansett Pier Granite, Rhode Island [abs.]: Geological Society of America Abstracts with Programs, v. 10, no. 2, p. 71.

Koteff, Carl, 1964, Geologic map of the Assawompset Pond quadrangle, Massachusetts: U.S. Geological Survey Geologic Quadrangle Map GQ-265, scale 1:24,000. 
LaForge, Laurence, 1932, Geology of the Boston area, Massachusetts: U.S. Geological Survey Bulletin 839, 105 p.

Le Fort, Jean-Pierre, 1983, A new geophysical criterion to correlate the Acadian and Hercynian orogenies of western Europe and eastern America, in Hatcher, R.D., Jr., Williams, Harold, and Zietz, Isidore, eds., Contributions to the tectonics and geophysics of mountain chains: Geological Society of America Memoir 158, p. $3-18$.

London, David, 1984, Ductile deformation in the Moodus area, Connecticut; Implications for regional structure and stratigraphy [abs.]: Geological Society of America Abstracts with Programs, v. 16, no. 1, p. 47.

Losh, Steven, and Bradbury, H.J., 1984, Late Paleozoic deformation within the Honey Hill-Lake Char fault zone, southern New England [abs.]: Geological Society of America Abstracts with Programs, v. 16, no. 1, p. 48.

Lundgren, L.W., Jr., 1963, The bedrock geology of the Deep River quadrangle: Connecticut Geological and Natural History Survey Quadrangle Report 13, $40 \mathrm{p}$.

1966, Muscovite reactions and partial melting in southeastern Connecticut: Journal of Petrology, v. 7, p. 421-453.

1967, The bedrock geology of the Old Lyme quadrangle: Connecticut Geological and Natural History Survey Quadrangle Report 21, $30 \mathrm{p}$

Lundgren, Lawrence, and Ebblin, Claude, 1972, Honey Hill fault in eastern Connecticut; Regional relations: Geological Society of America Bulletin, v. 83, no. 9, p. 2773-2794.

Lyons, J.B., Boudette, E.L., and Aleinikoff, J.N., 1982, The Avalonian and Gander zones in central eastern New England, in St-Julien, Pierre, and Beland, Jacques, eds., Major structural zones and faults of the northern Appalachians: Geological Association of Canada Special Paper 24, p. 43-66.

Lyons, P.C., 1977, Report on the bedrock of the Narragansett basin, Massachusetts and Rhode Island: U.S. Geological Survey OpenFile Report 77-816, 42 p., 24 pls., scale 1:31,250.

Lyons, P.C., and Chase, H.B., Jr., 1976, Coal stratigraphy and flora of the northwestern Narragansett basin, in New England Intercollegiate Geological Conference, 68th Annual Meeting, Boston, Mass., Oct. 8-10, 1976, Geology of southeastern New England, a guidebook for field trips to the Boston area and vicinity: Princeton, N.J., Science Press, p. 405-427.

McKniff, J.M., 1964, The petrology of the south half of the Blackstone quadrangle, Massachusetts and Rhode Island: Providence, R.I., Brown University, Master's thesis, $37 \mathrm{p}$.

McMaster, R.K., deBoer, Jelle, and Collins, B.P., 1980, Tectonic development of southern Narragansett Bay and offshore Rhode Island: Geology, v. 8, p. 496-500.

Mosher, Sharon, 1983, Kinematic history of the Narragansett basin, Massachusetts and Rhode Island; constraints on late Paleozoic plate reconstructions: Tectonics, v. 2, no. 4, p. 327-344.

Murray, D.P., and Mosher, Sharon, 1984, Permian deformation and metamorphism in southeastern New England [abs.]: Geological Society of America Abstracts with Programs, v. 16, no. 1, p. 53.

Murray, D.P., and Skehan, J.W., 1979, A traverse across the eastern margin of the Appalachian-Caledonide orogen, southeastern New England, in Skehan, J.W., and Osberg, P.H., eds., The Caledonides in the U.S.A., geological excursions in the northeast Appalachians, Caledonide Orogen Project 27: Weston, Mass., Weston Observatory, p. 1-36.

Nelson, A.E., 1974, Changes in nomenclature of upper Precambrian to lower Paleozoic(?) formations in the Natick quadrangle, eastern Massachusetts, and their tentative correlations with rocks in Rhode Island and Connecticut: U.S. Geological Survey Bulletin 1395-E, 15 p. 1975a, Bedrock geologic map of the Natick quadrangle, Middlesex and Norfolk Counties, Mass.: U.S. Geological Survey Geologic Quadrangle Map GQ-1208, scale 1:24,000.

1975b, Bedrock geologic map of the Framingham quadrangle, Middlesex and Worcester Counties, Massachusetts: U.S. Geological Survey Geologic Quadrangle Map GQ-1274, scale 1:24,000.

-1976, Structural elements and deformational history of rocks in eastern Massachusetts: Geological Society of America Bulletin, v. 87, p. 1377-1383.

Novotny, R.F., 1969, Geology of the seacoast region of New Hampshire: Concord, New Hampshire Division of Economic Development Quadrangle Report, $46 \mathrm{p}$.

O'Hara, K.D., and Gromet, L.P., 1983, Textural and Rb-Sr isotopic evidence for late Paleozoic mylonitization within the Honey Hill fault zone, southeastern Connecticut: American Journal of Science, v. 283, p. $762-779$.

-1984, Identification, characterization, and age of a ductile shear zone separating two late Precambrian terranes, southeastern New England [abs.]: Geological Society of America Abstracts with Programs, v. 16, no. 1, p. 54 .

Olszewski, W.J., Jr., 1980, The geochronology of some stratified metamorphic rocks in northeastern Massachusetts: Canadian Journal of Earth Sciences, v. 17, p. 1407-1416.

Osberg, P.H., 1978, Synthesis of the geology of the northeastern Appalachians, U.S.A., in International Geologic Correlation Program Project 27, Contribution No. 1, Caledonian-Appalachian orogen of the North Atlantic Region: Canada Geological Survey Paper 78-13, p. 137-147.

Osberg, P.H., Hussey, A.M., and Boone, G.M., eds., 1984, Bedrock geologic map of Maine: Maine Geological Survey Open File 84-1, scale 1:500,000.

Pease, M.H., Jr., 1982, The Bonemill Brook fault in eastern Connecticut, in New England Intercollegiate Geological Conference, 74th Annual Meeting, Storrs, Conn., Oct. 2-3, 1982, Guidebook for fieldtrips in Connecticut and south-central Massachusetts: Connecticut Geological and Natural History Survey Guidebook 5, p. $263-287$.

Peck, J.H., 1975, Preliminary bedrock geologic map of the Clinton quadrangle, Worcester County, Mass.: U.S. Geological Survey Open-File Report 75-658, 30 p., 3 pls., scale 1:24,000.

Peper, J.D., and Wilson, F.A., 1978, Reconnaissance bedrock geologic map of the Fitchburg quadrangle and part of the Ashby quadrangle, north-central Massachusetts: U.S. Geological Survey Miscellaneous Field Studies Map MF-959, scale 1:24,000.

Pignolet, Susanne, Grant, K., and Hickman, M.H., 1980, Rb-Sr geochronology of the Honey Hill fault area, eastern Connecticut [abs.]: Geological Society of America Abstracts with Programs, v. 12, no. 2 , p. 77 .

Pollock, S.J., 1964, Bedrock geology of the Tiverton quadrangle, Rhode Island-Massachusetts: U.S. Geological Survey Bulletin 1158-D, $16 \mathrm{p}$.

Quinn, A.W., 1951, Bedrock geology of the North Scituate quadrangle, Rhode Island: U.S. Geological Survey Geologic Quadrangle Map GQ-13, scale 1:31,680.

1971, Bedrock geology of Rhode Island: U.S. Geological Survey Bulletin $1295,68 \mathrm{p}$.

Rast, Nicholas, 1980, The Avalonian plate in the Northern Appalachians and Caledonides, in Wones, D.R., ed., The Caledonides in the U.S.A., International Geologic Correlation Program Project 27-Caledonide Orogen, 1979 Meeting, Blacksburg, Virginia: Virginia Polytechnic Institute and State University Memoir 2, p. 63-66.

Rast, Nicholas, O'Brien, B.H., and Wardle, R.J., 1976, Relationship between Precambrian and lower Paleozoic rocks of the "Avalon 
Platform" in New Brunswick, the northeast Appalachians and the British Isles: Tectonophysics, v. 30, p. 315-338.

Rast, Nicholas, and Skehan, J.W., 1981, The geology of Precambrian rocks of Newport and Middletown, Rhode Island, in New England Intercollegiate Geological Conference, 73d Annual Meeting, Kingston, R.I., Oct. 16-18, 1981, Guidebook to geologic field studies in Rhode Island and adjacent areas: Kingston, R.I., University of Rhode Island, p. 67-92.

-1983, Assembly of the Avalonian terrane of North America and the British Isles [abs.]: Geological Society of America Abstracts with Programs, v. 15, no. 3, p. 196.

1984, Avalon zone in relation to Alleghanian deformation [abs.]: Geological Society of America Abstracts with Programs, v. 16, no. 1, p. 56.

Robinson, G.R., Jr., 1978, Bedrock geology of the Pepperell, Shirley, and Townsend quadrangles and part of the Ayer quadrangle, Massachusetts and New Hampshire: U.S. Geological Survey Miscellaneous Field Studies Map MF-957, scale 1:24,000.

-1981, Bedrock geology of the Nashua River area, Massachusetts-New Hampshire: U.S. Geological Survey OpenFile Report 81-470, 172 p.

Robinson, Peter, and Hall, L.M., 1980, Tectonic synthesis of southern New England, in Wones, D.R., ed., The Caledonides in the U.S.A., International Geologic Correlation Program Project 27-Caledonide Orogen, 1979 Meeting, Blacksburg, Virginia: Virginia Polytechnic Institute and State University Memoir 2, p. 73-82.

Robinson, Peter, and Tucker, R.D., 1982, The Merrimack synclinorium in northeastern Connecticut, Discussion: American Journal of Science, v. 282, no. 10, p. 1735-1744.

Rodgers, John, 1970, The tectonics of the Appalachians: New York, Interscience Publishers, $271 \mathrm{p}$.

1981, The Merrimack synclinorium in northeastern Connecticut: American Journal of Science, v. 281, p. 176-186.

-_comp., 1982, Yet another preliminary geological map of Connecticut, in New England Intercollegiate Geological Conference, 74th Annual Meeting, Storrs, Conn., Oct. 2-3, 1982, Guidebook for fieldtrips in Connecticut and south-central Massachusetts: Connecticut Geological and Natural History Survey Guidebook 5, p. 1-4, map in pocket, scale 1:250,000.

Rose, Stuart, and Murray, Daniel, 1984, Age relationships in the Woonsocket and Scituate basins, southeastern New England [abs.]: Geological Society of America Abstracts with Programs, v. 16, no. 1, p. 60.

Ross, Martin, 1981, Mafic dikes in northeastern Massachusetts, in New England Intercollegiate Geological Conference, 73d Annual Meeting, Kingston, R.I., Oct. 16-18, 1981, Guidebook to geologic field studies in Rhode Island and adjacent areas: Kingston, R.I., University of Rhode Island, p. 285-302.

Schenk, P.E., 1971, Southeastern Atlantic Canada, northwestern Africa, and continental drift: Canadian Journal of Earth Sciences, v. 8 , p. 1218-1251.

Shaler, N.W., Woodworth, J.B., and Foerste, A.G., 1899, Geology of the Narragansett basin: U.S. Geological Survey Monograph 33, $402 \mathrm{p}$.

Shaw, C.E., Jr., 1967, Geology and petrochemistry of the Milford area, Massachusetts: Providence, R.I., Brown University, Ph.D. thesis, $141 \mathrm{p}$.

Shride, A.F., 1971, Igneous rocks of the Seabrook, New HampshireNewbury, Massachusetts area, Trip B-5, in New England Intercollegiate Geological Conference, 63d Annual Meeting, Concord, N.H., 1971, Guidebook: Durham, N.H., University of New Hampshire, Geology Department, p. 105-117. 1976a, Preliminary maps of the bedrock geology of the Newburyport East and Newburyport West quadrangles, Massachusetts-New Hampshire: U.S. Geological Survey Open-File Report 76-488, 4 pls., scale 1:24,000.

$-1976 \mathrm{~b}$, Stratigraphy and correlation of the Newbury Volcanic Complex, northeastern Massachusetts, in Page, L.R., ed., Contributions to the stratigraphy of New England: Geological Society of America Memoir 148, p. 147-178.

Simpson, R.W., Bothner, W.A., and Shride, A.F., 1980, Offshore extension of the Clinton-Newbury and Bloody Bluff fault systems of northeastern Massachusetts, in Wones, D.R., ed., The Caledonides in the U.S.A., International Geologic Correlation Program Project 27-Caledonide Orogen, 1979 Meeting, Blacksburg, Virginia: Virginia Polytechnic Institute and State University Memoir 2, p. 229-233.

Skehan, J.W., 1967, Geology of the Wachusett-Marlborough tunnel, east-central Massachusetts, a preliminary report, in Farquhar, 0 , ed., Economic geology in Massachusetts-Conference Amherst, Proceedings: Amherst, Massachusetts University Graduate School, p. 237-244.

- 1968, Fracture tectonics of southeastern New England as illustrated by the Wachusett-Marlborough tunnel, east-central Massachusetts, in Zen, E-an, White, W.S., Hadley, J.B., and Thompson, J.B., Jr., eds., Studies of Appalachian geology-Northern and maritime: New York, Interscience Publishers, p. 281-290.

1969, Tectonic framework of southern New England and eastern New York, in Kay, Marshall, ed., North Atlantic-Geology and continental drift; a symposium: American Association of Petroleum Geologists Memoir 12, p. 793-814.

Skehan, J.W., and Abu-Moustafa, A.A., 1976, Stratigraphic analysis of rocks exposed in the Wachusett-Marlborough tunnel, east-central Massachusetts, in Page, L.R., ed., Contributions to the stratigraphy of New England: Geological Society of America Memoir 148, p. 217-240.

Skehan, J.W., and Murray, D.P., 1980a, A model for the evolution of the eastern margin (EM) of the northern Appalachians, in Wones, D.R., ed., The Caledonides in the U.S.A., International Geologic Correlation Program Project 27-Caledonide Orogen, 1979 Meeting, Blacksburg, Virginia: Virginia Polytechnic Institute and State University Memoir 2, p. 67-72.

- 1980b, Geologic profile across southeastern New England: Tectonophysics, v. 69 , p. 285-316.

Skehan, J.W., Murray, D.P., Hepburn, J.C., Billings, M.P., Lyons, P.C., and Doyle, R.G., 1979, The Mississippian and Pennsylvanian (Carboniferous) Systems in the United States-Massachusetts, Rhode Island, and Maine: U.S. Geological Survey Professional Paper 1110-A, $30 \mathrm{p}$.

Skehan, J.W., Murray, D.P., Palmer, A.R., Smith, A.T., and Belt, E.S., 1978, Significance of fossiliferous Middle Cambrian rocks of Rhode Island to the history of the Avalonian microcontinent: Geology, v. 6, p. 694-698.

Smith, P.V., and Barosh, P.J., 1981, Structural geology of the Nashua trough, southern New Hampshire [abs.]: Geological Society of America Abstracts with Programs, v. 13, no. 3, p. 178.

1983 , Detailed structure of a small segment of the Bloody Bluff fault zone in the Concord quadrangle, Massachusetts [abs.]: Geological Society of America Abstracts with Programs, v. 15, no. 3, p. 130 .

Snyder, G.L., 1964, Bedrock geology of the Willimantic quadrangle, Connecticut: U.S. Geological Survey Geologic Quadrangle Map GQ-335, scale 1:24,000.

Sriramadas, Alaru, 1966, Geology of the Manchester quadrangle, New Hampshire: New Hampshire Department of Resources and Economic Development Bulletin 2, 92 p. 
Stanley, R.S., and Hatch, N.L., Jr., 1988, The pre-Silurian geology of the Rowe-Hawley zone, in Hatch, N.L., Jr., ed., The bedrock geology of Massachusetts: U.S. Geological Survey Professional Paper 1366, p. B1-B34.

Stewart, D.B., Unger, J.D., Phillips, J.D., Goldsmith, Richard, Poole, W.H., Spencer, C.P., Green, A.G., Loiselle, M.C., and St-Julien, Pierre, 1986, The Quebec-western Maine seismic line reflection profile; setting and first year results, in Reflection seismology, the continental crust: American Geophysical Union, Geodynamics series, v. 14, p. 189-199.

Stewart, D.B., and Wones, D.R., 1974, Bedrock geology of the northern Penobscot Bay area, in New England Intercollegiate Geological Conference, 66th Annual Meeting, Orono, Maine, Oct. 12-13, 1974, Guidebook for field trips in east-central and northcentral Maine: Orono, Maine, University of Maine, p. 223-239.

Strong, D.F., 1979, Proterozoic tectonics of northwest Gondwanaland: New evidence from eastern Newfoundland: Tectonophysics, v. 54, p. 81-101.

Sundeen, D.A., 1971, The bedrock geology of the Haverhill 15' quadrangle, New Hampshire: New Hampshire Department of Resources and Economic Development Bulletin 5, 125 p.

Thompson, J.B., Jr., and Norton, S.A., 1968, Paleozoic regional metamorphism in New England and adjacent areas, in Zen, E-an, White, W.S., Hadley, J.B., and Thompson, J.B., Jr., eds., Studies of Appalachian geology-Northern and maritime: New York, Interscience Publishers, p. 319-328.

Thompson, J.B., Jr., and Robinson, Peter, 1976, Geologic setting of the Harvard Conglomerate, Harvard, Massachusetts, in New England Intercollegiate Geological Conference, 68th Annual Meeting, Boston, Mass., Oct. 8-10, 1976, Geology of southeastern New England, a guidebook for field trips to the Boston area and vicinity: Princeton, N.J., Science Press, p. 345-351.

Toulmin, Priestley, III, 1964, Bedrock geology of the Salem quadrangle and vicinity, Massachusetts: U.S. Geological Survey Bulletin $1163-\mathrm{A}, 79 \mathrm{p}$.

Tucker, R.D., 1978, Contact relations and deformation at the west margin of the Fitchburg pluton, Wachusett Mountain area, central Massachusetts [abs.]: Geological Society of America Abstracts with Programs, v. 10, no. 2, p. 89-90.

U.S. Geological Survey, 1969, Faults in eastern Massachusetts and Connecticut, in Geological Survey research, 1969: U.S. Geological Survey Professional Paper 650-A, p. A21-A22.

1971a, Aeromagnetic map of the Fall River East quadrangle, Bristol County, Massachusetts: U.S. Geological Survey Geophysical Investigations Map GP-799, scale 1:24,000.

1971b, Aeromagnetic map of part of the Westport quadrangle, Bristol County, Massachusetts, and Newport County, Rhode Island: U.S. Geological Survey Geophysical Investigations Map GP-809, scale 1:24,000.

1980, Physical characteristics of faults, northeastern Masssachusetts, in Geological Survey research, 1980: U.S. Geological Survey Professional Paper 1175, p. 62.

Van der Voo, Rob, 1983, A plate tectonics model for the Paleozoic assembly of Pangea based on paleomagnetic data, in Hatcher, R.D., Jr., Williams, Harold, and Zietz, Isidore, eds., Contributions to the tectonics and geophysics of mountain chains: Geological Society of America Memoir 158, p. 19-24.

Volckmann, R.P., 1977, Bedrock geologic map of the Holliston and Medfield quadrangles, Middlesex, Norfolk, and Worcester Coun- ties, Massachusetts: U.S. Geological Survey Miscellaneous Investigations Map I-1053, scale 1:48,000.

Weston Observatory, Boston College, 1976, Interim report of the Pennsylvanian coal-bearing strata of the Narragansett basin, June 1976-December 1976: National Science Foundation NSF/RA 76-0337, $32 \mathrm{p}$.

Williams, Harold, and Hatcher, R.D., Jr., 1983, Appalachian suspect terranes, in Hatcher, R.D., Jr., Williams, Harold, and Zietz, Isidore, eds., Contributions to the tectonics and geophysics of mountain chains: Geological Society of America Memoir 158, p. $33-53$.

Williams, J.R., and Willey, R.E., 1973, Bedrock topography and texture of unconsolidated deposits, Taunton River Basin, southeastern Massachusetts: U.S. Geological Survey Miscellaneous Investigations Map I-742, scale 1:48,000.

Williams, J.R., Willey, R.E., and Tasker, G.D., 1975, Hydrologic data of the coastal drainage basins of southeastern Massachusetts Weir River, Kingston: U.S. Geological Survey Massachusetts Hydrologic-Data Report 16, $63 \mathrm{p}$.

Wintsch, R.P., 1979, The Willimantic fault: a ductile fault in eastern Connecticut: American Journal of Science, v. 279, p. 367-393.

Wintsch, R.P., and Hudson, M.R., 1978, Southeastward thrusting in eastern Connecticut [abs.]: Geological Society of America Abstracts with Programs, v. 10, no. 2, p. 91.

Wintsch, R.P., and Le Fort, Jean-Pierre, 1983, A temperaturetime-strain path as a memory of late Hercynian intraplate deformation [abs.]: Geological Society of America Abstracts with Programs, v. 15, no. 3, p. 196.

Wones, D.R., and Thompson, Woodrow, 1979, The Norumbega fault zone: a major regional structure in central eastern Maine [abs.]: Geological Society of America Abstracts with Programs, v. 11, no. 1, p. 60 .

Zartman, R.E., Hurley, P.M., Krueger, H.W., and Giletti, B.J., 1970, A Permian disturbance of K-Ar radiometric ages in New England-its occurrence and cause: Geological Society of America Bulletin, v. 81, p. 3359-3373.

Zartman, R.E., and Marvin, R.F., 1971, Radiometric age (Late Ordovician) of the Quincy, Cape Ann, and Peabody granites from eastern Massachusetts: Geological Society of America Bulletin, v. 82 , p. $937-958$.

Zartman, R.E., Pease, M.H., Jr., and Hermes, O.D., 1983, Encroachment of the late Paleozoic Variscan Front in southern New England [abs.]: Geological Society of America Abstracts with Programs, v. 15, p. 147.

Zen, E-an, 1983, Exotic terranes in the New England AppalachiansLimits, candidates, and ages: A speculative essay, in Hatcher, R.D., Jr., Williams, Harold, and Zietz, Isidore, eds., Contributions to the tectonics and geophysics of mountain chains: Geological Society of America Memoir 158, p. 55-81.

Zen, E-an, editor, and Goldsmith, Richard, Ratcliffe, N.M., Robinson, Peter, and Stanley, R.S., compilers, 1983, Bedrock geologic map of Massachusetts: Reston, Va., U.S. Geological Survey, 3 sheets, scale 1:250,000.

Zen, E-an, and Palmer, A.R., 1981, Did Avalonia form the eastern shore of Iapetus Ocean? [abs.]: Geological Society of America Abstracts with Programs, v. 13, no. 7, p. 587.

Zietz, Isidore, Haworth, R.T., Williams, Harold, and Daniels, D.L., 1980, Magnetic anomaly map of the Appalachian orogen: Memorial University of Newfoundland Map 2a, scale 1:1,000,000. 



\section{Intrusive Rocks of Eastern Massachusetts}

By DAVid R. WONES, Virginia Polytechnic Institute and State University, and RICHARD GOLDSMITH, U.S. Geological Survey

THE BEDROCK GEOLOGY OF MASSACHUSETTS

U.S. GEOLOGICAL SURVEY PROFESSIONAL PAPER 1366-I 


\section{CONTENTS}

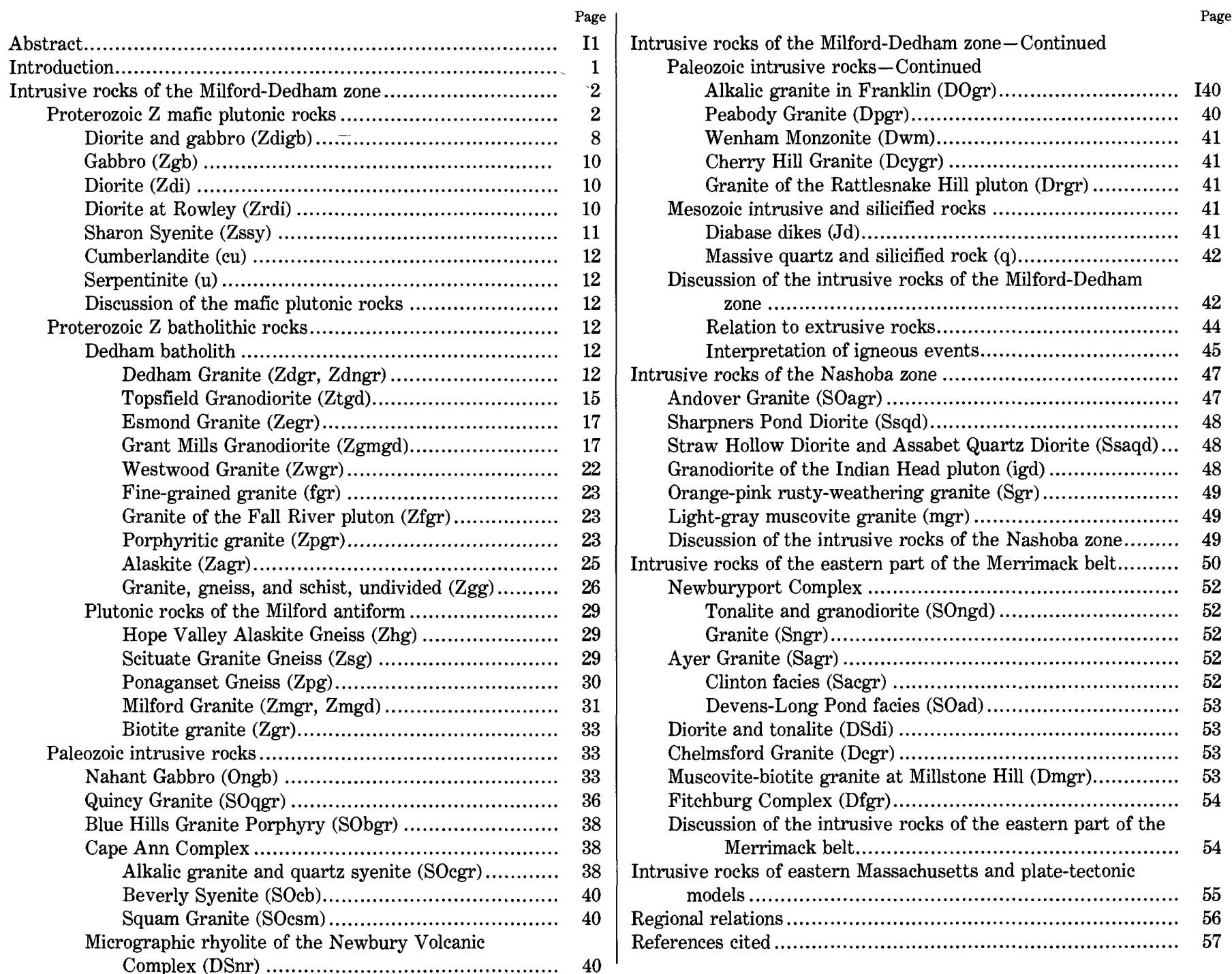

\section{ILLUSTRATIONS}

FIGURE 1. Map showing distribution of intrusive rocks of eastern Massachusetts....

2. Correlation diagram of intrusive rocks and selected sedimentary and volcanic rocks and their metamorphic equivalents in eastern Massachusetts.

3. Map showing distribution of Proterozoic $\mathrm{Z}$ batholithic rocks in the Milford-Dedham zone. 
Fage

4. Map showing distribution of Proterozoic $\mathrm{Z}$ mafic plutonic and volcanic rocks in the Milford-Dedham zone ................... I9

5. Quartz-plagioclase-K-feldspar-mafic minerals diagram of modes of Proterozoic Z intrusive rocks of the Milford-Dedham zone.

6. Plot showing $\mathrm{CaO}$ and $\mathrm{Na}_{2} \mathrm{O}+\mathrm{K}_{2} \mathrm{O}$ against $\mathrm{SiO}_{2}$ for Proterozoic $\mathrm{Z}$ intrusive rocks of the Milford-Dedham zone $\ldots \ldots \ldots \ldots \ldots$

7. Ternary plot of normative albite, anorthite, and orthoclase for Proterozoic $\mathrm{Z}$ intrusive rocks of the Milford-Dedham

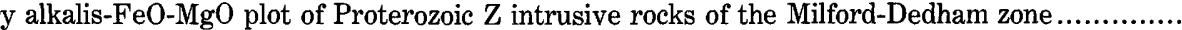

9. Chondrite-normalized plot of rare-earth elements in Proterozoic Z mafic plutonic rocks of the Milford-Dedham zone ........ 17

10. Plot of thorium against uranium for Proterozoic $Z$ intrusive rocks of the Milford-Dedham zone .............................. 17

11. Map showing distribution of Proterozoic $Z$ batholithic rocks in the Milford-Dedham zone ..................................... 18

12-14. Quartz-plagioclase-K-feldspar-mafic minerals diagram of modes of:

12. Dedham Granite and Topsfield Granodiorite.

13. Westwood Granite; Westwood Granite in Plymouth quarry, Weymouth; and Milford Granite...........

14. Fall River pluton including the porphyritic granite.

15. Chondrite-normalized plot of rare-earth elements in Proterozoic $Z$ batholithic rocks, northeastern Massachusetts: $A$, Dedham Granite; $B$, Dedham Granite north of Boston, Westwood and Esmond Granites, and Topsfield Granodiorite.

16. Chondrite-normalized plot of rare-earth elements of Proterozoic $\mathrm{Z}$ batholithic rocks in the Milford-Dedham zone, southeastern Massachusetts.

17. Map showing locations of drill holes encountering bedrock in Cape Cod and the adjacent mainland.....

18. Chondrite-normalized plot of rare-earth elements of Proterozoic $Z$ batholithic rocks, Milford antiform.

19. Map showing distribution of Paleozoic intrusive rocks in the Milford-Dedham zone .....

20. Geologic map and cross section for Andrews Point, Cape Ann

21. Ternary quartz-plagioclase-K-feldspar plot of modal composition of Dedham Granite as compared with fields of composition of Dedham Granite of

22. Plot of a part of the ternary system $\mathrm{Na}_{2} \mathrm{O}-\mathrm{K}_{2} \mathrm{O}-\mathrm{Al}_{2} \mathrm{O}_{3}$ in molecular percent for intrusive rocks of the Milford-Dedham zone.

23. Ternary plot of normative albite, anorthite, and orthoclase for Paleozoic intrusive rocks of the Milford-Dedham zone........

24. Ternary alkalis-FeO-MgO plot of Paleozoic intrusive rocks of the Milford-Dedham zone showing field of Proterozoic Z intrusive rocks of the Milford-Dedham zone.

25. Chondrite-normalized plot of rare-earth elements of Paleozoic intrusive rocks

26. Map showing distribution of intrusive rocks in the Nashoba zone....

27. Map showing distribution of intrusive rocks in the eastern part of the Merrimack belt

27. Map showing distribution of intrusive rocks in the eastern part of the Mernimack belt ...

\section{TABLES}

TABLE 1. Ages and age relations of intrusive rocks of the Milford-Dedham zone....

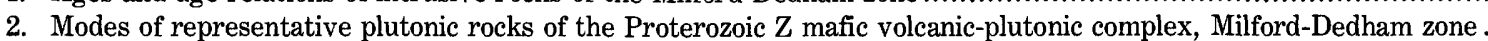

3. Major-oxide, normative-mineral, and trace-element compositions of plutonic rocks of the Proterozoic $\mathrm{Z}$ mafic volcanic-plutonic complex .....

4. Major constituents determined by point-count of stained slabs of intrusive rocks of the Milford-Dedham zone .....................

5. Modes of plutonic rocks of the Dedham batholith in northeastern Massachusetts

6. Major-oxide, normative-mineral, and trace-element compositions of Proterozoic $\mathrm{Z}$ intrusive rocks, Milford-Dedham zone, northeastern Massachusetts.

7. Modes of plutonic rocks of the Dedham batholith, southeastern Massachusetts.

8. Major-oxide, normative-mineral, and trace-element compositions of Proterozoic $\mathrm{Z}$ intrusive rocks, southeastern Massachusetts.

9. Modes of plutonic rocks of the Milford antiform

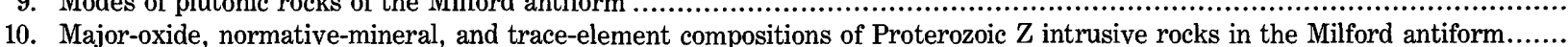

11. Modes of some Paleozoic intrusive rocks of the Milford-Dedham zone

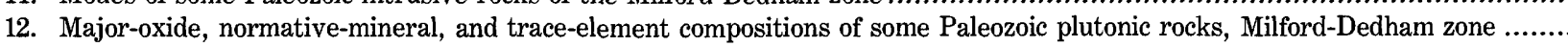

13. Ages and age relations of intrusive rocks of the Nashoba zone and the eastern part of the Merrimack belt..........................

14. Modes of intrusive rocks of the Nashoba zone.....

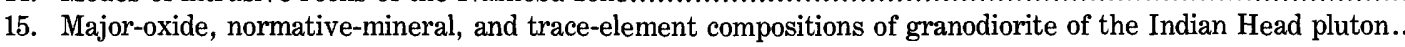

16. Modes of intrusive rocks of the Merrimack belt east of the Wekepeke fault. 


\title{
INTRUSIVE ROGKS OF EASTERN MASSACHUSETTS
}

\author{
By David R. WONEs ${ }^{1,2}$ and Richard GOLdSMITH ${ }^{3}$
}

\begin{abstract}
The intrusive rocks of eastern Massachusetts east of the Wekepeke fault form three distinctly different assemblages coinciding with the three lithotectonic terranes that form eastern Massachusetts: the Milford-Dedham zone, the Nashoba zone, and the eastern part of the Merrimack belt. In the Milford-Dedham zone, a largely mafic voleanicplutonic complex of Proterozoic $\mathrm{Z}$ age is intruded by $630-\mathrm{Ma}$ batholiths of calc-alkaline granite to granodiorite. These batholithic rocks occupy two regions. To the east, the Dedham-Fall River batholith consists of partly altered but mostly nongneissic granites and granodiorites; to the southwest, the Milford antiform consists of gneissic to partly gneissic granites and granodiorites. The batholithic rocks in the two regions are similar in age and chemistry. Slightly younger granite is associated with a Proterozoic $Z$ rifting(?) event that produced a bimodal volcanic suite in the area of the Boston basin. During the early and middle Paleozoic, the Proterozoic $\mathrm{Z}$ rocks were intruded by discrete alkaline and peralkaline plutons ranging from gabbro to granite, which lie primarily in a northeast-trending belt northwest of the Narragansett basin. No late Paleozoic intrusive rocks are known in the Milford-Dedham zone in Massachusetts, although they are present in southern Rhode Island. Mesozoic intrusive rocks are confined to mafic dikes associated with early Mesozoic rifting.

Intrusive rocks of the Nashoba zone are all Paleozoic; they range from the peraluminous, S-type, partly gneissic Andover Granite of Late Ordovician to Silurian age but including some rock of Devonian age, to postmetamorphic I-type quartz-diorite and to granite of Silurian age. Since the bedrock map of Massachusetts (Zen and others, 1983) was prepared, the latter granite has been found to include rock of Devonian age. The Silurian plutonic rocks contrast in composition with the Andover Granite and with the Paleozoic rocks of the MilfordDedham zone and are I-type granite associated with volcanic arcs. Data on the shallow intrusions of the nearby Late Silurian and Early Devonian Newbury Volcanic Complex are insufficient to determine whether they are chemically related to the Silurian plutons of the Nashoba zone. Some of the granite that has recently been determined to be Devonian in age is peraluminous, like the older Late Ordovician and Silurian Andover Granite. These changes in composition with time imply a changing crustal source for the material.

The intrusive rocks of the eastern part of the Merrimack belt constitute a different assemblage. These rocks are primarily calc-
\end{abstract}

\footnotetext{
Manuscript approved for publication November 16, 1987.

${ }^{1}$ Deceased.

${ }^{2}$ Virginia Polytechnic Institute and State University, Blacksburg, Va.

${ }^{3}$ U.S. Geological Survey.
}

alkaline granodiorite and granite of Silurian to Ordovician age and include small masses of diorite and, in one pluton, norite. Some of these rocks, such as parts of the Ayer Granite, are gneissic and appear to have been deformed during Acadian metamorphism and intrusion. Younger muscovite-bearing granite of Devonian age forms small aligned plutons that are probably satellitic to the larger Fitchburg Complex west of the area but that extend into Connecticut as the Canterbury Gneiss. The Ordovician and Silurian Newburyport Complex bears mineralogical resemblance to some of the Silurian intrusions of the Nashoba zone. Recently determined ages of the intrusions in the eastern part of the Merrimack belt indicate that some or all of the strata in this part of the Merrimack belt are somewhat older than shown on the State bedrock map.

The differences in the compositions, styles of emplacement, and times of intrusion of the intrusive rocks of the three lithotectonic belts of eastern Massachusetts are a basis for attempting to establish a history of accretion of crustal blocks during the Paleozoic. The MilfordDedham zone was a cratonic element during the Paleozoic and was not joined to the Nashoba zone until after intrusion of the Devonian granites. The Nashoba zone could have been close to the east flank of the Merrimack belt somewhat earlier. The two seem to share a Devonian magmatic event and possibly an earlier one as well. The three belts clearly were assembled by the Pennsylvanian, although their present boundaries involve Permian events.

The Proterozoic Z rocks of the Milford-Dedham zone consist of many more intrusive rocks and many fewer supracrustal rocks than the Avalon terrane of Newfoundland. The Proterozoic $\mathrm{Z}$ rocks of the zone bear some resemblance to rocks in the Charlotte belt of North and South Carolina in both age and volume of intrusive rocks, although the intrusive rocks in the Charlotte belt are more mafic. The Ordovician and Silurian intrusive rocks of the Nashoba zone resemble intrusions in the lithotectonically equivalent Passagassawakeag terrane in southeastern Maine. The intrusive rocks of the east flank of the Merrimack belt in Massachusetts are in part older and are more deformed and metamorphosed than the intrusive rocks in the Merrimack belt to the north in Maine. The Ordovician to Silurian rocks of the east flank of the Merrimack belt in Massachusetts do not have obvious counterparts along strike to the north beyond New Hampshire. The Devonian intrusions of the Merrimack belt in Massachusetts are compositionally similar to those in eastern Maine but were generally more affected by Acadian dynamothermal metamorphism than were the mostly highlevel, postmetamorphic plutons of northeastern New England.

\section{INTRODUCTION}

Eastern Massachusetts is divided into three lithotectonic terranes: a part of the Merrimack belt east of the 
Wekepeke fault and the Fitchburg Complex and northwest of the Clinton-Newbury fault; the Nashoba zone, between the Clinton-Newbury fault and the Bloody Bluff fault; and the Milford-Dedham zone, southeast of the Bloody Bluff fault (fig. 1). These three terranes have distinctive strata and distinct intrusive, deformational, and metamorphic histories (Zen and others, 1983; Hatch and others, 1984). Fossils are present in the supracrustal rocks of the Milford-Dedham zone, but they are found only in the Pennsylvanian strata at Worcester in the eastern part of the Merrimack belt and are lacking in the Nashoba zone. Therefore, lithologic correlations within each terrane have been made in varying degrees on the basis of comparisons of the strata alone (Goldsmith, this vol., chaps. E and F; Robinson and Goldsmith, this vol., chap. G). The oldest known rocks are in the MilfordDedham terrane. The stratified rocks of this zone consist of metasedimentary, metavolcanic, and metaplutonic rocks of probable Proterozoic $\mathrm{Z}$ age (fig. 2 ). These are intruded by calc-alkaline batholithic rocks of Proterozoic $\mathrm{Z}$ age, which form a basement for weakly metamorphosed to unmetamorphosed sedimentary and volcanic rocks ranging in age from latest Proterozoic $\mathrm{Z}$ and Cambrian to Pennsylvanian.

The strata of the Nashoba zone are high-metamorphicgrade pelitic schists and gneisses, calc-silicate rocks, minor marble, feldspathic gneisses, and amphibolite. The protoliths of some of these rocks contained a large proportion of mafic volcanic or volcaniclastic material. Their high grade of metamorphism contrasts sharply with the lower grade strata in the Milford-Dedham zone on the east and in the east part of the Merrimack belt on the west, indicating that the faults bounding these terranes are of significant magnitude. The age of these rocks is somewhat uncertain. On the geologic bedrock map of Massachusetts (Zen and others, 1983; hereafter referred to as the State bedrock map), they are shown as Ordovician or Proterozoic Z.

The strata in the eastern part of the Merrimack belt are primarily a low- to middle-metamorphic-grade turbidite sequence of calcareous metasiltstone and phyllite containing minor quartzite and rare conglomerate beds near the base. These rocks, equivalent to the Berwick, Eliot, and Kittery Formations of the Merrimack Group of southeastern New Hampshire and the Oakdale Formation of Massachusetts, are of uncertain age. On the State bedrock map, they were considered to be of Silurian age and were correlated with the Paxton Formation of central Massachusetts, but radiometric dating of intrusive rocks in Massachusetts (Zartman and Marvin, this vol., chap. J) and recent radiometric dating and mapping in southern New Hampshire (Lyons and others, 1982; Bothner and others, 1984) have indicated that these strata may be much older, and they may belong to a separate terrane.

The intrusive rocks of the three terranes (fig. 1) also have histories and compositions that are quite distinct from each other. In this report, we describe the intrusive rocks of each terrane and explain the reasons behind the particular groupings and splits that were used on the State bedrock map. We also offer an interpretation of the thermal history of eastern Massachusetts. This analysis depends greatly on the radiometric determinations discussed and summarized by Zartman and Naylor (1984), Zartman and Marvin (this vol., chap. J), and Hermes and Zartman (1985). We have been greatly aided in the preparation of this chapter by reviews by O. Don Hermes, J. Christopher Hepburn, G. William Leo, and David B. Stewart. Because of the death of the senior author during preparation of this manuscript, material is included in it that was intended for a future paper developing more fully some ideas and concepts regarding the intrusive rocks of eastern Massachusetts. Thus, these ideas and concepts as expressed in the present chapter may be somewhat fragmentary, but the data are presented for others to use as they see fit.

\section{INTRUSIVE ROCKS OF THE MILFORD-DEDHAM ZONE}

The intrusive rocks of the Milford-Dedham zone (table 1) range in age from Proterozoic $Z$ to Jurassic, but they form four major groups. The first is a suite of Proterozoic $\mathrm{Z}$ rocks consisting of gabbro, diorite, and syenite (Sharon Syenite) that form the plutonic part of a largely mafic volcanic-plutonic complex, the volcanic part of which is described in chapter $\mathrm{E}$ of this volume (Goldsmith, this vol.). The second consists of calc-alkaline granitic to granodioritic rocks of Proterozoic $\mathrm{Z}$ age that form two batholithic masses intruding the mafic plutonic rocks and older metasedimentary and metavolcanic rocks. The two batholithic masses are the Dedham batholith, in which we include the granite of the Fall River pluton and associated rocks in southeastern Massachusetts, and the plutonic rocks of the Milford antiform (fig. 3). The third major group consists of plutons of alkalic granite and gabbro of Ordovician to Devonian age. The fourth group consists of dikes of Mesozoic age.

\section{PROTEROZOIC Z MAFIC PLUTONIC ROCKS}

The Proterozoic $\mathrm{Z}$ mafic plutonic rocks occupy a large area in northeastern Massachusetts (fig. 4) where there are also numerous masses of metavolcanic rocks. South and west of Boston, the mafic plutonic rocks occupy scattered roof pendants and enclaves in the granitic 


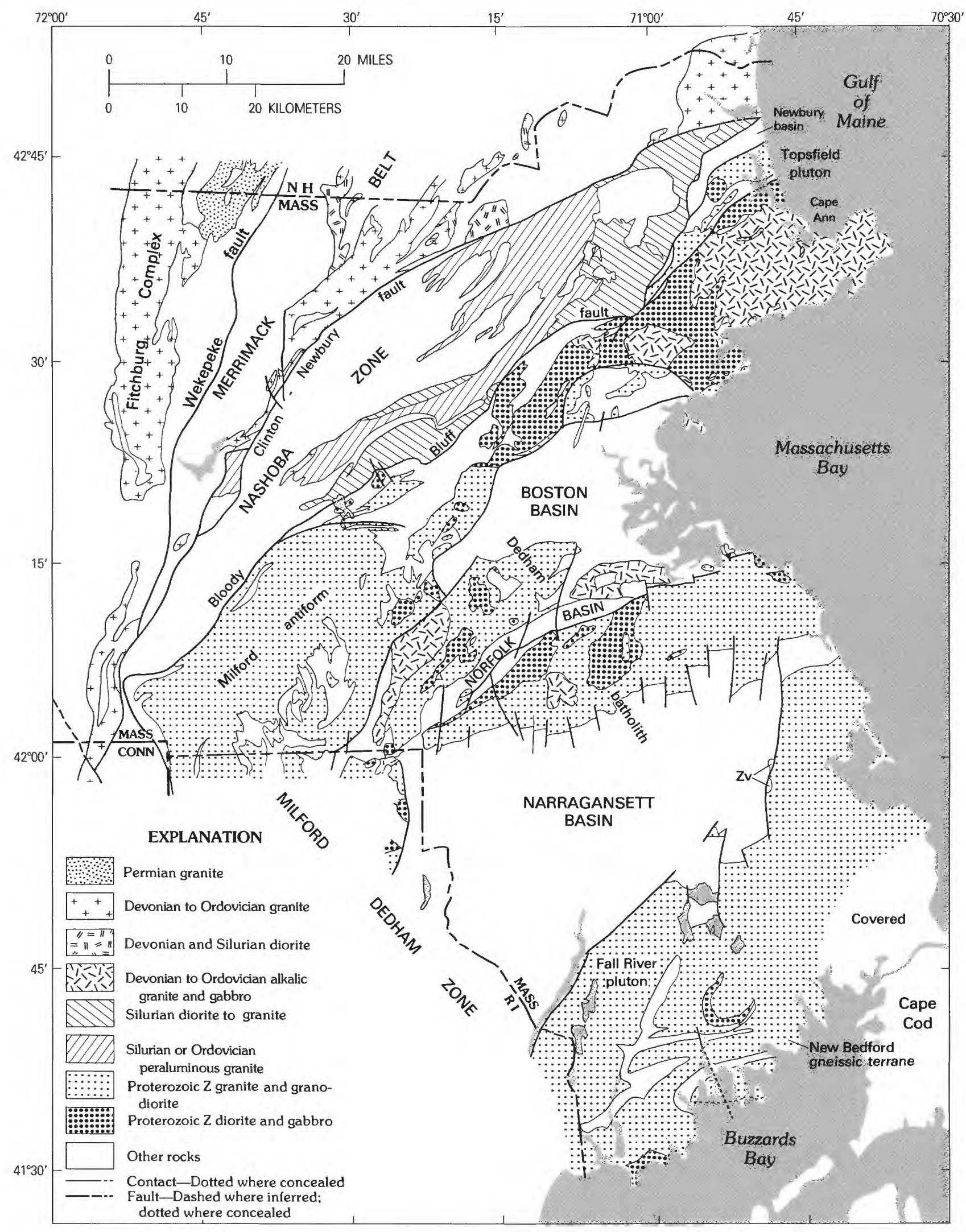

Figure 1.-Distribution of intrusive rocks of eastern Massachusetts. 


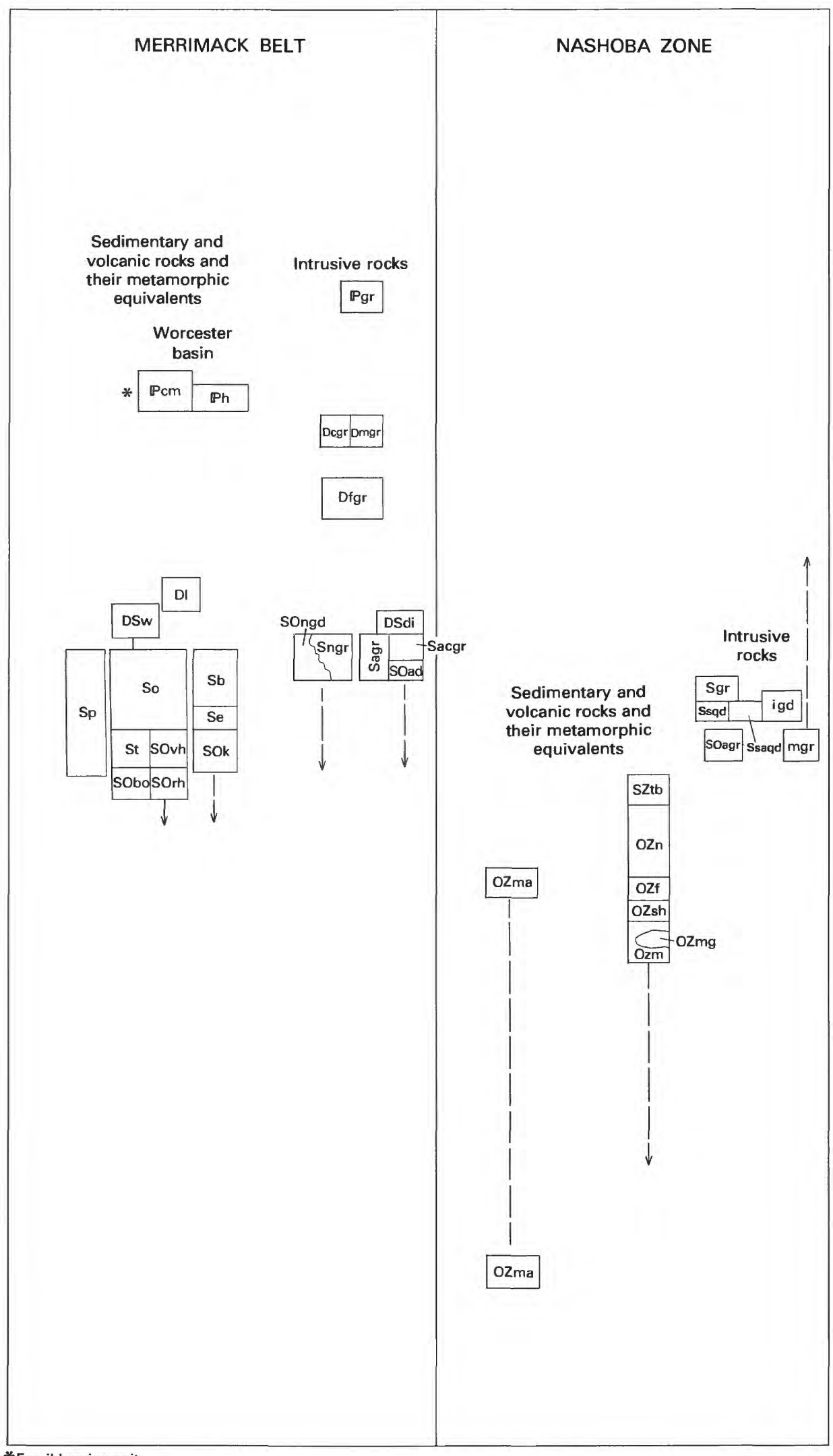

* Fossil-bearing unit

FIGURE 2.-Correlation of intrusive rocks and selected sedimentary and volcanic rocks and their metamorphosed equivalents in eastern Massachusetts; adapted from Zen and others (1983). 


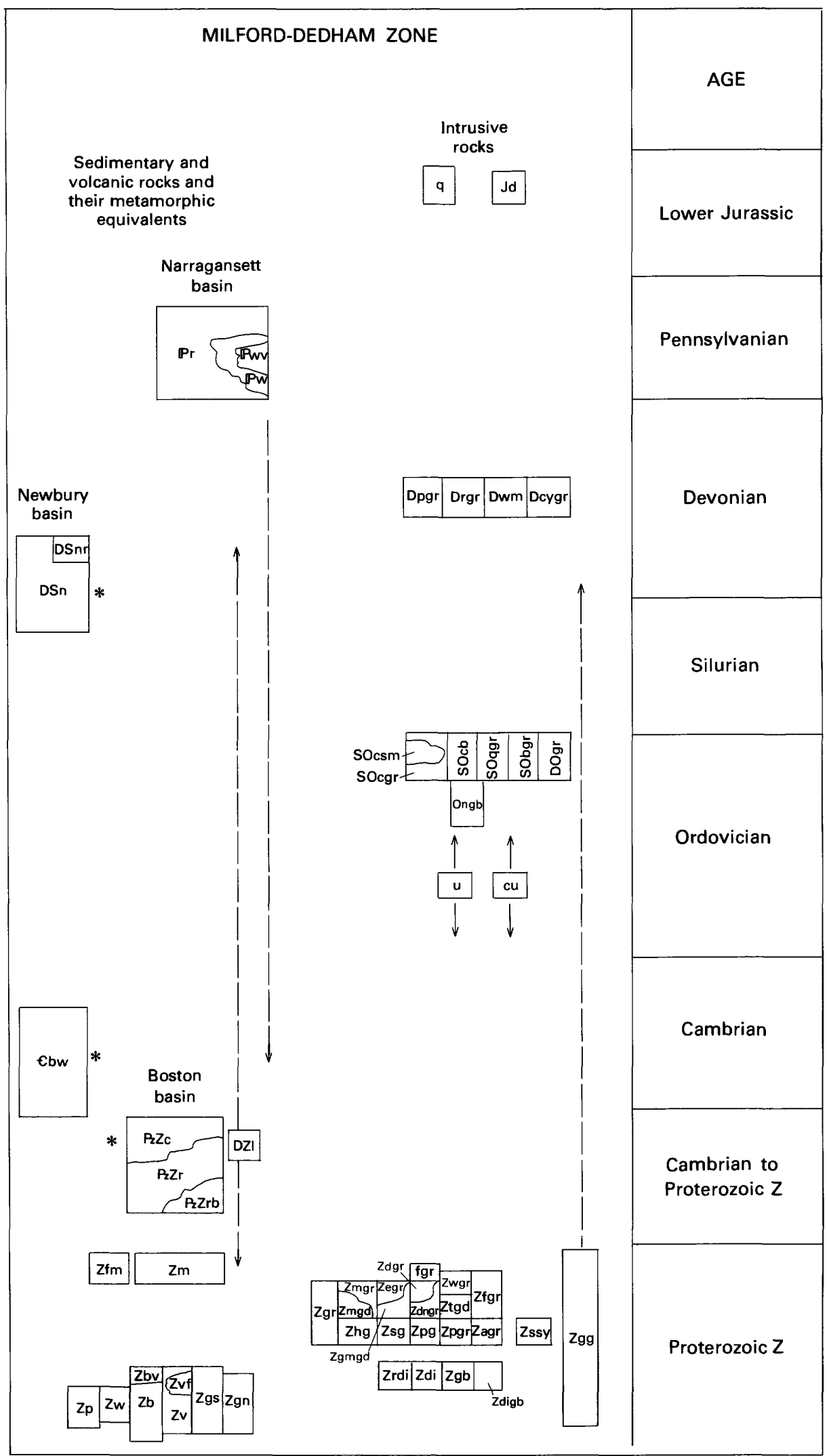

FIGURE 2.-Continued. 

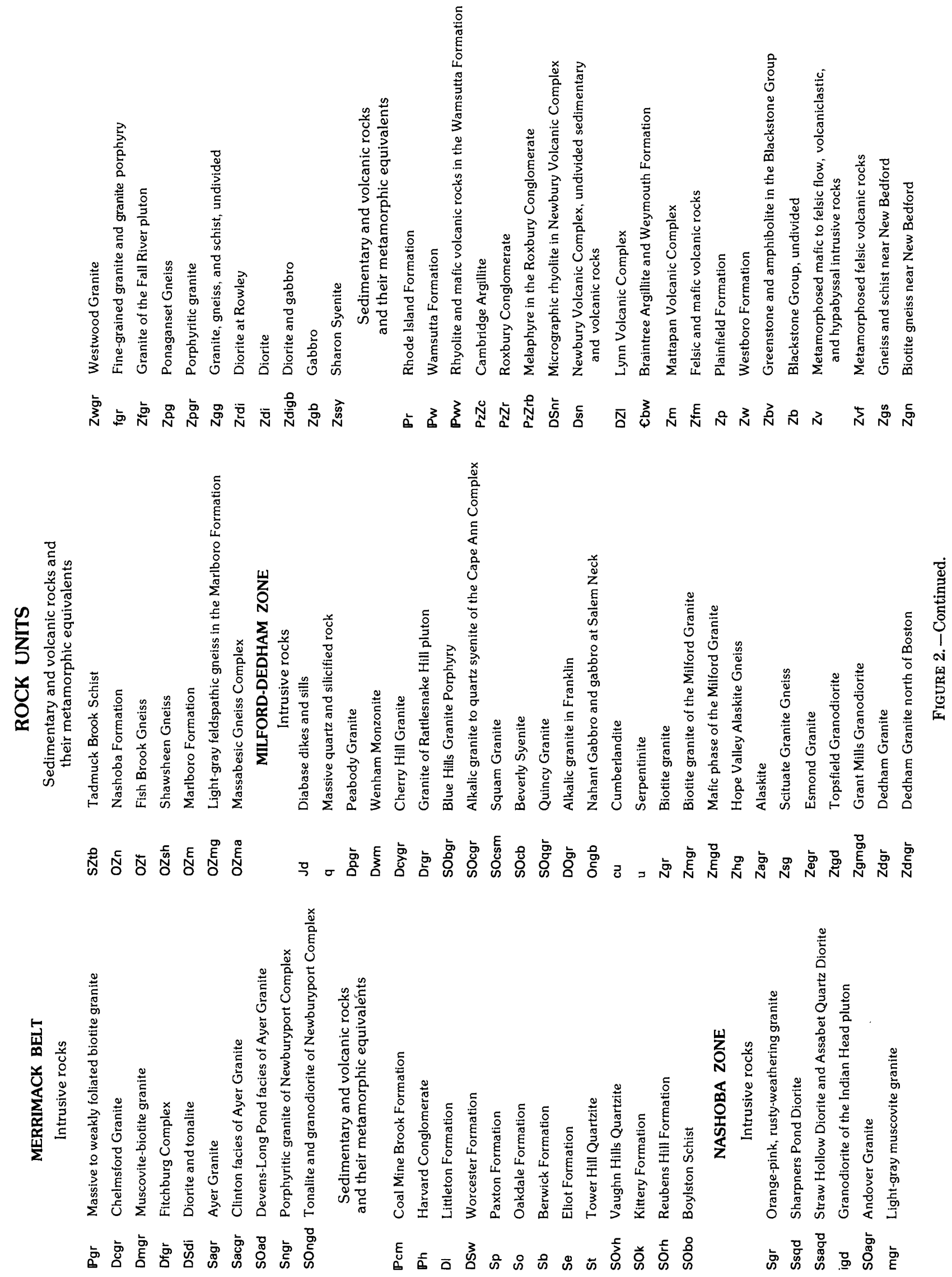
TABLE 1.-Ages and age relations of intrusive rocks of the Milford-Dedham zone

[Radiometric age data from Zartman and Marvin, this vol., chap. J, table 1. Ages are interpreted to be within 5 percent of primary age of the intrusion except as noted. bio, biotite; hbl, hornblende; rieb, riebeckite; wr, whole rock. -, no data]

\begin{tabular}{|c|c|c|c|}
\hline Map unit & Name & Intrudes & Age (Ma), method \\
\hline \multicolumn{4}{|c|}{ Mesozoic and younger rocks } \\
\hline $\mathrm{Jd}$ & Medford Diabase & - & $194 \pm 6, \mathrm{~K}-\mathrm{Ar} / \mathrm{bio}$ \\
\hline$u$ & Serpentinite & - & - \\
\hline \multicolumn{4}{|c|}{ Paleozoic rocks } \\
\hline Dpgr & Peabody Granite & $\begin{array}{l}\text { Zdigb; } \mathrm{Zv} \text {, metamorphosed mafic to } \\
\text { felsic volcanic rocks. }\end{array}$ & $\begin{array}{l}359 \pm 24, \mathrm{Rb}-\mathrm{Sr} / \mathrm{wr}, 395 \pm 20, \mathrm{U}-\mathrm{Pb} / \\
\text { zircon. }\end{array}$ \\
\hline Dwm & Wenham Monzonite & $\mathrm{Zdigb}, \mathrm{Zv}_{\mathrm{V}}$ & $395 \pm 20, \mathrm{U}-\mathrm{Pb} /$ zircon. \\
\hline Drgr & Granite of the Rattlesnake Hill pluton & $\mathrm{Zdgr}$ & $382 \pm 14, \mathrm{~K}-\mathrm{Ar} / \mathrm{rieb}$ \\
\hline DOgr & Alkalic granite in Franklin & - & - \\
\hline $\begin{array}{l}\text { SOcgr, } \\
\text { SOcb, } \\
\text { SOcsm. }\end{array}$ & Cape Ann Complex & Zdigb, Zv & $\begin{array}{l}426 \pm 6, \mathrm{Rb}-\mathrm{Sr} / \mathrm{wr}, 450 \pm 25, \mathrm{U}- \\
\mathrm{Pb} / \text { zircon. }\end{array}$ \\
\hline SOqgr & Quincy Granite & $\begin{array}{l}\text { Ebw, Braintree and Weymouth } \\
\text { Formations. }\end{array}$ & $\begin{array}{l}450 \pm 25 \text {, U-Pb/zircon, } 466 \pm 14, \mathrm{~K}- \\
\text { Ar/rieb. }\end{array}$ \\
\hline SObgr & Blue Hills Granite Porphyry & - & - \\
\hline Ongb & Nahant Gabbro and gabbro at Salem & Ebw & $450 \pm 13, \mathrm{Rb}-\mathrm{Sr} / \mathrm{bio}, 483 \pm 21, \mathrm{~K}-\mathrm{Ar} / \mathrm{bio}$ \\
\hline
\end{tabular}

Batholithic plutonic rocks of Proterozoic $Z$ age

\begin{tabular}{|c|c|c|c|}
\hline Zdgr & Dedham Granite & $\begin{array}{l}\text { Zdigb; Zv; Zdi; Zb, Blackstone Group; } \\
\text { Zw, Westboro Formation. }\end{array}$ & $630 \pm 15, \mathrm{U}-\mathrm{Pb} /$ zircon. \\
\hline Zdngr & Dedham Granite north of Boston & Zdi, Zgb, Zdigb, Zv, Zw & $595 \pm 17, \mathrm{Rb}-\mathrm{Sr} / \mathrm{wr}, 640 \pm 14, \mathrm{~K}-\mathrm{Ar} / \mathrm{hbl}$. \\
\hline Ztgd & Topsfield Granodiorite & Zdigb, Zrdi, Zv & - \\
\hline Zwgr & Westwood Granite & $\mathrm{Zdgr}$ & $579 \pm 28, \mathrm{Rb}-\mathrm{Sr} / \mathrm{wr}^{1}{ }^{1}$ \\
\hline Zegr & Esmond Granite & $\mathrm{Zb}$ & $621 \pm 8, \mathrm{U}-\mathrm{Pb} /$ zircon. $^{2}$ \\
\hline Zgmgd & Grant Mills Granodiorite & $\mathrm{Zb}$ & - \\
\hline fgr & Fine-grained granite & - & - \\
\hline Zfgr & Granite of the Fall River pluton & $\begin{array}{l}\text { Zgs, gneiss and schist near New Bed- } \\
\text { ford. }\end{array}$ & $630 \pm 15, \mathrm{U}-\mathrm{Pb} /$ zircon. \\
\hline Zpgr & Porphyritic granite & Zgs & - \\
\hline Zagr & Alaskite & $\begin{array}{l}\text { Zgs; Zgn, biotite gneiss near New Bed- } \\
\text { ford. }\end{array}$ & - \\
\hline Zgg & Granite, gneiss, and schist, undivided & - & - \\
\hline $\mathrm{Zgr}$ & Biotite granite & $\begin{array}{l}\text { Zdi; Zgb; Zw; Zvf, metamorphosed fel- } \\
\text { sic volcanic rocks. }\end{array}$ & - \\
\hline Zmgr & Milford Granite & $\mathrm{Zb}$ & $630 \pm 15, \mathrm{U}-\mathrm{Pb} /$ zircon. \\
\hline Zmgd & Milford Granite, mafic phase & $\mathrm{Zb}$ & - \\
\hline Zhg & Hope Valley Alaskite Gneiss & Zsg; Zp, Plainfield Formation & $\begin{array}{l}630 \pm 15, \mathrm{U}-\mathrm{Pb} / \text { zircon, } 601 \pm 5, \mathrm{U}-\mathrm{Pb} / \\
\text { zircon. }^{2}\end{array}$ \\
\hline Zsg & Scituate Granite Gneiss ${ }^{3}$ & $\mathrm{Zb}$ & $630 \pm 15, \mathrm{U}-\mathrm{Pb} /$ zircon. \\
\hline Zpg & Ponaganset Gneiss & - & - \\
\hline \multicolumn{4}{|c|}{ Proterozoic $\mathrm{Z}$ mafic plutonic rocks } \\
\hline Zrdi & Diorite at Rowley & $\mathrm{Zv}$ & $656 \pm 16, \mathrm{~K}-\mathrm{Ar} / \mathrm{hbl}$ \\
\hline Zdi & Diorite & - & - \\
\hline Zdigb & Diorite and gabbro & - & - \\
\hline $\mathrm{Zgb}$ & Gabbro & - & - \\
\hline Zssy & Sharon Syenite & - & - \\
\hline $\mathrm{cu}$ & Cumberlandite & - & - \\
\hline
\end{tabular}

batholithic rocks. It is possible that not all the rocks included in this category on the State bedrock map (Zdigb, Zgb, Zdi, Zssy) are of Proterozoic Z age. Some gabbros, for example, may be found to be of Ordovician or Devonian age and may be associated with the alkalic plutons. However, contact relations for many bodies 

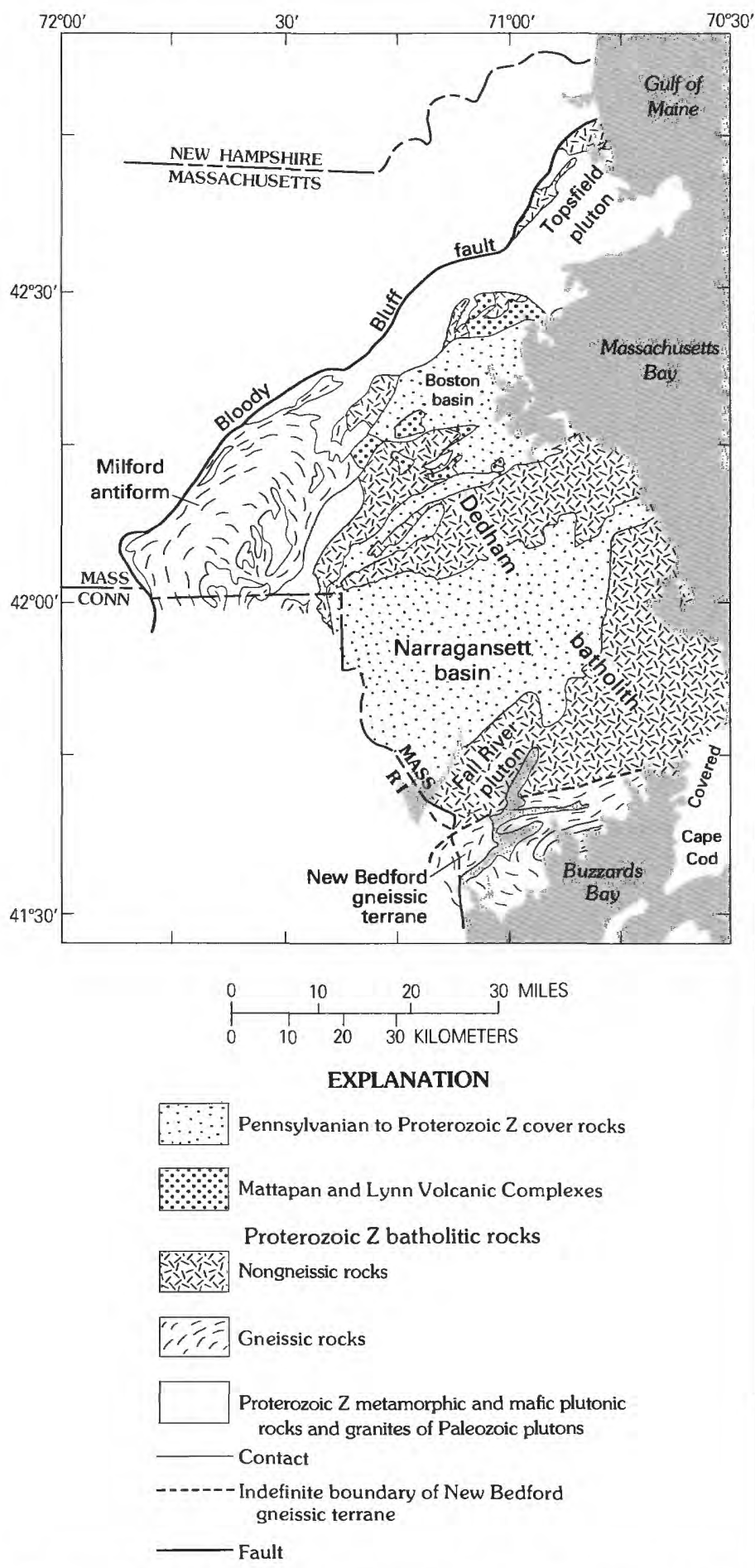

Figure 3.-Distribution of Proterozoic $\mathrm{Z}$ batholithic rocks in the Milford-Dedham zone.

indicate that the mafic rocks are older, possibly only slightly older, than the granite to granodiorite batholiths. Modes for some of these rocks are given on table 2.

\section{DIORITE AND GABBRO (Zdigb)}

The "diorite and gabbro" (Zdigb) designation was used on the State bedrock map for masses of diorite and gabbro, separated by many screens of stratified, largely mafic, metavolcanic rocks, that cannot be distinguished separately on the scale of the map. These masses are mostly northwest and north of Boston. In addition, small-scale intrusions of granitic rock of Proterozoic Z age are scattered through the unit. All of the rocks formerly mapped as Newburyport Quartz Diorite and all of the rocks that earlier workers (Emerson, 1917; Toulmin, 1964; Dennen, 1981) assigned to the Salem GabbroDiorite, except the gabbros at Salem Neck, have been included in Zdigb. Also included are intrusive mafic dikes and sills and light-colored dikes that may be contemporary or younger. Probably most of the rock mapped as Zdigb is gabbro rather than diorite, as for example the rock labeled diorite (table 3, no. 4) by Emerson. The two diorites (table 2, nos. 1-2) have a quartz content in the gabbro range. The Sharon Syenite (table 3, no. 3) is actually closer to a monzonite than a syenite.

The suite of mafic plutonic and metavolcanic rocks is well exposed in roadcuts along Route 2 in Arlington and Lexington (fig. 4). In Forest River Park, Salem, volcanic fabrics are preserved, and several ages of dikes are evident. These dikes may be equivalent to the Ordovician Nahant Gabbro, the Proterozoic Z Brighton Melaphyre, the diorite at Rowley, or the metavolcanic rocks.

The urbanization of the region and the superposed Pleistocene glacial deposits, coupled with several periods of fracturing and alteration, make distinguishing these mafic rocks a formidable task. Dennen $(1975,1981)$ suggested that much of the diorite and gabbro in the Cape Ann area is coeval with the Cape Ann Complex, the gabbro at Salem Neck, and the Nahant Gabbro. However, because much of the gabbro and diorite west of Cape Ann is intruded by the Dedham Granite and its equivalents in age, we have chosen to classify most of these rocks as Proterozoic $\mathrm{Z}$. The 656-Ma age of the diorite at Rowley (Zrdi) (table 1) and the 630-Ma age established by Zartman and Naylor (1984) for the granitic rocks at Lexington and Saugus (Zdngr, Zdgr) that in this area intrude gabbro and diorite and amphibolite ( $\mathrm{Zdigb}, \mathrm{Zv}$ ) indicate that much of the material called Salem Gabbro-Diorite by earlier workers is Proterozoic $\mathrm{Z}$ in age. Careful geologic mapping of individual outcrops at large scales, coupled with geochronologic studies, will be required to sort out the mafic rocks within this map designation. The wide variations in reported geochronologic ages may be true, even the suspicious $\mathrm{K}-\mathrm{Ar}$ age of $886 \pm 22 \mathrm{Ma}$ (Zartman and Marvin, this vol., chap. $\mathrm{J}$, table 1) for hornblende from a gabbroic pegmatite in Lexington. 


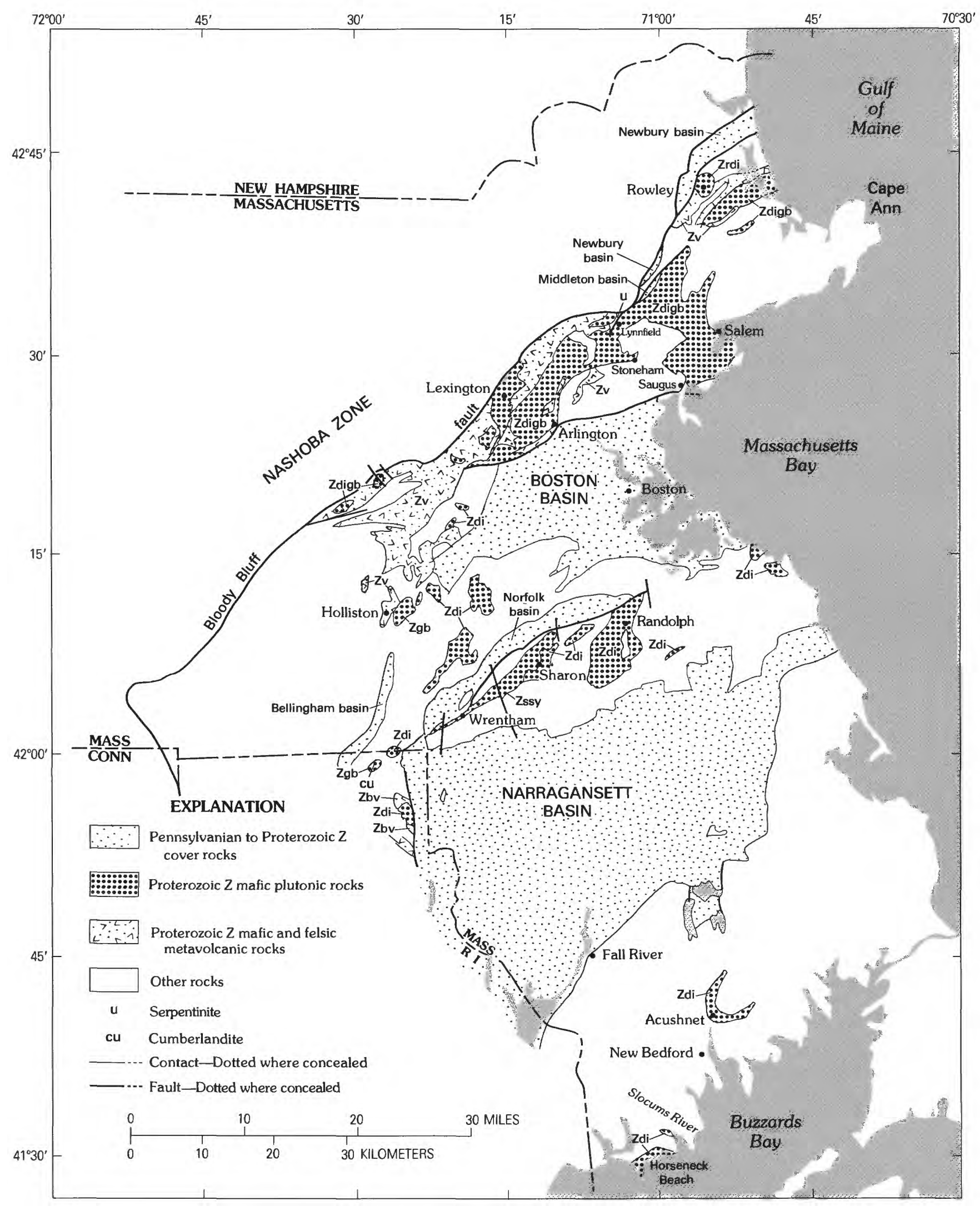

FIgURe 4.-Distribution of Proterozoic Z mafic plutonic and volcanic rocks in the Milford-Dedham zone. Zrdi, Diorite at Rowley; Zv, metamorphosed mafic to felsic volcanic rocks; Zdigb, diorite and gabbro; Zdi, diorite; Zgb, gabbro; Zssy, Sharon Syenite; Zbv, greenstone and amphibolite of the Blackstone Group. 
TABLE 2.-Modes, in percent, of representative plutonic rocks of the Proterozoic Z mafic volcanic-plutonic complex, Milford-Dedham zone

[Samples 1-4 are single thin sections of representative samples; sample 5 is an average of modes from 6 thin sections (Lyons, 1977); figures in parentheses give range of modes. Zdi, diorite; Zssy, Sharon Syenite. Sample localities shown by field number in Wones and others (1986). $n$, andesine; $n r$, not reported; tr, trace]

\begin{tabular}{|c|c|c|c|c|}
\hline $\begin{array}{lc}\text { Sample no....... } & 1 \\
\text { Unit ........... } & \text { Zdi } \\
\text { Points } & \\
\quad \text { counted ......... } & 1223 \\
\text { Field no........ } & \text { F-32 }\end{array}$ & $\begin{array}{c}1210 \\
\text { We- } 9^{*}\end{array}$ & $\begin{array}{c}1185 \\
\text { NBN-21a* }\end{array}$ & $\begin{array}{c}1528 \\
W-40^{*}\end{array}$ & $\begin{array}{c}5 \\
\text { Zssy }\end{array}$ \\
\hline Quartz......... 2.2 & 4.4 & 11.0 & 2.9 & $1.4(0.2-2.8)$ \\
\hline Plagioclase..... $7.4^{* *}$ & $42.8 n$ & 36.0 & 22.0 & $\mathrm{nr}$ \\
\hline Microcline...... 0 & 0 & .2 & 64.7 & $87.3(82.8-94.4)$ \\
\hline Biotite...... 26.8 & 13.7 & 14.0 & .7 & $\mathrm{nr}$ \\
\hline Epidote....... $34.4^{* *}$ & 3.6 & 7.8 & 0 & $\mathrm{nr}$ \\
\hline Hornblende .... 23.1 & 33.6 & 26.8 & .6 & $5.0(0.8-7.0)$ \\
\hline Chlorite........ .2 & .3 & 2.9 & 0 & $\mathrm{nr}$ \\
\hline Magnetite..... 2.0 & .7 & .4 & .9 & $1.8(0.5-3.3)^{\frac{*}{7}}$ \\
\hline Titanite....... 3.5 & .1 & .7 & 0 & $\mathrm{nr}$ \\
\hline Apatite........ . .3 & .8 & .2 & .3 & $\mathrm{nr}$ \\
\hline Allanite......... 0 & 0 & 0 & $\operatorname{tr}$ & $\mathrm{nr}$ \\
\hline Pyroxene...... 0 & 0 & 0 & 7.9 & $3.6(1.0-6.6)$ \\
\hline Other.........n nr & $\mathrm{nr}$ & $\mathrm{nr}$ & $\mathrm{nr}$ & $.8(0-1.3)$ \\
\hline
\end{tabular}

" Chemical analysis in table 3 .

** Most plagioclase converted to epidote.

${ }^{*}$ Reported as opaque minerals.

\section{GABBRO (Zgb)}

Gabbro (Zgb) of the State bedrock map comprises masses of gabbro that intrude older stratified rocks and have been intruded by younger Proterozoic rocks. Some masses are equivocal in their age limits and could be Paleozoic in age. Age relations are especially well preserved in the Holliston area (fig. 4; Volckmann, 1977), where the older stratified rocks, the intrusive gabbro, and the intruding Milford Granite can all be found. In the large roof pendant in this area, layering is well preserved in a gabbro that has been partly uralitized. A small mass of anorthositic gabbro is spatially associated with cumberlandite (cu) east of Woonsocket, R.I., but the contact relations are not known (Rutherford and Carroll, 1981; Rutherford and Hermes, 1984).

\section{DIORITE (Zdi)}

The diorite (Zdi) consists of undifferentiated masses of plagioclase-hornblende rock (tables 2, 3; fig. 4) that formed intrusive masses of intermediate composition; some recrystallized older volcanic rocks may be included in the category. The modal variations in the diorite are large. Some are quite rich in plagioclase, whereas others are enriched in amphibole or biotite. Much of the rock northeast of Boston that earlier workers assigned to the Newburyport Quartz Diorite has been included in this unit.
Many of the diorite masses are intruded by the Proterozoic $\mathrm{Z}$ batholithic assemblage of granite and granodiorite. In the large roof pendant near Randolph, and west of Spot Pond, Stoneham, recrystallization of the older volcanic rocks to dioritic- and quartz dioritic-appearing rocks in contact zones of the Dedham Granite is well exhibited. At Canton, between Randolph and Sharon, intrusive dikes of diorite can be found in the older volcanic rocks. We are unaware of any localities where diorite (Zdi) intrudes the Dedham Granite or its equivalents. A mass of altered diorite (Zdi) (table 2, no. 1; fig. 4) straddling the Massachusetts-Rhode Island State line southwest of Wrentham has septa of metavolcanic rocks of the Blackstone Group and apparently has intruded these rocks. Several masses of diorite crop out in the New Bedford area of southeastern Massachusetts (fig. 4). One of these forms a phacolithic mass well exposed in a local crushed-rock quarry (Warren Brothers quarry) at Acushnet. Two other partly lenticular masses crop out in scattered exposures near the mouth of Slocums River and along the shore at Horseneck Beach, Westport. The rock in the plutons ranges from gabbroic diorite to quartz diorite (table 2 , nos. 2-3; table 3, nos. 1-2). The diorite is dark gray, medium grained, and mostly nongneissic to faintly gneissic but is markedly foliated in and near shear zones. The rock consists mostly of hornblende, some of which contains relic pyroxene cores, and plagioclase and subordinate biotite and quartz. The plagioclase is a zoned, lathlike calcic andesine to labradorite in the Horseneck Beach pluton but is saussuritized in the Acushnet pluton. Accessory minerals are pyrite, titanite, apatite, and secondary chlorite and epidote.

Relations with the adjacent granitic rocks are not everywhere clear, and more than one age of diorite may be present. Most of the diorite masses of southeastern Massachusetts appear to be older than the granitic rocks. At Slocum's Neck, in the Slocums River area, diorite containing dark greenstone inclusions is cut by dikes of granite, and in one place an intrusion breccia consisting of fragments of diorite in a granitic matrix is exposed. On a point across the river to the east, however, a finegrained dike of diorite sharply cuts coarse-grained inequigranular granite. This dike is interpreted to be of Paleozoic or Mesozoic age. At Horseneck Beach, diorite is cut by alaskite and biotite granite. In the Warren Brothers quarry at Acushnet, diorite is intruded by even-grained granite or granodiorite that has a contact zone of spotted rock containing clots of biotite and hornblende. A few aplite and pegmatite dikes intrude all the rocks in this quarry.

\section{DIORITE AT ROWLEY (Zrdi)}

The diorite at Rowley (Zrdi) is a $5-\mathrm{km}^{2}$ circular stock of hornblende diorite that intrudes the metavolcanic rocks 
TABLE 3.-Major-oxide, normative-mineral, and trace-element compositions, volatiles omitted, of plutonic rocks of the Proterozoic $Z$ mafic volcanic-plutonic complex

[Major-oxide compositions for samples 1-3 from X-ray spectroscopy by Paul Hearn and Susan Wargo; all $\mathrm{Fe}$ reported as $\mathrm{Fe}_{2} \mathrm{O}_{3}$; sample 4, whole-rock analysis by H.S. Washington (in Emerson, 1917). Trace-element abundances from instrumental neutron activation analyses by L.J. Schwartz except $\mathrm{Rb}$ and Sr determined by X-ray spectroscopy by G.A. Sellars and B. McCall. Trace elements not determined for sample 4. nd, not determined]

\begin{tabular}{|c|c|c|c|c|}
\hline $\begin{array}{l}\text { Sample no. } \ldots \ldots \ldots \ldots \ldots \ldots \\
\text { Unit } \ldots \ldots \ldots \ldots \ldots\end{array}$ & $\begin{array}{c}1 \\
\text { Zdi }\end{array}$ & $\begin{array}{c}2 \\
Z \mathrm{Zdi}\end{array}$ & $\begin{array}{c}3 \\
\text { Zssy }\end{array}$ & $\begin{array}{c}4 \\
\text { Zdigb }\end{array}$ \\
\hline \multicolumn{5}{|c|}{$\begin{array}{l}\text { Major-oxide composition, in weight percent, } \\
\text { and alkali-alumina ratio }\end{array}$} \\
\hline $\mathrm{SiO}_{2} \ldots \ldots$ & 51.7 & 52.5 & 58.8 & 51.52 \\
\hline $\mathrm{Al}_{2} \mathrm{O}_{3} \ldots \ldots \ldots \ldots \ldots$ & 16.5 & 16.3 & 15.4 & 17.06 \\
\hline $\mathrm{Fe}_{2} \mathrm{O}_{3} \ldots \ldots \ldots \ldots \ldots$ & 9.46 & 8.37 & 9.65 & 1.97 \\
\hline $\mathrm{FeO} \ldots \ldots \ldots \ldots \ldots \ldots$ & nd & nd & nd & 8.60 \\
\hline $\operatorname{MnO} \ldots \ldots \ldots \ldots \ldots \ldots$ & .15 & .15 & .33 & 0 \\
\hline MgO................ & 6.2 & 7.2 & .1 & 4.87 \\
\hline $\mathrm{CaO} \ldots \ldots \ldots \ldots \ldots \ldots \ldots$ & 8.1 & 7.4 & 3.7 & 8.59 \\
\hline $\mathrm{Na}_{2} \mathrm{O} \ldots \ldots \ldots \ldots \ldots \ldots$ & 2.6 & 2.9 & 3.6 & 3.44 \\
\hline $\mathrm{K}_{2} \mathrm{O} \ldots \ldots \ldots \ldots \ldots \ldots$ & 1.44 & .71 & 4.92 & 1.77 \\
\hline $\mathrm{TiO}_{2} \ldots \ldots \ldots \ldots \ldots \ldots$ & 1.32 & .85 & .84 & 2.45 \\
\hline $\mathrm{P}_{2} \mathrm{O}_{5} \ldots \ldots \ldots \ldots \ldots \ldots$ & .35 & .16 & .18 & \\
\hline$\left(\mathrm{Na}_{2} \mathrm{O}+\mathrm{K}_{2} \mathrm{O}\right) / \mathrm{Al}_{2} \mathrm{O}_{3} \ldots \ldots$ & .24 & .22 & .55 & .30 \\
\hline \multicolumn{5}{|c|}{$\begin{array}{l}\text { Normative-mineral composition, in weight percent, } \\
\text { and differentiation index (DI) }\end{array}$} \\
\hline Qtz. . & 2.2 & 3.8 & 5.1 & 0 \\
\hline Crn $\ldots \ldots \ldots \ldots \ldots \ldots$ & 0 & 0 & 0 & 0 \\
\hline Or................... & 8.5 & 4.2 & 29.1 & 10.4 \\
\hline $\mathrm{Ab} \ldots \ldots \ldots \ldots \ldots \ldots \ldots$ & 21.9 & 24.5 & 30.4 & 29.1 \\
\hline An $\ldots \ldots \ldots \ldots \ldots \ldots$ & 29.1 & 29.4 & 11.3 & 25.8 \\
\hline Di.................. & 7.3 & 5.3 & 3.3 & 8.0 \\
\hline $\mathrm{Hd} \ldots \ldots \ldots \ldots \ldots \ldots$ & 0 & 0 & 0 & 5.8 \\
\hline Fo $\ldots \ldots \ldots \ldots \ldots \ldots$ & 0 & 0 & 0 & 4.5 \\
\hline $\mathrm{Fa} \ldots \ldots \ldots \ldots \ldots \ldots$ & 0 & 0 & 0 & 4.2 \\
\hline En $\ldots \ldots \ldots \ldots \ldots \ldots$ & 13.7 & 16.6 & .2 & 5.1 \\
\hline 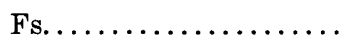 & 13.6 & 13.0 & 16.9 & 4.3 \\
\hline $\operatorname{Ilm} \ldots \ldots \ldots \ldots \ldots \ldots$ & 2.5 & 1.6 & 1.6 & 4.6 \\
\hline Ap $\ldots \ldots \ldots \ldots \ldots \ldots$ & .8 & .4 & .4 & 0 \\
\hline DI $\ldots \ldots \ldots \ldots \ldots \ldots$ & 33 & 32 & 65 & 39 \\
\hline
\end{tabular}

Trace-element abundances, in parts per million, and selected ratios

\begin{tabular}{|c|c|c|c|}
\hline $\mathrm{Rb} \ldots \ldots \ldots \ldots \ldots \ldots$ & 52 & 26 & 51 \\
\hline Cs................... & 1.8 & 1.2 & 3.7 \\
\hline $\operatorname{Sr} \ldots \ldots \ldots \ldots \ldots \ldots \ldots$ & 469 & 395 & 113 \\
\hline $\mathrm{Ba} \ldots \ldots \ldots \ldots \ldots \ldots$ & 477 & 216 & 2603 \\
\hline $\mathrm{Rb} / \mathrm{Cs} \ldots \ldots \ldots \ldots \ldots \ldots$ & 29 & 22 & 14 \\
\hline $\mathrm{Rb} / \mathrm{Sr} . \ldots \ldots \ldots \ldots \ldots$ & .1 & .06 & .4 \\
\hline Se..... & 22.6 & 25.8 & 20.3 \\
\hline Cr................... & 187 & 371 & nd \\
\hline 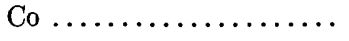 & 38.8 & 33.4 & 1.2 \\
\hline $\mathrm{Zn} \ldots \ldots \ldots \ldots \ldots \ldots$ & 115 & 122 & 132 \\
\hline La ................... & 24 & 21 & 31 \\
\hline $\mathrm{Ce}, \ldots \ldots \ldots \ldots \ldots \ldots$ & 50 & 65 & 41 \\
\hline Nd $\ldots \ldots \ldots \ldots \ldots \ldots \ldots$ & 26 & 21 & 42 \\
\hline $\operatorname{Sm} \ldots \ldots \ldots \ldots \ldots \ldots$ & 6 & 4 & 8 \\
\hline $\mathrm{Eu}, \ldots \ldots \ldots \ldots \ldots \ldots$ & 1.60 & 1.33 & 7.33 \\
\hline Gd $\ldots \ldots \ldots \ldots \ldots \ldots \ldots$ & 4.2 & 3.8 & 5.7 \\
\hline Но $\ldots \ldots \ldots \ldots \ldots \ldots$ & .6 & .6 & .7 \\
\hline
\end{tabular}

(Zv) in the town of Rowley. Contact relations with the adjacent Topsfield Granodiorite are not known. The only radiometric age from this group of rocks, $656 \mathrm{Ma}$ (table 1), comes from this stock. The diorite consists of plagioclase, hornblende, and biotite; it has been fractured and silicified, and the minerals have been altered to epidote and chlorite (Dennen, 1981).

\section{SHARON SYENITE (Zssy)}

The Sharon Syenite forms a long narrow mass along the southeast side of the Norfolk basin (fig. 4) of gray to dark-gray syenite and minor ferrogabbro. Both rock types are intruded by the Dedham Granite (Zdgr), but their relationship to other Proterozoic $\mathrm{Z}$ gabbros is unknown. Near Sharon, the map pattern suggests that the syenite is intruded by diorite ( $\mathrm{Zdi}$ ).

The syenite is gray and relatively unaltered; it is marked by ubiquitous minor hornblende (table 2, nos. 4-5; table 3, no. 3). Its modal composition is closer to that of a monzonite than of a syenite because of the amount of plagioclase. Pyrite is common and contributes to the

TABLE 3.-Major-oxide, normative-mineral, and trace-element compositions, volatiles omitted, of plutonic rocks of the Proterozoic $Z$ mafic volcanic-plutonic complex-Continued

\begin{tabular}{lcccc}
\hline Sample no. $\ldots \ldots \ldots \ldots \ldots \ldots$ & 1 & 2 & 3 & 4 \\
Unit $\ldots \ldots \ldots \ldots \ldots \ldots \ldots$ & Zdi & Zdi & Zssy & Zdigb
\end{tabular}

\begin{tabular}{|c|c|c|c|}
\hline \multicolumn{4}{|c|}{$\begin{array}{c}\text { Trace-element abundances, in parts per million, } \\
\text { and selected ratios-Continued }\end{array}$} \\
\hline$\Gamma \mathrm{b}$ & .81 & .70 & 1.07 \\
\hline $\operatorname{Tm} .$. & .32 & .29 & .47 \\
\hline$\ldots \ldots$ & 2.1 & 2.3 & 2.7 \\
\hline Lu ... & .29 & .34 & .45 \\
\hline $\mathrm{La} / \mathrm{Yb} \ldots \ldots \ldots \ldots \ldots \ldots$ & 11 & 9 & 11 \\
\hline Hf........... & 3.7 & 3.4 & 2.4 \\
\hline Zr.. & nd & nd & nd \\
\hline $\mathrm{Th}^{2}$ & 5.0 & 3.4 & 2.3 \\
\hline Th . . & 4.6 & 3.2 & 2.6 \\
\hline $\mathrm{U}^{2} \ldots \ldots \ldots \ldots \ldots \ldots$ & 1.4 & .9 & .6 \\
\hline $\mathrm{U} \ldots \ldots \ldots \ldots \ldots \ldots \ldots$ & 1.4 & 1.0 & nd \\
\hline
\end{tabular}

${ }^{1} \mathrm{Fe}_{2} \mathrm{O}_{3}$ calculated as $\mathrm{FeO}$, except sample 4 .

${ }^{2}$ Delayed neutron reactivation determination by H.T. Millard, Jr., and C. McFee.

Description of samples

Sample localities shown in Wones and others (1986)

1. We-9. Diorite; biotite hornblende diorite cut by alaskite and granite; ledges east end of East Horseneck Beach, 200 m east of Horseneck Road. UTM grid: N45968-E3312.

2. NBN-21a. Diorite; biotite hornblende quartz diorite; Warren Brothers quarry, Main St., $1 \mathrm{~km}$ south of Acushnet center. UTM grid: N46151-E3414.

3. W-40. Sharon Syenite; loose blocks at water tank at top of Knuckup Hill, $1.1 \mathrm{~km}$ south of Wrentham center. UTM grid: N46585-E3069.

4. Diorite and gabbro; diorite; Peaches Neck, Salem; from Emerson (1917, p. 180 , no. 1 in table), $\mathrm{H}_{2} \mathrm{O}$ also reported. 
characteristic deep rusty weathering of the Sharon Syenite (Chute, 1966) and its high iron content. Lyons (1969) described the syenite and found the ranges in modal composition shown in table 2 . The mafic-mineral content of these rocks ranges between 7 and 16 percent.

The Dedham Granite intrudes the Sharon Syenite in outcrops along Route I-95 southwest of Sharon, where small dikes of Dedham lithology have become desilicated and crystallized as quartz syenite. These syenites are distinctly different from the dark, coarse-grained, sulfide-bearing rocks typical of the Sharon Syenite.

\section{CUMBERLANDITE (cu)}

Cumberlandite (cu, fig. 4), actually a mela-troctolite, is an unusual cumulate rock that crops out in northeastern Rhode Island (Rutherford and Carroll, 1981; Rutherford and Hermes, 1984); it is presumably genetically related to the adjacent anorthositic gabbro (Zgb), which intrudes the Blackstone Group ( $\mathrm{Zb})$. The contact relations of the cumberlandite itself with the Blackstone Group or with the adjacent Esmond Granite (Zegr) of Rhode Island are not known (O.D. Hermes, written commun., 1984). Hermes has found chemical evidence to suggest that the gabbro could be related to the Paleozoic alkalic magmatic rocks rather than to the Proterozoic $\mathrm{Z}$ suite. The cumberlandite is a black, dense rock that contains tabular plagioclase in a preferred orientation. Rutherford and Carroll (1981) reported a mode of 49 percent olivine, 32 percent titaniferous magnetite, 15 percent plagioclase, and accessory ilmenite and Al-rich spinel.

\section{SERPENTINITE (u)}

Serpentinite forms a poorly exposed, ill-defined mass (u, fig. 4) within the undifferentiated diorite and gabbro (Zdigb) in the town of Lynnfield. It may be part of the Proterozoic $\mathrm{Z}$ plutonic and volcanic complex, but, as it lies along a highly faulted zone (Goldsmith, this vol., chap. H), assigning an age is difficult. Kaye (1983, p. 1076), for example, suggested that it is ultramafic material injected into a shear zone. If so, it is more likely to be middle to late Paleozoic in age, or possibly Mesozoic. We feel, however, that it is more likely a highly sheared and altered ultramafic rock of the Proterozoic $\mathrm{Z}$ mafic complex.

\section{DISCUSSION OF THE MAFIC PLUTONIC ROCKS}

The diorites (Zdi, Zdigb, tables 2 and 3) appear to be normal mafic rocks of a calc-alkaline suite (figs. 5-8) and to have normal rare-earth-element (REE) patterns (fig. 9). The Sharon Syenite, on the other hand, differs from others of the suite and from the Proterozoic $\mathrm{Z}$ batholithic rocks. The Sharon is off the calc-alkaline trend in the
Peacock diagram (fig. 6) and has a positive rather than a negative europium anomaly (fig. 9), suggesting cumulate plagioclase or K-feldspar. It does, however, fall on trend with the diorites in thorium-uranium ratio (fig. 10).

\section{PROTEROZOIC Z BATHOLITHIC ROCKS}

The Proterozoic $\mathrm{Z}$ batholithic rocks fall into two major groups, those in the Dedham batholith and those in the Milford antiform (figs. 3, 11). The former tend to be nongneissic, primarily brittlely deformed, whereas the latter tend to be gneissic or partly gneissic and to have been ductilely deformed. An exception to this grouping is the plutonic rocks at the south end of the Dedham batholith, southeast of the Fall River pluton, which tend also to be gneissic. The Topsfield Granodiorite is considered to be an outlier of the Dedham batholith. All these rocks are approximately the same age, about $630-580 \mathrm{Ma}$ (table 1). These batholithic rocks have been sampled more extensively (Wones and others, 1986) than the Proterozoic Z mafic plutonic rocks, and so more mineralogical and chemical data are available. Major constituents of these rocks (derived from point-counts of stained slabs) are listed in table 4, and their relative amounts are plotted in figures 5 and 12-14. Modes from point-counts of thin sections from some of these rocks and chemical compositions of some of these rocks are listed in tables 5-10.

\section{DEDHAM BATHOLITH}

\section{Dedham Granite (Zdgr, Zdngr)}

The Dedham Granite (Zdgr) occupies a large area within several regions in the Milford-Dedham zone (fig. 11). The Dedham north and west of the Boston basin consists of both granite and granodiorite (Zdngr; table 5 , no. 6; table 6, nos. 7-8). The Dedham intrudes rocks of the Blackstone Group ( $\mathrm{Zb})$, the Westboro Formation $(\mathrm{Zw})$, and the mafic volcanic-plutonic complex (Zdigb, Zdi, Zgb, Zv).

Contacts with older rocks are particularly well exposed in Saugus, Stoneham, Canton (C, fig. 11), and Cohasset, although dikes of granitic rocks similar to the Dedham are found throughout the Proterozoic $\mathrm{Z}$ terrane southeast of the Bloody Bluff fault zone. Igneous breccias in which the Dedham encloses blocks of mafic rock are well exposed west of Spot Pond in Stoneham and in Cohasset. Near Arlington, granite dikes grade into syenite where they terminate within the older masses of amphibolite and gabbro. Small masses of pink granite intruding diorite and gabbro north of the Boston basin are considered to belong to the northern, more mafic phase of the Dedham (Zdngr); this pink granite is the most mafic of the rocks mapped as Dedham. 


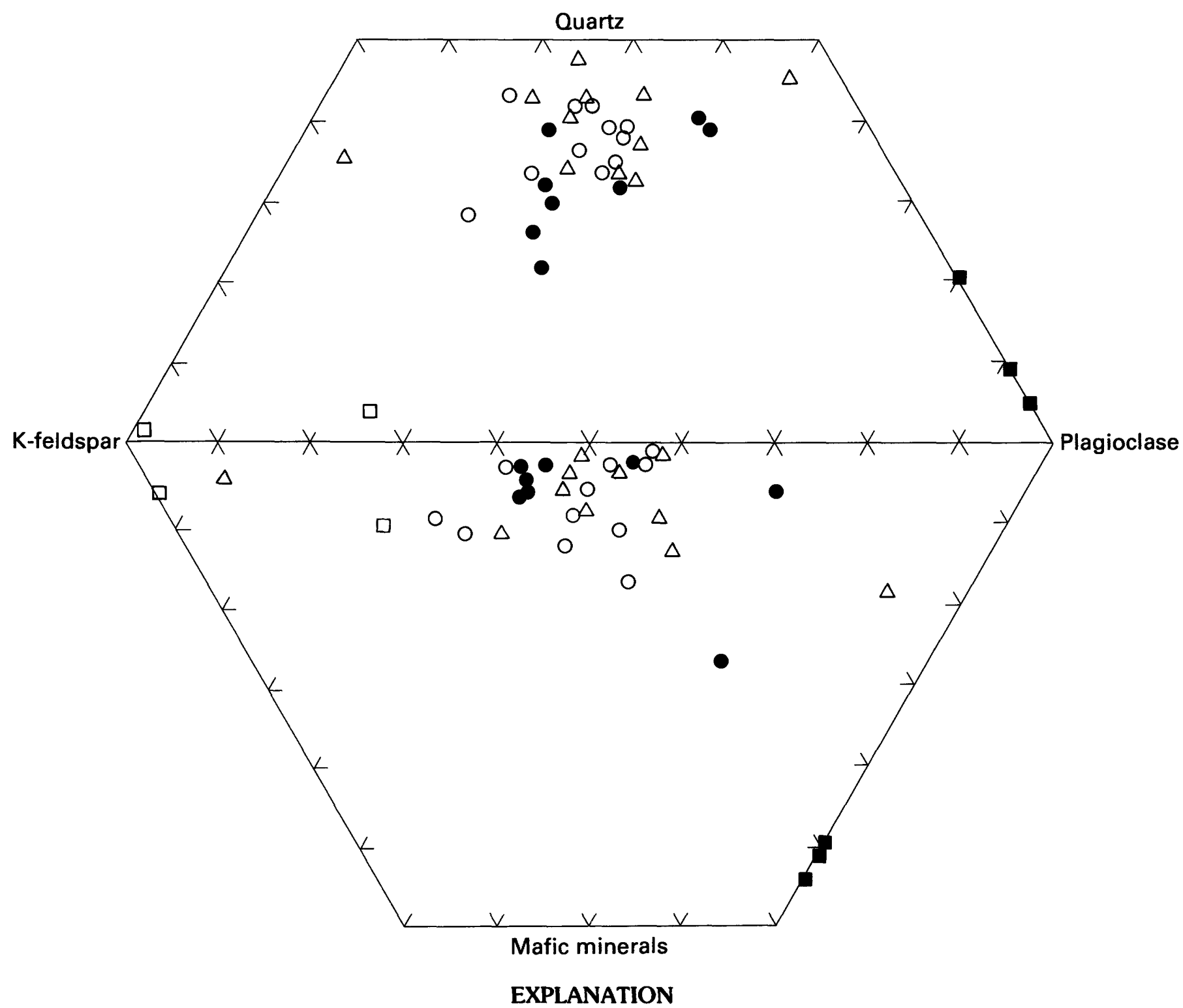

- Dedham Granite, Esmond Granite, and Westwood Granite (table 5)

- Granites of southeastern Massachusetts (table 7)

$\triangle$ Plutonic rocks of the Milford antiform (table 9)

- Proterozoic $\mathrm{Z}$ mafic plutonic rocks (table 2)

$\square \quad$ Sharon Syenite (table 2)

FIGURE 5. -Q-P-K-M (quartz-plagioclase-K-feldspar-mafic minerals) diagram of modes of Proterozoic Z intrusive rocks of the Milford-Dedham zone from tables 2, 5, 7, and 9. Mafic minerals used are biotite, hornblende, pyroxene, iron oxides, and chlorite.

The Dedham Granite is typically medium to coarse grained, is commonly fractured, and usually has a salmon color mottled by green clots of epidote and chlorite formed by alteration. Fresh rocks that do not contain closely spaced (less than $1 \mathrm{~m}$ ) joints are gray. Weathered surfaces commonly have prominent knobs of quartz, the so-called "hob-nailed boot" texture. Modes of Dedham Granite (tables 4-6) and ternary plots (figs. 5, 12) show that the composition ranges mostly from granite to granodiorite. A few are quartz monzodiorite to 


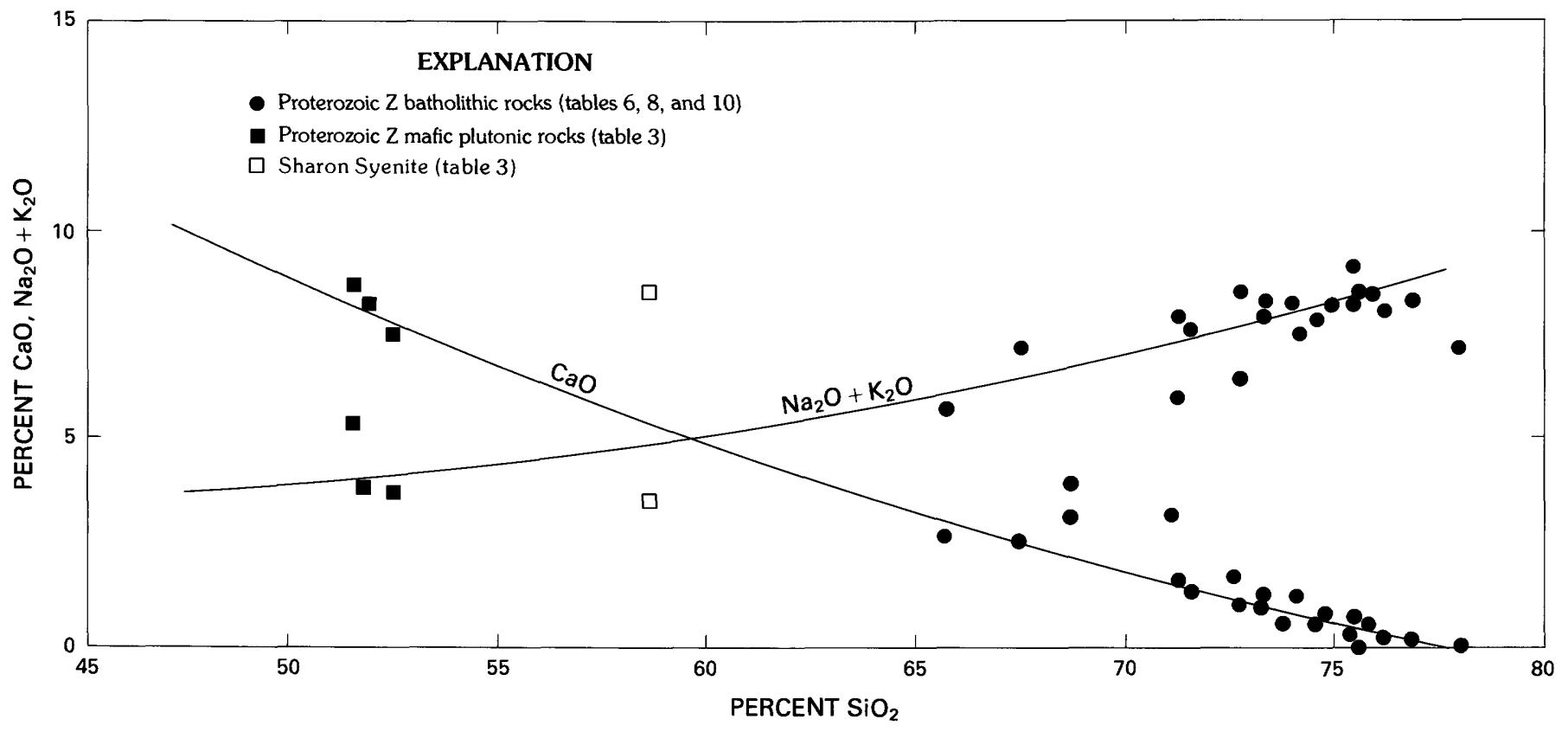

FIGURE 6. $-\mathrm{CaO}$ and $\mathrm{Na}_{2} \mathrm{O}+\mathrm{K}_{2} \mathrm{O}$ plotted against $\mathrm{SiO}_{2}$ for Proterozoic $\mathrm{Z}$ intrusive rocks of the Milford-Dedham zone. Lines are approximate fit to data.

monzonite. The K-feldspar crystals are perthitic and subhedral, and they appear to have formed with plagioclase and quartz early in the crystallization sequence. The plagioclase is partly saussuritized; chemical analyses (table 6) indicate that the plagioclase probably ranged from albite to andesine but was mostly oligoclase. Biotite is the dominant mafic mineral, although there are trace amounts of hornblende in some rocks. Titanite is ubiquitous as euhedral primary crystals and as anhedral products of biotite alteration. Apatite, zircon, magnetite, and other opaque minerals are common accessories. Plagioclase has been altered to the assemblage albite-sericiteepidote, and biotite and hornblende have altered to chlorite, epidote, and titanite. A hematite dust in the alkali feldspars gives the rock its characteristic salmon color.

REE analyses show a general enrichment in light REE and a negative europium anomaly (fig. 15), although two samples ( 2 and 3 , table 6 ) show a lower and flatter pattern of heavy REE with respect to chondrite than the others, and sample 9 is less enriched in light REE. The profile of the mafic sample of Dedham Granite north of Boston is similar to the other profiles but is elevated above them, suggesting an overall enrichment of some sort.

The Dedham Granite is enriched in anorthite, hornblende, and biotite where it is close to the older mafic rocks, confirming Crosby's (1913) ideas on assimilation of wall rocks. Most of the modes that plotted in the granodiorite and tonalite fields (figs. 5, 12) were collected from rocks close to the older rocks. The K-feldspar content increases from north to south within the Dedham Granite and its related rocks. This increase may be an actual gradient, or perhaps a deeper erosional level is exposed in the south and assimilated roof pendant material has contaminated the shallower portions of the batholith exposed toward the north.

The Dedham Granite also contains porphyritic varieties, not distinguished in table 4 , that contain alkali feldspar megacrysts $1-4 \mathrm{~cm}$ long and $0.5-2 \mathrm{~cm}$ wide. Lyons (1969) identified a separate pluton of this variety in the area north of Mansfield that he named the Barefoot Hill quartz monzonite (no. 1, table 6). The Barefoot Hill quartz monzonite of Lyons is included in the Dedham Granite on the State bedrock map because it is in gradational contact with the Dedham in the region of Brockton (Chute, 1950) and is herewith referred to as the porphyritic variety of Dedham. The REE pattern for the porphyritic granite is only slightly richer in heavy REE than samples 2 and 3 (table 6 ). Porphyritic rocks occupy large areas near Brockton and Assawompset Pond. According to Lyons, the same rock appears in the inlier of basement near Middleboro (fig. 11) and is probably the porphyritic granite (Zpgr) of the Fall River-New Bedford area. There is an apparent concentration of this variety of the Dedham Granite to the southeast in the Milford-Dedham zone.

The Dedham Granite as mapped on the State bedrock map may include small masses of younger granite, such as the Westwood Granite, whose boundaries have not 


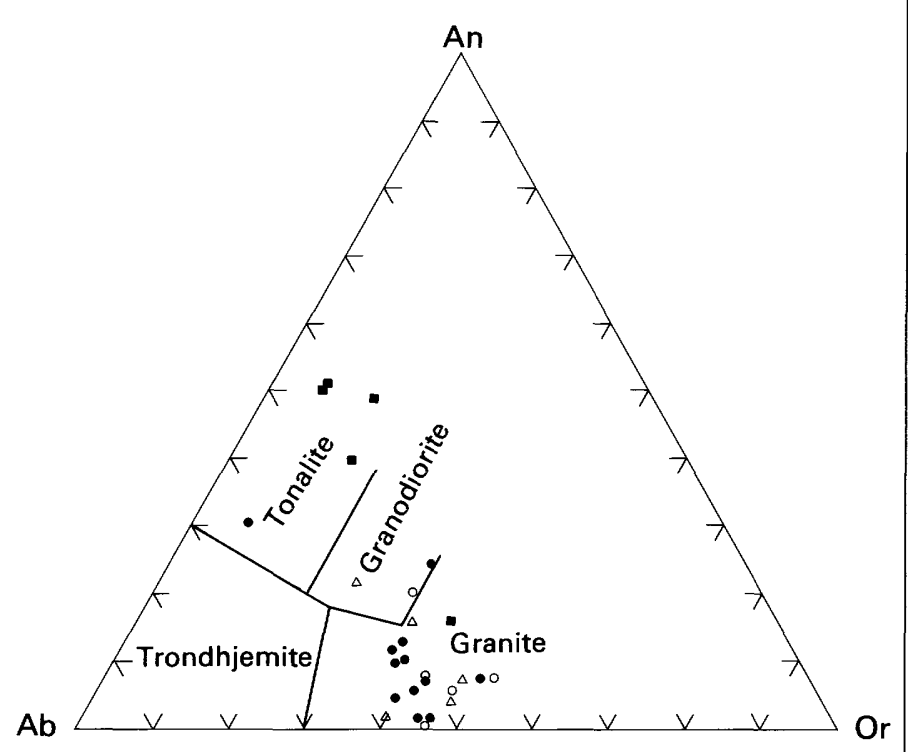

EXPLANATION

- Plutonic rocks of northeastern Massachusetts (table 6)

- Plutonic rocks of southeastern Massachusetts (table 8)

$\triangle$ Plutonic rocks of the Milford antiform (table 10)

- Proterozoic $\mathrm{Z}$ mafic plutonic rocks (table 3)

FIGURE 7. - Ternary plot of normative albite (Ab), anorthite (An), and orthoclase (Or) for Proterozoic Z intrusive rocks of the MilfordDedham zone. Fields of silica-saturated rocks from O'Connor (1965) as modified by Barker (1979).

been determined. The rock that Chute (1965b) mapped as Westwood Granite in the Scituate and Marshfield areas was believed by Wones to be a phase of the Dedham and not the typical Westwood. It is possible, but not certain, that the terrane underlain by the Dedham Granite is a composite of many smaller plutons. Bateman and others (1963) demonstrated that the Sierra Nevada batholith is a composite batholith but that individual plutons within it are commonly larger than the $1,400 \mathrm{~km}^{2}$ estimated for the Dedham Granite. The cover of glacial deposits, urban development, and extensive faulting in eastern Massachusetts have made it difficult to resolve this question.

\section{Topsfield Granodiorite (Ztgd)}

The Topsfield Granodiorite (Ztgd), first described by Toulmin (1964), occupies an area of $80 \mathrm{~km}^{2}$ between Middleton and Newbury (fig. 11). It intrudes the diorite and gabbro (Zdigb) and mafic and felsic metavolcanic rocks $(\mathrm{Zv})$. It is bounded on the northwest by faults bordering the Newbury and Middleton basins and northward extensions of the Bloody Bluff (and Mystic?) fault zones (Goldsmith, this vol., chap. $\mathrm{H}$ ), and on the south- east by a splay(?) off the Bloody Bluff fault. Although the Topsfield Granodiorite has not been dated, we consider it to be part of the Proterozoic $\mathrm{Z}$ batholithic assemblage because it is similar in mineralogy and alteration to the Dedham Granite and because it intrudes the Proterozoic $\mathrm{Z}$ mafic complex. It is probably overlain by the Silurian and Devonian Newbury Volcanic Complex (Dennen, 1975). The contact is now a fault.

The composition of the Topsfield ranges from granite to tonalite. The only sample shown in figure 12 happens to be a tonalite. The Topsfield is typically altered to red and green. The plagioclase is altered to sericite and epidote, and it is strongly dusted with hematite. In places, blue quartz forms large anhedral grains or mosaics of grains. Much of the rock is transected by recrystallized mylonite bands that truncate and incorporate altered grains, implying that some of the deformation postdates the alteration. The one sample described here (table 4; table 6, no. 9) is a typical tonalite. The REE profiles (fig. 15) are flat and are approximately three times the values for chondrites, quite unlike rocks of similar bulk composition (Frey and others, 1978). The thorium content is unusually low relative to uranium, which may reflect the relatively high degree of alteration of the rock.

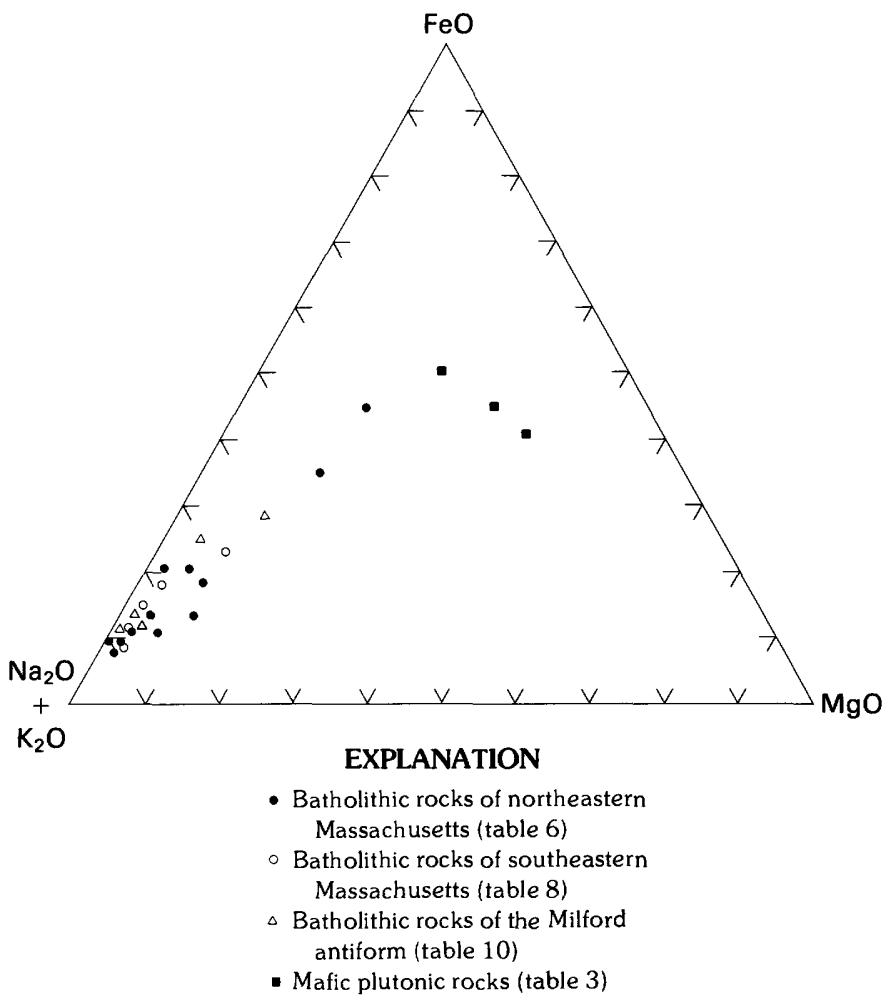

Figure 8. - Ternary AFM (alkalis-FeO-MgO) plot of Proterozoic Z intrusive rocks of the Milford-Dedham zone. 
TABLE 4.-Major constituents, in percent, determined by point-count of stained slabs of intrusive rocks of the Milford-Dedham zone $[1,200-2,000$ points counted per slab. Totals may not sum to 100 because of rounding. Sample localities shown by field number in Wones and others (1986)]

\begin{tabular}{|c|c|c|c|c|c|c|}
\hline \multirow{2}{*}{$\begin{array}{c}\text { Sample } \\
\text { no. }\end{array}$} & \multicolumn{2}{|c|}{ UTM grid } & \multirow{2}{*}{ Quartz } & \multirow{2}{*}{ K-feldspar } & \multirow{2}{*}{ Plagioclase } & \multirow{2}{*}{$\begin{array}{c}\text { Mafic } \\
\text { minerals }\end{array}$} \\
\hline & N. & E. & & & & \\
\hline \multicolumn{7}{|c|}{ Dedham Granite south of the Boston basin (Zdgr) } \\
\hline DMA-30 ... & 46770 & 3220 & 33.0 & 28.5 & 33.6 & 5.0 \\
\hline DMA-32 ... & 46781 & 3196 & 29.4 & 23.8 & 45.6 & 1.2 \\
\hline DMA-33 ... & 46779 & 3197 & 29.6 & 35.8 & 32.6 & 2.1 \\
\hline DMA-34 ... & 46767 & 3196 & 10.2 & 15.3 & 62.5 & 12.0 \\
\hline DMA-34A... & 46766 & 3190 & 29.7 & 29.4 & 37.5 & 3.4 \\
\hline DMA-41 $\ldots$ & 46481 & 3050 & 46.7 & 30.5 & 22.5 & .3 \\
\hline DMA-93 ... & 46813 & 3242 & 31.0 & 38.1 & 24.3 & 6.6 \\
\hline DMA-94 . . . & 46603 & 3158 & 34.4 & 36.7 & 24.7 & 4.5 \\
\hline DMA-98 . . . & 46729 & 3360 & 30.9 & 38.4 & 29.1 & 1.5 \\
\hline DMA-99 . . . & 46729 & 3360 & 25.7 & 39.7 & 31.9 & 2.7 \\
\hline DMA-100 ... & 46717 & 3361 & 20.0 & 42.1 & 30.9 & 7.0 \\
\hline DMA-101 $\ldots$ & 46701 & 3369 & 31.2 & 20.0 & 43.2 & 5.6 \\
\hline DMA-102 $\ldots$ & 46677 & 3358 & 25.0 & 29.8 & 39.3 & 5.9 \\
\hline DMA-104 ... & 46718 & 3387 & 22.4 & 44.4 & 24.6 & 8.5 \\
\hline DMA-105 . . & 46723 & 3388 & 19.6 & 10.8 & 64.5 & 5.1 \\
\hline DMA-108 ... & 46621 & 3429 & 30.0 & 35.8 & 32.5 & 1.6 \\
\hline DMA-109B . . & 46720 & 3425 & 30.9 & 29.3 & 35.2 & 4.5 \\
\hline DMA-116 ... & 40787 & 3421 & 15.4 & 30.8 & 44.0 & 9.8 \\
\hline DMA-117A . . & 46798 & 3462 & 21.0 & 18.4 & 51.2 & 9.2 \\
\hline DMA-119 . . & 46799 & 3475 & 20.3 & 33.5 & 39.6 & 6.7 \\
\hline DMA-120 ... & 46804 & 3485 & 29.4 & 35.4 & 29.4 & 5.8 \\
\hline DMA-121 . . & 46807 & 3494 & 19.4 & 22.4 & 45.0 & 13.2 \\
\hline DMA-123 ... & 46773 & 3524 & 29.7 & 36.8 & 28.8 & 4.7 \\
\hline DMA-129 . . & 46597 & 3568 & 30.2 & 47.6 & 19.9 & 2.3 \\
\hline DMA-132 ... & 46566 & 3571 & 30.1 & 45.0 & 22.3 & 2.6 \\
\hline DMA-138 ... & 46601 & 3552 & 38.5 & 32.8 & 23.4 & 5.3 \\
\hline DMA-140 . . & 46588 & 3536 & 35.0 & 11.1 & 49.8 & 4.1 \\
\hline DMA-143 ... & 46618 & 3456 & 37.0 & 28.3 & 33.3 & 1.4 \\
\hline DMA-146 . . & 46644 & 3392 & 30.0 & 28.0 & 38.9 & 3.1 \\
\hline DMA-147 . . & 46646 & 3390 & 24.4 & 15.0 & 48.9 & 11.6 \\
\hline DMA-150 . . . & 46632 & 3353 & 26.1 & 28.5 & 41.4 & 4.0 \\
\hline DMA-151 ... & 46649 & 3346 & 29.2 & 37.9 & 30.9 & 2.0 \\
\hline DMA-153B . . & 46653 & 3316 & 30.8 & 39.2 & 27.9 & 2.0 \\
\hline DMA-157 ... & 46614 & 3248 & 26.9 & 20.4 & 46.3 & 6.3 \\
\hline DMA-158 . . & 46590 & 3231 & 32.1 & 29.8 & 33.9 & 4.2 \\
\hline DMA-159 . . & 46587 & 3205 & 29.7 & 24.9 & 34.1 & 6.3 \\
\hline DMA-160 ... & 46613 & 3182 & 34.7 & 41.6 & 19.3 & 4.4 \\
\hline DMA-166 ... & 46609 & 3295 & 26.7 & 24.4 & 43.6 & 5.2 \\
\hline DMA-196 . . . & 46558 & 3009 & 27.9 & 35.0 & 34.0 & 3.0 \\
\hline DMA-201 . . & 46695 & 3018 & 33.9 & 39.1 & 23.5 & 3.6 \\
\hline DMA-203 ... & 46663 & 3048 & 34.1 & 39.4 & 24.8 & 1.7 \\
\hline DMA-204 ... & 46654 & 3018 & 29.5 & 33.2 & 35.4 & 1.9 \\
\hline DMA-208 ... & 46805 & 3150 & 26.7 & 39.0 & 30.0 & 4.3 \\
\hline$F-1 \ldots \ldots \ldots$ & 46588 & 3000 & 39.1 & 36.1 & 24.2 & .6 \\
\hline$W-3 \ldots \ldots \ldots$ & 46576 & 3042 & 2.6 & 51.4 & 34.0 & 11.9 \\
\hline$W-4 \ldots \ldots \ldots$ & 46568 & 3059 & 24.9 & 28.4 & 40.0 & 6.7 \\
\hline $\mathrm{W}-6 \ldots \ldots \ldots$ & 46567 & 3061 & 35.3 & 28.3 & 28.3 & 8.1 \\
\hline \multicolumn{7}{|c|}{ Dedham Granite north of the Boston basin (Zdngr) } \\
\hline DMA-65 ... & 47038 & 3328 & 29.0 & 12.1 & 41.9 & 17.1 \\
\hline DMA-66 ... & 47040 & 3329 & 26.4 & 32.5 & 36.9 & 4.2 \\
\hline DMA-67 . . . & 47052 & 3321 & 26.1 & 2.8 & 59.1 & 17.0 \\
\hline DMA-127 ... & 46995 & 3148 & 27.6 & 29.9 & 35.9 & 6.6 \\
\hline \multicolumn{7}{|c|}{ Topsfield Granodiorite (Ztgd) } \\
\hline DMA-60 $\ldots$ & 47334 & 3480 & 30.6 & $\mathbf{0}$ & 47.5 & 21.9 \\
\hline \multicolumn{7}{|c|}{ Dedham Granite west of the Boston basin (Zdgr) } \\
\hline DMA-1 . . . & 46925 & 3134 & 36.6 & 31.7 & 27.5 & 4.2 \\
\hline DMA-3 . . . & 46907 & 3128 & 37.0 & 20.2 & 37.1 & 5.7 \\
\hline DMA-5 . . . & 46882 & 3089 & 31.8 & 30.0 & 34.1 & 3.8 \\
\hline DMA-6 . . . & 46883 & 3089 & 33.4 & 17.9 & 43.3 & 5.5 \\
\hline DMA-7 . . . & 46851 & 3105 & 34.2 & 39.5 & 25.9 & .4 \\
\hline
\end{tabular}

TABLE 4.-Major constituents, in percent, determined by point-count of stained slabs of intrusive rocks of the Milford-Dedham zoneContinued

\begin{tabular}{|c|c|c|c|c|c|c|}
\hline \multirow{2}{*}{$\begin{array}{c}\text { Sample } \\
\text { no. }\end{array}$} & \multicolumn{2}{|c|}{ UTM grid } & \multirow{2}{*}{ Quartz } & \multirow{2}{*}{ K-feldspar } & \multirow{2}{*}{ Plagioclase } & \multirow{2}{*}{$\begin{array}{c}\text { Mafic } \\
\text { minerals }\end{array}$} \\
\hline & N. & E. & & & & \\
\hline \multicolumn{7}{|c|}{ Dedham Granite west of the Boston basin (Zdgr)-Continued } \\
\hline DMA-8 . & 46839 & 3089 & 28.3 & 50.4 & 18.4 & 2.8 \\
\hline DMA-9 $\ldots \ldots$ & 46817 & 3060 & 34.8 & 7.2 & 48.9 & 8.8 \\
\hline DMA-10 .... & 46827 & 3064 & 4.7 & 30.4 & 53.0 & 10.9 \\
\hline DMA-13 .... & 46813 & 3022 & 28.8 & 35.9 & 28.2 & 7.1 \\
\hline DMA-19 .... & 46891 & 2984 & 39.9 & 26.1 & 25.9 & 8.1 \\
\hline DMA-20 .... & 46885 & 2987 & 28.8 & 23.5 & 40.8 & 7.0 \\
\hline DMA-174 ... & 46844 & 3038 & 38.2 & 39.1 & 18.8 & 3.9 \\
\hline \multicolumn{7}{|c|}{ Westwood Granite (Zwgr) } \\
\hline DMA-29. & 46772 & 3218 & 26.2 & 35.9 & 33.6 & 4.3 \\
\hline DMA-31. & 46790 & 3184 & 31.5 & 36.5 & 28.4 & 3.6 \\
\hline DMA-36 . & 46744 & 3182 & 35.0 & 29.3 & 32.5 & 3.2 \\
\hline DMA-44 .... & 46687 & 3315 & 28.5 & 35.7 & 30.9 & 3.9 \\
\hline DMA-70 .... & 46688 & 3318 & 31.9 & 34.2 & 28.9 & 5.0 \\
\hline DMA-206 ... & 46794 & 3182 & 30.7 & 33.4 & 32.4 & 3.6 \\
\hline DMA-209 $\ldots$ & 46774 & 3124 & 28.5 & 37.3 & 32.1 & 2.1 \\
\hline DMA-109 ... & 46720 & 3425 & 28.8 & 35.6 & 32.9 & 3.3 \\
\hline DMA-110 ... & 46725 & 3427 & 19.6 & 35.0 & 41.6 & 3.7 \\
\hline DMA-117B. & 46790 & 3462 & 26.3 & 47.5 & 25.1 & 1.0 \\
\hline DMA-137 ... & 46715 & 3414 & 24.5 & 33.4 & 38.4 & 3.8 \\
\hline \multicolumn{7}{|c|}{ Milford Granite (Zmgr; Zmgd where noted) } \\
\hline DMA-14. & 46837 & 2970 & 38.8 & 36.3 & 18.7 & 6.2 \\
\hline DMA-22 .... & 46709 & 2926 & 32.3 & 38.3 & 26.3 & 3.1 \\
\hline DMA-27 .... & 46729 & 3072 & 28.1 & 34.8 & 33.4 & 3.2 \\
\hline DMA-28 $\ldots$. & 46703 & 3108 & 28.4 & 29.5 & 38.7 & 2.9 \\
\hline DMA-179 ... & 46726 & 2957 & 28.6 & 43.7 & 25.6 & 2.2 \\
\hline DMA-183 ... & 46775 & 2960 & 32.0 & 26.1 & 32.5 & 9.3 \\
\hline DMA-194 $\ldots$ & 46865 & 2972 & 17.9 & 55.3 & 24.1 & 2.6 \\
\hline Mi-3 ....... & 46702 & 2931 & 36.1 & 33.4 & 23.2 & 7.3 \\
\hline Mi-4 (Zmgd). & 46718 & 2918 & 37.0 & 38.4 & 17.3 & 7.3 \\
\hline Mi-5 ...... & 46727 & 2910 & 38.4 & 4.9 & 42.1 & 14.2 \\
\hline
\end{tabular}

Granite of the Fall River pluton (Zfgr)

\begin{tabular}{lllllll}
\hline $\mathrm{A}-2 \ldots \ldots \ldots$ & 46313 & 3338 & 30.5 & 34.0 & 32.2 & 3.2
\end{tabular}

$\begin{array}{lllllll}\mathrm{A}-3 \ldots \ldots \ldots & 46310 & 3315 & 30.9 & 31.4 & 36.2 & 1.5\end{array}$

$\begin{array}{lllllll}\mathrm{A}-5 \mathrm{~b} \ldots \ldots . & 46290 & 3309 & 38.2 & 34.2 & 24.7 & 2.8\end{array}$

$\begin{array}{lllllll}\mathrm{A}-7 \ldots \ldots \ldots & 46300 & 3306 & 33.9 & 35.2 & 28.7 & 2.2\end{array}$

$\begin{array}{lllllll}\text { A }-8 \ldots \ldots \ldots & 46285 & 3291 & 24.8 & 41.4 & 28.1 & 5.7\end{array}$

$\begin{array}{lllllll}\mathrm{A}-9 \ldots \ldots & 46283 & 3294 & 36.5 & 33.0 & 28.9 & 1.7\end{array}$

$\begin{array}{lllllll}\mathrm{A}-10 \ldots \ldots & 46242 & 3276 & 32.5 & 39.4 & 24.2 & 3.9\end{array}$

$\begin{array}{lllllll}\mathrm{A}-11 \ldots \ldots & 46253 & 3263 & 37.1 & 38.4 & 21.7 & 2.7\end{array}$

$\begin{array}{lllllll}\text { AP-1a ...... } & 46269 & 3371 & 32.6 & 28.9 & 33.7 & 4.8\end{array}$

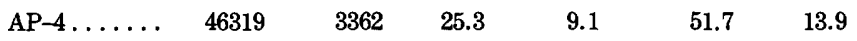

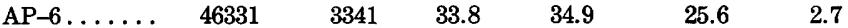

$\begin{array}{lllllll}\text { AP-7 . . . . . } 46293 & 3374 & 31.5 & 35.3 & 29.4 & 3.7\end{array}$

$\begin{array}{lllllll}\text { FR-2 . . . . } & 46165 & 3224 & 19.5 & 42.8 & 31.7 & 6.0\end{array}$

$\begin{array}{lllllll}\text { FR }-3 \ldots \ldots & 46163 & 3187 & 32.3 & 21.4 & 39.5 & 6.8\end{array}$

$\begin{array}{lllllll}\text { FR-8 } \ldots \ldots . . .6 & 46187 & 3221 & 35.9 & 35.9 & 20.2 & 7.9\end{array}$

$\begin{array}{lllllll}\text { FR-12 } \ldots \ldots . . .6 & 46184 & 3202 & 42.0 & 40.1 & 15.6 & 2.3\end{array}$

$\begin{array}{lllllll}\text { FR-15 ..... } & 46162 & 3223 & 29.2 & 25.4 & 34.7 & 10.8\end{array}$

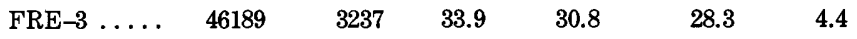

$\begin{array}{lllllll}\text { FRE-4 } \ldots . .6 & 46231 & 3234 & 36.3 & 33.8 & 19.8 & 10.1\end{array}$

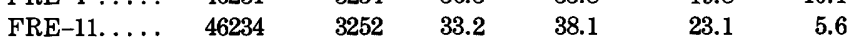

$\begin{array}{lllllll}\text { FRE-12.... } & 46211 & 3261 & 37.2 & 33.9 & 25.2 & 3.7\end{array}$

\begin{tabular}{lllllll}
$\mathrm{T}-1 \ldots \ldots \ldots$ & 46099 & 3178 & 40.0 & 28.1 & 27.2 & 5.0 \\
\hline
\end{tabular}

\begin{tabular}{|c|c|c|c|c|c|c|}
\hline \multicolumn{7}{|c|}{ Porphyritic granite (Zpgr) } \\
\hline NBN-9 & 46146 & 3411 & 30.6 & 28.0 & 34.1 & 7.3 \\
\hline We-2. . & 45968 & 3240 & 16.2 & 55.1 & 21.8 & 5.9 \\
\hline We-4... & 45987 & 3270 & 25.4 & 45.3 & 20.7 & 8.5 \\
\hline NBN-22 & 46179 & 3422 & 30.0 & 25.4 & 27.4 & $14.0^{*}$ \\
\hline
\end{tabular}




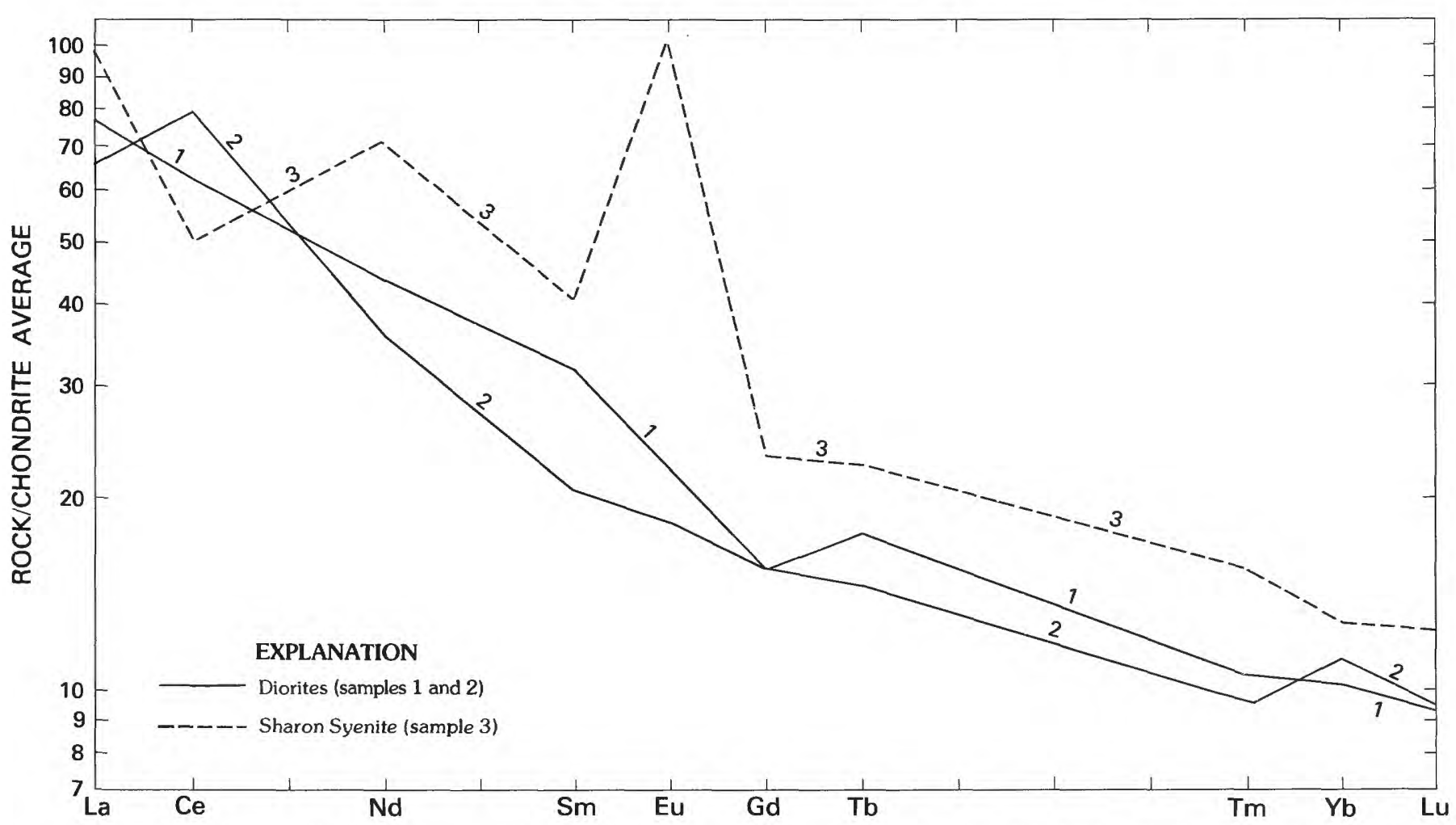

FIGURE 9.-Chondrite-normalized plot of rare-earth elements in Proterozoic Z mafic plutonic rocks of the Milford-Dedham zone. Sample numbers from table 3 .

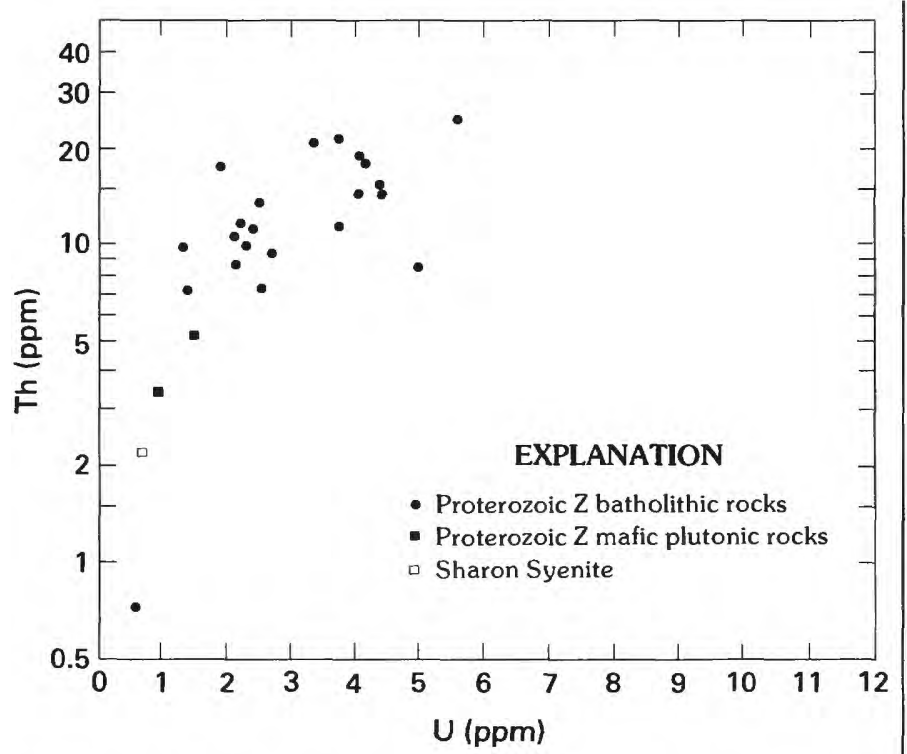

FigURE 10. - Plot of Th (thorium) against U (uranium) for Proterozoic $\mathrm{Z}$ intrusive rocks of the Milford-Dedham zone.

ESMOND GRANITE (Zegr)

The Esmond Granite (Zegr) occupies nearly $100 \mathrm{~km}^{2}$ of Rhode Island. It forms an elongate pluton southeast of Woonsocket of which only the northern part is in Massachusetts (fig. 11). A similar pluton lies west of Woon- socket, and phases of the biotite granite ( $\mathrm{Zgr})$ and the Milford Granite (Zmgr) resemble it. In fact, Quinn (1971) thought the Esmond and the Milford might be the same rock. A coarse-grained facies of the Esmond intrudes the Blackstone Group and a related tonalite. A fine-grained facies intrudes both the tonalite and the coarse-grained facies (Hermes and Zartman, 1985). Contact relations with the Milford Granite are not known. The age of the Esmond $(621 \pm 8 \mathrm{Ma})$ appears to be close to that of the Milford (table 1). The Esmond Granite is mottled red and green, like the Dedham Granite, and is massive except where foliated by local deformation. The representative modes (Quinn, 1971; table 5, no. 7) and chemical content (table 6, no. 10) indicate that the dominant rock type is biotite granite poor in mafic minerals. The plagioclase is altered to muscovite and epidote, and the biotite is usually chloritized. The REE pattern (fig. 15) is similar to that of the Dedham Granite.

\section{Grant Mills Granodiorite (Zgmgd)}

The Grant Mills Granodiorite (Zgmgd) occupies an area of $25 \mathrm{~km}^{2}$ in northeastern Rhode Island (fig. 11). According to Quinn (1971), it intrudes older quartz diorite and is gradational with the Esmond Granite. O. Don Hermes (written commun., 1985; Hermes and Zartman, 1985) considered it to be a porphyritic variety of 


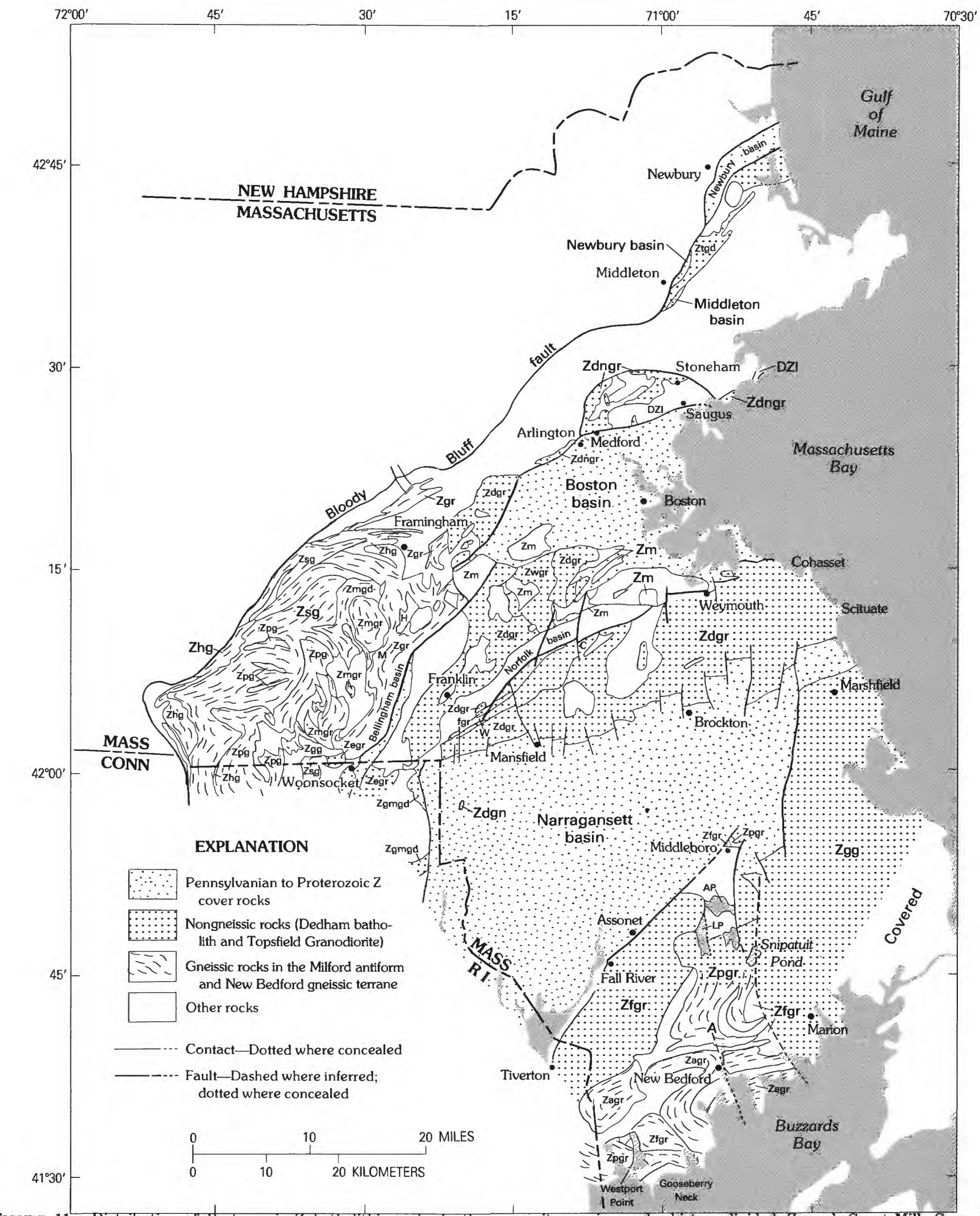

FiguRe 11.-Distribution of Proterozoic $Z$ batholithic rocks in the Milford-Dedham zone. W, Wrentham; C, Canton; A, Acushnet; LP, Long Pond; AP, Assawompset Pond; H, Holliston; M, Milford. Ztgd, Topsfield Granodiorite; Zdngr, Dedham Granite north of Boston; Zdgr, Dedham Granite; Zwgr, Westwood Granite; Zfgr, granite of the Fall River pluton; Zpgr, porphyritic granite; Zagr, alaskite; Zgg,

granite, gneiss, and schist, undivided; Zgmgd, Grant Mills Granodiorite; Zegr, Esmond Granite; Zsg, Scituate Granite Gneiss; Zpg, Ponaganset Gneiss; Zhg, Hope Valley Alaskite Gneiss; Zmgr, biotite granite of the Milford Granite; Zmgd, mafic phase of the Milford Granite; Zgr, biotite granite; Zm, Mattapan Volcanic Complex; DZl, Lynn Volcanic Complex. 


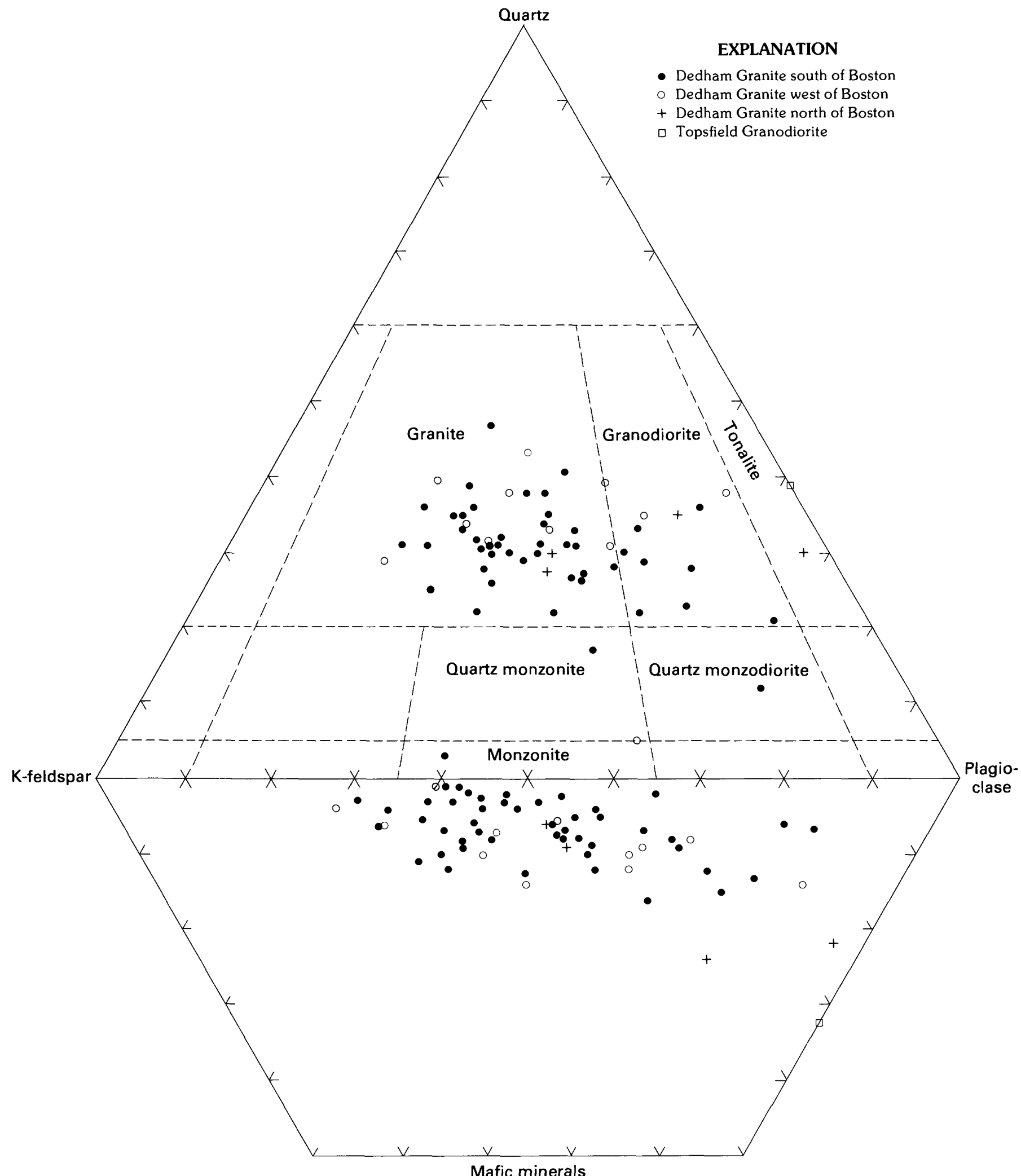

FIGURE 12. -Q-P-K-M (quartz-plagioclase-K-feldspar-mafic minerals) diagram of modes of Dedham Granite and Topsfield Granodiorite, from table 4. Fields of igneous rocks from Streckeisen (1973). 


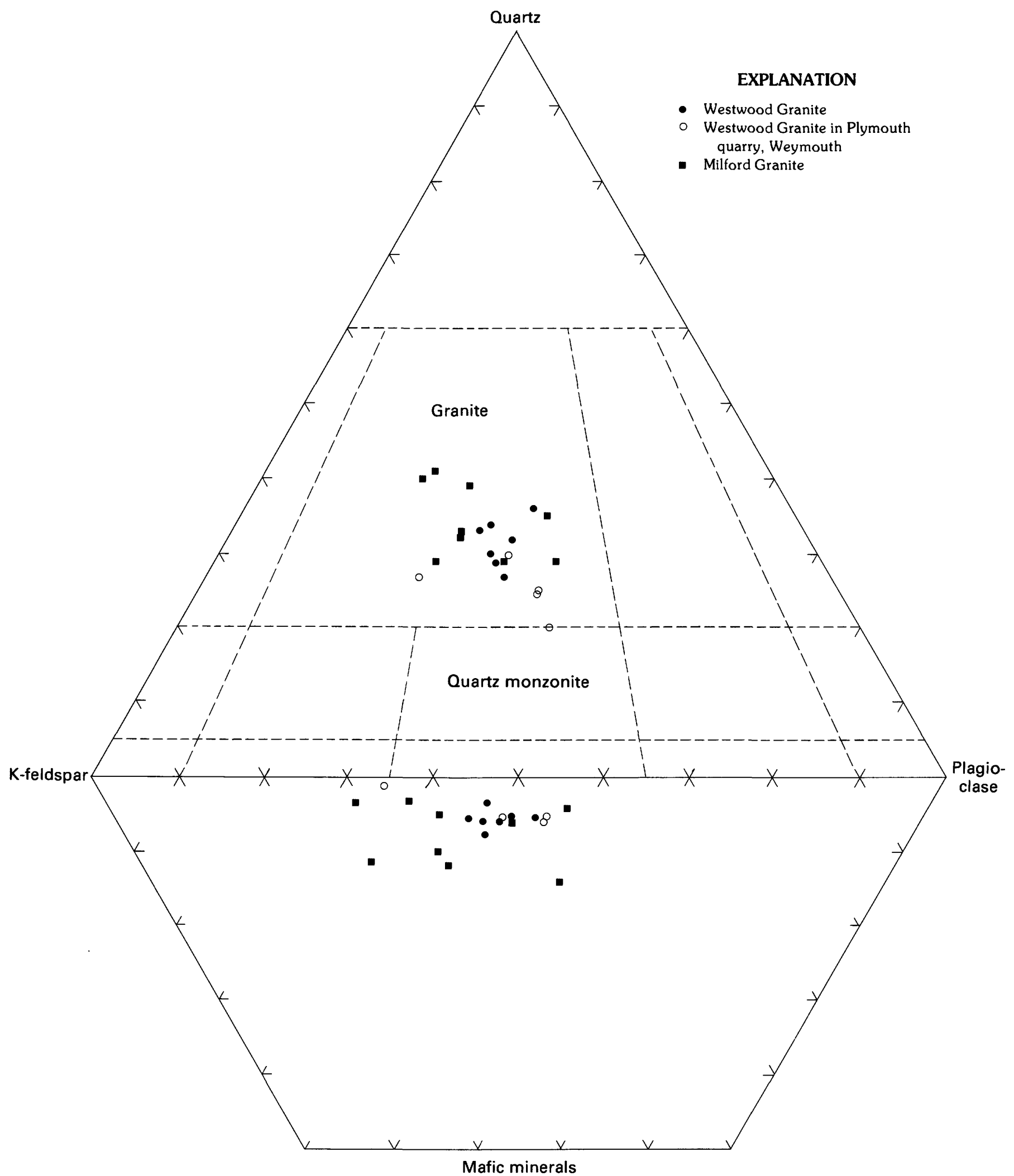

FIGURE 13. -Q-P-K-M (quartz-plagioclase-K-feldspar-mafic minerals) diagram of modes of Westwood Granite; Westwood Granite in Plymouth quarry, Weymouth; and Milford Granite, from table 4. Fields of igneous rocks from Streckeisen (1973). 


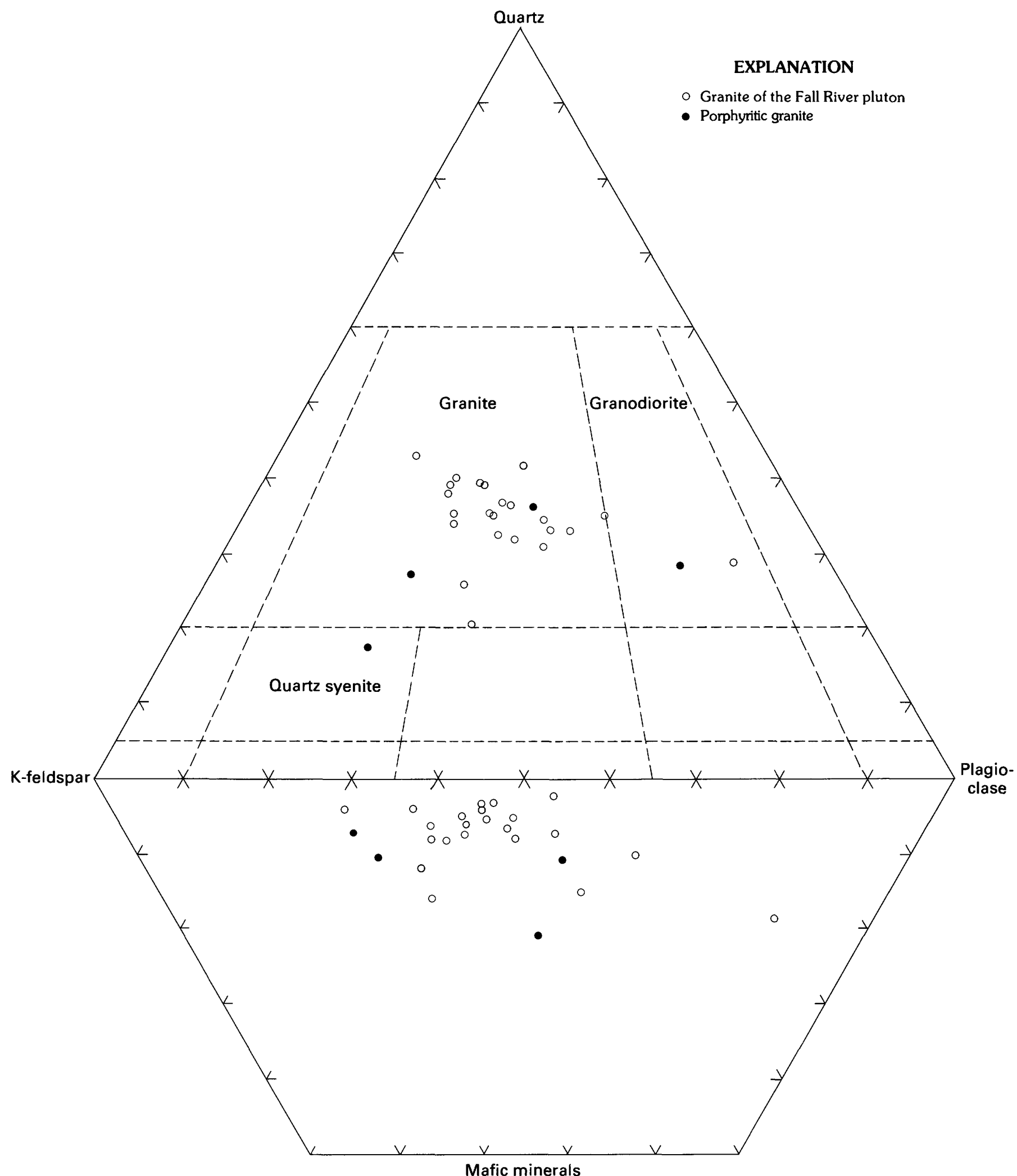

FIGURE 14.-Q-P-K-M (quartz-plagioclase-K-feldspar-mafic minerals) diagram of modes from the Fall River pluton including the porphyritic granite, from table 4. Fields of igneous rocks from Streckeisen (1973). 
TABLE 5.-Modes, in percent, of plutonic rocks of the Dedham batholith in northeastern Massachusetts

[Zdgr, Dedham Granite; Zdngr, Dedham Granite north of Boston; Zegr, Esmond Granite; Zwgr, Westwood Granite. Sample localities shown by field number in Wones and others (1986). a, albite; $n$, andesine; $p$, perthitic; tr, trace]

\begin{tabular}{|c|c|c|c|c|c|c|c|c|}
\hline $\begin{array}{l}\text { Sample no. } \ldots \ldots \ldots \\
\text { Unit } \ldots \ldots \ldots \ldots \ldots\end{array}$ & $\begin{array}{c}1 \\
\mathrm{Zdgr}\end{array}$ & $\begin{array}{c}2 \\
\mathrm{Zdgr}\end{array}$ & $\begin{array}{c}3 \\
\mathrm{Zdgr}\end{array}$ & $\begin{array}{c}4 \\
Z \mathrm{dgr}\end{array}$ & $\begin{array}{c}5 \\
\mathrm{Zdgr}\end{array}$ & $\begin{array}{c}6 \\
\text { Zdngr }\end{array}$ & $\begin{array}{c}7 \\
\text { Zegr }\end{array}$ & $\begin{array}{c}8 \\
\text { Zwgr }\end{array}$ \\
\hline Points counted ...... & 2009 & 1485 & 1451 & 1586 & 1811 & 1761 & 2101 & 1728 \\
\hline Field no........... & $\mathrm{N}-3$ & $\mathrm{~F}-40$ & $\mathrm{~F}-29$ & W-6* & W-37 & $\mathrm{BN}-1$ & $P-5^{*}$ & $\mathrm{BH}-3$ \\
\hline Quartz............. & 32.2 & 31.5 & 25.3 & 37.2 & 21.6 & 32.8 & 38.8 & 29.3 \\
\hline Plagioclase ........ & $27.6 \mathrm{a}$ & $36.6 \mathrm{a}$ & $28.9 \mathrm{a}$ & $41.6 \mathrm{a}$ & $33.0 \mathrm{a}$ & $33.8 \mathrm{n}$ & 25.9 & $30.4 \mathrm{a}$ \\
\hline Microcline.......... & $37.8 \mathrm{p}$ & $30.2 \mathrm{p}$ & $40.0 \mathrm{p}$ & $16.9 \mathrm{p}$ & $44.5 \mathrm{p}$ & 14.8 & 35.4 & $37.9 \mathrm{p}$ \\
\hline Biotite . . . . . . . . & $1.0 \ddagger$ & $.8 \ddagger$ & 3.9 & 0 & .2 & .1 & 1.3 & .1 \\
\hline Muscovite......... & $1.0 \ddagger$ & $.7 \ddagger$ & 0 & 0 & 0 & 0 & .9 & .3 \\
\hline Epidote.......... & 0 & 0 & .7 & .4 & .5 & 4.9 & 1.1 & 1.0 \\
\hline Hornblende ....... & 0 & 0 & $\operatorname{tr}$ & $\operatorname{tr}$ & 0 & $\operatorname{tr}$ & 0 & 0 \\
\hline Chlorite........... & 0 & 0 & 0 & 3.6 & 3.0 & 12.9 & .5 & .9 \\
\hline Magnetite......... & .6 & $\begin{array}{llll}.1 & & & \end{array}$ & .2 & $\operatorname{tr}$ & .2 & $\begin{array}{llll}.1 & & \\
\end{array}$ & 0 & .1 \\
\hline Hematite ........ & $.2 \ddagger$ & 0 & 0 & 0 & 0 & 0 & 0 & 0 \\
\hline Titanite........... & 0 & 0 & 0 & .1 & $\operatorname{tr}$ & .2 & 0 & 0 \\
\hline Apatite .......... & 0 & 0 & 0 & $\operatorname{tr}$ & 0 & .1 & 0 & 0 \\
\hline Allanite........... & 0 & 0 & .4 & 0 & 0 & 0 & 0 & $\operatorname{tr}$ \\
\hline Garnet............ & 0 & 0 & .6 & 0 & 0 & 0 & 0 & 0 \\
\hline Zircon............. & 0 & 0 & $\operatorname{tr}$ & 0 & 0 & 0 & 0 & 0 \\
\hline Calcite............ & 0 & 0 & 0 & 0 & 0 & 0 & .1 & 0 \\
\hline
\end{tabular}

Chemical analysis in table 6.

\$iotite altered to muscovite and hematite.

the Esmond. The dominant rock type is granodiorite (Quinn, 1971). It has the pink and green coloration due to alteration that is characteristic of the Dedham Granite and related rocks. Earlier workers (Warren and Powers, 1914; Emerson, 1917; Quinn, 1971) considered the Grant Mills to be equivalent to the Dedham Granite in both age and texture.

Westwood Granite (Zwgr)

The Westwood Granite (Zwgr) forms small (less than $10 \mathrm{~km}^{2}$ ) masses of light-colored granite (fig. 11) that intrude the Dedham Granite and older rocks (Dowse, 1949; Chute, 1950, 1966). Some masses that resemble Westwood Granite, such as those exposed in the Plymouth quarries in Weymouth and in scattered outcrops near Scituate, have been included within the Dedham Granite on the State bedrock map. The Westwood Granite crops out in the areas dominantly of Dedham Granite, and parts of it were included by Kovach and others (1977) in an investigation of the age of the Dedham by $\mathrm{Rb}-\mathrm{Sr}$ dating methods. Extensive intrusion breccias occur at the contacts of the Westwood with older mafic rocks. The contacts with the Dedham Granite commonly are abrupt, with dikes of Westwood cutting the Dedham and rare inclusions of Dedham within the Westwood (Chute, 1966). There have been no reports of Westwood cobbles within the Roxbury Conglomerate, so it is possible that the Westwood is an intrusive equivalent of the extrusive Mattapan Volcanic Complex that underlies the Roxbury.
The Westwood was therefore not exposed to erosion at the time of deposition of the Roxbury.

The Westwood Granite is fine grained and low in mafic minerals (tables 4-6). Much of the plagioclase is altered to sericite and the biotite to chlorite. It is usually lighter in color than the Dedham Granite but does contain microscopic hematite, which gives the rock a pink cast. It does not appear to be as deformed as the Dedham Granite. The Westwood Granite occupies a very compact field when projected onto the quartz-plagioclaseK-feldspar plane (fig. 13). The ranges of modes from this study (table 5) and from Chayes (1952) and Chute (1966) are 26-35 percent quartz, 29-45 percent K-feldspar, 17-34 percent plagioclase, and 1-5 percent micas. Common accessories are biotite, magnetite, titanite, and apatite.

The mineral assemblage of the Westwood Granite is more like that of the Dedham Granite than that of any other intrusive unit in the Milford-Dedham zone. The Westwood differs from the Dedham Granite in having a finer grain size, lower An content of the plagioclase, lack of hornblende, and lower color index. It has a slightly lower heavy-REE content (fig. 15). It may represent a late-stage aplitic differentiate of the Dedham magma or a later, separate magma from a similar source material. Part of a small elliptical pluton of the Westwood Granite in Weymouth (not shown separately on the State bedrock map) partly exposed in the Plymouth quarries differs from the type locality in having a lower quartz content, slightly lower REE content, and higher $U$ and $T h$ contents. As mentioned above, the Westwood may be 
the intrusive equivalent of the Mattapan and Lynn Volcanic Complexes (Zm and DZl, fig. 11). A somewhat questionable $579 \pm 28$-Ma age (table 1) obtained from the Westwood indicates that it might be younger than the Dedham. It may be about the same age as the Mattapan, from which a $\mathrm{U}-\mathrm{Pb}$ age on zircon of $602 \pm 3 \mathrm{Ma}$ has been obtained (Kaye and Zartman, 1980). The granitic intrusion at Pine Hill, Medford, which intrudes the Lynn Volcanic Complex (Zarrow, 1978), is probably the Westwood Granite.

\section{Fine-Grained Granite (fgr)}

Two small bodies of fine-grained biotite granite (fgr) lie in fault blocks near the southwest end of the Norfolk basin near Wrentham (W, fig. 11). Each is less than 5 $\mathrm{km}^{2}$ in area. They appear to intrude the Dedham Granite, although they may be close to it in age.

Granite of the fall River Pluton (Zfgr)

The granite of the Fall River pluton (Zfgr) occupies an area of $300 \mathrm{~km}^{2}$ southeast of the Narragansett basin between Middleboro and Buzzards Bay (fig. 11). The radiometric age of the granite (table 1 ) shows the rock to be the same age as the Dedham Granite, $630 \pm 15 \mathrm{Ma}$, and the mineralogy and texture of the granite of the Fall River pluton make it most probable that this body is equivalent to the Dedham Granite. A minimum age of $516 \mathrm{Ma}$ has been obtained by $\mathrm{Rb}-\mathrm{Sr}$ whole-rock methods (Galloway, 1973) on rock in the southern part of the pluton, south of Fall River, called the Bulgarmarsh Granite (Pollock, 1964). We were unable to distinguish the Bulgarmarsh from the rest of the Fall River pluton in our reconnaissance for the State bedrock map. Skehan and others (1978) and Skehan and Murray (1980) suggested that the granite of the Fall River pluton might be equivalent to a porphyritic granite (Kay and Chapple, 1976) on Aquidneck Island, R.I., that was dated at $592 \pm 12 \mathrm{Ma}$ by $\mathrm{Rb}-\mathrm{Sr}$ methods (Smith, 1978). We think this unlikely because the granite of the Fall River pluton is not typically porphyritic. The Fall River pluton may contain younger intrusions not to date distinguished.

The granite of the Fall River pluton is light gray to gray, locally light reddish orange, medium grained, equigranular to slightly seriate, and rarely porphyritic. Most of the rock is fresh, and it is only locally fractured and altered. In the Assonet area, along the edge of the Narragansett basin, the granite is fractured and more severely altered than elsewhere. Modes and chemical compositions of the granite (tables $4,7,8$ ) lie within the field of the Dedham Granite (figs. 5, 14), and the REE patterns (fig. 16) are similar to those of the Dedham Granite. Some quartz forms mosaic aggregates. Much of the microcline is perthitic. Plagioclase ranges in anor- thite content from $\mathrm{An}_{10}$ to $\mathrm{An}_{30}$ but is partly saussuritized. Biotite is less than 5 percent. The muscovite is usually next to plagioclase, and we suggest that some, if not all, of the muscovite (table 7) may be sericite recrystallized to muscovite during a Permian thermal high. Accessory minerals are opaque minerals, zircon, apatite, sparse titanite, garnet, and allanite. Sericite, epidote, and titanite are common alteration phases.

The rock is not gneissic in the north, although local cataclastic textures are present, but south of Fall River it becomes gneissic, particularly in the Westport area. The rock is more leucocratic at Freeport and is coarse grained east of Assawompset Pond. No distinct contact between the main mass of the Fall River pluton and the Bulgarmarsh Granite of Pollock (1964) was observed by us. At a roadcut on Route 24 north of Tiverton, in the area of the Bulgarmarsh Granite, the rock contains granular quartz aggregates similar to those in the Milford Granite (table 7, no. 4; table 8, no. 4). Emerson (1917), on the earlier State map, showed an area of Quincy Granite northeast of Assonet. Although the granite in this region is more varied in texture than elsewhere, we were unable to locate any Quincy Granite.

\section{Porphyritic Granite (Zpgr)}

Porphyritic granite (Zpgr) is a distinct rock type in the southeastern part of the Dedham batholith (fig. 11). It lies mostly east of the Fall River pluton and extends from Long Pond (LP, fig. 11) south to Buzzards Bay and east and north to Middleboro, where it is exposed in an outlier surrounded by Pennsylvanian rocks. Lyons (1969) considered the porphyritic granite to be equivalent to his Barefoot Hill quartz monzonite of the Mansfield area (see description of Dedham Granite above); its analysis in table 4 (DMA-166) shows that it fits within the spread of modes of the porphyritic granite (table 7). Chemically, however, if no. 1 , table 6 , and no. 5 , table 8 , are truly representative, the porphyritic granite is somewhat more mafic than Lyons' Barefoot Hill.

The porphyritic granite is gray to greenish gray, seriate to porphyritic, with microcline phenocrysts (locally $2 \mathrm{~cm}$ long) set in a finer grained matrix of quartz, plagioclase, microcline, and biotite aggregates. It is retrogressively sheared or foliated in varying degrees in the northern part of its area; near New Bedford it is pervasively gneissic but much less altered. Gneissic varieties may be seen in gravel pits north of Acushnet, and in the Westport shore area (for example, at Gooseberry Neck). An outcrop of gneissic rock north of Marion included in the area of granite, gneiss, and schist, undivided ( $\mathrm{Zgg})$, may be equivalent. Inclusions of dark schist and porphyritic mafic rock are oriented parallel to the feldspar orientation. In the more foliated rocks, gray 
TABLE 6.-Major-oxide, normative-mineral, and trace-element compositions, volatiles omitted, of Proterozoic $Z$ intrusive rocks, MilfordDedham zone, northeastern Massachusetts

[Major oxides determined by X-ray spectroscopy by Paul Hearn and Susan Wargo; all Fe reported as $\mathrm{Fe}_{2} \mathrm{O}_{3}$. Trace-element abundances determined by instrumental neutron activation analyses by L.J. Schwartz except $\mathrm{Rb}$ and $\mathrm{Sr}$ by X-ray spectroscopy by J. Lindsay, B. McCall, and G.A. Sellars. nd, not determined]

\begin{tabular}{|c|c|c|c|c|c|c|c|c|c|c|c|c|}
\hline $\begin{array}{l}\text { Sample no. } \ldots \ldots \ldots \ldots \\
\text { Unit. ............. }\end{array}$ & $\begin{array}{c}1 \\
\mathrm{Zdgr}\end{array}$ & $\begin{array}{c}2 \\
\mathrm{Zdgr} \\
\end{array}$ & $\begin{array}{c}3 \\
\mathrm{Zdgr}\end{array}$ & $\begin{array}{c}4 \\
\mathrm{Zdgr} \\
\end{array}$ & $\begin{array}{c}5 \\
\mathrm{Zdgr} \\
\end{array}$ & $\begin{array}{c}6 \\
\mathrm{Zdgr} \\
\end{array}$ & $\begin{array}{c}7 \\
\text { Zdngr } \\
\end{array}$ & $\begin{array}{c}8 \\
\text { Zdngr }\end{array}$ & $\begin{array}{c}9 \\
\text { Ztgd } \\
\end{array}$ & $\begin{array}{c}10 \\
\text { Zegr }\end{array}$ & $\begin{array}{c}11 \\
\text { Zwgr }\end{array}$ & $\begin{array}{c}12 \\
\text { Zwgr } \\
\end{array}$ \\
\hline \multicolumn{13}{|c|}{ Major-oxide composition, in weight percent, and alkali-alumina ratio } \\
\hline $\mathrm{SiO}_{2} \ldots \ldots \ldots \ldots$ & 71.34 & 73.42 & 74.98 & 75.41 & 76.89 & 71.48 & 65.94 & 72.84 & 68.85 & 75.78 & 73.81 & 74.11 \\
\hline $\mathrm{Al}_{2} \mathrm{O}_{3} \ldots \ldots \ldots \ldots$ & 14.90 & 13.66 & 13.18 & 13.63 & 13.52 & 13.93 & 15.85 & 14.49 & 13.98 & 12.50 & 14.04 & 14.40 \\
\hline $\mathrm{Fe}_{2} \mathrm{O}_{3} \ldots \ldots \ldots \ldots \ldots$ & 2.21 & 1.54 & 1.43 & .86 & .95 & 2.37 & 4.63 & 2.54 & 5.31 & 1.19 & 1.00 & 1.10 \\
\hline $\mathrm{MnO} . . . \ldots \ldots \ldots$ & .08 & .04 & .05 & .02 & .03 & .09 & .10 & .05 & .12 & .05 & .05 & .05 \\
\hline $\mathrm{MgO} . . . \ldots \ldots \ldots$ & .92 & 1.05 & .41 & .22 & .04 & .54 & 1.78 & .23 & 1.74 & .61 & .17 & .26 \\
\hline $\mathrm{CaO} \ldots \ldots \ldots \ldots \ldots$ & 1.72 & 1.28 & .93 & .25 & .24 & 1.66 & 2.84 & 1.04 & 3.16 & .83 & .69 & 1.29 \\
\hline $\mathrm{Na}_{2} \mathrm{O} \ldots \ldots \ldots \ldots$ & 4.06 & 4.11 & 3.17 & 4.25 & 3.70 & 3.79 & 2.66 & 3.88 & 3.53 & 3.92 & 4.15 & 3.76 \\
\hline $\mathrm{K}_{2} \mathrm{O} \ldots \ldots \ldots \ldots \ldots$ & 3.94 & 4.08 & 4.99 & 4.92 & 4.60 & 3.88 & 3.15 & 4.71 & .58 & 4.42 & 4.21 & 3.98 \\
\hline $\mathrm{TiO}_{2} \ldots \ldots \ldots \ldots \ldots$ & .36 & .26 & .16 & .10 & .10 & .29 & .74 & .30 & .46 & .04 & .21 & .16 \\
\hline $\mathrm{P}_{2} \mathrm{O}_{5} \ldots \ldots \ldots \ldots \ldots$ & .11 & .08 & .04 & .04 & .02 & .08 & .17 & .10 & .08 & .02 & .05 & .04 \\
\hline$\left(\mathrm{Na}_{2} \mathrm{O}+\mathrm{K}_{2} \mathrm{O}\right) / \mathrm{Al}_{2} \mathrm{O}_{3} \ldots$ & .54 & .60 & .62 & .67 & .61 & .55 & .37 & .59 & .29 & .67 & .59 & .54 \\
\hline \multicolumn{13}{|c|}{ Normative-mineral composition, in weight percent, ${ }^{1}$ and differentiation index (DI) } \\
\hline Qtz............... & 26.3 & 28.8 & 34.1 & 30.5 & 36.5 & 29.6 & 27.3 & 28.0 & 33.5 & 32.7 & 31.8 & 33.4 \\
\hline Crn............... & 1.1 & .3 & 1.0 & 1.0 & 2.1 & .4 & 3.4 & 1.4 & 2.0 & 0 & 1.5 & 1.7 \\
\hline Or................. & 23.4 & 24.2 & 30.7 & 29.2 & 27.2 & 23.0 & 19.0 & 27.8 & 3.5 & 26.3 & 25.3 & 23.7 \\
\hline $\mathrm{Ab} \ldots \ldots \ldots \ldots \ldots$ & 34.5 & 34.9 & 27.0 & 36.1 & 31.3 & 32.0 & 23.0 & 32.8 & 30.5 & 33.4 & 35.7 & 32.1 \\
\hline An $\ldots \ldots \ldots \ldots \ldots$ & 7.8 & 5.9 & 4.4 & 1.0 & 1.1 & 8.2 & 13.3 & 4.5 & 15.5 & 3.5 & 3.1 & 6.2 \\
\hline Wo $\ldots . . \ldots \ldots \ldots \ldots$ & 0 & 0 & 0 & 0 & 0 & 0 & 0 & 0 & 0 & .2 & 0 & 0 \\
\hline En $\ldots \ldots \ldots \ldots \ldots \ldots$ & 2.3 & 2.6 & 1.0 & .6 & .1 & 1.3 & 4.5 & .6 & 4.4 & 1.5 & .4 & .7 \\
\hline Fs.............. & 3.6 & 2.5 & 2.5 & 1.5 & 1.6 & 4.0 & 7.6 & 4.3 & 9.4 & 2.2 & 1.6 & 1.9 \\
\hline $\operatorname{Ilm} \ldots \ldots \ldots \ldots \ldots$ & .7 & .5 & .3 & .2 & .2 & .5 & 1.4 & .6 & .9 & .1 & .4 & .3 \\
\hline Ap $\ldots \ldots \ldots \ldots \ldots$ & .3 & .2 & .1 & .1 & 0 & 0 & .4 & .7 & .2 & 0 & .1 & .1 \\
\hline DI.............. & 84 & 88 & 92 & 96 & 95 & 85 & 69 & 89 & 79 & 92 & 93 & 89 \\
\hline \multicolumn{13}{|c|}{ Trace-element abundances, in parts per million, and selected ratios } \\
\hline ............ & 130 & 94 & 144 & 174 & 145 & 159 & 114 & 119 & 20 & 130 & 131 & 112 \\
\hline Cs............... & 2.6 & 0.7 & 1.9 & 1.4 & 1.2 & 3.9 & 2.1 & 1.5 & 1.6 & 1.1 & 1.4 & 1.1 \\
\hline Sr................ & 291 & 314 & 118 & 58 & 54 & 155 & 284 & 142 & nd & 94 & 133 & 335 \\
\hline Ba.............. & 1217 & 1292 & 628 & 430 & 386 & 522 & 580 & 773 & 137 & 727 & 1084 & 1451 \\
\hline $\mathrm{Rb} / \mathrm{Cs} \ldots \ldots \ldots \ldots \ldots$ & 50 & 134 & 76 & 124 & 121 & 41 & 54 & 79 & 12 & 118 & 94 & 109 \\
\hline $\mathrm{Rb} / \mathrm{Sr} . \ldots \ldots \ldots \ldots$ & .4 & .3 & 1.2 & 3.0 & 2.5 & 1.0 & .4 & .8 & nd & 1.4 & 1.0 & .3 \\
\hline Sc............... & 4.2 & 2.5 & 2.3 & 4.2 & 4.2 & 5.9 & 13.1 & 4.1 & 23.6 & 2.7 & 2.1 & 11.5 \\
\hline $\mathrm{Cr} . \ldots \ldots \ldots \ldots \ldots$ & 3.2 & 2.3 & 2.4 & 5.3 & 5.6 & nd & 7.6 & 2.6 & 5.4 & 6.0 & 4.9 & 4.2 \\
\hline Co................ & 3.7 & 3.3 & 1.6 & .3 & .3 & 2.2 & 12.0 & 2.6 & 11.2 & .2 & .7 & 1.2 \\
\hline Zn................ & 44 & 22 & 27 & 17 & 18 & 49 & 79 & 63 & 85 & 31 & 42 & 12 \\
\hline La............... & 39 & 26 & 39 & 27 & 35 & 35 & 35 & 75 & 6 & 21 & 38 & 36 \\
\hline Ce............... & 68 & 50 & 73 & 55 & 72 & 67 & 64 & 133 & 14 & 43 & 71 & 57 \\
\hline Nd $\ldots \ldots \ldots \ldots \ldots$ & 27 & 18 & 28 & 25 & 34 & 33 & 28 & 64 & 7 & 19 & 24 & 18 \\
\hline $\operatorname{Sm} \ldots \ldots \ldots \ldots \ldots$ & 4 & 2 & 4 & 6 & 7 & 7 & 6 & 14 & 3 & 5 & 4 & 2 \\
\hline $\mathrm{Eu} \ldots \ldots \ldots \ldots \ldots$ & .85 & .54 & .75 & .44 & .45 & .77 & 1.18 & 1.55 & .65 & .79 & .63 & .46 \\
\hline Gd.............. & 3.7 & 1.4 & 2.0 & 4.0 & 5.0 & 5.0 & 5.3 & 10.0 & 3.0 & 3.5 & 3.0 & 3.3 \\
\hline Tb............... & .51 & .24 & .50 & .84 & .97 & 1.08 & .72 & 2.13 & .77 & .64 & .43 & .18 \\
\hline Ho .............. & .7 & .6 & .7 & .9 & 1 & 1 & .7 & 2.2 & .8 & .5 & .3 & .2 \\
\hline $\operatorname{Tm} \ldots \ldots \ldots \ldots \ldots$ & .33 & .24 & .26 & .63 & .67 & .51 & .33 & 1.0 & .47 & .46 & .28 & .28 \\
\hline Yb $\ldots \ldots \ldots \ldots \ldots \ldots$ & 2.0 & .8 & 1.8 & 3.4 & 4.0 & 4.0 & 2.3 & 6.3 & 3.3 & 2.1 & 1.5 & .6 \\
\hline Lu............... & .28 & .13 & .28 & .50 & .60 & .55 & .34 & .86 & .48 & .31 & .23 & .12 \\
\hline $\mathrm{La} / \mathrm{Yb} \ldots \ldots \ldots \ldots$ & 19 & 32 & 22 & 8 & 9 & 9 & 15 & 12 & 2 & 10 & 25 & 60 \\
\hline Hf............... & 4.5 & 3.4 & 3.7 & 3.6 & 3.9 & 5.6 & 5.2 & 11.6 & 1.9 & 2.7 & 4.1 & 2.8 \\
\hline $\mathrm{Zr} \ldots \ldots \ldots \ldots \ldots \ldots$ & 202 & 157 & 178 & 210 & 186 & 277 & 273 & 383 & 510 & 54 & 153 & 118 \\
\hline $\operatorname{Th}^{2} \ldots \ldots \ldots \ldots \ldots$ & 11.0 & 14.3 & 17.9 & 7.2 & 11.2 & 20.2 & 11.6 & 13.2 & .7 & 10.2 & 10.9 & 14.2 \\
\hline Th............... & 11.1 & 15.6 & 16.3 & 12.6 & 18.5 & 15.9 & 14.2 & 13.2 & .9 & 11.2 & 12.7 & 16.7 \\
\hline $\mathrm{U}^{2} \ldots \ldots \ldots \ldots \ldots$ & 2.4 & 4.4 & 4.1 & 2.5 & 3.7 & 3.3 & 2.1 & 2.5 & .5 & 2.5 & 2.1 & 4.3 \\
\hline $\mathrm{U} \ldots \ldots \ldots \ldots \ldots \ldots$ & 2.4 & 4.4 & 3.5 & 3.5 & 4.1 & 3.8 & 2.0 & 2.5 & 1.0 & 2.1 & 2.3 & 4.2 \\
\hline $\mathrm{Zr} / \mathrm{Hf} . . . \ldots \ldots \ldots$ & 45 & 46 & 48 & 58 & 48 & 49 & 52 & 33 & nd & 20 & 37 & 42 \\
\hline
\end{tabular}


TABLE 6.-Major-oxide, normative-mineral, and trace-element compositions, volatiles omitted, of Proterozoic $Z$ intrusive rocks, Milford-Dedham zone, northeastern Massachusetts-Continued

\section{Description of samples}

Sample localities shown in Wones and others (1986)

1. DMA-166. Inequigranular biotite granite, Dedham Granite; Barefoot Hill quartz monzonite of Lyons (1969). Rockland and Rockland Circle, Brockton. UTM grid: N46609-E3295.

2. DMA-123. Dedham Granite; Government Island, Cohasset. UTM grid: N46773-E3524.

3. DMA-94. Dedham quartz monzonite of Lyons (1969), Dedham Granite; Roadcut, I-95, $906 \mathrm{~m}$ south of Cocasset St., Foxborough. UTM grid: N46603-E3158.

4. DMA-105. Aplite dike ( $35 \mathrm{~cm}$ wide), Dedham Granite, intruding hornblende-bearing granodiorite; west end of rest area, south side of Rte. 3, Weymouth. UTM grid: N46723-E3388.

5. DMA-73. Biotite granite, Dedham Granite; Roadcut, northwest side of intersection of Rte. 128 and U.S. Rte. 1A. UTM grid: N46776-E3197. 6. W-6. Slightly altered biotite granite, Dedham Granite; roadcut, I $-495,360 \mathrm{~m}$ east of U.S. Rte. 1A intersection. UTM grid: N46567-E3061.

7. DMA-65. Granodiorite intruding quartzite, Dedham Gramite north of Boston; SW. corner intersection of Main St. and Middlesex Fells Parkway, Saugus. UTM grid: N47038-E3328.

8. DMA-127. Granite intruding amphibolite and diorite, Dedham Granite north of Boston; Spring St., Lexington, 100 m north of Rte. 2. UTM grid: N46995-E3148.

9. DMA-60. Granodiorite, Topsfield Granodiorite; Topsfield granite of Toulmin (1964), Granodiorite of Oxpasture Brook of Bell and others (1977). UTM grid: N47334-E3480.

10. P-5. Esmond Gramite, slightly altered, locally contains garnet; roadcut, I-295, $300 \mathrm{~m}$ east of Woonsocket Reservoir, Smithfield-Lincoln town line, Rhode Island. UTM grid: N46458-E2938.

11. DMA-206. Granite, Westwood Granite (Chute, 1966); roadcut, Rtes. 128 and 109, Norwood. UTM grid: N46794-E3182.

12. DMA-110. Granite, Westwood Granite; Plymouth quarries, Weymouth. UTM grid: N46725-E3427. or bluish quartz occurs in aggregates or granular streaks, plagioclase is saussuritized, microcline is white to pink, and biotite, titanite, and epidote occur in clusters. Accessory minerals are apatite, opaque minerals, allanite, epidote, sericite, and chlorite. Plagioclase and microcline show recrystallization at their margins.

Porphyritic granite is well exposed along Route 140 west of Long Pond and in Fall River (near Quarry Street Church and at the Route 24-Brayton Street interchange). Finer grained porphyritic varieties crop out to the northeast near Snipatuit Pond. O.D. Hermes and D.P. Murray (written commun., 1985) have identified a mass of undeformed alkalic granite within the area mapped as porphyritic granite on the State bedrock map near the small mass of diorite (Zdi) on the southwest side of Slocums River.

\section{Alaskite (Zagr)}

Light-colored gneissic alaskite (Zagr) forms phacolithic masses near New Bedford that extend east toward Buzzards Bay and Cape Cod (fig. 11). The rock is resistant to weathering and is well exposed southwest of New Bedford. It has a remarkable resemblance to the Hope Valley Alaskite Gneiss (Zhg) of south-central Massachusetts, western Rhode Island, and adjacent Connecticut.

The rock is pale orange to cream colored, fine to medium grained, and equigranular and has a weak foliation and lineation imparted by preferred orientation of micas and flattened quartz aggregates. Coarsegrained phases contain lenses of gray quartz and pinkishorange K-feldspar.

TABLE 7.-Modes, in percent, of plutonic rocks of the Dedham batholith, southeasterm Massachusetts

[Zfgr, granite of the Fall River pluton; Zpgr, porphyritic granite; Zagr, alaskite. Sample localities shown by field number in Wones and others (1986). a, albite; $o$,ohgoclase; $p$, perthite; tr, trace]

\begin{tabular}{|c|c|c|c|c|c|c|c|c|c|c|c|}
\hline $\begin{array}{l}\text { Sample no. } \ldots \ldots \ldots \ldots \ldots \\
\text { Unit } \ldots \ldots \ldots \ldots \ldots \ldots \\
\text { Points counted } \ldots \ldots \ldots \ldots \\
\text { Field no.......... }\end{array}$ & $\begin{array}{c}1 \\
\mathrm{Zfgr} \\
1728 \\
\text { FRE-3* }\end{array}$ & $\begin{array}{c}2 \\
\text { Zfgr } \\
1559 \\
\text { FRE-10 }\end{array}$ & $\begin{array}{c}3 \\
\mathrm{Zfgr} \\
1613 \\
\mathrm{Mn}-10\end{array}$ & $\begin{array}{c}4 \\
\mathrm{Zfgr} \\
1870 \\
\mathrm{~T}-1\end{array}$ & $\begin{array}{c}5 \\
\text { Zpgr } \\
1725 \\
\text { Ap-2 }\end{array}$ & $\begin{array}{c}6 \\
\text { Zpgx } \\
1967 \\
\text { FR-16 }\end{array}$ & $\begin{array}{c}7 \\
\mathrm{Zpgr} \\
1632 \\
\mathrm{NBN}-22\end{array}$ & $\begin{array}{c}8 \\
\text { Zpgr } \\
1587 \\
\text { We-2 }\end{array}$ & $\begin{array}{c}9 \\
\text { Zagr } \\
1543 \\
\text { We-14 }\end{array}$ & $\begin{array}{c}10 \\
\text { Zagr } \\
1680 \\
\text { FRE-6 }\end{array}$ & $\begin{array}{c}11 \\
\text { Zagr } \\
1500 \\
\text { NBN-3 }\end{array}$ \\
\hline Quartz.............. & 33.9 & 32.5 & 36.1 & 40.0 & 37.7 & 39.7 & 30.0 & 25.8 & 33.0 & 38.0 & 36.7 \\
\hline Plagioclase ........... & $28.3 \mathrm{a}$ & $26.5 \mathrm{a}$ & 30.1 & $27.5 \mathrm{a}$ & 24.8 & 16.2 & 27.4 & $20.5 \mathrm{a}$ & $34.0 \mathrm{a}$ & $34.0 \mathrm{a}$ & 33.70 \\
\hline Microcline.......... & $30.8 p$ & $39.3 p$ & 26.3 & $28.1 p$ & 21.1 & 34.2 & 25.4 & 44.3 & 31.2 & 25.5 & 26.7 \\
\hline Biotite........... & 3.9 & .1 & 6.9 & 2.0 & 2.7 & 2.5 & 9.4 & 5.5 & 1.2 & 0 & 1.4 \\
\hline Muscovite.......... & 1.0 & .8 & .1 & .8 & 4.5 & 4.3 & 3.1 & 1.1 & 0 & 1.6 & 1.3 \\
\hline Epidote............. & 1.5 & 0 & .1 & .4 & 7.9 & 2.2 & 4.2 & 1.8 & 0 & 0 & 0 \\
\hline Chlorite............ & .1 & .3 & 0 & .8 & 1.0 & .5 & 0 & .1 & $\operatorname{tr}$ & 0 & 0 \\
\hline Magnetite............ & 0 & .1 & .1 & .2 & .1 & 0 & 0 & .2 & .3 & .1 & .2 \\
\hline Titanite............. & .2 & 0 & .3 & 0 & .1 & .3 & .3 & .6 & 0 & 0 & 0 \\
\hline Apatite ............ & 0 & .1 & 0 & $\operatorname{tr}$ & .1 & .1 & .1 & .1 & .2 & .1 & .1 \\
\hline Allanite............. & .1 & 0 & $\operatorname{tr}$ & $\operatorname{tr}$ & 0 & $\operatorname{tr}$ & 0 & .1 & .1 & 0 & 0 \\
\hline Garnet............. & .1 & 0 & 0 & .1 & 0 & 0 & 0 & 0 & 0 & .7 & .1 \\
\hline Zircon .............. & 0 & .1 & 0 & 0 & 0 & 0 & 0 & 0 & 0 & 0 & 0 \\
\hline Calcite.............. & 0 & .4 & 0 & 0 & 0 & 0 & 0 & 0 & 0 & 0 & 0 \\
\hline
\end{tabular}

"Chemical analysis in table 8. 
TABLE 8.-Major-oxide, normative-mineral, and trace-element compositions, volatiles omitted, of Proterozoic $Z$ intrusive rocks, southeastern Massachusetts

[Major-oxide compositions from X-ray spectroscopy by Paul Hearn and Susan Wargo; all $\mathrm{Fe}$ reported as $\mathrm{Fe}_{2} \mathrm{O}_{3}$. Trace-element abundances from instrumental neutron activation analyses by L.J. Schwartz except $\mathrm{Rb}$ and $\mathrm{Sr}$ determined by X-ray spectroscopy by G. Sellars, B. McCall, and R. Johnson. nd, not determined]

\begin{tabular}{|c|c|c|c|c|c|}
\hline $\begin{array}{l}\text { Sample no.... } \\
\text { Unit. . . . }\end{array}$ & $\begin{array}{c}1 \\
\mathrm{Zfor}\end{array}$ & $\begin{array}{c}2 \\
\mathrm{Zfgr}\end{array}$ & $\begin{array}{c}3 \\
\mathrm{Zfgr}\end{array}$ & $\begin{array}{c}4 \\
\text { Zfgr }\end{array}$ & $\begin{array}{c}5 \\
\text { Zpgr }\end{array}$ \\
\hline
\end{tabular}

Major-oxide composition, in weight percent, and alkali-alumina ratio

\begin{tabular}{|c|c|c|c|c|c|}
\hline $\mathrm{SiO}_{2}$ & 75.64 & 74.73 & 77.9 & 73.08 & 67.48 \\
\hline $\mathrm{Al}_{2} \mathrm{O}_{3} \ldots \ldots \ldots \ldots \ldots \ldots$ & 12.46 & 12.70 & 12.2 & 14.47 & 15.81 \\
\hline $\mathrm{Fe}_{2} \mathrm{O}_{3} \ldots \ldots \ldots \ldots \ldots \ldots$ & .87 & 1.20 & 1.4 & 2.13 & 2.71 \\
\hline $\mathrm{MnO} \ldots \ldots$ & .10 & .05 & .04 & .07 & .08 \\
\hline $\mathrm{MgO}$. & .26 & .20 & .20 & .21 & .94 \\
\hline $\mathrm{CaO}$. & .13 & .70 & .08 & 1.08 & 2.78 \\
\hline $\mathrm{Na}_{2} \mathrm{O}$. & 3.71 & 3.34 & 2.6 & 3.35 & 3.42 \\
\hline $\mathrm{K}_{2} \mathrm{O} \ldots \ldots \ldots \ldots \ldots \ldots \ldots$ & 4.68 & 4.60 & 4.58 & 4.55 & 3.76 \\
\hline $\mathrm{TiO}_{2} \ldots \ldots \ldots \ldots \ldots \ldots$ & .06 & .14 & .17 & .23 & .40 \\
\hline $\mathrm{P}_{2} \mathrm{O}_{5} \ldots \ldots \ldots \ldots \ldots \ldots$ & .01 & .04 & .01 & .07 & .13 \\
\hline$\left(\mathrm{Na}_{2} \mathrm{O}+\mathrm{K}_{2} \mathrm{O}\right) / \mathrm{Al}_{2} \mathrm{O}_{3} \ldots \ldots$ & .67 & .62 & .59 & .55 & .45 \\
\hline
\end{tabular}

Normative-mineral composition, in weight percent, ${ }^{1}$ and differentiation index (DI)

\begin{tabular}{|c|c|c|c|c|c|}
\hline $\mathrm{Qtz}, \ldots \ldots \ldots \ldots \ldots \ldots \ldots$ & 35.5 & 35.0 & 42.2 & 31.1 & 24.8 \\
\hline Crn $\ldots \ldots \ldots \ldots \ldots \ldots$ & 1.1 & .9 & 1.5 & 1.9 & 1.4 \\
\hline Or... & 28.2 & 27.2 & 27.1 & 27.0 & 22.8 \\
\hline $\mathrm{Ab}$. & 32.1 & 28.3 & 21.9 & 32.2 & 29.7 \\
\hline An $\ldots \ldots \ldots \ldots \ldots \ldots$ & .6 & 3.3 & 4.0 & 4.9 & 13.3 \\
\hline En................... & .7 & .5 & .5 & .5 & 2.4 \\
\hline Fs $\ldots \ldots \ldots \ldots \ldots \ldots$ & 1.7 & 2.0 & 2.3 & 3.7 & 4.6 \\
\hline $\operatorname{Ilm} \ldots \ldots \ldots \ldots \ldots \ldots$ & .1 & .2 & .3 & .4 & .8 \\
\hline Ap................. & 0 & 0 & 0 & .2 & .3 \\
\hline DI $\ldots \ldots \ldots \ldots \ldots \ldots \ldots$ & 96 & 90 & 91 & 90 & 77 \\
\hline
\end{tabular}

Trace-element abundances, in parts per million, and selected ratios

\begin{tabular}{llccccc}
\hline $\mathrm{Rb} \ldots \ldots \ldots \ldots \ldots \ldots \ldots \ldots \ldots$ & 290 & 143 & 152 & 142 & 135 \\
$\mathrm{Cs} \ldots \ldots \ldots \ldots \ldots \ldots \ldots \ldots \ldots$ & 3.0 & 4.0 & 1.9 & 1.7 & 3.0 \\
$\mathrm{Sr} \ldots \ldots \ldots \ldots \ldots \ldots \ldots \ldots \ldots$ & 28 & 48 & 55 & 80 & 302 \\
$\mathrm{Ba} \ldots \ldots \ldots \ldots \ldots \ldots \ldots \ldots \ldots$ & 93 & 274 & 286 & 465 & 546 \\
$\mathrm{Rb} / \mathrm{Cs} \ldots \ldots \ldots \ldots \ldots \ldots \ldots$ & 97 & 36 & 80 & 84 & 45 \\
$\mathrm{Rb} / \mathrm{Sr} \ldots \ldots \ldots \ldots \ldots \ldots \ldots$ & 10.3 & 3.0 & 2.8 & 1.8 & .4 \\
$\mathrm{Sc} \ldots \ldots \ldots \ldots \ldots \ldots \ldots \ldots$ & 4.5 & 5.9 & 5.2 & 7.0 & 6.9 \\
$\mathrm{Cr} \ldots \ldots \ldots \ldots \ldots \ldots \ldots$ & 3.0 & nd & nd & 4.2 & 3.0
\end{tabular}

The alaskite consists of quartz, microcline and microcline perthite, albite to sodic oligoclase, and typically less than 2 percent biotite. It contains accessory muscovite, garnet, magnetite, apatite, zircon, and rare allanite and monazite. Secondary minerals are calcite, chlorite, and epidote. Chemically the alaskite is inferred to be similar in composition to the Hope Valley Alaskite Gneiss. If the albite were plotted as alkali feldspar rather than plagioclase, the location of the alaskite on the ternary plot (fig.
TABLE 8.-Major-oxide, normative-mineral, and trace-element compositions, volatiles omitted, of Proterozoic $Z$ intrusive rocks, southeastern Massachusetts-Continued

\begin{tabular}{|c|c|c|c|c|c|}
\hline $\begin{array}{l}\text { Sample no.. } \\
\text { Unit...... }\end{array}$ & $\begin{array}{c}1 \\
\mathrm{Zfgr}\end{array}$ & $\begin{array}{c}2 \\
\text { Zfgr }\end{array}$ & $\begin{array}{c}3 \\
\mathrm{Zfgr}\end{array}$ & $\begin{array}{c}4 \\
\text { Zfgr }\end{array}$ & $\begin{array}{c}5 \\
\text { Zpor }\end{array}$ \\
\hline
\end{tabular}

Trace-element abundances, in parts per million, and selected ratios-Continued

\begin{tabular}{|c|c|c|c|c|c|}
\hline Co... & .3 & 2.2 & 1.2 & 1.5 & 5.7 \\
\hline $\mathrm{Zn} \ldots \ldots \ldots \ldots \ldots \ldots \ldots$ & 32 & 30 & 36 & 46 & 41 \\
\hline La.. & 22 & 24 & 31 & 70 & 29 \\
\hline $\mathrm{Ce} .$. & 51 & 59 & 95 & 137 & 54 \\
\hline$\ldots \ldots \ldots \ldots \ldots$ & 28 & 23 & 44 & 57 & 22 \\
\hline $\mathrm{Sm} \ldots \ldots \ldots \ldots \ldots \ldots \ldots$ & 9.0 & 4.6 & 7.9 & 11 & 4.0 \\
\hline Eu................... & .40 & .50 & .75 & .97 & .85 \\
\hline $\operatorname{Gd}, \ldots \ldots \ldots \ldots \ldots \ldots$ & 7.8 & 3.3 & 5.8 & 7.4 & 3.2 \\
\hline$\ldots \ldots \ldots \ldots \ldots \ldots \ldots$ & 1.58 & .55 & .96 & 1.32 & .49 \\
\hline Ho. $\ldots, \ldots, \ldots, \ldots$, & 2.2 & .8 & .8 & .9 & .7 \\
\hline$\ldots \ldots \ldots \ldots \ldots \ldots \ldots$ & .67 & .25 & .41 & .80 & .41 \\
\hline $\mathrm{Yb}, \ldots \ldots \ldots \ldots \ldots \ldots \ldots \ldots$ & 7.2 & 1.7 & 3.3 & 4.4 & 2.0 \\
\hline $\mathrm{Lu} . \ldots \ldots \ldots \ldots \ldots \ldots$ & 1.0 & .25 & .47 & .62 & .30 \\
\hline $\mathrm{La} / \mathrm{Y} b \ldots \ldots \ldots \ldots \ldots \ldots$ & 3 & 14 & 9 & 16 & 14 \\
\hline Hf. & 3.8 & 4.3 & 4.6 & 6.1 & 3.0 \\
\hline $\mathrm{Zr}$. & 145 & 145 & nd & 255 & 138 \\
\hline $\mathrm{Th}^{2} \ldots \ldots \ldots \ldots \ldots \ldots \ldots$ & 24.8 & 17.3 & 19.0 & 14.4 & 8.3 \\
\hline Th..................... & 30.2 & 15.9 & 18.7 & 14.5 & 9.9 \\
\hline 然 & 5.6 & 2.0 & 4.2 & 4.0 & 5.0 \\
\hline Un................... & 6.6 & 2.4 & 4.0 & 4.0 & 4.9 \\
\hline $\mathrm{Zr} / \mathrm{Hf} \ldots \ldots \ldots \ldots \ldots \ldots$ & 38 & 34 & nd & 42 & 46 \\
\hline
\end{tabular}

${ }^{1} \mathrm{Fe}_{2} \mathrm{O}_{3}$ calculated as $\mathrm{FeO}$.

${ }^{2}$ Delayed neutron reactivation analyses by H.T. Millard, Jr., C.M. Ellis, and V.C. Smith.

Description of samples

Sample localities shown in Wones and others (1986)

1. AP-5. Granite of the Fall River pluton; leucocratic granite; roadcut, Rte. 140, just west of Pickens St. overpass, Lakeville. UTM grid: N46326-E3352.

2. FRE-3. Granite of the Fall River pluton; biotite granite; roadcut, Rte. 24, $1.1 \mathrm{~km}$ south of interchange 40, Fall River. UTM grid: N46189-E3237.

3. FR-17. Granite of the Fall River pluton; biotite granite, Bulgarmarsh Granite of Pollock (1964); roadcut, Rte. 24, $500 \mathrm{~m}$ east of interchange with Rte. 138, Tiverton. UTM grid: N46123-E3168.

4. BG-72. Granite of the Fall River pluton; biotite granite, Bulgarmarsh Granite; sampled by Galloway (1973); same location as sample 3. 5. DMA-172. Porphyritic granite; inequigranular gneissic biotite granite, roadcut, Rte. $140,1.6 \mathrm{~km}$ south of exit 9, on the LakevilleFreetown town line. UTM grid: N46277-E3369.

5) would be shifted to the quartz-K-feldspar side of the diagram and would identify it as an alkali-feldspar granite.

\section{Granite, Gneiss, And Schist, Undivided (Zgg)}

Cape Cod and the adjacent mainland south of Plymouth are covered by Pleistocene glacial materials, which conceal the bedrock to such an extent that only 
TABLE 9.-Modes, in percent, of plutonic rocks of the Milford antiform

[Zhg, Hope Valley Alaskite Gneiss; Zsg, Scituate Granite Gneiss; Zpg, Ponaganset Gneiss; Zgr, biotite granite; Zmgr, Milford Granite; Zmgd, mafic phase of the Milford Granite. Sample localities shown by field number in Wones and others (1986). a, albite; o, oligoclase; p, perthite; tr, trace]

\begin{tabular}{|c|c|c|c|c|c|c|c|c|c|}
\hline $\begin{array}{l}\text { Sample no. } \ldots \ldots \ldots \\
\text { Unit. ............. } \\
\text { Points counted. . } \\
\text { Field no. ......... }\end{array}$ & $\begin{array}{c}\text { 1 } \\
\text { Zhg } \\
1390 \\
\text { M-10" }\end{array}$ & $\begin{array}{c}3 \\
\text { Zsg } \\
1817 \\
\text { Ge-8 }\end{array}$ & $\begin{array}{c}4 \\
Z s g \\
1619 \\
U-6^{*}\end{array}$ & $\begin{array}{c}5 \\
\text { Zsg } \\
1819 \\
\text { B-31 }\end{array}$ & $\begin{array}{c}6 \\
\mathrm{Zpg} \\
1525 \\
\mathrm{C}-1\end{array}$ & $\begin{array}{c}7 \\
\mathrm{Zgr} \\
1568 \\
\mathrm{~B}-20\end{array}$ & $\begin{array}{c}8 \\
\mathrm{Zgr} \\
1493 \\
\mathrm{H}-6 \mathrm{~b}\end{array}$ & $\begin{array}{c}9 \\
\mathrm{Zmgr} \\
1634 \\
\mathrm{Mi}-4\end{array}$ & $\begin{array}{c}10 \\
\text { Zmgd } \\
1621 \\
\text { Mi-5 }\end{array}$ \\
\hline Quartz............ & 40.1 & 38.7 & 40.3 & 33.0 & 39.0 & 33.8 & 33.8 & 46.6 & 38.4 \\
\hline Plagioclase ....... & $28.5 \mathrm{a}$ & $20.7 a$ & $26.9 \mathrm{a}$ & 29.20 & 30.7 & 33.5 & 5.0 & 24.40 & 42.1 \\
\hline Microcline....... & $29.9 p$ & 32.3 & $27.6 \mathrm{p}$ & 33.1 & 20.4 & 23.8 & $55.4 \mathrm{p}$ & 26.7 & 4.9 \\
\hline Biotite.......... & 0 & 6.8 & 4.5 & 2.1 & 7.4 & 5.7 & 0 & 1.9 & 9.9 \\
\hline Muscovite........ & 1.2 & 0 & .3 & 1.1 & .1 & 2.0 & 2.7 & .1 & .2 \\
\hline Epidote ......... & 0 & 1.1 & 0 & .6 & 1.0 & .9 & 0 & .1 & 3.5 \\
\hline Hornblende....... & 0 & 0 & 0 & 0 & .3 & 0 & 0 & 0 & 0 \\
\hline Chlorite.......... & 0 & .1 & 0 & .4 & 0 & .2 & 0 & $\operatorname{tr}$ & .3 \\
\hline Magnetite........ & .3 & .1 & 0 & $\operatorname{tr}$ & 0 & 0 & 1.6 & 0 & $\operatorname{tr}$ \\
\hline Hematite......... & 0 & 0 & 0 & 0 & 0 & 0 & 1.5 & 0 & 0 \\
\hline Titanite.......... & 0 & .1 & .1 & .2 & .7 & .1 & $\operatorname{tr}$ & $\operatorname{tr}$ & .5 \\
\hline Apatite ......... & 0 & 0 & .3 & $\operatorname{tr}$ & .2 & .1 & 0 & $\operatorname{tr}$ & .2 \\
\hline Allanite......... & 0 & .2 & $\operatorname{tr}$ & 0 & .2 & $\operatorname{tr}$ & 0 & $\operatorname{tr}$ & $\operatorname{tr}$ \\
\hline Garnet.......... & 0 & $\operatorname{tr}$ & 0 & $\operatorname{tr}$ & 0 & 0 & 0 & .1 & 0 \\
\hline Zircon ........... & $\operatorname{tr}$ & $\operatorname{tr}$ & $\operatorname{tr}$ & 0 & 0 & 0 & 0 & $\operatorname{tr}$ & $\operatorname{tr}$ \\
\hline Calcite ........... & 0 & 0 & 0 & .2 & 0 & 0 & 0 & 0 & 0 \\
\hline
\end{tabular}

${ }^{*}$ Chemical analysis in table 10.

rare scattered outcrops and a few deep drill holes give clues as to the nature of the bedrock (fig. 17). Therefore, the units mapped in the Fall River-New Bedford area cannot be mapped in this region. The diverse rock types encountered in the few exposures and in the drill holes are assigned to an undivided unit of granite, gneiss, and schist (Zgg). Presumably most of the plutonic and metamorphic rock units in the Fall River-New Bedford area project into the concealed area to the east. A marked north-south topographic lineament, parallel to faults bounding the Assawompset Pond graben, that passes through Snipatuit Pond (fig. 11) forms a convenient boundary for separating the region on the west, in which recognizable rock units can be mapped, from the region to the east, in which units cannot be mapped.

The bedrock is known in this region in a few places west of Cape Cod. Both gneissic biotite granite and gneissic alaskite crop out on Front Street north of Marion center. North of Marion, no outcrops are known. Goldsmith was unable to locate outcrops indicated by Williams and Willey (1973) in the Plympton area southwest of Plymouth. Deep coreholes drilled by Bechtel Corporation for the Boston Edison Company at Rocky Point near Manomet (fig. 17) encountered a gray, medium-grained granodiorite (sample DMA-167) and gray aplite. In the Duxbury area, bedrock exposures were numerous enough for Chute (1965a) to assign a light-colored pinkish-gray granite to the Westwood Granite and one outcrop of coarse-grained granite to the Dedham Granite and to identify as a separate unit a medium-gray foliated biotite granite that intrudes the
Westwood. Most of the outcrops in the Duxbury area are light-colored granite. It is not certain that the lightcolored granite in the Duxbury area is actually the same Westwood Granite mapped north of the Narragansett basin. None of the rocks in the Duxbury area have been shown separately on the State bedrock map; all are included in the undivided granite, gneiss, and schist unit. Chute (1965a) also identified an exposure of light-pink to lavender-gray porphyritic rhyolite at Cripple Rocks (CR, fig. 17) in Kingston Bay and another of greenish rhyolite in Green Harbor cut by aplite dikes. The age of these rocks is unknown. Larger areas of rhyolite could quite likely be present under the glacial cover.

Even less information is available for Cape Cod (Weed, in Goldsmith, this vol., chap. E, table 8, fig. 15). A 300-m drill hole in Harwich, Mass. (1, fig. 17), reported by Koteff and Cotton (1962) penetrated $171 \mathrm{~m}$ of steeply dipping, medium-gray, fine-grained, phyllitic schist containing layers of greenish-gray to gray crystalline limestone in the upper $15.2-18.3 \mathrm{~m}$. Two 300-m holes in Brewster reported by R.Z. Gore (written commun., 1978; 2 and 3, fig. 17) penetrated plutonic rocks. One of these holes went through $131 \mathrm{~m}$ of granite containing diorite and quartz-diorite inclusions. The granite is flanked above and below by granodiorite. A shear zone or foliated zone separates the upper granodiorite from the granite, and an alteration zone passes through the lower granodiorite near the bottom of the hole. The second hole penetrated sheared granodiorite. Another hole near Brewster (4, fig. 17) ended in till or granite. Unidentified bedrock has been reported from other wells on Cape Cod 
TABLE 10.-Major-oxide, normative-mineral, and trace-element compositions, volatiles omitted, of Proterozoic $Z$ intrusive rocks in the Milford antiform

[Major oxides determined by X-ray spectroscopy by Paul Hearn and Susan Wargo; all $\mathrm{Fe}$ reported as $\mathrm{Fe}_{2} \mathrm{O}_{3}$. Trace-element abundances determined by instrumental neutron activation analyses by L.J. Schwartz except for $\mathrm{Rb}$ and Sr by X-ray fluorescence analyses by G. Sellars and B. McCall]

\begin{tabular}{|c|c|c|c|c|c|}
\hline 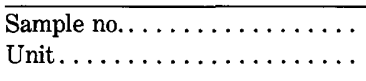 & $\begin{array}{c}1 \\
\mathrm{Zmgr}\end{array}$ & $\begin{array}{c}2 \\
\text { Zmgd }\end{array}$ & $\begin{array}{c}3 \\
\mathrm{Zgr}\end{array}$ & $\begin{array}{c}4 \\
\text { Zsg }\end{array}$ & $\begin{array}{c}5 \\
\text { Zhg }\end{array}$ \\
\hline \multicolumn{6}{|c|}{$\begin{array}{l}\text { Major-oxide composition, in weight percent, } \\
\text { and alkali-alumina ratio }\end{array}$} \\
\hline $\mathrm{SiO}_{2}$ & 75.82 & 71.08 & 72.59 & 75.51 & 76.01 \\
\hline $\mathrm{Al}_{2} \mathrm{O}_{3} \ldots \ldots \ldots \ldots \ldots \ldots$ & 12.74 & 13.36 & 13.24 & 13.39 & 11.72 \\
\hline $\mathrm{Fe}_{2} \mathrm{O}_{3} \ldots \ldots \ldots \ldots \ldots$ & 1.18 & 3.27 & 2.64 & 1.42 & 1.20 \\
\hline $\mathrm{MnO} \ldots$ & .05 & .08 & .07 & .05 & .02 \\
\hline $\mathrm{MgO} \ldots$ & .31 & 1.18 & .45 & .21 & .18 \\
\hline $\mathrm{CaO} \ldots$ & .62 & 3.13 & 1.88 & .97 & .22 \\
\hline $\mathrm{Na}_{2} \mathrm{O}$ & 3.58 & 3.61 & 3.24 & 3.35 & 4.11 \\
\hline $\mathrm{K}_{2} \mathrm{O} \ldots \ldots \ldots \ldots \ldots \ldots \ldots$ & 4.94 & 2.58 & 3.44 & 4.90 & 4.02 \\
\hline $\mathrm{TiO}_{2} \ldots \ldots \ldots \ldots \ldots \ldots$ & .09 & .48 & .36 & .17 & .07 \\
\hline $\mathrm{P}_{2} \mathrm{O}_{5} \ldots \ldots \ldots \ldots \ldots \ldots$ & .04 & .11 & .10 & .04 & .02 \\
\hline$\left(\mathrm{Na}_{2} \mathrm{O}+\mathrm{K}_{2} \mathrm{O}\right) / \mathrm{Al}_{2} \mathrm{O}_{3} \ldots \ldots$ & .67 & .46 & .50 & .62 & .69 \\
\hline
\end{tabular}

Normative-mineral composition, in weight percent, ${ }^{1}$ and differentiation index (DI)

\begin{tabular}{|c|c|c|c|c|c|}
\hline $\mathrm{Qtz} \ldots \ldots \ldots \ldots$ & 33.7 & 30.5 & 34.9 & 33.9 & 35.9 \\
\hline Crn ............ & .5 & 0 & 1.0 & .9 & .3 \\
\hline Or......... & 29.4 & 15.4 & 20.7 & 29.0 & 24.3 \\
\hline $\mathrm{Ab}, \ldots \ldots \ldots \ldots \ldots \ldots \ldots$ & 30.5 & 30.9 & 28.0 & 28.3 & 35.6 \\
\hline 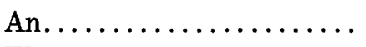 & 2.8 & 12.8 & 8.8 & 4.6 & 1.0 \\
\hline Wo $\ldots \ldots \ldots \ldots \ldots \ldots$. & 0 & .8 & 0 & 0 & 0 \\
\hline En................... & .8 & 3.0 & 1.1 & .5 & .5 \\
\hline Fs.... & 2.1 & 5.4 & 4.5 & 2.4 & 2.2 \\
\hline $\operatorname{Ilm} \ldots \ldots \ldots \ldots \ldots \ldots$ & .2 & .9 & .7 & .3 & .1 \\
\hline Ap................... & .1 & .3 & .2 & .1 & 0 \\
\hline DI $\ldots \ldots \ldots \ldots \ldots \ldots \ldots$ & 94 & 77 & 84 & 91 & 96 \\
\hline
\end{tabular}

Trace-element abundances, in parts per million, and selected ratios

\begin{tabular}{|c|c|c|c|c|c|}
\hline$R b, \ldots, \ldots, \ldots, \ldots, \ldots$ & 116 & 73 & 77 & 172 & 137 \\
\hline Cs $\ldots \ldots \ldots \ldots \ldots \ldots \ldots$. & 1.1 & 2.2 & .7 & 2.3 & .6 \\
\hline $\mathrm{Sr} \ldots \ldots \ldots \ldots \ldots \ldots \ldots$ & 66 & 261 & 208 & 63 & 51 \\
\hline $\mathrm{Ba} \ldots \ldots \ldots \ldots \ldots \ldots \ldots$ & 540 & 927 & 1038 & 297 & 593 \\
\hline $\mathrm{Rb} / \mathrm{Cs} \ldots \ldots \ldots \ldots \ldots \ldots$ & 105 & 33 & 110 & 75 & 228 \\
\hline $\mathrm{Rb} / \mathrm{Sr} \ldots$. & 1.8 & .3 & .4 & 2.7 & 2.7 \\
\hline & 1.2 & 11.6 & 4.1 & 2.8 & 5.6 \\
\hline $\mathrm{Cr} \ldots \ldots \ldots \ldots \ldots \ldots$ & 2.0 & 3.0 & 6.8 & .2 & 5.5 \\
\hline
\end{tabular}

(J. Givens and D. LeBlanc, written commun., 1977). A hole near Woods Hole (5, fig. 17; Weed, in Goldsmith, this vol., chap. E, table 8 , fig. 15) encountered gray to pink granodiorite at $83 \mathrm{~m}$ below sea level. Thus, the concealed basement under Cape Cod appears to consist of rocks similar to those exposed on the mainland to the northwest. As confirmation of this conclusion, seismic compressional-wave velocities in the vicinity of the Brewster and Woods Hole holes were 18,000-20,000 feet
TABLE 10.-Major-oxide, normative-mineral, and trace-element compositions, volatiles omitted, of Proterozoic $Z$ intrusive rocks in the Milford antiform-Continued

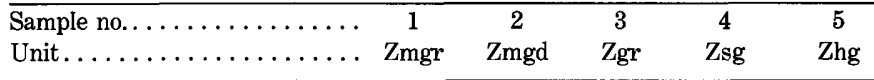

Trace-element abundances, in parts per million, and selected ratios-Continued

\begin{tabular}{|c|c|c|c|c|c|}
\hline Co. & .4 & 3.6 & 3.5 & 1.1 & .1 \\
\hline $\mathrm{Zn}$. & 30 & 64 & 59 & 34 & 28 \\
\hline 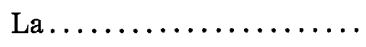 & 32 & 40 & 50 & 36 & 21 \\
\hline $\mathrm{Ce} \ldots \ldots \ldots \ldots \ldots \ldots \ldots$ & 65 & 84 & 92 & 73 & 72 \\
\hline Nd.................. & 29 & 43 & 47 & 34 & 26 \\
\hline $\mathrm{Sm} \ldots \ldots \ldots \ldots \ldots \ldots \ldots$ & 5.6 & 8.8 & 9.7 & 7.1 & 6.0 \\
\hline Eu................... & 1.06 & 2.01 & 1.93 & .62 & .71 \\
\hline $\mathrm{Gd}, \ldots \ldots \ldots \ldots \ldots \ldots$ & 2.8 & 7.1 & 6.8 & 5.8 & 4.6 \\
\hline $\mathrm{Tb} \ldots \ldots \ldots \ldots \ldots \ldots \ldots$ & .49 & 1.15 & 1.21 & 1.06 & .92 \\
\hline Ho................... & .5 & 1.1 & 1.7 & 1.1 & 1.0 \\
\hline $\operatorname{Tm} \ldots \ldots \ldots \ldots \ldots \ldots \ldots$ & .23 & .46 & .63 & .74 & .76 \\
\hline Yb.................... & 1.1 & 3.5 & 3.5 & 4.8 & 4.6 \\
\hline Lu.................. & .16 & .48 & .48 & .69 & .62 \\
\hline $\mathrm{La} / \mathrm{Yb}, \ldots \ldots \ldots \ldots \ldots$ & 29 & 11 & 14 & 7 & 5 \\
\hline Hf. & 3.3 & 5.8 & 6.0 & 4.0 & 6.9 \\
\hline$\ldots \ldots \ldots \ldots \ldots$ & 109 & 288 & 230 & 175 & 228 \\
\hline $\mathrm{Th}^{2} \ldots \ldots \ldots \ldots \ldots \ldots$ & 7.1 & 8.5 & 9.9 & 20.3 & 9.0 \\
\hline 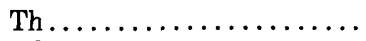 & 8.3 & 8.8 & 9.2 & 21.0 & 11.2 \\
\hline $\mathrm{U}^{2} \ldots \ldots \ldots \ldots \ldots \ldots \ldots$ & 1.3 & 2.1 & 1.4 & 3.7 & 2.6 \\
\hline $\mathrm{U}, \ldots \ldots \ldots \ldots \ldots \ldots \ldots$ & 1.2 & 1.9 & 1.5 & 3.5 & 2.5 \\
\hline $\mathrm{Zr} / \mathrm{Hf} \ldots \ldots \ldots \ldots \ldots \ldots$ & 33 & 50 & 38 & 44 & 33 \\
\hline
\end{tabular}

${ }^{1} \mathrm{Fe}_{2} \mathrm{O}_{3}$ calculated as $\mathrm{FeO}$.

${ }^{2}$ Delayed neutron determination analysis by H.T. Millard, Jr., and B. McCall.

Description of samples

Sample localities shown in Wones and others (1986)

1. DMA-22. Milford Granite; massive granite; roadcut, southeast side of intersection of Rtes. 85 and I-495, Milford. UTM grid: N46710-E2927.

2. Mi-5. Milford Granite, mafic phase; gray, seriate granite; roadcut, northbound lane I-495 at Haven St. overpass, Milford. UTM grid: N46727-E2911.

3. DMA-19. Biotite granite; cataclastic granite; Winch Road, $200 \mathrm{~m}$ southwest of Edmands Rd., Framingham. UTM grid: N46886-E2986. 4. U-6. Scituate Granite Gneiss; splotchy, gneissic, biotite granite; quarry, Quarry Hill, on Hartford Ave. West, $1.5 \mathrm{~km}$ west of North Uxbridge, Uxbridge. UTM grid: N46623-E2801.

5. M-10. Hope Valley Alaskite Gneiss; leucocratic gneissic granite; roadcut, I-495, northbound lane, $1 \mathrm{~km}$ south of interchange 10 (Massachusetts Turnpike), Hopkinton. UTM grid: N46812-E2889.

per second (fps), similar to velocities in the areas of Dedham Granite on the mainland (Oldale and Tuttle, 1965). Seismic velocities in the vicinity of the Harwich hole had a similar but wider range of 17,800-21,500 fps (Oldale and Tuttle, 1964), indicating the greater variability of rock types in this area. The granite, gneiss, and schist unit is inferred to underlie upper Cape Cod, the Elizabeth Islands, and the sedimentary and volcanic rocks of Mesozoic age beneath Nantucket Sound. 
PLUTONIC ROCKS OF THE MILFORD ANTIFORM

The plutonic rocks of the Milford antiform (fig. 11) are flanked by, and contain belts of, older metamorphic rocks of the Plainfield and Westboro Formations and the Blackstone Group (included in other rocks of fig. 11). The plutonic rocks are granitic in composition, although the Milford Granite (Zmgr) has a granodioritic phase (Zmgd). The plutonic rocks are similar in composition to rocks in the Dedham batholith, ranging from alkali feldspar granite to granodiorite (fig. 5); however, most tend to have a well-developed to poorly developed gneissic fabric, unlike the granitic rocks of the Dedham batholith except those in the New Bedford area. The Hope Valley Alaskite Gneiss (Zhg) and associated granitic gneisses in the Milford antiform are the northern continuation of a belt of Proterozoic Z plutonic rocks that extends from the New London anticlinorium in southeastern Connecticut (Goldsmith, 1985; Rodgers, 1985) and adjacent Rhode Island along the Connecticut-Rhode Island border into southern Massachusetts, where they bend around the north side of the Milford antiform in the Framingham area. Age relations seen in southeastern Connecticut and in the Milford antiform indicate that the Hope Valley is the youngest of the gneissic suite. This age is also suggested by the $601 \pm 5$-Ma age obtained from the Hope Valley in southern Rhode Island by Hermes and Zartman (1985). Its age relative to the Milford Granite in the core of the antiform is not known; the two may lie in separate terranes (O'Hara and Gromet, 1985). The plutonic rocks of the Milford antiform are less gneissic to the east than to the west; within the antiform are zones of shearing bounding areas of less sheared to unsheared rock. O'Hara and Gromet (1985; Gromet and O'Hara, 1984) have placed their major terrane boundary along one of these.

\section{Hope Valley Alaskite Gneiss (Zhg)}

The Hope Valley Alaskite Gneiss (Zhg) forms tabular masses along the west side of the Rhode Island anticlinorium from southern Rhode Island and eastern Connecticut to northwestern Rhode Island; it flanks the west side of the Milford antiform and terminates at the north end of the anticlinorium in Massachusetts (fig. 11). The Hope Valley intrudes the Plainfield Formation in Connecticut and rocks mapped as Blackstone Group in Rhode Island (Hermes and others, 1981). The 630-Ma radiometric age (table 1) of this suite of rocks comes from this unit in Massachusetts; the $601 \pm 5$ - $\mathrm{Ma}$ age comes from the Hope Valley in southern Rhode Island.

The rock is light pink to tan. It contains little biotite and sparse magnetite (table 9); in some places, magnetite is more abundant than biotite. Rodded aggregates of quartz give the rock a pronounced lineation in some places. A foliation is produced in other places by a preferred orientation of flat lenses of quartz and flat lenses of feldspar as well as by parallel orientation of biotite where present. Quinn (1971) gave modal values of 24-43 percent quartz, 18-40 percent K-feldspar, 20-40 percent plagioclase, and 1-4 percent biotite and magnetite for the Hope Valley in Rhode Island. Muscovite is a typical accessory mineral, and some rock contains small garnets. Chemically the rock is poor in mafic constituents (table 10, no. 5; figs. 7, 8). It shows enrichment in rare-earth elements and a negative europium anomaly (fig. 18), like most of the other Proterozoic $\mathrm{Z}$ rocks.

\section{Scituate Granite Gneiss (Zsg)}

The Scituate Granite Gneiss (Zsg) on the State bedrock map forms elongate masses in northwestern Rhode Island and Massachusetts (fig. 11). The name Scituate Granite Gneiss is no longer appropriate because the type Scituate Granite Gneiss of Quinn (1971) at Scituate, R.I., has been shown by Hermes and others (1981) and Hermes and Zartman (1985) to be Middle Devonian (373 \pm 7 $\mathrm{Ma}$ ), on the basis of a radiometric determination of zircons from the type Scituate, and is part of a Devonian alkalic suite. The Scituate Granite Gneiss of the type area in central Rhode Island described by Quinn (1971) is here renamed Scituate Granite and assigned a Middle Devonian age. The area of the Scituate Granite coincides with that shown as the main mass of Scituate by Quinn (1971) but with minor adjustments of boundaries (O.D. Hermes and Peter Gromet, oral commun., 1984). The type Scituate Granite Gneiss of Quinn is henceforth referred to as the Scituate Granite. The Scituate Granite Gneiss shown on the Massachusetts bedrock map contains roof pendants of Plainfield Formation and is Proterozoic $\mathrm{Z}$ in age (table 1). We suggest reviving Emerson's old name Northbridge Granite Gneiss for this unit, although detailed mapping in this part of Massachusetts may reveal that several distinct types of granite are present. The Middle Devonian Scituate Granite is at present not known in Massachusetts.

The Scituate Granite Gneiss of the State bedrock map is medium to coarse grained, weathers to a pink or tan, and has a foliation and pronounced lineation defined by aggregates of biotite. Of the modes given in table 9, no. 4 is probably the most representative. The Scituate Granite Gneiss, like the Hope Valley Alaskite Gneiss, contains accessory muscovite and garnet; it is gradational with the Hope Valley Alaskite Gneiss. These two units may represent products of a large zoned magma chamber that has undergone deformation after primary crystallization. In chemical composition, the Scituate is similar to the Hope Valley in many respects except that it contains more mafic constituents (table 10). The REE pattern is similar to that of the Hope Valley (fig. 18). 


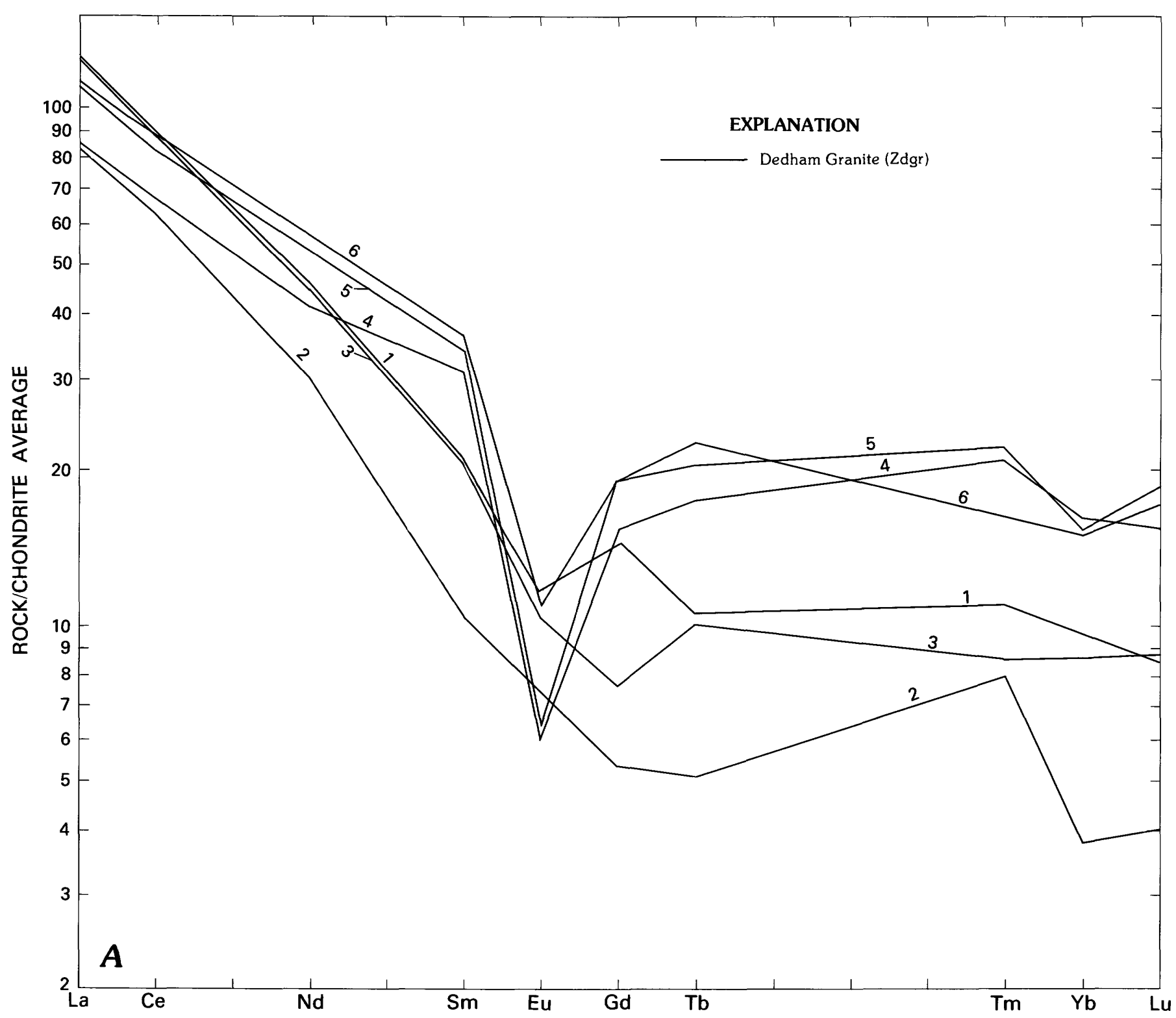

FIGURE 15. - Chondrite-normalized plot of rare-earth elements in Proterozoic $\mathrm{Z}$ batholithic rocks, northeastern Massachusetts: $A$, Dedham Granite; $B$, Dedham Granite north of Boston, Westwood and Esmond Granites, and Topsfield Granodiorite. Numbers are sample numbers from table 6 .

Ponaganset Gneiss (Zpg)

The Ponaganset Gneiss (Zpg) is largely confined to Rhode Island, but masses of porphyritic biotite gneiss assigned to the Ponaganset project into Massachusetts (fig. 11). The Ponaganset Gneiss intrudes the Blackstone Group in Rhode Island (Quinn, 1971). In southern Rhode Island, Feininger (1963) demonstrated that the Ponaganset Gneiss is older than the Hope Valley Alaskite Gneiss and appears to be the oldest granitic intrusive in the Milford-Dedham terrane.

The rock is highly variable in color index, quartz content, and ratio of plagioclase to total feldspar, but most of it, as mapped in Massachusetts, is a gray, biotitic, inequigranular, granitoid rock (table 9, no. 6) with a gneissic foliation produced by parallel orientation of the biotite and elongation of megacrysts. The trace of hornblende in sample 6 (table 9) indicates that this rock is more mafic than the other plutonic rocks of the antiform. In eastern Connecticut, the unit typically contains large round to ellipsoidal megacrysts of $\mathrm{K}$ feldspar and aggregates of K-feldspar and plagioclase (Harwood and Goldsmith, 1971). In places, particularly in Massachusetts, the megacrysts are flattened, or less commonly rodded, to produce a markedly lineated gneiss, as in outcrops at the gaging station on the West River, north of Route 16 in the town of Uxbridge. The 


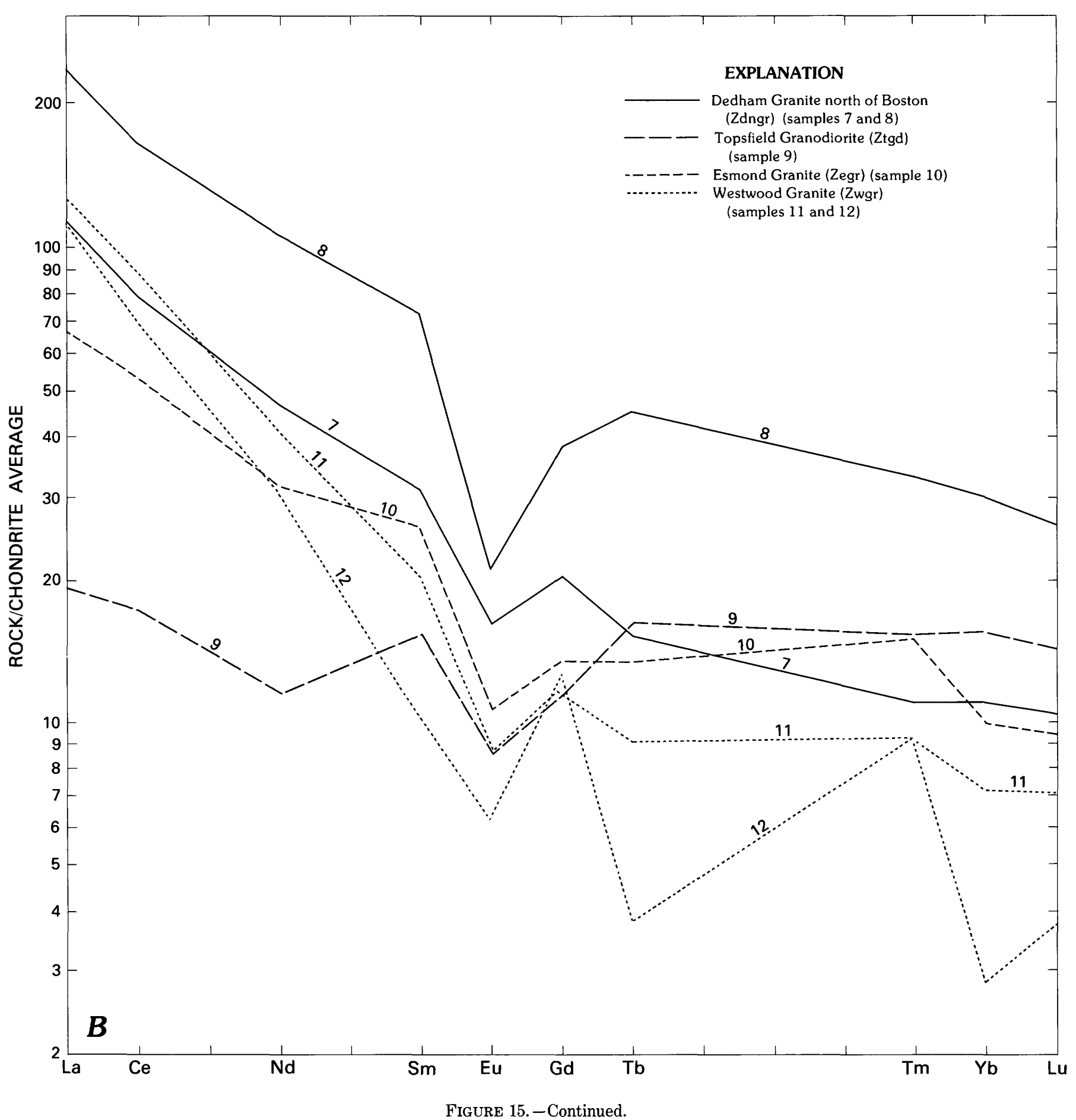

inequigranular texture persists in Massachusetts and is one of the bases for mapping the unit there. In places in northern Rhode Island, some rock that has been mapped as Ponaganset Gneiss is equigranular. The gneissic fabric may be due to Paleozoic deformation. As mapped, the Ponaganset Gneiss may actually consist of several rock types.
Milford Granite (Zmgr, Zmgd)

The Milford Granite (Zmgr, Zmgd) occupies an area of about $100 \mathrm{~km}^{2}$. Its central mass near Milford (fig. 11) is elliptical and has been divided into two phases: a lightcolored phase (Zmgr) and a dark-colored phase (Zmgd) that defines an irregular border for the largest of the light-colored plutons. The Milford intrudes the Black- 


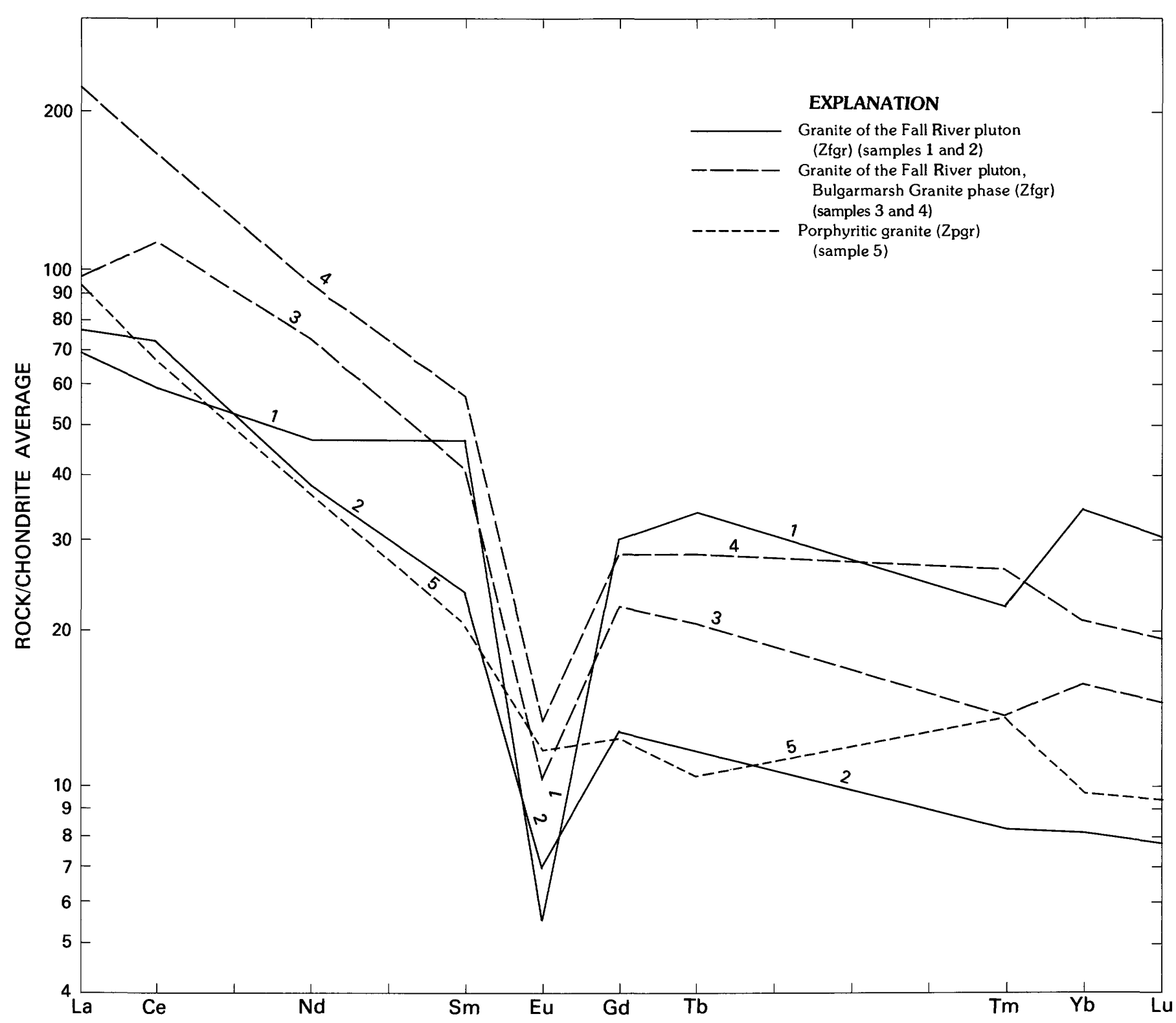

FIGURE 16. - Chondrite-normalized plot of rare-earth elements of Proterozoic Z batholithic rocks in the Milford-Dedham zone, southeastern Massachusetts. Numbers refer to sample numbers in table 8.

stone Group $(\mathrm{Zb})$ and the Ponaganset Gneiss and has been deformed with them at a later undefined time.

The Milford Granite is characterized by a distinctive salmon-pink color, bluish quartz on weathered surfaces, and a lineation defined by lenticular mosaics of quartz and oriented patches of biotite. This lineation contrasts distinctly with the brittle fractures and massive texture of the Dedham Granite and with the cataclastic fabrics commonly found in the biotite granite $(\mathrm{Zgr})$ of the Framingham area.

The light-colored phase is granitic in composition, whereas the dark-colored phase is granodioritic (tables $4,9)$. Biotite is the most abundant ferromagnesian mineral. In the dark-colored phase, clots of epidote and biotite are suggestive of hornblende as a primary magmatic phase, although no hornblende has been observed in these rocks. The light-colored phase of the Milford contains garnet, entrained epidote grains, and muscovite as accessory minerals, whereas the mafic phase contains titanite and opaque minerals. Both phases contain apatite, allanite, and zircon.

The limited chemical data of table 10 (plotted in figs. 7, 8) illustrate the difference in composition between the two phases. Both the granite and granodiorite phases have marked light-REE enrichment, but the granite has heavy-REE depletion relative to the granodiorite, which 


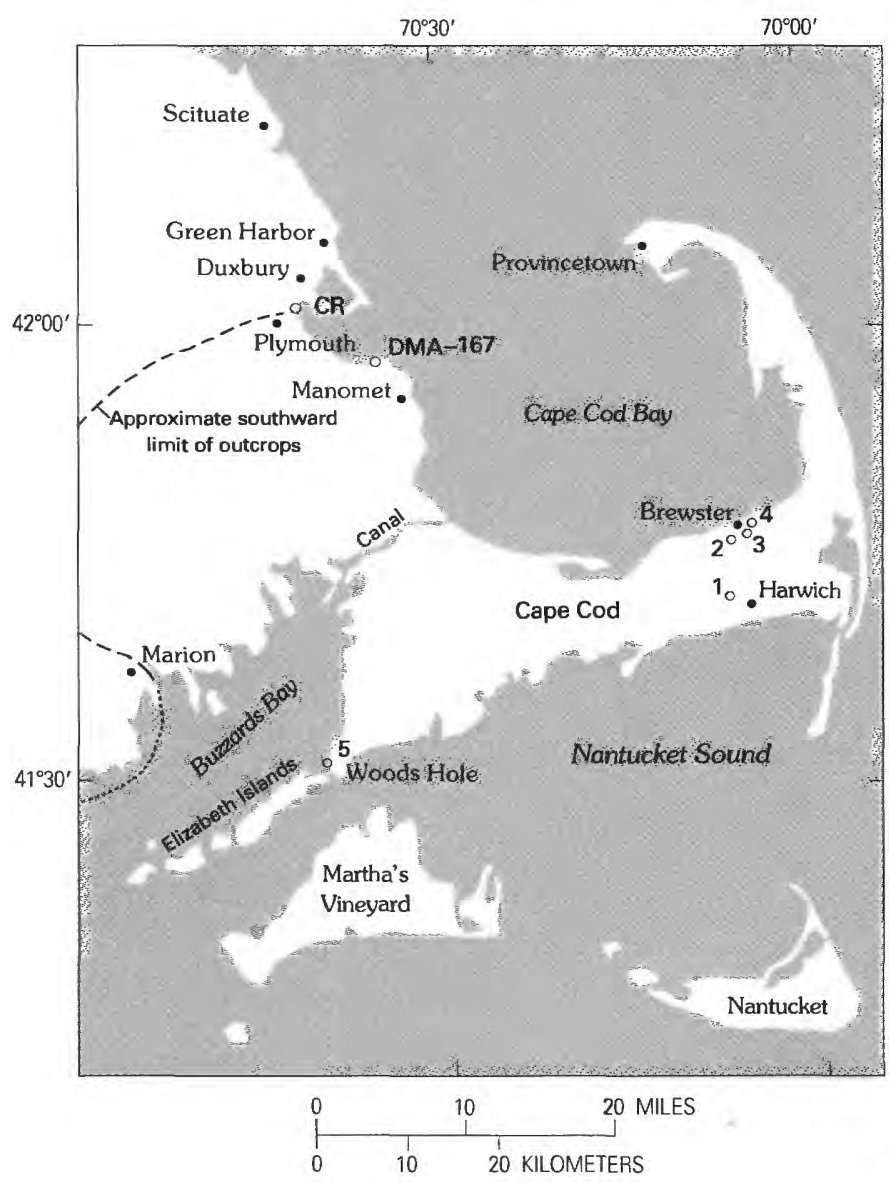

FigURE 17. - Locations of drill holes encountering bedrock in Cape Cod and the adjacent mainland and limit of mappable rock units. CR, Cripple Rocks. Numbers refer to drill holes discussed in text. DMA-167, granodiorite from a hole near Manomet.

has a fairly flat profile (fig. 18). The granodiorite contains more scandium (11.6 ppm) than does the granite (1.2 $\mathrm{ppm})$. These results are typical, but not definitive, of plutons found in compressive tectonic regimes, where zoned plutons are common (Bateman and Chappell, 1979; Noyes and others, 1983) and where hornblende fractionation may cause the development of peraluminous magmas (Cawthorn and O’Hara, 1976; Guy, 1980).

\section{Biotite Granite (Zgr)}

The biotite granite (Zgr) crops out over $180 \mathrm{~km}^{2}$ south of the Bloody Bluff fault zone in the Framingham, Holliston, and Franklin areas (fig. 11). It intrudes earlier gabbro (Zgb), diorite (Zdi), and Proterozoic Z stratified rocks (Zv, Zvf, and Zw) (Nelson, 1975a,b; Volckmann, 1977). The granite as mapped has different textures in different places, and later detailed mapping may show that it can be separated into several units or assigned to other existing units. Much of the biotite granite in its northern part was mapped previously as Milford Granite (Nelson, 1975a,b; Volckmann, 1977), and further map- ping may delineate areas of rock that should be reassigned to that unit. The biotite granite is deformed by mylonitization and cataclasis near fault zones; in places it has the brittle fractures characteristic of the Dedham terrane, and elsewhere it has a gneissic fabric like the other granite gneisses of the Milford terrane.

The biotite granite is gray to light gray and weathers to pink or buff. It lacks the conspicuous red and green coloration characteristic of the Dedham Granite. The unit is mainly granite but is in part granodiorite and tonalite. Some of the rock is quite poor in mafic minerals. The muscovite reported in the modes (table 9) is probably secondary, as are the epidote and chlorite. Some of the granite contains phenocrysts of plagioclase and perthitic alkali feldspar, although the superposed deformation makes the identification of primary igneous textures difficult. Biotite is the dominant mafic phase. Adjacent to the Bloody Bluff fault zone, allanite is a conspicuous accessory that distinguishes the biotite granite from the Dedham and Milford Granites, which contain only minor amounts of allanite. The biotite granite lacks the euhedral titanites characteristic of the Dedham Granite and the garnet characteristic of the Milford Granite and the Hope Valley Alaskite Gneiss. The sample analyzed (table 10 , no. 3) comes from near the Bloody Bluff fault zone and may not be representative of the larger mass of granite south and southwest of Framingham. The biotite granite is assigned a Proterozoic $\mathrm{Z}$ age because of its compositional and textural similarities to the other Proterozoic $\mathrm{Z}$ intrusive rocks of the Milford antiform.

\section{PALEOZOIC INTRUSIVE ROCKS}

The Paleozoic intrusive rocks of the Milford-Dedham zone (fig. 19) comprise a group of relatively discrete plutons ranging in age from Ordovician to Devonian (table 1) and in composition from gabbro to granite. The granitic plutons are alkalic in composition and include the quartz-poor phases syenite and monzonite. The dated gabbroic and dioritic plutons are Ordovician in age. Some might be younger and related to the Ordovician and Silurian to Devonian alkalic granites. In addition to the gabbro and alkalic granite plutons, micrographic rhyolite (DSnr) intrudes the Silurian and Devonian Newbury Volcanic Complex, and dikes of diabase and basalt of Mesozoic age cut the older rocks of the zone. All these rocks in Massachusetts appear to be unmetamorphosed but are locally cut by faults of late Paleozoic and Mesozoic age.

\section{NAHANT GABBRO (Ongb)}

The Nahant Gabbro (Ongb) intrudes the Lower Cambrian Weymouth Formation at Nahant (fig. 19) and thus is younger than the gabbroic or dioritic rocks that are 


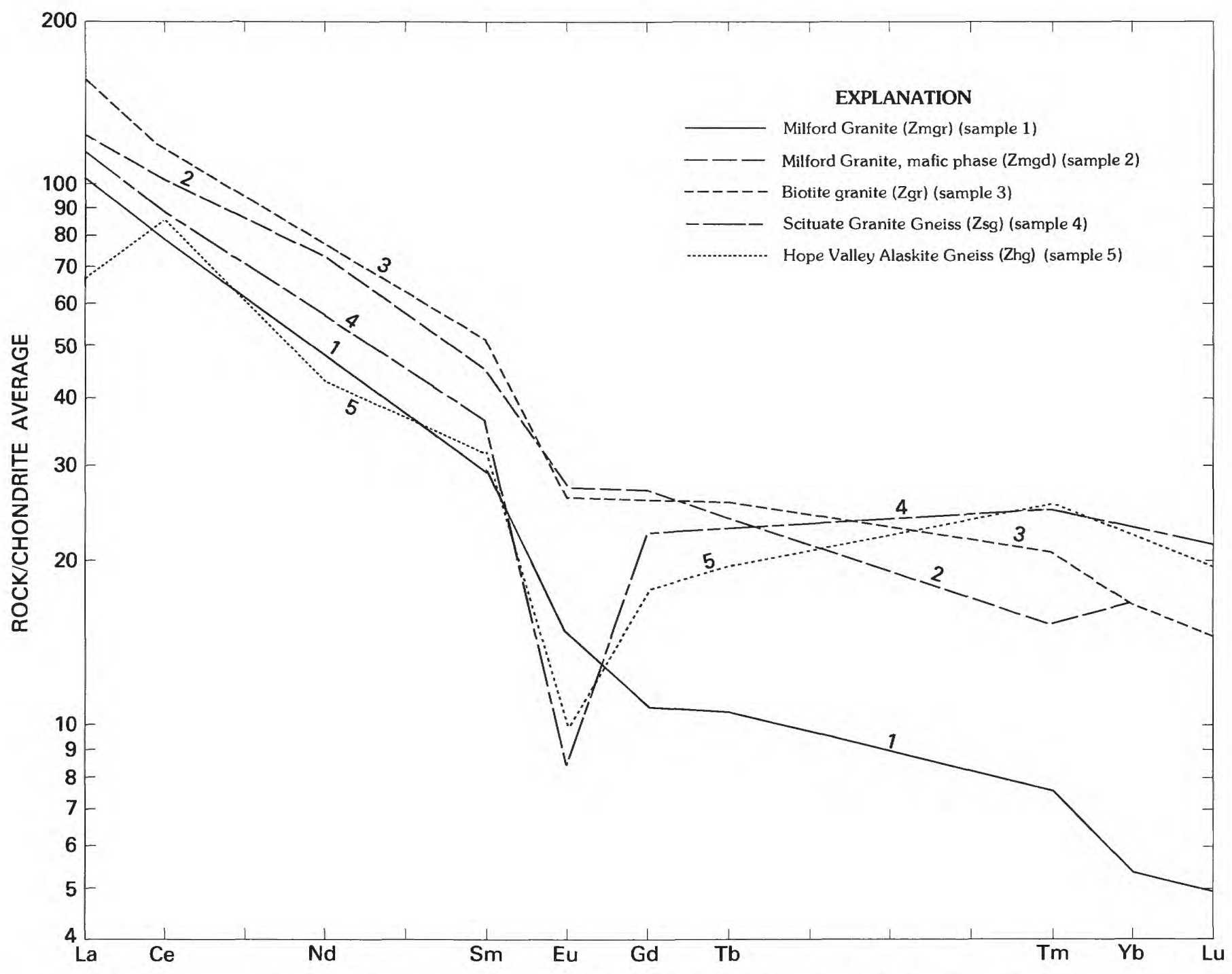

FIGURE 18. - Chondrite-normalized plot of rare-earth elements of Proterozoic Z batholithic rocks, Milford antiform. Numbers refer to sample numbers in table 10.

intruded by the Dedham Granite and Topsfield Granodiorite. It appears from its aeromagnetic pattern (Harwood and Zietz, 1976) to be a shallow cylindrical plug about $0.3 \mathrm{~km}$ in diameter. The Nahant Gabbro is projected to lie at depth beneath the Cape Ann Granite, as shown in cross section $B-B^{\prime}$ of the State bedrock map, on the basis of the magnetic signature over the pluton. Unrecognized equivalents to the Nahant Gabbro at Nahant and at Salem Neck (see p. I36) may be present within the gabbros and diorites (Zdigb, Zgb) shown on the State bedrock map (see Nelson, 1975b).

Bell (1977) described three facies at Nahant, which are included within the Nahant Gabbro on the State bedrock map: pyroxene gabbro, olivine gabbro, and quartz diorite. The pyroxene gabbro (table 11, no. 2), which forms the main mass at Nahant, is described by Bell (1977) as a massive equigranular rock that locally has subophitic texture. The plagioclase is tabular. In addition to the minerals shown in table 11, the rock contains accessory zircon. Alteration products include epidote, chlorite, and calcite.

The olivine gabbro (table 11, no. 3) crops out on the north shore of Nahant and is compositionally banded. It has a mottled appearance with white or gray flecks within a black matrix and contains accessory sulfide minerals. $\mathrm{Rb}-\mathrm{Sr}$ and $\mathrm{K}-\mathrm{Ar}$ analyses of biotite from this rock were made for the Ordovician age determination (table 1).

The quartz diorite crops out on Little Nahant west of Nahant proper. The quartz diorite (table 11, no. 4) is fine to medium grained. Some samples contain accessory apatite and titanite; chlorite, epidote, and calcite are alteration products. The quartz diorite has undergone more brittle deformation and alteration than have the 


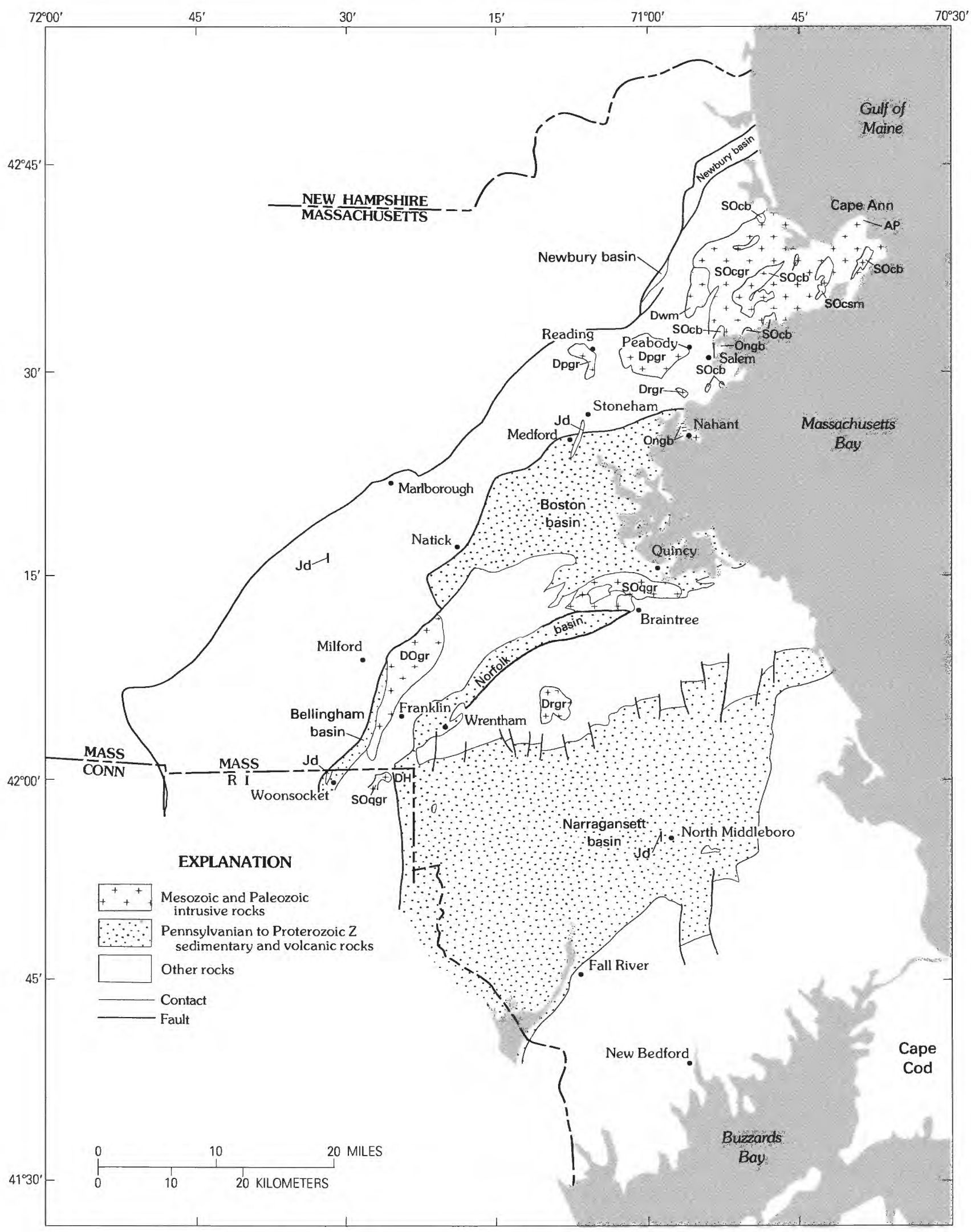

FiguRe 19.-Distribution of Paleozoic intrusive rocks in the Milford-Dedham zone. DH, Diamond Hill; AP, Andrews Point. SOcgr, alkalic granite and quartz syenite of the Cape Ann Complex; SOcb, Beverly Syenite; SOcsm, Squam Granite; Ongb,
Nahant Gabbro; Dpgr, Peabody Granite; Dwm, Wenham Monzonite; Jd, Jurassic dike; SOqgr, Quincy Granite; DOgr, alkalic granite in Franklin; Drgr, granite of the Rattlesnake Hill pluton. 
TABLE 11.-Modes, in percent, of some Paleozoic intrusive rocks of the Milford-Dedham zone

[DOgr, alkalic granite in Franklin; Ongb, Nahant Gabbro; SOqgr, Quincy Granite; SOcgr, granite of the Cape Ann Complex; SOcb, Beverly Syenite; Dpgr, Peabody Granite; Dwm, Wenham Monzonite; Drgr, granite of the Rattlesnake Hill pluton. a, albite; L, labradorite; p, perthite; c, orthoclase; $u$, augite; g, pigeonite; $r$, riebeckite; - , not reported]

\begin{tabular}{|c|c|c|c|c|c|c|c|c|c|c|c|c|c|}
\hline $\begin{array}{l}\text { Sample no............. } \\
\text { Unit............. }\end{array}$ & $\begin{array}{c}1 \\
\operatorname{DOg} r\end{array}$ & $\begin{array}{c}2 \\
\text { Ongb }\end{array}$ & $\begin{array}{c}3 \\
\text { Ongb }\end{array}$ & $\begin{array}{c}4 \\
\text { Ongb }\end{array}$ & $\begin{array}{c}5 \\
\text { Ongb }\end{array}$ & $\begin{array}{c}6 \\
\text { SOqgr }\end{array}$ & $\begin{array}{c}7 \\
\text { SOcgr }\end{array}$ & $\begin{array}{c}8 \\
\text { SOcb }\end{array}$ & $\begin{array}{c}9 \\
\text { Dpgr }\end{array}$ & $\begin{array}{c}10 \\
\text { Dwm }\end{array}$ & $\begin{array}{c}11 \\
\text { Drgr }\end{array}$ & $\begin{array}{c}12 \\
\text { Drgr }\end{array}$ & $\begin{array}{c}13 \\
\text { Drgr }\end{array}$ \\
\hline$\ldots \ldots \ldots \ldots$ & 34.6 & $0-5$ & 0 & 5-15 & 0 & 31 & 24 & 0 & 28 & 3 & $26-47$ & $27-31$ & $23-41$ \\
\hline Plagioclase ......... & $19.4 \mathrm{a}$ & $55-65$ & $5-20$ & $25-40$ & $50 \mathrm{~L}$ & 0 & 3 & 0 & - & 41 & 0 & 0 & 0 \\
\hline Microcline .......... & $36.7 \mathrm{p}$ & $0-6 c$ & 0 & $25-40 p$ & 0 & $60 \mathrm{p}$ & $63 p$ & $77-97$ & $63 p$ & 43 & $51-71$ & $64-67$ & $53-72$ \\
\hline Biotite..$\ldots \ldots \ldots \ldots$. & 7.5 & $0-2$ & $2-5$ & $3-7$ & 15 & 0 & 1 & $1-5$ & .3 & 2 & $1-5$ & 0 & 0 \\
\hline Muscovite .......... & .4 & - & - & - & - & - & - & - & - & $\operatorname{tr}$ & 0 & 0 & 0 \\
\hline Epidote ........... & .4 & $\operatorname{tr}$ & - & $3-5$ & $\operatorname{tr}$ & - & - & - & - & - & - & - & - \\
\hline Hornblende......... & $\operatorname{tr}$ & $0-10$ & $5-15$ & $5-10$ & 5 & $10^{\#}$ & 5 & $1-7$ & 6 & 9 & 0 & $3-4 r$ & $1-6 r$ \\
\hline Other amphibole ..... & - & - & - & - & - & - & - & - & .3 & 1 & - & - & - \\
\hline Pyroxene........... & 0 & $30-45 \mathrm{~g}$ & $25-40 \mathrm{~g}$ & - & $20 \mathrm{u}$ & - & - & $1-9$ & .3 & - & 0 & 0 & 0 \\
\hline Olivine ............ & - & $0-2$ & $20-50$ & - & 4 & - & - & - & - & - & - & - & - \\
\hline Chlorite ........... & .4 & $\operatorname{tr}$ & - & $\operatorname{tr}$ & $\operatorname{tr}$ & - & - & - & - & - & - & - & - \\
\hline Opaque minerals ..... & $\operatorname{tr}$ & $3-10$ & $\operatorname{tr}$ & $2-5$ & 5 & - & $0.2-8.1$ & $0-2$ & .9 & 1 & - & - & - \\
\hline Titanite .......... & .2 & - & - & $\operatorname{tr}$ & - & - & - & - & - & $\operatorname{tr}$ & - & - & - \\
\hline Apatite............ & .1 & $0-1$ & - & $0.2-0.7$ & $\operatorname{tr}$ & - & - & - & - & .3 & - & - & - \\
\hline Other .............. & $.2^{*}$ & $\operatorname{tr}^{* *}$ & $2-5 \$$ & $0.5-1^{* *}$ & $\operatorname{tr}^{* *}$ & - & - & - & $.3+4$ & - & - & - & - \\
\hline
\end{tabular}

Description of samples

1. Alkalic granite in Franklin, F-49 (Wones and others, 1986); 1,924 points counted.

2-4. Pyroxene gabbro from Nahant, olivine gabbro from Nahant, and quartz diorite from Little Nahant (Bell, 1977, p. 20e-25e).

5. Gabbro at Salem Neck (Toulmin, 1964, p. A58).

6. Quincy Granite from Quincy (Dale, 1923; Warren, 1913).

7, 8. Alkalic granite and quartz syenite of Cape Ann Complex and Beverly Syenite (Dennen, 1981).

9, 10. Peabody Granite (average of five samples) and Wenham Monzonite (average of two samples) (Toulmin, 1964, p. A31, A44).

11-13. Biotite granite, coarse-grained granite, and fine-grained granite (Lyons and Krueger, 1976).

other phases, and quite possibly it lies close to a fault zone (Goldsmith, this vol., chap. H). Wones suggested that the rock might be a more mafic phase of the Dedham Granite.

The gabbro at Salem Neck (Toulmin, 1964; Ongb near Salem in fig. 19) is the same general age as the Nahant Gabbro (table 1). It is a pyroxene gabbro similar in composition to the Nahant Gabbro, but it contains more biotite (table 11, no. 5). It is less altered than the diorite and gabbro (Zdigb) surrounding it and is intimately mixed with syenitic material.

\section{QUINCY GRANITE (SOqgr)}

The Quincy Granite (SOqgr) intrudes the Middle Cambrian Braintree Argillite at several localities along its eastern margin within the towns of Quincy and Braintree (Nellis and Hellier, 1976; fig. 19). The southern contact of the body is with the chemically and mineralogically similar Blue Hills Granite Porphyry (Chute, 1969). The Quincy Granite is bounded on the northwest by a reverse fault, the Blue Hills thrust (Billings, 1976; Goldsmith, this vol., chap. H), and on the west by the Neponset fault. No clasts of the Quincy Granite have been observed in the Lower Pennsylvanian Pondville Con- glomerate, but clasts of the overlying and probably related Blue Hills Granite Porphyry (see below) are common in the Pondville Conglomerate (Chute, 1969). The combined area of the Quincy Granite and the Blue Hills Granite Porphyry is $55 \mathrm{~km}^{2}$. Billings (1982) suggested that the Quincy Granite formed as a product of Ordovician cauldron subsidence.

The fresh rock is dark gray to gray green but weathers to buff brown or salmon; its texture is hypidiomorphic granular. Joint and slickenside surfaces are typically coated with riebeckite. The amphiboles in the granite (table 11, no. 6) are riebeckitic, and the pyroxene is acmitic. The averaged analyses from the type Quincy Granite (table 12, no. 4) indicate the peralkalinity of the rock, as does the high alkali-to-alumina ratio. The mafic minerals are interstitial to subhedral quartz and perthite and clearly were late in the order of crystallization. Accessory minerals are astrophyllite, aenigmatite, ilmenite, magnetite, titanite, fluorite, and, uncommonly, biotite. The late crystallization of mafic minerals suggests significant subsolidus reactions. Late-stage quartz and calcite have been observed in vugs and fractures, along with chlorite, hematite, and limonite.

Textural variants within the Quincy Granite include a fine-grained phase, especially abundant near the con- 
TABLE 12.-Major-oxide, normative-mineral, and trace-element compositions, volatiles omitted, of some Paleozoic plutonic rocks, Milford-Dedham zone

[Major-oxide compositions for samples 1-2 from X-ray spectroscopy by Pau] Hearn and Susan Wargo, all $\mathrm{Fe}$ reported as $\mathrm{Fe}_{2} \mathrm{O}_{3}$; sample 3, whole-rock analysis by H.S. Washington (in Emerson, 1917); samples 4 and 6, whole-rock analyses by C.H. Warren and H.S. Washington (in Emerson, 1917); sample 5 analyses by $\mathrm{O}$.D. Hermes, L. Kwak, C. Mandeville, and C. Olson; sample 7 by O.F. Tuttle and N.L. Bowen. Trace-element abundances from instrumental neutron activation analyses by L.J. Schwartz except $\mathrm{Rb}$ and $\mathrm{Sr}$ determined by X-ray spectroscopy by G. Sellars and B. McCall. No trace-element analyses available for samples 3-7. nd, not determined]

\begin{tabular}{lccccccc}
\hline $\begin{array}{c}\text { Sample no. } \ldots \ldots \ldots \\
\text { Unit } \ldots \ldots \ldots \ldots \ldots\end{array}$ & $\begin{array}{c}1 \\
\text { DOgr }\end{array}$ & $\begin{array}{c}2 \\
\text { DSnr }\end{array}$ & $\begin{array}{c}3 \\
\text { Ongb }\end{array}$ & $\begin{array}{c}4 \\
\text { SOggr }\end{array}$ & $\begin{array}{c}5 \\
\text { SOggr }\end{array}$ & $\begin{array}{c}6 \\
\text { SOcgr }\end{array}$ & $\begin{array}{c}7 \\
\text { Dpgr }\end{array}$ \\
\hline \multicolumn{7}{c}{ and alkali-alumina ratio } \\
\hline $\mathrm{SiO}_{2} \ldots \ldots \ldots \ldots \ldots$ & 75.22 & 76.7 & 43.73 & 74.9 & 70.24 & 77.6 & 72.24 \\
$\mathrm{Al}_{2} \mathrm{O}_{3} \ldots \ldots \ldots \ldots \ldots$ & 15.42 & 12.3 & 20.17 & 11.6 & 9.80 & 11.9 & 13.18 \\
$\mathrm{Fe}_{2} \mathrm{O}_{3} \ldots \ldots \ldots \ldots \ldots$ & 1.10 & 1.15 & 4.23 & 2.29 & 7.17 & .55 & .24 \\
$\mathrm{FeO} \ldots \ldots \ldots \ldots \ldots$ & nd & nd & 6.93 & 1.25 & 2.50 & .87 & 2.77 \\
$\mathrm{MnO} \ldots \ldots \ldots \ldots \ldots$ & .02 & .03 & 0 & .02 & .14 & 0 & .10 \\
$\mathrm{MgO} \ldots \ldots \ldots \ldots \ldots$ & 0 & 0 & 3.91 & .04 & .06 & 0 & .20 \\
$\mathrm{CaO} \ldots \ldots \ldots \ldots \ldots$ & .42 & .5 & 10.99 & .41 & .58 & .31 & 1.10 \\
$\mathrm{Na}_{2} \mathrm{O} \ldots \ldots \ldots \ldots \ldots$ & 3.24 & 3.9 & 2.42 & 4.30 & 5.26 & 3.80 & 3.99 \\
$\mathrm{~K}_{2} \mathrm{O} \ldots \ldots \ldots \ldots \ldots$ & 4.56 & 3.83 & 1.45 & 4.64 & 4.24 & 4.98 & 5.01 \\
$\mathrm{TiO}_{2} \ldots \ldots \ldots \ldots \ldots$ & .08 & .10 & 4.23 & .20 & .17 & .25 & .36 \\
$\mathrm{P}_{2} \mathrm{O}_{5} \ldots \ldots \ldots \ldots \ldots$ & .02 & 0 & .15 & 0 & 0 & 0 & .07 \\
$\mathrm{ZrO}_{2} \ldots \ldots \ldots \ldots \ldots$ & 0 & 0 & nd & 0 & .20 & 0 & 0 \\
$\left(\mathrm{Na}_{2} \mathrm{O}+\mathrm{K}_{2} \mathrm{O}\right) / \mathrm{Al}_{2} \mathrm{O}_{3} \ldots$ & .51 & .63 & .19 & .77 & .97 & .74 & .68 \\
\hline
\end{tabular}

Normative-mineral composition, in weight percent, ${ }^{1}$ and differentiation index (DI)

\begin{tabular}{|c|c|c|c|c|c|c|c|}
\hline Qtz ........... & 37.1 & 37.4 & 0 & 34.8 & 25.2 & 35.5 & 25.7 \\
\hline Crn ............ & 4.4 & .8 & 0 & 0 & 0 & 0 & 0 \\
\hline Or $\ldots \ldots \ldots \ldots$ & 26.9 & 22.6 & 8.6 & 27.5 & 24.9 & 29.5 & 29.6 \\
\hline $\mathrm{Ab} . \ldots \ldots \ldots \ldots$ & 27.4 & 33.0 & 20.4 & 36.3 & 26.6 & 32.1 & 33.7 \\
\hline 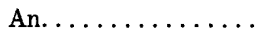 & 2.0 & 2.5 & 39.8 & 1.6 & 0 & .7 & 3.3 \\
\hline Di............ & 0 & 0 & 9.5 & .2 & 0 & 0 & .2 \\
\hline $\mathrm{Hd} \ldots \ldots \ldots \ldots \ldots$ & 0 & 0 & 1.9 & .2 & 0 & .7 & 1.4 \\
\hline Ac. $\ldots \ldots \ldots \ldots$ & 0 & 0 & 0 & 0 & 15.5 & 0 & 0 \\
\hline Wo $\ldots \ldots \ldots \ldots$. & 0 & 0 & 0 & 0 & 1.2 & 0 & 0 \\
\hline En. . . . . . . . & 0 & 0 & 3.3 & .02 & .15 & 0 & .4 \\
\hline Fs............. & 2.1 & 2.0 & .7 & .01 & 3.1 & .4 & 3.7 \\
\hline Fo............. & 0 & 0 & 1.4 & 0 & 2.6 & 0 & 0 \\
\hline Fa............ & 0 & 0 & .7 & 0 & 0 & 0 & 0 \\
\hline $\operatorname{Ilm} \ldots \ldots \ldots \ldots$ & .2 & .2 & 8.0 & .4 & .3 & .5 & .6 \\
\hline Mag. . . . . . . . . . & 0 & 0 & 6.1 & 0 & 0 & 0 & 0 \\
\hline Ap. ............ & 0 & 0 & .3 & 0 & 0 & 0 & .2 \\
\hline DI $\ldots \ldots \ldots \ldots \ldots$ & 91 & 93 & 29 & 98 & 77 & 97 & 89 \\
\hline
\end{tabular}

Trace-element abundances, in parts per million, and selected ratios

\begin{tabular}{llc}
\hline $\mathrm{Rb} \ldots \ldots \ldots \ldots \ldots \ldots$ & \multicolumn{2}{c}{101} \\
$\mathrm{Cs} \ldots \ldots \ldots \ldots \ldots \ldots$ & 6.0 & \multicolumn{1}{c}{.9} \\
$\mathrm{Sr} \ldots \ldots \ldots \ldots \ldots \ldots$ & 24 & 48
\end{tabular}

tacts, that has micrographic textures of quartz and perthite. The latter mineral is seriate in this phase of the Quincy and, when coarse, gives a porphyritic appearance to hand specimens. In other places, pegmatitic segregations contain very coarse crystals of acmitic pyroxene and amphibole. There were probably several pulses of magma, closely spaced in time and of similar composition.
TABLE 12.-Major-oxide, normative-mineral, and trace-element compositions, volatiles omitted, of some Paleozoic plutonic rocks, Milford-Dedham zone-Continued

\begin{tabular}{llcccccc}
\hline Sample no. $\ldots \ldots \ldots \ldots$ & 1 & 2 & 3 & 4 & 5 & 6 & 7 \\
Unit $\ldots \ldots \ldots \ldots \ldots$ & DOgr & DSnr & Ongb & SOqgr & SOqgr & SOcgr & Dpgr
\end{tabular}

Trace-element abundances, in parts per million, and selected ratios-Continued

Ba.......... $144 \quad 298$

$\mathrm{Rb} / \mathrm{Cs} \ldots \ldots \ldots \ldots, 60 \quad 112$

$\mathrm{Rb} / \mathrm{Sr} \ldots \ldots \ldots \ldots \quad 15.0 \quad 2.1$

Sc $\ldots \ldots \ldots \ldots \ldots \ldots, \quad 1.1 \quad 3.5$

Cr........ 4.7 nd

Co......... . 2 .4

Zn.......... $22 \quad 22$

La.......... $46 \quad 39$

Ce.......... $98 \quad 83$

$\mathrm{Nd} \ldots \ldots \ldots \ldots \ldots 41 \quad 42$

$\mathrm{Sm} \ldots \ldots \ldots \ldots \ldots \quad 9.7 \quad 9.3$

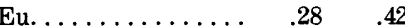

Gd......... $6.9 \quad 8.6$

$\mathrm{Tb} \ldots \ldots \ldots \ldots \ldots \quad 1.60 \quad 1.78$

Ho. ......... $1.5 \quad 1.8$

$\operatorname{Tm} \ldots \ldots \ldots \ldots \ldots, 1.98 \quad 1.23$

Yb............ $7.3 \quad 8.7$

Lu. . . . . . .

$\mathrm{La} / \mathrm{Yb} \ldots \ldots \ldots \ldots, 6 \quad 6 \quad 4$

Hf......... $6.8 \quad 6.8$

$\mathrm{Zr} \ldots \ldots \ldots \ldots \ldots 189$ nd

$\mathrm{Th}^{2} \ldots \ldots \ldots \ldots \ldots .37 .3 \quad 17.3$

Th. . . . . .

$\mathrm{U}^{2} \ldots \ldots \ldots \ldots \ldots, 9.7 \quad 3.3$

$\mathrm{U} \ldots \ldots \ldots \ldots+9.0 \quad 9.0 \quad 3.2$

$\mathrm{Zr} / \mathrm{Hf} \ldots \ldots \ldots \ldots 28$ nd

${ }^{1} \mathrm{Fe}_{2} \mathrm{O}_{3}$ calculated as $\mathrm{FeO}$.

${ }^{2}$ Delayed neutron determination analyses by H.T. Millard, Jr., C. MeFee, and C. Bliss.

Description of samples

1. Alkalic granite in Franklin; massive granite but in this place cut by quartz veins and mylonite seams; Ledgewood, Franklin Apartments, Unionville, Franklin. Field number DMA-197, locality shown in Wones and others (1986). UTM grid: N46624-E2999.

2. Micrographic rhyolite from Newbury Volcanic Complex; collected by A.F. Shride. Field number $957-\mathrm{C}$.

3. Nahant Gabbro, Nahant; from Emerson (1917, p. 182).

4. Quincy Granite; average of three samples from Quincy, Mass.; from Emerson (1917, p. 191, no. 4 in table).

5. Quincy Granite, Cumberland, Rhode Island, from Hermes and others (1981, p. 319 , table 1 , no. 1 ).

6. Alkalic granite to quartz syenite of Cape Ann Complex; hornblende granite, old Rockport Granite Co. quarry, Rockport; from Emerson (1917, p. 191, no. 6 in table).

7. Peabody Granite; old quarry, South Lynnfield; from Tuttle and Bowen (1958, table 11; cited by Toulmin, 1964).

The small mass of "Quincy Granite" (SOqgr) east of Woonsocket (fig. 19) near the Massachusetts-Rhode Island border is similar in texture to the Quincy Granite at Quincy but is more peralkaline (table 12, no. 5). The mass at Woonsocket was thought at the time of map compilation to be the same general age as the granite at Quincy. Its age has more recently been determined to be Devonian, or possibly Carboniferous, rather than Late 
Ordovician and Early Silurian (Hermes and Zartman, 1985). It has been most recently described by Rutherford and Carroll (1981), who distinguished an equigranular variety and a porphyritic variety. The latter contains amphibole with less riebeckite component.

\section{BLUE HILLS GRANITE PORPHYRY (SObgr)}

Naylor and Sayer (1976) considered the Blue Hills Granite Porphyry (SObgr; called Blue Hill Granite Porphyry on the State bedrock map) to be equivalent in composition and age to the Quincy Granite. Chute (1969) recognized inclusions of Quincy Granite within the Blue Hills Granite Porphyry in Quincy and considered it comagmatic with, but slightly younger than, the Quincy Granite. Warren (1913) observed dikes of Quincy Granite in the Blue Hills and suggested that the Quincy Granite was the younger unit. Rb-Sr work by Bottino and others (1970) suggested a late Paleozoic age for the Blue Hills, but Naylor and Sayer (1976) argued that this age was reset. The Blue Hills was assigned a Late Ordovician and Early Silurian age because of its close similarities, in both mineralogy and chemistry, to the Quincy Granite. Cobbles of the Blue Hills Granite Porphyry have been found in the Pondville Conglomerate of Early Pennsylvanian age (Chute, 1969). The Blue Hills is bounded by the Quincy Granite on the north and east and the Neponset fault on the west and is overlain unconformably by the Pondville Conglomerate on the south.

The Blue Hills is dark gray to blue gray and weathers to buff brown and salmon. Quartz (12 percent) and microperthite (40 percent) phenocrysts are set in a matrix of quartz, perthite, amphibole, and acmitic pyroxene. Some of the pyroxene occurs as inclusions in the perthite, indicating early crystallization of this pyroxene. Accessory minerals are aenigmatite, astrophyllite, magnetite, ilmenite, hematite, fluorite, zircon, and calcite.

Chemically, the Blue Hills is similar to the Quincy Granite and shows some similarities to the Peabody Granite and the alkalic granite and quartz syenite of the Cape Ann Complex (Buma and others, 1971; Naylor and Sayer, 1976). However, both the Quincy and the Blue Hills Granite Porphyry are more peralkaline than the Peabody Granite and the granite and quartz syenite of the Cape Ann Complex. The latter are chemically similar to the granite of the Rattlesnake Hill pluton (Lyons and Krueger, 1976).

\section{CAPE ANN COMPLEX}

Most of the Cape Ann Complex forms the Cape Ann peninsula of northeastern Massachusetts (fig. 19), but two small stocks lie south of Salem. The Cape Ann consists of three rock units: alkalic granite to quartz syenite (SOcgr), forming the main phase, the Beverly
Syenite (SOcb), and the Squam Granite (SOcsm). The whole forms a pluton covering $385 \mathrm{~km}^{2}$. The Cape Ann intrudes greenschist, diorite, and gabbro (Zv, Zdigb) that earlier workers (Toulmin, 1964; Dennen, 1981) assigned to the Marlboro Formation, Salem GabbroDiorite, or Middlesex Fells Volcanic Complex. Radiometric ages for the unit straddle the Ordovician-Silurian boundary (table 1).

Dennen $(1975,1981)$ considered masses of diorite and gabbro mapped as Salem Gabbro-Diorite within and adjacent to the Cape Ann Complex to be cogenetic with it and to be equivalent in age to the Nahant Gabbro and the gabbro at Salem Neck described above. We recommend that the term "Salem Gabbro-Diorite" be restricted, in future usage, to these masses of diorite and gabbro in and around the Cape Ann pluton that are younger than the Dedham Granite and cogenetic with the Late Ordovician to Early Silurian Cape Ann Complex. The gabbro at Salem Neck is probably representative.

Alkalic Granite and Quartz Syenite (SOcgr)

The alkalic granite to quartz syenite (table 11, no. 7; table 12, no. 6 ) is medium to coarse grained; it is grayish green and weathers to tan and salmon. Quartz and feldspar content vary widely; rock lacking quartz is mapped as Beverly Syenite (Toulmin, 1964; Dennen, 1981). Numerous inclusions of anorthositic, dioritic, and granitic rocks, as well as segmented mafic dikes, are interpreted to have been emplaced contemporaneously with the cooling granitic magma. Late-stage aplites and pegmatites are common.

Dennen (1981) has studied the Cape Ann Complex extensively and has contoured the variations in its quartz content. Mineral contents vary on a scale of meters to kilometers. In addition to the major constituents, clinopyroxene, fayalite, titanite, zircon, fluorite, allanite, magnetite, and ilmenite have been found among the accessory minerals. Toulmin (1964) suggested that alkali feldspar cumulates are the main cause of the variations. Dennen (1981) ascribed the abrupt changes in areal extent to later faulting, which displaced the contacts of these cumulate masses.

An outcrop at Andrews Point (fig. 20) illustrates the complicated relationships among the textural variations (Martin, 1977). Here a foundered block of fine-grained granite contains disjointed diabase dikes. The diabase contains miarolitic cavities with terminated quartz and alkali feldspar. This block is intruded on the north side by the main phase of the Cape Ann Complex. On the south side, the block and the main phase of the Cape Ann are intruded by an aplitic dike that contains pegmatite pods with coarse crystals of quartz, feldspar, amphibole, and fayalite. Much of the fayalite has been altered to grunerite and magnetite and is rimmed by a titaniferous annite. 


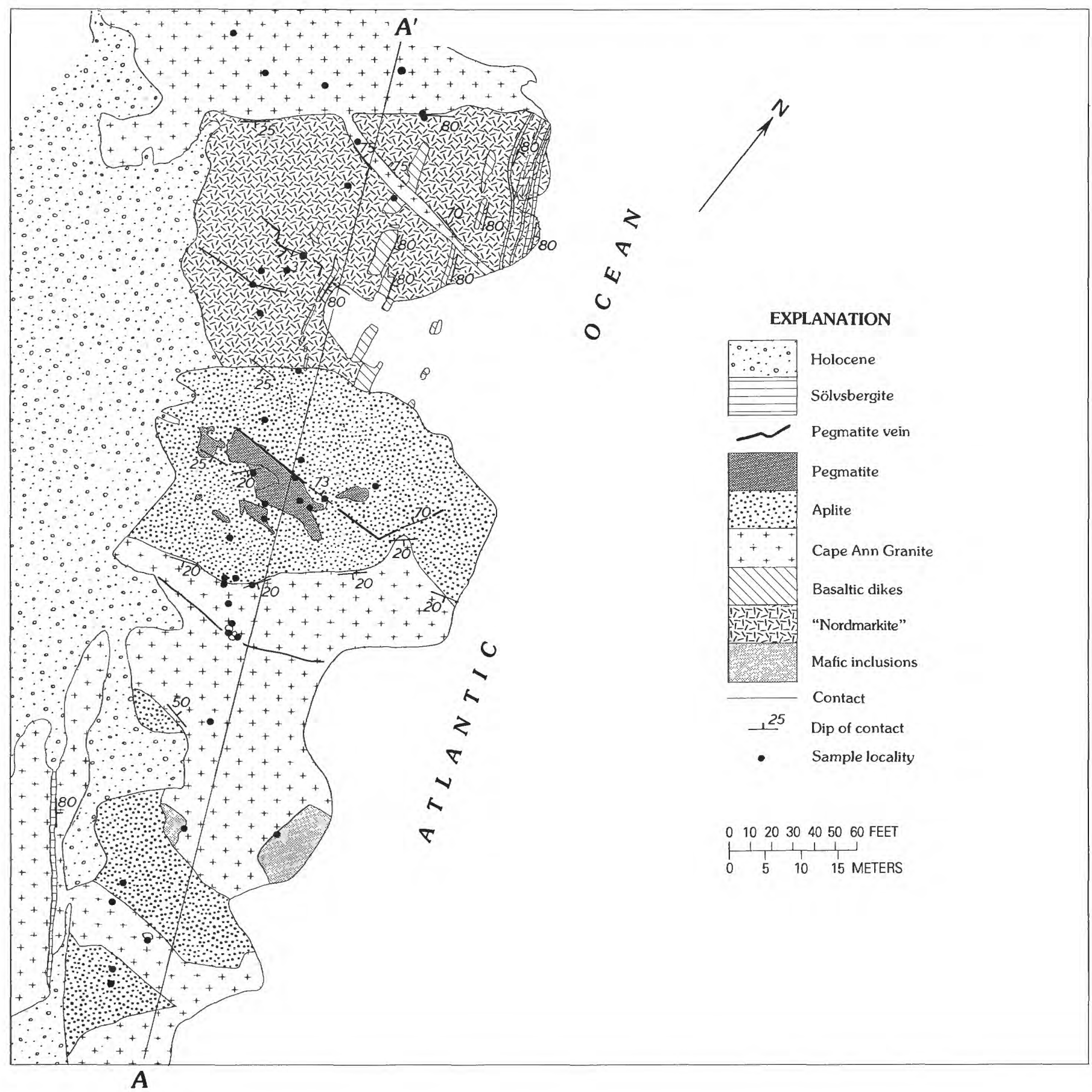

A

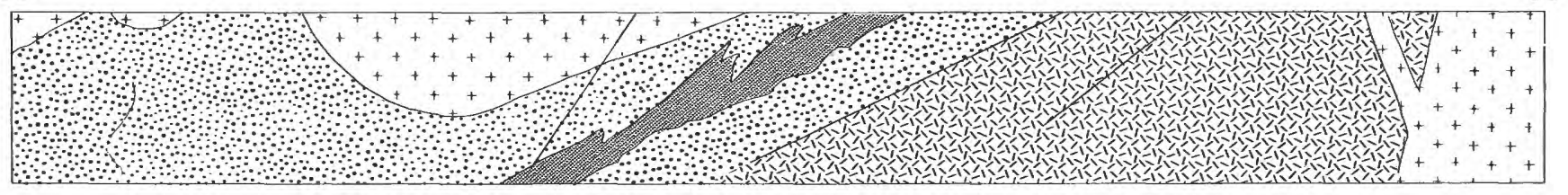

Figure 20.-Geology of Andrews Point, Cape Ann (see fig. 19 for location). Mapped by D.R. Wones and P.L. Pelke in 1971. 
The youngest rock at Andrews Point is a metasomatic mass of sölvsbergite, formed in a late fracture where solutions replaced the host rocks (Martin, 1977).

Numerous light-colored dikes southwest of the Cape Ann Complex have been labeled Quincy or Cape Ann. Such dikes may be related not only to the Cape Ann Complex but also to the Peabody Granite or even to Dedham Granite. Ross (1984) has suggested a wide range of ages for lamprophyre and dolerite dikes in the Boston area.

\section{Beverly Syenite (SOcb)}

The Beverly Syenite (SOcb) phase of the Cape Ann Complex was described by Toulmin (1964) and Dennen (1981). It forms subordinate elongate masses within the main phase of the Cape Ann (fig. 19), suggesting that it is most probably a cumulate. However, dikes of syenite do intrude the gabbro at Salem Neck, and other dikes of syenite are common in the Salem area (Toulmin, 1964), suggesting that the Beverly is in part, at least, a differentiate.

The syenite is medium to coarse grained, cream colored, and rich in alkali feldspar (table 11, no. 8). Accessory minerals are apatite, zircon, titanite, magnetite, sulfides, allanite, and astrophyllite.

\section{Squam Granite (SOcsm)}

The Squam Granite (SOcsm) forms a modally variable $5-\mathrm{km}^{2}$ mass within the Cape Ann Complex (fig. 19). Dennen (1981) recognized smaller masses of this rock elsewhere in the Cape Ann. Contact relations suggest that the Squam is an inclusion of perhaps an earlier cognate phase; however, it could be a synchronous textural variant of the alkalic granite.

The Squam Granite is fine to medium grained, is gray, and weathers to brown. The texture ranges from aplitic to porphyritic. The plagioclase content is highly variable ( $5-40$ percent), and the anorthite content lies between 30 and 55 percent. The rock contains both microcline and orthoclase microperthite. Quartz ranges from 15 to 30 percent; hornblende and biotite, from 5 to 20 percent. Rare pigeonite remains as unreacted cores in hornblende. Accessory minerals include opaque minerals, apatite, zircon, monazite, allanite, and titanite.

\section{MICROGRAPHIC RHYOLITE OF THE NEWBURY VOLCANIC COMPLEX (DSnr)}

Lenticular sills of micrographic rhyolite (DSnr) 100-600 m thick intrude the Newbury Volcanic Complex of the northern Newbury basin. These hypabyssal intrusions are contemporaneous with deposition of the volcaniclastic strata in the basin. They are brownish gray to orange pink and aphanitic to sugary-textured massive felsite characterized by micrographic and spherulitic intergrowths (Shride, 1976). The composition of one sample of rhyolite is shown in table 12 . The sample is included in the ternary diagram for chemically analyzed Paleozoic intrusive rocks in the Milford-Dedham zone (see fig. 23).

\section{ALKALIC GRANITE IN FRANKLIN (DOgr)}

The alkalic granite in Franklin (DOgr), mislabeled SOqgr on the State bedrock map (DOgr in the explanation), forms a north-trending pluton of about $70 \mathrm{~km}^{2}$ north of Franklin (fig. 19). Volckmann (1977) mapped this rock as Milford Granite. The pluton is fault bounded on the north, south, and west. The eastern contact with the Dedham Granite may be intrusive, but mylonitization seen in places along this contact suggests that it too might be a fault. The rock is considerably more aluminous than the other alkalic units (table 12, no. 1), but the traces of hornblende, the ubiquitous presence of fluorite (table 11, no. 1), and hypersolvus texture suggested to Wones that the rock belongs with the Ordovician to Devonian alkalic granite suite.

The light-gray rock weathers to buff or brown. The hypidiomorphic granular texture is dominated by subhedral to anhedral perthite and quartz. Plagioclase, biotite, and fluorite are all anhedral. The zircons are euhedral and are confined to regions of recrystallized biotite. The biotite crystals may be pseudomorphs after amphibole, a trace of which is present in sample 1 , table 11. The zircons are all within biotite aggregates, which themselves are interstitial to the perthite and quartz. The lack of inclusions of mafic minerals or zircon within the quartz or the perthite, implying a late-stage crystallization of the mafic minerals and zircon, is characteristic of peralkaline rocks (Watson, 1979).

Mylonitic fabrics are common and tend to concentrate quartz, sericite, and fluorite. Mylonitic zones contain lenticles of equigranular (0.1-mm) quartz and also, in places, biotite. Quartz on the margins of the lenticles shows undulose extinction, and the enclosing perthite and plagioclase are highly fractured. A partly crushed rock, not listed in table 11 , consists of 41 percent perthite, 35 percent quartz, 14 percent plagioclase, 5 percent biotite, and 5 percent sericite. Sericite is confined to plagioclase and zones of mylonite.

\section{PEABODY GRANITE (Dpgr)}

The Peabody Granite (Dpgr) occurs in two plutons (fig. 19) that total approximately $50 \mathrm{~km}^{2}$ in area. The large mass at Peabody (Peabody pluton) is the main body (Toulmin, 1964). The smaller mass near Reading (Reading pluton) is lithologically similar to the Peabody Granite in the Peabody pluton. Both masses intrude the rocks of the Proterozoic Z mafic volcanic-plutonic complex $(\mathrm{Zv}$, Zdigb). 
The Peabody is a creamy- to tan-weathering graygreen rock (Toulmin, 1964), consisting of alkali feldspar, quartz, ferrohornblende (table 11, no. 9), and accessory pyroxene, biotite, magnetite, ilmenite, zircon, titanite, allanite, and sulfide minerals. Xenoliths are locally abundant. The paucity of aplite and pegmatite is in striking contrast to the Cape Ann Complex.

Chemical analyses of the Peabody (Toulmin, 1964; table 12 , no. 7) show values of $\left(\mathrm{Na}_{2} \mathrm{O}+\mathrm{K}_{2} \mathrm{O}\right) / \mathrm{Al}_{2} \mathrm{O}_{3}$ less than 1 , indicating a subalkaline magma. Buma and others (1971) observed an early saturation of zircon in the Peabody magma in contrast to the Quincy Granite in which zircon crystallized late in the sequence. However, the rock still tends toward the alkaline field, as do the Quincy and Cape Ann. These observations fit well with the experimental work of Watson (1979), who suggested that peralkaline magmas have higher $\mathrm{Zr}$ solubilities than subalkaline magmas. Although the major minerals and bulk compositions of the Quincy Granite, the Cape Ann Complex, and the Peabody Granite are similar, their petrography, fabrics, and ages of intrusion indicate that they resulted from distinct magmatic events.

\section{WENHAM MONZONITE (Dwm)}

The Wenham Monzonite (Dwm) (Toulmin, 1964) is a body of $10-\mathrm{km}^{2}$ area north of Peabody (fig. 19) that intrudes the Proterozoic $\mathrm{Z}$ mafic volcanic-plutonic complex ( $\mathrm{Zv}, \mathrm{Zdigb})$. The rock is gray, weathering to a cream color, is medium grained, and is made up of alkali feldspar, plagioclase, amphibole (table 11, no. 10), and accessory biotite, quartz, opaque minerals, apatite, zircon, and titanite (Toulmin, 1964). The presence of plagioclase and biotite and the interstitial nature of the quartz distinguish this unit from the rocks of the Cape Ann Complex.

\section{CHERRY HILL GRANITE (Dcygr)}

The Cherry Hill Granite (Dcygr) is a $3-\mathrm{km}^{2}$ body of coarse-grained leucocratic granite that intrudes the Wenham Monzonite. It contains 1 percent or less magnetite and sparse zircon (Toulmin, 1964). The feldspar is microperthitic microcline that weathers to pink.

\section{GRANITE OF THE RATTLESNAKE HILL PLUTON (Drgr)}

The granite of the Rattlesnake Hill pluton (Drgr) (Lyons and Krueger, 1976) has an area of $22 \mathrm{~km}^{2}$ east of Wrentham (fig. 19) and intrudes the Dedham Granite. The granite is made up of three separate phases. The coarse biotite granite (table 11, no. 11) is light to medium gray, weathers yellowish brown, and consists of quartz, alkali feldspar, biotite, and accessory magnetite, zircon, apatite and fluorite. The coarse riebeckite granite (table 11, no. 12) is a gray, tan- to orange-weathering rock that consists of quartz, alkali feldspar, riebeckite, and acces- sory biotite, magnetite, zircon, and fluorite. The finegrained riebeckite granite (table 11, no. 13) is light gray, weathers to pink to orange, and consists of quartz, alkali feldspar, riebeckite, and accessory magnetite, zircon, and apatite. The western margin of the fine-grained granite contains irregular masses of pegmatite containing riebeckite (Lyons and Krueger, 1976).

\section{MESOZOIC INTRUSIVE AND SILICIFIED ROCKS}

\section{DIABASE DIKES (Jd)}

Many mafic dikes cut the Proterozoic $\mathrm{Z}$ and Paleozoic rocks of the Milford-Dedham zone, but only those that can be traced any distance are shown on the State bedrock map. Most are considered, or are known, to be Triassic or Jurassic in age, but some in northeastern Massachusetts range in age from Devonian to Carboniferous (Ross, 1984). Some dikes seem to be lamprophyres related to the Paleozoic alkalic granites. LaForge (1932) distinguished at least four sets of diabase dikes in the Milford-Dedham zone. He recognized that an east-west set that was highly altered intruded the Dedham Granite but was cut by the Quincy Granite. A set of northwestsoutheast dikes may be related to these older east-west dikes, because they are also highly altered and their age relationships are obscure. A younger east-west set is not as severely altered. A set of north-trending unaltered dikes may be correlative with the Medford Diabase dike (see below). These observations agree with those made by Ross (1984).

Ross (1981) observed that dikes of Triassic or Jurassic age in this region tend to strike north or close to north. The large north-trending Medford Diabase dike (fig. 19) of Jurassic age (table 1) cuts the Boston Bay Group and crosses the northern border fault of the Boston basin into the Melrose block containing the Lynn Volcanic Complex. An undated north-trending dike cuts rocks of the Bellingham basin at Woonsocket. Lyons (1977) found a small north-trending trap dike cutting Pennsylvanian strata at North Middleboro. Basalt dikes and sills cut the Boston Bay Group on islands in the Boston Harbor (C.A. Kaye, written commun., 1979). All these dikes have been assigned to the Jurassic on the State bedrock map on the basis of the age of the Medford Diabase dike. Other narrow north-trending dikes not shown on the State bedrock map have been observed in roadcuts in the area, such as at several places on I-90 between Natick and Marlborough and on I-495 in Wrentham, Franklin, and Milford.

The Medford dike is the largest diabase dike in the Milford-Dedham zone. This particular dike trends northnortheast and, as mentioned above, crosses without offset the northern border fault of the Boston basin (Goldsmith, this vol., chap. H), but centimeter-scale 
left-lateral displacements along east-west faults are present west of Spot Pond, Stoneham. The Medford dike weathers deeply, and immature soil profiles have developed on the glaciated surfaces. The fresh diabase is made up of plagioclase and augite with accessory orthoclase, biotite, magnetite, and ilmenite. It contains 1.7 percent $\mathrm{K}_{2} \mathrm{O}$ (Emerson, 1917, p. 77) and is an alkaline rock. McHone (1981) and Hermes and others (1978) have shown that alkaline mafic dikes of Mesozoic age are common in New England, and the Medford dike appears to be part of that group.

\section{MASSIVE QUARTZ AND SILICIFIED ROCK (q)}

Masses of quartz and silicified rock (q) are common near many of the faults in eastern Massachusetts (Goldsmith, this vol., chap. $H$ ). The only one large enough to show on the State bedrock map is the large mass at Diamond Hill (DH, fig. 19) east of Woonsocket (Quinn, 1971). The host rock that was silicified was a felsic volcanic rock of presumed Pennsylvanian age. The silicification lies along a north-trending fault, which cuts the Lower and Middle Pennsylvanian Wamsutta Formation. Terminated quartz crystals suggest open voids and a brittle fracture regime. The faulting is postPennsylvanian and from its style is presumed to be Mesozoic in age.

\section{DISCUSSION OF THE INTRUSIVE ROCKS OF THE MILFORD-DEDHAM ZONE}

The oldest dated intrusive rock in this zone is the diorite at Rowley (Zrdi) (table 1). The diorite at Rowley and gabbroic dikes intrude the metavolcanic rocks $(\mathrm{Zv})$ northwest of the Boston basin. These rocks and the extensive diorite and gabbro (Zdigb) may be penecontemporaneous with the volcanic material and form part of a volcanic-plutonic complex in which the mafic plutons have intruded the volcanic cover. The diorite at Rowley appears to be undeformed relative to the older rocks and is perhaps the youngest of the intrusive suite. On the other hand, it may be the earliest recognized intrusion that is comagmatic with the Milford and Dedham Granites, as is suggested by the apparent fit of the other Proterozoic $Z$ diorites (Zdi) of table 3 to the lines through the batholithic rocks shown on the Peacock diagram (fig. 6 ) and by the $\mathrm{Th} / \mathrm{U}$ ratios plotted on figure 10 . If so, the sequence is similar to mafic to felsic intrusive sequences recognized from the circum-Pacific Mesozoic batholiths (Silver and others, 1979; Bateman, 1983). The polarity of such a sequence in eastern Massachusetts is not discernible because the exposed zone is narrow and disrupted. The greater abundance of mafic rocks north of Boston is attributed more to the level of erosion across a north-

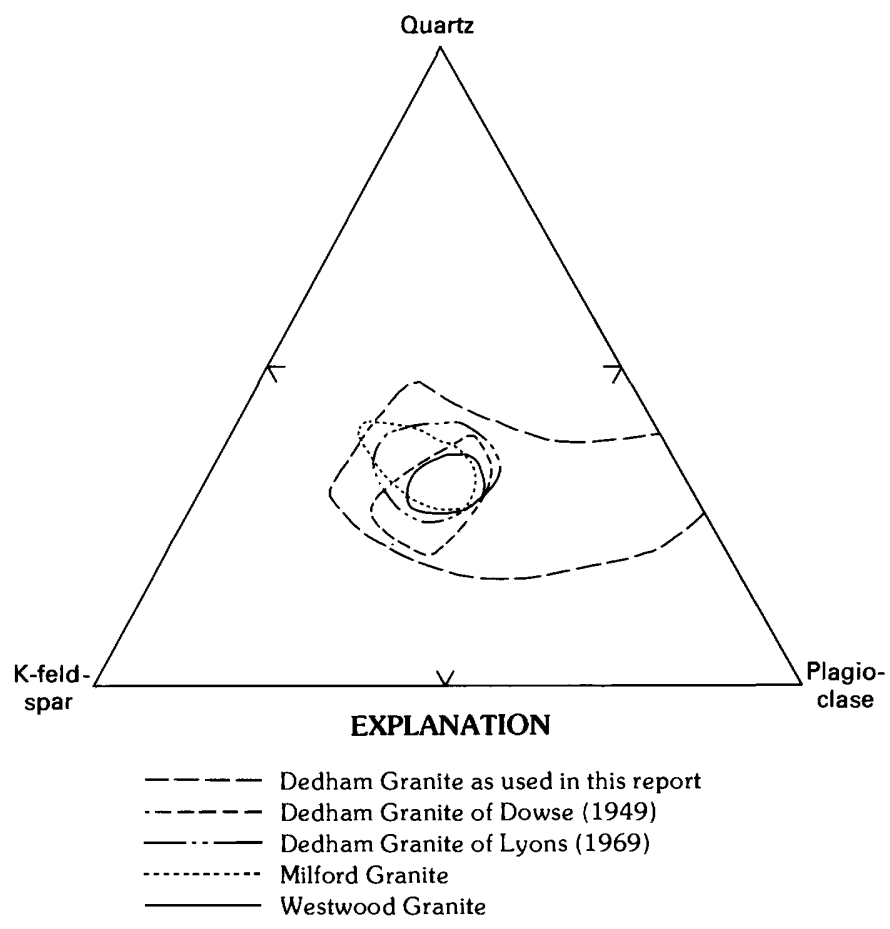

FIGURE 21.-Ternary quartz-plagioclase-K-feldspar plot of modal composition of Dedham Granite as compared with fields of composition of Dedham Granite of Dowse (1949), Dedham Granite of Lyons (1969), Milford Granite, and Westwood Granite.

plunging structure than to a lateral change in composition of intrusions across a belt.

Most of the batholithic rocks fall in the granite field (figs. 5, 12-14). A few of the batholithic rocks, like some of the Dedham Granite north of Boston (Zdngr) and the Topsfield Granodiorite (Ztgd), fall in the granodiorite field (fig. 12). The mafic phase of the Milford Granite approaches tonalite (fig. 13). The Westwood Granite samples (fig. 13) cluster closely in the granite field. Porphyritic phases, such as the porphyritic granite of the New Bedford area and the Ponaganset Gneiss, range from granite to granodiorite (fig. 14), the same range as the other batholithic rocks. The field of Dedham Granite established in our study for the State bedrock map is broader than the fields established in the more areally limited studies of Dowse (1949) and Lyons (1969) (fig. 21). The REE patterns of the Dedham Granite and granite of the Fall River pluton are closer to the REE patterns of the Hope Valley Alaskite Gneiss and the Scituate Granite Gneiss than to those of the Milford Granite and the biotite granite (Zgr) (figs. 15, 16, 18), although the small number of samples of all these rocks diminishes the significance of this.

The peraluminous Milford Granite and the metaluminous Dedham Granite are contemporary, according to the available radiometric ages, but they differ in their mineralogy, composition, and deformational history. The 


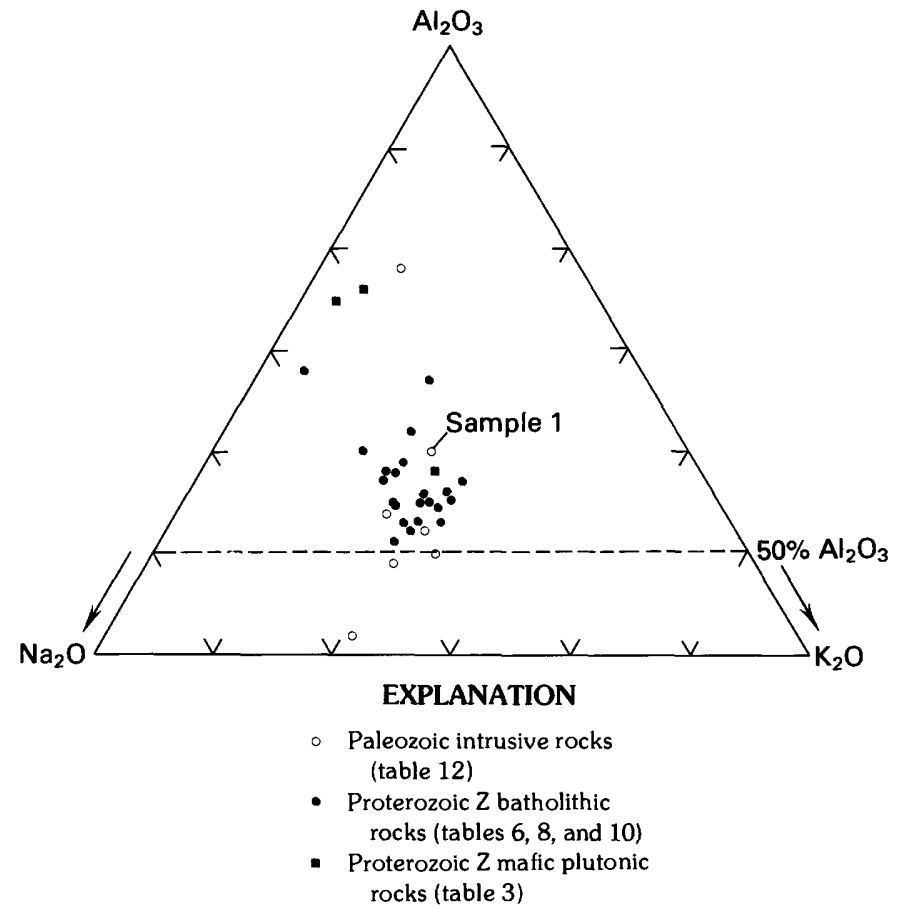

FIGURE 22. - Plot of a part of the ternary system $\mathrm{Na}_{2} \mathrm{O}-\mathrm{K}_{2} \mathrm{O}-\mathrm{Al}_{2} \mathrm{O}_{3}$ in molecular percent for intrusive rocks of the Milford-Dedham zone. Sample 1 is alkalic granite in Franklin; see table 12 for further data.

Milford contains garnet, muscovite, and lensoid quartz that has been annealed. The Dedham contains titanite and magnetite, and hornblende is commonly found adja-

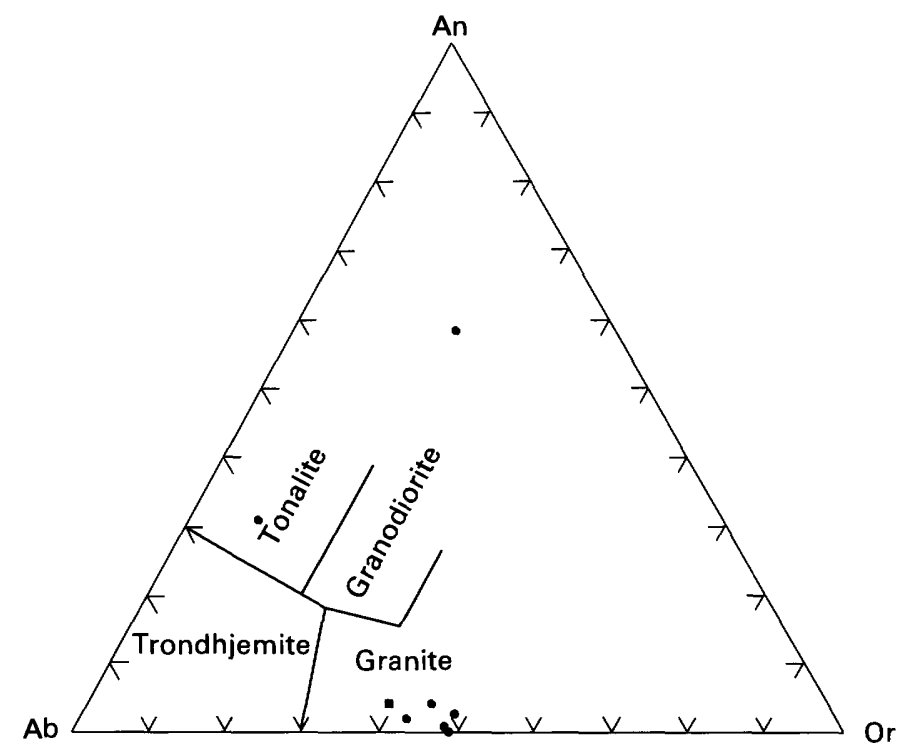

FIGURE 23. - Ternary plot of normative albite $(\mathrm{Ab})$, anorthite (An), and orthoclase (Or) for Paleozoic intrusive rocks of the MilfordDedham zone, from table 12. Fields of silica-saturated rocks from O'Connor (1965) as modified by Barker (1979). cent to the contacts with older mafic rocks. The Dedham is brittlely deformed and altered by hydrolysis and oxidation to a characteristic red color with green veins and patches of epidote and chlorite. The Dedham is characteristic of plutonic rocks that form in subduction regimes, with its great volume relative to enclosed and adjacent metasedimentary and metavolcanic material, its intrinsically high oxidation state, and its chemistry. The high but variable percentage of K-feldspar in the Dedham and Milford (tables 4, 5, 7, 9; figs. 5, 12-14) is similar to that found in subduction zone batholiths farthest "inboard" from the continental margin (Brown and others, 1984).

Gromet and O'Hara (1984; O'Hara and Gromet, 1984, 1985) have proposed a major tectonic boundary within the Milford-Dedham zone between the terrane containing the Hope Valley Alaskite Gneiss and the terrane containing the Milford Granite in the Milford antiform. Such a boundary could have formed before intrusion of the Middle Devonian Scituate Granite and the granite in Franklin, but these rocks must have been emplaced before the major motion on the boundary because they are deformed along it.

Our data on the Paleozoic rocks are limited, but it is clear that they tend to be alkalic. They plot in the part of the $\mathrm{Na}_{2} \mathrm{O}-\mathrm{K}_{2} \mathrm{O}-\mathrm{Al}_{2} \mathrm{O}_{3}$ diagram (fig. 22) in which the amount of $\mathrm{Al}_{2} \mathrm{O}_{3}$ is only slightly greater than the sum of the alkalis and towards the alkalic side of figures 23 and 24. The granite in Franklin (DOgr) has a higher $\mathrm{Al}_{2} \mathrm{O}_{3}$ content than the other alkalic granites of table 12 . An

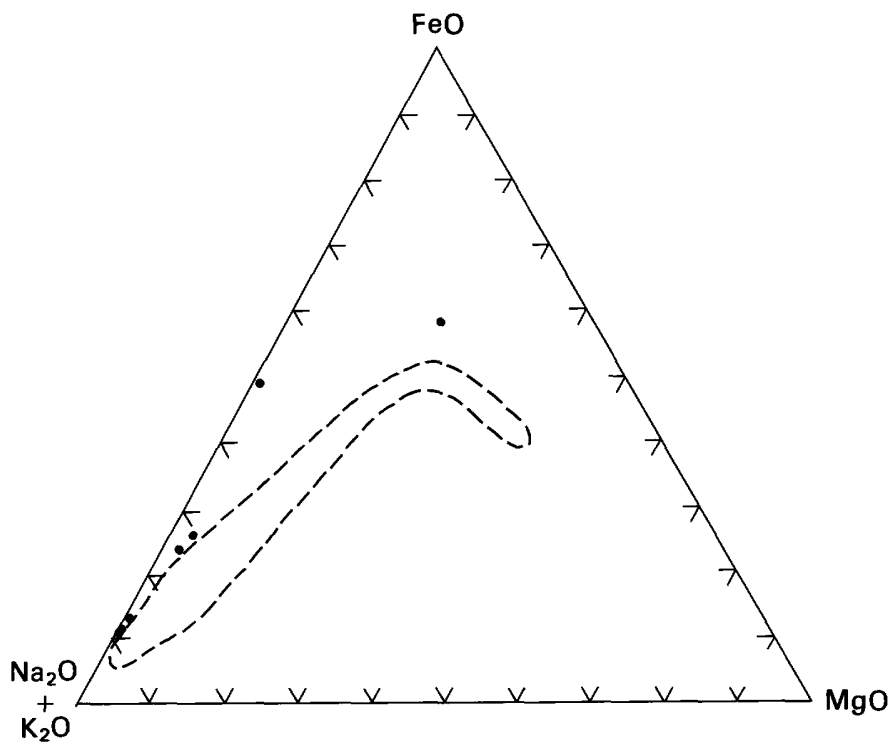

FIGURE 24. - Ternary AFM (alkalis-FeO-MgO) plot of Paleozoic intrusive rocks of the Milford-Dedham zone, from table 12, showing field of Proterozoic $\mathrm{Z}$ intrusive rocks of the Milford-Dedham zone (dashed line) from figure 8. 


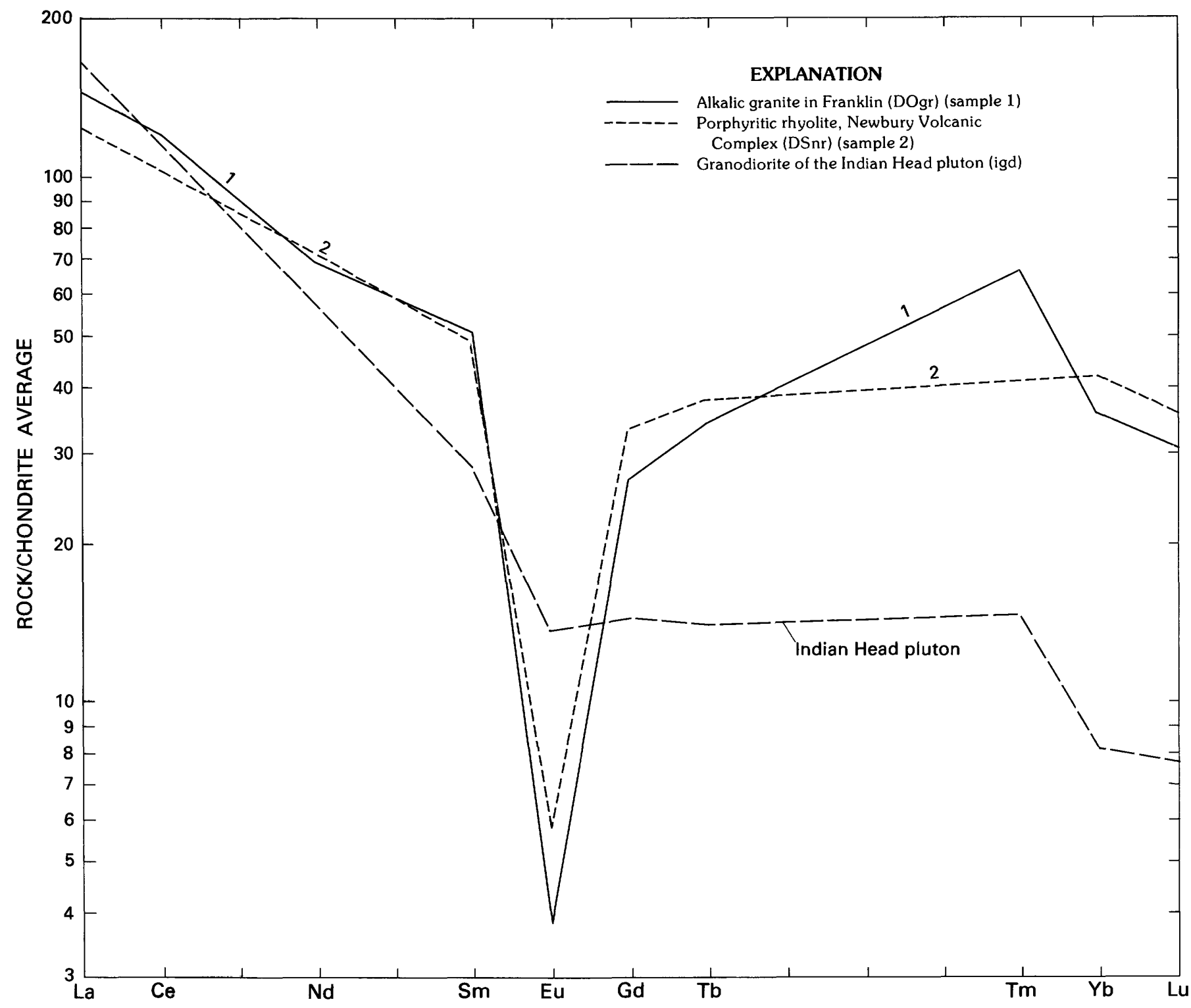

FIGURE 25. - Chondrite-normalized plot of rare-earth elements of Paleozoic intrusive rocks. Numbers refer to sample numbers in table 12; data for granodiorite of the Indian Head pluton from table 15.

REE pattern of a sample from this unit (fig. 25, no. 1) shows marked REE enrichment and a pronounced negative europium anomaly, remarkably similar to the pattern of the rhyolite (DSnr) from the Newbury Volcanic Complex (fig. 25, no. 2). Possibly they are cogenetic.

\section{RELATION TO EXTRUSIVE ROCKS}

Some or all of the Proterozoic $\mathrm{Z}$ volcanic rocks around the Boston basin and at a few places elsewhere in the Milford-Dedham zone may be related petrogenetically to the batholithic rocks. These rocks are described in the chapter in this volume on the stratigraphy of the MilfordDedham zone (Goldsmith, this vol., chap. E). In this chapter, the principal extrusive units discussed that are equivalent to or younger than the southeastern Massachusetts batholith are the Lynn and Mattapan Volcanic Complexes (DZl, Zm) and the Brighton Melaphyre ( $\mathrm{zZZrb}$ ) of the Boston Bay Group. Felsic metavolcanic rocks (Zvf) in the Framingham area are probably cogenetic with the batholithic rocks.

The Mattapan and Lynn Volcanic Complexes consist largely of rhyolite and rhyodacite flows, in part porphyritic, but andesitic rocks have been reported (Nelson, 1974). Chute (1966) reported that the rocks tend to be sodic rather than potassic. The volcanic rocks in the Blue Hills, the aporhyolite of Emerson (1917), are devitrified rhyolitic flows assigned to the Mattapan Volcanic Complex $(\mathrm{Zm})$. The evidence for the stratigraphic positions of 
the Mattapan and Lynn is conflicting. LaForge (1932) and Bell (1976) cited evidence for nonconformable relations between the Lynn and the Dedham Granite. On the other hand, Zarrow (1978) described inclusions of Lynn in the Dedham and noted that the Lynn and the Dedham have similar trace-element contents. Kaye and Zartman (1980) described places where the Dedham Granite grades upwards texturally into fine-grained rhyolitic rock. Chute (1966) noted that fine-grained phases of the Westwood Granite resemble the Mattapan. The U-Th- $\mathrm{Pb}$ isotopic age of $602 \pm 3 \mathrm{Ma}$ for the Mattapan (Kaye and Zartman, 1980) indicates that the Mattapan is younger than the Dedham, although possibly close in age to the Westwood. Volcanic rocks cogenetic with the Dedham and Westwood would differ in time of extrusion but might be difficult to sort out in the field. The felsic metavolcanic rocks (Zvf) in the Framingham area are considered to be part of the prebatholithic, largely mafic volcanic complex $(\mathrm{Zv})$. Felsic metavolcanic rocks in this suite have been described and mapped by Nelson (1975a,b) and Volckmann (1977). The affiliation with the batholithic rocks is suggested by the fact that some of the felsic rocks were mapped as Milford Granite. In outcrop these are not unlike fine-grained phases of the Hope Valley Alaskite Gneiss of southeastern and eastern Connecticut and adjacent Rhode Island. Both felsic and mafic metavolcanic rocks of pre-Dedham age have been identified in the Middlesex Fells area. The Brighton Melaphyre in the Brookline Member of the Roxbury Conglomerate interfingers with and overlies the Mattapan, and dikes of Brighton cut the Mattapan. The Brighton consists primarily of quartz keratophyre, keratophyre, and spilite. Nelson (1975a) described basaltic and andesitic flows and tuffs. Bouchard (1979) described basaltic extrusive rocks and subordinate andesitic to rhyolitic lavas and tuffs. These volcanic rocks are a suite clearly younger than the batholithic rocks; they record a separate igneous event that is probably related to the deposition of the Proterozoic Z turbiditic material forming the Boston Bay Group in the Boston basin.

Little volcanic rock that can be associated with the suite of Paleozoic alkalic granite intrusions is preserved in Massachusetts. The Blue Hills Granite Porphyry is clearly associated with the Quincy Granite, and volcanic rocks of the Newbury Volcanic Complex may be cogenetic with the alkalic plutons. In Rhode Island, the Spencer Hill Volcanics (Quinn, 1971) represent extrusive equivalents of mid-Paleozoic intrusions.

\section{INTERPRETATION OF IGNEOUS EVENTS}

The age relations and the composition and character of the plutonic rocks indicate the following history of events in the Milford-Dedham zone. A volcanic-plutonic arc developed probably in Proterozoic Z time. The early plutonic rocks in this arc were mafic; the later were primarily granitoid batholithic rocks such as the Dedham Granite. These later rocks may have been consanguineous with the mafic rocks. The sparseness of tonalite and granodiorite in the batholithic rocks suggests that they were intruded within a continental craton, which in turn suggests that the volcanic-plutonic arc formed at the edge of a continental mass. After the intrusion of the Dedham batholith, a small graben (rift basin?), the Boston basin, formed, siliceous lavas and pyroclastic rocks (Mattapan and Lynn Volcanic Complexes) were extruded, and the basin was filled by a sedimentary sequence (Boston Bay Group) that included basaltic lavas (Brighton Melaphyre) in Proterozoic Z and Early Cambrian time (Kaye and Zartman, 1980; Goldsmith, this vol., chap. E). The Westwood Granite may be the intrusive equivalent of the Mattapan and Lynn, whereas the swarms of older east-west-trending mafic dikes (parallel to the faults defining the basin) may be the intrusive equivalent of the basaltic lava flows of the Brighton.

The next period of activity was during the Ordovician, when the Nahant Gabbro was intruded into the Boston basin at Nahant and into the Proterozoic Z basement at Salem Neck. This gabbro is $30 \mathrm{~m}$.y. older than alkalic feldspar granites like those of the Cape Ann Complex and the Quincy Granite that followed it (table 1). The compositions of these alkalic granites indicate that the crust had matured sufficiently that no $\mathrm{H}_{2} \mathrm{O}$-rich material melted to make more typical granites. The Cape Ann Complex and Quincy Granite are similar to rocks usually associated with intracratonic plutonism or a continental rift zone. Similar rocks extend well into the Gulf of Maine to the north (Hermes and others, 1978) and into Rhode Island to the south (Hermes and Zartman, 1985).

A period of apparent quiescence, between about 450 and $400 \mathrm{Ma}$, was followed during the Devonian by intrusion into stable crust of another group of alkaline rocks such as the Wenham Monzonite, Peabody Granite, granite of the Rattlesnake Hill pluton, and the Scituate Granite of central Rhode Island. Zartman (1977) believed, however, that the intrusions may be sequential rather than falling into two distinct groups. The composition of these Devonian granites is distinctly different from that of the widespread Devonian plutons west of the Milford-Dedham and Nashoba zones.

The final intrusions in the Milford-Dedham zone were of Permian age, the Westerly and Narragansett Pier Granites in Rhode Island. These granites are $\mathrm{H}_{2} \mathrm{O}$ rich, are meta- to peraluminous, and from their composition and contact effects (Grew and Day, 1972; Day and others, 1980; Hermes and others, 1981) must have intruded Pennsylvanian-age sediments from depths of about 12-15 $\mathrm{km}$. Their mineralogy suggests that they were derived from a crustal source different from the source of the 


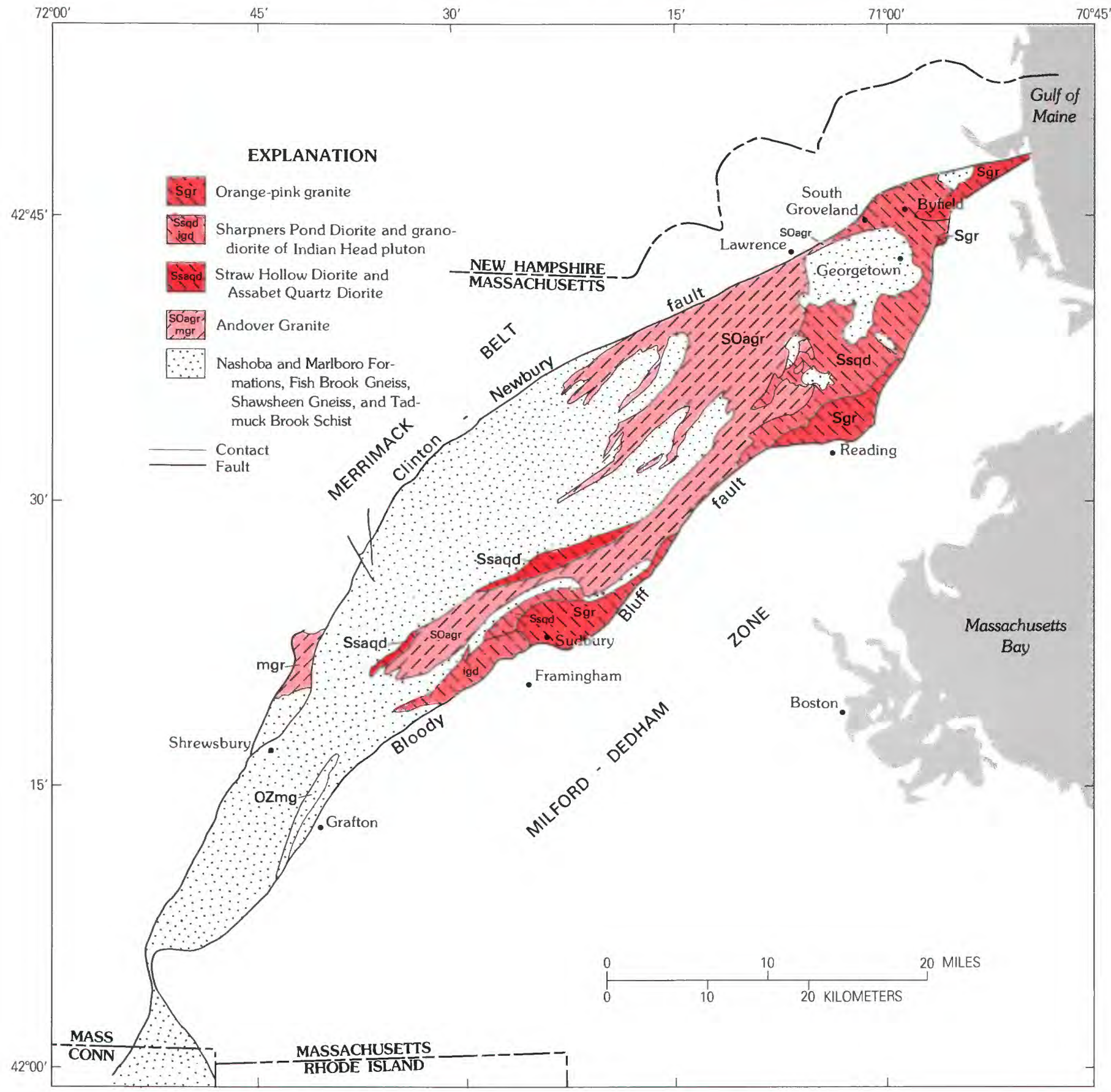

FIGURE 26.-Distribution of intrusive rocks in the Nashoba zone. OZmg, feldspathic gneiss in the Marlboro Formation; mgr, light-gray muscovite granite.

earlier Paleozoic intrusions. This new source or modification of an older source for the siliceous magma formed between the Devonian and Permian probably is best explained by thrusting of the Milford-Dedham zone over a thick sequence of sediments before Permian time, or possibly by underplating of entirely different material as indicated by Zartman and Hermes (1984). Thus, the plutonic record documents a period of Precambrian subduction, a long period through the early and middle Paleozoic during which the crust had matured so that alkaline magmas were generated as a result of lower crustal heating, and finally the transport of the MilfordDedham rocks over sedimentary rocks during the late Paleozoic. 
TABLE 13.-Ages and age relations of intrusive rocks of the Nashoba zone and the eastern part of the Merrimack belt [Radiometric data from Zartman and Marvin, this vol., chap. J, table 1, except where noted. Ages are interpreted to be within 5 percent of the primary age of intrusion. wr, whole rock; -, no data]

\begin{tabular}{|c|c|c|c|}
\hline Map unit & Name & Intrudes & Age (Ma), method \\
\hline Dfgr & Fitchburg Complex & $\begin{array}{l}\text { Sp, Paxton Formation; Dl, Littleton } \\
\text { Formation; DSw, Worcester } \\
\text { Formation. }\end{array}$ & $\begin{array}{l}390 \pm 15, \mathrm{U}-\mathrm{Pb} / \text { zircon, } 402 \pm 11, \mathrm{Rb}- \\
\mathrm{Sr} / \mathrm{wr} \text {. }\end{array}$ \\
\hline Dmgr & Granite at Millstone Hill & So, Oakdale Formation & $372 \pm 7, \mathrm{Rb}-\mathrm{Sr} / \mathrm{wr}$ \\
\hline Dcgr & Chelmsford Granite & $\begin{array}{l}\text { Sb, Berwick Formation; Sagr; DSdi, } \\
\text { diorite and tonalite. }\end{array}$ & $389 \pm 5, \mathrm{~Pb}-\mathrm{Pb} /$ zircon. $^{1}$ \\
\hline igd & Granodiorite of Indian Head pluton & OZm, Marlboro Formation & $402 \pm 5, \mathrm{Rb}-\mathrm{Sr} / \mathrm{wr} .^{2}$ \\
\hline Sgr & Orange-pink granite & Ssqd & - \\
\hline Ssqd & Sharpners Pond Diorite & $\begin{array}{l}\text { OZn, Nashoba Formation; OZm, Marl- } \\
\text { boro Formation; SOagr, older phase. }\end{array}$ & $430 \pm 5, \mathrm{U}-\mathrm{Pb} /$ zircon. \\
\hline Ssaqd & $\begin{array}{l}\text { Straw Hollow Diorite and Assabet } \\
\text { Quartz Diorite. }\end{array}$ & $\mathrm{OZn}$ & - \\
\hline Sacgr & Ayer Granite, Clinton facies & So, SOrh, Reubens Hill Formation & $433 \pm 5, \mathrm{U}-\mathrm{Pb} /$ zircon. \\
\hline SOad & $\begin{array}{l}\text { Ayer Granite, Devens-Long Pond } \\
\text { facies. }\end{array}$ & $\mathrm{Sb}$, Berwick Formation & $433 \pm 5$, U-Pb/zircon. \\
\hline SOagr & $\begin{array}{l}\text { Andover Granite: } \\
\text { younger phase } \\
\text { older, gneissic phase }\end{array}$ & $\begin{array}{l}\text { OZn, OZm, SOagr, older phase } \\
\text { OZn, OZm }\end{array}$ & $\begin{array}{l}408 \pm 22, \mathrm{Rb}-\mathrm{Sr} / \mathrm{wr},{ }^{1} 415, \mathrm{Rb}-\mathrm{Sr} / \mathrm{wr} .^{2} \\
446 \pm 32, \mathrm{Rb}-\mathrm{Sr} / \mathrm{wr},{ }^{1} 450 \pm 23, \mathrm{Rb}-\mathrm{Sr} / \mathrm{wr} \\
\quad 460, \mathrm{Rb}-\mathrm{Sr} / \mathrm{wr} .\end{array}$ \\
\hline Sngr & Newburyport Complex granite & $\begin{array}{l}\text { Se, Eliot Formation; SOk, Kittery } \\
\text { Formation. }\end{array}$ & - \\
\hline SOngd & Newburyport Complex granodiorite & - & $455 \pm 15, \mathrm{U}-\mathrm{Pb} /$ zircon. \\
\hline
\end{tabular}

${ }^{1}$ Data from Zartman and Naylor (1984).

${ }^{2}$ Data from Hill and others (1984).

\section{INTRUSIVE ROCKS OF THE NASHOBA ZONE}

The intrusive rocks of the Nashoba zone (fig. 26) range in age from Ordovician to Devonian (table 13) and are dominated by the Ordovician and Silurian, peraluminous, gneissic Andover Granite and a Silurian calc-alkaline suite consisting of quartz diorite, granodiorite, and granite. The largest masses of intrusive rocks are in the northern part of the Nashoba zone. The area of the Andover Granite shown on the State bedrock map includes granite of several ages. Most of it is Ordovician in age, but it contains some Devonian granite and pegmatite. A feldspathic gneiss (OZmg) near Grafton in the southern part may be an intrusive rock (Hepburn, 1978) or may be a metavolcanic unit in the Nashoba Formation. This gneiss is discussed in the description of the stratigraphic units in the Nashoba zone (Goldsmith, this vol., chap. F).

\section{ANDOVER GRANITE (SOagr)}

The Andover Granite (SOagr) is a light-colored muscovite- and garnet-bearing, mostly gneissic granite (table 14, no. 1) that intrudes the Nashoba Formation $(\mathrm{OZn})$ at all scales. Within the Andover are nongneissic granitic rocks that are apparently younger than the main mass of the unit (Hansen, 1956; Castle, 1964). Dikes and apophyses of aplite and pegmatite infiltrate much of the Nashoba terrane and contribute to the migmatitic aspect
TABLE 14.-Modes, in percent, of intrusive rocks of the Nashoba zone [Modes 1-6 from Castle (1964); a, albite; 0 , oligoclase; $n$, andesine; tr, trace]

\begin{tabular}{|c|c|c|c|c|c|c|}
\hline $\begin{array}{lc}\text { Sample no. ... } & 1 \\
\text { Unit ......... } & \text { sOagr }\end{array}$ & $\begin{array}{c}2 \\
\text { SOagr }\end{array}$ & $\begin{array}{c}3 \\
\text { SOagr }\end{array}$ & $\begin{array}{c}4 \\
\text { Ssqd }\end{array}$ & $\begin{array}{c}5 \\
\text { Ssqd }\end{array}$ & $\begin{array}{c}6 \\
\text { Ssqd }\end{array}$ & $\begin{array}{c}7 \\
\text { igd }\end{array}$ \\
\hline Quartz. ......24-49 & $27-38$ & $25-39$ & $0-7$ & $13-18$ & $25-40$ & 32.5 \\
\hline Plagioclase . . 20-30a, 0 & $26-46$ & $32-49$ & $35-52 \mathrm{n}$ & $44-49 n$ & $28-570, \mathrm{n}$ & 35.90 \\
\hline Microcline . . . 18-41 & $10-44$ & $0-33$ & 0 & 0 & $0-33$ & 22.8 \\
\hline Muscovite.... 2-14 & $0-11$ & $0.2-17$ & 0 & 0 & 0 & $\operatorname{tr}$ \\
\hline Biotite. . . . . . 0-6 & $0-11$ & $0-4$ & $0-13$ & $10-23$ & $2-24$ & 7.4 \\
\hline Hornblende. .. 0 & 0 & 0 & $19-38$ & $11-22$ & $0-4$ & 0 \\
\hline Garnet ...... & $0-0.6$ & $0-3$ & 0 & 0 & $\operatorname{tr}$ & 0 \\
\hline Titanite..... 0 & $\operatorname{tr}$ & 0 & 1 & 2 & $0-1.6$ & 0 \\
\hline \multicolumn{7}{|l|}{ Opaque } \\
\hline minerals $\ldots$ tr & $0-0.2$ & $\operatorname{tr}$ & $2-7$ & .2 & .4 & 0 \\
\hline Others $^{1} \ldots \ldots$ tr & $0-6.5$ & $\operatorname{tr}$ & $1-3$ & 1 & $0-10$ & 1.4 \\
\hline
\end{tabular}

${ }^{1}$ Others $=$ sphene, zircon, and alteration minerals sericite, chlorite, epidote, and carbonate minerals.

1. Andover Granite; biotite granite gneiss facies, range of 14 samples.

2. Andover Granite; binary granite facies, range of 24 samples.

3. Andover Granite; pegmatitic granite facies, range of 9 samples.

4. Sharpners Pond Diorite; hornblende-diorite facies, range of 5 samples.

5. Sharpners Pond Diorite; biotite-hornblende tonalite facies, range of 4 samples.

6. Sharpners Pond Diorite; biotite-tonalite facies, range of 9 samples.

7. Granodiorite of the Indian Head pluton; roadcut on I-495 at Southboro-Marlborough town line. Field no. M-6; sample locality given in Wones and others (1986); 1,152 points counted.

of much of the Andover. The Acton Granite of Hansen (1956) probably belongs to the older material. The preferred orientation of muscovite defines a pronounced foliation conformable to the regional trend. Mortar tex- 
tures and recrystallized quartz are common. The gneissic Andover Granite is about $445-450 \mathrm{Ma}$, and the younger phase of granite and pegmatite is $410-415 \mathrm{Ma}$ (table 13).

A crosscutting muscovite granite of the younger phase (table 14, no. 2), termed "binary granite" by Castle (1964), is white to gray and weathers to chalk white. The texture is seriate at most localities. Alteration minerals are chlorite (0-3 percent), epidote ( $0-2$ percent), and carbonate minerals (0-3 percent). Myrmekite is well developed in this younger facies.

Pegmatitic granite of the younger phase (table 14, no. 3 ) is abundant in the southern parts of the Lawrence and South Groveland areas (fig. 26). It intrudes the gneissic facies of the Andover and the Sharpners Pond Diorite and is therefore younger than the rest of the Andover. It is gradational with the younger muscovite granite. Crystal shape and grain size vary randomly among the outcrops of this unit. Rutile and chlorite are alteration minerals from biotite. All three facies contain traces of zircon and apatite, in addition to the ubiquitous small amounts of garnet.

\section{SHARPNERS POND DIORITE (Ssqd)}

The Sharpners Pond Diorite (Ssqd) covers about 150 $\mathrm{km}^{2}$ and includes diorite, tonalite, and small amounts of granodiorite. It intrudes the Nashoba $(\mathrm{OZn})$ and Marlboro $(\mathrm{OZm})$ Formations and the older gneissic phase of the Andover Granite. It is intruded by pegmatites, the younger phase of the Andover, and the orange-pink, rusty-weathering biotite granite (Sgr). The Sharpners Pond has a reliable age of $430 \mathrm{Ma}$ (table 13).

Castle (1964) recognized three separate facies within the Sharpners Pond: hornblende diorite, biotitehornblende tonalite, and biotite tonalite. These three facies are gradational in composition and were intruded penecontemporaneously. Some of the hornblende diorite, where gneissic, may be recrystallized Marlboro Formation, although much of the gneissic diorite clearly is intrusive.

The hornblende diorite (table 14 , no. 4 ) is equigranular, medium grained, and hypidiomorphic to allotriomorphic. Some rocks are quite altered and contain appreciable chlorite (2-10 percent), white mica ( $0-20$ percent), epidote (0.5-3 percent), and carbonate minerals (less than 0.6 percent). Plagioclase ranges in composition from $\mathrm{An}_{28}$ to $\mathrm{An}_{55}$, averages $A n_{40}-\mathrm{An}_{45}$, and displays weak zoning. Some hornblende encloses clinopyroxene.

The biotite-hornblende tonalite (table 14 , no. 5) is slightly younger than the hornblende diorite. The higher biotite content gives this facies a more foliate appearance. Alteration minerals include chlorite (1-2 percent), white mica (less than 3 percent), epidote (0.3-2 percent), and traces of carbonate minerals. The plagioclase compositions are $\mathrm{An}_{30}-\mathrm{An}_{40}$.

The biotite tonalite (table 14, no. 6) is limited to about $10 \mathrm{~km}^{2}$ in the Reading area, and its boundaries with both the Andover Granite and the other facies of the Sharpners Pond Diorite are ill defined (Castle, 1964). The rocks are fine to medium grained and variably foliated. Rocks with little K-feldspar are hypidiomorphic, whereas those with more K-feldspar are allotriomorphic. Alteration minerals are chlorite $(0-5$ percent), epidote $(0.1-2.4$ percent), white mica (0-0.3 percent), and carbonate minerals. Plagioclase compositions are $\mathrm{An}_{15}-\mathrm{An}_{33}$. Secondary K-feldspar has formed along early fractures.

\section{STRAW HOLLOW DIORITE AND ASSABET QUARTZ DIORITE (Ssaqd)}

The Straw Hollow Diorite and Assabet Quartz Diorite (fig. 26) are shown as one unit (Ssaqd) on the State bedrock map because of their similar occurrence and general lithology and their small size. The Straw Hollow Diorite, only $3 \mathrm{~km}^{2}$ in area, intrudes the Nashoba Formation and is in fault contact with the Marlboro Formation. The rock is light gray to dark green, medium grained, and weakly foliated and contains hornblende, biotite, and accessory magnetite, titanite, garnet, and pyrite. It is considered to be Silurian in age because of its lithologic similarity to the Sharpners Pond Diorite.

The Assabet Quartz Diorite, $23 \mathrm{~km}^{2}$ in area, is believed to intrude the Marlboro Formation (although Hansen (1956) did not observe any intrusive contact) and the Andover Granite. The rock is weakly foliated and is composed of andesine, hornblende, quartz, and biotite with accessory apatite, titanite, and hematite. The gneissosity is defined by parallel orientation of hornblende. Hansen (1956) reported that the Assabet is cut by dikes of aplite and pegmatite, which may be equivalent to the granite (Sgr) that intrudes the Sharpners Pond Diorite.

\section{GRANODIORITE OF THE INDIAN HEAD PLUTON (igd)}

The granodiorite of the Indian Head pluton (igd) (fig. 26) consists of a normal and a coarse-grained facies (Hepburn and DiNitto, 1978), which intrude the Marlboro Formation. It ranges from light gray where fresh to pink on weathering, is massive, and ranges in composition from granodiorite to monzogranite. A mode given in table 14 (no. 7) indicates a granitic composition. A chemical composition of another sample given in table 15 also indicates a granitic composition verging towards granodiorite. Accessory minerals are muscovite, epidote, and hornblende. This granitic sample may correspond to a two-mica granite phase of the Indian Head 
TABLE 15.-Major-oxide, normative-mineral, and trace-element compositions of granodiorite of the Indian Head pluton

[Major-oxide composition from X-ray spectroscopy by Paul Hearn and Susan Wargo; all $\mathrm{Fe}$ reported as $\mathrm{Fe}_{2} \mathrm{O}_{3}$. Trace-element abundances from instrumental neutron activation analyses by L.J. Schwartz except $\mathrm{Rb}$ and $\mathrm{Sr}$ determined by X-ray spectroscopy by G. Sellars and B. McCall. Sample locality (field no. DMA-191) given in Wones and others (1986)]

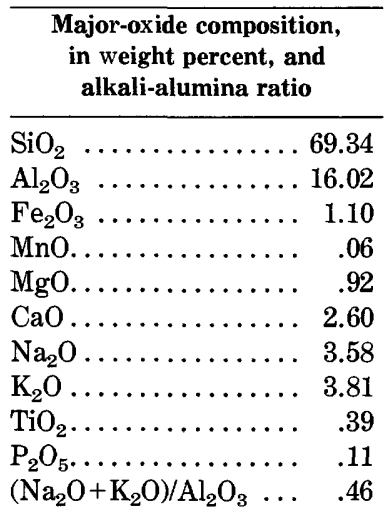

Normative-mineral composition, in weight percent, ${ }^{1}$ and differentiation index (DI)

$\overline{\text { Qtz................25.4 }}$

Crn .............. 1.5

Or............... 22.6

$\mathrm{Ab} \ldots \ldots \ldots \ldots \ldots, 30.4$

An .............. 12.2

En $\ldots \ldots \ldots \ldots \ldots \ldots, 2.3$

Fs............. 4.5

$\operatorname{Ilm} \ldots \ldots \ldots \ldots \ldots . .7$

Ap $\ldots \ldots \ldots \ldots \ldots \ldots . .3$

DI $\ldots \ldots \ldots \ldots \ldots \ldots, 78$

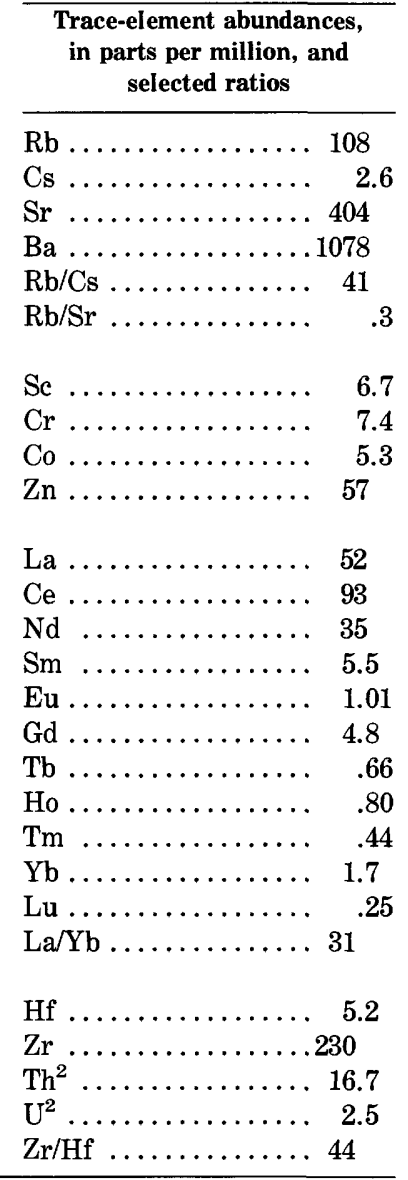

${ }^{1} \mathrm{Fe}_{2} \mathrm{O}_{3}$ calculated as $\mathrm{FeO}$.

${ }^{2}$ Delayed neutron reactivation analysis (by H.T. Millard, Jr., C. McFee, and C. Bliss) gave same result as did instrumental neutron activation analysis.

Description of sample

Granodiorite, Farm Road, $300 \mathrm{~m}$ southwest of Cook Lane, Marlborough. UTM grid: N46902-E2918.

pluton that cuts an older, more mafic gneissic phase described by Hill and others (1984). They dated the older phase at $402 \mathrm{Ma}$. Our sample has an REE pattern (fig. 25) that falls between the patterns of the two phases of Hill and others. This granite has a relatively high $\mathrm{Th} / \mathrm{U}$ ratio compared with those of the Proterozoic rocks shown on figure 10. The Indian Head is the granodiorite described by Nelson (1975a) in the Framingham area. The entire mass in the Framingham area is about $70 \mathrm{~km}^{2}$ in area. The Indian Head may be equivalent in age to small (less than $1 \mathrm{~km}^{2}$ ) masses of monzogranite near South Groveland and Georgetown reported by Castle (1964) and to the orange-pink rusty-weathering granite (Sgr) described next.

\section{ORANGE-PINK RUSTY-WEATHERING GRANITE (Sgr)}

The orange-pink rusty-weathering granite (Sgr) forms three masses, near Byfield, near Reading, and near Sudbury (fig. 26). The distribution of the granite shown on the State bedrock map is derived from reconnaissance mapping by Shride (written commun., 1979). The orange-pink granite consists of both medium-grained and coarse-grained facies. The granite at Byfield is a medium-grained, equigranular to porphyritic biotite granite that contains about equal amounts of white oligoclase and gray quartz, lesser amounts of perthitic microcline, and about 5 percent biotite (Shride, 1971). The rock is only altered near contacts and where faulted. It contains many inclusions and is contaminated by wallrock material in contact zones; in these places it is difficult to tell from Sharpners Pond Diorite. It does, however, intrude the Sharpners Pond Diorite (Shride, 1976). Hansen (1956) mapped the mass at Sudbury as Dedham granodiorite, but part of the rock Hansen mapped as Dedham is granodioritic to tonalitic in composition and was subsequently mapped by Hepburn and DiNitto (1978) as Indian Head Hill granodiorite.

The orange-pink granite may be equivalent in age to the granodiorite of the Indian Head pluton or to the younger muscovite granite and pegmatite phase of the Andover Granite.

\section{LIGHT-GRAY MUSCOVITE GRANITE (mgr)}

The light-gray muscovite granite (mgr) forms a pluton in the isolated fault block of the Nashoba Formation in the Clinton-Newbury fault zone near Shrewsbury (fig. 26). This mass was called the Rattlesnake Hill pluton by Skehan and Abu-Moustafa (1976) (not the Rattlesnake Hill pluton of the Milford-Dedham zone). It is uncertain whether this muscovite granite is equivalent to the Devonian muscovite granite at Millstone Hill (Dmgr) or the Chelmsford Granite (Degr) of the Merrimack belt or is equivalent to the older gneissic phase of the Andover Granite.

\section{DISCUSSION OF THE INTRUSIVE ROCKS OF THE NASHOBA ZONE}

The sequence of intrusion in the Nashoba zone began with pre- or synkinematic intrusion of muscovite-bearing granite. This was followed by postkinematic intrusion of diorite to tonalite, succeeded by less mafic tonalite, granodiorite, and monzogranite, and finally intrusion of muscovite-bearing pegmatite and aplite at a late stage to produce migmatite in many areas.

Confusion exists concerning the age of these sequences, as both the oldest and the youngest intrusive 
rocks have been included in the Andover Granite map unit and both are peraluminous. The early Andover Granite is foliate but also has the fabric of a migmatite in places. Resolving the age of this material will require precise geochronology after careful mapping of local areas. Zartman and Marvin (this vol., chap. J) consider the 450-Ma age reliable for the gneissic Andover. The 415-Ma age of Hill and others (1984) can be considered to represent the age of the younger pegmatite and granite in the Andover. Both the older gneissic and the younger nongneissic Andover have the muscovite and garnet (table 14) typical of S-type granites derived from deepseated sedimentary material in a high-temperature regime. This compositional similarity suggests regeneration of magma derived from the original source or generation of magma from a newly arrived but similar source. The age of metamorphism and intrusion of the gneissic phase is considered to be $450 \mathrm{Ma}$ (Zartman and Naylor, 1984).

The Sharpners Pond Diorite and related intrusions form a suite that has mineralogies characteristic of lower pressure I-type intrusives. We have chemical analyses from only the granodiorite of the Indian Head pluton from this suite (table 15). This rock is relatively granitic and is probably the younger phase of the Indian Head Hill pluton of Hill and others (1984). Their older gneissic mafic phase dated at $402 \mathrm{Ma}$ (table 13) would fit into a Late Silurian and Early Devonian plutonic-volcanic sequence of which the Newbury Volcanic Complex may be a part. The younger phase of the Indian Head granodiorite and the orange-pink granite could be a late granitic phase of a plutonic-volcanic suite having a calcalkaline trend, as illustrated by Hill and others (1984); the dioritic intrusions, the Sharpners Pond Diorite and the Assabet Quartz Diorite, were an earlier mafic phase of this plutonic-volcanic suite. The Assabet Quartz Diorite and the Sharpners Pond Diorite intrusions are very suggestive of the formation of a short-lived continental arc. Hill and others (1984) suggested that the suite of rocks is the product of processes at convergent plate boundaries and contains assimilated crustal material of Proterozoic $\mathrm{Z}$ to early Paleozoic age, a suggestion with which we concur.

The exposed Nashoba zone is too narrow to develop a sense of polarity for the plutons within it, so that determining the direction of subduction is difficult, if not impossible. Zartman and Naylor (1984) have dated the younger intrusions at $408 \pm 22 \mathrm{Ma}$ (table 13). If this age is correct, then the precursor event at $446 \pm 32 \mathrm{Ma}$ may represent the initial melting of trench sediments and may be analogous to the event that produced the Cretaceous granitoids of the Ryoke-Sanba region in Japan (Czamanske and others, 1981). Thus, we may be observing a record of about $30 \mathrm{~m}$.y. of subduction. At a rate of
$1 \mathrm{~cm} / \mathrm{yr}, 300 \mathrm{~km}$ of oceanic crust could have been subducted during this time. However, uncertainty in field identification of the different phases of the Andover and the scatter of the radiometric ages make such an assessment speculative.

The intrusion of the younger muscovitic granites, the young phases of the Andover Granite and the Indian Head pluton, and possibly the orange-pink granite may represent another major event rather than part of a continuum. Wones $(1974,1976,1985)$ identified a similar sequence of intrusive events in the Orrington-Liberty anticlinorium, Passagassawakeag terrane, eastern Maine. Zircon dates on material collected by Wones yielded an age of $410 \mathrm{Ma}$ for the formation of muscoviteand garnet-rich migmatite in that terrane (Marvin and Dobson, 1979, p. 18-19). Rb-Sr whole-rock ages from the same terrane include an older age of $1,360 \pm 68 \mathrm{Ma}$ and younger ages of $494 \pm 25 \mathrm{Ma}$ and $426 \pm 27 \mathrm{Ma}$, the latter ages being not unlike those from the Andover. The similarities between the Passagassawakeag (including the Casco Bay Group) and Nashoba terranes have been recognized earlier (Hussey, 1968). If the ages of 408 to $415 \mathrm{Ma}$ for the Andover (table 13) are correct, then the younger Andover Granite is analogous to the Manaslu granite of Nepal (Le Fort, 1981) and may reflect thrusting followed by decoupling of the Avalon terrane as it moved westward under the eastern part of the Merrimack belt. These ages roughly correspond to the age of nappe formation in central Massachusetts and New Hampshire. It is important to note that the apparently younger diorites of the western and eastern Merrimack terrane have no counterparts in the Nashoba terrane.

\section{INTRUSIVE ROCKS OF THE EASTERN PART OF THE MERRIMAGK BELT}

The intrusive rocks of the Merrimack belt east of the Wekepeke fault are dioritic to granitic intrusions of Late Ordovician to Early Devonian age (table 13) that lie primarily along the east side of the belt west of the Clinton-Newbury fault (fig. 27). Most of these intrusions are clustered in a zone from Clinton to the Pepperell area, where they consist primarily of the Ayer Granite and its facies. The Ayer Granite continues south of Worcester into Connecticut, where it is called the Canterbury (and formerly Eastford) Gneiss. In northeastern Massachusetts, the Newburyport Complex forms an isolated pluton. The Ordovician and Silurian granites tend to be calc-alkaline, and the Devonian granites tend to be at least in part peraluminous. We have undertaken no chemical studies of the rocks in the eastern part of the Merrimack belt, and our descriptions are all from the observations of others. Masses of Ayer Granite and its equivalents in Connecticut lie on both sides of the 


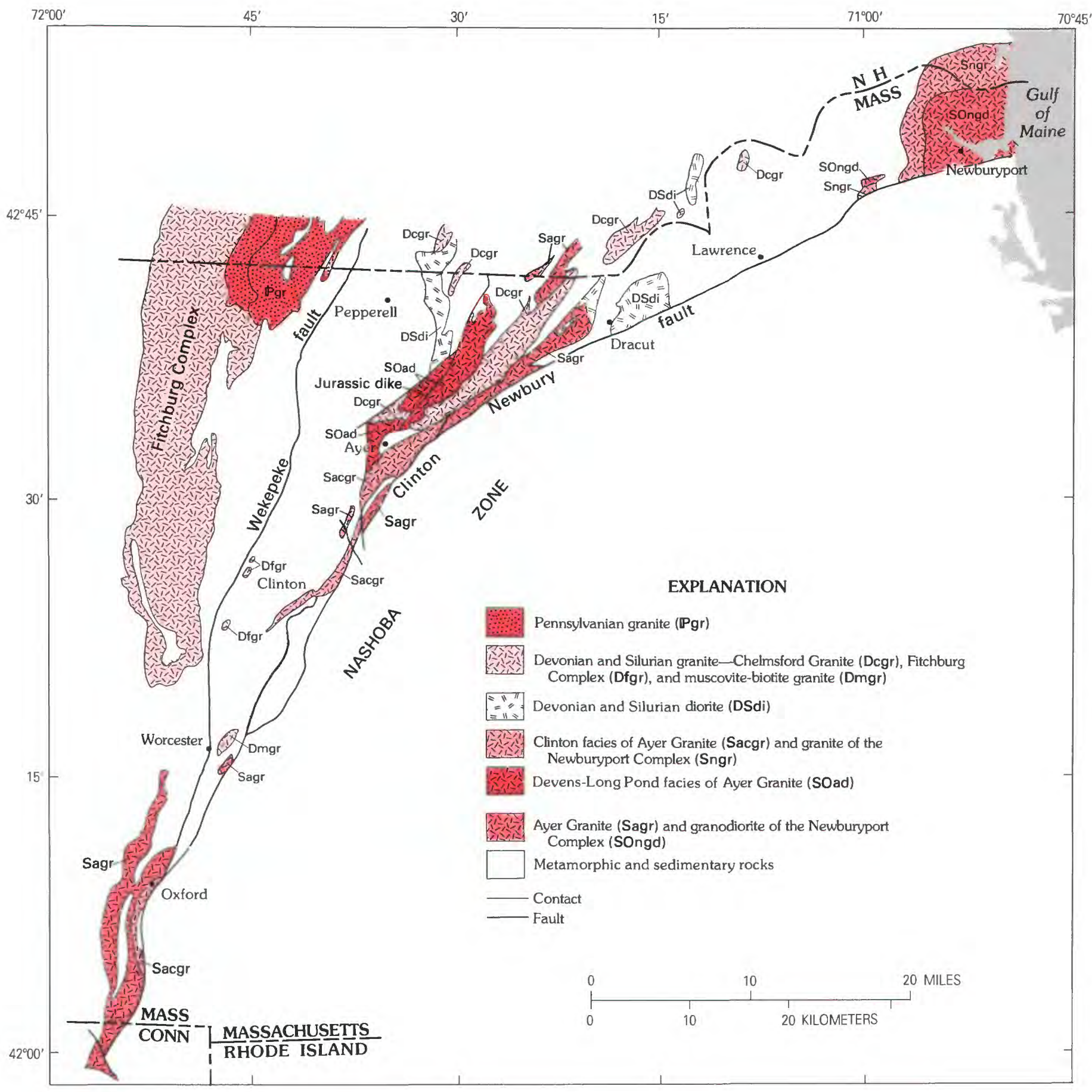

FiguRE 27.-Distribution of intrusive rocks in the eastern part of the Merrimack belt.

Wekepeke fault as it is projected south from the Worcester area, but all the Ayer and Canterbury granitic intrusions lie west of the Clinton-Newbury fault and its possible projection into Connecticut (see Pease, 1982, p. 264, for example), indicating that the Clinton-Newbury fault is a more significant terrane boundary than the
Wekepeke. East of the Wekepeke fault, west of Clinton, in the part of the Merrimack belt we are describing, are a few small granite stocks of the Devonian Fitchburg Complex, whose main mass lies west of the Wekepeke fault. These stocks are the only intrusions in Massachusetts in the western part of the belt we are describing. 
TABLE 16. - Modes, in percent, of intrusive rocks of the Merrimack belt east of the Wekepeke fault

[o, oligoclase; $\mathrm{m}$, microcline]

\begin{tabular}{|c|c|c|c|c|}
\hline 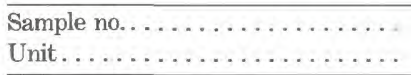 & $\begin{array}{c}1 \\
\text { Sngr }\end{array}$ & $\begin{array}{c}2 \\
\text { SOngd }\end{array}$ & $\begin{array}{c}3 \\
\text { Sacgr }\end{array}$ & $\begin{array}{c}4 \\
\text { SOad }\end{array}$ \\
\hline Quartz .................. & 33 & $6-33$ & 27 & 26 \\
\hline Plagioclase...$\ldots \ldots \ldots \ldots$. & 35 & $30-48$ & 360 & 40 \\
\hline K-feldspar ................. & 27 & $3-35$ & $28^{1}$ & $29 m$ \\
\hline Mafic minerals $^{2} \ldots \ldots \ldots \ldots$ & 5 & $12-33$ & 8 & 4 \\
\hline
\end{tabular}

${ }^{1} 20$ percent as phenocrysts, 8.5 percent in groundmass.

${ }^{2}$ Mafic minerals unidentified in samples 1-2; includes biotite, chlorite, and opaque minerals in samples 3-4.

Description of samples

1. Granite of Newburyport Complex. Average of two point-counts of stained slabs.

2. Tonalite and granodiorite of the Newburyport Complex. Range of modes from point-counts of stained slabs.

3. Clinton facies of Ayer Granite. Average modal composition from Gore (1976).

4. Porphyroblastic variety of Devens-Long Pond facies of Ayer Granite. From Gore (1976).

\section{NEWBURYPORT COMPLEX}

Shride (1971) divided the Newburyport Complex into two facies: tonalitic granodiorite and granite. The tonalitic facies was originally termed the Newburyport Quartz Diorite, which also included dioritic rocks south of the Clinton-Newbury fault zone that are now called Sharpners Pond Diorite in the Nashoba zone and Topsfield Granodiorite in the Milford-Dedham zone. These correlations are not tenable on grounds of both age and composition. For this reason, the name Newburyport is restricted to the two facies in the Newburyport area. The complex forms a large mass near Newburyport (fig. 27) and a small mass to the west of it. Both are truncated by the Clinton-Newbury fault.

\section{TONALITE AND GRANODIORITE (SOngd)}

The tonalite and granodiorite facies (SOngd) occupies the core of the Newburyport Complex at Newburyport and is intruded on the northwest by the granite facies. Medium- to dark-gray in fresh rock, the tonalite weathers to both green and red. Rock along joints has been altered to brick red. An age of $455 \pm 15 \mathrm{Ma}$ was determined on zircon of the tonalite (table 13).

The rock is fine to medium grained and is highly variable in mineralogy (table 16 , no. 2). The mafic minerals include hornblende, biotite, titanite, pyrite, and other opaque minerals. The euhedral biotite is usually completely chloritized. Ovoid inclusions are common.

\section{GRANITE (Sngr)}

The granite of the Newburyport Complex (Sngr) intrudes both the Kittery Formation and the tonalite and granodiorite facies; it is at least $45 \mathrm{~km}^{2}$ in area. The granite (table 16, no. 1) is porphyritic and is light gray to dark gray, weathering to buff. Phenocrysts of K-feldspar $(0.5-0.9 \mathrm{~cm})$ are set in a medium-grained matrix. Kfeldspar is uncommon in the groundmass (Shride, 1976). Dioritic inclusions are common and, where oriented, define a foliation. No radiometric ages are available for this facies, so it is conceivable that the tonalite and granodiorite and the granite facies are distinctly different in age.

\section{AYER GRANITE (Sagr)}

Gore (1976) divided the Ayer Granite (Sagr) in its type locality into two facies, the Clinton facies (Sacgr) and the Devens-Long Pond facies (SOad). In addition, there are masses of granite to tonalite (Sagr), not assigned to either of these facies, that intrude the Berwick Formation (Sb) west and northwest of Lawrence (fig. 27) and masses that intrude the Paxton and Oakdale Formations (Sp, So) south of Worcester and west of the probable southern continuation of the Wekepeke fault. Radiometric ages obtained on the facies of the Ayer pose a problem in assigning ages to the unfossiliferous metasedimentary rocks that they intrude. The Clinton facies has a well-defined Early Silurian age and the Devens-Long Pond facies a similar age (table 13), which greatly compresses the time available for the deposition, burial, deformation, and metamorphism of the Berwick and Paxton Formations, if these units are truly Silurian. Some of the bodies labeled Sagr on the map might have been more properly correlated with the Lower Devonian Chelmsford Granite and muscovite-biotite granite at Millstone Hill. The bodies south of Worcester that intrude the Paxton Formation might more properly be correlated with the Canterbury Gneiss of Connecticut, which lies on strike and has an Early Devonian age of $392 \pm 9 \mathrm{Ma}$ (Zartman and Naylor, 1984). Zartman and Naylor (1984) believed that the Ayer Granite is of the same age range as the Newburyport Complex.

\section{CLINTON FACIES (Sacgr)}

The Clinton facies of the Ayer Granite (Sacgr) occupies $35 \mathrm{~km}^{2}$ northwest of, and within, the Clinton-Newbury fault zone (fig. 27). The Clinton intrudes the Oakdale and Berwick Formations and, from Gore's (1976) map pattern, may intrude the Devens-Long Pond facies.

The Clinton facies of the Ayer Granite is a foliated, porphyritic, coarse-grained, light- to dark-gray granite (table 16, no. 3) that weathers to a buff color. Apatite, allanite, zircon, opaque minerals, and muscovite are present as primary accessory minerals. Biotite is partly altered to chlorite. Epidote, sericite, chlorite, titanite, 
and carbonate minerals are alteration products. The mean composition of the K-feldspar megacrysts is $\mathrm{Or}_{80}$, and the Or-rich lamellae are maximum microclines (Gore, 1976). The Clinton facies is different in texture and mineralogy from the Devens-Long Pond facies and could represent a distinct and different magmatic event.

DEVENS-LONG POND FACIES (SOad)

The Devens-Long Pond facies of the Ayer Granite (SOad) forms an elongate pluton of $45 \mathrm{~km}^{2}$ southeast of Pepperell (fig. 27), entirely west of bodies of the Clinton facies. The facies consists of both equigranular and porphyroblastic varieties. Both varieties are gneissic, whereas the Clinton facies is gneissic only in the ClintonNewbury fault zone. The contact relations between the Devens-Long Pond facies and the Oakdale and Berwick Formations are indeterminate. Gore (1976) thought the contact could be an unconformity. Goldsmith, following mapping by Robinson (1978, and written commun., 1978) in the Pepperell-Ayer area, made the contact with the Oakdale a fault on the State bedrock map. However, the contact relations of the Devens-Long Pond facies with the Berwick Formation are not determined. The map pattern suggests that the Devens-Long Pond facies is intruded by the Clinton facies, but no diagnostic outcrops have been observed. The Chelmsford Granite clearly intrudes the Devens-Long Pond facies (Gore, 1976).

The porphyroblastic variety (table 16 , no. 4) typically is light to medium gray and exhibits granoblastic textures. Quartz and plagioclase grains are $3-8 \mathrm{~mm}$ long and porphyroblasts of microcline are 1-2 cm long. Accessory minerals are allanite, tourmaline, zircon, apatite, opaque minerals, and muscovite. Alteration minerals are chlorite, epidote, sericite, titanite, and carbonate minerals. The alkali-feldspar porphyroblasts have the bulk composition of $\mathrm{Or}_{95}$ (Gore, 1976). The equigranular variety has a similar mineralogy but ranges in composition from quartz monzonite (granite) to quartz diorite and in texture from homogeneous to inhomogeneous. Some of the rock contains schlierenlike bands (Gore, 1976). The gneissic texture of the rock gives it the appearance of being older than the radiometric age $(433 \pm 5 \mathrm{Ma}$; see table 13) would indicate. Wones thought it resembles the Passagassawakeag Gneiss of Bickel (1976) in Maine. Gore's studies of the megacrysts of the Clinton facies and the porphyroblasts of the Devens-Long Pond facies demonstrated that the rocks have undergone different histories. Possibly the Devens-Long Pond facies should be a separate unit from the rest of the Ayer Granite.

\section{DIORITE AND TONALITE (DSdi)}

The diorite and tonalite designation (DSdi) includes all dioritic or gabbroic rocks that intrude the Berwick
Formation and the Ayer Granite and are intruded by dikes of two-mica granite that may be correlative with the Chelmsford. Two main masses-one in Dracut (Dracut Diorite) and one east of Pepperell (fig. 27)-are assumed to be correlative with the Exeter Diorite in New Hampshire that intrudes the Eliot Formation. Other smaller masses intrude the Berwick Formation (SOb) in northern Massachusetts and southeastern New Hampshire. The Exeter had been dated at $408 \mathrm{Ma}$ (Bothner, 1974), but since the State bedrock map was prepared the Exeter has been found to be $473 \pm 37 \mathrm{Ma}$ (Bothner and others, 1984; Gaudette and others, 1984).

Dennen (1943) described the stock at Dracut as a norite, as it contains hypersthene, augite, hornblende, olivine, plagioclase $\left(\mathrm{An}_{37}-\mathrm{An}_{71}\right)$, and opaque minerals. Plagioclase is interstitial or poikilitic to hypersthene and augite. Hornblende occurs as a late-stage magmatic mineral and as an alteration product (uralite) with biotite, sericite, chlorite, talc, serpentine, kaolin, and hematite. Opaque minerals include ilmenite, magnetite, pyrrhotite, chalcopyrite, and pentlandite. The Dracut Diorite has been mined for nickel from a pyrrhotitepentlandite-chalcopyrite assemblage.

\section{CHELMSFORD GRANITE (Dcgr)}

The Chelmsford Granite (Dcgr) intrudes the Berwick Formation, the Ayer Granite, and the Dracut Diorite northwest of the Clinton-Newbury fault. It occurs in two elongate bodies that strike parallel to the regional northeast trend and occupy an area of $60 \mathrm{~km}^{2}$ (fig. 27). Zartman and Naylor (1984) could not obtain a definitive age on the Chelmsford but believed it to be in the range of the Ayer Granite because the age would lie within the margin of error of their age determinations. The Devonian designation for the age of the Chelmsford given on the State bedrock map is based on a ${ }^{207} \mathrm{~Pb} /{ }^{206} \mathrm{~Pb}$ age of $389 \pm 5 \mathrm{Ma}$ (Zartman and Naylor, 1984). The difficulties in obtaining acceptable age determinations from the Chelmsford may be due to the pervasive ductile deformation in this granite.

The Chelmsford is light colored and gneissic; it consists of quartz, microcline, plagioclase $\left(\mathrm{An}_{5}-\mathrm{An}_{13}\right)$, muscovite, and biotite. Zircon and garnet are accessory minerals, and epidote, chlorite, and titanite are alteration products. Much of the foliation in parts of the Chelmsford is produced by elongate quartz grains aligned parallel to the preferred orientation of muscovite and biotite; this foliation indicates the pervasive ductile deformation of the unit.

\section{MUSCOVITE-BIOTITE GRANITE AT MILLSTONE HILL} (Dmgr)

A small stock of muscovite biotite granite (Dmgr) intrudes the Oakdale Formation at Millstone Hill in 
Worcester (fig. 27). An Rb-Sr age of $372 \pm 7 \mathrm{Ma}$ has been obtained from this rock (table 13).

\section{FITCHBURG COMPLEX (Dfgr)}

Three small stocks of muscovite granite that intrude the Worcester Formation (DSw) east of the Wekepeke fault and west of Clinton were mapped as Fitchburg granite by Peck (1975). The granite in these stocks contains muscovite, and most samples contain biotite. Tourmaline is a characteristic accessory mineral, according to Peck, and garnet, magnetite, apatite, and zircon are other accessory minerals. These stocks are shown as Fitchburg Complex (Dfgr) on the State bedrock map.

\section{DISCUSSION OF THE INTRUSIVE ROCKS OF THE EASTERN PART OF THE MERRIMACK BELT}

The oldest intrusion recognized in the eastern part of the Merrimack belt is the tonalite and granodiorite of the Newburyport Complex at $455 \pm 15 \mathrm{Ma}$. This calc-alkaline unit is older and richer in K-feldspar than the tonalite of the Sharpners Pond pluton in the Nashoba zone. The two facies of the Ayer Granite have an age similar to that of the Sharpners Pond Diorite in the Nashoba zone (table 13). In New England, these early Silurian ages are unique to the eastern Merrimack belt. The diorites, gabbros, and norites of the Merrimack belt in Massachusetts are undated but may be equivalent to the Exeter pluton, which has now been dated as Early Ordovician. The youngest unit in this belt of plutons is the granite at Millstone Hill at $372 \mathrm{Ma}$ (table 13). The Chelmsford Granite is a muscovitic granite thought to be equivalent in age to the granite at Millstone Hill because of its muscovite content, but the radiometric data are equivocal (Zartman and Marvin, this vol., chap. J). Zircons in the Chelmsford are dated at $430 \mathrm{Ma}$, but an $\mathrm{Rb}-\mathrm{Sr}$ whole-rock age is $356 \pm 71 \mathrm{Ma}$. The margin of error of the $\mathrm{Rb}$-Sr age permits the Chelmsford to be the same age as the Ayer. On the other hand, each of the ages of the Chelmsford may be approximately correct, reflecting both the original intrusion and the later deformation. The data of Zartman and Marvin make the equivalence in age of the Chelmsford to the granite at Millstone Hill uncertain but possible.

The igneous rocks of the eastern part of the Merrimack belt do not appear to correspond to those of the western part of the belt, nor to those in any other part of New England. The nearest possible equivalent group is in the Nashoba zone, where the Newburyport tonalite may be approximately equivalent to the Sharpners Pond tonalite, and the younger phase of the Andover Granite to the granite at Millstone Hill. However, the metamorphic grade and lithologies of the host rocks make such a correlation highly unlikely. The host-rock lithologies (Merrimack Group, SOk, Se, Sb, and Oakdale Formation, So) of the Ayer and Newburyport intrusions in the eastern part of the Merrimack belt were considered by Goldsmith and Robinson to be similar enough to the Paxton Formation (Sp) and associated rocks in the region to the west to combine the two regions into a single Merrimack belt on the State bedrock map. Wones felt that the ages and nature of the plutonic rocks argue against a straightforward correlation, no matter how similar the lithologies of the nonfossiliferous host rocks. The ages of the Merrimack Group have been recently suggested to be Proterozoic Z (Lyons and others, 1982; Bothner and others, 1984) on the basis of conformity of the Berwick Formation of the Merrimack Group with the Proterozoic Z to Ordovician Massabesic Gneiss Complex (OZma) of southern New Hampshire and adjacent Massachusetts. If these relations are true, an older age for the Merrimack Group solves the problem of Ordovician rocks like the Newburyport Complex intruding a supposedly Silurian section. It may be that Gore's (1976) suggestion of an unconformity between the Oakdale Formation and the Devens-Long Pond facies of the Ayer Granite is correct and that the Merrimack belt east of the Wekepeke fault lies unconformably above the Nashoba terrane as Skehan and Murray (1980) suggested (see Robinson and Goldsmith, this vol., chap. G) and is somewhat older than Silurian. The relationship is complicated because east-directed thrusts in the ClintonNewbury fault system place Merrimack-belt rocks over the Nashoba-zone rocks (Skehan and Murray, 1980). Goldsmith believes that the Wekepeke fault is not a major terrane boundary but juxtaposes similar regions of a single terrane that were at different crustal levels. Both the Ayer Granite and the Fitchburg Complex lie on both sides of the Wekepeke fault.

The mineral compositions of the Ordovician and Silurian intrusions in the eastern part of the Merrimack belt resemble those derived from processes along convergent plate margins (Hepburn and others, 1987); these rocks may represent part of a volcanic-plutonic arc developed near or on a continental margin. The sequence of intrusion appears to be from mafic rocks and granodiorite to muscovite granite. The Devonian plutons, because they tend to be two-mica granites, were derived from more sedimentary source material than the older rocks, and their ages indicate that they were at least in part emplaced during Acadian deformation and metamorphism (Robinson and Hall, 1980). The source for the Devonian plutons, like that for the intrusions of the Nashoba zone, was probably a westward-subducting Avalonian plate (Wones, 1984). 


\section{INTRUSIVE ROCKS OF EASTERN MASSACHUSETTS AND PLATE-TECTONIC MODELS}

The contrast in both the age and the style of the intrusive rocks of the Milford-Dedham and Nashoba zones and eastern part of the Merrimack belt that form eastern Massachusetts indicates that eastern Massachusetts was consolidated over a period of time from at least three different terranes (Hatch and others, 1984; Hill and others, 1984). The ages of the intrusive rocks permit reconstruction of events in time, and the compositions of the rocks permit an estimation of the tectonic setting. Some of these matters have been discussed elsewhere in this chapter; here we consider them in reference to plate-tectonic models. A number of analyses of the structural framework of New England with reference to lithotectonic belts and accretionary terranes have been published in recent years (Osberg, 1978; Robinson and Hall, 1980; Hall and Robinson, 1982; Williams and Hatcher, 1983; Zen, 1983). We do not present an exhaustive discussion of these matters here but only point out how the intrusive rocks of eastern Massachusetts constrain the formation of eastern Massachusetts.

The Proterozoic $\mathrm{Z}$ mafic volcanic-plutonic rocks represented by the diorite and gabbro (Zdigb, Zdi, Zgb) and the mafic and felsic volcanic rocks ( $\mathrm{Zv}, \mathrm{Zvf}$ ) in the Milford-Dedham zone represent part of a volcanicplutonic arc that was subsequently intruded by calcalkaline granitic rocks of batholithic dimensions, the Dedham Granite (Zdgr) and similar rocks. Some evidence exists that the rocks of the mafic complex were metamorphosed before intrusion by the 630-Ma granites (Goldsmith, this vol., chap. H). Mosher (1983) suggested a back-arc setting for the Blackstone Group of northern Rhode Island, which we consider to be part of the prebatholithic complex. The sparsity of tonalite and granodiorite in the Proterozoic $\mathrm{Z}$ batholithic rocks suggests that they were intruded into a sialic continental craton.

After the intrusion of the batholiths, a graben developed in the Boston area accompanied by bimodal volcanism, which formed the Mattapan and Lynn Volcanic Complexes (Zm, DZl) and Brighton Melaphyre ( $\mathrm{ZzZrb})$, and further intrusion of granite, the Westwood (Zwgr). During the early and middle Paleozoic, the MilfordDedham terrane acted as a stable platform intruded by alkaline and peralkaline granite and gabbro under conditions of crustal extension. These intrusions correspond to continental intraplate activity and could be construed as being associated with a failed rift. Following intrusion of Devonian plutons, intrusive activity ceased in eastern Massachusetts although some bimodal volcanism (Pwv) accompanied deposition in the Narragansett basin in the Pennsylvanian. However, Permian granite was intruded in southern Rhode Island and in the Massabesic Gneiss Complex of southern New Hampshire and adjacent Massachusetts following compressive deformation of the Pennsylvanian strata (Mosher, 1983). A high thermal regime (Zartman and others, 1970) and compressive deformation during the Permian may have produced the gneissosity in the Proterozoic $\mathrm{Z}$ rocks of the New Bedford area.

The Nashoba zone shares none of this plutonic history. The peraluminous Andover Granite (SOagr) intruded metamorphosed slope-facies sediments and off-arc volcanic rocks of the Marlboro and Nashoba Formations that are for the most part unlike the rocks of the MilfordDedham zone. The Ordovician, gneissic phase of the Andover, an S-type granite (Chappell and White, 1974), was emplaced at considerable depth, and the Nashoba Formation is at high metamorphic grade. No Proterozoic intrusive rocks are known in the Nashoba zone in eastern Massachusetts. The Silurian intrusive rocks of the Nashoba zone are I-type quartz-diorite to granite and are quite different from the middle Paleozoic alkaline granites of the Milford-Dedham zone. Hill and others (1984) have shown that the Silurian intrusive rocks of the Nashoba zone are isotopically heterogeneous; they interpreted this as indicating that the intrusions developed at a convergent plate boundary and assimilated varying proportions of Proterozoic Z to early Paleozoic crustal rock. There is some evidence, discussed above in this chapter, that the granite and pegmatite that intruded the rocks of the Nashoba zone in Devonian time were peraluminous like the Ordovician gneissic phase of the Andover Granite, suggesting a recurrence of the crustal conditions that produced the earlier granite. The difference in the Paleozoic intrusive rocks in the two zones indicates that they were derived from different crust under different conditions at least until after most of the Devonian and accordingly must have become joined after that time.

The intrusions in the eastern part of the Merrimack belt bear a greater similarity to the intrusions in the Nashoba zone than the intrusions of the Nashoba zone do to those of the Milford-Dedham zone, except that there is no equivalent to the Ordovician peraluminous Andover Granite. The early intrusions, the Newburyport Complex and part of the Ayer Granite, are calc-alkaline. The peraluminous muscovitic granites in the Merrimack belt are Devonian in Massachusetts, although there is some question as to the age of the Chelmsford Granite. Carboniferous peraluminous granite does form plutons in southern Maine and New Hampshire, however (Gaudette and others, 1982; Hayward and Gaudette, 1984). The Devonian granites of the eastern part of the Merrimack belt, such as the Ayer and its equivalent the Canterbury Gneiss of Connecticut, tend to be sheetlike, gneissic, 
and involved in the regional dynamothermal metamorphism; they did not produce recognizable hornfels aureoles in the host rocks. The rocks of the eastern part of the Merrimack belt in Massachusetts were affected by the Acadian metamorphism that predominates in central Massachusetts (Hall and Robinson, 1982). In contrast, the Milford-Dedham zone and most of the Nashoba zone, except possibly the west flank, show no indication of an Acadian dynamothermal metamorphic event. The recently recognized Devonian peraluminous granite and pegmatite associated with the Late Ordovician and Silurian Andover Granite may reflect an Acadian event, however, and suggest that at this time a source for the magmas of the eastern part of the Merrimack belt may have been Nashoba-zone material at depth and at high grade during the Silurian. Later faulting along the Clinton-Newbury fault has separated the Nashoba-type rocks beneath the Merrimack-belt rocks from the rocks now forming the Nashoba zone at the surface.

The age and nature of the intrusive rocks, then, indicate that the eastern part of the Merrimack belt and the Nashoba belt may have been joined together by the end of the Devonian but that the Milford-Dedham zone may not have been accreted to the Nashoba until after the Devonian. Continental crust was the major source for the Paleozoic intrusive rocks of the Milford-Dedham zone, the Nashoba zone, and the east part of the Merrimack belt, but the crust differed in kind and level at different times within and between each zone. The Nashoba and Milford-Dedham zones represented separate crustal blocks, if not microcontinents, early in the Paleozoic-although at one time, elsewhere, they might have been part of a single plate before being split and migrating differentially to arrive at their present positions. We suggest that rocks similar to those in the Nashoba zone are the basement on which the Merrimackbelt rocks were deposited. The Massabesic Gneiss Complex within this belt resembles the rocks of the Nashoba zone. However, if the strata in the east flank of the Merrimack belt are as old as the intrusions indicate, they may be a more basinward facies of Nashoba-zone rock and may represent the dislocated basin-fill of a progenitor basin to the subsequent Silurian and Devonian trough of the Merrimack synclinorium.

The intrusive rocks of Massachusetts have a complex history because they occupy different lithotectonic belts, whose relations have changed through time in response to plate-tectonic processes. The earlier Proterozoic $\mathrm{Z}$ mafic intrusive rocks and the later Proterozoic $\mathrm{Z}$ granitic batholithic rocks of the Milford-Dedham zone are the products of a subduction-related cycle of magma generation. The latest Proterozoic $\mathrm{Z}$ volcanic rocks, such as the Mattapan and Lynn, could be related to a rifting center. The anhydrous peralkaline magmas that formed the
Paleozoic plutons of the Milford-Dedham zone are the result of subsequent heating of crust under the influence of underplating of crust in the subduction process during the Paleozoic.

The Nashoba zone has undergone a more repetitious history, during which there are renewed cycles of activity. The older and younger phases of the Andover Granite were probably formed from magmas generated from added new sedimentary crustal material during the subduction process, whereas the intermediate-in-time Assabet Quartz Diorite, the Sharpners Pond Diorite, and the orange-weathering granite represent a cycle of magmas derived from mantle material.

The origin and source for the calc-alkaline Paleozoic plutons of the eastern part of the Merrimack belt are somewhat more enigmatic, but there seems to be a mafic to felsic trend with time. This is interpreted as meaning that early, predominantly mantle-derived plutons were succeeded by plutons derived from continental crust. The sequence of plutons probably formed near a convergent plate boundary during subduction, although Wones (1984) ascribed the Devonian plutons farther west and north in Vermont, New Hampshire, Massachusetts, central Maine, and coastal Maine to underplating of crustal material. The Carboniferous and late Paleozoic peraluminous intrusions of adjacent New Hampshire may be derived from overridden crust during westward thrusting of material during late Paleozoic plate collision.

\section{REGIONAL RELATIONS}

The Milford-Dedham zone is one of the Appalachian terranes considered to be Avalonian by Williams and Hatcher (1983). It does, however contain much more intrusive rock and much less extensive, and thinner, Proterozoic $\mathrm{Z}$ and Paleozoic supracrustal strata than the Avalonian terrane in Newfoundland. Other Avalonian terranes in the Appalachians have been recognized in New Brunswick and Nova Scotia (Rast and others, 1976b; Skehan and others, 1978; Rast, 1980; Rast and Skehan, 1981) and in the southeastern Piedmont of the United States (St. Jean, 1973; Seiders, 1978).

The intrusive rocks of the Milford-Dedham zone are in some respects similar in lithology, age relations, and setting to those of the Charlotte belt of North Carolina and South Carolina (Goldsmith and others, 1988). In the Charlotte belt of North Carolina, Proterozoic Z calcalkaline plutonic rocks of batholithic dimensions intrude metavolcanic and metasedimentary rocks, which are present as roof pendants, screens, and mantling sequences. These granitoids consist primarily of quartz diorite to granodiorite, with lesser amounts of gabbro and diorite, an assemblage less mafic than the prebath- 
olithic, Proterozoic Z mafic plutonic rocks of the MilfordDedham zone but more mafic than the granitoids of the Dedham batholith and Milford antiform. In the Charlotte belt, discrete plutons of early to middle Paleozoic age include syenite and gabbro, an assemblage found also in the Milford-Dedham zone in Massachusetts. However, other early to mid-Paleozoic granites in the Charlotte belt are not particularly alkaline (Butler and Ragland, 1969; Butler and Fullagar, 1978), in contrast to the early to mid-Paleozoic granites of the Milford-Dedham zone. In addition, the Charlotte belt contains large masses of late Paleozoic muscovite-bearing granite (Speer and others, 1980) not found in the Milford-Dedham zone except in southern Rhode Island. The Paleozoic intrusions in the Charlotte belt of North Carolina are types that are present over a wide area of central and eastern New England and not specifically confined to the MilfordDedham zone. Although the Charlotte belt does not have the Proterozoic $\mathrm{Z}$ and Paleozoic sedimentary basins that are found in the Milford-Dedham zone, Proterozoic $\mathrm{Z}$ to Cambrian rocks, both sedimentary and volcanic, which in many respects are similar to those in and around the Boston basin and which truly correlate with rocks of the Avalon Peninsula, Newfoundland, are present in the adjacent Carolina slate belt.

The intrusive rocks of the Nashoba zone can less clearly be correlated with the intrusive rocks of similar lithotectonic terranes in the Appalachians. As pointed out above, the younger peraluminous intrusive rocks of the Nashoba zone are similar in composition and field relations to intrusive rocks in the Passagassawakeag block in southeastern Maine (Bickel, 1976; Osberg and others, 1984) as described by Stewart and Wones (1974, p. 231) and Kaszuba and Wones (1985); an older synmetamorphic phase, the Winterport Granite (Stewart and Wones, 1974), similar to the gneissic phase of the Andover Granite, is also present. Rocks like the Silurian Sharpners Pond Diorite, however, seem to be absent in this block in Maine. The host rocks are similar, however, in lithology and metamorphic grade to those in the Nashoba zone. The two terranes are not on strike with each other and are inferred to be separate slices or blocks of what once was a single lithotectonic terrane. They apparently did not share all aspects of early Paleozoic intrusive history. Terranes similar to the Nashoba are present in the Maritime Provinces in Canada (Rast and others, 1976a), and some observers (for example, Williams and Hatcher, 1983) have placed the Nashoba zone within the Gander zone as defined in Newfoundland. Similar terranes have not been identified in the southern Appalachians.

The intrusions into the eastern flank of the Merrimack belt in Massachusetts are only in part similar to those in the eastern part of the Merrimack belt of Maine. The older Ordovician to Silurian intrusions are not found there, and only Devonian granite forms plutons (Osberg and others, 1984). The synkinematic fabric and sheetlike nature of some of the Devonian intrusions in Massachusetts and Connecticut (Dixon and Pessl, 1966; Snyder, 1967; Pease, 1972; Tucker, 1977; Maczuga, 1981) correspond to the style of emplacement of Devonian plutons in the Merrimack belt farther north in New England (Hayward and Gaudette, 1984), but the metamorphic evidence indicates that the southern plutons were emplaced at a slightly deeper structural level than the northern ones.

\section{REFERENCES CITED}

Barker, Fred, 1979, Trondhjemite: Definition, environment and hypotheses of origin, in Barker, Fred, ed., Trondhjemites, dacites, and related rocks: New York, Elsevier, p. 1-12.

Bateman, P.C., 1983, A summary of critical relations in the central part of the Sierra Nevada batholith, California, U.S.A., in Roddick, J.A., ed., Circum-Pacific plutonic terranes: Geological Society of America Memoir 159, p. 241-254.

Bateman, P.C., and Chappell, B.W., 1979, Crystallization, fractionation and solidification of the Tuolumne Intrusive Series, Yosemite National Park, California: Geological Society of America Bulletin, v. 90 , p. $465-482$.

Bateman, P.C., Clark, L.O., Huber, N.K., Moore, J.G., and Rinehart, C.D., 1963, The Sierra Nevada batholith-A synthesis of recent work across the central part: U.S. Geological Survey Professional Paper 414-D, p. D1-D46.

Bell, K.G., 1976, Pre-Silurian stratified rocks southeast of the Bloody Bluff fault, in New England Intercollegiate Geological Conference, 68th Annual Meeting, Boston, Mass., Oct. 8-10, 1976, Geology of southeastern New England; a guidebook for field trips to the Boston area and vicinity: Princeton, N.J., Science Press, p. 289-290.

1977, Preliminary bedrock geologic maps of the Lynn and Marblehead South quadrangles, Massachusetts: U.S. Geological Survey Open-File Report 77-180, 76 p., 2 pls.

Bell, K.G., Shride, A.F., and Cuppels, N.P., 1977, Preliminary bedrock geologic map of the Georgetown quadrangle, Essex County, Massachusetts: U.S. Geological Survey Open-File Report 77-179, 30 p., 4 pls., scale 1:24,000.

Bickel, C.E., 1976, Stratigraphy of the Belfast quadrangle, Maine, in Page, L.R., ed., Contributions to the stratigraphy of New England: Geological Society of America Memoir 148, p. 97-128.

Billings, M.P., 1976, Bedrock geology of the Boston basin, in New England Intercollegiate Geological Conference, 68th Annual Meeting, Boston, Mass., Oct. 8-10, 1976, Geology of southeastern New England; a guidebook for field trips to the Boston area and vicinity: Princeton, N.J., Science Press, p. 28-45.

1982, Ordovician cauldron subsidence of the Blue Hills Complex, eastern Massachusetts: Geological Society of America Bulletin, v. 93, p. 909-920.

Bothner, W.A., 1974, Gravity study of the Exeter pluton, southeastern New Hampshire: Geological Society of America Bulletin, v. 85, p. $51-56$.

Bothner, W.A., Boudette, E.L., Fagan, T.J., Gaudette, H.E., Laird, Jo, and Olszewski, W.J., 1984, Geologic framework of the Massabesic anticlinorium and the Merrimack trough, southeastern New Hampshire, in New England Intercollegiate Geological Confer- 
ence, 76th Annual Meeting, Danvers, Mass., Oct. 12-14, 1984, Geology of the coastal lowlands, Boston to Kennebunk, Maine: Salem, Mass., Salem State College, Department of Geological Sciences, p. 186-206.

Bottino, M.L., Fullagar, P.D., Fairbairn, H.W., Pinson, W.H., Jr., and Hurley, P.M., 1970, The Blue Hills igneous complex, Massachusetts: Geological Society of America Bulletin, v. 81, p. 3739-3746.

Bouchard, Robert, 1979, The stratigraphy and petrography of the Brighton Volcanics in the Boston basin, Massachusetts: Chestnut Hill, Mass., Boston College, Ph.D. thesis, 165 p.

Brown, G.C., Thorpe, R.S., and Webb, P.C., 1984, The geochemical characteristics of granitoids in contrasting ares and comments on magma sources: Journal of the Geological Society, v. 141, pt. 3, p. $413-426$.

Buma, Grant, Frey, F.A., and Wones, D.R., 1971, New England granites: Trace element evidence regarding their origin and differentiation: Contributions to Mineralogy and Petrology, v. 31, no. 4, p. $300-320$

Butler, J.R., and Fullagar, P.D., 1978, Petrochemical and geochronological studies of plutonic rocks in the southern Appalachians, III, Leucocratic adamellites of the Charlotte belt near Salisbury, North Carolina: Geological Society of America Bulletin, v. 89, no. 3, p. 460-466.

Butler, J.R., and Ragland, P.C., 1969, A petrochemical survey of plutonic intrusions in the Piedmont, southeastern Appalachians, U.S.A: Contributions to Mineralogy and Petrology, v. 24, no. 2, p. 164-190.

Castle, R.O., 1964, Geology of the Andover Granite and surrounding rocks, Massachusetts: U.S. Geological Survey Open-File Report, 550 p., 50 pls., 30 figs., 28 tables.

Cawthorne, R.G., and O'Hara, M.J., 1976, Amphibole fractionation in calcalkaline magma genesis: American Journal of Science, v. 276 p. 309-329.

Chappell, B.W., and White, A.J.R., 1974, Two contrasting granite types: Pacific Geology, v. 8, p. 173-174.

Chayes, Felix, 1952, The finer-grained calcalkaline granites of New England: Journal of Geology, v. 60, no. 3, p. 207-254.

Chute, N.E., 1950, Bedrock geology of the Brockton quadrangle, Massachusetts: U.S. Geological Survey Geologic Quadrangle Map GQ-5, scale 1:31,680.

-1965a, Geologic map of the Duxbury quadrangle, Plymouth County, Massachusetts: U.S. Geological Survey Geologic Quadrangle Map GQ-466, scale 1:24,000.

- 1965b, Geologic map of the Scituate quadrangle, Plymouth County, Massachusetts: U.S. Geological Survey Geologic Quadrangle Map GQ-467, scale 1:24,000.

- 1966, Geology of the Norwood quadrangle, Norfolk and Suffolk Counties, Massachusetts: U.S. Geological Survey Bulletin 1163-B, $78 \mathrm{p}$.

1969, Bedrock geologic map of the Blue Hills quadrangle, Norfolk, Suffolk, and Plymouth Counties, Massachusetts: U.S Geological Survey Geologic Quadrangle Map GQ-796, scale $1: 24,000$.

Crosby, W.0., 1913, Genetic and structural relations of the igneous rocks of the lower Neponset Valley, Massachusetts: American Geology, v. 36, p. 34-47, 69-83.

Czamanske, G.K., Ishihara, Shunso, and Atkin, S.A., 1981, Chemistry of rock-forming minerals of the Cretaceous-Paleocene batholith in southwestern Japan and implications for magma genesis: Journal of Geophysical Research, v. 86, p. 10431-10469.

Dale, T.N., 1923, The commercial granites of New England: U.S. Geological Survey Bulletin 738, 488 p.

Day, H.W., Brown, V.M., and Abraham, Kurt, 1980, Precambrian(?) crystallization and Permian(?) metamorphism of hypersolvus gran- ite in the Avalonian terrane of Rhode Island: Geological Society of America Bulletin, pt. II, v. 91, p. 1669-1741.

Dennen, W.H., 1943, A nickel deposit near Dracut, Massachusetts: Economic Geology, v. 38, p. 25-55.

1975, Preliminary bedrock geologic map of the Ipswich quadrangle, Massachusetts: U.S. Geological Survey Open-File Report 75-544, 26 p., 2 pls., scale 1:24,000.

1981, Bedrock geology of the Cape Ann area, Massachusetts: U.S. Nuclear Regulatory Commission, Document NUREG/ CR0881, 83 p.

Dixon, H.R., and Pessl, Fred, Jr., 1966, Geologic map of the Hampton quadrangle, Windham County, Connecticut: U.S. Geological Survey Geologic Quadrangle Map GQ-468, scale 1:24,000.

Dowse, A.M., 1949, Geology of the Medfield-Holliston area, Massachusetts: Cambridge, Mass., Radcliffe College, Ph.D. thesis, $125 \mathrm{p}$.

Emerson, B.K., 1917, Geology of Massachusetts and Rhode Island: U.S. Geological Survey Bulletin 597, 289 p.

Feininger, Tomas, 1963, Westerly Granite and related rocks of the Westerly-Bradford area, in New England Intercollegiate Geological Conference, 55th Annual Meeting, Providence, R.I., Oct. 4-6, 1963, Guidebook: Providence, R.I., Brown University, Department of Geology, p. 48-52.

Frey, F.A., Chappell, B.W., and Roy, S.D., 1978, Fractionation of rare-earth elements in the Tuolumne Intrusive Series, Sierra Nevada batholith, California: Geology, v. 6, p. 239-242.

Galloway, W.B., 1973, The Rb-Sr whole rock age of the Bulgarmarsh Granite, Rhode Island, and its geologic implications: Providence, R.I., Brown University, M.S. thesis, $23 \mathrm{p}$.

Gaudette, H.E., Bothner, W.A., Laird, Jo, Olszewski, W.J., Jr., and Cheatham, M.M., 1984, Late Precambrian/early Paleozoic deformation and metamorphism in southeastern New Hampshire-Confirmation of an exotic terrane [abs.]: Geological Society of America Abstracts with Programs, v. 16, no. 6, p. 516.

Gaudette, H.E., Kovach, Adam, and Hussey, A.M., II, 1982, Ages of some intrusive rocks of southwestern Maine, U.S.A.: Canadian Journal of Earth Sciences, v. 19, p. 1350-1357.

Goldsmith, Richard, 1985, Bedrock geologic map of the Old Mystic and part of the Mystic quadrangles, Connecticut, New York, and Rhode Island: U.S. Geological Survey Miscellaneous Investigations Map I-1524, scale 1:24,000.

Goldsmith, Richard, Milton, D.F., and Horton, J.W., Jr., 1988, Geologic map of the Charlotte $1^{\circ} \times 2^{\circ}$ quadrangle, North Carolina and South Carolina: U.S. Geological Survey Miscellaneous Investigations Map I-1251-E, scale 1:250,000.

Gore, R.Z., 1976, Ayer crystalline complex of Ayer, Harvard, and Clinton, Massachusetts, in Lyons, P.C., and Brownlow, A.H., eds., Studies in New England geology: Geological Society of America Memoir 146, p. 103-124.

Grew, E.S., and Day, H.W., 1972, Staurolite, kyanite, and sillimanite from the Narragansett basin of Rhode Island: U.S. Geological Survey Professional Paper 800-D, p. D151-D167.

Gromet, L.P., and O'Hara, K.D., 1984, Two distinct late Precambrian terranes within the Avalon zone, southeastern New England, and their late Paleozoic juxtaposition [abs.]: Geological Society of America Abstracts with Programs, v. 16, no. 1, p. 20.

Guy, R.E., 1980, The Dinkey Creek intrusive series, Huntington Lake quadrangle, Fresno County, California: Blacksburg, Va., Virginia Polytechnic Institute and State University, M.S. thesis, 185 p.

Hall, L.M., and Robinson, Peter, 1982, Stratigraphic-tectonic subdivisions of southern New England, in St-Julien, Pierre, and Beland, Jacques, eds., Major structural zones and faults of the northern Appalachians: Geological Association of Canada Special Paper 24, p. $15-41$. 
Hansen, W.R., 1956, Geology and mineral resources of the Hudson and Maynard quadrangles, Massachusetts: U.S. Geological Survey Bulletin 1038, $104 \mathrm{p}$.

Harwood, D.S., and Goldsmith, Richard, 1971, Bedrock geologic map of the Oneco quadrangle, Connecticut and Rhode Island: U.S. Geological Survey Geologic Quadrangle Map GQ-930, scale 1:24,000.

Harwood, D.S., and Zietz, Isidore, 1976, Geologic interpretation of an aeromagnetic map of southern New England: U.S. Geological Survey Geophysical Investigations Map GP-906, scale 1:250,000.

Hatch, N.L., Jr., Zen, E-an, Goldsmith, Richard, Ratcliffe, N.M., Robinson, Peter, Stanley, R.S., and Wones, D.R., 1984, Lithotectonic assemblages as portrayed on the new bedrock geologic map of Massachusetts: American Journal of Science, v. 284, p. 1026-1034.

Hayward, J.A., and Gaudette, H.E., 1984, Carboniferous age of the Sebago and Effingham plutons, Maine and New Hampshire [abs.] Geological Society of America Abstracts with Programs, v. 16, no. 1, p. 22.

Hepburn, J.C., 1978, Preliminary reconnaissance bedrock geologic map of the Shrewsbury quadrangle, Worcester County, Massachusetts: U.S. Geological Survey Open-File Report 78-951, 14 p., 1 pl., scale 1:24,000.

Hepburn, J.C., and DiNitto, R.G., 1978, Preliminary bedrock geologic map of the Marlborough quadrangle, Middlesex and Worcester Counties, Massachusetts: U.S. Geological Survey Open-File Report 78-222, 29 p., 1 pl., scale 1:24,000.

Hepburn, J.C., Hill, Malcolm, and Hon, Rudolph, 1987, The Avalonian and Nashoba terranes, eastern Massachusetts, USA; An overview, in The Avalon terrane of the northern Appalachian orogen, part II: Maritime Sediments and Atlantic Geology, v. 23, p. 1-12.

Hermes, O.D., Ballard, R.D., and Banks, P.O., 1978, Upper Ordovician peralkalic granites from the Gulf of Maine: Geological Society of America Bulletin, v. 89, no. 12, p. 1761-1774.

Hermes, O.D., Gromet, L.P., and Zartman, R.E., 1981, Zircon geochronology and petrology of plutonic rocks in Rhode Island, in New England Intercollegiate Geological Conference, 73d Annual Meeting, Kingston, R.I., Oct. 16-18, 1981, Guidebook to geologic field studies in Rhode Island and adjacent areas: Kingston, R.I., University of Rhode Island, Department of Geology, p. 315-338.

Hermes, O.D., and Zartman, R.E., 1985, Late Proterozoic and Devonian plutonic terrane within the Avalon zone of Rhode Island: Geological Society of America Bulletin, v. 96, p. 272-282.

Hill, M.D., Hepburn, J.C., Collins, R.D., and Hon, Rudolph, 1984, Igneous rocks of the Nashoba block, eastern Massachusetts, in New England Intercollegiate Geological Conference, 76th Annual Meeting, Danvers, Mass., Oct. 12-14, 1984, Geology of the coastal lowlands, Boston to Kennebunk, Maine: Salem, Mass., Salem State College, Department of Geological Sciences, p. 61-80.

Hussey, A.M., II, 1968, Stratigraphy and structure of southwestern Maine, in Zen, E-an, White, W.S., Hadley, J.B., and Thompson, J.B., Jr., eds., Studies of Appalachian geology-Northern and maritime: New York, Interscience Publishers, p. 291-301.

Kaszuba, J.P., and Wones, D.R., 1985, Early Devonian thrusting in the Penobscot Bay area, Maine [abs.]: Geological Society of America Abstracts with Programs, v. 17, no. 1, p. 27.

Kay, S.M., and Chapple, W.M., 1976, Pre-Pennsylvanian rocks of Aquidneck and Conanicut Islands, Rhode Island, in New England Intercollegiate Geological Conference, 68th Annual Meeting, Boston, Mass., Oct. 8-10, 1976, Geology of southeastern New England; a guidebook for field trips to the Boston area and vicinity: Princeton, N.J., Science Press, p. 428-446.
Kaye, C.A., 1983, Discovery of a late Triassic basin north of Boston, Massachusetts, and some implications as to post-Paleozoic faulting in northeastern Massachusetts: American Journal of Science, v. 283, p. 1060-1079.

Kaye, C.A., and Zartman, R.E., 1980, A late Proterozoic Z to Cambrian age for the stratified rocks of the Boston basin, Massachusetts, in Wones, D.R., ed., The Caledonides in the USA, Proceedings, International Geological Correlation Program Project 27, Caledonide orogen: Virginia Polytechnic Institute and State University Memoir 2, p. 257-261.

Koteff, Carl, and Cotton, J.E., 1962, Preliminary results of recent deep drilling on Cape Cod, Massachusetts: Science, v. 137, no. 3523, p. 34 .

Kovach, Adam, Hurley, P.M., and Fairbairn, H.W., 1977, Rb-Sr whole rock age determinations of the Dedham granodiorite, eastern Massachusetts: American Journal of Science, v. 277, p. 905-912.

LaForge, Laurence, 1932, Geology of the Boston area, Massachusetts: U.S. Geological Survey Bulletin 839, 105 p.

Le Fort, Patrick, 1981, Manaslu Leucogranite: A collision signature of the Himalaya, a model for its genesis and emplacement: Journal of Geophysical Research, v. 86, p. 10545-10568.

Lyons, J.B., Boudette, E.L., and Aleinikoff, J.N., 1982, The Avalonian and Gander zones in central eastern New England, in St-Julien, Pierre, and Beland, Jacques, eds., Major structural zones and faults of the northern Appalachians: Geological Association of Canada Special Paper 24, p. 43-66.

Lyons, P.C., 1969, Bedrock geology of the Mansfield quadrangle, Massachusetts: Boston, Mass., Boston University, Ph.D. thesis, $282 \mathrm{p}$.

-1977, Report on the bedrock of the Narragansett basin, Massachusetts and Rhode Island: U.S. Geological Survey Open-File Report 77-816, 42 p., 24 pls., scale 1:31,250.

Lyons, P.C., and Krueger, H.W., 1976, Petrology, chemistry and age of the Rattlesnake pluton and implications for other alkalic granite plutons of southern New England, in Lyons, P.C., and Brownlow, A.H., eds., Studies in New England geology: Geological Society of America Memoir 146, p. 71-102.

Maczuga, D.E., 1981, The petrology and geochemistry of the Fitchburg Plutonic Complex, central Massachusetts: University of Massachusetts, Department of Geology Contribution No. 36, 128 p.

Martin, R.F., 1977, The association hypersolvus granite-subsolvus granite-"sölvsbergite" at Andrew's Point, Cape Ann, Massachusetts: a case of localized fenitization: American Journal of Science, v. 277 , p. $273-287$.

Marvin, R.F., and Dobson, S.W., 1979, Radiometric ages; compilation B, U.S. Geological Survey: Isochron/West, the Bulletin of Isotopic Geochronology, no. 26, 32 p.

McHone, J.G., 1981, Lamprophyre dikes of New England: Chapel Hill, N.C., University of North Carolina, Ph.D. thesis, 217 p.

Mosher, Sharon, 1983, Kinematic history of the Narragansett basin, Massachusetts and Rhode Island; constraints on late Paleozoic plate reconstructions: Tectonics, v. 2 , no. 4, p. 327-344.

Naylor, R.S., and Sayer, Suzanne, 1976, The Blue Hills Igneous Complex, Boston area, Massachusetts, in New England Intercollegiate Geological Conference, 68th Annual Meeting, Boston, Mass., Oct. 8-10, 1976, Geology of southeastern New England; a guidebook for field trips to the Boston area and vicinity: Princeton, N.J., Science Press, p. 135-146.

Nellis, D.A., and Hellier, N.W., 1976, Geologic relationships of the southern portion of the Boston basin from the Blue Hills eastward, in New England Intercollegiate Geological Conference, 68th Annual Meeting, Boston, Mass., Oct. 8-10, 1976, Geology of southeastern New England; a guidebook for field trips to the Boston area and vicinity: Princeton, N.J., Science Press, p. 147-157. 
Nelson, A.E., 1974, Changes in nomenclature of upper Precambrian to lower Paleozoic(?) formations in the Natick quadrangle, eastern Massachusetts, and their tentative correlations with rocks in Rhode Island and Connecticut: U.S. Geological Survey Bulletin 1395-E, $15 \mathrm{p}$.

1975a, Bedrock geologic map of the Framingham quadrangle, Middlesex and Worcester Counties, Massachusetts: U.S. Geolog ical Survey Geologic Quadrangle Map GQ-1274, scale 1:24,000.

-1975b, Bedrock geologic map of the Natick quadrangle, Middlesex and Norfolk Counties, Massachusetts: U.S. Geological Survey Geologic Quadrangle Map GQ-1208, scale 1:24,000.

Noyes, H.A., Frey, F.A., and Wones, D.R., 1983, A tale of two plutons: geochemical constraints of the history of the Red Lake and Eagle Peak plutons, central Sierra Nevada, California: Journal of Geology, v. 91 , p. 353-380.

O'Connor, J.T., 1965, A classification of quartz-rich igneous rocks based on feldspar ratios: U.S. Geological Survey Professional Paper 525-B, p. B79-B84.

O'Hara, K.D., and Gromet, L.P., 1984, Identification, characterization, and age of a ductile shear zone separating two late Precambrian terranes, southeastern New England [abs.]: Geological Society of America Abstracts with Programs, v. 16, no. 1, p. 54.

1985, Two distinct late Precambrian (Avalonian) terranes in southeastern New England and their late Paleozoic juxtaposition: American Journal of Science, v. 285, p. 673-709.

Oldale, R.N., and Tuttle, C.R., 1964, Seismic investigations on Cape Cod, Massachusetts: U.S. Geological Survey Professional Paper 475-D, p. D118-D122.

1965, Seismic investigations in the Harwich and Dennis quadrangles, Cape Cod, Massachusetts: U.S. Geological Survey Professional Paper 525-D, p. D101-D105.

Osberg, P.H., 1978, Synthesis of the geology of the northeastern Appalachians, in Caledonian-Appalachian orogen of the North Atlantic region: Canada Geological Survey Paper 78-13, p. 137-147.

Osberg, P.H., Hussey, A.M., and Boone, G.M., eds., 1984, Bedrock geologic map of Maine: Maine Geological Survey Open File 84-1, scale 1:500,000.

Pease, M.H., Jr., 1972, Geologic map of the Eastford quadrangle, Windham and Tolland Counties, Connecticut: U.S. Geological Survey Geologic Quadrangle Map GQ-1023, scale 1:24,000.

1982, The Bonemill Brook fault in eastern Connecticut, in New England Intercollegiate Geological Conference, 74th Annual Meeting, Storrs, Conn., Oct. 2-3, 1982, Guidebook for field trips in Connecticut and south-central Massachusetts: Connecticut Geological and Natural History Survey Guidebook 5, p. 263-287.

Peck, J.H., 1975, Preliminary bedrock geologic map of the Clinton quadrangle, Worcester County, Massachusetts: U.S. Geological Survey Open-File Report 75-658, 30 p., 3 pls., scale 1:24,000.

Pollock, S.J., 1964, Bedrock geology of the Tiverton quadrangle, Rhode Island-Massachusetts: U.S. Geological Survey Bulletin $1158-\mathrm{D}, 16 \mathrm{p}$.

Quinn, A.W., 1971, Bedrock geology of Rhode Island: U.S. Geological Survey Bulletin 1295, 68 p.

Rast, Nicholas, 1980, The Avalonian plate in the northern Appalachians and Caledonides, in Wones, D.R., ed., The Caledonides in the USA, Proceedings, International Geological Correlation Program Project 27, Caledonide orogen: Virginia Polytechnic Institute and State University, Department of Geological Sciences Memoir 2, p. 63-66.

Rast, Nicholas, Kennedy, M.J., and Blackwood, R.F., 1976a, Comparison of some tectonostratigraphic zones in the Appalachians of Newfoundland and New Brunswick, Canada: Canadian Journal of Earth Sciences, v. 13, p. 868-875.
Rast, Nicholas, O'Brien, B.H., and Wardle, R.J., 1976b, Relationships between Precambrian and lower Paleozoic rocks of the Avalon platform in New Brunswick, the northeast Appalachians and the British Isles: Tectonophysics, v. 30, p. 315-338.

Rast, Nicholas, and Skehan, J.W., 1981, Possible correlation of Precambrian rocks of Newport, Rhode Island with those of Anglesey, Wales: Geology, v. 9, p. 596-601.

Robinson, G.R., Jr., 1978, Bedrock geology of the Pepperell, Shirley, and Townsend quadrangles and part of the Ayer quadrangle, Massachusetts and New Hampshire: U.S. Geological Survey Miscellaneous Field Studies Map MF-957, scale 1:24,000.

Robinson, Peter, and Hall, L.M., 1980, Tectonic synthesis of southern New England, in Wones, D.R., ed., The Caledonides in the USA, Proceedings, International Geological Correlation Program Project 27, Caledonide orogen: Virginia Polytechnic Institute and State University, Department of Geological Sciences Memoir 2, p. $73-82$.

Rodgers, John, 1985, Bedrock geologic map of Connecticut: Hartford, Conn., Connecticut Geological and Natural History Survey, scale $1: 125,000$.

Ross, M.E., 1981, Mafic dikes in northeastern Massachusetts, in New England Intercollegiate Geological Conference, 73d Annual Meeting, Kingston, R.I., Oct. 16-18, 1981, Guidebook to geologic field studies in Rhode Island and adjacent areas: Kingston, R.I., University of Rhode Island, Department of Geology, p. 285-302.

1984, Mafic dikes from Boston to Cape Ann, in New England Intercollegiate Geological Conference, 76th Annual Meeting, Danvers, Mass., Oct. 12-14, 1984, Geology of the coastal lowlands, Boston to Kennebunk, Maine: Salem, Mass., Salem State College, Department of Geological Sciences, p. 81-102.

Rutherford, M.J., and Carroll, M.R., 1981, Igneous rocks of northern Rhode Island, in New England Intercollegiate Geological Conference, 73d Annual Meeting, Oct. 16-18, 1981, Kingston, R.I., Guidebook to geologic field studies in Rhode Island and adjacent areas: Kingston, R.I., University of Rhode Island, Department of Geology, p. 103-124.

Rutherford, M.J., and Hermes, O.D., 1984, Meta-troctoliteanorthositic gabbro complex, Cumberland, Rhode Island; petrology, origin, and regional setting: Geological Society of America Bulletin, v. 95, p. 844-854.

St. Jean, Joseph, 1973, A new Cambrian trilobite from the Piedmont of North Carolina: American Journal of Science, v. 273-A, p. 196-216.

Seiders, V.M., 1978, A chemically bi-modal calc-alkalic suite of volcanic rocks, Carolina volcanic slate belt, central North Carolina: Southeastern Geology, v. 19, p. 241-265.

Shride, A.F., 1971, Igneous rocks of the Seabrook, New HampshireNewbury, Massachusetts, area, Trip B-5, in New England Intercollegiate Geological Conference, 63d Annual Meeting, Concord, N.H., 1971, Guidebook: Durham, N.H., University of New Hampshire, Geology Department, p. 105-117.

1976, Preliminary maps of the bedrock geology of the Newburyport East and Newburyport West quadrangles, Massachusetts-New Hampshire: U.S. Geological Survey Open-File Report 76-488, 4 pls., scale 1:24,000.

Silver, L.T., Taylor, H.P., and Chappell, B.W., 1979, Some petrological, geochemical, and geochronological observations of the Peninsular Ranges batholith near the international border of the USA and Mexico, in Abbott, P.V., ed., Mesozoic crystalline rocks; Peninsular Ranges batholith and pegmatites; Point Sal ophiolite: San Diego, Calif., San Diego State University, p. 83-110.

Skehan, J.W., and Abu-Moustafa, A.A., 1976, Stratigraphic analysis of rocks exposed in the Wachusett-Marlborough tunnel, east-central 
Massachusetts, in Page, L.R., ed., Contributions to the stratigraphy of New England: Geological Society of America Memoir 148, p. $217-240$.

Skehan, J.W., and Murray, D.P., 1980, Geologic profile across southeastern New England: Tectonophysics, v. 69, p. 285-319.

Skehan, J.W., Murray, D.P., Palmer, A.R., Smith, A.T., and Belt, E.S., 1978, Significance of fossiliferous Middle Cambrian rocks of Rhode Island to the history of the Avalonian microcontinent: Geology, v. 6, p. 694-698.

Smith, B.M., 1978, The geology and Rb-Sr whole-rock age of granitic rock of Aquidneck and Conanicut Islands, Rhode Island: Providence, R.I., Brown University, M.S. thesis, 94 p.

Snyder, George, 1967, Bedrock geologic map of the Columbia quadrangle, east-central Connecticut: U.S. Geological Survey Geologic Quadrangle Map GQ-592, scale 1:24,000.

Speer, J.A., Becker, S.W., and Farrar, S.S., 1980, Field relations and petrology of the postmetamorphic, coarse-grained granitoids and associated rocks of the southern Appalachian Piedmont, in Wones, D.R., ed., The Caledonides in the U.S.A., Proceedings, International Geological Correlation Program Project 27, the Caledonide orogen: Virginia Polytechnic Institute and State University, Department of Geological Sciences Memoir 2, p. 137-148.

Stewart, D.B., and Wones, D.R., 1974, Bedrock geology of the northern Penobscot Bay area, in New England Intercollegiate Geological Conference, 66th Annual Meeting, Orono, Maine, Oct. 12-13, 1974, Geology of east-central and north-central Maine: Orono, Maine, University of Maine, p. 223-239.

Streckeisen, A.W., chairman, 1973, Plutonic rocks: Classification and nomenclature recommended by the IUGS Subcommission on the Systematics of Igneous Rocks: Geotimes, v. 18, no. 10, p. 26-30.

Toulmin, Priestley, III, 1964, Bedrock geology of the Salem quadrangle and vicinity, Massachusetts: U.S. Geological Survey Bulletin 1163-A, $79 \mathrm{p}$.

Tucker, R.D., 1977, Bedrock geology of the Barre area, central Massachusetts: University of Massachusetts, Department of Geology Contribution No. 30, $132 \mathrm{p}$.

Tuttle, O.F., and Bowen, N.L., 1958, Origin of granite in the light of experimental studies in the system $\mathrm{NaAlSi}_{3} \mathrm{O}_{8}-\mathrm{KAlSi}_{3} \mathrm{O}_{8}-\mathrm{SiO}_{2}$ $\mathrm{H}_{2} \mathrm{O}$ : Geological Society of America Memoir 74, $153 \mathrm{p}$.

Volckmann, R.P., 1977, Bedrock geologic map of the Holliston and Medfield quadrangles, Middlesex, Norfolk, and Worcester Counties, Massachusetts: U.S. Geological Survey Miscellaneous Investigations Map I-1053, scale 1:48,000.

Warren, C.H., 1913, Petrology of the alkali granites and porphyries of Quincy and the Blue Hills, Massachusetts: American Academy of Arts Proceedings 49, p. 203-331.

Warren, C.H., and Powers, Sidney, 1914, Geology of the Diamond Hill-Cumberland district in Rhode Island-Massachusetts: Geological Society of America Bulletin, v. 25, p. 435-476.

Watson, E.B., 1979, Zircon saturation in felsic liquids: experimental results and applications to trace element geochemistry: Contributions to Mineralogy and Petrology, v. 70, p. 407-419.

Williams, Harold, and Hatcher, R.D., Jr., 1983, Appalachian suspect terranes, in Hatcher, R.D., Jr., Williams, Harold, and Zietz,
Isidore, eds., Contributions to the tectonics and geophysics of mountain chains: Geological Society of America Memoir 158, p. 33-53.

Williams, J.R., and Willey, R.E., 1973, Bedrock topography and texture of unconsolidated deposits, Taunton River Basin, southeastern Massachusetts: U.S. Geological Survey Miscellaneous Investigations Map I-742, scale 1:48,000.

Wones, D.R., 1974, Igneous petrology of some plutons in the northern part of the Penobscot Bay area, in New England Intercollegiate Geological Conference, 66th Annual Meeting, Orono, Maine, Oct. 12-13, 1974, Geology of east-central and north-central Maine: Orono, Maine, University of Maine, p. 99-125.

1976, Granitic intrusives of the Penobscot Bay region, Maine, and their structural settings, in Pajari, G.E., Jr., ed., Field guide to the geology and plutonic rocks of southwestern New Brunswick and the Penobscot Bay area of Maine, IGCP Canadian Plutonics group, Project Caledonide Orogen: Frederickton, New Brunswick, University of New Brunswick, Department of Geology, v. 1, p. $39-69$.

1984, Plutonic sequences in orogenic zones; the New England collage [abs.]: Geological Society of America Abstracts with Programs, v. 16 , no. 6 , p. 699-700.

1985, Plutonic evidence for a major Carboniferous thrust in western Maine and eastern New Hampshire [abs.]: Geological Society of America Abstracts with Programs, v. 17, no. 1, p. 70.

Wones, D.R., Kostick, D.S., and Goldsmith, Richard, 1986, Table of major constituents, in percent, determined by point-count of stained slabs of intrusive rocks of the Milford-Dedham zone, eastern Massachusetts, and locality map of samples: U.S. Geological Survey Open-File Report 86-215, 4 p., 1 pl., scale 1:250,000.

Zarrow, L., 1978, Structural relationships and geochemical investigations of Lynn volcanic complex, Pine Hill, Boston North quadrangle, Massachusetts: Cambridge, Mass., Massachusetts Institute of Technology, M.S. thesis, $184 \mathrm{p}$.

Zartman, R.E., 1977, Geochronology of some alkalic rock provinces in eastern and central United States: Annual Reviews of Earth and Planetary Science, v. 5, p. 257-286.

Zartman, R.E., and Hermes, O.D., 1984, Evidence from inherited zircon for Archean basement under the southeastern New England Avalon terrane [abs.]: Geological Society of America Abstracts with Programs, v. 16 , no. 6, p. 704 .

Zartman, R.E., Hurley, P.M., Krueger, H.W., and Giletti, B.J., 1970 , A Permian disturbance of $\mathrm{K}$-Ar radiometric ages of igneous rocks in New England; its occurrence and cause: Geological Society of America Bulletin, v. 81, p. 3359-3374.

Zartman, R.E., and Naylor, R.S., 1984, Structural implications of some radiometric ages of igneous rocks in southeastern New England: Geological Society of America Bulletin, v. 95, p. 522-539.

Zen, E-an, 1983, Exotic terranes in the New England AppalachiansLimits, candidates and ages: A speculative essay, in Hatcher, R.D., Jr., Williams, Harold, and Zietz, Isidore, eds., Contributions to the tectonics and geophysics of mountain chains: Geological Society of America Memoir 158, p. 55-82.

Zen, E-an, editor, and Goldsmith, Richard, Ratcliffe, N.M., Robinson, Peter, and Stanley, R.S., compilers, 1983, Bedrock geologic map of Massachusetts: Reston, Va., U.S. Geological Survey, 3 sheets, scale 1:250,000. 



\section{Radiometric Ages of Rocks in Massachusetts}

By ROBERT E. ZARTMAN and RICHARD F. MARVIN

THE BEDROCK GEOLOGY OF MASSACHUSETTS

U.S. GEOLOGIGAL SURVEY PROFESSIONAL PAPER 1366-J 



\section{CONTENTS}

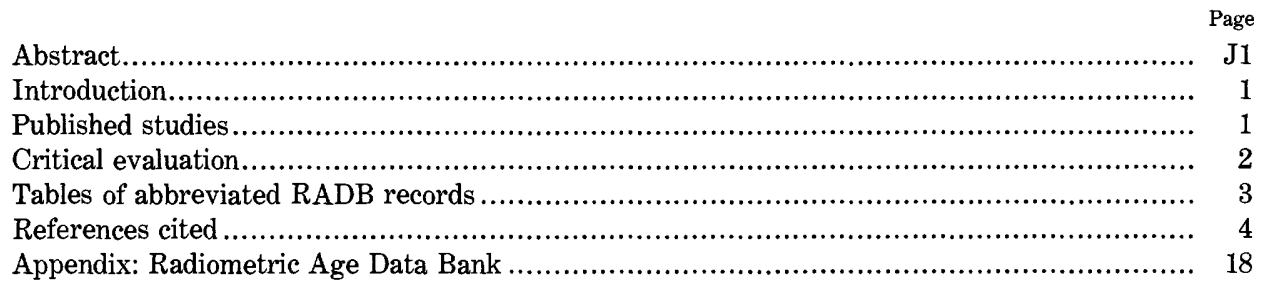

\section{ILLUSTRATION}

FIGURE 1. Map of Massachusetts showing locations of radiometrically dated samples .......

Ficure 1. Map of Massachusetts showing locations of radiometrical

\section{TABLES}

[Tables follow References Cited]

TABLE 1. Published K-Ar, Rb-Sr, and zircon U-Pb ages of rocks from Massachusetts.......... J6

2. Published zircon $\mathrm{Pb}$-alpha and apatite fission-track ages of rocks from 

THE BEDROCK GEOLOGY OF MASSACHUSETTS

\title{
RADIOMETRIC AGES OF ROCKS IN MASSACHUSETTS
}

\author{
By Robert E. Zartman and Richard F. Marvin
}

\begin{abstract}
In this chapter, $\mathrm{K}-\mathrm{Ar}, \mathrm{Rb}-\mathrm{Sr}, \mathrm{U}-\mathrm{Pb}, \mathrm{Pb}$-alpha, and fission-track analyses published through 1986 are tabulated and critically evaluated for use in assigning geologic ages to the rock units of Massachusetts. The compilation was facilitated by the use of the U.S. Geological Survey's Radiometric Age Data Bank (RADB), a computer-based data storage and retrieval system for geochronological information. Approximately 400 individual radiometric ages are contained herein in a synoptic table derived from the RADB. Each entry is identified according to lithotectonic zone, town or village, latitude and longitude, rock unit, analyzed mineral(s), method of dating, an interpretive coding, and reference.

A complete RADB record is described in the appendix, which illustrates how the various information fields are arranged and can be interrogated. A printout of all RADB records for Massachusetts is available as U.S. Geological Survey Open-File Report 87-170.
\end{abstract}

\section{INTRODUCTION}

Geologic interpretation requires that stratigraphic units and structural elements be placed into a time framework of sufficient accuracy to resolve the sequence of events affecting the rocks. Age assignments are made both in a relative sense, by determining the order of interrelated features, and in an absolute sense, by paleontologic and radiometric dating. In a State as geologically complex as Massachusetts, many problems arise when we attempt to construct such a time framework. Long-range correlation with fossil localities has sometimes been made over distances of hundreds of kilometers, even where mapping is inadequate and stratigraphic continuity is, at best, uncertain. The juxtaposing of distinct tectonic blocks across major faults further inhibits the extrapolation of meager stratigraphic control. Indeed, entire rock sequences are now known to abruptly terminate at such boundaries.

The purpose of this chapter is to provide a general documentation for the radiometric ages from Massachu-

Manuscript approved for publication November 16, 1987. setts that bear on the time framework of primary stratigraphic units and superimposed metamorphic fabrics. To this end, a tabulation (table 1) has been made of all published ages that were used for compilation of the State bedrock map (Zen and others, 1983). This table thus serves as (1) an abbreviated summary of the radiometric ages and (2) a link to the original literature. The specific application of these data in establishing a relative and absolute chronology within each compilation area is incorporated into the appropriate chapters elsewhere in this professional paper.

Although modern isotopic geochronology spans barely three decades, a vast body of analytical data has already accumulated. To take proper advantage of the radiometric ages pertinent to this study, it was necessary to catalogue the published literature bearing on the isotopic dating in Massachusetts and to critically evaluate these data. Particular attention was given to providing time control on the primary stratigraphic ages of rock units and to recognizing patterns of metamorphic overprinting that are recorded by disturbed or recrystallized mineral systems. A comprehensive treatment of the rock chronology, of course, cannot be carried out independent of firm paleontologic and stratigraphic correlations, and the age assignments accompanying the geologic map represent an attempt to accommodate all evidence. Generally, if the responses of the various dating methods, the regional pattern of metamorphic overprinting, and other geologic constraints are carefully examined, even very complex isotopic systematics can contribute important age control.

\section{PUBLISHED STUDIES}

Approximately 400 individual radiometric ages have been reported in the literature for rocks of Massachusetts. As of the end of 1986, these data included 140 $\mathrm{K}-\mathrm{Ar}, 174 \mathrm{Rb}-\mathrm{Sr}, 49 \mathrm{U}-\mathrm{Pb}, 32 \mathrm{~Pb}$-alpha, and 4 fissiontrack analyses determined on 300 separate samples. A 


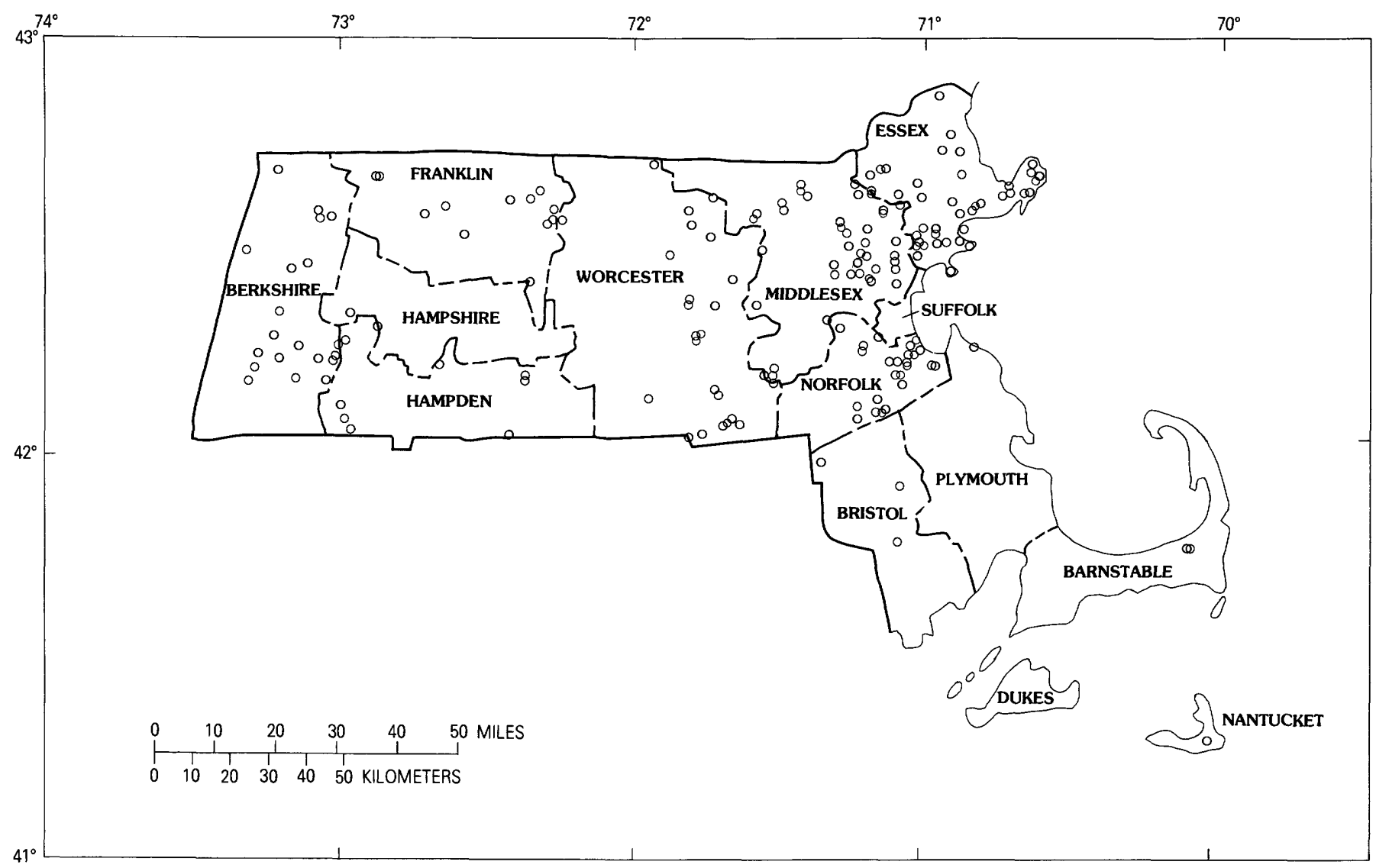

FIGURE 1.-Locations of radiometrically dated samples, Massachusetts.

similar number of ages from adjacent States also bear directly on a regional time framework; they were evaluated during compilation of the map, but only Massachusetts localities are contained in the tabulation of this chapter. Taken at face value, the radiometric ages are a complex mixture of chronometric systems, some yielding the time of primary deposition of strata or emplacement of plutons, others recording various episodes of metamorphic overprinting, and a substantial number providing ambiguous or minimally useful information. They represent the measurements of many different rock types, tectonic environments, and grades of metamorphism found within this statewide transect of the Appalachian orogen (fig. 1). Only after careful evaluation of interrelated sets of data, often containing apparent contradictions, could we hope to construct a significantly precise chronology of events. Although this goal has certainly not yet everywhere been reached, many revised or confirmed age assignments incorporated into the new State map arise either entirely or in large part from modern radiometric dating.

Some years ago it was realized that the manual recovery of all data bearing on a specific age assignment was becoming increasingly difficult because of the rapidly growing quantity of radiometric age information. The ever-expanding literature on the subject, which includes easily overlooked articles in obscure publications and geochronologic data buried in broader studies, demanded that abstracted records of radiometric ages be systematically stored by a computer for more ready identification and retrieval. The Radiometric Age Data Bank (RADB) was established by the U.S. Geological Survey (Zartman and others, 1976) to fulfill this objective. Its application in compiling the pertinent information for the geologic map of Massachusetts represents the first attempt to use the RADB on a comprehensive statewide basis. Additional information about the RADB is given in an appendix to this chapter, in which a record, the basic unit of the data storage and retrieval system, is described in some detail. Tables 1 and 2 have been abstracted and compiled from the inventory of all Massachusetts records. A printout of all RADB records for Massachusetts was prepared by Zartman and Marvin (1987).

\section{CRITICAL EVALUATION}

If the observed parent and daughter isotopic contents of a whole-rock or mineral sample were determined 
solely by radioactive transformation subsequent to its formation, a calculated "age" would always relate straightforwardly to the origin of that rock or mineral. However, because physicochemical conditions also influence the behavior of these isotopic species, some amount of interpretation is usually necessary in order to translate calculated "ages" into a meaningful time framework. Although for a rock having a simple history, such as a rapidly cooled granitic rock that encounters no subsequent metamorphism after its initial crystallization, all the radiogenic systems would ideally yield the correct crystallization age, this situation rarely prevails for the rocks of a polymetamorphic terrane. In fact, many of the geochronologic studies in southern New England make sense only after one recognizes the different responses to subsequent metamorphism of isotopes used in the various dating methods. Success in deciphering the complex age patterns found even within a single rock unit relies heavily on an understanding of both the relative stability of the radiogenic systems during later thermal and hydrothermal events and the constraints placed on each sample by the local and regional geologic setting.

What, then, are the distorting factors that can cause a calculated "age" of, say, an igneous rock to deviate from the true age of crystallization? Basically, two types of problem may beset any radiometric system: (1) the initial presence of daughter isotopes in the crystallizing rock or mineral and (2) movement of parent or daughter isotopes into or out of the rock or mineral after its original crystallization. Examples of the former are radiogenic argon trapped into a newly forming pyroxene and an overgrowth of zircon nucleating on an inherited core of the same mineral. Examples of the latter are the diffusive loss of radiogenic argon from a biotite during thermal metamorphism and the metasomatic removal of radiogenic strontium from a retrogressively altered rock. All of these complicating processes were operative, at least locally, during the geologic development of Massachusetts and have affected the radiometric systems to varying degrees. It is not surprising, therefore, that early attempts to establish the ages of rocks were sometimes unsuccessful because neither the stratigraphic and structural complexities nor the vagaries of the chronometers were fully appreciated. Only as modern field mapping revealed the true nature of the geology and as the stability ranges of the various dating methods were determined have studies been designed to produce a time framework of necessary accuracy.

Particularly valuable for deciphering the temporal relations within orogenic terranes, such as the Appalachians, is the intercomparison of "ages" obtained from several radiometric systems with quite different responses to superimposed physicochemical conditions. Although it has proven difficult to quantify precisely the temperature, pressure, and chemical environment necessary to reset a given radiometric system, a relative ranking and semiquantitative calibration for each system have evolved from field and laboratory attempts to determine the activation energies associated with diffusion and recrystallization. In practice, however, there are rarely enough geochronologic data to permit a thorough intercomparison of radiometric systems involving numerous dating methods and many sample localities for a rock unit. Rather, the recognition of isotopic age patterns has often been haphazard. The synthesis of a number of separate studies may be required to sort out the effects of primary crystallization and later metamorphic overprintings. Eventually, the accumulating body of data allows one to identify and delineate areas in which, say, all K-Ar analyses of biotite give a Permian thermal event age even for host rocks formed at a much earlier time. Likewise, certain granitic rocks may contain ancient inherited zircon in addition to newly crystallizing zircon where magmas have penetrated a considerably older sialic basement. When brought to light, these patterns not only contribute to an increased understanding of the time dimension of geologic processes but also provide information about the physical and chemical conditions surrounding these processes.

\section{TABLES OF ABBREVIATED RADB RECORDS}

All pertinent radiometric age data for rock units of Massachusetts and relevant parts of adjacent States were reviewed in conjunction with the preparation of the State bedrock map. A judgment based on this information together with paleontologic and stratigraphic evidence has resulted in the age assignments appearing on the map and in this report. Documenting this effort are two tables giving the abbreviated RADB records of $\mathrm{K}-\mathrm{Ar}, \mathrm{Rb}-\mathrm{Sr}$, and $\mathrm{U}-\mathrm{Pb}$ ages (table 1 ) and $\mathrm{Pb}$-alpha and fission-track ages (table 2) for the Massachusetts localities.

The records in each table are arranged by increasing geologic age within lithotectonic zones (Hatch and others, 1984) in a west-to-east progression across the State. Record locality is identified geographically by town or village, latitude, and longitude. Rock units are named according to the terminology of the State bedrock map, which may be revised from the original author's usage. Map symbols of rock units are also included except where the dated rock is not given map status (for example, pegmatite, dike, and minor intrusion). Each record contains one or more radiometric ages listed under the appropriate dating method by mineral analyzed, numerical value and uncertainty of calculated or interpreted age, and an explanatory symbol. This latter explanatory symbol serves the very important function of providing 
some critical evaluation of the radiometric age data. Generally, the critical evaluation was made by the original authors, but sometimes subsequent information available at the time that the RADB record was being compiled has resulted in a reevaluated interpretation. Accordingly, one can recognize at a glance those ages that closely constrain the primary stratigraphic time framework or that record some superimposed disturbing event.

The $\mathrm{Pb}$-alpha ages in table 2 are not well defined analytically or geologically, and they are presented here mainly for historical purposes and completeness of the compilation. The four fission-track ages in table 2 record times of final uplift and cooling-when the terrane experienced broad upwarping long after igneous and metamorphic activity of the Paleozoic orogenies had ceased.

The last column of tables 1 and 2 gives reference to the publication from which the RADB record was compiled. The reader should go to this primary literature for more information about the dated sample and for a detailed explanation of its geologic interpretation.

\section{REFERENCES CITED}

Hatch, N.L., Jr., Zen, E-an, Goldsmith, Richard, Ratcliffe, N.M., Robinson, Peter, Stanley, R.S., and Wones, D.R., 1984, Lithotectonic assemblages as portrayed on the new bedrock geologic map of Massachusetts: American Journal of Science, v. 284, p. 1026-1034.

Steiger, R.H., and Jäger, E., 1977, Convention on the use of decay constants in geo- and cosmochronology: Earth and Planetary Science Letters, v. 36, p. 359-362.

Zartman, R.E., Cole, J.C., and Marvin, R.F., 1976, User's guide to the Radiometric Age Data Bank (RADB): U.S. Geological Survey Open-File Report 76-674, $77 \mathrm{p}$.

Zartman, R.E., and Marvin, R.F., 1987, Radiometric ages on file in the Radiometric Age Data Bank (RADB) of rocks from Massachusetts: U.S. Geological Survey Open-File Report 87-170, 421 p.

Zen, E-an, editor, and Goldsmith, Richard, Ratcliffe, N.M., Robinson, Peter, and Stanley, R.S., compilers, 1983, Bedrock geologic map of Massachusetts: Reston, Va., U.S. Geological Survey, 3 sheets, scale $1: 250,000$. 
TABLES 1 AND 2 AND APPENDIX 


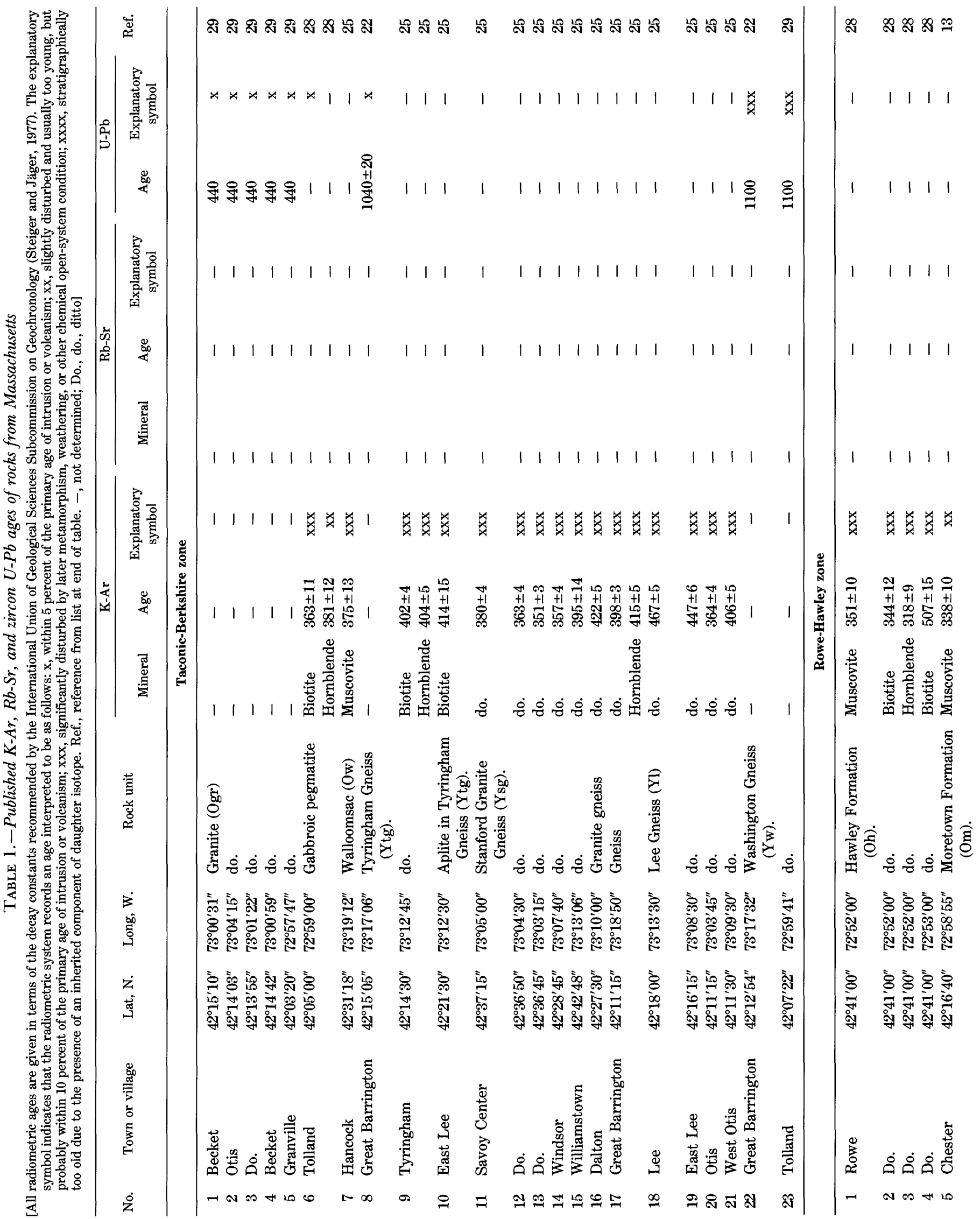


RADIOMETRIC AGES OF ROCKS IN MASSACHUSETTS

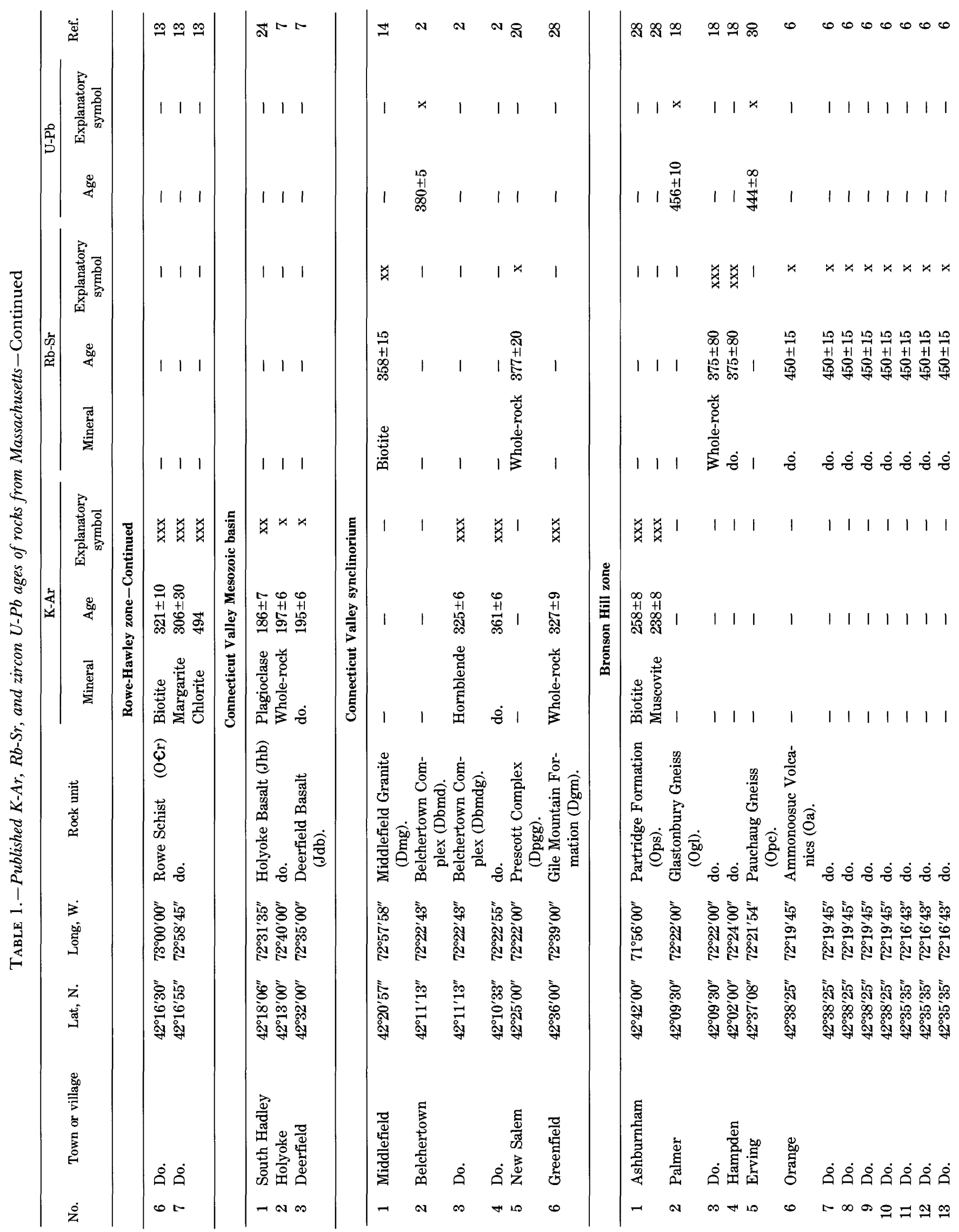


THE BEDROCK GEOLOGY OF MASSACHUSETTS

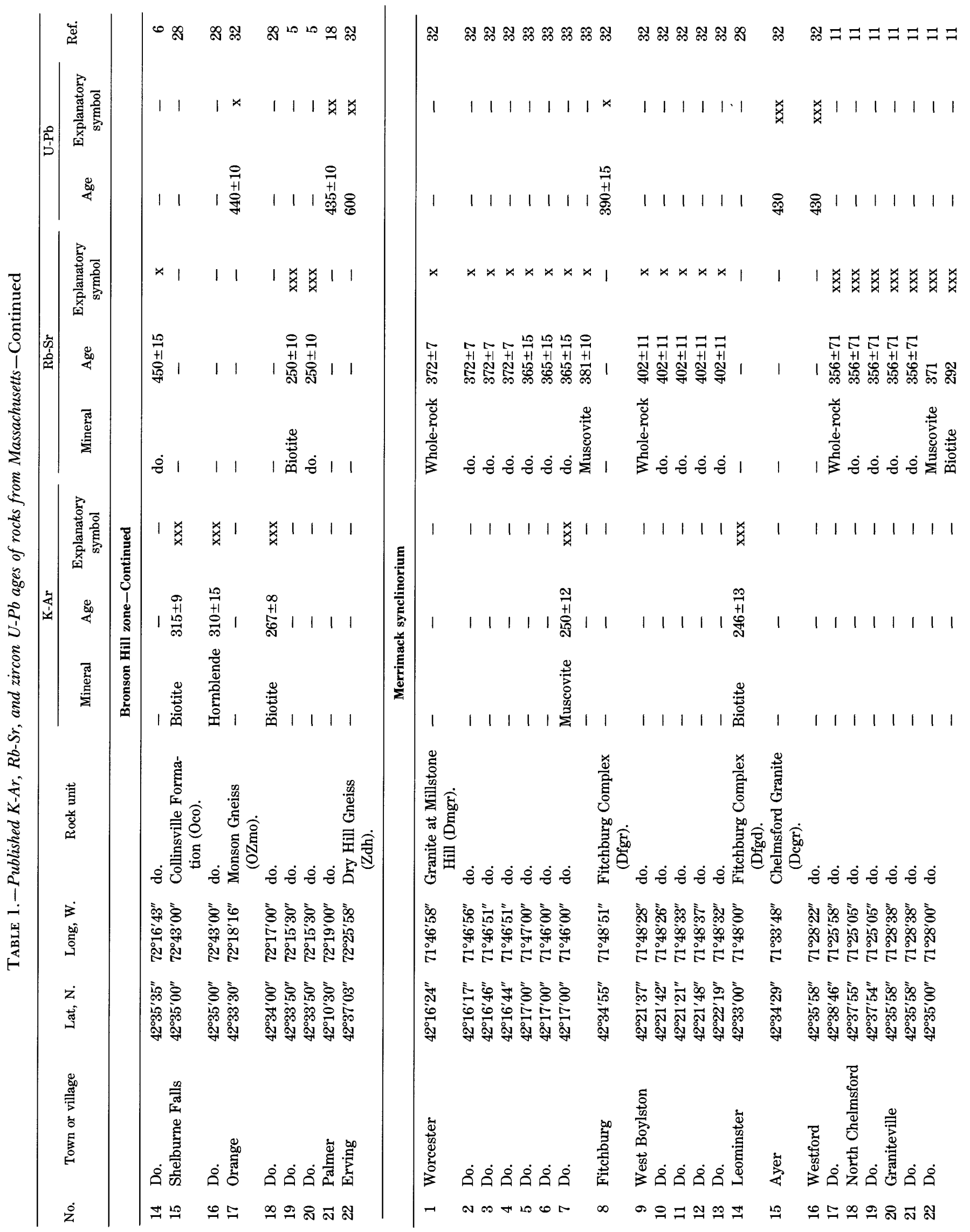




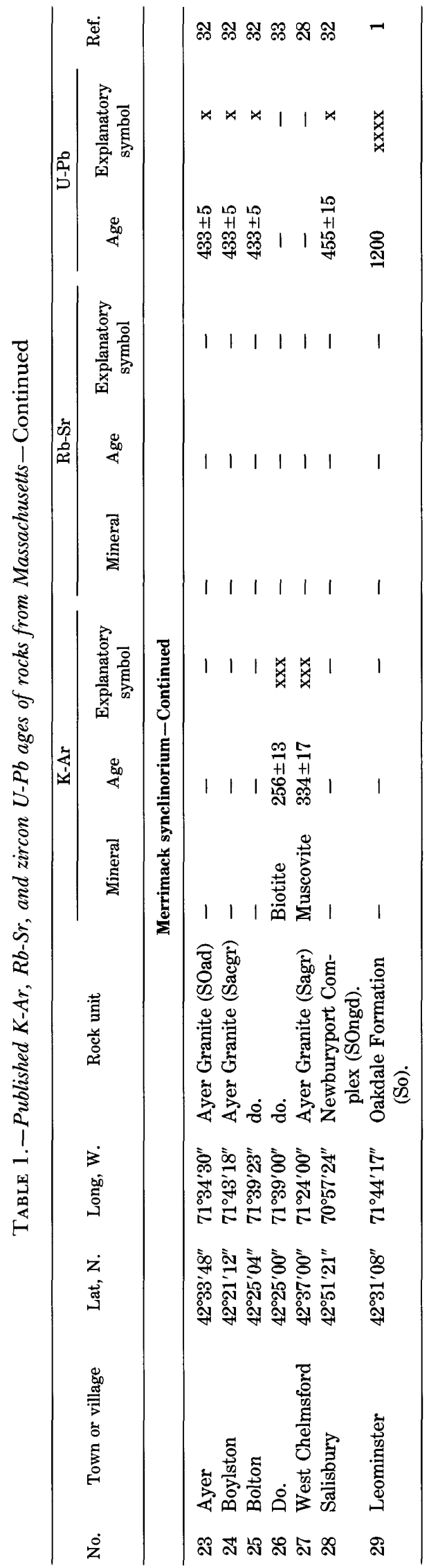

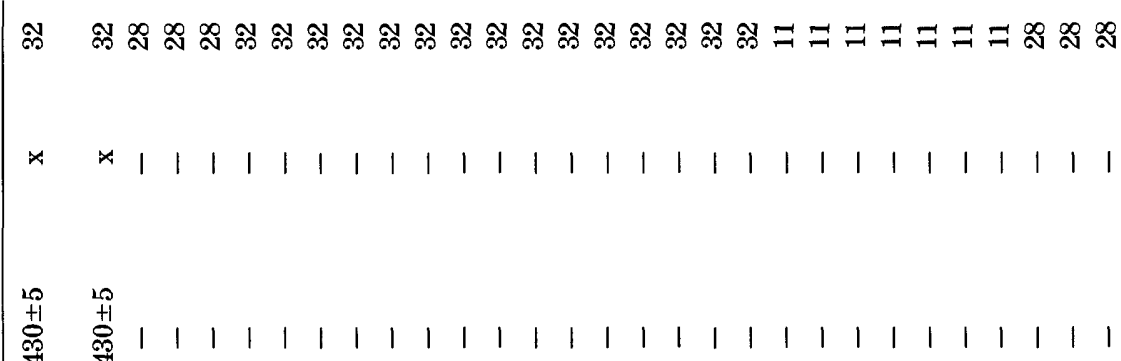

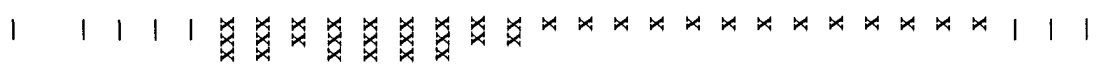

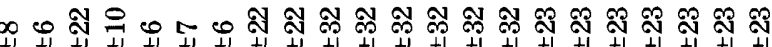

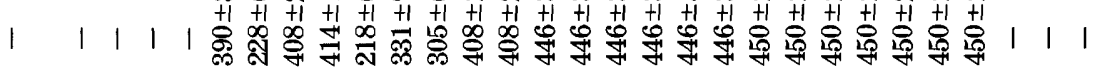

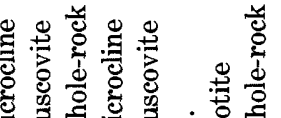

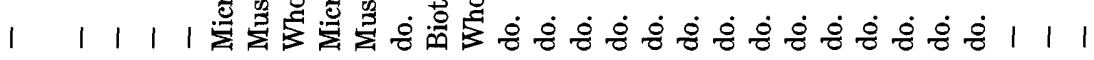

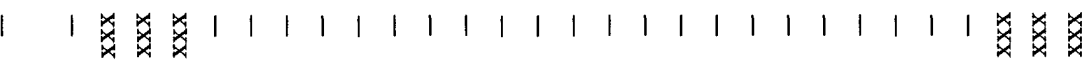

.

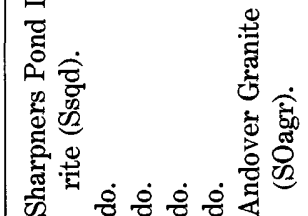

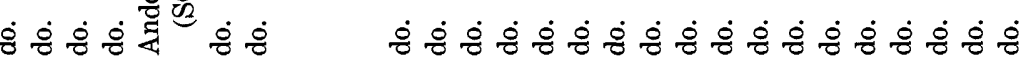

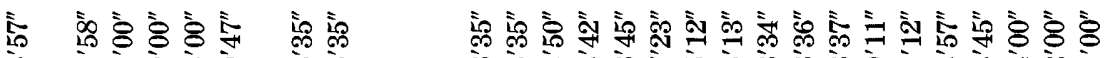

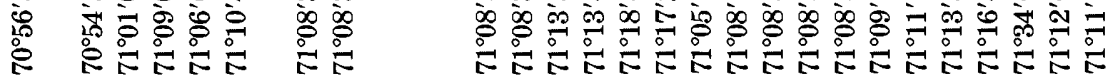
音 密

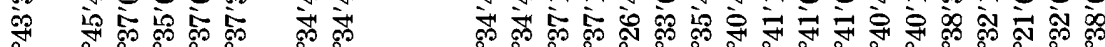

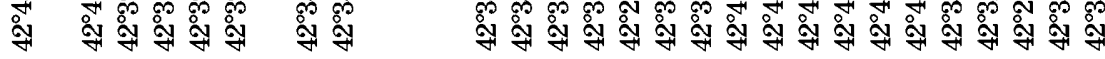
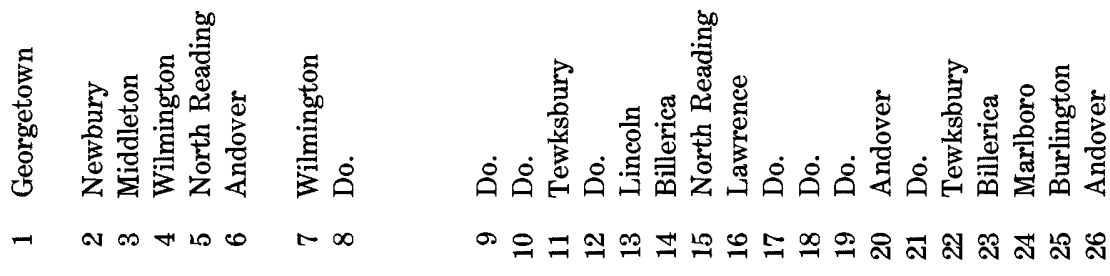


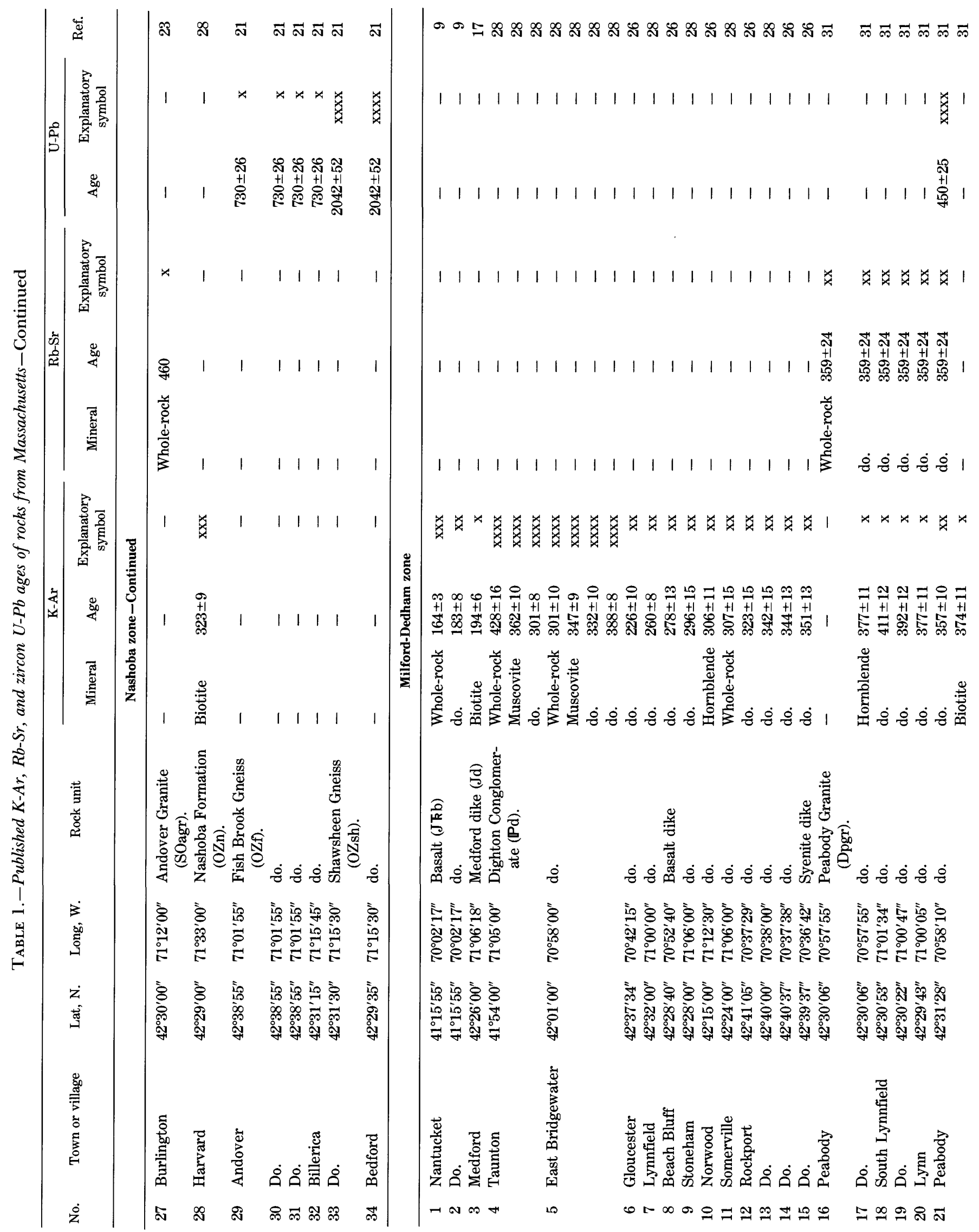


RADIOMETRIC AGES OF ROCKS IN MASSACHUSETTS

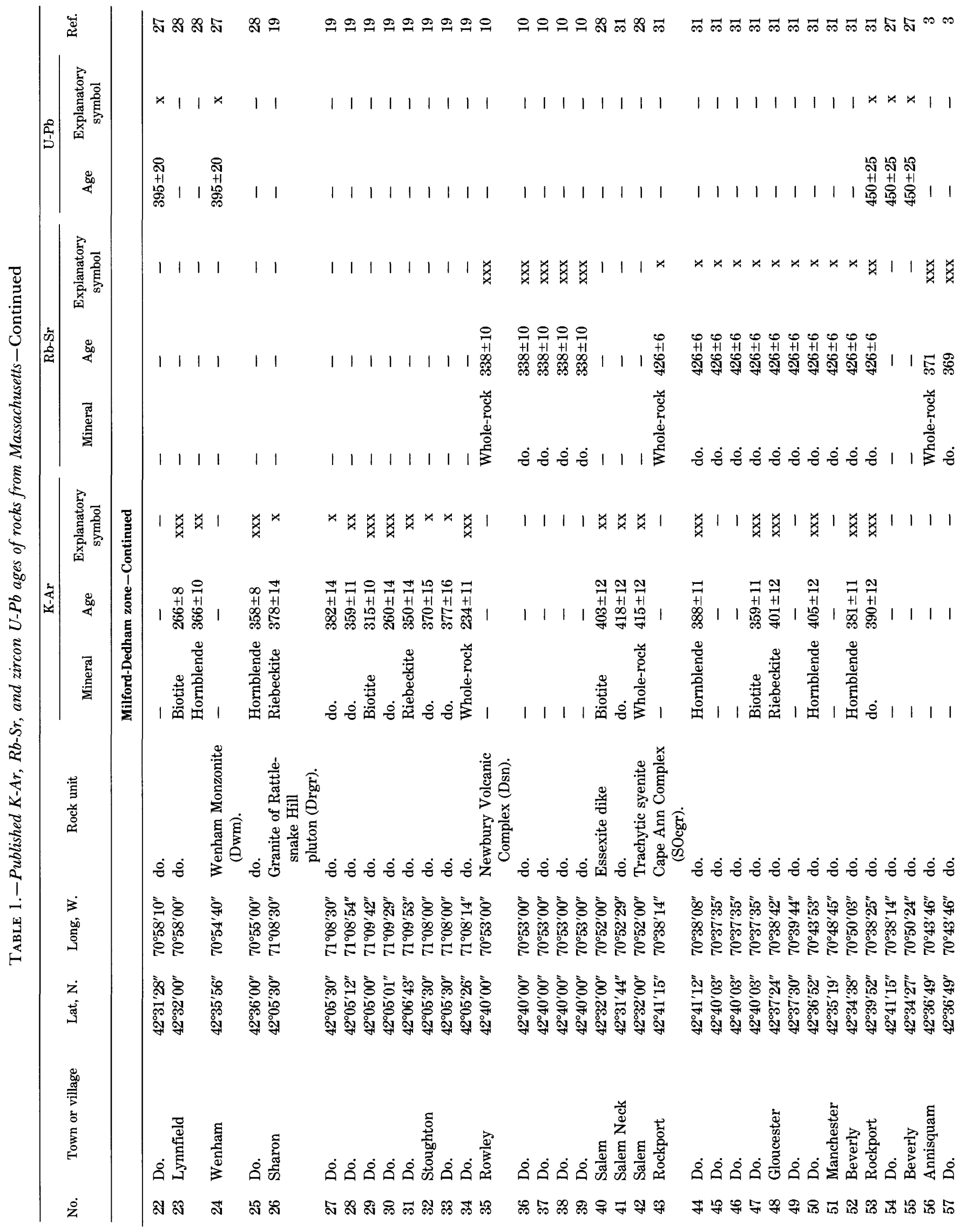




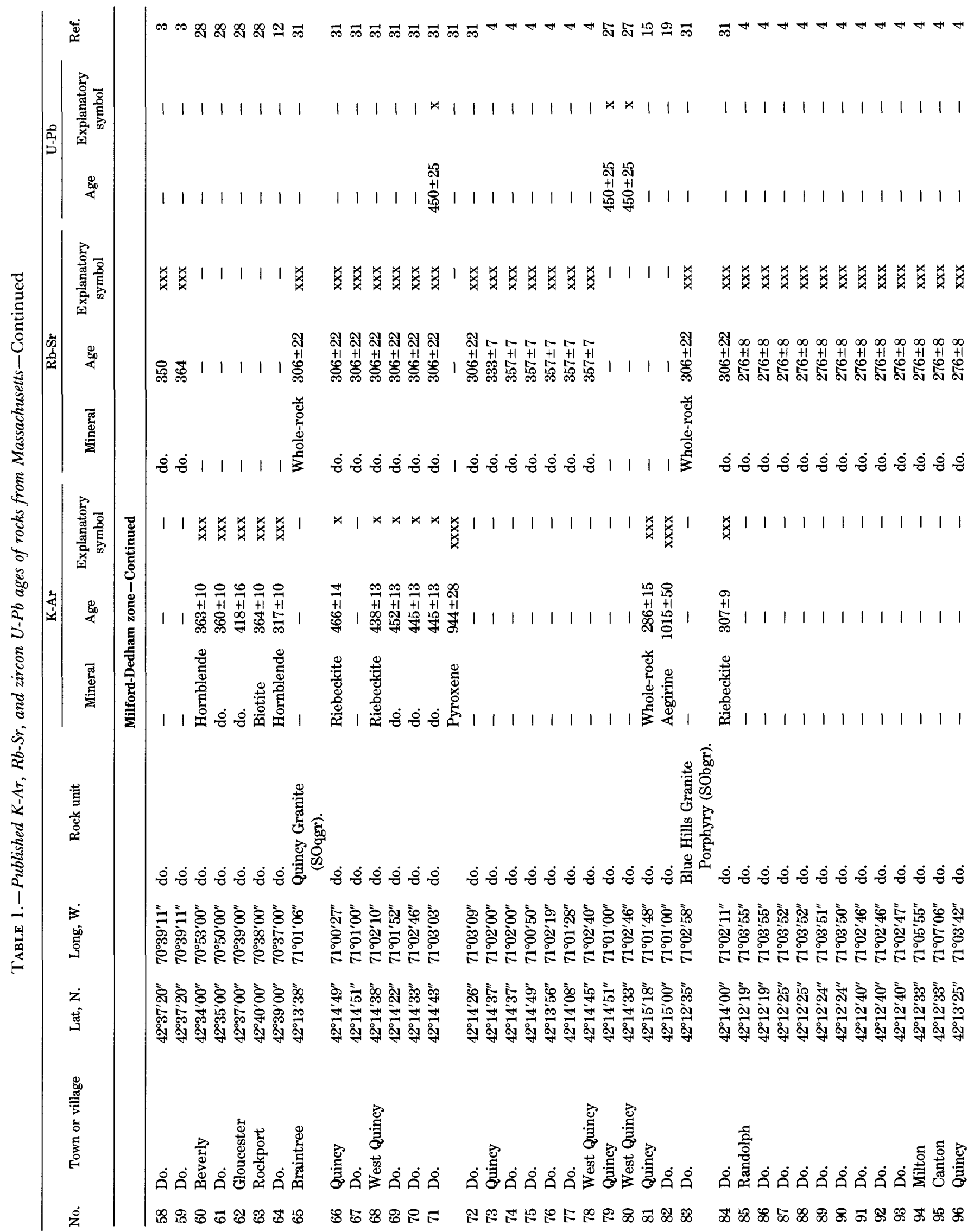




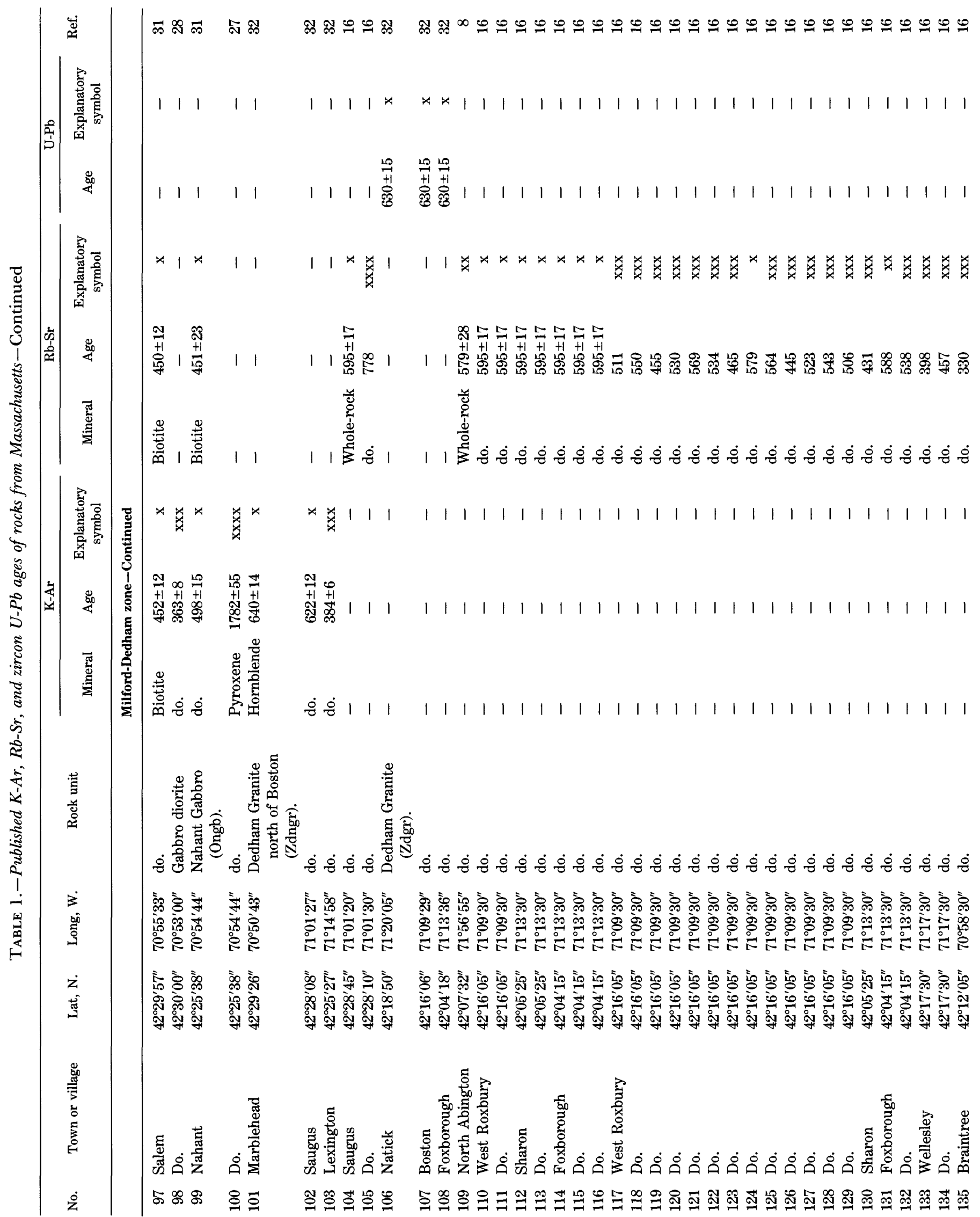




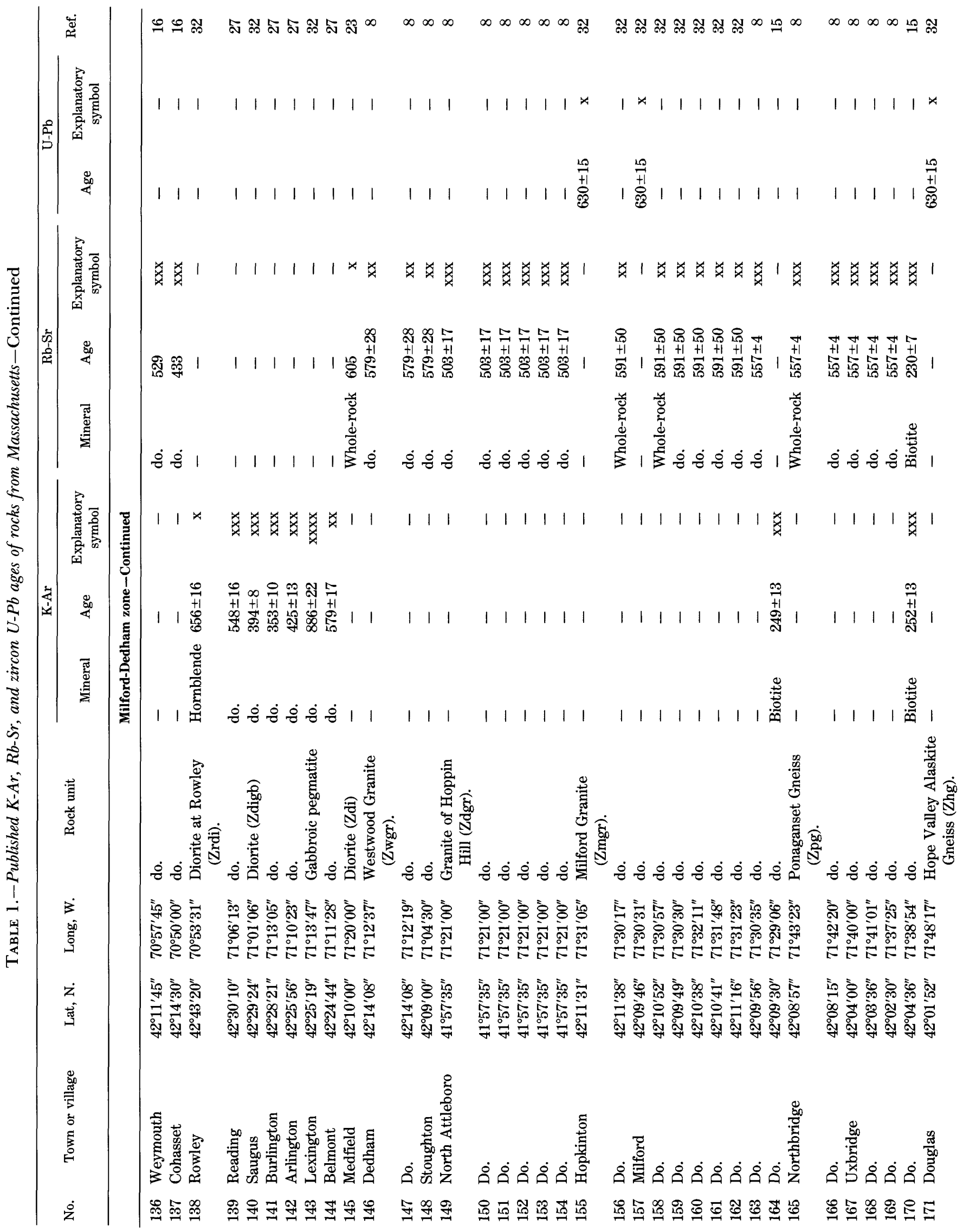


RADIOMETRIC AGES OF ROCKS IN MASSACHUSETTS

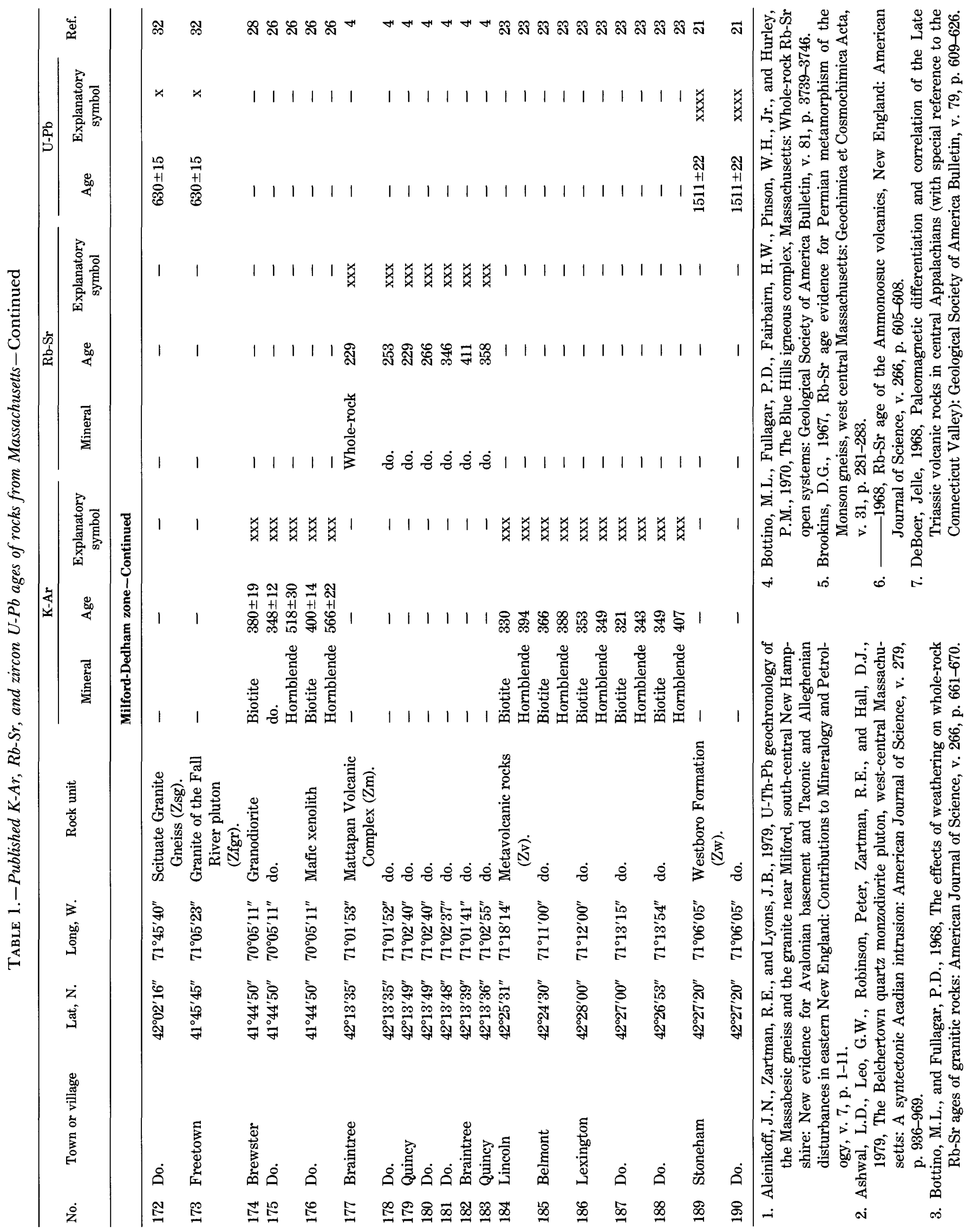




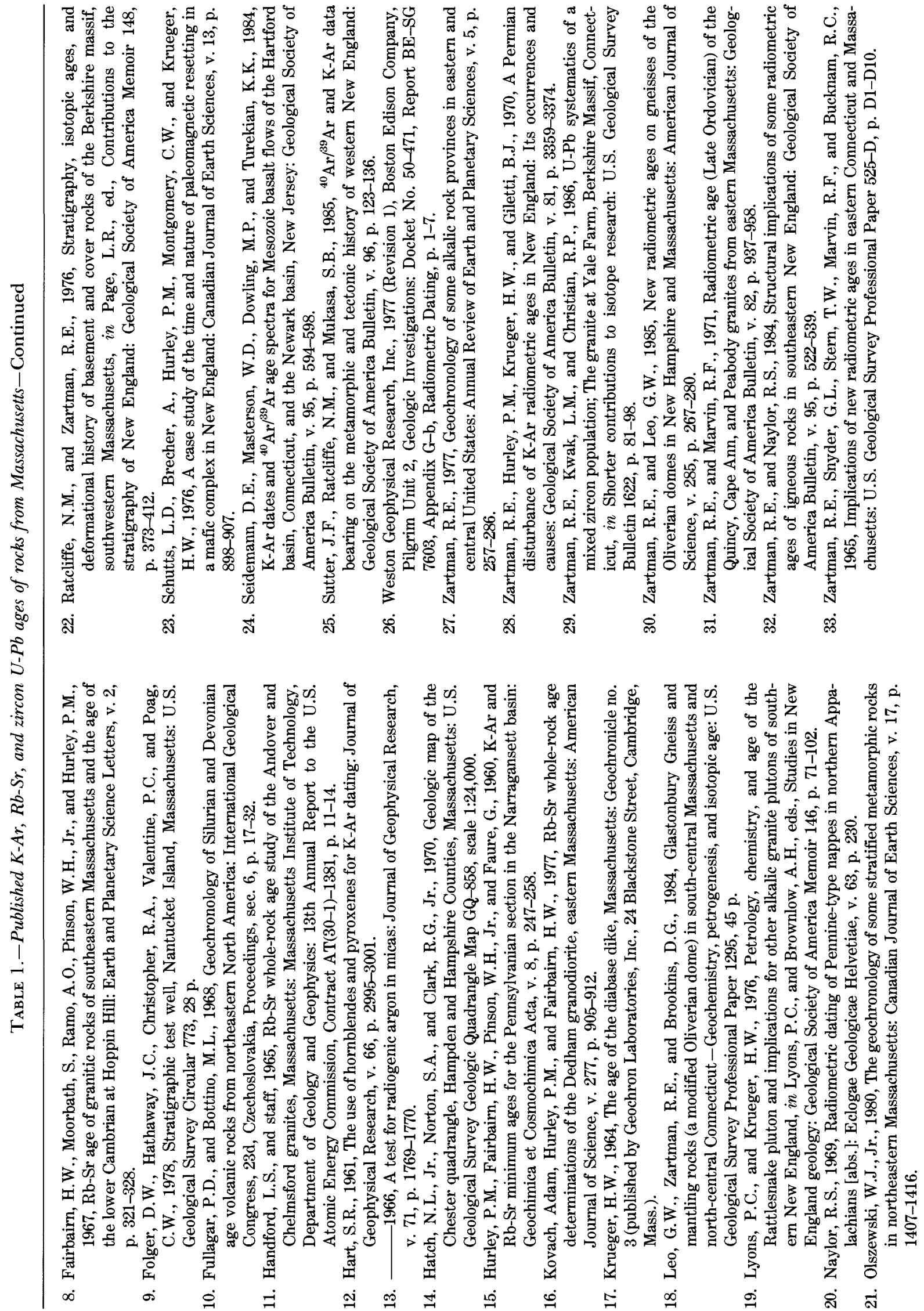


TABLE 2.-Published zircon Pb-alpha and apatite fission-track ages of rocks from Massachusetts

[Lead-alpha ages calculated by the equation, $t$ (m.y.) $=\mathrm{K} \times(p / a)$, where $p$ is lead content in ppm, $a$ is alpha activity in alphas $/ \mathrm{mg}$-hr, and $\mathrm{K}=2580$. Fission-track ages are given in terms of the decay constant, $\lambda_{\mathrm{f}}=8.46 \times 10^{-17} \mathrm{yr}^{-1}$. The explanatory symbol $(\mathrm{x})$ indicates that the radiometric system records an age interpreted to be time of uplift and cooling below $110^{\circ} \mathrm{C} ;(\mathrm{xx})$ indicates that the age is of questionable analytical or geological meaning. Ref., reference from list below. -, not determined; Do., do., ditto]

\begin{tabular}{|c|c|c|c|c|c|c|c|c|c|}
\hline \multirow[b]{2}{*}{ No. } & \multirow[b]{2}{*}{ Town or village } & \multirow[b]{2}{*}{ Lat, N. } & \multirow[b]{2}{*}{ Long, W. } & \multirow[b]{2}{*}{ Rock unit } & \multicolumn{2}{|c|}{ Pb-alpha } & \multicolumn{2}{|c|}{ Fission-track } & \multirow[b]{2}{*}{ Ref. } \\
\hline & & & & & Age & $\begin{array}{c}\text { Explanatory } \\
\text { symbol }\end{array}$ & Age & $\begin{array}{c}\text { Explanatory } \\
\text { symbol }\end{array}$ & \\
\hline \multicolumn{10}{|c|}{ Bronson Hill zone } \\
\hline 1 & Erving & $42^{\circ} 37^{\prime} 18^{\prime \prime}$ & $72^{\circ} 22^{\prime} 06^{\prime \prime}$ & Pauchaug Gneiss (Opc) & - & - & $97 \pm 5$ & $\mathrm{x}$ & 4 \\
\hline 2 & Orange & $42^{\circ} 33^{\prime} 30^{\prime \prime}$ & $72^{\circ} 18^{\prime} 12^{\prime \prime}$ & Monson Gneiss (OZmo) & - & - & $82+3$ & $\mathrm{x}$ & 4 \\
\hline 3 & Erving & $42^{\circ} 36^{\prime} 00^{\prime \prime}$ & $72^{\circ} 22^{\prime} 00^{\prime \prime}$ & Fourmile Gneiss (OZfm) & - & - & $94 \pm 5$ & $\mathrm{x}$ & 4 \\
\hline \multicolumn{10}{|c|}{ Merrimack synclinorium } \\
\hline 1 & Leominster & $42^{\circ} 31^{\prime} 45^{\prime \prime}$ & $71^{\circ} 48^{\prime} 00^{\prime \prime}$ & Fitchburg Complex (Dfgd) & $230 \pm 25$ & $\mathrm{xx}$ & - & - & 2 \\
\hline 2 & West Chelmsford & $42^{\circ} 37^{\prime} 57^{\prime \prime}$ & $71^{\circ} 25^{\prime} 05^{\prime \prime}$ & Chelmsford Granite (Dcgr) & $480 \pm 51$ & $\mathrm{xx}$ & - & - & 2 \\
\hline 3 & Bolton & $42^{\circ} 25^{\prime} 00^{\prime \prime}$ & $71^{\circ} 39^{\prime} 00^{\prime \prime}$ & Ayer Granite (Sacgr) & $410 \pm 50$ & $\mathrm{xx}$ & - & - & 3 \\
\hline 4 & Clinton & $42^{\circ} 23^{\prime} 50^{\prime \prime}$ & $71^{\circ} 41^{\prime} 15^{\prime \prime}$ & do. & $420 \pm 50$ & $\mathrm{xx}$ & - & - & 3 \\
\hline \multicolumn{10}{|c|}{ Nashoba zone } \\
\hline 1 & Berlin & $42^{\circ} 23^{\prime} 25^{\prime \prime}$ & $71^{\circ} 40^{\prime} 40^{\prime \prime}$ & Muscovite granite (mgr) & $520 \pm 60$ & $\mathrm{xx}$ & - & - & 3 \\
\hline \multicolumn{10}{|c|}{ Milford-Dedham zone } \\
\hline 1 & Peabody & $42^{\circ} 31^{\prime} 00^{\prime \prime}$ & $70^{\circ} 58^{\prime} 00^{\prime \prime}$ & Peabody Granite (Dpgr) & $275 \pm 28$ & $\mathrm{xx}$ & - & - & 1 \\
\hline & & & & & $273 \pm 27$ & $\mathrm{xx}$ & - & - & 1 \\
\hline \multirow[t]{3}{*}{2} & Do. & $42^{\circ} 30^{\prime} 05^{\prime \prime}$ & $70^{\circ} 57^{\prime} 55^{\prime \prime}$ & do. & $260 \pm 21$ & $\mathrm{xx}$ & - & - & 2 \\
\hline & & & & & $290 \pm 23$ & $\mathrm{xx}$ & - & - & 2 \\
\hline & & & & & $260 \pm 21$ & $\mathbf{x x}$ & - & - & 2 \\
\hline \multirow[t]{3}{*}{3} & Rockport & $42^{\circ} 40^{\prime} 50^{\prime \prime}$ & $70^{\circ} 38^{\prime} 04^{\prime \prime}$ & Cape Ann Complex (SOcgr) & $290 \pm 33$ & $\mathrm{xx}$ & - & - & 2 \\
\hline & & & & & $230 \pm 18$ & $\mathrm{xx}$ & - & - & 2 \\
\hline & & & & & $265 \pm 25$ & $\mathrm{xx}$ & - & - & 2 \\
\hline \multirow[t]{2}{*}{4} & Do. & $42^{\circ} 40^{\prime} 41^{\prime \prime}$ & $70^{\circ} 39^{\prime} 00^{\prime \prime}$ & do. & $235 \pm 15$ & $\mathrm{xx}$ & - & - & 2 \\
\hline & & & & & $265 \pm 22$ & $\mathrm{xx}$ & - & - & 2 \\
\hline 5 & Beverly & $42^{\circ} 33^{\prime} 18^{\prime \prime}$ & $70^{\circ} 52^{\prime} 12^{\prime \prime}$ & do. & - & - & $64 \pm 4$ & $\mathrm{x}$ & 4 \\
\hline 6 & Norfolk & $42^{\circ} 07^{\prime} 00^{\prime \prime}$ & $71^{\circ} 20^{\prime} 00^{\prime \prime}$ & Dedham Granite (Zdgr) & $225 \pm 25$ & $\mathrm{xx}$ & - & - & 2 \\
\hline \multirow[t]{3}{*}{7} & Foxborough & $42^{\circ} 03^{\prime} 18^{\prime \prime}$ & $71^{\circ} 17^{\prime} 32^{\prime \prime}$ & do. & $390 \pm 30$ & $\mathrm{xx}$ & - & - & 2 \\
\hline & & & & & $335 \pm 31$ & $\mathbf{x x}$ & - & - & 2 \\
\hline & & & & & $380 \pm 33$ & $\mathrm{xx}$ & - & - & 2 \\
\hline 8 & Do. & $42^{\circ} 02^{\prime} 30^{\prime \prime}$ & $71^{\circ} 17^{\prime} 30^{\prime \prime}$ & do. & $365 \pm 35$ & $\mathrm{xx}$ & - & - & 2 \\
\hline 9 & Wrentham & $42^{\circ} 02^{\prime} 30^{\prime \prime}$ & $71^{\circ} 20^{\prime} 00^{\prime \prime}$ & do. & $220 \pm 22$ & $\mathrm{xx}$ & - & - & 2 \\
\hline \multirow[t]{2}{*}{10} & Milford & $42^{\circ} 09^{\prime} 45^{\prime \prime}$ & $71^{\circ} 30^{\prime} 00^{\prime \prime}$ & Milford Granite (Zmgr) & $385 \pm 38$ & $\mathrm{xx}$ & - & - & 2 \\
\hline & & & & & $365 \pm 33$ & $\mathrm{xx}$ & - & - & 2 \\
\hline \multirow[t]{3}{*}{11} & Do. & $42^{\circ} 09^{\prime} 45^{\prime \prime}$ & $71^{\circ} 30^{\prime} 15^{\prime \prime}$ & do. & $310 \pm 28$ & $\mathrm{xx}$ & - & - & 2 \\
\hline & & & & & $360 \pm 33$ & $\mathrm{xx}$ & - & - & 2 \\
\hline & & & & & $355 \pm 32$ & $\mathrm{xx}$ & - & - & 2 \\
\hline \multirow[t]{3}{*}{12} & Whitinsville & $42^{\circ} 07^{\prime} 00^{\prime \prime}$ & $71^{\circ} 40^{\prime} 00^{\prime \prime}$ & Ponaganset Gneiss (Zpg) & $270 \pm 30$ & $\mathrm{xx}$ & - & - & 2 \\
\hline & & & & & $270 \pm 29$ & $\mathrm{xx}$ & - & - & 2 \\
\hline & & & & & $265 \pm 31$ & $\mathrm{xx}$ & - & - & 2 \\
\hline \multirow[t]{3}{*}{13} & Uxbridge & $42^{\circ} 04^{\prime} 36^{\prime \prime}$ & $71^{\circ} 38^{\prime} 54^{\prime \prime}$ & do. & $215 \pm 17$ & $\mathrm{xx}$ & - & - & 2 \\
\hline & & & & & $245 \pm 26$ & $\mathrm{xx}$ & - & - & 2 \\
\hline & & & & & $620 \pm 53$ & $\mathrm{xx}$ & - & - & 2 \\
\hline
\end{tabular}

1. Quinn, A.W., Jaffe, H.W., Smith, W.L., and Waring, C.L., 1957, Lead-alpha ages of Rhode Island granitic rocks compared to their geologic ages: American Journal of Science, v. 255, p. $547-560$.

2. Webber, G.R., Hurley, P.M., and Fairbairn, H.W., 1956, Relative ages of eastern Massachusetts granites by total lead ratios in zircon: American Journal of Science, v. 254, p. 574-583.
3. Zartman, R.E., Snyder, G.L., Stern, T.W., Marvin, R.F., and Bucknam, R.C., 1965, Implications of new radiometric ages in eastern Connecticut and Massachusetts: U.S. Geological Survey Professional Paper 525-D, p. D1-D10.

4. Zimmerman, R.A., Reimer, G.M., Foland, K.A., and Faul, H., 1975 , Cretaceous fission-track dates of apatites from northern New England: Earth and Planetary Science Letters, v. 28, p. 181-188. 


\section{APPENDIX: RADIOMETRIC AGE DATA BANK}

The Radiometric Age Data Bank (RADB) is a means for collecting and organizing the approximately 100,000 radiometric ages presently published for the United States. Although the goal of providing complete coverage for the entire country has not yet been reached, a concentrated effort directed toward the six New England States (Maine, New Hampshire, Vermont, Massachusetts, Rhode Island, and Connecticut) has resulted in the incorporation of at least 95 percent of the ages published through 1986 for this area into our data file. The RADB is constructed such that sample location, petrography, analytical data, calculated age(s) together with interpretive remarks, and literature citation are linked to form an independent record for each sample. The record can accommodate, singly or in combination, all results on a sample pertinent to the $\mathrm{K}-\mathrm{Ar}, \mathrm{Rb}-\mathrm{Sr}$, $\mathrm{U}-\mathrm{Th}-\mathrm{Pb}, \mathrm{Pb}$-alpha, and fission-track methods.

Data are processed by using the General Information Processing System (GIPSY) developed at the University of Oklahoma, which maintains the data file and builds, updates, searches, and prints the records through simple yet versatile command statements. The retrieval of records is accomplished by specifying the presence, absence, or numeric or alphabetic value of any element of information in the data bank. For example, searches can be made for all records relating to the Quincy Granite, all records containing $\mathrm{Rb}$-Sr biotite ages between $400 \mathrm{Ma}$ and $600 \mathrm{Ma}$, or all records derived from a particular literature citation. Output is available in the form of complete or abbreviated records, listings of specified record elements, columnar tabulations, or input data for certain ancillary programs, such as map or histogram plots. A typical RADB record is discussed below to illustrate the sort of information available from the data bank. The reader with further interest in the operational aspects of RADB is referred to the user's guide to the Radiometric Age Data Bank (Zartman and others, 1976) and additional references contained therein.

As an example, a slightly abridged RADB record (a few coded elements, which, for our purpose, would be redundant, have been deleted from the original record) for a sample of granite from the Cape Ann Complex from Rockport, Mass., is shown in figure Al. Many of the individual elements of the record are self-explanatory, but certain entries that are given in code or may be otherwise enigmatic require further definition. The italicized letters next to some of the elements are keyed to the following comments. A, General information about each sample, including a unique record number, a reference code (a complete reference is given at the end of the record), and a code for the laboratory or laboratories that performed the analytical determinations. $B$, Name of person who compiled this record and the date (month and year) of compilation. $C$, A one-digit code indicating accuracy of sample location given by latitude and longitude coordinates. $D, \mathrm{~A}$ one-digit code indicating the source of the sample; that is, outcrop, core, quarry, mine, and so forth. $E$, A four-letter code of a formalized geologic name conforming to the Standard Stratigraphic Code of the U.S. Geological Survey. $F$, The known or most probable stratigraphic age of the unit (which may or may not coincide with the measured radiometric age) given in three-digit code conforming to the Standard Stratigraphic Code of the U.S. Geological Survey. G, A four-character petrographic code for the rock from which the sample was taken; this code is used in searches for general rock groupings. $H$, The laboratory sample number as given by the author(s) of the published article. I, A three-character mineralogic code for the analyzed mineral; this code is used in searches for general mineral family groupings. $J$, A two-digit code identifying the method of analysis. $K$, Interpretive comments about the radiometric age and its geologic significance. $L$, A suite number. If a calculated age is related to the analyses of other samples, as for a $\mathrm{Rb}-\mathrm{Sr}$ whole-rock isochron or $\mathrm{U}-\mathrm{Pb}$ zircon discordia array, it is designated as being part of a suite. A unique number ties together all analyses belonging to the suite and can be used to retrieve the other members of the suite.

Each sample locality is represented by a record similar to the one shown in figure $\mathrm{A} 1$, and each record contains 1-6 individual ages (our example gives a K-Ar hornblende, an $\mathrm{Rb}-\mathrm{Sr}$ whole-rock, and a U-Th- $\mathrm{Pb}$ zircon age). This pool of information provides the data base from which tables 1 and 2 have been compiled. The entire set of unabridged records is not reproduced here, but a copy of it is available as U.S. Geological Survey Open-File Report 87-170 (Zartman and Marvin, 1987). Of course, the data bank must be recognized as only a convenient method of processing information originating elsewhere, and primary references remain those of the published articles. The list of primary references from which the Massachusetts RADB records were compiled is included in tables 1 and 2. 
RADIOMETRIC AGE DATA BANK - U.S.G.S. BRANCH OF ISOTOPE GEOLOGY

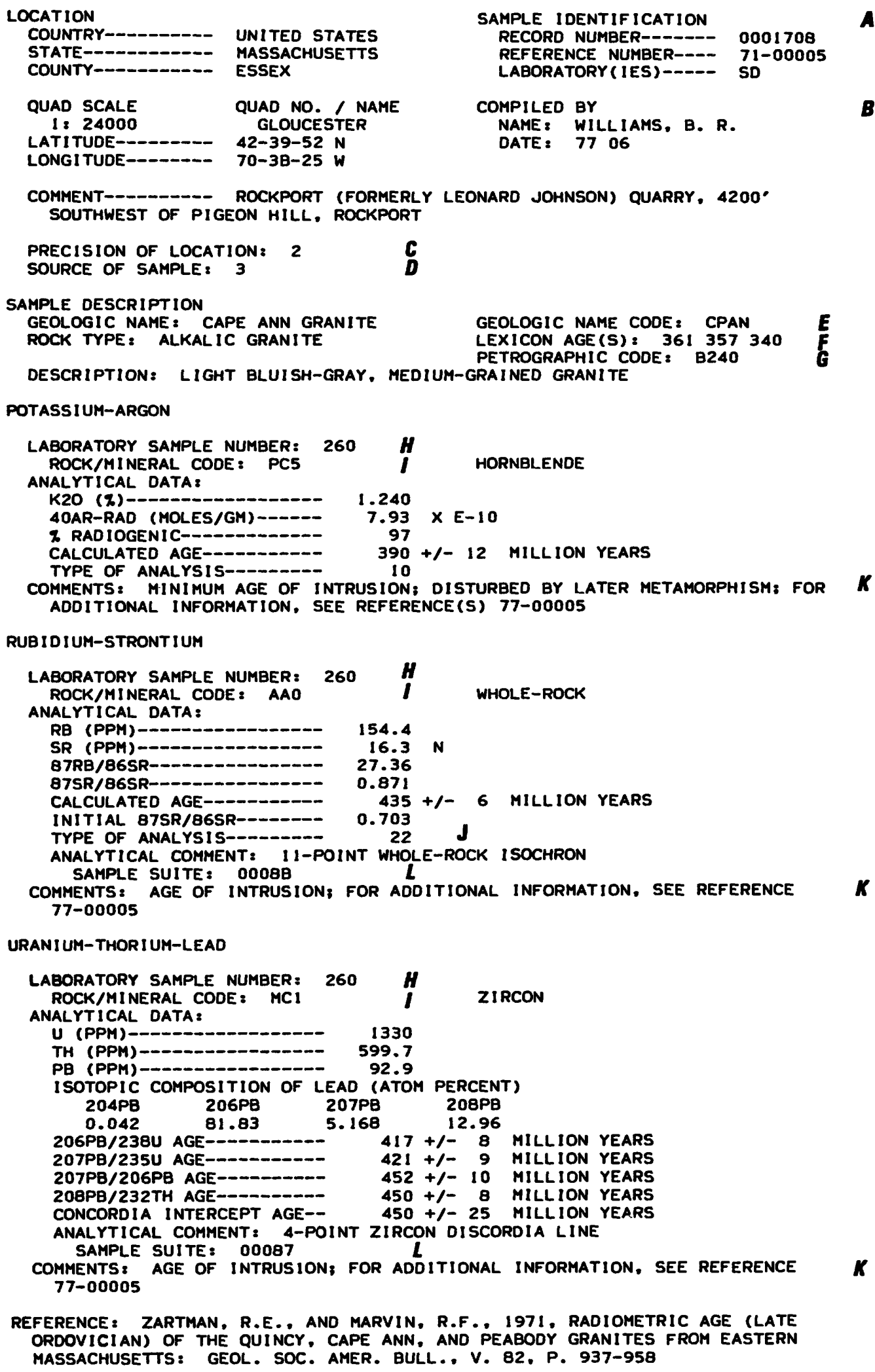

REFERENCE: ZARTMAN, R.E.. AND MARVIN, R.F.. 1971, RADIOMETRIC AGE (LATE ORDOVICIAN) OF THE QUINCY, CAPE ANN, AND PEABODY GRANITES FROM EASTERN MASSACHUSETTS: GEOL. SOC. AMER. BULL.. V. 82, P. 937-958

FIgURE A1. -A Radiometric Age Data Bank (RADB) record for a sample of granite from the Cape Ann Complex from Rockport, Mass. For explanation of abbreviations and italicized letters, see facing page. 